$-3 x^{2}=x^{2}$

wis 


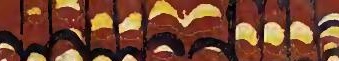
An

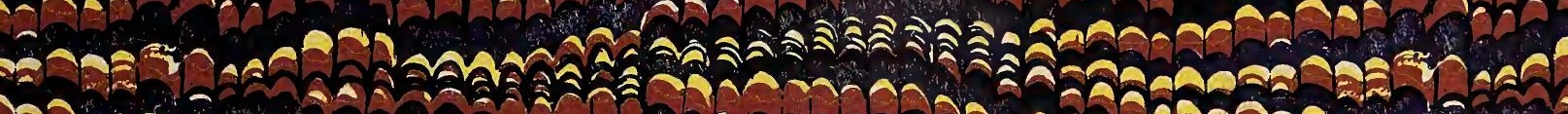

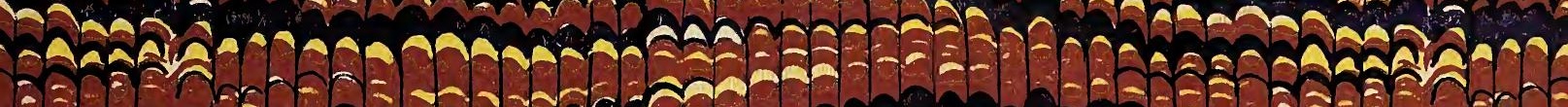
- If

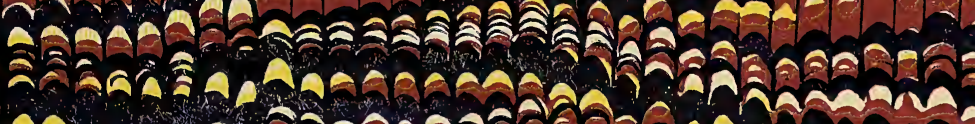

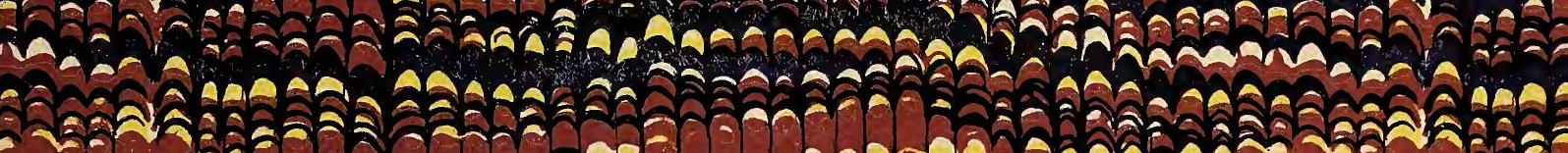

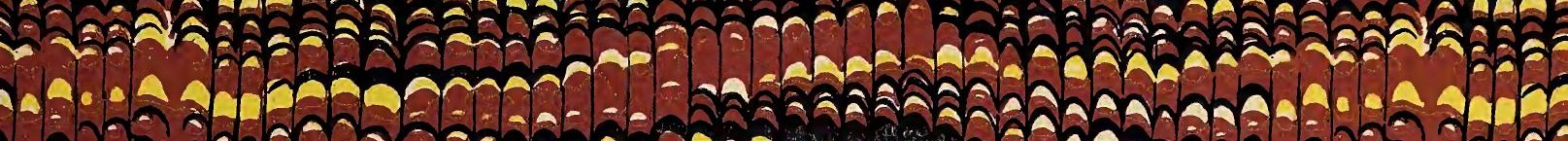

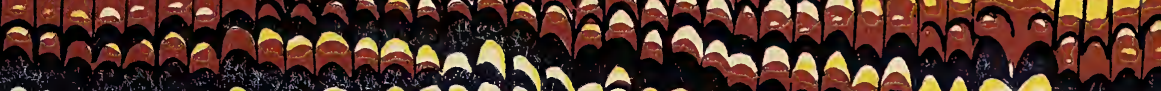

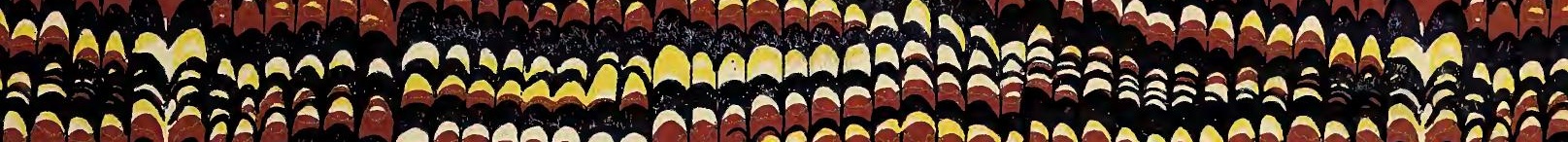

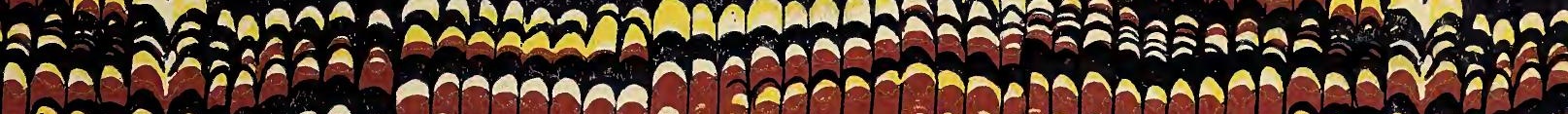

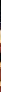

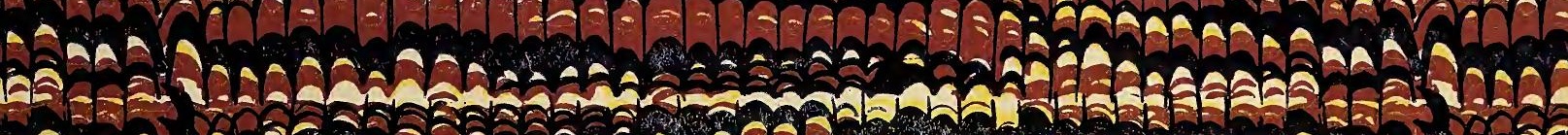

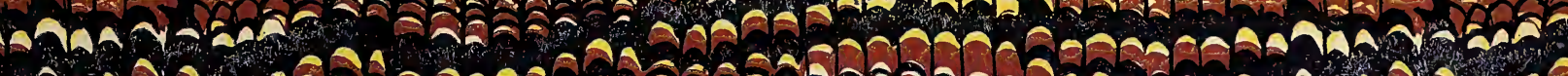

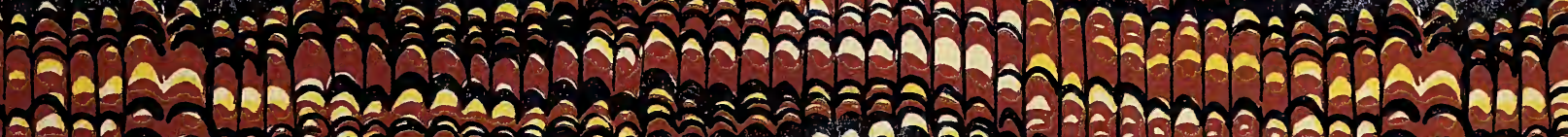

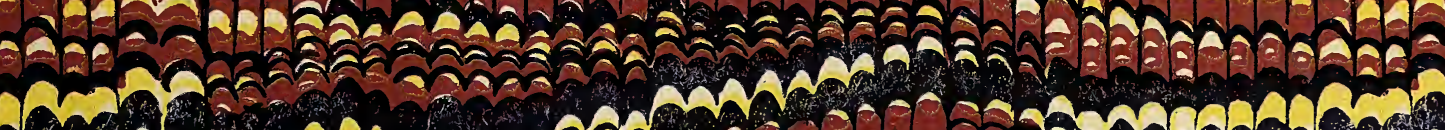

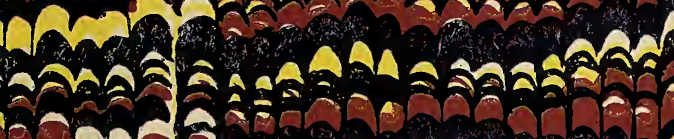
Ta 2 -

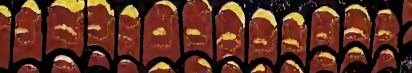

A 120 ?

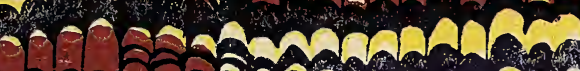

and

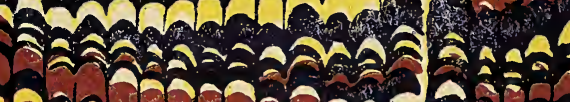

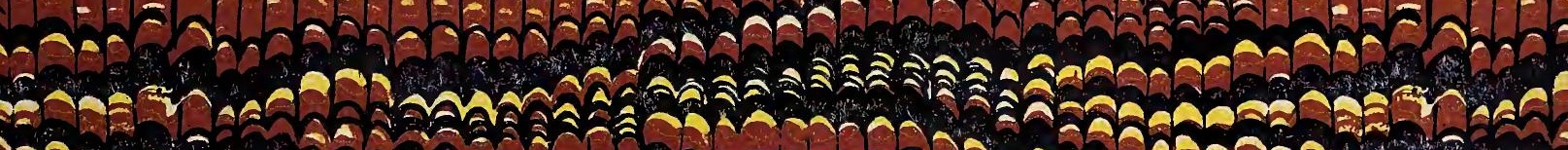

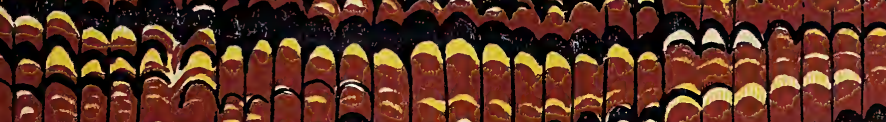

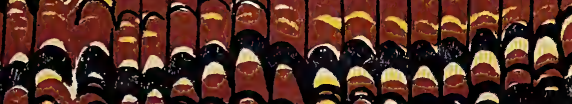

ion

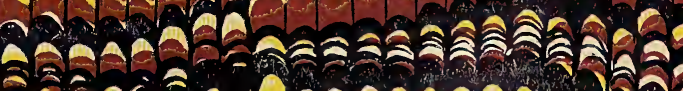

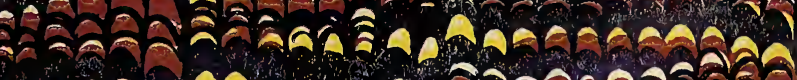

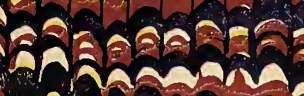

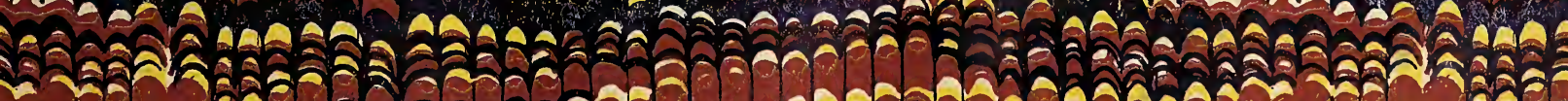

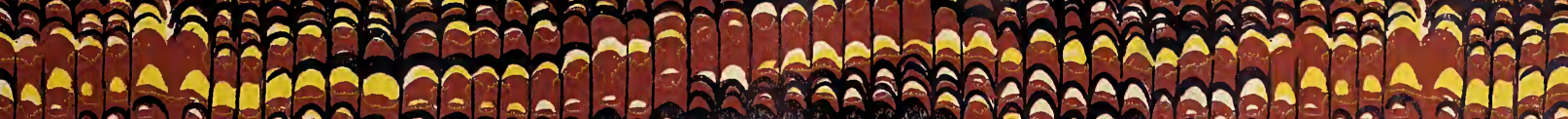

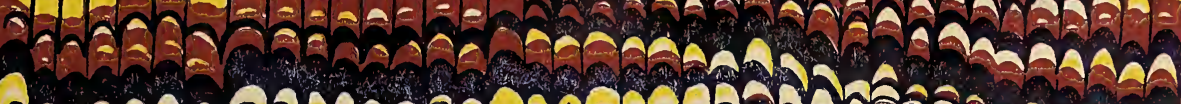

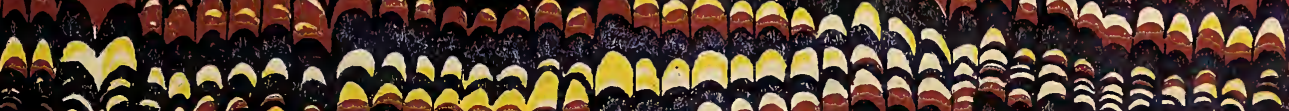
2.1 

. 

26680 


\section{MONOGRAPHIE}

\section{nesa $\because \because \ldots$ \\ ORDNUNG THYSANOPTERA.....}

VON

HEINRICH UZEL.

MIT 10 TAFELN UND 9 TEXTBILDERN.

GEKRÖNT MIT DEM JUBILÄUMSPREISE DER BÖHMISCHEN AKADEMIE DER IVISSENSCHAFTEN ETC. IN PRAG.

KöNIGGRÄTZ 1895.

SELBSTVERLAG DES VERFASSERS. - IN COMMISSION BEI B. E. TOLMAN IN KÖNNIGGRÄTZ, BÖHMEN. 


\section{MONOGRAFIE}

\section{R̈ADU „THYSANOPTERA“.}

SEPSAL

\section{JINDR̈ICH UZZL.}

S 10 TABULEMI A 9 OBRAZY V TEXTU.

DILO POCTENE JUbILEJNi CENOU CESKE AKADEMIE CÍSAlE FRANTIŚKA JOSEFA PRO VÉDY, SLOVESNOST' A UMĖNI Y PRAZE.

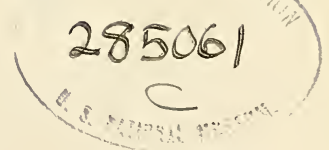

Y HRADCT KRÁLOVÉ 1895.

NAKLADEM SPISOVATELOVÝN. - V KOMMISSI U B. E. TOLMANA V HRADGI KRALOTE. 
Véechna práva vyhrazena.

Allo Rechte vorbehalten.

TISKLI BRATŔI PEŘINOVE V HRADGI KRALLO'É. 


\section{PREDMLUVA.}

Je tomu osm let, kdy pojal jsem úmỵsl zpracovali české lỉásněnky*), na něž upozornilo mne několik jimi vyssátých listủ fikusorých. Již tenkrát počal jsem sbírati material. Mezi tím však bylo mi dokončiti dissertaci svou o českịch šupinuškách, takže lěmi hlavně jsem se zabýval. Hned polom rrhlı jsem se plnou silou opět na studium trásnènek a sebral jsem po Čechách veliké jich zásoby. Bẻhem práce poznal jsem, že více ně̌ dvè tr̀ctiny z Evropy dosud popsanỵch d’uhủ téz̆ v Čechách se vyskytuje, a kromè toho mnoho druhủ a rodû nových. I uzrál ve mnè poznenáhla úmysil shmouti vše, co posud známo bylo o třásněnkách. v jeden spis, a pokud možno, dosavadní práce vlasłními výzkumy bud potvrditi neb doplniti. K lomu cíli bỵlo nutno opatrovati si po

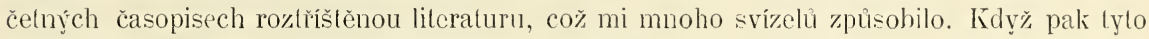
prekonány byly, jal jsem se spisovati monografii hınyzu tǐásnokiridlého, poznav také anatomii jeho a zpracovav ještě druhy, kleré jsem na ostrově Ilelgolandè a u Berlína sbíral, a jiné, které mi \% Pešli a z Rěky zaslány bỵly.

Nedostatek monografie toho rádu byl ršeobecnè pocitovín. coz nejlépe vysvílá z okolnosti, že v posledních palnácti letech nebỵlo v systematice jeho, ač i v oekonomii veliký význam má, téměr̆ nic pracováno, a to jen \% lé príčiny, žc existoval v literature neobyčcjnỵ zmatek (způsobený hlavně príliš krátlị̂mi a tím nepresnými diagnosami staršími a poměrně príliš malým počtem druhủ popsanỵch), jehož odklizení vỵzadovalo podrobného zpracovíní celého předmètu

Práci svou dokončil jsem již v kvètnu roku 1894., a v červnu odevzdal jsem skoro úphnou sbírku ěeských druhủ do zemského musea.

Dne 8. ríjna téhož roku ucházel jsem se rukopisem télo monografie o jubilejní cenu Ċeské Akademie, takže teprv nỵní, právě rok po dokončeni svého dila, mohu prìkročiti k publikaci jeho, kterou mi umožn̆uje obělavost mého drahého otce.

Pohližím-li na spis svủj dokončený, jsou pocity mé velmi smišeny. Musím vy-

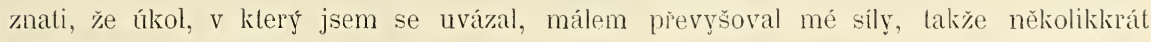

*) Výklad toho jména viz na str. 439. 
jsem bỵl nucen od práce uslati, kdỵž oči a prsa mi hrozily službu odepríti. Konečnẽ však překonala láska k vyvolenému pĩedmètu všechna protivenství, a po opětované námaze popřáno mi dospěti cíle. Strasti zakoušené byly ovšem plnou měrou vyváženy radostmi, spojenými se shro maždováním materialu. Tyto arcit' oceniti mủže jen milovník prírody a zvláště sběratel. Dále oblažuje mne pocit, že zároveñ mohu svou hr̃ivnou prìspěti k poznání naši drahé vlasti. Také mocně pohnula mne vysoká pocta, které dostalo se manuskriptu mého dila od České Akademie. Budiž Ji za to vysloven zde můj nejvroucnèjší dík!

Ke konci dovoluji si ješlě poprositi, aby mi za neskromnost nebylo vykládáno, zmíním-li se o tom, že jsem k této práci užival vlastních nástrojů, vlastní pracorny a převážnou většinou vlastní knihovny, a že jsem sám vedl náklad na výzkumné cesty.

V HRADCI KRÁLOVÉ, v kvètnu 1895.

Spisovatel. 


\section{VORREDE.}

Die Handschrift zur vorliegenden Monographie, das Resultat langjähriger Studien, wurde schon im Mai 1894, bis auf umbedeutende Zusälze, beendet. Durch Preisbewerbung hat sich jedoch die Publication sehr verspätel, so dass sie erst heuer erfolgt.

Das Bedürfnis einer Monographie der Thysanopteren war sehr fühlbar. Dies ist am besten daraus zu ersehen, dass volle 15 Jahre ungemein wenig in ihrer Systematik gearbeitet wurde, und zwar deswegen, weil in der Literatur eine ungewöhnliche Verwirrung herrschte (welche hauptsächlich durch zu kurze und infolge dessen nicht hinreichende Diagnosen der älteren Autoren und durch die verhältnismässig geringe Zahl der beschriebenen Arten verursacht wurde), deren Abschaffung eine specielle Bearbeitung des ganzen Gegenstandes erforderte.

Um das Werk breiteren Kreisen zugänglich zu machen, hat der Verfasser den ganzen systematischen Theil auch deutsch niedergeschrieben und den übrigen Theilen dieses Werkes (dem palaeontologischen, anatomischen, entwicklungsgeschichtlichen, biologischen, oekonomischen und historischen) deutsche Résumés beigefügt. Der oekonomische und historische Theil ist ausserdem durch die Art und Weise der Zusammenstellung, und der anatomische und entwicklungsgeschichtliche durch die Abbildungen auch für den der böhmischen Sprache nicht Kundigen brauchbar. Die Tafelerklärungen und die Erklärungen der Textbilder sind böhmisch und zugleich deutsch gegeben.

Möge diese Schrift, die dem Verfasser sehr viel Mühe kostete, jedoch auch zu mancher Freude gereichte, zur regen Forschung in dieser sehr vernachlässigten Ordnung Anlass geben!

KÖNIGGRÄTZ, im Mai 1895 .

\section{Der Verfasser.}





\section{I. ĊÁS SYSTEMATICKA.}

\section{SYSTEMATISCHER THEIL.}





\section{ÚVODNÍ POZNÁMKY. EINLEITENDE BEMERKUNGEN.}

$\mathrm{V}$ této části podávám popisy všech dosud známých druhư třảsněnek, pokud jsem o nich dovèdèti se mohl. Mimo to popsáno zde 11 nových rodü*), 63 nových druhư (z těch $34 \mathrm{v}$ obou pohlavích) a 25 nových variet. Dále obsaženy jsou zde diagnosy dosud nepopsaných samců čtyřiadvaceti druhủ, jichž samičky však již známy byly. Všecky nové druhy (také nové variety a novẽ popsaní samci) byly vesměs $v$ Čechách nalezeny, některé však mezi nimi také na Helgolandě, u Pešti, Rěky, u Berlína a v Laponsku.

Třásněnky dřive popsané rozdělovány byly jen $\mathrm{v}$ malý počet rodủ, které často nejrůznějši elementy zahrnovaly. I odhodlal jsem se, naleznuv v př́rodě zástupce všech posud známých rodủ evropských a mimo to cetné zástupce rodủ nových, rozvrhnouti třásněnky vůbec v 36 rodů. Přes to nemohl jsem arcit' některé (počtem 18) z druhư známých vpraviti do rodů uvedených, ježto nebylo $\mathrm{v}$ popisech jejich (často kusých) zmínky o znacích, které jednotlivé rody charakterisuji, a poněvadž neměl jsem príležitost' sám je ohledati. I uvádím diagnosy těchto druhů za každým z obou podřádů třásněnek.

Dále podotýkám, že popisy všech rodủ (kromè tropického rodu Idolothrips) a popisy 37 známých druhủ, jež jsem sám v prííodě nalezl**), zakládají se jen na vlastních pozorováních. U těchto druhủ doplnil jsem popisy starší, obyčejně velmi neúplné a krátké. Diagnosy ostatních druhủ známých, jež jsem sám neviděl: uvádím v pủvodním zněni. - Synonymiku sestavil jsem sám z literatury. — Biologická data, u jednotlivých druhů uvedená, jsou podána dle vlastních zkušeností.

Konečně poznamenávám, že připojil jsem na konec také druhy, jejichž popisy jsou př́liš neúplné aneb obsahují zřejmé odpory a tím platnosti pozbývají. Mezi nimi uvádím tẹ́ž jména třásněnek bez popisu uveřejněných (druhy nominalní).

$\mathrm{V}$ celku jest 135 druhů známých třásnènek, z nichž na Evropu pŕ̛ipadá 117 druhủ. Zde větši pozornost věnována jejich systematice jen $\mathrm{v}$ Anglii (34 druhy) a ve Finnsku $\left.(28 \text { druhů })^{* * * *}\right)$.

*) Kromě těchto je 13 rodů nově navržených.

**) Tyto rody a druhy známé, rovněž jako rody a druhy mnou objevené (tedy všecky evropské rody vůbec a všecky druhy, jež jsem sám ohledal) popisuji česky a německy.

***) V Čechách nalezl jsem 100 druhů trásnènek. 


\section{H. UZEL, MONOGRAPHIE DER ORDNUNG THYSANOPTERA.}

Myslím, že prospěšno bude pr̃ipojiti poučení o tom, jakým zpủsobem nejvýhodněji třásněnky sbíráme, a jak je vhodně $\mathrm{k}$ pozdẽjšímu studiu upravujeme. $\mathrm{K}$ tomu hodlám přidati, než ještě přilkročím $\mathrm{k}$ věci samé, seznam lokalit, $\mathrm{z}$ nichž mé zásoby třạsnènek pocházejí.

In diesem Theile biete ich die Beschreibungen aller bis jetzt bekannten Arten der Thysanopteren, soweit ich sie auszukundschaften vermochte. Ausserdem werden hier 11 ganz neue Gattungen*), 63 neue Arten (von diesen 34 in beiden Geschlechtern) und 25 neue Varietäten beschrieben. Weiter befinden sich hier Diagnosen von bis jetzt unbekannten, 24 Arten angehörenden Männchen, deren Weibchen schon bekannt waren.

Die früher beschriebenen Thysanopteren wurden nur in eine kleine Anzahl von Gattungen eingetheilt, welche oft die verschiedensten Elemente umfassten. Ich entschloss mich deshalb, nachdem ich in der Natur Vertreter aller bisher bekannten europäischen Gattungen und ausserdem viele Vertreter neuer Gattungen aufgefunden hatte, die Thysanopteren überhaupt in 36 Genera einzutheilen. Trotzdem konnte ich einige (18 an der Zahl) der bekannten Arten in diese Genera nicht unterbringen, weil in ihren oft mangelhaften Beschreibungen keine Erwähnung von Merkmalen, welche die einzelnen Genera charakterisieren, geschieht, und weil ich nicht Gelegenheit hatte, sie selbst zu untersuchen. Ich führe die Diagnosen dieser Arten, so wie sie von den einzelnen Autoren veröffentlicht wurden, hinter jeder der beiden Unterordnungen der Thysanopteren an.

Weiter erwähne ich, dass die Beschreibungen aller Gattungen (ausser der tropischen Gattung Idolothrips) und die Beschreibungen von 37 bekannten Arten, welche ich selbst in der Natur auffand, nur auf eigenen Beobachtungen begründet sind. Bei diesen Arten habe ich die älteren, oft sehr unvollkommenen und kurzen Beschreibungen ergänzt. Die Diagnosen der übrigen bekannten Arten (17 europäische und 18 aussereuropäische), welche ich selbst nicht gesehen habe, führe ich im ursprünglichen Wortlaute an. Die Synonymik stellte ich selbst aus der Literatur zusammen. Die biologischen Thatsachen, welche bei den einzelnen Arten angeführt werden, sind nach eigenen Erfahrungen gegeben.

Endlich bemerke ich, dass ich am Schlusse dieses Theiles eine Zusammenstellung der Arten beitügte, deren Beschreibungen zu unvollkommen sind, oder offenbare Gegensprüche enthalten und infolge dessen auf Aufrechthaltung keinen Anspruch machen können. Unter ihnen befinden sich auch jene Arten, welche ohne Beschreibung überhaupt veröffentlicht wurden.

Im ganzen kennen wir bis jetzt (sammt den hier beschriebenen neuen) 135 Arten von Thysanopteren, von denen 117 Europa zukommen**). Hier wurde ihrer Systematik grössere Aufmerksamkeit nur in England (34 Arten) und in Finnland (28 Arten) geschenkt.

*) Nebstdem werden noch 13 Gattungen von mir aufgestellt, die theilweise schon bekannte Arten umfassen.

**) Es sind also nur 18 aussereuropäische Arten bekannt! Möge dieser Hinweis zum Sammeln der jedenfalls sehr zahlreichen aussereuropäischen Thysanopteren aneifern! 


\section{J. UZEL, MONOGRAFIE ŔADU "THYSANOPTERA“.}

SBÍRÁNI TŘÁSNĚNEK.

\section{ÜBER DAS SAMMELN DER THYSANOPTEREN.}

Způsob sbírání třásněnek ř́dí se dle způsobu jejich života. Jinak nutno sbírati druhy, které v květech žijí, jinak druhy na listech se zdržujicí, jinak třásněnky v drnu, pod spadaným listím a hnijiçími látkami rostlinnými schované, a opèt jinak druhy, které pod zpuchřelou korou se ukrývaji.

$\mathrm{V}$ květech žije většina tř́śsnènek. Kdo by venku chytati je chtěl, musel by květy nad šátkem neb papírem vỵklepávati a vypadávající třásněnky namočenou v lihu štětičkou nabírati a vpravovati do malých, číslem opatřených lahviček, líhem naplněných, čímž by se značně zdržoval a po veliké námaze, překonav nejrůzněǰši protivenství, praskrovného poměrně by dosábl výsledku. - Nejvhodnèjší dle mých zkušeností způsob nasbírati brzy hojný material třasněnek květinových dle jednotlivých druhů květů, ve kterých žijí, spolehlivě roztříděný, jest následujicí: Zaopatříme si množství nevelikých čtyrhraných kornoutů (pytlíků) papírových, kterých kupci užívají. Při tom nutno však k tomu přihližeti, aby papír jejich byl dosti tuhý a snadno se nelámal, a hlavně toho dbáti, aby byly dobře lepené a direk žádných, zvláště v rozích, neměly. Kromě většího počtu těchto kornoutů vezmeme s sebou na vycházky dlouhé, neohýbající se špendlíky s velikými (skleněnými) hlavičkami. Nejlépe $\mathrm{k}$ tomu hodí se onen druh špendlíkủ, které továrníci zhotovují z nepodařených jehel. Konečně nesmíme zapomenouti na velmi měkkou tužku a nějakou objemnější schránku, at již je to botanická torba neb nějaký vak ze zelené látky, který pro lehkost svou přednost zasluhuje. $V$ prírodẽ pak naplñujeme jednotlivé kornouty vždy jedním druhem květủ, načež hořejší kraj jejich dvakrát přeložíme, dobře prsty stlačíme a špendlíkem uprostřed zapíchnutým tak upevníme, aby se přeložená část nerozvírala. Kromě toho dobře je ohnouti hořejší rohy kornoutu takto složeného, aby třásněnky nikudy uniknouti nemohly. Na kornout pak napíšeme mèkkou tužkou (tvrdá by papír protrhávala) nejprve jméno rostliny, abychom tak již zevně poznali obsah jeho, a pak též naleziště, což zvláště při větších cestách se odporučuje. Kornout jednou uzavřený na cestě již neotvírejme a dávejme radēji tỵtéž květy z jiného, třeba blízkého naleziště do nového kornoutu, nebot hledáním a otevíráním upotřebeného už jednou kornoutu ztrácí se jednak čas, a jednak nedrži podruhé přeložené okraje již pevně při sobě, takže pak někdy propoušlěji hmyz tak malý, jako jsou třásněnky. — Naplněné kornouty vkládáme do schránky, o níž jsme nahoře se zmínili. - Podobným způsobem můžeme sbírati v zimě seschlá květenství nejrůznějších rostlin, která často obsahují množství přezimujících zde třásněnek.

Druhy, jež na listech stromů neb keřů žiji, hledáme okem, prohližejíce spodní stranu listủ těch. Chceme-li však brzy seznati, které druhy třásněnek se na tom neb na onom stromu neb keři vyskytují, trháme jeho listí a třásněnkám velmi milé mladé jeho větvičky do objemné botanické torby s dobře přiléhajícími dvířkami aneb do ně- 


\section{H. UZEL, MONOGRAPHIE DER ORDNUNG THYSANOPTERA.}

jakého vaku (při čemž je výhodno hleděti, abychom nestali se nápadnými přiliš svědomitým lesníkưm neb hlídačủm). $\mathrm{V}$ tom případě lze na jedné vycházce ovšem jen jeden druh listí sbírati, a proto nejlépe jest míti nějakého prủvodce, jenž nese větší počet vaků, z nichž každý opatřen jest malým kouskem lepenky, na níž jeho obsah jest poznamenán. Vaky ty musí býti tak zařizeny, aby jejich okraj dal se tkanicí stáhnouti, která mimo to ještě několikráte se ovine, aby třásněnky nemohly vylézti. - Podobným způsobem dopravujeme si domů květenství různých trav, klasy obilní a nekvetoucí rostliny nízké, které živí často mnohý vzácný druh. Po nekvetoucích rostlinách mủžeme však též sítkou smykati, načež uschováme smetené odpadky rostlinné do kornoutu, kdy̌̃ jsme byli napřed nechali vyběhnouti hrubý hmyz, jako brouky, ploštice atd.

Třásněnky, které $\mathrm{v}$ drnu, pod spadaným listím, pod hnijicimi látkami rostlinnými a různým smetím, v mechu a na podobných místech se vyskytují, nejvýhodněji prosíváme. $\mathrm{K}$ tomu účelu necháme si shotoviti zvláštní síto, jež lze složiti. Podám zde popis důležitého toho nástroje. Ze silného plátna sešitý vak, jenž jest asi $27 \mathrm{~cm}$ vysoký a právẽ tak široký, má místo dna síto s velikými $\left(1 \mathrm{~cm}^{2}\right)$ oky, vpletené do kruhu ze silného drátu, $\mathrm{k}$ němuž je plátno přišito. Okraj otvoru toho vaku jest taktéž opatřen kruhem drátěným. Do tohoto síta naházime hmoty nahoře vyjmenované (při čemž hledíme, abychom co možná nejméně hliny nabírali) a prosíváme je do nějakého podvázaného vaku. Propadané smetí pak doma po částkách na bílém papíru prohledáváme. Tento způsob sbíráni odporučuje se též $\mathrm{v}$ zimě, na místech nezasněžených, kdež kromě třásněnek, po celý rok v drnu a podobných látkách žijicích, nalezneme také množství třásněnek přezimujících, jež bychom marně v létě hledali. - Podobným způsobem prosíváme též v létě i v zimě zpuchřelou kůru stromovou, kterou silným dlátem odlupujeme.

Konečně budiž ještě připomenuto, že je nutno, aby sběratel třasněnek vždy nosil s sebou malý počet drobných lahviček líhem naplněných a malou štětičku pro případ, žeby nalezl nějakou nápadnější třásněnku bud v letu, neb někde na zdi, na vlastním šatu a podobnè.

Die Art des Sammelns der Thysanopteren richtet sich nach ihrer Lebensweise. Anders muss man die Blütenbewohner sammeln, anders die Bewohner der Blätter, anders die Arten, welche sich unter abgefallenem Laube und faulenden Pflanzentheilen aufhalten, und wieder anders die Arten, welche unter morscher Rinde versteckt leben.

In den Blüten kommt die Mehrzahl der Thysanopteren vor. Man bemächtigt sich ihrer am vortheilhaftesten, wenn man die Blütenköpfchen sammt den darin wohnenden Insecten in viereckige Papierdüten einschliesst, worauf man den oberen Rand der nicht ganz gefüllten Düten zweimal umschlägt und mit einer Stecknadel befestigt. Man hat darauf zu achten, dass nur Blüten einer Sorte in eine bestimmte Düte gelangen. Zu Hause angekommen, sucht man die Blüten auf einem Bogen weissen Papiers durch und fängt 


\section{J. UZEL, MONOGRAFIE R̈ÁDU „THYSANOPTERA“.}

die fliehenden Thierchen mit Hülfe eines in Spiritus getauchten winzigen Pinsels. Auf diese Weise kann man in kurzer Zeit ein grosses und verlässlich nach den Wohnblüten eingetheiltes Material von Thysanopteren zusammenbringen. Ähnlich sammelt man im Winter mit gutem Erfolge die trockenen Blütenstände der verschiedenen Pflanzen.

Die Blattbewohner erreicht man leicht, indem man sich Säcke mit Laub einzelner Baum- und Straucharten eintragen lässt und dasselbe partienweise über weissem Papier in einem Drahtsiebe schüttelt. In kleineren Säcken kann man nichtblühende niedere Pflanzen, ausserdem auch Blütenstände verschiedener Grasarten und Getreideähren nach Hause bringen lassen und ähnlich verfahren. Man kann auch nichtblühende Pflanzen abketschern und die in den Ketscher gefallenen Pflanzenabfälle in Papierdüten füllen. Auf diese Weise findet man manchmal Seltenheiten.

Die Arten, welche sich im Rasen, unter abgefallenem Laube, unter faulenden Pflanzenabfällen, im Moose und unter ähnlichen Verhältnissen aufhalten, siebt man an Ort und Stelle mit einem zusammenlegbaren Käfersiebe mit Leinwandumfassung in einen untergebundenen Sack durch. Das erlangte Siebgut durchsucht man zu Hause partienweise auf weissem Papier und tupft die vorkommenden Thysanopteren mit dem Pinsel auf. Diese Art und Weise zu sammeln ist die dankbarste und liefert im Sommer und im Winter eine Fülle von eigenthümlichen Arten. Ähnlich kann das ganze Jahr hindurch morsche Baumrinde mit gutem Erfolge durchgesiebt werden.

\section{ÚPRAVA TŘÁSNĚNEK PRO POZDĚJ ŠÍ STUDIUM. ÜBER DAS PRÄPARIEREN DER THYSANOPTEREN.}

Třásněnky zachováme nejlépe $\mathrm{v}$ líhu (as 78\%). Nasbírané zásoby rozdèlíme dle nalezišt do malých, velmi úzkých skleněných lahviček, hrdélkem opatřených a jen as 3 cm vysokých (objedná je každý materialista). Zátky, které musí býti úplně zdravými, jakož i lahvičku samu opatříme číslicí, která vztahuje se na poznámky v seznamu pod tímtéž číslem se nalézající. $V$ seznamu tom poznamenáváme pečlivě všecky důležitější okolnosti, za kterých jsme tu neb onu část třásněnek nalezli. Když pak máme dostatečný material, mũžeme přikročiti $\mathrm{k}$ určení jeho, načež teprv zásoby dle druhủ rozdělujeme.

Třásněnky lze také nalepovati pomocí arabského klí na malé proužky papíru. $\mathrm{K}$ tomu cíli usmrtíme je $\mathrm{v}$ parách benzinových neb lépe cyankaliových. Sbírka taková zjednává nám sice jakỵ́si přehled forem třásněnek, nemá však vědecké ceny, poněvadž nelze užiti při tomto zpủsobu praeparace větších zvětšení mikroskopických. Kromě toho ještě jest spodní část těla nalepených třásněnek zraku nepřístupna.

Chceme-li některou třásněnku spolehlivě určiti, jest nutno, abychom si z ní shotovili mikroskopický praeparat glycerinový, a abychom ji aspoň zvětšením 170násobným 


\section{H. UZEL, MONOGRAPHIE DER ORDNUNG THYSANOPTERA.}

ohledávali*). Praeparaty zmíněné maji tu přednost před jinými, že můžeme předmět uzavřený kdykoli vyndati a jehlami jakkoli upraviti; větší trvalosti zjednáme jim tím, že krycí sklo opatřime dle známého způsobu rámečkem z mikroskopického laku. - Dobře také hodí se $\mathrm{k}$ praeparatům třásněnek glycerinová gelatina**) (čistá, ve vodě močená gelatina rozpustí se v horkém glycerinu); látka tato stuhne ihned, když vychladne, avšak zase velmi snadno se roztápí. Rámečkủ lakových zde není zapotřebí. - Chceme-li téměř věčné praeparaty shotoviti, položíme třásněnky na čtvrf' hodiny do absolutního alkoholu, pak na čtvrt' hodiny do terpentinové neb hřebičkové silice, načež je známým zpủsobem v kanadský balsam uzavíráme.

Die Thysanopteren bleiben am besten in Spiritus (etwa $78 \%$ ) erhalten und werden vortheilhaft in kleinen Fläschchen, welche mit Nummern versehen sind und in nebeneinanderstehende Papierhülsen passen, aufgehoben. Unzweckmässig ist es, sie trocken aufzubewahren (auf Papier anzukleben), da sie schrumpfen und der Betrachtung mit dem Mikroskope ziemlich unzugänglich sind. Wollen wir irgend eine Art verlässlich bestimmen, ist es nothwendig, sie in einem Tropfen Glycerin unter dem Deckgläschen mit dem Mikroskope zu untersuchen***). Zur Beobachtung der Details reicht man meist mit 170facher Vergrösserung aus. Ein Lackrahmen um das Deckgläschen macht das Präparat dauerhafter. Es ist angezeigt, erst einen Rahmen aus Glycerin-Gelatine (reine, in Wasser aufgeweichte Gelatine wird in heissem Glycerin zerlassen) heiss aufzutragen (sie verbindet sich leicht mit dem unter dem Deckgläschen hervorgetretenen Glycerin), und nachdem er kalt und starr geworden, den Lack darüberzustreichen. Auch sind Präparate aus reiner GlycerinGelatine, welche durch Wärme flüssig gemacht werden kann, zu empfehlen, weil sie sehr schnell hergestellt werden können. Dauerpräparate verfertigt man auf bekannte Weise vermittelst Canadabalsam; eine Sammlung von Thysanopteren in solchen Präparaten ist zum raschen Vergleichen sehr geeignet.

*) Chceme-li se jen orientovati, můžeme třásněnky pozorovati při napadajicím světle a se slabým zvětšením v lihu (v hodinovém skličku), při čemž je výhodno vsunouti pod skličko kousek bílého papiru, poněvadž tak zbarveni jejich pěknè vystoupi.

**) L. Dip pel, Grundzüge der allgerneinen Mikroskopie. Braunschweig 1885. Strana 509.

***) Zur Orientierung kann man die Thysanopteren bei auffallendem Lichte in Spiritus selbst (in einem Uhrglas) mit schwacher Vergrösserung untersuchen, wobei es rathsam ist, unter das Uhrglas ein Stückchen weissen Papiers zu schieben, weil so die Färbung der Thiere schön hervortritt. 


\section{SEZNAM STANOVISK, NA KTERÝCH MÉ ZÁSOBY TĽ́́SNĚNEK SEBRÁNY BYLY. VERZEICHNIS DER FUNDORTE.}

$\mathrm{V}$ Čechách počal jsem, jak $\mathrm{v}$ předmluvě řečeno, již před osmi lety shromaždovati zásoby. Největši část materialu sebral jsem v okolí pražském, královéhradeckém, třebechovickém, opočenském a za svého dvojího pobytu na Krkonoších. Mimo to hledal jsem třásněnky hlavně u Hořic, Jaroměře, Nové Paky, Pecky, Jilemnice, Trutnova, Turnova, Vrajtu, Vrchlabí, v horách Orlických, u Solnice, Častolovic. Mukařova, na Milešovce, u Peruce, Slaného, Prachatic a na Boubíně. - Dále přenechal mi laskavě pan professor Lad. Duda svůj material, který svého ěasu sbiral u Jindřichova Hradce a z malé éásti téż u Soběslavi. Obsahoval 32 nerozlř́lěných druhů, z nichž byly čtyři (Cryptothırips dentipes, Acanthothrips nodicornis, Parthenothrips dracaenae a Aeolothrips albocincta) určeny. V zásobách těch byl také jeden druh (Cephalothrips monilicornis), kterého jsem z Čech ještě nemèl. — Nèkteré druhy sbíral mi též můj prítel, univ. assistent D a limil V a řečka, nyní již bohužel zesnulý. Pocházely z okolí Unhoště, Písku, Jihlavy, Chotěboře a Pardubic. - Také prítel mủj professor Frant. Bubák přinesl několik druhủ z Turnova, z Čerěan a z Postoloprt. - Dále zaslala mi slečna Aloisie Bubáková bedničku květin s třásaěnkami z Turnova. — Část' materialu přinesla mi též slečna Anna Haková z Jablonce a Liberce. — Nèkolik druhủ třásněnek sbíral jsem na Helgolandè a v okolí Berlína. - Z Pešti a z Rěky poslala květiny s tř́sněnkami slečna Eugenie Ganzová. Nalezl jsem tu však jen druhy, jež též v Čechách se vyskytují. - Konečnẽ dostal jsem jeden druh z Laponska (Trichothrips copiosa nov. sp., též v Čechách żijíci) od pana prof. Dudy.

Všem, kteří k rozmnožení mého materialu třásněnek nějak přispěli, ryjadruji tímto svůj srdečný dík, zvláště pak svému milému otci, professoru Vinc. Uzlovi, i drahé své matce a slečně Anně Hakové, která mne co nejvydatněji a s obdivuhodnou neunavností podporovala při sbírání zásob v okolí Hradce Králové, Třebechovic a Opočna.

Mein Material von Thysanopteren habe ich zum grössten Theil an verschiedenen Orten in Böhmen gesammelt; alle neuen Arten (auch die neuen Varietäten und die neu beschriebenen Männchen), ausserdem 37 von den bekannten 54 europäischen Arten wurden hier gefunden. Einige Arten sammelte ich jedoch auch noch auf Helgoland und bei Berlin, andere wurden mir in Blumen aus Budapest und Fiume geschickt, und eine habe ich aus Lappland bekommen; es war jedoch unter diesen keine Art, die ich in Böhmen nicht schon gefunden hätte. Die einzelnen Arten der Thysanopteren scheinen überhaupt eine grosse Verbreitung zu haben, was wohl mit der leichten Verbreitungsfähigkeit durch Wind, wovon noch später im biologischen Theil die Rede sein wird, zusammenhängt. 


\section{H. UZEL, MONOGRAPHIE DER ORDNUNG THYSANOPTERA.}

\section{STSTEMATICKÉ POSTAVENÍ Tř́́SNĚNEK. SYSTEMATISCHE STELLUNG DER THYSANOPTEREN.}

Postavení třásněnek v soustavě kolísalo během času značnou měrou, čehož hlavně přičinou jest jejich drobnost' (jsout nejmenšim hmyzem vůbec), takže tvar jednotlivých částí, pro systematické postavení důležitý, zvláště pak tvar ústrojủ ústních, bỵlo těžko spolehlivě rozeznati u zviŕátek tak malých nedostatečıými dř́ve nástroji. $\mathrm{V}$ následujícím podáme obraz toho kolísání od počátku.

R. 1744. shrnuje Degeer (L. č. 2.)*) obě třásněnky, které popisuje, v jeden rod (slägt, genus), jejž nazývá Physapus. - R. 1746. nazývá Linné (L. č. 3.) tento rod Degeerùv Thrips a ěitá ho r. 1761. (L. č. 4.), rovněž jako již v dřívějších vydáních díla Systema Naturae, k oddílu hmyzu: Coleoptera v širš. slova smyslu (brouci, kobylky, švábi, cvrčkové), což i Sulze r (L. č. 5.) téhož roku dle něho činí. - R. 1763. klade Sco poli (L. č. 6.) trásněnky do druhého r̀ádu hmyzû, jejž jmenuje Proboscidea (os proboscide inflexa; Cicada, Notonecta, Nepa, Cimex, Aphis, Chermes, Thrips). - R. 1764. radí je Geoffroy (L. č. 9.) do první "sekce" hmyzu, totiž Coleoptera s. l. (alae coleoptris seu elytris tectae, os maxillosum), ač praví, že tvoři prechod mezi sekcemi Coleoptera a Hemiptera. R. 1767. čitá Linné (L. č. 10.) třásněnky mezi „Ordo II. Hemiptera“ (alae quatuor, superiores membranaceae incumbentes; Blatta, Mantis, Gryllus, Fulgora, Cicada, Notonecta, Nepa, Cimex, Aphis, Chermes, Coccus, Thrips). - R. 1773. klade je Degeer (L. ě. 11.) k 5. trídě hmỵzi̊ (Thrips, Aphis, Chermes, Psylla, Cicada). - R. 1776. radí O. F. Müller (L. č. 13.) tř́sněnky k oddílu hmyzủ Coleoptera (Leptura, Attelabus, Meloë, Necydalis, Thrips, Silpha, Forficula, Staphylinus, Acridium, Locusta). Téhož roku číá je Sulzer (L. ě. 14.) mezi Hemiptera (v Linnéově smyslu), což r. 1781. také činí Schrank (L. č. 19.). - R. 1787. raadí je Fabricius (L. č. 21.) mezi Rhyngota (. . . Cicada . . Nepa . . . Cimex, Reduvius, Pulex, Aphis, Chermes, Coccus, Thrips). - R. 1806. povýšil Duméril (L. č. 36.) třásněnky z rodu na ěeled (familia), kterou čítá mezi rád „Hemiptères“. Nazývá je „Vésitarses ou Physapodes“ a uvádi je uprostřed mezi skupinami „IIydrocorées“ (Ranatra, Nepa etc.) a „Auchénorinques" (Cercopis etc.). - R. 1829. čítá je Latreille (L. č. 38.) k Hemipterům (pod jménem Physapi) a uvádí pozorování Strauss Dürkheimova, na základẽ nichž je tento čitá $\mathrm{k}$ Orthopterům. - Téhož roku přiraduje Stephens (L. č. 39.) třásněnky k druhé éásti (Pars) hmy̧zu, kterou nazývá Haustellata, a sice ku „Ordo VII. Homo. ptera“, jakožto „Familia Thripidae“ (uprostřed mezi merami a mšicemi). - R. 1835. počíá je Newman (L. č. 42.) mezi „Division III. Tetraptera Isomorpha“ (Larva resembling the imago in structure, appearance, mode of feeding, etc. wings only being wanted. Pupa, or quiescent state, none.) a uvádi je uprostřed mezi "Classis V. Orthoptera“

*) L. č. 2., tolik co Literatura č. 2., znamená, že dotyčná práce nalézá se v naši Části literarni pod čislem 2. 


\section{J. UZEL, HONOGRAFIE RÁDU „THYSANOPTERA“.}

a „Classis VI. Hemiptera“ jakožto »Natural Order" (majicí platnost skupiny), jehož postavení prý posud jest pochybné. - R. 1836. poryšuje Haliday (L. č. 43.) třásněnky na rád a nazývá je Thysanoptera. Rád tento staví na roveñ r̀ádu Orthoptera a Hemiptera. - Téhož roku klade Bur me ister (L. č. 45.) tîńsněnky mezi svủj řád Gymnognatha (hmyzové s volnými kusadly) jakožto „Tribus Physopoda“. - R. 1838. považuje Westwood (L. č. 48.) třásněnky za přechodní řád (Ordo Thysanoptera) uprostřed mezi rády: Orthoptera a Neuroptera. - R. 1843. jednají Amyot a Serville (L. č. 54.) o triásnènkách („Plıysopoda“) v přívěsku své práce o Hemipterech. - R. 1851. nazývá je Blanchard (L. č. 59.) „Orden Tisamopteros“. - R. 1852. uveřejn̆uje Walker (L. č. 61.) Halida yov y manuskripty o třásnènkách. Uvedeny jsou zde mezi Homoptery, a sice jakožto „Order III. Physapoda“. - R. 1855. r̀adí Newman (L. č. 68.) třásnènky ku "Classis Neuroptera“ jakožto „Order Thripsina“ a praví, że s Neuroptery v užším slova smyslu shoduji se v proměně, v rázu kǐídel a ve tvaru kusadel. — R. 1856. jmenuje Fitch (L. č. 69.) třásněnky „Thripididae“ a považuje je za řád. — R. 1859. klade Walker (L. č. 73.) „Order Physapoda“ na tentýž stupeň jako „Order Oithoptera“. R. 1876. považuje Butler (L. č. 107.) „Physopoda“ za Hemiptera. - R. 1878. jmenuje Reuter (L. č. 113.) tr̃ásnènky „Ordo Thysamoptera“ a podává roku 1880. (L. č. 118.) obšírnèjši diagnosu toho řádu. - R. 1882. a r. 1883. jmenují je P e r gan de (L. č. 125.) a Osborn (L. č. 131.) „Thripidae“. - R. 1883. shrnuje Packard (L. č. 129.) třásněnky, Mallophaga, Heteroptera a Homoptera v oddíl hmyzu, který nazývá Eurhynchota. - R. 1885. dèlí Brauer (L. č. 139.) po dủkladných studiích hmyz na 16 řádů, mezi nimiž také nalézá se ráa Thysanoptera (Dermaptera, Ephemeridae, Odonata, Plecoptera, Orthoptera gemina, Corrodentia, Thysanoptera, Rhynchota etc.). - R. 1888. uznává taktéž J ordan (L. č. 162.) oprávněnost řádu hmyzu třásnokǐídlého. Užívá pro ìád ten jména „Plıysapoda“, poněvadž jest prý starší než jméno Thysanoptera a podává obšírnou diagnosu jeho. - Kionečně sluší ještẽ podotknouti, že v učebnicích uváději se třásněnky někdy jakožto podřád Orthopter v širším slova smyslu, obyčejně však jakožto podřád neb skupina Pseudoneuropter, $\mathrm{k}$ nimž počítávají šídla, jepice, pošvatky, ršekaze a pisivky.

Ze sestavení toho je patrno, že všichni autoři, kteří se třásněnkami více zabývali, za samostatný řád je považují.

Pokud se phyylogenie tř́sněnek týče, možno souditi z okohnosti, že třásněnky mají kromè mnoha znaků Rhynchotům (zvláště Phytophthirům) príslušících (velmi koncentrovaná soustava nervová, čtyr̃i malpighické żlázy, jednoduchá varlata, malý počet rourek vaječných, sporé žilky v křídlech, parthenogenesis a způsob rýživy), také některé znaky Orthopter (desítičlenný abdomen a ústroje ústní, které, ač jsou již ssavé, ještě složením svým upomínají na Orthoptera), že odvětvily se z rady přechodú, spojujicí, jak se zdá, Orthoptera s predky nynějších Rhynchot, a sice $\mathrm{v}$ tom místě, kide již znaky Rhynchot 


\section{H. UZEL, MONOGRAPHIE DER ORDNUNG THYSANOPTERA.}

značně převládaly. Poněvadž pak Coccidae (červci) jsou nejnižšími Rhynchoty, tedy již pr̉edem by se mohlo souditi, že velmi blízce jsou přibuzny s třásněnkami, čemuž také skutečně tak jest.

Die Stellung der Thysanopteren im System schwankte im Laufe der Zeit ausserordentlich, und zwar hauptsächlich wegen der mit ihrer Kleinheit zusammenhängenden Undeutlichkeit der Mundwerkzeuge, über die man erst in der neuesten Zeit ins Klare kam. Bezeichnend ist jedoch, dass alle Autoren, die sich mit den Thysanopteren eingehender beschäftigten, sie als Ordnung betrachten, was auch, wie wir sehen werden, vollkommen berechtigt ist.

\section{PODOBA PRVOTNÝCH TǨ́́SNĚNEK. GESTALT DER URSPRUTGLICHEN THYSANOPTEREX.}

Předkové třásněnek podobali se, dle mého náhledu, značně našim coleoptratûm (-Aeolothripidae), jedné skupině to hmyzu tř̌ásnokřídlého. Pokusím se tento náhled svủj odůvodniti.

Krìdla jak tubulifer (= Phloeothripidae), tak stenopter (= Thripidae; Tab. VI., fig. 97.) dají se snadno odvoditi z krídel coleoptrat (Tab. V., fig. 39.). Pokud tubulifer se týče, mají křídla jejich charakteristický tvar křídel oněch, to jest značnou šírku, zaokrouhlený konec a někdy i zúžení uprostřed. Žilky ovšem vymizely skoro úplně. V předním kǐ́dle zachoval se $z$ hořejší žilky podélné jen zbytek, který u většiny druhủ jest velice krátký, u některých však ještě poloviny kř́ílla dosahuje (u druhủ Megalothrips Bonamii, Idolothrips Schotti a Phloeothrips angustifrous). Kírídlo stenopter stalo se značně užším a konec jeho se přiostřil. Dle žilek předních křídel jejich však zjevně poznáváme, že vyvinula se také z křídla coleoptrat. Hořejší žilka podélná zachovala se úphně (Tab. VI., fig. 97., c). dolejší však jen onou částí (d), která u coleptrat leží za žilkou přičnou*), spojujićí ve středu kǐídla obě žilky podélné. Tato přičná žilka zachovala se $\mathrm{v}$ mnohých případech taktéž (p) a splývá s počátkem zbytku dolejší žilky podélné. Kde však přička vymizela, nen ovšem ona zbylá část' dolejší źilky ve spojení s podélnou žilkou hořejší. Z ostatních přičných žilek zachovaly se u stenopter obě žilky coleoptrat, které spojují hořejší žilku podélnou s přední ěástí žilky okružní (Tab. VI., obr. 97., $f, g$ ), byly však posud pro nezřetelnost' svou přehlédnuty. - Tykadla prvotných tř́sněnek byla asi devítičlenná, jako posud tykadla coleoptrat; srůstáním pak menšího neb většiho počtu posledních

*) U nèkterých třetihornich třásněnek zachovala se i tato żilka $\mathrm{v}$ celé své délce. Viz ku př. fig. 5. na obr. 1. 


\section{J. UZEL, MONOGRAFIE ŔDU "THYSANOPTERA“.}

článkủ, jak to již u rodủ Aeolothrips (Tab. V., fig. 46.) a Rhipidothrips (fig. 43.) velmi zřetelně je naznačeno, vytvořilo se osmičlenné tykadlo tubulifer a některých stenopter a sedmičlenná neb šestičlenná tykadla stenopter ostatních, na nichž dobře lze poznati, že některé články (zvláště šestý) povstaly srůstem několika článkủ prvotných. — Také makadla našich coleoptrat poukazuji $\mathrm{k}$ tomu, že skupina tato zachovala si pủvodnější podobu svou. Jejich makadla maxillarní skládají se vždy ze tř́ článkủ, v kterémžto ohledu také mnohá stenoptera se s nimi shodují, kdežto ostatek stenopter a všecka tubulifera mají prvý pár makadel o dvou článcích, z nichž druhý, jak zřetehě (zvl. u dotyčných stenopter) bývá naznačeno (Tab. VII., fig. 109.), povstal srůstem dvou článkủ prvotných. Makadla labialní skládají se u většiny celeoptrat ze čtyř článků, u ostatních třásněnek vždy jen ze drou, při čemž je nápadno, že druhý článek jest proti prvému neobyčejně dlouhý a dobře mohl povstati srůstem tři článků prvotných.

Pokusíme se ještě vysvětliti, jakým způsobem asi mohla tubulifera vzniknouti z třásněnek našim coleoptratům podobných. - Př́činou zvláštního tvaru těla tubulifer jest přizpủsobení se jeho $\mathrm{k}$ poměrủm životním. Tubulifera zdržují se totiž pod korou a v drnu a tu zajisté velmi výhodno jest pro ně značně sploštilé tělo, jež mohou nejužšími skulinami protahovati pomocí svých neobyčejně rozšírených stehen předního páru noh a pomocí nehtu na předních tarsech u mnohých se nalézajiciho. Rourovitý poslední článek abdomenu jest zajisté schopen velmi dobré služby konati př̀ protlačování těla skrze skuliny*). Dalším následkem jejich způsobu života jest úzká hlava a klínovitá podoba předohrudi. (Také u některých stenopter má prothorax podobný tvar; tak u rodu Chirothrips [Tab. I., fig. 2. a 7.] a druhủ Oxythrips firma a parviceps.) Poněvadž křídel málo upotřebovala, mizela i pevnost jejich a sice tím, že žilky se ztrácely. Také pohyby jejich staly se nutně volnějšími, jak to shledáváme též u mnohých stenopter pod drnem žijících (Limothrips, Prosopothrips etc.). Ztráta kladélka pak vysvětluje se snadno tím, že nutnost skrývati vajička pomocí ústroje toho do pletiva rostlinného, aby k úrazu nepřišla, u tubulifer přestávala, nebot pod korou a $v$ drnu nalézá se bezpečných skrýší s dûstatek**).

Z toho všeho vyplývá, že bezprostřední předkové třásněnek podobali se asi značnè našim coleoptratům, která tedy prímo odvozuji se z jejich kmene, z něhož vypučely ještě dvě větve, totiž tubulifera, značně následkem zvláštního způsobu života pozměněná, a stenoptera, od coleoptrat se tak daleko neodchylivší.

*) Mezi úzkým rourovitým tubem, který také u některých stenopter se objevuje (u druhů Oxythrips hastata a Belothrips acuminata) a mezi tubem konickým, podobným poslednímu c̀lánku abdominalnimu četných stenopter, lze sledovati u jednotlivých druhủ tubulifer všechny prechody.

**) Rod Anthothrips, jenż $\mathrm{k}$ tubuliferům náleži, żije $\mathrm{v}$ květech a prìjal zajisté sekundernè tento způsob života, když již tèlo jeho żivotu pod korou neb v drnu se bylo prìizpůsobilo. Pozoruhodno jest, že druh Anthothrips aculeata żije mimo ve kvètech také ještè v drnu, v mechu, pod spadaným listim a výjimkou též pod korou a že v zimě rád pod zpuchřelou kưru se uchyluje. 


\section{H. UZEL, MONOGRAPHIE DER ORDNUNG THYSANOPTERA.}

Die Vorfahren der Thysanopteren ähnelten, meiner Ansicht nach, bedeutend unseren Aeolothripiden (Coleoptrata Halid.), einer der drei Familien dieser Ordnung. Ich will es versuchen, meine Ansicht zu bekräftigen.

Die Flügel der Phloeothripiden (Tubulifera Halid.; Taf. III, Fig. 19; Taf. IV, Fig. 28 und 29) und der Thripiden (Stenoptera Burm.; Taf. VI, Fig. 97) lassen sich leicht aus den Flügeln der Aeolothripiden (Taf. V, Fig. 39) ableiten. Was die Phloeothripiden anbelangt, so haben ihre Flügel die charakteristische Form der Aeolothripiden, nämlich die bedeutende Breite, das abgerundete Ende und manchmal auch die Verengung in der Mitte. Die Adern verschwanden freilich fast vollkommen. In Oberflügel blieb von der oberen Längsader nur ein Rest übrig, welcher bei der Mehrzahl der Arten sehr kurz ist, bei manchen jedoch noch die Flügelmitte erreicht (so bei den Arlen Megalothrips Bonamnii [Taf. III, Fig. 19], Idolothrips Schotti und Phloeothrips angustifrons). Der Flügel der Thripiden wurde sehr schmal und sein Ende wurde spitzig. Aus der Bildung der Adern im Oberflügel geht jedoch klar hervor, dass dieselben sich aus den Flügeln der Aeolothripiden entwickelt haben. Die obere Längsader blieb vollständig erhalten (Taf. VI, Fig. 97, $c$ ), die untere jedoch nur in jenem Theil $(d)$, welcher bei den Aeolothripiden hinter der Querader*), die in der Flügelmitte beide Längsadern verbindet, liegt. Diese Querader blieb in vielen Fällen ebenfalls erhalten $(p)$ und vereinigt sich mit dem Anfange des Restes der unteren Längsader. Wo jedoch die Querader verschwand, ist natürlich jener Rest der unteren Längsader in keiner Verbindung mit der oberen Längsader. Von den übrigen Queradern blieben bei den Thripiden jene beiden Adern der Aeolothripiden erhalten, welche die obere Längsader mit der Vorderrandader verbinden (Taf. VI, Fig. 97, $f, g$ ), wurden jedoch bis jetzt wegen ihrer Undeutlichkeit übersehen.

Die Fühler der ursprünglichen Thysanopteren waren wohl neungliedrig, wie bis jetzt die Fühler der Aeolothripiden; durch Zusammenwuchs einer kleineren oder grösseren Anzahl der letzten Glieder, wie es schon bei den Gattungen Aeolothrips (Taf. V, Fig. 46) und Rhipidothrips (Fig. 43) sehr gut angedeutet ist, entstand der achtgliedrige Fühler der Phloeothripiden und mancher Thripiden, und der sieben- oder sechsgliedrige Fühler der übrigen Thripiden, an welchem oft deutlich zu erkennen ist, dass das sechste Glied durch Zusammenwuchs mehrerer ursprünglicher Glieder gebildet wurde.

Auch die Taster unserer Aeolothripiden geben davon Zeugenschaft ab, dass diese Familie ursprünglichere Verhältnisse aufweist. Ihre Maxillartaster setzen sich immer aus drei Gliedern zusammen, in welcher Hinsicht auch viele Thripiden mit ihnen übereinstimmen, wogegen bei den übrigen Thripiden und allen Phloeothripiden die Naxillartaster aus zwei Gliedern bestehen, von denen das zweite, wie klar angedeutet

*) Bei manchen tertiären Thysanopteren blieb (nach den Abbildungen v. Schlechtendals zu schliessen) auch diese Ader ihrer ganzen Länge nach erhalten. Sieh z. B. Fig. 5 auf dem 1. Textbild. 


\section{J. UZEL, MONOGRAFIE ṘDU „THYSANOPTERA“.}

zu sein pflegt (Taf. VII, Fig. 109), durch Zusammenwuchs zweier ursprünglicher Glieder entstand. Die Labialtaster setzen sich bei der Mehrzahl der Aeolothripiden aus vier Gliedern zusammen, bei den übrigen Thysanopteren immer nur aus zwei, wobei es auffallend ist, dass das zweite Glied im Vergleiche zum ersten ungewöhnlich lang ist und gut durch Zusammenwuchs dreier ursprünglichen Glieder sich bilden konnte.

Wir wollen es noch versuchen, zu erklären, auf welche Weise die Phloeothripiden aus unseren Aeolothripiden ähnlichen Insecten entstehen konnten. Der Grund des eigenthümlichen Körperbaues der Phloeothripiden ist Folge der Anpassung an besondere Verhältnisse. Die Phloeothripiden halten sich nämlich unter der Rinde und im Rasen auf, und hier ist ein flacher Körper für sie jedenfalls sehr vortheilhaft; denn er befähigt sie, durch die engsten Spalten zu kriechen, wobei sie sich ihrer starken, ungewöhnlich erweiterten Vorderschenkel und des Zahnes auf den Vordertarsen, der bei vielen Arten vorkommt, mit Vortheil bedienen. Das röhrenförmige letzte Abdominalsegment ist ihnen dabei ohne Zweifel auch recht behilflich*). Eine weitere Folge ihrer Lebensweise ist der schmale Kopf und die keilförmige Gestalt des Prothorax. (Auch bei einigen Thripiden hat der Prothorax eine ähnliche Gestalt; so bei der Gattung Chirothrips [Taf. I, Fig. 2 u. 7] und den Arten Oxythrips firma und parviceps.) Weil sie wenig von den Flügeln Gebrauch machen, schwand auch ihre Festigkeit, und zwar dadurch, dass die Adern verloren giengen. Auch ihre Bewegungen wurden nothwendigerweise langsamer, wie wir es auch bei vielen unter Rasen lebenden Thripiden beobachten (Limothrips, Prosopothrips etc.). Der Verlust des Legebohrers lässt sich leicht daraus erklären, dass die Nothwendigkeit, die Eier vermittelst dieses Instrumentes in das Pflanzenparenchym zu verbergen, bei den Phloeothripiden abfiel, da unter der Rinde und im Rasen es genug sichere Schlupfwinkel gibt**).

Aus allem dem Gesagten geht also hervor, dass die unmittelbaren Vorfahren der Thysanopteren wohl sehr unseren Aeolothripiden ähnelten.

*) Zwischen dem schmalen röhrenförmigen Tubus, welcher auch bei einigen Thripiden vorkommt (so bei den Arten Oxythrips hastata und Belothrips acuminata) und zwischen dem konischen Tubus, welcher dem letzten Abdominalsegmente zahlreichen Thripiden ähnelt, existieren bei den einzelnen Phloeothripidenarten alle Übergänge.

**) Die Gattung Anthothrips, welche zu den Phloeothripiden gehört, lebt in Blüten und nahm diese Lebensweise jedenfalls erst secundär an, nachdem sich schon ihr Körper dem Leben unter Rinde oder im Rasen angepasst hatte. Zu bemerken ist noch, dass die Art Anthothirips aculeata ausser in Blüten auch im Rasen, Moos, unter abgefallenern Laube und ausnahmsweise auch unter Rinde vorkommt, wohin sie sich überhaupt im Winter gerne verkriecht. 


\title{
ORDO'THYSANOP'TERA HALID.
}

\author{
1744. PHYSAPUS DEGEER. \\ 1746. THRIPS LINNE. \\ (1806. VESTTARSES OU PHYSAPODES DUMÉRIL.) \\ 1829. PHYSAPI LATREILLE. \\ 1829. THRIPIDAE STEPIENS. \\ 1835. THRIPSITES NEWMAN. \\ 1836. THYSANOPTERA IIALIDAY. \\ 1836. PHYSOPODA BURMEISTER. \\ 1852. PHYSAPODA WALKER. \\ 1855. THRIPSINA NEWMAN. \\ 1856. THRIPIDIDAE FITCH.
}

Tèlo více nebo méně sploštilé, obyčejně $0 \cdot 47-4 \mathrm{~mm}$, výjimkou až skoro $1 \mathrm{~cm}$ dlouhé. Čelo nalézá se na spodní straně hlavy. Tykadla jsou šesti- až devítičlenná, nitkovitá. Oči vždy prítomny; mezi nimi nalézají se obyčejně tr̆i jednoduchá očka. Ústroje ústní $\mathrm{k}$ ssání uzpûsobené mají podobu kužele a jsou více nebo méně pod předohrud zatlačeny. Plášt' kužele ústního utvořen jest z hořejšího pysku, z kusadel druhého páru a z pysku dolejšího, kteréžto části vespolek srostly. V jeho dutině pohybuji se kusadla prvého páru (mandibulae) v podobě dvou bodavých štětin a lichý bodec ústni (proměněný to epipharynx) na levé straně ležicí a zaviñujicí nesouměrnost' ústrojů ústních, pro třásněnky význačnou. Makadla maxillarní jsou dvou- neb tríičlenná, makadla labialní dvou- neb čtyřčlenná. Předohrud jest volnè pohyblivá, středohrud a větší zadohrud srůstají v jeden celek. Nohy jsou krátké; jednočlenné neb droučlenné, chodidlo ukončeno jest dvěma drápky, které přirůstaji k stẽnám vỵchlípitelného měchỵirku, mezi nimi se nalézajícího. Křídla jsou velmi úzká, blánitá, s okrajem dlouze třásnitým a s žilkami velmi sporými; často jsou zkrácená a nèkdy úplně chybí. Abdomen skládá se z desíti článkủ, z nichž poslední bývá rourovitý. Hřbetní část prvého článku jest pravidlem velmi krátká a souvisí úzce s metanotem; břišní část jeho jest více nebo méně zakrnělá. Soustava nervová jest koncentrovaná; všecky zauzliny abdominalní splývají v jednu nervovou hmotu, která se nalézá bud $\mathrm{v}$ basi abdomenu aneb vstupuje až do hrudi, 


\section{J. UZEL, MONOGRAFIE RADU ,THYSANOPTERA“.}

kdež přikládá se k srostlým zauzlinám stredo- a zadohrudi. Kommissury (kromě jícnové) a provazec nervový v abdomenu (na němž zauzlin není) jsou liché. Zažívací roura jest v jedinou okliku složená. Velmi dlouhý jícen sahá někdy až do prvních článkủ abdomenu. Žaludek skládá se ze dvou odstavcủ. Tenké strevo jest velmi králké, tlusté střevo jest objemné a vřetenovité. Do střeva vyústuji člyrìi dlouhé malpighické žlázy. Slinnỵch žlaz jsou dva páry, zř́lka tři. Srdce má podobu malého vaku a lě̌i mezi sedmỵ́m a osmým článk̇em zadku. Otvorủ dychacích nalézáme vždy člyři páry, a sice na středohrudi, na zadohrudi a pak na 2. a 8. článku abdominalním. Ústroje pohlavní skládají se u samcu ze dvou jednoduchých varlat; do base společného chámovodu ústí se jeden neb dva páry žlaz príidavných; u samic pozủstávaji oba vaječníky ze čtyř rourek vaječných. Do lichého vejcovodu ústí se zásobárna chámová, bez zvláštní žlázy prǐivěsné a někdy objemná žláza mazová. Otvor ústrojủ pohlavních nalézá se mezi 9. a 10. čl. abdom.; u samic terebrantií však mezi 8. a 9. Některé třásněnky (Terebrantia) mají kladélko ze čtyr̃ chlopní složené. Rozmnožování děje se často parthenogeneticky a rozšiřování bezkřidlých druhủ okřídlenými stěhovavými samičkami (feminae disseminantes). Vajičko vyvíji se dle onoho typu, u kterého proužka zárodec̀ná vchlipuje se dovnitř žloutku, čímž zárodek dostává se do polohy obrácené (vzhledem k stěnám vạječným); pročež nastává později převrat plodu. Pokud proměny se týče, patři třásněnky mezi Paurometabola, ač od nich odchylují se tím, že nymfa jejich jest málo pohyblivá, ba někdy i nehybná, a že neprịijimá potravy. Třásněnky živí se pravidlem štavami rostlinnými, zř́idka živočišnými. R. 1836. rozdělil Haliday (L. č. 43.) třásněnky na dva podřády (Stirpes), totiž Terebrantia a Tubulifera. Tolo rozdèlení jest velmi prìrozené a zachovalo se tudíz až podnes, právě tak jako jeho rozdělení terebrantii v čeledi: Coleoptrata (= Aeolothripidae) a Stenelytra (kteréžlo jméno, jsouc zadáno jisté skupinè broukủ, bylo nahrazeno jménem Stenoptera [-Thripidae]).

Körper mehr oder weniger flach, gewöhnlich $0.47-4 \mathrm{~mm}$, ausnahmsweise bis fast $1 \mathrm{~cm}$ lang. Die Stirn befindel sich auf der Unterseile des Kopfes. Die Fühler sind sechs- bis neungliedrig, fadenförmig. Augen immer vorhanden; zwischen denselben befinden sich gewöhnlich drei Ocellen. Die Mundwerkzeuge, welche zum Saugen eingerichtel sind, haben die Form eines Kegels und sind mehr oder weniger unter die Vorderbrust verschoben. Der Nantel des Mundkegels besteht aus der Oberlippe, aus den Maxillen und der Unterlippe; alle diese Theile sind untereinander verwachsen. In der Höhlung des Mundkegels bewegen sich die Mandibeln in Form zweier Stechborsten und der unpaare Mundstachel (wohl ein umgebildeter Epipharynx), welcher linkerseits liegt und den für die Thysanopteren charakleristischen unsymmetrischen Bau der Mundwerkzeuge bedingt. Maxillartaster zwei- oder dreigliedrig, Labialtaster zwei- oder viergliedrig. 


\section{H. UZEL, MONOGRAPHIE DER ORDNUNG THYSANOPTERA.}

Prothorax frei beweglich, Mesothorax und der grössere Metathorax zu einem Ganzen verwachsen. Beine kurz; der ein- bis zweigliedrige Tarsus am Ende mit zwei mehr oder weniger deutlichen Klauen, welche an die Wände einer zwischen ihnen befindlichen Blase anwachsen. Flügel sehr schmal, häutig, mit wenigen Adern; ihre Ränder mit langen Fransen besetzt. Oft sind die Flügel verkürzt, und manchmal fehlen sie vollkommen. Abdomen aus zehn Segmenten bestehend, von denen das letzte oft röhrenförmig ist. Die Rückenplatte des ersten Segmentes regelmässig sehr kurz und mit dem Metanotum eng verbunden; die Bauchplatte mehr oder weniger verkümmert. Das Nervensystem sehr concentriert; alle Abdominalganglien zu einer Masse verwachsen, welche sich entweder im Grunde des Abdomens befindet oder bis in den Thorax steigt, wo sie sich an die vereinigten Ganglien der Mittel- und Hinterbrust eng anlegt. Der Darmcanal ist in eine einzige Schlinge zusammengelegt. Der sehr lange Oesophagus reicht manchmal bis zu den ersten Abdominalsegmenten. Der Magen wird aus zwei Abschnitten zusammengesetzt. Der Dünndarm ist sehr kurz, der Dickdarm voluminös und spindelförmig. In den Darm münden vier lange Malpighische Gefässe. Speicheldrüsen sind in zwei, selten in drei Paaren vorhanden. Das Herz hat die Gestalt eines kurzen kleinen Sackes und liegt zwischen dem siebenten und achten Abdominalsegmente. Stigmen stets in vier Paaren vorhanden, von denen das erste auf dem Mesothorax, das zweite auf dem Netathorax, das 3. u. 4. auf dem 2. u. 8: Abdominalsegmente sich befinden. Die Geschlechtsorgane der Männchen sind aus zwei einfachen compacten Hoden zusammengesetzt; in den Grund des gemeinschaftlichen Samenleiters (ductus ejaculatorius) münden ein oder zwei Paar accessorischer Drüsen. Bei den Weibchen bestehen beide Eierstöcke aus je vier Eiröhren. In den unpaaren Eileiter mündet das Receptaculum seminis, welches keine besondere Anhangsdrüse hat, und manchmal eine grosse Schmierdrüse. Die Mündung der Geschlechtsorgane befindet sich 'zwischen dem 9. u. 10., bei den Weibchen der Terebrantia jedoch zwischen dem 8. и. 9. Abdominalsegmente. Die letzteren haben einen aus vier Klappen zusammengesetzten Legebohrer. Die Vermehrung geschieht oft parthenogenetisch und die Verbreitung der flügellosen Arten durch wandernde geflügelte Weibchen (feminae disseminantes). Das Ei entwickelt sich nach jenem Typus, bei welchem der Keimstreif sich von hinten nach vorn in den Dotter einstülpt, wodurch der Embryo in eine verkehrte (mit Rücksicht auf die Eiwände) Lage gelangt; deswegen findet später eine Umrollung des Embryos statt. Was die Verwandlung anbelangl, muss man die 'Thysanopteren zwischen die Paurometabola einreihen (weil ihre Larven dem vollkommenen Insecte sehr ähneln, weil ihre Verwandlung durch successives Wachsthum vor sich geht, weil die Lebensweise der Larven dieselbe wie die des vollkommenen Insectes ist, und weil auch ihre Mundwerkzeuge dieselben sind), obwohl sie von ihnen dadurch sich unterscheiden, dass ihre Nymphe wenig beweglich, ja manchmal (nach Heeger) sogar unbeweglich ist, und dass sie nicht Nahrung aufnimmt. Die Thysanopteren leben von Pflanzen-, ausnahmsweise von Thiersäften. 


\section{Klíče k určování českých třásněnek. I. KLÍČ K URČENÍ PODŘÁDŮ A ČELEDí.}

I. Samice maji na břišni straně 7. a 8. čl. abdom. čtyřchlopñové zatažitelné kladélko (Tab. X., fig. 170.). Hořejši křidla jsou dvěma podélnỵmi ̌̌ilkami (Tab. Vl., fig. 97.) a žilkou okružní (Tab. V., fig. 39., $a, b$; Tab. VI., fig. 97., $a, b$ ) opalřena. Tèlo jest v celku málo sploštilé.

PODR̆ÁD TEREBRANTIA HALID.

A. Tỵkadla jsou devítičlenná (Tab. V., fig. 35., 43., 46.). Kladélko nahoru prohnuté. ČELED̃ COLEOPTRATA HALID. (- AEOLOTHRIPIDAE).

B. Tỵkadla jsou šesti- až osmičlenná (Tab. VI., fig. 78., 79.; Tab. VII., fig. 108.). Kladélko dolủ prohnuté.

CELED STENOPTERA BURM. (= THRIPIDAE).

II. Samice nemají kladélka. Hořejši (i dolejší) kỉidla bez žilek (Tab. IV.. fig. 28.), aneb jen s jedinou podélnou žilkou zkrácenou (Tab. III.. fig. 19.). Tykadla osmičlenná (Tab. VII., fig. 117.). Poslední článek abdomenu (tubus) vždy rourovitý (Tab. IV., fig. 28.). Tělo ploché. PODŔÁD TUBULIFERA HALID. S ČELEDÍ PHLOEOTHRIPIDAE.

\section{KLÍČE K URČENÍ RODU.}

\section{1. ČELED COLEOPTRATA HALID. (- AEOLOTHRIPIDAE).}

A. Všecky články v tykadle volné (Tab. V., fig. 35.). Nakadla labialní dvoučlenná. 1. Rod Melanothrips Halid.

B. Několik posledních článkủ v tykadle srůstá. Makadla labialní čtyrřčlenná.

1. Tr̆i poslední články v tykadle srủstaji (Tab. V., fig. 43.). Křídla beze stuh.

2. Rod Rhipidothrips nov. gen.

2. Pèt posledních článkủ v tykadle srủstá (Tab. V., figg. 46.). Křidla se stuhami (Tab. I., fig. 4.).

3. Rod Acolothrips Halid.

2. ČELEL STENOPTERA BURM. ( $=$ THRIPIDAE).

A. Tỵkadla osmičlenná.

1. Tèlo jest sítkované.

a. Křídla scházejí. (Tab. II., fig. 9.)

16. Rod Prosopothrips nov. gen. 
b. Kǐidla u obou pohlaví prítomna.

a'. Barva těla černohnědá nebo žlutohnědá. Poslední článek tỵkadel mnohem delší než př̀edcházející (Tab. VI., fig. 91.).

17. Rod Heliothrips Halid.

b. Barva tèla žlutá. Poslední čl. tỵkadel asi tak dlouhý jako předcházející (Tab. VI.. fig. 81.).

14. Rod Dictyothrips nov. gen.

2. Tèlo není sítkované.

a. Abdomen přejemnými chloupky hedvábitý; tělo krátké, tmavé. (Tab. 1., fig. 1.)

6. Rod Sericothrips Halid.

b. Abdomen neni hedvábitý.

a. Poslední dva články tykadel (stylus) delši neb jen nepatrně kratši než 6. čl. jejich.

a". Stylus nepatrně kratši než 6. čl. (Tab. VI., fig. 80.). I)va poslední čl. abdomenu značně zúžené; poslední tvoři dlouhou tenkou rouru. Prothorax bez delšich chlupủ. (Tab. II., fig. 10.)

13. Rod Belothrips Halid.

b". Stylus mnohem delší než 6. čl. (Tab. VI., fig. 70.). Konec abdomenu nápadně nezúžený.

8. Rod Rhaphidothrips nor. gen.

b. Posledni dva články tỵkadel patrně kratši než 6. čl. jejich.

a". Třetí čl. tykadla na vnější straně ve výběžek prodloužený (Tab. I., fig. 8.). Konec abdomenu u samic trnitý.

5. Rod Limothrips Halid.

b. Třetí čl. tỵkadla bez rýběžku.

a"'. Pr̉ední femora neobycčejně rozšírená (Tab. I., fig. 2. a 7.) a konec jejich rně $\mathrm{r}$ zoubek prodloužený.

4. Rod Chirothrips Halid.

b"'. Přední femora užší a bez zoubku.

๘. Chloupky na konci abdomenu jsou krátké a pravidlem relmi slabé.

ж. Očka (i kîílla) scházejí. (Tab. II., fig. 17.)

12. Rod Aptimothrips Halid.

$\beta^{\prime}$ Očka prítomna.

๙". Tèlo velmi zavalité (Tab. II., fig. 15.); makadla maxillarní dvoučlennạ́.

15. Rod Dendrothrips nov. gen. 
J. UZEL, NONOGRAFIE RADU „THYSANOPTERA“.

ß". Tèlo není zavalité; makadla maxillarní tríčlenná.

11. Rod Anaphothrips m.

3. Chlupy na konci abdomenu jsou dosti dlouhé a pomèrnè silné.

$\varkappa^{\prime}$. Konec abdomenu jest nápadně, někdy velmi značně zúžený (Tab. V., fig. 66.; Tab. VI., fig 74.). Samci mají na 9. čl. jeho nahoře dva páry velmi krátkých silných ostnủ (Tab. VI., fig. 71.).

๙". Tèlo ryniká svou mohutností a šírkou. Kǐrídel jen premalá rudimenta. 10. Rod Pachythrips m.

?". Tèlo užší. Kîídla obycejně vyvinuta. Hořejší mají na předním okraji mezi třásnèmi slabé brvy.

9. $\operatorname{Rod}$ Oxythrips m.

ß’. Konec abdomenu není nápadnè zúžený. Samci maji 9. čl. neozbrojený. Kǐridla jsou obyčejně prítomna. Hořejší mají na předním okraji mezi třásnèmi silné dlouhé brvy. (Tab. l., fig. 5. a 6 .)

7. Rod Physopus (Deg.) Am. et Serv.

B. Tykadla sedmičlenná neb šestičlenná.

1. Makadla maxillarní dvoučlenná.

a. Hořejší krííla s černỵmi stuhami.

a. Tèlo sifkované. (Tab. Il., fig. 12.) 18. Rod Parthenothrips m.

b. Tělo není sítkované.

20. Rod Baliothrips m.

b. Hořejši kìidla (jsou-li pritomna) beze sluh.

a'. Tèlo široké. Kiřídla i očka scházejí.

25. Rod Platythrips m.

b. Tèlo velıni úzké. Krî́ídla i očka prítomna. (Tab. II. fig. 16.)

22. Rod Stemothrips nov. gen.

2. Makadla maxillarní zřetelnè třičlenná.

a. Tykadla šsstičlenná (Tab. Vl., fig. 79.; Tab. Vll., fig. 113.).

a. Očka i kř́dla prílomna.

24. Rod Drepanothrips nov. gen.

b'. Očka i kìídla scházejí. (Tab. Il., fig. 17.)

12. Rod Aptinothrips Halid. 
b. Tykadla sedmičlenná.

a'. Tělo neobyčejně úzké (Tab. VII., fig. 112.). Očka scházejí neb jsou velmi nezřetelná. Křídla scházejí úplně.

23. Rod Bolacothrips nov. gen.

b. Tělo není nápadně úzké.

a". Konec predních tibií bezbranný.

19. Rod Thrips (L.).

b". Konec předních tibií dvouzubý (Tab. VII., fig. 111.).

21. Rod Sminyothrips nov. gen.

3. ĊELED TUBULIFERA HALID. (- PHLOEOTHRIPIDAE).

A. Hlava a prothorax asi stejné délky, aneb prothorax trochu delši hlavy.

1. Křídla vždy přitomna; jsou uprostřed zúžená, takže mají podobu protáhlé podešve. Žijí hojně v květech.

28. Rod Anthothrips m.

2. Křídla obyčejně scházejí; jsou-li přitomna, nemaji uprostřed žádného zúžení. Žijí pod korou neb v drnu (Tab. II., fig. 18.).

31. Rod Trichothrips m.

$B$. Hlava patrně delší než prothorax.

1. Přední stehna před koncem uvnitř se zubem (Tab. IV., fig. 28.).

33. Rod Acanthothrips m.

2. Pr̀ední stehna bezbranná.

a. Celá hrud (i prothorax) po obou stranách okrášlena sněhobilou stuhou, která se prodlužuje na první články abdomenu (Tab. III., fig. 25.).

35. Rod Poecilothrips nov. gen.

b. Hrud bez takových kreseb.

a'. Prothorax i vzadu nemnoho širši hlavy (Tab. VII., fig. 134.).

30. Rod Cephalothrips $\mathrm{m}$.

b. Prothorax vzadu značně širší hlavy.

a". Sosák na konci široce zaokrouhlený (Tab. IV., fig. 31.).

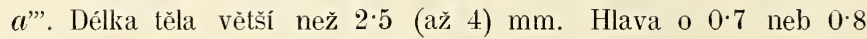
delší než širší (Tab. III., fig. 19.).

26. Rod Megalothrips m.

$b$ "'. Délka těla až $2 \cdot 1 \mathrm{~mm}$. Hlava nejvýše $\quad 0 \quad 0 \cdot 5$, obyčejně $0 \quad 0 \cdot 2$ delší než širší.

27. Rod Cryptothrips m. 
b". Sosák ke konci zúžený.

a”'. Strany hlavy opatřené malými bradavkami, které se zakončují malým osténkem (Tab. IV.. fig. 29.).

32. Rod Phloeothrips Halid.

b"'. Strany hlavy bez takových ostnitých bradavek.

ж. Čtvrtý čl. tykadla není nápadně široký. Délka těla větší než $1.7 \mathrm{~mm}$. Kř́íla všude stejně široká.

34. Rod Liothrips m.

ß. Čtvrtý čl. jest nejširším v celém tykadle (Tab. VII., fig. 133.). Délka těla as $1.1 \mathrm{~mm}$. Křídla, jsou-li přítomna, uprostřed značně zúžená, takže mají podobu protáhlé podešve.

29. Rod Zygothrips nov. gen.

\section{KLÍČE K URČOVÁNÍ DRUHU゚*).}

1. ROD MELANOTHRIPS HALID.

Jediný zástupce jest druh:

1. M. fusca Sulz.

2. ROD RHIPIDOTHRIPS nov. gen.

Jediný zástupce jest druh:

2. R. gratiosa nov. $\mathrm{sp}$.

\section{ROD AEOLOTHRIPS HALID.}

a. Kř̌idla se dvěma stuhami (Tab. I., fig. 4.). Někdy křídla scházejí.

๙. Druhý a 3. čl. abdom. bílý, sousední černé (Tab. I., fig. 3.).

7. Ae. albocincta Halid.

ß. Druhý a 3. čl. abdom., jako sousední, tmavě zbarvené. (Tab. I., fig, 4.)

6. Ae. fasciata L.

b. Křídla na basi a na konci světlá, ostatek zkalený.

๙. Zkalená část' krílla uprostřed se světlou skvrnou (Tab. V., fig. 45.).

4. Ae. melaleuca Halid.

3. Zkalená část' křídla beze skvrny.

3. Ae. versicolor nov. sp.

*) Znaky uvedené týkaji se samic (není-li výslovně jinak podotčeno), poněvadž tyto jsou samců mnohem četnèjši. - Znaky, jimiž lissi se samci od samic, sestaveny jsou pro oba podřády na str. 
H. UZEL, MONOGRAPHIE DER ORDNUNG THYSANOPTERA.

\section{ROD CHIROTHRIPS HALID.}

a. Druhý čl. tykadla má na vnější straně výběžek (Tab. V., fig. 49.).

9. Ch. manicata Halid.

b. Druhý čl. tykáalla bez výběžku (Tab. V., fig. 50.).

10. Ch. Dudae nov. sp.

5. ROD LIMOTHRIPS HALID.

Jediný český zástupce jest druh:

11. L. denticornis Halid.

6. ROD SERICOTHRIPS HALID.

Jediný zástupce jest druh:

13. S. staphylinus Halid.

7. ROD PHYSOPUS (DEG.) AH. et SERV.

1. Na předních rozích prothoraxu po jednom dlouhém chlupu smyslovém (Tab. V., fig. 53.). Obě podélné žilky hoř. kr̂́ílla po celé délce chlupy posety.

a. Hlava nazad zúżená (Tab. V., fig. 53.).

a'. Barva samic tmavě šedohnědá až černá, první dva čl. tykadla tmavé.

ж. Pátý čl. tykadla celý neb aspoñ na basi svètlý.

14. Ph. vulgatissima Halid.

ß. Pátý čl. tykadla celý tmavý. Tykadla nápadnè tenká.

15. Ph. tenuicornis nov. sp.

b. Barva samic žlutavá, prvé dva čl. tỵkadla světlé.

16. Ph. pallida nov. sp.

b. Hlava nazad nezúžená.

a'. Barva těla černohnědá.

๙. Konec predního chodidla se zoubkem (Tab. V., fig. 55.). 18. Ph. robusta nov. sp.

ß. Konec predního chodidla bez zoubliu.

17. Ph. nervosa nov. sp.

b. Hlava a thorax žlutavé, abdomen černohnědý.

20. Ph. nigriventris nov. sp.

2. Na předních rozich prothoraxu není dlouhých chlupủ smyslových.

a. Pr̃ední tibie na konci se zuhem. Hořejší žilka hořejšiho křídla jest skoro po celé své délce chlupy poseta. 
a'. Na tmavỵch kîídlech dvè světlé stuhy. Přední tarsus nemá dole hrbolikin.

a. Vedle zubu na konci prodních tibií nalézá se ostry̧ hrbolek, u něhož stojí silná šlětinka (Tab. V., fig. 59.). Čtvrtý čl. tykadla černohnèdý. U samců prodlužuje se 4.-7. čl. abdom. dole na zadním kraji uprostřed v okrouhlý čípek.

23. Ph. phalerata Halid.

ß. Ostrỵ hrbolek vedle zubu na konci přednich tibií se nalézající jest štětinkou zakončen (Tab. V., fig. 61.). Člvrlý čl. tykadla žlutý, slaběji neb silněji šedohnědẽ zkalený. Samec bez oněch čípkovitých prodlouženin na abdomenu.

24. Ph. intermedia nov. sp.

$b$. Kř́idla jen před basí svètlá. Přední tarsus dole se dvěma hrbolky (Tab. V., fig. 61.).

25. Ph. ulicis Halid.

b. Přední tibie bez zubu.

a'. Kř́dla a očka vyvinutá.

a". Křídla před koncem s širokou nad okolí více nebo méně světlejší neurčitou stuhou. Oči značnou měrou vykoulené (Tab. V., fig. 62.).

a. Střední a zadní libie černohnědé, na konci žluté.

27. Ph. primulae Halid.

$\beta$. Střední a zadní tibie žluté, vně slabẽ hnědě zkalené.

28. Ph. distincta nov. sp.

$b$ ". Kř́idla, kromě světlé base, stejnoměrně více nebo méně zkalená.

a. Hořejši žilka podélná $\mathrm{v}$ hor̆. křídle má $\mathrm{v}$ druhé své polovině tři chlupy, $z$ nichž jeden jest od ostatních dvou oddálen.

a. Pterothorax nemnoho větší než prothorax. Poslední články abdomenu opatřeny jsou silnými ostnitými chlupy postranními.

31. Ph. Friči nov. sp.

ß. Pterothorax značně větši než prothorax.

๙". Třetí čl. tykadla značně delší než 2 ; 3 . a 4. čl. dlouze vřetenovité (Tab. V., fig. 57.). Délka těla $1.3 \mathrm{~mm}$.

22. Ph. pallipemis nov. sp.

ß". Třetí čl. tykadla jen trochu delší než 2.; 3. a 4. ěl. ke konci mnohem méně zúžené. Délka těla $0.9 \mathrm{~mm}$.

30. Ph. pini nov. sp. 
ß. Hořejši žilka podélná $\mathrm{v}$ druhé polovině jen se dvěma chlupy, na konci jejím stojícími. Pátý čl. tykadel přiléhá širokou plochou k šestèmu (Tab. V., fig. 63.).

29. Ph. ulmifoliorum Halid.

\% Hořejší žilka podélná $\mathrm{v}$ druhé polovinẽ s osmi chlupy. Tykadla celá černohnědá. Hořr. křídla, kromé čiré base, velmi silnè zkalená.

21. Ph. atrata Halid.

o. Hořejší żilka podélná $\mathrm{v}$ druhé polovině $\mathrm{s}$ velmi nestálỵ́m počtem chlupủ. Hlava trochu delši než širší. Oči dosti značně vỵkoulené. Na konci předního tarsu malý zoubek.

26. Pli. inconsequens nov. sp.

b. Kr̉ídel jen nepatıná rudimenta; očka částečně neb docela zakrnělá.

a. Hlava vzadu tmavohnědá, mezi očima a $\mathrm{v}$ předu světle červenožlutá. Thorax tmavohnědý, abdomen černý.

32. Ph. frontalis nov. sp.

ß. Barva těla žlutavá; abdomen silnỵini odstávajícími chlupy opatren.

33. Ph. pilosa nov. sp.

8. ROD RHAPHIDOTHRIPS nov. gen.

Jediný zástupce jest druh:

34. R. longistylosa nov. sp.

\section{ROD OXYTHRIPS $\mathrm{m}$.}

a. Barva těla (aspoñ hlavy a thoraxu) žlutavá. Na zadních rozích prothoraxu po jednom chlupu smyslovém.

๔. Desátý čl. abdom. u samic jest velmi dlouhỵ, pourovitý (Tab. V., fig. 66.). Hořejší podélná žilka má v druhé polovici 5 chlupů.

35. O. hastata $\mathrm{m}$.

ß. Desátý čl. abdom. jest značně kratší. Hořejši podélná žilka má $\mathbf{v}$ druhé polovici 3 chlupy. Na předních tarsech na konci nehýtek.

36. O. ajugae nov. sp.

b. Barva těla šedohnědá až čemá. Na zadních rozích prothoraxu po dvou chlupech smyslových.

๙. Hlava do předu trochu zúžená. Přední tarsy na konci s nehỵtkem (Tab. V., fig. 69.).

37. O. firma nov. sp. 
J. UZEL, MONOGRAFIE RADU "THYSANOPTERA“.

ß. Hlava nazad trochu zúžená, neobỵčejně malá (Tab. VI., fig. 72.).

38 O. parviceps nov. sp.

10. ROD PACHYTHRIPS $\mathrm{m}$.

Jediný zástupce jest druh:

39. P. subaptera Halid.

\section{ROD ANAPHOTHRIPS $m$.}

a. Tykadla od čtvrtého článku černohnèdá.

$a$. Tretí čl. tykadel delší než 4. Barva těla žlutohnědá.

40. A. ferruginea nov. sp.

b'. Třetí a ětvrtý článek tykadel skoro stejně dlouhé. Barva těla tmavě šedohnẽdá.

41. A. similis nov. sp

b. Tykadla jinak zbarvená.

a'. Barva těla tmavá. Chloupky na konci abdomenu slaboučké.

a. Pátý čl. tykadla přiléhá dosti širokou plochou $k$ šestému. U samců mají 3.--6. čl. abdom. dole dlouhou, dosti širokou, uprostřed trochu staženou světlou prohlubinu. Barva těla

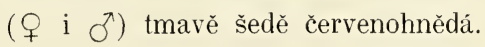

43. A. euphorbiae nov. sp.

ß. Pátý čl. tykadla od šestého oddělený. U samcủ má 3.—6. čl. abdom. dole velikou elliptickou světlou prohlubinu. Barva těla $\left(\sigma^{\pi}\right)$ zelenavě tmavošedá.

42. A. armata nov. sp.

b'. Barva tèla světlá. Devátý čl. abdomenu nahoře na zadním okraji se ětyřmi krátkými silnými chlupy.

a. Šestý čl. tykadla má šikmou přehrádku (Tab. VI., fig. 75.). Krî́dla obyčejně scházejí.

44. A. virgo $\mathrm{m}$.

ß. Šestý čl. tykadla bez takovéto přehrádky.

45. A. sordida nov. sp.

12. ROD APTINOTHRIPS HALID.

Jediný český zástupce jest druh:

46. A. Pufa Gmel.

\section{ROD BELOTHRIPS HALID.}

Jediný zástupce jest druh:

48. B. acuminata Halid. 
H. UZEL, MONOGRAPHIE DER ORDNUNG THYSANOPTERA.

14. ROD DICTYOTHRIPS nov. gen.

Jediný zástupce jest druh:

49. D. betae nov. sp.

15. ROD DENDROTHRIPS nov. gen.

a. Kř́idla s bílými stuhami príčními.

50. D. tiliae nov. sp.

b. Kî́dla beze stuh.

๙. Hlava dvakrát širší než delší. Barva tèla tmavá.

51. D. Degeeri nov. sp.

3. Hlava jen $0 \quad 0 \cdot 4$ širší než delší. Barva těla světlá.

52. D. saltatrix nov. sp.

16. ROD PROSOPOTHRIPS nov. gen.

Jediný zástupce jest druh:

53. P. Vejdovskýi nov. sp.

\section{ROD HELIOTHRIPS HALID.}

Jediný český zástupce jest druh:

54. H. haemorrhoidalis Bouché.

\section{ROD PARTHENOTHRIPS $\mathrm{m}$.}

Jediný zástupce jest druh:

56. P. dracacnae Heeg.

\section{ROD THRIPS (L.).}

1. Hlava patrně širší než delší.

a. Hlava nazad patrnè zúžená (Tab. X., fig. 172.). Tỵkadlo svètlé, prvé dva články, šestý čl. v druhé polovinè a sedmý tmavé. Nohy tmavé, všecky larsy a přední tibie svẽtlé.

57. T. physophus L.

b. Hlava nazad nezúžená. Barva tykadel a noh jiná.

a'. Abdomen není nápadně široký.

a". Barva tèla $(q)$ tmavá.

a”. Č́trrtý a pátý čl. tykadla skoro stejně dlouhé.

a. Barva těla tmavohnědá až černohnèdá. Pátý čl. tykadla tmavý, neb jen na basi světlejší. Hořejší žillka má $\mathrm{v}$ druhé polovině obyčejnẽ trì chlupy.

๙. Hor̆. kí̛dla jsou slabě zkalená. Nohy dosti světlé. Třetí čl. tykadla srětlý, 4. taktéž svètlý, ke konci zkalený.

59. T. major nov. sp. 
P. Hořejší kî́dla jsou silně zkalená.

๙". První ěl. tykadla šedý, nepatrnè průsvitný, ostatní čl. černošedé. jen třetí kromè konce a čtvrtý na basi žlulavé.

58. T. communis nov. sp. var. pulla.

§". Prrní dva ěl. tykadla černé, 3. žlutý, 4. žlutý, velmi slabě zkalený, 5. černý, na samé basi světlý. Postara mohutnějši.

61. T. salicaria nov. sp.

ß. Barva těla žlutohnědá. Pátý čl. tykadla světlý, jen ke konci velmi slabě šedě zkalený. Hoř. žilka má v druhé polovině obyčejnè jen 2 chlupy, na konci jejím se nalézající.

60. T. sambuci. Heeg.

b”'. Pátý ěl. tykadla malý, značně kratší než 4.

a. Barva tẽla černohnědá až skoro černá. Dva poslední čl. abdomenu nejsou tmavši než ostatní tělo.

๙. Délka těla $1 \cdot 2 \mathrm{~mm}$. Čtvrtý čl. tykadla světlý, jen ke konci zkalený, 5. do polou svèllý, od polou zkalený.

62. T. valida nov. sp.

ध. Délka těla $0.9 \mathrm{~mm}$. Čtvrtý i 5. čl. černošedé.

68. T. linaria nov. $\mathrm{sp}$

ß. Barva těla hnědožlutá neb žlutohnèdá. Dva poslední články abdom. černé.

63. T. adusta nov. sp.

b". Barva těla svěllá.

a"'. Chlupy na těle nápadně tmavé.

a. Pátý čl. tykadel skoro do dvou třetin běložlutý, pak náhle černošedý; 6 čl. na basi světlejší. $\quad 64$. T. Hava Schr.

ß. Pátý čl. tykadel a následující celé tmavé.

$\alpha^{\prime}$. Pátý čl. tỵkadel $\mathrm{v}$ předu utatý, takže přiléhá širokou plochou k článku šestému.

65. T. alni nov. sp.

ß'. Pátý čl. od šestého oddělenỵ. Kr̂̌ídel obyčejně jen rudimenta.

73. T. nigropilosa nov. sp.

$b$ "'. Chlupy na těle světlejší.

๙. Hořejší žilka podélná jest ve své druhé polovině opatřena čtyřmi chlupy, z nichž první dva a poslední dva jsou sblíženy. Články tykadla dosti zavalité.

58. T. communis nov. sp. 
ß. Hořejší žilka podélná jest ve své druhé polovině opatřena obyčejně osmi chlupy. Tr̆i prvé články dosti zavalité ho tykadla světlé, ostatní šedohnědé.

69. T. minutissima L.

భ. Hořejší žllka podélná jest ve své druhé polovině opatřena třemi chlupy, z nichž jeden od obou ostatních jest oddálen. $\alpha^{\prime}$. Pátý čl. tykadla jen trochu kratši než 4., v předu utatý, takže přiléhá dosti širokou plochou k článku šestému. Sedmý článek poměrně dlouhý.

66. T. albopilosa nov. sp.

ß’. Pátý čl. tykadla značně kratši než 4., v předu užší než u druhu předcházejícího. Sedmỹ čl. kratší.

64. T. flava Schr. var. obsoleta.

$b$. Abdomen neobycěejnè široký.

75. T. dilatata nov. $\mathrm{sp}$.

2. Hlava tak dlouhá jako široká aneb delší.

a. Přední tarsus opatřen dlouhým zubem (Tab. VI., fig. 104.).

b. Přední tarsus bezbranný.

70. T. calcarata nov. sp.

$a$. Hlava a thorax ochrové až hnědožluté, celý abdomen černyy.

74. T. discolor Halid.

b'. Barva těla šedohnědá až černá.

a". Tělo mohutné, 1.3 mm dlouhé. Oči vykoulené (Tab. VI., fig. 107.).

76. T. Klapáleki nov. sp.

b". Tèlo slabší, jen $0 \cdot 7-0.9 \mathrm{~mm}$ dlouhé. Oči nevykoulené.

a"'. Hořejší žilka má ve své druhé polovině ke konci pět chlupủ. Křidla někdy scházejí. Hlava malá, do předu trochu zúžená (Tab. VI., fig. 101.).

67. T. angusticeps nov. sp.

b"'. Hořejší žilka má ve své druhé polovinẽ trri chlupy, z nichž jeden jest od ostatnich dvou oddálen.

๔. Pátý ěl. tykadla jen trochu kratší než 4 .

71. T. viminalis nov. $\mathrm{sp}$.

ß. Pátý ěl. tykadla značně kratší než 4. Prothorax v poměru $k$ hlavě delší než obyčejně.

72. T. longicollis nov. sp. 
J. ITEL, MONOGRAFIE RADU "THYSANOPTERA“.

20. ROD BALIOTHRIPS $\mathrm{m}$.

Jediný zislupce jest druh:

78. B. dispar Halid.

21. ROD SMINYOTHRIPS nov. gen.

a. Zuby na konci předních tibií drobné (Tab. VII., fig. 110.).

79. S. biuncinata nov. sp.

b. Zuby na konci předních tibií veliké a silné (Tab. VII., fig. 111.).

80. S. biumcata nov. sp.

22. ROD STENOTHRIPS nov. gen.

Jediný zástupce jest druh:

81. S. graminum nov. sp.

23. ROD BOLACOTHRIPS nov, gen.

Jediný zástupce jest druh:

82. B. Jordani nov. sp.

24. ROD DREPANOTRIPS nov. gen.

Jediný záslupce jest druh: 。

83. D. Reuteri nov. sp.

25. ROD PLATYTHRIPS m.

Jedinỵ zástupce jest druh:

84. P. tunicata Halid.

26. ROD MEGALOTHRIPS $\mathrm{m}$.

a. Délka těla $2 \cdot 5-3 \mathrm{~mm}$. Vśecky tibie hnèdožluté.

96. II. lativentris Heeg.

b. Délka tèla $4 \mathrm{~mm}$. Všecky tibie černé.

97. II. Bonannii nov. sp.

\section{ROD CRYPTOTHRIPS $\mathrm{m}$.}

a. Prothorax tmavý.

$a^{\prime}$. Hlava se stranami skoro rovnoběžnỵmi. Tèlo velmi široké (Tab. IlI., fig. 24.).

99. C. lata nov. sp.

b. Hlava v zadu zúžená.

a". Ċtvrtý čl. tỵkadla tmavý. 
H. UZEL, MONOGRAPHIE DER ORDNUNG THYSANOPTERA.

$$
\begin{aligned}
& \text { a"'. Hlava skoro v } 0 \cdot 5 \text { delší než širší (Tab. VII., fig. 123.). } \\
& \text { Tělo dosti úzké. } \\
& \text { 100. C. angusta nov. sp. } \\
& \text { b"'. Hlava jen as o } 0 \cdot 2 \text { delší než širši (Tab. IV., fig. 33.). }
\end{aligned}
$$

b". Čtvrtý čl. tykadla žlutý, jen na konci zkalený.

101. C. Icarus nov. sp.

b. Prothorax hnědožlutý.

103. C. bicolor Heeg.

\section{ROD ANTHOTHRIPS $m$.}

a. Tubus o 0.2 kratši hlavy, skoro všude se stejným prùměrem (Tab. VII., fig. 129.). Kř́dla více nebo ménè šedohnèdè zkalená. Barva těla leskle černá.

104. A. statices Halid.

b. Tubus o 0.26 kratši hlavy, směrem $\mathrm{k}$ basi se rozšiřující. Krídla čirí. Barva tèla leskle černá.

105. A. distinguenda nov. $\mathrm{sp}$.

c. Tubus o 0.4 kratší hlavy, na basi rozšíriený (Tab. VII., fig. 131.). Kř́ídla čirá. Barva těla černohnědá až červenohnědá.

106. A. aculeata Fabr.

29. ROD ZYGOTHRIPS nov, gen.

Jediný zástupce jest druh:

108. Z. minuta nov. sp.

\section{ROD CEPHALOTHRIPS $\mathrm{m}$.}

Jediný zástupce jest druh:

109. C. monilicornis Reut.

\section{ROD TRICHOTHRIPS m.}

a. Tykadla vice než dvakrát hlavy delší. První čl. tykadla svètlyy. Délka těla nejvýše $1.4 \mathrm{~mm}$.

a'. Délka samic jen $0.9 \mathrm{~mm}$. Hlava žlutá, ostatní tèlo tmavohnědé. Žije v drnu.

111. T. caespitis nov. sp.

b. Délka samic as $1.4 \mathrm{~mm}$. Žiji pod korou.

a". Tubus svètlý, někdy uprostřed velmi slabě zkalený. Konec abdomenu žlutý. Hlava často světlá. 110. T. pedicularia Halid.

b". Tubus, kromè base, černý. Prothorax tmavší než ostatní tělo, jež jest šedě žlutavé.

112. 'T. semicaeca nov. sp. 
J. UZEL, MONOGRAFIE RADU "THYSANOPTERA".

b. Tykadla skoro dvakrát hlavy delší. První čl. tykadla velmi tmavỵ. Délka tèla as $2 \mathrm{~mm}$.

115. T. copiosa nov. sp.

32. ROD PHLOEOTHRIPS HALID.

a. Délka těla 2:3-3 mm. (Tab. IV., fig. 29.) 116. Phl. coriacea Halid. b. Délka tèla $1 \cdot 3-1.7 \mathrm{~mm}$.

๙. Třetí čl. tykadla delši než prvé dva dohromady (Tab. VII., fig. 143.).

117. Phl. minor nov. sp.

३. Třetí čl. tykadla kratší než prvé dva dohromady (Tab. VII., fig. 144.).

118. Phl. parva nov. sp.

33. ROD ACANTHOTHRIPS $m$.

Jediný zástupce jest druh:

120. A. nodicornis Reut.

\section{ROD LIOTHRIPS m.}

a. Tykadlo žluté, jen první a poslední článek tmavé. 122. L. setinodis Reut.

b. Všecky články tykadla, kromě třetího, částečně neb celé tmavé.

121. L. hradecensis nov. sp.

35. ROD POECILOTHRIPS nov. gen.

Jediný zástupce jest druh:

123. P. albopicta nov. sp. 


\section{Schlüssel zum Bestimmen der europäischen Thysanopteren.}

\section{SCHLÜSSEL ZUM BESTIMMEN DER UNTERORDNUNG UND FAMILIE.}

I. Weibchen auf der Bauchseite des 9. u. 8. Abdominalsegmentes mit einem aus vier Klappen zusammengesetzten Legebohrer (Taf. X. Fig. 170), welcher eingezogen werden kann. Oberflügel mit zwei Längsadern (Taf. VI, Fig. 97) und einer Ringader (Taf. V. Fig. 39, $a, b$; Taf. VI, Fig. 97, $a, b)$ versehen. SUbordo TEREBRANTIA HaLid.

A. Fühler neungliedrig (Taf. V, Fig. 35, 43, 46). Legebohrer aufwärts gebogen.

FAY. AEOLOTHRIPIDAE (= COLEOPTRATA HALID.).

B. Fühler sechs- bis achigliedrig (Taf. VI, Fig. 78, 79; Taf. VII, Fig. 108). Legebohrer niederwärts gebogen.

FAM. THRIPIDAE (= STENOPTERA BURM.).

II. Weibchen ohne Legebohrer. Flügel ohne Adern (Taf. IV, Fig. 28) oder nur mit einer verkürzten Längsader (Taf. III, Fig. 19). Fühler achtgliedrig (Taf. VII, Fig. 117). Das letzte Abdominalsegment (der Tubus) immer röhrenförmig (Taf. IV, Fig. 28). Körper flach. SUBORDO TLBLLIFERA HALID. - FAII. PHLOEOTHRIPIDAE.

\section{SCHLÜSSEL ZUM BESTIMMEN DER GATTUNG.}

1. FAM. AEOLOTHRIPIDAE (- COLEOPTRATA HALID.).

A. Alle Glieder im Fühler frei (Taf. V, Fig. 35). Labialtaster zweigliedrig.

1. Gen. Melanothrips Halid.

$B$. Einige der letzlen Glieder im Fühler untereinander verwachsen. Labialtaster viergliedrig.

1. Die drei letzten Glieder im Fühler untereinander verwachsen (Taf. V, Fig. 43). Flügel ohne Binden.

2. Gen. Rhipidothrips nov. gen.

2. Die fünf letzten Glieder im Fühler untereinander verwachsen (Taf. V. Fig. 46). Flügel mil Binden geziert (Taf. I, Figg. 4).

3. Gen. Aeolothrips Halid. 


\section{J. UZEL, MONOGRAFIE RADU "THYSANOPTERA“.}

\section{FAM. THRIPIDAE ( STENOPTERA BURM.).}

A. Fühler achtgliedrig.

1. Körper mit netzförmiger Structur.

a. Flügel fehlend. (Taf. II, Fig. 9.)

16. Gen. Prosopothrips nov, gen.

b. Flügel bei beiden Geschlechtern vorhanden.

a'. Körperfarbe schwarzbraun oder gelbbraun. Das letze Fühlerglied viel länger als das vorhergehende (Taf. VI, Fig. 91). Glashausbewohner. 17. Gen. Heliothrips Halid.

b' Körperfarbe gelb. Das letzle Fühlerglied etwa so lang wie das vorhergehende (Taf. VI, Fig. 81). 14. Gen. Dictyothrips nov. gen. $\checkmark$

2. Körper ohne netzförmige Structur.

a. Der Hinterleib gewinnt infolge äusserst feiner Härchen einen seidenartigen Glanz (im trockenen Zustande). Körper kurz und dunkel. (Taf. 1, Fig. 1.)

6. Gen. Sericothrips Halid.

b. Der Hinterleib ohne seidenartigen Glanz.

$a^{\prime}$. Die letzten zwei Fühlerglieder (der Stylus) länger oder kaum kürzer als das 6. Glied.

a". Stylus kaum kürzer als das 6. Glied (Taf. VI. Fig. 80). Die zwei letzten Abdominalsegmente bedeutend verengt; das letzte bildet eine lange dünne Röhre. Prothorax ohne längere Haare. (Taf. II, Fig. 10.)

13. Gen. Belothrips Halid.

b". Stylus viel länger als das 6. Glied (Taf. VI, Fig. 70). Das Abdomenende nicht auffallend verengt.

8. Gen. Rhaphidothrips nov. gen. $\checkmark$

$b$. Die letzten zwei Fühlerglieder deutlich kürzer als das 6. Glied.

a". Das Abdomenende der Weibchen dornig (Taf. 1, Fig. 8). Das dritte Fühlerglied aussen in einen dreieckigen Fortsalz verlängert (bei der Art cerealium einfach). 5. Gen. Limothrips Halid.

$b$ ". Das Abdomenende nicht dornig. Das dritte Fühlerglied einfach.

a"'. Vorderschenkel ungewöhnlich erweitert (Taf. I, Fig. 2 u. 7), am Ende aussen mit einem kleinen Zahne. (Bei der Art manicata ist das 2. Fühlerglied nach aussen in einen Fortsatz verlängert.)

4. Gen. Chirothrips Halid.

b"'. Vorderschenkel schmäler und ohne Zahn.

๙. Härchen auf dem Abdomenende kurz und in der Regel sehr schwach. 
$\alpha^{\prime}$. Ocellen (und Flügel) fehlend. (Taf. II, Fig. 17.)

12. Gen. Aptinothrips Halid.

$\beta^{\prime}$. Ocellen vorhanden.

$\alpha^{\prime \prime}$. Körper sehr gedrungen (Taf. II. Fig. 15); Maxillartaster zweigliedrig. 15. Gen. Dendrothrips nov. gen.

$\beta^{\prime \prime}$. Körper nicht gedrungen; Maxillartaster dreigliedrig.

11. Gen. Anaphothrips m.v

3. Haare auf dem Abdomenende ziemlich lang und verhältnismässig stark.

$a^{\prime}$. Abdomenende auffallend, manchmal sehr stark verengt

(Taf. V, Fig. 66; Taf. VI, Fig. 74). Männchen auf dem

9. Abdominalsegmente oben mit zwei Paar kurzer starker

Dornen (Taf. VI, Fig. 71).

$\alpha^{\prime \prime}$. Körper durch seine Mächtigkeit und Breite ausgezeichnet. Von den Flügein nur winzige Reste.

10. Gen. Pachythrips m.

$\beta^{\prime \prime}$. Körper schmäler. Flügel gewöhnlich vorhanden. Die oberen am Vorderrande zwischen den Fransen mit schwachen Wimpern.

9. Gen. Oxythrips m.

ß'. Abdomenende nicht auffallend verengt. Männchen ohne Dornen auf dem 9. Abdominalsegmente. Flügel gewöhnlich vorhanden. Die oberen am Vorderrande zwischen den Fransen mit starken langen Wimpern. (Taf. I, Fig. 5 u. 6.)

7. Gen, Physopus (Deg.) Am. et Serv.

B. Fühler sieben- oder sechsgliedrig.

1. Maxillartaster zweigliedrig.

a. Oberflügel mit schwarzen Querbinden.

a'. Körper mit netzförmiger Structur. (Taf. II, Fig. 12.) Glashausbewohner. 18. Gen. Parthenothrips m.

b'. Körper ohne netzförmige Structur.

20. Gen. Baliothrips m.

b. Oberflügel, wenn vorhanden, ohne schwarze Querbinden.

a'. Körper breit. Flügel und Ocellen fehlend.

25. Gen. Platythrips m.

b'. Körper sehr schmal. Flügel und Ocellen vorhanden. (Taf. II, Fig. 16.) 22. Gen. Stenothrips nov. gen. $\checkmark$ 
2. Maxillartaster deutlich dreigliedrig.

a. Fühler sechsgliedrig (Taf. VI, Fig. 79; Taf. VII, Fig. 113).

a'. Ocellen und Flügel vorhanden.

24. Gen. Drepanothrips nov. gen.

b. Ocellen und Flügel fehlend. (Taf. II, Fig. 17.)

12. Gen. Aptinothrips Halid.

b. Fühler siebengliedrig.

a'. Körper ungewöhnlich schmal (Taf. VII. Fig. 112). Ocellen fehlend oder sehr undeutlich. Flügel fehlend.

23. Gen. Bolacothrips nov. gen.

b'. Körper nicht auffallend schmal.

a”. Ende der Vordertibien wehrlos.

19. Gen. Thrips (L.).

b". Ende der Vordertibien innen mit zwei Zähnen. (Taf. VII, Fig. 111.)

21. Gen. Sminyothrips nov. gen.

3. FAII. PHLOEOTHRIPIDAE ( TUBULIFERA HALID.).

A. Kopf und Prothorax etwa gleichlang, oder Prothorax etwas länger als der Kopf.

1. Flügel immer vorhanden; dieselben sind in der Mitte verengt, so dass sie die Form einer langgestreckten Sohle haben. Blütenbewohner.

28. Gen. Anthothrips m. $J$

2. Flügel gewöhnlich fehlend; wenn vorhanden, sind sie in der Mitte nicht verengt. Rinden- oder Rasenbewohner. (Taf. II, Fig. 18.)

31. Gen. Trichothrips m.

B. Kopf ausgesprochen länger als der Prothorax.

1. Vorderschenkel vor dem Ende innen mit einem Zahne (Taf. IV, Fig. 28).

33. Gen. Acanthothrips m.

2. Vorderschenkel wehrlos.

a. Der ganze Thorax (auch der Prothorax) jederseits mit einer schneeweissen Binde verziert, welche sich auf die ersten Abdominalsegmente verlängert (Taf. III, Fig. 25).

35. Gen. Poecilothrips nov. gen.

$b$. Thorax ohne weisse Binden.

a'. Prothorax auch hinten nicht viel breiter als der Kopf (Taf. VIl, Fig. 134).

30. Gen. Cephalothrips m.

b. Prothorax hinten bedeutend breiter als der Kopf.

a". Rüssel auf dem Ende breit gerundet (Taf. IV, Fig. 31). 


\section{H. UZEL, MONOGRAPHIE DER ORDNUNG THYSANOPTERA.}

a”. Körperlänge grösser als 2.5 (bis 4 ) $\mathrm{mm}$. Kopf um 0.7 oder 0.8 mehr lang als breit. Männchen auf dem 6 . Abdominalsegmente jederseits mit einem röhrenförmigen Anhang; ihre Vordertarsen wehrlos (Taf III, Fig. 19).

26. Gen. Megalothrips m.

b". Körperlänge bis $2 \cdot 1 \mathrm{~mm}$. Kopf höchstens um 05 , gewöhnlich um 0.3 oder um 0.2 , ausnahmsweise zweimal (C. nigripes Reut.) mehr lang als breit. Männchen ohne seitliche Abdominalanhänge; ihre Vordertarsen mit einem Zahne bewaffnet.

27. Gen. Cryptothrips m.

b". Rüssel gegen das Ende zu verengt.

„‘. Wangen mit einigen sehr kleinen Wärzchen, von denen jedes mit einem winzigen Stachel versehen ist (Taf. IV. Fig. 29).

32. Gen. Phloeothrips Halid.

b". Wangen ohne solche Wärzchen.

ж. Das vierte Fühlerglied ist nicht auffallend breit. Körperlänge grösser als $1.7 \mathrm{~mm}$. Flügel überall gleichbreit.

34. Gen. Liothrips m.

ß. Das vierte Fühlerglied ist das breiteste im ganzen Fühler (Taf. VII, Fig. 133). Körperlänge etwa $1 \cdot 1 \mathrm{~mm}$. Flügel, wenn vorhanden, in der Mitte bedeutend verengt und infolge dessen gestreckt sohlenförmig. 29. Gen. Zygothrips nov. gen.

\section{SCHLÜSSEL ZUM BESTIMMEN DER ART*). 1. GEN. MELANOTHRIPS HALID.}

Der einzige Vertreter ist die Art:

1. II. fusca Sulz.

\section{GEN. RHIPIDOTHRIPS nor. gen.}

Der einzige Vertreter ist die Art:

2. R. gratiosa nov. sp.

*) In diesen Schlüssel habe ich die sieben europäischen Arten: Thrips (s. l.) ericae, Benseleri, flacicomis, Phloeothrips (s.l.) ammliconis, subtilissima. paripemis und albosignata nicht aufgenommen, weil ihre Gattungszuständigkeit nicht festgestellt werden konnte, da ich die erwähnten Arten nicht selbst gesehen habe und ihre Beschreibungen ausserdem unzureichend sind. Ich verweise hinsichtlich derselben auf die bezüglichen Originalbeschreibungen, welche auch in rorliegender Monographie enthalten sind.

Die Charaktere beziehen sich hier, wenn sonst keine Erwähnung geschieht, auf Weibchen, da dieselben die weit häufigeren sind. - Die Merkmale, nach denen man die Männchen der Terebrantia und Tubulifera erkennt, sind auf S. 62 u. S. 2.3 zusammengestellt. 
J. UZEL, MONOGRAFIE RADU, "THYSANOPTERA“.

3. GEN. AEOLOTHRIPS HALID.

a. Flügel, wenn vorhanden, mit zwei Querbinden (Taf. I, Fig. 4).

a. Das 2. u. 3. Abdominalsegment weiss, die Nachbarsegmente schwarz. (Taf. I, Fig. 3.)

7. Ae. albocincta Halid.

3. Das 2. und 3. Abdominalsegment ebenso wie die Nachbarsegmente dunkel gefärbt. (Taf. I, Fig. 4.)

6. Ae. fasciata L.

$b$. Flügel auf dem Grunde und auf dem Ende licht, übrigens getrübt.

$a^{\prime}$. Der getrübte Theil des Flügels inmitten mit einem lichten Fleck (Taf. V, Fig. 45).

4. Ae. melaleuca Hahid.

b'. Der getrübte Theil des Flügels ohne Fleck.

a. Kopf, Prothorax und Mesothorax rothbraun, Metathorax und

Abdomen gelblich, dieses auf dem Ende graubraun.

3. Ae. versicolor nov. sp.

↔. Der ganze Körper glänzend schwarz.

5. Ae. vittata Halid.

4. GEN. CHIROTHRIPS HALID.

a. Das 2. Fühlerglied aussen in einen Fortsatz verlängert (Taf. V, Fig. 49).

9. Ch. manicata Halid.

b. Das 2. Fühlerglied einfach (Taf. V, Fig. 50).

10. Ch. Dudae nov. sp.

5. GEN. LIMOTHRIPS HALID.

a. Das 3. Fühlerglied aussen in einen Fortsatz verlängert (Taf. I, Fig. 8.).

11. L. denticornis Halid.

b. Das 3. Fühlerglied einfach.

12. L. cerealium Halid.

6. GEN. SERICOTHRIPS HALID.

Der einzige Vertreter ist die Art:

13. S. staphỵlinus Halid.

7. GEN. PHYSOPUS (DEG.) AM. et. SERT.

1. Auf den Vorderecken des Prothorax je eine lange Borste (Taf. V, Fig. 53). Die beiden Längsadern des Oberflügels sind der ganzen Länge nach mit Borsten besetzt. 
a. Kopf nach hinten deutlich verengt (Taf. V, Fig. 53).

$a$ '. Farbe der Weibchen dunkel graubraun bis schwarz, die ersten zwei Fühlerglieder dunkel.

๙. Das 5. Fühlerglied ganz oder wenigstens am Grunde licht. -

Das Männchen licht. 14. Ph. vulgatissima Halid.

ß. Das 5. Fühlerglied ganz dunkel. Die Fühler auffallend dünn.

15. Pl. tenuicornis nov. sp.

$b$. Farbe der Weibchen gelblich, die ersten zwei Fühlerglieder licht.

$b$. Kopf nach hinten nicht verengt.

16. Ph. pallida nov. sp.

a'. Körperfarbe schwarzbraun.

๙. Vordertarsus ain Ende mit einem kleinen scharfen Zähnchen (Taf. V, Fig. 55). - Das Männchen hat auf dem 8. Abdominalsegmente jederseits einen starken Dorn. Alle Schenke schwarz, Vordertibien gelb, oben und unten braun getrübt. Die übrigen Tibien ganz schwarz. Alle Tarsen gelb. Körperlänge der Weibchen $1.4 \mathrm{~mm}$.

18. Ph. robusta nov. sp.

ß. Vordertarsus ohne Zähnchen. Die Adern im Oberflügel sehr stark. Körperlänge $1 \mathrm{~mm}$.

17. Pl.. nervosa nov. sp.

b. Kopf und Thorax gelblich, Abdomen schwarzbraun. Wenn die Flügel rudimentär sind, ist das vordere Nebenauge verkümmert.

20. Ph. nigriventris nov. sp.

2. Auf den Vorderecken des Prothorax keine langen Borsten.

a. Vordertibien am Ende mit einem Zahne. Die obere Längsader des Oberflügels ist fast der ganzen Länge nach mit Borsten besetzt.

a'. Auf den dunklen Oberflügeln zwei lichte Binden. Vordertarsus unten ohne Höckerchen.

๙. Neben dem Zahne am Ende der Vordertibien befindet sich ein scharfes Höckerchen, bei dem eine kleine starke Borste steht (Taf. V, Fig. 59). Das 4. Fühlerglied schwarzbraun. Bei den Männchen verlängert sich das 4.-7. Abdominalsegment unten am Hinterrande in der Mitte in je einen sehr kleinen gerundeten Lappen.

23. Pl. phalerata Halid.

ß. Das scharfe Höckerchen, welches sich neben dem Zahne am Ende der Vordertibien befindet, trägt auf seinem Gipfel 
eine kleine Borste (Taf. V., Fig. 61). Das 4. Fühlerglied gelb, stärker oder schwächer graubraun getrübt. Das Männchen ohne die lappenförmigen Fortsätze der Abdominalsegmente.

24. Ph. intermedia nov. sp.

b. Die Flügel nur vor dem Grunde licht. Vordertarsus unten mit zwei Höckerchen (Taf. V, Fig. 61).

25. Ph. ulicis Halid.

b. Vordertibien ohne Zahn.

$a$ '. Flügel und Ocellen entwickelt.

a”. Die Oberflügel vor dem Ende mit einer breiten unbestimmten Binde, welche mehr oder weniger lichter als ihre Umgebung ist. Augen stark hervorgequollen (Taf. V, Fig. 62).

๙. Nittel- und Hintertibien schwarzbraun, am Ende gelb. Das 3. Fühlerglied gelb, das 4. in der ersten Hälfte gelb, in der zweiten graubraun, die folgenden schwarzbraun. In der zweiten Hälfte der oberen Längsader im Oberflügel drei Borsten.

27. Ph. primulae Halid.

३. Nittel- und Hintertibien gelb, aussen schwach braun getrübt. Das 3. und 4. Fühlerglied ganz gelb, das 5. bis zur Hälfte gelb, von der Hälfte an schwarzbraun, das 6. schwarzbraun, am Grunde gelb. Die obere Längsader der ganzen Länge nach mit Borsten besetzt. 28. Ph. distincta nov. sp.

b". Die Oberflügel, ihre lichte Basis ausgenommen, gleichmässig mehr oder weniger getrübt.

๙. Die obere Längsader im Oberflügel hat in ihrer zweiten Hälfte drei Borsten, von denen eine von den übrigen zwei entfernt steht.

$\alpha^{\prime}$. Pterothorax nicht viel grösser als der Prothorax. Körperfarbe grünlich dunkelgrau oder graubraun, Abdomen gegen das Ende zu dunkler. Kopf nach hinten etwas verengt. Die lezten Abdominalsegmente an den Seiten mit sehr starken Borsten besetzt. Körperlänge $0.9 \mathrm{~mm}$.

31. Ph. Friči nov. sp.

$\beta^{\prime}$. Pterothorax bedeutend grösser als der Prothorax. Körperfarbe dunkel graubraun. - Fühler dunkel, nur das 3. Glied gelblich.

$\alpha^{\prime \prime}$. Das 3. Fühlerglied bedeutend länger als das 2.; das 3. u 4. gestreckt spindelförmig (Taf. V, Fig. 57). Das 
6. Fühlerglied elwas kürzer als das 3. Die Flügel auffallend licht. Körperlänge $1.3 \mathrm{~mm}$.

\section{Ph. pallipennis nov. sp.}

३". Das 3. Fühlerglied nur etwas länger als das 2.; das 3. u. 4. gegen das Ende zu viel weniger verengt. Das 6. Glied etwas länger als das 3. Körperlänge $0.9 \mathrm{~mm}$.

30. Ph. pini nov. sp.

ß. Die obere Längsader hat in ihrer zweilen Hälfte nur zwei Borsten, welche auf ihrem Ende stehen. Das 5. Fühlerglied legt sich mit breiter Fläche an das 6. an (Taf. V, Fig. 63).

29. Ph. ulmifoliorum Halid.

$\gamma$. Die obere Längsader hat in ihrer zweiten Hälfte acht Borsten.

Fühler ganz schwarzbraun. Die Oberflügel, der helle Grund ausgenommen, sehr stark getrübt.

21. Ph. atrata Halid.

§. Die obere Längsader hat in ihrer zweiten Hälfte eine sehr unstete Anzahl von Borsten. Kopf etwas mehr lang als breit. Augen ziemlich stark hervorgequollen. Am Ende des Vordertarsus unten ein kleines Zähnchen. Körperfarbe gelbgrau bis graubraun; der Pterothorax pflegt rothbraun zu sein. Körperlänge $1.3 \mathrm{~mm}$.

26. Ph. inconsequens nov. sp.

b'. Flügel rudimentär; Ocellen theilweise oder ganz verkümmert.

a. Kopf hmten dunkelbraun, zwischen den Augen und vorn licht rothgelb. Thorax dunkelbraun, Abdomen schwarz. Der Stylus (die letzten zwei Fühlerglieder) verhältnismässig lang. Pterothorax nur etwa so lang wie der Prothorax. Körperlänge $0.9 \mathrm{~mm}$.

32. Ph. frontalis nov. sp.

ß. Körperfarbe gelblich. Abdomen mit starken abstehenden Borsten rersehen. Pterothorax kürzer als der Prothorax. Körperlänge $0.7 \mathrm{~mm}$.

33. Ph. pilosa nov. $s p$

Neben Ph. robusta gehört wohl die mir unbekannte Art: Ph. asprea Halid., welche sich von jener schon durch andere Färbung der Beine unterscheidet.

8. GEN. RHAPHIDOTHRIPS nov, gen.

Der einzige Vertreter ist die Art:

34. R. longistylosa nov. sp. 


\section{GEN. OXYTHRIPS m.}

a. Körperfarbe (wenigstens Kopf und Thorax) gelblich. Auf den Hinterecken des Prothorax je eine Borste. Derselbe etwas länger als der Kopf.

a. Das 10. Abdominalsegment bei den Weibchen sehr lang, röhrenförmig, fast dreimal so lang als das 9 (Taf. V, Fig. 66). Die obere Längsader trägt auf ihrer zweiten Hälfte 5 Borsten. Körperlänge $0.9 \mathrm{~mm}$.

35. O. hastata $\mathrm{m}$.

ß. Das 10. Abdominalsegment bedeutend kürzer. Die obere Längsader trägt auf ihrer zweiten Hälfte 3 Borsten. Vordertarsus am Ende mit einem kleinen Nagel. Körperlänge $0.8 \mathrm{~mm}$.

36. O. ajugae nov. sp.

b. Körperfarbe graubraun bis schwarz. Auf den Hinterecken des Prothorax je zwei Borsten. Derselbe bedeutend länger als der Kopf.

ж. Kopf nach vorne etwas verengt. Die Vordertarsen am Ende mit einem kleinen Nagel (Taf. V, Fig. 69). Die Flügel bei den Weibchen manchmal, bei den Männchen immer rudimentär. Körperlänge $0.9 \mathrm{~mm}$.

37. O. firma nov. sp.

ß. Kopf nach hinten etwas verengt, ungewöhnlich klein (Taf. VI, Fig. 72). Körperlänge $0.8 \mathrm{~mm}$.

38. O. parviceps nov. sp.

10. GEN. PACHYTHRIPS $\mathrm{m}$.

Der einzige Vertreter ist die Art:

39. P. subaptera Halid.

\section{GEN. ANAPHOTHRIPS m.}

a. Fühler vom vierten Gliede an schwarzbraun; die ersten zwei Glieder sind braungrau, das 3. gelblich. Die Nebenader verliert sich im letzten Fünftel des Oberflügels vollständig.

a. Das 3. Fühlerglied länger als das 4. Körperfarbe gelbbraun. Körperlänge $0.9 \mathrm{~mm}$.

40. A. ferruginea nov. sp.

3. Das 3. u. 4. Fühlerglied fast gleich lang. Körperfarbe dunkel graubraun. Körperlänge $1 \mathrm{~mm}$.

41. A. similis nov. sp.

$b$. Fühler anders gefärbt.

$a$ '. Körperfarbe dunkel. Die Haare auf dem Abdomenende schwach.

a. Das 5. Fühlerglied legt sich mit ziemlich breiter Fläche an das 6. an. Bei den Männchen hat das 3.--6. Abdominal-

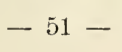


segment unten je eine lange, ziemlich breite, in der Mitte etwas verengte lichte Vertiefung. Körperfarbe beider Geschlechter dunkel graurothbraun.

43. A. euphorbiae nov. sp.

ß. Das 5. Fühlerglied rom 6. gesondert. Bei den Männchen hat das 3.-6. Abdominalsegment unten je eine grosse elliptische lichte Vertiefung. Körperfarbe des Männchens grünlich dunkelgrau. Körperlänge desselben $0.6 \mathrm{~mm}$.

42. A. armata nov. sp.

b. Körperfarbe licht. Das 9. Abdominalsegment oben auf dem Hinterrande mit vier kurzen starken Borsten.

a. Das 6. Fühlerglied hat eine schiefe Querwand (Taf. VI, Fig. 75). Die Flügel fehlen gewöhnlich. Kopf etwa so lang wie breit, nach vorn verengt.

44. A. virgo $\mathrm{m}$.

ß. Das 6. Fühlerglied ohne Querwand. Der Körper oben mit grauen Zeichnungen. Kopf mehr breit als lang, nach vorn nicht rerengt. Körperlänge $0.8 \mathrm{~mm}$. Das 9. Abdominalsegment der Männchen oben ohne Dornen.

45. A. sordida nov. sp.

12. GEN. APTINOTHRIPS HALID.

a. Körperfarbe licht braungelblich. Körperlänge $0.8 \mathrm{~mm}$.

46. A. rufa Ginel.

b. Körperfarbe dunkel braungelb. Körperlänge bedeutend kleiner.

47. A. nitidula Halid.

13. (iEN. BELOTHRIPS HALID.

Der einzige Vertreter ist die Art:

48. B. acuminata Halid

14. GEN. DICTYOTHRIPS nov. gen.

Der einzige Vertreter ist die Art:

49. D. betae nov. sp.

15. GEN. DENDROTHRIPS nov. gen.

a. Oberflügel mit weissen Querbinden. - Körperfarbe schwarz- bis graubraun, Prothorax weiss, oben mit schwarzer Zeichnung. Kopf zweimal so breit als lang. Fühler nur um 0.2 länger als die Kopfbreite. Körperlänge $0.7 \mathrm{~mm}$. 50. I). tiliae nov. sp. 
b. Oberflügel ohne Querbinden, gelblichgrau, am Grunde licht.

ж. Kopf zweimal so breit als lang. Körperfarbe dunkel, Prothorax weisslich mit dunklen Zeichnungen. Fühler etwa um 0.2 länger als die Kopfbreite. Körperlänge $0.8 \mathrm{~mm}$.

51. D. Degeeri nov. sp.

ß. Kopf etwa um 0.4 mehr breit als lang. Körperfarbe weissgelblich, oben mit grauen Zeichnungen. Fühler um $0 \cdot 5$ länger als die Kopfbreite. Körperlänge $0.7 \mathrm{~mm}$.

52. D. saltatrix nov. sp.

16. GEN. PROSOPOTHRIPS nov. gen.
Der einzige Vertreter ist die Art:
53. P. Vejolorskýi nov. sp.

17. GEN. HELIOTHRIPS HALID.
a. Dic ganzen Beine gelblich.
54. H. haemorrhoidalis Bouché.
b. Die Mittel- und Hinterschenkel schwarzbraun.
55. H. femoralis Reut.

\section{GEN. PARTHENOTHRIPS $\mathrm{m}$.}

Der einzige Vertreter ist die Art:

56. P. Iracacnae Heeg.

\section{GEN. THRIPS (L.).}

1. Kopf deutlich mehr breit als lang.

a. Kopf nach hinten deutlich verengt (Taf. X, Fig. 172). Fühler licht, die ersten zwei Glieder, das 6. Glied in seiner zweiten Hälfte und das 7. Glied dunkel. Beine dunkel, alle Tarsen und die Vordertibien licht.

57. T. physopus L.

b. Kopf nach hinten nicht verengl. Farbe der Fühler und der Beine eine andere.

a'. Abdomen nicht auffallend breit.

a". Körperfarbe (der Weibchen) dunkel.

a”. Viertes und fünftes Fühlerglied fast gleichlang.

๙. Kiörperfarbe dunkelbraun bis schwarzbraun. Fünfles Fühlerglied dunkel oder nur am Grunde lichter. Die obere Längsader des Oberflügels hat in ihrer zweiten Hälfte gewöhnlich drei Borsten. 
$\alpha^{\prime}$. Oberflügel schwach getrübt. Beine ziemlich licht. Das 3 . Fühlerglied licht, das 4. ebenfalls licht, gegen das Ende zu getrübt.

59. T. major nov. sp.

$\beta^{\prime}$. Oberflügel stark getrübt.

๙ . Erstes Fühlerglied graı, etwas durchscheinend, die übrigen schwarzgrau, nur das 3., sein Ende ausgenommen, und das 4. am Grunde gelblich.

58. T. communis nov. sp. var. pulla.

$\beta^{\prime \prime}$. Die ersten zwei Fühlerglieder schwarz, das 3. gelb, das 4. gelb. sehr schwach getrübt, das 5. schwarz, am untersten Grunde licht. Gestalt mächtiger.

61. T. salicaria nov. sp.

3. Körperfarbe gelbbraun. Das 5. Fühlerglied licht. nur gegen das Ende zu sehr schwach grau getrübt. Die obere Längsader des Oberflügels hat in ihrer zweiten Hälfte gewöhnlich nur zwei Borsten, die auf ihrem Ende stehen.

60. T. sambuci Heeg.

b’”. Das fünfte Fühlerglied klein, bedeutend kürzer als das vierte.

๙. Körperfarbe schwarzbraun bis fast schwarz. Die zwei letzten

Abdominalsegmente sind nicht dunkler als der übrige Körper.

$\alpha^{\prime}$. Körperlänge $1.2 \mathrm{~mm}$. Das 4 . Fühlerglied licht, nur gegen das Ende zu getrübt, das 5. in der ersten Hälfte licht, in der zweiten getrübt.

62. T. valida nov. sp.

ß'. Körperlänge $0.9 \mathrm{~mm}$. Das 4. u. 5. Fühlerglied schwarzgrau.

68. T. linaria nov. sp.

3. Körperfarbe braungelb oder gelbbraun. Die zwei letzten Abdominalsegmente schwarz.

63. T. adusta nov. sp.

b". Körperfarbe licht.

a”. Die Borsten auf dem Körper auffallend dunkel.

๙. Das 5. Fühlerglied in den ersten zwei Dritteln weissgelb, im letzten Drittel plötzlich schwarzgrau; das 6. Glied schwarzgrau, am Grunde lichter. Körperlänge $1.2 \mathrm{~mm}$.

64. T. flava Schr.

३. Das 5. Fühlerglied und die folgenden ganz dunkel. Körperlänge $0.8 \mathrm{~mm}$. 
J. UZEL, MONOGRAFIE RADU "THYSANOPTERA".

$a^{\prime}$. Das 5. Fühlerglied vorn abgestutzt, so dass es sich mit breiter Fläche an das 6. anlegt.

65. T. alni nov. sp.

ß. Das 5. Fühlerglied rom 6 , getrennt. Flügel gewöhnlich rudimentär.

73. 'T. nigropilosa nov. sp.

b"'. Die Borsten auf dem Körper lichter.

๙. Die obere Lüngsader des Oberflügels ist in ihrer zweiten Hälfte mit 4 Borsten beselzt, von denen die zwei ersten und die zwei letzten einander genähert sind. Fühlerglieder ziemlich gedrungen. Körperlänge $0.8 \mathrm{~mm}$.

58. T. communis nov. sp.

ß. Die obere Längsader des Oberflügels ist in ihrer zweiten Hälfte gewöhnlich mit \& Borsten besetzt. Die drei ersten Glieder des ziemlich gedrungenen Fühlers licht, die übrigen graubraun.

69. T. minutissima L.

$\gamma$. Die obere Längsader des Oberflügels ist in ihrer zweiten. Hälfte mit 3 Borsten besetzt, von denen die eine von den übrigen zwei entfernt steht.

$a^{\prime}$. Das 5. Fühlerglied nur etwas kürzer als das 4., rorn abgestutzt, so dass es sich mit ziemlich breiter Fläche an das 6. Glied anlegt. Der Stỵlus verhältnismässig lang. Die Borsten auf dem Körper und auf den Flügeln weiss.

66. T. albopilosa nov. sp.

$\wp^{\prime}$. Das 5. Fühlerglied bedeutend kürzer als das 4, vorn schmäler. Der Stylus kürzer. - Der Körper kleiner und blasser als bei der typischen Form, oben oft grau getrübt. 64. T. flava Schr. var. obsoleta.

b'. Abdomen ungewöhnlich breit. - Körperfarbe schwarz. Fühlerfärbung graubraun, das 3. Glied gelblich. Flügel oft rudimentär. Körperlänge $0.9 \mathrm{~mm}$.

75. T. dilatata nov. sp. $\checkmark$

2. Kopf so lang als breit oder länger.

a. Vordertarsen mit einem langen Zahne bewaffnet (Taf. VI, Fig. 104).

70. T. calcarata nov. sp.

b. Vordertarsen wehrlos.

a'. Kopf und Thorax ochergelb bis braungelb, das ganze Abdomen schwarz. 
H. UZEL, MONOGRAPHIE DER ORDNUNG THYSANOPTERA.

b'. Körperfarbe graubraun bis schwarz.

$a$ ". Körper mächtig, $1.3 \mathrm{~mm}$ lang. Augen hervorgequollen (Taf. VI, Fig. 107). Fühler lang. Mitteltibien in der ersten Hälfte schwarzbraun, in der zweiten Hälfte gelblich; Hintertibien ganz schwarzbraun, nur ihre Spitzen gelblich.

76. T. Klapáleki nov. sp.

b". Körper schwächer, nur $0.7-0.9 \mathrm{~mm}$ lang. Augen nicht hervorgequollen.

a”. Die obere Längsader des Oberflügels in ihrer zweiten Hälfte gegen das Ende zu mit 5 Borsten. Kopf klein, nach vorn etwas verengt (Taf. VI, Fig. 101). Flügel manchmal verkümmert.

67. T. angusticeps nov. sp.

b"'. Die obere Längsader des Oberflügels in ihrer zweiten Hälfte mit 3 Borsten, von denen eine von den übrigen zwei entfernt steht.

. Das 5. Fühlerglied nur etwas kürzer als das 4. Körperlänge $0.9 \mathrm{~mm}$.

71. T. viminalis nov. sp.

3. Das 5. Fühlerglied bedeutend kürzer als das 4. Prothorax im Verhältnis zum Kopfe länger als gewöhnlich.

72. T. longicollis nov. sp.

Zu dieser Gattung gehört auch die mir unbekannte Art: T. fuscipennis Halid. Sieh deren Beschreibung auf S. 204.

20. GEN. BALIOTHRIPS $m$,

Der einzige Vertreter ist die Art:

78. B. dispar Halid.

21. GEN. SMINYOTHRIPS nov. gen.

a. Zähne am Ende der Vordertibien klein (Taf. VII, Fig. 110). Körperfarbe graugelb. Körperlänge $0.8 \mathrm{~mm}$.

79. S. biunciuata nov. sp.

b. Zähne am Ende der Vordertibien gross und stark (Taf. VII, Fig. 111). Körperfarbe dunkel gelbgrau. Körperlänge $1 \mathrm{~mm}$.

80. S. biuncata nov. sp.

22. GEN. STENOTHRIPS nov. gen.

Der einzige Vertreter ist die Art:

81. S. graminum nov. sp. 
23. GEN. BOLACOTHRIPS nov, gen.

Der einzige Vertreter ist die Art:

82. B. Jordani nov. sp.

24. GEN. DREPANOTRHIPS nov, gen.

Der einzige Vertreter ist die Art:

83. D. Reuteri nov. sp.

\section{GEN. PLATYTHRIPS $\mathrm{m}$.}

Der einzige Vertreter ist die Art:

84. P. tunicata Halid.

26. GEN. MEGALOTHRIPS $\mathrm{m}$.

a. Körperlänge $2 \cdot 5-3 \mathrm{~mm}$. Alle Tibien braungelb.

96. M. lativentris Heeg.

b. Körperlänge $4 \mathrm{~mm}$. Alle Tibien schwarz.

97. II. Bonannii nov. sp.

\section{GEN. CRYPTOTHRIPS $\mathrm{m}$.}

a. Prothorax dunkel.

$a^{\prime}$. Die Seiten des Kopfes fast parallel.

a. Kopf um 0.4 mehr lang als breit. Fühler um 0.6 länger als der Kopf. - Der Körper sehr breit (Taf. III, Fig. 24) Fühler schwarz, das 3. Glied gelb. Prothorax fast um 0.5 kürzer als der Kopf. Beine schwarz, nur die Tarsen schwarzbraun.

99. C. lata nov. sp.

3. Kopf zweimal so lang als breit. Fühler nur wenig länger als der Kopf.

98. C. nigripes Reut.

$b$. Kopf hinten verengt.

$a$ ". Das 4. Fühlerglied dunkel.

ж. Kopf fast um 0.5 mehr lang als breit. Körper schmal (Taf. VII, Fig. 123). - Fühler schwarz, das 3. Glied gelbbraun, das 4. um 0.3 länger als das 3. Prothorax um 0.4 kürzer als der Kopf. Beine schwarz, alle Tarsen und die Enden der Tibien gelb. Körperlänge $1 \cdot 6 \mathrm{~mm}$.

100. C. angusta nov. sp.

ß. Kopf nur etwa um 0.2 mehr lang als breit (Taf. IV, Fig. 33).

102. C. dentipes Reut. 
b". Das 4. Fühlerglied gelb, nur am Ende getrübt. - Kopf um 0.3 mehr lang als breit. Prothorax um 0.3 kürzer als der Kopf. Beine dunkelbraun, Tarsen, Schenkel und Tibien gegen das Ende zu lichter, oder die ganzen Beine sehr licht. Flügel rollkommen fehlend. Abdomen vor dem Ende erweitert. Körperlänge $2 \mathrm{~mm}$.

101. C. Tearus nov. sp.

b. Prothorax braungelb, der übrige Körper schwarz.

103. C. bicolor Heeg.

\section{GEN. ANTHOTHRIPS $m$.}

a. Tubus um 0.2 kürzer als der Kopf, fast überall gleich breit (Taf. VII, Fig. 129). Flügel mehr oder weniger graubraun getrübt. Körperfarbe glänzend schwarz.

104. A. statices Halid.

b. Tubus um 0-26 kürzer als der Kopf, gegen den Grund zu bedeutend erweitert. Flügel hell. Körperfarbe glänzend schwarz.

105. A. distinguenda nov. sp.

c. Tubus um 0.4 kürzer als der Kopf, am Grunde bedeutend erweitert (Taf. VII, Fig. 131). Flügel hell. Körperfarbe schwarzbraun bis rothbraun.

106. A. aculeata Fabr.

29. GEN. ZYGOTHRIPS nov. gen.

Der einzige Vertreter ist die Art:

108. Z. minuta nov. sp.

\section{GEN. CEPHALOTHRIPS $\mathrm{m}$.}

Der einzige Vertreter ist die Art:

109. C. monilicornis Reut.

\section{GEN. TRICHOTHRIPS $\mathrm{m}$.}

a. Fühler mehr als zweimal so lang als der Kopf. Das 1. Fühlerglied licht. Körperlänge höchstens $1.4 \mathrm{~mm}$.

a'. Körperlänge der Weibchen nur $0.9 \mathrm{~mm}$. Kopf gelb, der übrige Körper dunkelbraun. Der Saugrüssel reicht nur etwa bis zur Nitte des Prosternum. Rasenbewohner.

111. T. caespitis nov. sp.

b'. Körperlänge der Weibchen etwa $1.4 \mathrm{~mm}$. Der Saugrüssel reicht bis zum Hinterrand des Prosternum. Rindenbewohner. 
a. Tubus licht, manchmal in der Mitte sehr schwach getrübt. Abdomenende gelb. Kopf oft licht. $\quad$ 110. T. pedicularia Halid.

ß. Tubus, der Grund ausgenommen, schwarz. Prothorax dunkler als der übrige Körper, welcher graugelblich ist.

112. T. semicacea nov. sp.

b. Fühler fast zweimal so lang als der Kopf. Das 1. Fühlerglied sehr dunkel. Körperlänge bedeutend grösser. Rindenbewohner.

a'. Alle Schenkel graubraun. Alle Tibien ganz gelb. Larven weiss, fein roth gesprenkelt.

115. T. copiosa nov. sp.

b. Alle Schenkel schwarzbraun. Vordertibien ganz gelb, Nittel- und Hintertibien schwarzbraun, auf beiden Enden braungelb.

a. Flügel, wenn ausnahmsweise vorhanden, schwach getrübt. Larven weiss.

113. T. ulmi Halid.

ß. Flügel, wenn ausnahmsweise vorhanden, stark getrübt. Körperlänge etwas grösser. Vorderschenkel, hauptsächlich die der Männchen, breiter. Larven weiss, fein roth gesprenkelt. 114. T. pini Halid.

\section{GEN. PHLOEOTHRIPS HALID.}

a. Körperlänge $2 \cdot 3-3 \mathrm{~mm}$. Vordertarsen bei beiden Geschlechtern mit starkem Zahne (Taf. IV, Fig. 29).

116. Phl. coriacea Halid.

b. Körperlänge $1 \cdot 3-1 \cdot 7 \mathrm{~mm}$. Vordertarsen der Weibchen mit einem sehr kleinen scharfen Zähnchen.

a'. Das 3. Fühlerglied länger als die zwei ersten zusammen (Taf. VII, Fig. 143). Tibien schwarzbraun, ihre Enden gelb. Körperlänge $1.7 \mathrm{~mm}$.

117. Phl. minol nov. sp.

b'. Das 3. Fühlerglied kürzer als die zwei ersten zusammen.

๙. Vordertibien gelb. Körperlänge $1.3 \mathrm{~mm}$.

118. Phl. parva nov. sp.

ß. Vordertibien braunschwarz, auf beiden Enden gelb. Körperlänge $1.6 \mathrm{~mm}$.

119. Phl. annulipes Reut.

33. GEN. ACANTHOTHRIPS $m$.

Der einzige Vertreter ist die Art:

120. A. nodicornis Reut. 
H. UZEL, MONOGRAPHIE DER ORDNUNG THYSANOPTERA.

\section{GEN. LIOTHRIPS m.}

a. Fühler gelb, ihr erstes und letztes Glied dunkel. Kopf um $0 \cdot 2$ mehr lang als breit.

122. I. setinodis Reut.

b. Alle Fühlerglieder, das 3. ausgenommen, theilweise oder ganz dunkel. Kopf fast um 0.3 mehr lang als breit. Vordertibien ganz gelb, Mittel- und Hintertibien schwarz, auf dem Ende plötzlich gelb.

121. I. hradecensis nov. sp.

35. GEN. POECILOTHRIPS nov. gen.

Der einzige Vertreter ist die Art:

123. P. albopicta nov. sp. 


\section{Subordo TEREBRANTIA Halid.}

Tỵkadla šesti- až devítičlenná. Makadla maxillarní dvoučlenná, někdy třičlenná; makadla labialní dvoučlenná. zřídka ětyručlenná. Očka jsou obyčejně prítomna, často ršak scházejí bud' oběma pohlavím téhož druhu, neb jen samcủm. Prothorax obyčejnè vzadu sotva širší neż v předu; jen rýjimkou nazad značněji se rozširuje. Přední nohy jsou často širší než ostatní; zadní jsou nejdelší. Hořejší kř́idla širší, tužší a tmavèji zbarvená než dolejší. Oba páry krídel mají na zadním okraji dlouhé tenké třásně. Hořejši krǐidla mají na předním okraji kromě trásní ješlě kratši a silnější brvy; někdy scházejí tam trísně, jindy brvy, a někdy schází oboje. Dolejši křídla opatřena jsou na předním okraji krátkỵmi rídkỵ́mi rlásky. Hoìejši liřídlo má kromè žilky okružní, obrubující je kol do kola, ješlě dvě žilky podélné; dolejši pak nemá žilky okružní a prostoupeno jest jedinou žilkou podélnou (rýjimkou dvẽma), ktelá ršak mủže také scházeti. V klidu leží hořejší křídla na tẽle vedle sebe. často ke konci od sebe se vzdalujice Pod každţm hořejším leží, úplně jím skryto, príslušné křídlo dolejši. Kirídla často zakrñuji. Poslední článek abdomenu jest velmi zřídka rourovitý; obyčejně má podobu kužele; u samcủ jest abdomen tupý. Otror pohlavní nalézá se u samic mezi osmým a devátým ěl. abdonenu, u samců však mezi článkem devátỵm a desátỵm. Samice mají kladélko pozủstávající ze ètyř chlopní, z nichž dvẽ ryrůstají z osmého článku abdominalního, dvě pak z článku devátého. V klidu jest tento přistroj ukryt v pochvě, nalézajíci se na ventralní stranẽ tří posledních ċlánkủ abdomenu. Pyjový apparat, je-li vychlípen, pìečnívá abdomen a jest nahoru ohnut. Tèlo jest válcovité, zřídka ponèliud sploštilé; abdomen na basi trochu zúžený. Samci jsou menší, užší a často světlejší než samice. Pohỵby třásněnek, do tohoto podruádu náležejících, jsou obyčejně čilé, někdy neunavné, někdy však též velmi volné. Mnohé jsou způsobilé ke skákání.

Poznámka. Samce rozeznáme od samice dle nedostatku kladélka, dle menšich rozměrû těla, dle tupého zakončeni abdomenu (Tab. I., fig. 2. a 6.; Tab. X., fig. 172.). dle zbarvení často svěllejšího a dle pohỵbů čilejších.

Fühler sechs- bis neungliedrig. Maxillartaster zweigliedrig, manchmal dreigliedrig; Labialtaster zwei-, selten viergliedrig. Ocellen gewöhnlich vorhanden, oft jedoch beiden Geschlechtern derselben Art oder nur den Männchen fehlend. Prothorax gewöhnlich 
hinten kaum breiter als vorn und nur ausnahmsweise nach hinten stärker verbreitert. Vorderbeine oft breiter als die übrigen; Hinterbeine am längsten. Oberflügel breiter, steifer und dunkler gefärbt als die Unterflügel. Beide Flügelpaare am Hinterrande mit langen dümnen Fransen versehen. Die Oberflügel haben am Vorderrande ausser den Fransen noch kürzere und stärkere Wimpern; manchmal fehlen hier die Fransen, manchmal die Wimpern und manchmal beides. Die Unterflügel tragen am Vorderrande kurze dünn stehende Härchen. Der Oberflügel hat ausser der Ringader, welche den Flügel ringsherum umsäumt, noch zwei Längsadern. Der Unterflügel hat keine Ringader und wird nur von einer (ausnahmsweise zwei) Längsader durchzogen, welche jedoch auch fehlen kann. In der Ruhe liegen die Oberflügel am Körper neben einander, nur gegen das Ende zu oft von einander entfernt. Unter jedem Oberflügel liegt, vollkommen durch ihn verdeckt, der bezügliche Unterflügel. Die Flügel verkümmern oft. Das letzte Abdominalsegment ist sehr selten röhrig; gewöhnlich ist es kegelförmig; bei den Männchen ist das Abdomen stumpf. Die Geschlechtsöffnung befindet sich bei den Weibchen zwischen dem 8. und 9., bei den Männchen jedoch zwischen dem 9. und 10. Abdominalsegment. Die Weibchen haben eine Legeröhre, aus vier Klappen zusammengesetzt, von welchen zwei dem 8 . und zwei dem 9. Abdominalsegment angehören. In der Ruhe ist dieser Apparat in einer auf der Ventralseite der letzten drei Abdominalsegmente befindlichen Scheide verborgen. Der ausgestreckte Pennisapparat überragt die Abdomenspitze und ist aufwärts gebogen. Körper cylindrisch, selten etwas abgeplattet; das Abdomen an der Basis ein wenig verengt. Die Männchen sind kleiner, schmäler und oft lichter als die Weibchen. Die Bewegungen der in diese Unterordnung gehörenden Thysanopteren sind gewöhnlich rasch, manchmal unermüdlich, bisweilen auch sehr langsam. Viele besitzen ein Springvermögen.

Bemerkung. Die Männchen unterscheiden sich von den Weibchen durch den Mangel des Legebohrers, durch kleinere Körperdimensionen, durch ein stumpfes Abdomenende (Taf. I, Fig. 2 u. 6; Taf. X, Fig. 172) und oft durch lichtere Färbung und raschere Bewegungen.

\section{FAM. Aeolothripidae. (= COLEOPTRATA HALID.)}

Tykadla jsou devítičlenná. Makadla maxillarní vždy třičlenná, třetí ělánek jejich obyčejně velmi krátký; makadla labialní obyčejně čtyřčlenná, někdy dvoučlenná. Křídla široká, na konci zaokrouhlená. Přední okraj hořejších křídel nemá nikdy třásní a jest bud opatřen velmi malými chloupky, takže se zdá, že jest úplně holým, aneb má krátké silné brvy. Obě žilky podélné $\mathrm{v}$ hořejším krídle vznikaji z kořene jeho. Podélné žilky mezi sebou a s okružní žilkou spojeny jsou v celku čtyřmi až pěti žilkami přičnými. 


\section{J. UZEL. MONOGRAFIE RADU "THYSANOPTERA“.}

Dolejši kirídlo nemá žilek vủbec a jen na jeho basi shlédáváme zbytek žilky podélné. KKladélko samic jest nahoru prohnuté. Samci mají proý článek abdom. prodloužený. Druhy sem náležejicí nemají způsobilosti ku skákání.

Fühler neungliedrig. Maxillartaster immer dreigliedrig, ihr drittes Glied gewöhnlich sehr kurz; Labialtaster gewöhnlich vier-, manchmal zweigliedrig. Flügel breit, am Ende abgerundet. Oberflügel am Vorderrande stets ohne Fransen und entweder mit sehr kleinen Härchen besetzt, so dass er ganz kahl zu sein scheint, oder mit kurzen, starken Wimpern versehen. Beide Längsadern im Oberflügel entspringen aus seiner Wurzel. Die Längsadern werden mit einander und mit der Ringader im ganzen durch vier bis fünf Queradern verbunden. Unterflügel ohne Adern überhaupt; nur an seiner Basis ein Überbleibsel von einer Längsader. Der Legebohrer der Weibchen ist aufwärts gebogen. Die Männchen haben das erste Abdominalsegment verlängert. Die her gehörigen Arten haben kein Springvermögen.

\section{GENUS MELANOTHRiPS HALID.*)}

Hlava o něco širší než delší. Očka u obou pohlaví přítomna. Třetí článek tykadel sotva delší než druhý; poslední články nesrostlé. Makadla maxillarní o trech skoro stejnè dlouhỵch ěláncích; makadla labialní o dvou ěláncích, z nichž záliladní jest velmi nízký. Prothorax as tak dlouhý jako hlava. Přední rohy jeho maji po jedðom dlouhém chlupu; na zadních jest po dvou takovỵch chlupech, a zadní jeho okraj nese několik brv. Nohy jsou dlouhé, přední nejsilnější; jejich fermora zxlášlè stlustlá. Přední tibie ukončeny jsou dole u obou pohlaví velmi silným zubovitým výběžkem. Kîídla jsou u samic i samců prítomna a velmi široká. Hořejší pár má kromě žilky okružní dvě žilky podélné, které vycházejí z base kǐídla a ústí před koncem jeho do žilky okružní. Spojeny jsou před prostředkem kî́ídla krátkou žilkou přični. Hořejší žilku podélnou spojují s přední částí žilky okružní dvě žilky přičné, a to na konci prvé třetiny délky křídla a na konci druhé třetiny. Pod nimi nalézají se na zadní části křídel dvě značnè slabši žilky přičné, které spojuji dolejší žilku podélnou se zadní části žilky okružní. Pr̃ední okiaj hoř. křídla má tuhé brvy. Hořejší křídla jsou stejnoměrně žlutavě zkalená, dolejší skoro čirá. Samci maji pruni článek abdom. skoro sedmkrát delši než druhý a nahoře dvěma podélnými kýly opatřený; 9. článek není nijak vyzbrojen.

Kopf etwas breiter als lang. Ocellen bei beiden Geschlechtern vorhanden. Drittes Fühlerglied kaum länger als das 2.; die letzten Glieder nicht zusammengewachsen. Naxillartaster aus drei fast gleichlangen Gliedern zusammengesetzt; Labialtaster aus zwei

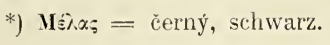




\section{H. UZEL, MONOGRAPHIE DER ORDNUNG THYSANOPTERA.}

Gliedern bestehend, von denen das basale sehr niedrig ist. Prothorax etwa so lang wie der Kopf. Seine Vorderecken mit einer langen Borste, seine Hinterecken mit zwei solchen Borsten und sein Hinterrand mit einigen Wimpern versehen. Beine lang, die vorderen am stärksten; hauptsächlich ihre Schenkel verdickt. Vordertibien am Ende unten bei beiden Geschlechtern mit einem starken zahnförmigen Fortsatz versehen. Flügel bei den Weibchen und Männchen vorhanden und sehr breit. Das obere Flügelpaar hat ausser der Ringader zwei Längsadern, welche aus der Basis des Flügels entspringen und vor seinem Ende in die Ringader münden. Sie sind vor der Flügelmitte durch eine kurze Querader verbunden. Die obere Längsader verbinden mit dem vorderen Theil der Ringader zwei Queradern, und zwar am Ende des ersten und zweiten Drittel der Flügellänge. Darunter befinden sich aü der hinteren Seite der Flügel zwei bedeutend schwächere Queradern, welche die untere Längsader mit dem hinteren Theil der Ringader verbinden. Der Vorderrand des Oberflügels trägt starke Wimpern. Die Oberflügel sind gleichmässig gelblich getrübt, die Unterflügel fast klar. Beim Männchen ist das erste Abdominalsegment fast siebenmal so lang als das zweite und oben mit zwei Längsleisten versehen; das 9. Abdominalsegment ist nicht bewaffnet.

\section{Melanothrips fusca Sulz.*)}

Tab. V., fig. 34.-41.

1776. Thrips fuscus Sulzer, Abgek. Geschichte d. Insecten, pag. 112.; fig. 12. 1788. - fusca Gmelin, Caroli a Linné Systema Nat., pag. 2223.

1836. Melanthrips obesa Haliday, F.ntomological Magazine, pag. 450.

1836. Melanothrips - Burmeister, Handb. d. Entomologie, II, pag. 417.

1843. - - Amyot et Serville, Ins. Hémiptères, pag. 645.

1852 Melanthrips - Haliday, Walker: Homopt. ins. of Brit. Museum, pag. 1116.; tab. V., fig. 12. et 13 .

1852. Melanothrips obesa Heeger, Sitzb. Akad. Wiss. Wien, VIII, pag. 133.; tab. XX.

$$
\text { q. }
$$

Barva těla šedohnědá neb tmavě červenohnědá, jindy černohnědá až černá. Zřídka jsou hlava a thorax šedě žlutavohnědé a abdomen světle šedožlutavý. První čl. tykadel značně kratši než 2.; tento nemnoho širší než následujici články; 3 . čl. má krátkou, velmi úzkou stopku a jest sotva delší než $2 . ; 3 ., 4$. a 6 . èl. skoro stejnè dlouhé, 5. trochu kratší a užší 6. mezi sousedními články nejširši; 7. značně kratší než předcházejíci; 8. a 9. malé, dohromady as tak dlouhé jako 3.; poslední trochu delši než pred-

*) Doklad nalézá se ve sbirce Musea královstvi Českého, praep. č. 1. - Sammlung des böhmischen Landesmuseums, Praep. Nr. 1. 


\section{J. UZEL, MONOGRAFIE RADU „THYSANOPTERA“.}

poslední. Barva tykadel šedo- neb černohnědá, 3. čl. žlutý, slabě šedě zkalený. Prothorax má rohy zaokrouhlené. Pterothorax značně širši a delši než prothorax. K zubovitému vỵ́běžku předních tibii přiléhá na basi z každé strany malý lupínek. Na konci zadních tibií jsou silné ostny. Barva noh černohnědá až černá. Přední tibie žluté, často slabě šedě zkalené, vně a uvnitř úzce černé; přední tarsy žluté, často slabě zkalené. Tarsy ostatních noh tmavé. Podélné žilky $\mathrm{v}$ hoř. křídle jsou po celé délce tuhými chlupy posety; příčné žillky nahé. Hoř. kř́ídlo jest stejnoměrně žlutavošedě zkaleno, žilky jeho jsou tmavější; dolejší jest skoro čiré, jen na samém konci někdy velmi slabě šedě zkalené. Abdomen na konci tenkými dosti dlouhými chlupy opatřen. Prrní ěì jeho skryt jest v hrudi. Délka tèla $1 \cdot 1 \mathrm{~mm}$.

\section{$\sigma^{\top}$ (dosud nepopsaný).}

Jest světlejší, značně menší a užší ně̌ $\nmid$. Hlava a prothorax šedohnědé, pterothorax tmavě žlutavošedý, abdomen téže barvy, na konci šedohnědý. Tykadla, nohy a kîídla jsou podobně zbarveny jako u $\supsetneq$; jen tibie na samém konci a strední i zadní tarsy jsou そ̌lutavé, těmně šedě zkalené.

Obẽ pohlaví této třásněnky vyskytuji se u nás v květnu v různých květech, zvláště pak v Cerastium arvense a Polygala vulgaris.

Čechy: Hradec Králové. Zde nalezl jsem ji jen r. 1888., a sice v dosti značném množství. Od té doby jsem ji tan již neviděl. Milešovka. Lovosice. — Na Helgolandě sbíral jsem nèkolik exemplářů v srpnu.

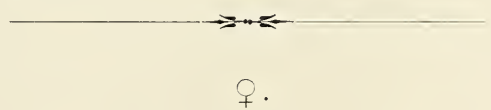

Körperfarbe graubraun oder dunkel rothbraun, manchmal schwarzbraun bis schwarz. Selten ist der Kopf und der Thorax grau gelblichbraun und das Abdomen licht graugelblich. Das erste Fühlerglied bedeutend kürzer als das 2.; dieses nicht viel breiter als die folgenden Glieder; das 3 . hat einen kurzen, sehr schmalen Stiel und ist kaum länger als das 2.; das 3., 4. und 6. fast gleichlang, das 5. etwas kürzer und schmäler; das 6. ist unter den Nachbargliedern das breiteste; das 7. bedeutend kürzer als das vorgehende; das 8. u. 9. klein, zusammen etwa so lang wie das 3.; das letzte etwas länger als das vorletzte. Farbe der Fühler grau- oder schwarzbraun; das 3. Glied gelb, schwach grau getrübt. Der Prothorax hat abgerundete Ecken. Der Pterothorax ist bedeutend breiter und länger als der Prothorax. An den zahnförmigen Fortsatz der Vordertibien legt sich am Grunde jederseits ein kleines Blättchen an. Am Ende der Hintertibien stehen starke Stachel. Farbe der Beine schwarzbraun bis schwarz. Vordertibien gelb, oft swach grau getrübt, aussen und innen schmal schwarz; Vordertarsen gelb, oft schwach getrübt. Tarsen der übrigen Beine dunkel. Längsadern im Oberflügel der ganzen 


\section{H. UZEL, MONOGRAPHIE DER ORDNUNG THYSANOPTERA.}

Länge nach mit steifen Borsten besetzt; Queradern nackt. Oberflügel gleichmässig gelblichgrau getrübt, die Adem dunkler; Unterflügel fast klar, nur am äussersten Ende manchmal sehr schwach grau getrübt. Abdomen am Ende mit dünnen ziemlich langen Borsten versehen. Sein erstes Segment im Thorax verborgen. Körperlänge $1.1 \mathrm{~mm}$.

ð (noch unbeschrieben).

Lichter, bedeutend kleiner und schmäler als das $q$. Kopf und Prothorax graubraun, dieser dunkel gelblichgrau; Abdomen ebenso gefärbt, am Ende graubraun. Fühler, Beine und Flügel sind von ähnlicher Färbung wie beim Weibchen, nur sind die Tibien am äussersten Ende und die Mittel- und Hintertarsen gelblich, düstergrau getrübt.

Vork ommen: Im Mai ( $\sigma^{\jmath}$ u. $\left.\subsetneq\right)$ in verschiedenen Blüten. - Fundor te: England (Haliday), Wien (Heeger), Böhmen, Helgoland (Uzel).

\section{GENUS RHIPIDOTHRIPS. (Nov. gen.)*)}

Hlava značně delší než širší. Očka u obou pohlaví přítomna. Tři poslední články tỵkadel tvorí dohromady celek; třetí článek velmi dlouhý. Makadla maxillarní o třech článcích, z nichž poslední jest překrátký; makadla labialní o čtyrech článcích. Prothorax trochu kratši neż hlava. Přední jeho rohy jsou bez dlouhých chlupủ, zadní mají po jednom dlouhém chlupu, a zadní okraj jeho poset jest kromě toho dosti dlouhými brvami. Přední femora u obou pohlaví značně stlustlá; přední tibie bez zabủ, za to však má druhý článek předního tarsu u samcủ i samic dva malé háčky. Křídla u obou pohlaví prítomna. Tvar a žilkovatost jejich jako u rodu předcházejícího; oba páry zúžuji se však poněkud směrem ke kořenu, a přičná žilka, spojující dolejší žilku podélnou se zadní částí žilky okružní v prvé třetině její délky, schází. Přední část žillky okružní opatřena jest v prvé třetině krííla krátkými chloupky, přes okraj křílla nemnoho odstávajícími. Za prvou třetinou mění se tyto chloupky v krátké brvy. Oba páry křídel jsou čiré. Samei mají první článek abdom. sice delší než druhý, ale daleko ne tak veliký jako u rodu předcházejícího; 9. čl. má vzadu po každé straně nepatrný hrbolek.

Kopf bedeutend länger als breit. Ocellen bei beiden Geschlechtern vorhanden. Die drei letzten Fühlerglieder bilden zusammen ein Ganzes; das 3. Glied sehr lang. Maxillartaster aus drei Gliedern bestehend, von denen das letzte überaus kurz ist; Labialtaster viergliedrig. Prothorax etwas kürzer als der Kopf. Seine Vorderecken ohne lange Borsten, seine Hinterecken mit je einer langen Borste und sein Hinterrand ausserdem mit ziemlich langen Wimpern. Vorderschenkel bei beiden Geschlechtern bedeutend verdickt, Vorder-

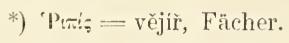




\section{J. UZEL, MONOGRAFIE RADU, "THYSANOPTERA“.}

tibien ohne Zahn; dafür hat jedoch das zweite Glied des Vordertarsus bei den Männchen und Weibchen zwei kleine Häckchen. Flügel bei beiden Geschlechtern vorhanden. Form und Äderung derselben wie bei dem vorhergehenden Genus, beide Paare jedoch etwas gegen den Grund verengt, und die Querader, welche die untere Längsader mit dem hinteren Theil der Ringader im ersten Drittel seiner Länge verbindet, fehlt. Der vordere Theil der Ringader ist im ersten Drittel mit kurzen Härchen besetzt, welche vom Flügelrand nicht viel abstehen. Hinter dem ersten Drittel werden diese Härchen zu kurzen Borsten. Beide Flügelpaare sind klar. Die Männchen haben das erste Abdominalsegment zwar länger als das zweite, aber weit nicht so lang wie bei dem vorhergehenden Genus; das 9. Segment jederseits mit einem kleinen Höcker versehen.

\section{Rhipidothrips gratiosa nov. sp.*)}

Tab. V., fig. 42 . et 43 .

f.

Hlava jest nejtmavší cástí celého těla. Jest tmavě šedohnědá. Prothorax jest žlutavý nebo bělavý a má nahoře rozvětvenou, všelijak utvořenou kresbu, pterothorax jest žlutavošedý, abdomen žlutavý, slabě šedè zkalený, na konci šedohnèdý. Hlava jest vzadu poněkud stažená. První dva články tykadel nejtlustší; 1. ěl. značně kratší než 2., 3. čl. jest nejtenčí a nejdelší; jest delší než prvé dva články dohromady; 4. čl. kratší než třetí a tlustší, zvláště ke konci; 5. trochu kratší než 4.; 6. trochu kratší a tlustší než $5 . ;$ 7. opět trochu kratší než 6. a o něco delší než poslední dva dohromady. Barva tykadel: 1. čl. černošedý, 2., 3. a 4. bílé, 3. nahoře ke konci úzce černošedě zkalený, 4. nahoře celý úzce černošedý; う. a ostatní černošedé. Pterothorax značně širší a delší než prothorax. Ke dvěma háčkủm, na druhẻm čl. předního tarsu se nalézajícím, sklání se několik chlupů. Barva noh jest šedohnědá, konce a kořeny všech stehen a středních i zadních tibií, pak všecky tarsy žlutavé. Přední tibie jsou žlutavé a vně (někdy slabě též uvnitř) šedohnědě zkalené. Podélné žilky $\mathrm{v}$ hoř. křídle jsou celé chlupy posety; přiecné jsou nahé. Žilky $\mathrm{v}$ hořejších křídlech jsou slabě žluté a zadní část žilky okružní jest šedá. Chlupy na konci abdomenu jsou dlouhé a čiré. Délka těla $1 \cdot 4-1 \cdot 6 \mathrm{~mm}$. Dosti značné množství exemplářů nalezeno.

\section{$\sigma^{\top}$.}

Jest značně menší a užší než + . Zbarvení těla, noh a tykadel totéž jako u ní. První článek abdomenu opatřen jest dvěma podélnými lištnami. - Tř̀i exempláre objeveny.

*) Doklad ve sbírce musejní, praep. č. 2. - Sammlung des böhmischen Landesmuseums, Praep. Nr. 2. 


\section{H. UZEL, MONOGRAPHIE DER ORDNUNG THYSANOPTERA.}

Třásněnku tuto nalezl jsem v červnu $\mathrm{v}$ obou pohlavích $\mathrm{v}$ květech zahradních. Jednoho samce vyklepal jsem z květenství nějaké trávỵ.

Čechy: Praha: V lese mezi Krči a Kundraticemi. Hradec Králové: Ve Věkoši.

f.

Der Kopf ist der dunkelste Theil des ganzen Körpers. Er ist dunkel graubraun. Prothorax gelblich oder weisslich, oben mit einer verästelten, verschieden geformten Zeichnung, Pterothorax gelblichgrau, Abdomen gelblich, schwach grau getrübt, am Ende graubraum. Kopf hinten etwas verengt. Die ersten zwei Fühlerglieder am dicksten; das 1. bedeutend kürzer als das 2., das 3. am dünnsten und am längsten, länger als die ersten zwei Glieder zusammen; das 4. Glied kürzer und dicker als das 3. und zwar hauptsächlich gegen das Ende zu; das 5. etwas kürzer als das 4.; das 6. etwas kürzer und dicker als das 5.; das 7. wieder etwas kürzer als das 6. und um etwas länger als die lezten zwei zusammen. Fühlerfärbung: 1. Glied schwarzgrau, 2., 3. u. 4. Glied weiss, das 3. oben gegen das Ende zu schmal schwarzgrau getrübt, das 4. oben ganz schwarzgrau; das 5. und die übrigen schwarzgrau. Pterothorax bedeutend breiter und länger als der Prothorax. Zu den zwei Häckchen, welche sich am zweiten Vordertarsusglied befinden, neigen sich einige Borsten. Farbe der Beine graubraun, die Enden und Wurzeln aller Schenkel und der Mittel- und Hintertibien, dann alle Füsse gelblich. Vordertibien gelblich und aussen (manchmal schwach auch innen) graubraun getrübt. Die Längsadern im Oberflügel ganz mit Borsten besäet; die Queradern nackt. Adern im Oberflügel lichtgelb und der hintere Theil der Ringader grau. Borsten am Ende des Abdomen lang und hell. Körperlänge $1 \cdot 4-1 \cdot 6 \mathrm{~mm}$.

ऽ.

Bedeutend kleiner und schmäler als das $q$. Farbe des Körpers, der Beine und der Fühler dieselbe. Erstes Abdominalsegment mit zwei Längsleisten versehen.

Vorkommen: Im Juni in Gartenblumen und Grasblüten. — F undort: Böhmen.

\section{GENUS AEOLOTHRIPS HALID.*)}

Hlava as tak široká jako dlouhá. Očka u obou pohlaví přítomna (u bezkřídlé formy druhu albocincta Halid. nápadně maličká). Tykadla devítičlenná, 5.-9. čl. tvoří dohromady celek; 3. čl. velmi dlouhý. Makadla maxillarní a labialní jako u rodu predcházejíciho. Prothorax as tak dlouhý jako hlava, neb o málo delší, bez větších chlupů; zadní okraj jeho poset jest obyčejně mnohými, velmi krátkými osténky. Nohy jsou ne-

*) Aickos $=$ hbitý, behend. 


\section{J. UZEL, MONOGRAFIE RADU, „THYSANOPTERA“.}

obyčejně dlouhé, prední nejsilnější; přední femora jsou u obou pohlaví značnè stlustlá a mimo to femora zadních noh jsou rozšířená. Přední tibie jsou bezbranné. Druhý článek předního tarsu má u obou pohlaví podobné dva háčky, jako je nalézíme u rodu předcházejícího. Kǐ́ídla obyčejně u samcủv i samic př́tomna, u druhu Ae. albocincta však scházejí, a to u samic obyčejně, u samcủ vždy; v tomto případě pak jest pterothorax značně menší a užší než u formy okrídlené. Tvar a žilkovatost křídel jako u rodu předcházejicího, jen hořejší jsou před polovinou trochu zúžená. Přední část žilky okružní opatřena jest velice krátkými chloupky, okraj krííla sotva přesahujícími. Hořejší krí́dla jsou bílá a maji tmavé stuhy. První článek abdom. u samců podobně utvořen jako u rodu předcházejícího. Devátý článek abdom. má někdy po obou stranách dvouhrotý výtvor přidržovací, jindy jest nevy̧zbrojený.

Kopf etwa so breit als lang. Ocellen bei beiden Geschlechtern vorhanden (bei der flügellosen Form der Art Ae. albocincta winzig). Fühler neungliedrig, das 5.-9. Glied bilden zusammen ein Ganzes; 3. Glied sehr lang. Maxillar- und Labialtaster wie bei dem vorhergehenden Genus. Prothorax etwa so lang wie der Kopf, oder wenig länger, ohne grössere Borsten; sein Hinterrand gewöhnlich mit vielen, sehr kurzen Stachelchen versehen. Beine sehr lang, die vorderen am längsten; Vorderschenkel bei beiden Geschlechtern bedeutend verdickt und ausserdem die Hinterschenkel erweitert. Vordertibien unbewaffnet. Das zweite Vordertarsusglied hat bei beiden Geschlechtern ähnliche zwei Häckchen wie bei dem vorhergehenden Genus. Flügel gewöhnlich bei den Männchen und Weibchen vorhanden; bei der Art Ae. albocincta jedoch fehlend, und zwar bei den Weibchen gewöhnlich, bei den Männchen immer; in diesem Falle ist der Pterothorax bedeutend kleiner und enger als bei der geflügelten Form. Gestalt und Äderung der Flügel wie bei der vorhergehenden Gattung, nur die oberen vor der Mitte etwas verengt. Der vordere Theil der Ringader mit äusserst kurzen Härchen versehen, die den Flügelrand kaum überragen. Oberflügel weiss und schwarz gebändert. Erstes Abdominalsegment beim Männchen ähnlich gebildet wie bei der vorigen Gattung. Das neunte Abdominalsegment hat manchmal jederseits ein zweizinkiges Anhalteorgan (bei der Begattung), manchmal entbehrt es jedoch eines solchen.

\section{Acolothrips versicolor nov. sp.*)}

Tab. V., fig. 44.

f.

Hlava, prothorax a mesothorax červenohnědé, metathorax a abdomen žlutavé, tento na konci šedohnědý. Hlava do předu zúžená, mezi očima týmž směrem prodloużená. Prvé dva čl. tykadel široké, první kratší než 2., 3, čl. velmi tenkị a velmi dlouhý.

*) Doklad ve sbirce autorově. 


\section{H. UZEL, MONOGRAPHIE DER ORDNUNG THYSANOPTERA.}

delši než prvé dva dohromady, 4. článek as o 0.4 kratší než třetí a zvláště ke konci tlustší 5. a ostatní články tvoři dohromady celek tlustši než 4. článek; 5. čl. trochu kratši než 4. a téže délky jako 6.—9. Tyto mezi sebou asi stejnè dlouhé, vždy tenčí a tenči. Celé tykadlo jest silně chlupaté. Barva tykadel: 1. a 2. čl. šedé až černošedé, 3. a 4. čl. bílé, 5. ěl. a ostatní zase šedé až černošedé. Pterothorax značně delší a širší než prothorax. Druhý ěl. předního tarsu má dvouzubý lýrovilý útvar, nad nějž se sklánèjí dva chlupy: jeden krátký a jeden dlouhý. Všecky nohy černohnědé, všecky tibje na konci a všecky tarsy čistě bílé. Všechnỵ přičné žillky v křídle jsou někdy velmi nepatrné. Hořejší křídla v prvé čtvrtině bílá, v druhé a třetí ětvrtině žlutavošedě zkalená, v poslední člvrtině opět bílá, zde však na dolejšim kraji zase, z prvu šíre, pak úže, žlutošedě zkalená. Dolejší kř́idla jsou bílá, jen uprostřed velmi slabě šedẽ zkalená. Abdomen na konci dosti dlouhými tenkými chlupy opatřen. Délka těla $1 \cdot 1 \mathrm{~mm}$. Dva exempláře nałezeny.

ō. Nebyl posud objeven.

Třásněnku tuto chytil jsem $\mathrm{v}$ květnu a $\mathrm{v}$ červnu na rostlinách nekvetoucích. Čechy: Praha: V lese mezi Krěi a Kundraticemi. Milešovka.

f.

Kopf, Prothorax und Mesothorax rothbraun, Metathorax und Abdomen gelblich, dieses auf dem Ende graubraun. Kopf nach vorn verengt, zwischen den Augen in derselben Richtung verlängert. Die ersten zwei Fühlerglieder breil, das 1. kürzer als das 2., das 3. sehr dünn und sehr lang, länger als die ersten zwei zusammen, das 4 . etwa um $0 \cdot 4$ kürzer als das 3. und besonders gegen das Ende zu dicker; das 5 . und die übrigen bilden zusammen ein Ganzes, welches dicker ist als das 4. Glied; das 5. Glied etwas kiürzer als das 4. und ebenso lang wie das 6.-9. zusammen. Diese untereinander fast gleich lang, immer dünner und dünner. Der ganze Fühler stark beborstet. Fühlerfärbung: 1. und 2. Gilied grau bis schwarzgrau, 3. und 4. weiss, das 5. und die übrigen grau bis schwarzgrau. Pterothorax bedeutend länger und breiter als der Prothorax. Das zweite Vordertarsusglied trägt ein zweizinkiges leierförmiges Gebilde, über welches zwei Borsten geneigt sind, von denen die eine kurz, die andere lang ist. Alle Beine schwarzbraun, alle Tibien auf dem Ende und alle Tarsen rein weiss. Alle Queradern im Flügel sind manchmal sehr undeutlich. Oberflügel im ersten Viertel weiss, im zweiten und dritten gelblichgrau getrüht, im letzten wieder weiss, hier jedoch am Hinlerrande von neuem. erst breiter, dann schmäler, gelbgrau getrübt. Unterflügel weiss, nur in der Mitte sehr schwach grau angeflogen. Abdomen am Ende mil ziemlich langen dünnen Borsten versehen. Körperlänge $1.1 \mathrm{~mm}$.

б. Noch unbekannt.

V o rk o m m en: Im Mai und Juni an nichtblühenden Pflanzen. - F un d ort: Böhmen. 


\section{J. UZEL, MONOGRAFIE RADU, "THYSANOPTERA“.}

\section{Aeolothrips melaleuca Halid.*)}

Tab. V., fig. 45 .

1852. Aeolothrips (Coleothrips) melaleuca Haliday, Walker: Homopt. ins. of Brit Museum, pag. 1117.

$$
\text { P. }
$$

Tvar a struktura všech částí jsou u tohoto druhu jako u druhu předcházejicího. Rozdíl spočívá v zcela rủzném, u druhu Ae. melaleuca velmi konstantním zbarvení těla a okončin. - Barva celého tèla a noh, kromě bílých koncủ tibií a tarsů, hnèdočervená. Prrní dva ěl. tykadel jsou téže barvy, 3. a 4. bílé, ostatní žlütošedé. Hořejši křídla jsou právě tak zbarvena jako u druhu předcházejícího, uprostred stuhy nalézá se však veliká, okrouhlá, bílá skvrna.

\section{ऽ. Nebyl posud objeven.}

Jediný exempl. vzácného tohoto druhu chytil jsem v lese mezi Krěi a Kundraticemi $\mathrm{v}$ květech smolničky.

\section{$\uparrow$.}

Form und Structur aller Theile wie bei der vorigen Art. Der Unterschied beruht in einer ganz verschiedenen, bei der Art Ae. melaleuca sehr constanten Färbung des Körpers und der Extremitäten. — Farbe des ganzen Körpers und der Beine, die weissen Tibienenden und Tarsen ausgenommen, braunroth. Die ersten zwei Fühlerglieder ebenso gefärbt, das 3. und 4. Glied weiss, die übrigen gelbgrau. Oberflügel wie bei der vorigen Art, inmitten der breiten Binde befindet sich jedoch ein grosser runder weisser Fleck.

$$
\text { đ. Noch unbekannt. }
$$

Vorkommen: Im Mai in den Blüten von Lychuis viscaria. - Fundort: Böhmen.

\section{Aeolothrips vittata Halid.}

1836. Aeolothrips (Coleothrips) vittata Haliday, Entom. Mag., pag. 451.

1836. - vittata Burmeister, Handb. d. Entomologie, II, pag. 418.

1843. Coleothrips - Amyot et Serville, Ins. Hémiptères, pag. 646.

1852. Aeolothrips (Coleothrips) vittata Haliday, Walker: Homopt. ins. of Brit. Museum, pag. 1117.

*) Doklad ve sbírce autorově. 


\section{H. UZEL, MONOGRAPHIE DER ORDNUNG THYSANOPTERA.}

1878-79. Aeolothrips (Coleothrips) limbata Reuter, Diagn. öfv. nya Thysanopt. f. Finland, pag. 16 .

Haliday (anno 1836.): "Elytrorum basi et costae dimidio exteriore albis."

Haliday (anno 1852.): »Nigra, hemelytrorum basi et costae dimidio exteriore albis; antennis medio albidis. Long. $3 / 4$ lin."

Reuter: "Nigra, nitida; capite longitudine vix duplo latiore*), antennis capite cum pronoto haud longioribus, articulis duobus primis nigris, articulo secundo crasso, tertio et quarto elongatis, albidis, illo duobus primis conjunctis paulo longioribus, quarto tertio fere breviore, quinto (ab articulis quatuor aegerrime discernendis composito) tertio longitudine aequali; pronoto capite longiore sub-rectangulari, mesonoto pronoto circiter dimidio latiore, lateribus angulato, pronoto aeque-longo; alis anticis albis, nitidis, iridescentibus, pone quintam aut sextam partem basalem fascia lata fusco-nigra medium fere alae attingente et versus eius apicem in margine posteriore fere usque ad quintam partem apicalem ut vitta marginali sat lata, $2 \%$ alae latitudinis occupante, producta, margine postico apiceque longissime nigro-ciliatis; pedibus totis nigris, tantum tarsis anticis basi fusco-testaceis. Long. $1^{2 / 5}-1^{1 / 2} \mathrm{~mm}$. - In speciminibus junioribus Abietis; in paroecia Pargas in horto Lofsdaliensi m. Augusti 1878 parce occurit."

\section{Aeolothrips fasciata L.**)}

Tab. I., fig. 4.; Tab. V., fig. 46.-48.

1746. Thrips elytris albis nigrisque fasciis, corpore atro; Linné, Fauna Svecica. Editio I., pag. 221.

1761. Thrips fasciata Linné. Fauna Srecica, pag. 266.

1761. (Bez jména. - Ohne Namen.) Sulzer, Kennzeichen d. Insekten, tab. 7., fig. 48. b. 1764. Thrips elytris albis nigrisque fasciis, corpore atro; Geoffroy, Histoire abrégée d. Insectes, pag. 385.

1767. Thrips fascirita Linné, Systema Naturae, pag. 743.

1781. - - Schrank, Enumeratio Ins. Austriae indig., pag. 297.

1781. - - Fabricius, Species Insectorum, pag. 397.

1787. - - Fabricius, Mantissa Insectorum, pag. 320.

1788. - - Gmelin, Caroli a Linné Systema Nat., pag. 2223.

1789. - - Berkenhout, Synopsis of Nat. Hist. of Gr. Britain and Ireland, pag. 133.

1789. - - de Viller's, Car. Linnaei Entomologia.

*) Hlava byla zajisté do předohrudi částeěně vtažena. - Der Kopf war jedenfalls in den Prothorax theilweise eingezogen. - **) Doklad ve sbirce musejní, praep. ̌̌. 3. - Sammlung des böhmischen Landesmuseums, Praep. Nr. 3. 


\section{J. UZEL, MONOGRAFIE RADU „THYSANOPTERA“.}

1794. Thrips fasciata Fabricius, Entomologia systematica, pag. 229.

1802. - - Stew, Elements of Nat. Hist., pag. 114.

1803. - - Fabricius, Systema Rhyngotorum, pag. 314.

1806. - - Turton, A General System of Nature, pag. 717 .

1836. Aeolothrips (Coleothrips) fasciata Haliday, Entomological Magazine, pag. 451.

1836. - fasciata Burmeister, Handb. d. Entomologie, II, pag. 417.

1843. Coleothrips - Amyot et Serville, Ins. Hémiptères, pag. 646.

1852. Aeolothrips (Coleothrips) fasciata Haliday, Walker: Homopt. Ins. of Brit.

Museum, pag. 1117.; tab. VII., fig. 31.-42.

1852. - fasciata Heeger, Sitzungsb. d. Akad. d. Wiss. Wien, VIII, pag. 135.; tab. XXI.

1852. - vittata Idem, ibidem, pag. 137., tab. XXII.

1871. Thrips fasciata de Man. Tijdschr. v. Entomol., pag. 147.

1878-79. Aeolothrips (Coleothrips) fasciata Reuter, Diagn. öfv. nỵa Thysanopt. f. Finland, pag. 7 .

q.

Barva těla černá, černohnědá, červenohnědá nob šedohnědá. Strany hlavy málo vypouklé. Články tykadel úzké, válcovité. První čl. kratší než 2., tento dlouhý, nemnoho širší ně̌ následující články; 3 . čl. má velice krátkou, úzkou stopku a jest mnohem delší než 2.; 4. trochu kratší než předcházející, 5. čl. asi tak dlouhý jako následujicí ětyrìi dohromady. Barva tykadel: 1. čl. černošedý až černý, 2. podobně zbarvený, ke konci však bílý, čtvrtý bílý, na konci černý, ostatní černé. Prothorax o málo delší než hlava, málo širší než delší, se stranami trochu vypouklými. Plerothorax značně delší a širší než prothorax. Druhý článek předniho tarsu má před koncem dole podobný ústroj jako oba druhy předcházející; pozůstává však ze dvou nestejně utvořených zubů, které špičkami k sobẽ přiléhaji. Nad tyto zuby sklání se chlup, stojíci na konci prvého článku tarsu. Barva noh jest černá, jen přední tarsy a přední tibie po obou stranách jsou temně šedožlutavé. Hoř. křídlo jest bílé a má dvě široké šedohnědé až černé přričné stuhy, které vyphnuuji druhou a ětvrtou pětinu jeho délky. Šupinka na basi je tmavá. Abdomen na konci dosti dlouhými tenkými chlupy opatřen. Délka těla $1 \cdot 3-1 \cdot 6 \mathrm{~mm}$.

Var. (nov.) adusta. Hlava a thorax černohnědé, červenohnědé neb šedohnědé až žlutohnědé, abdomen hnědě žlutavý až žlutavý, více nebo méně sedè zkalený, na konci tmavošedý. Barva noh jest šedohnědá, pr̉ední tibie jsou po obou stranách žlutavé, šedě zkalené, podobně i přední tarsy a někdy též base předních stehen

$$
\text { రా. }
$$

Menší než †. Zbarvení tèla pestré a velmi nestálé. Hlava a poslední dva články abdomenu jsou nejtmaršími částmi. Thorax jest tmavý, přední okraj prothoraxu, po- 


\section{H. UZEL, MONOGRAPHIE DER ORDNUNG THYSANOPTERA.}

stranní a spodní jeho části jsou bílé. Abdomen má první článek tmavý, následující bělavé neb žlutavé, nahoře sotva, jindy slabě šedè zkalené; ke konci jest abdomen, jak jiż řečeno, tmavější. Výjimkou nalézají se exempláře celé velmi tmavé. První dva články tykadel bělavé; 1 . celý šedě zkalený, 2. jen na basi; 3 . čl. bělavý, na konci tmavý; ostatek tykadla tmavý. Zbarvení noh jest nestálé. Obyčejně jsou přední nohỵ bělavé, femora a tibie jejich vně tmavé; strední nohy mají tibie často tmavší než femora, kteráž bývají až bělavá a ke konci tmavší. Zadní nohy bývají celé tmavé. Pátý čl. tykadel delší než následující čtyřri dohromady. První ěl. abdomenu jest dlouhý a má dvojitou podélnou lištnu. Čtvrtý a 5. èl. jeho mají nahoře po obou stranách tupý výrostek. Devátý čl. má nahoře černou trojhrannou desku, a kraje jeho prodlouženy jsou v dvouhrotý výtvor prìdržovací (při páření). Kř́idla jsou utvořena a zbarvena jako u samic.

Žije v obou pohlavích od konce dubna do posledních teplých dnů podzimních v nejrůznějších květech, avšak vždy jen jednotlivě. Nejoblíbenějšími jsou jí především květy od Linaria vulgaris, pak květy od Solanum tuberosum (zvláště samci navštěvované), Limum usitatissimum, Papaver somniferum, Hyoscyamus niger, Onobrychis sativa. Také květenství cukrovky a klasy prosa a ovsa ráda navštěvuje. - Var. adusta vyskytuje se porůznu mezi formou typickou.

Třásněnka tato jest všude $\mathrm{v}$ Čechách hojná. Na Krkonoších nalezl jsem ji na stráních Malého Sněžného března a na stráních Sněžky.

\section{q.}

Körperfarbe schwarz, schwarzbraun, rothbraun oder graubraun. Kopfseiten wenig gewölbt. Fühlerglieder schmal, walzig. Erstes Glied kürzer als das 2., dieses lang, nicht viel breiter als die folgenden Glieder; das 3. Glied hat einen sehr kurzen und dünnen Stiel und ist viel länger als das 2.; das 4. etwas kürzer als das vorhergehende, das 5 . etwa so lang wie die folgenden vier zusammen. Fühlerfärbung: 1. Glied schwarzgrau bis schwarz, das 2. ähnlich gefärbt, gegen das Ende jedoch weiss, das :2. weiss, am Ende schwarz, die übrigen schwarz. Prothorax wenig länger als der Kopf, wenig breiter als lang, mit gewölbten Seiten. Pterothorax bedeutend länger und breiter als der Prothorax. Das zweite Tarsusglied an den Vorderbeinen hat ein ähnliches Gebilde wie die zwei vorhergehenden Gattungen; es besteht jedoch aus zwei ungleichen Zähnen, welche sich mit ihren Spitzen berühren. Über diese Zähne neigt sich eine Borste, welche am Ende des ersten Tarsusgliedes steht. Farbe der Beine schwarz, nur die Vordertarsen und die Vordertibien beiderseits trüb graugelblich. Oberflügel weiss, mit zwei breiten graubraunen bis schwarzen Querbinden, welche das zweite und vierte Fünftel seiner Länge ausfüllen. Flügelschuppe am Grunde dunkel. Abdomen am Ende mit ziemlich langen dünnen Borsten besetzt. Körperlänge $1.3-1.6 \mathrm{~mm}$. 


\section{J. UZEL. MONOGRAFIE RADU „THYSANOPTERA“.}

Var. (nov.) adusta. Kopf und Thorax schwarzbraun, rothbraun oder graubraun bis gelbbraun, Abdomen braungelblich bis gelblich, mehr oder weniger grau getrübt, am Ende dunkelgrau. Farbe der Beine graubraun, Vordertibien beiderseits gelblich, grau getrübt, ebenso die Vordertarsen und manchmal auch die Vorderschenkel am Grunde. (Böhmen.)

$$
\sigma^{\top}
$$

Kleiner als das $\subsetneq$. Körperfarbe bunt und sehr unstät. Der Kopf und die zwei letzten Abdominalsegmente sind die dunkelsten Theile. Thorax dunkel, Vorderrand des Prothorax und seine Seitentheile und Unterseite weiss. Erstes Abdominalsegment dunkel, die folgenden weisslich oder gelblich, oben kaum oder schwach getrübt; Abdominalende, wie schon erwähnt, dunkler. Ausnahmsweise kommen ganz dunkle Exemplare vor. Die ersten zwei Fühlerglieder weisslich; das 1. ganz grau getrübt, das 2. nur am Grunde; das 3. weisslich, am Ende dunkel; die folgenden Glieder dunkel. Färbung der Beine veränderlich. Die Vorderbeine gewöhnlich weisslich, ihre Schenkel und Schienen aussen dunkel; die Schienen der Mittelbeine oft dunkler als ihre Schenkel, welche oft weisslich und gegen das Ende zu dunkler sind. Hinterbeine pflegen ganz dunkel zu sein. Fünftes Fühlerglied länger als die vier folgenden zusammen. Erstes Abdominalsegment lang und mit zwei Längsleisten versehen. Das 4. und 5. Segment tragen beiderseits oben einen kleinen stumpfen Auswuchs. Am 9. Segm. oben befindet sich eine schwarze dreieckige Platte; seine Seiten tragen je ein zweizinkiges Gebilde. Gestalt und Farbe der Flügel wie bei den Weibchen.

Vorkommen: Von Ende April bis zu den lezten warmen Herbsttagen in beiden Geschlechtern auf mancherlei Blüten (hauptsächlich Linaria vulgaris) einzeln. - Fundorte: England (Haliday), Wien (Heeger), Finnland (Reuter), Deutschland (Jordan, Bohls; bei Berlin Uzel), Böhmen.

\section{Aeolothrips albocincta Halid.*)}

Tab. I., fig. 3 .

1836. Aeolothrips albicincta Haliday, Entomolog. Magazine, pag. 451.

1836. - - Burmeister, Handb. d. Entomologie, II, pag. 418.

1843. - albocincta Amyot et Serville, Ins. Hémiptères, pag. 646.

1852. - albicincta Haliday, Walker: Homopt. ins. of Brit. Museum, pag. 1117.

1878-79 - - Reuter, Diagn. öfv, nya Thysanopt. f Finland, pag. 7.

*) Doklad ve sbírce musejni, praep. č. 4. - Sammlung des böhmischen Landesmuseums, Praep. Nr. 4. 
Jest velmi pestrá. Hlava a prothorax šedohnědé až černé, pterothorax bělavý, po stranách a někdy také vzadu šedo- až červenohnědý, jindy celý šedẽ zkalený. První čl. abdom. jest červenohnědý až černý, 2. a 3. čl. jeho jsou bílé, 4.-8. černé, 9. a 10. zlatožluté. Hlava v předu zaokrouhlená. Prvé dva články tykadel nejtlustší, 1. čl. značně kratší než 2., 3. čl. nejdelší z celého tykadla, tenký, značně delší než prvé dva dohromady, 4. značně kratší než 3., taktéž tenký, 5. trochu kratší a ke konci tlustší než 4. a trochu delší než 6.-9. čl. dohromady. Všecky články tykadla jsou značně chlupaté. Barva tykadel: 1., 2. a 3. čl. bílé, tento na samé špičce černošedý, ostatní černošedé až černé. Prothorax trochu delši než hlava, as tak široký jako tato, v zadu trochu zúžený. Dvouzubý ústroj na předním tarsu jest podobně utvořen jako $u$ druhu předcházejíciho. Barva noh jest žlutavě šedá, přední tarsy, přední tibie ke konci uvnitř a střední i zadní femora ke konci světlejší. U jednoho velmi tmavého exempláře, jejž jsem nalezl, jsou nohy šedohnědé, jen přední tibie ke konci a přední tarsy žlutošedé. Abdomen uprostřed značně rozšiřený, ke konci zúžený, ostře prìšpičatělý a na konci dlouhými tmavými chlupy opatřený. Délka těla $1.4 \mathrm{~mm}$.

FORMA MAGROPTERA (nově objevená). Křídla jsou úphě vyvinuta. Hořejší jsou hnědošedá, na basi a na konci úzce bilá a uprostred s neširokou bílou stuhou. Pterothorax jest značně delší a širší než prothorax. Nohy stejnoměrně tmavošedé. Jediný exemplár̆ nalezen.

FORMA APTERA. Krídel ani nejmenší rudimenta. Pterothorax velmi nápadně stažený. Tento jest delší než prothorax, avšak jen tak široký. Očka menší než u formy dlouhokřídlé.

$$
\text { đ. (novè objevený). }
$$

Hlava a prothorax šedohnědé, pterothorax bílý, vzadu červený, celý abdomen kromě 2. a 3. čl. červený, tyto jsou bilé. Tykadla a nohy zbarveny jako u q, jen 3. čl. tyk. jest od polovičky šedě zkalený. Křídel ani nejmenší rudimenta. První čl. abdom. jest as dvakrát delší než druhý a má dva podélné kýly. Abdomen jest úzký; devátý čl. jeho nemá zubů. Jediný exemplár nalezen.

Forma neokřídlená krásné této třásněnky objevuje se od dubna až do srpna. $\mathrm{V}$ dubnu sbíral jsem ji mezi drnem. Formu okřídlenou nalezl jsem na nekvetoucích nízkých rostlinách v srpnu, v kterémžto mẽsíci pan prof. Duda i samce (na Galium) objevil.

Čechy: Hradec Králové: U Věkoše. Třebechovice. Pod Vys. Újezdem (fma macroptera). Jind. Hradec: V lese za Skrejchovem (Duda). 
f.

Körperfarbe bunt. Kopf und Prothorax graubraun bis schwarz, Pterothorax weisslich, an den Seiten und manchmal auch hinten grau- bis rothbraun, zuweilen ganz grau getrübt. Erstes Abdominalsegment rothbraun bis schwarz, das 2. u. 3. Segm. weiss, das 4.-8. schwarz, das 9. u. 10. goldgelb. Kopf vorn abgerundet. Die ersten zwei Fühlerglieder am dickesten, 1. Glied bedeutend kürzer als das 2., das 3. das längste im ganzen Fühler, dünn, bedeutend länger als die ersten zwei zusammen, das 4. bedeutend kürzer als das 3., ebenfalls dünn, das 5̃. elwas kürzer und gegen das Ende dicker als das 4. und etwas länger als das 6.-9. zusammen. Alle Fühlerglieder sind stark beborstet. Fühlerfärbung: 1., 2. u. 3. Glied weiss, dieses an der äussersten Spitze schwarzgrau, die übrigen schwarzgrau bis schwarz. Prothorax etwas länger als der Kopf, etwa so breit wie derselbe, hinten etwas verengt. Das zweizinkige Gebilde am Vordertarsus hat eine ähnliche Gestalt wie bei der vorhergehenden Art. Farbe der Beine gelblichgrau, Vordertarsen $u$. Vordertibien gegen das Ende innen und die Mittel- und Hinterschienen gleichfalls gegen das Ende lichter. Bei einem sehr dunklen Exemplar, das ich fand, sind die Beine graubraun, nur die Vordertibien gegen das Ende und die Vordertarsen gelbgrau. Abdomen in der Nitte stark erweitert, gegen das Ende zu verengt, scharf zugespitzt und am Ende mit langen dunkeln Borsten besetzt. Körperlänge $1.4 \mathrm{~mm}$.

FORMA MACROPTERA (neu entdeckt). Flügel vollkommen entwickelt. Die oberen braungrau, an der Basis und am Ende schmal weiss und in der Mitte mit einer schmalen weissen Binde. Pterothorax bedeutend länger und breiter als der Prothorax. Die Beine sind gleichmässig dunkelgrau.

FORMA APTERA. Flügel vollkommen fehlend. Pterothorax auffalend zusammengezogen. Derselbe länger als der Prothorax, aber nur ebenso breit. Ocellen kleiner als bei der geflügelten Form.

$$
\text { ठ (neu entdeckt). }
$$

Kopf und Prothorax graubraun, Pterothorax weiss, hinten roth, das ganze Abdomen, mit Ausnahme des 2. u. 3. Segm., welche weiss sind, roth. Fühler und Beine ähnlich wie beim Weibchen gefärbt, nur ist das 3. Fühlerglied von seiner Mitte an grau getrübt. Flügel fehlen vollkommen. Erstes Abdominalsegment etwa zweimal so lang wie das zweite und mit zwei Längsleisten versehen. Abdomen schmal; sein neuntes Segment ohne Zinken.

Vorkommen: Die ungeflügelte Form lebt von April bis August im Rasen; die geflügelte Form (feminae disseminantes) fand ich im August auf nichtblühenden Pflanzen. Im Augụst wurde auch das Männchen entdeckt. - Fundorte: England (Haliday). Finnland (Reuter), Böhmen. 


\section{H. UZEL, MONOGRAPHIE DER ORDNUNG THYSANOPTERA.}

\section{Aeolothrips fasciatipennis Blanch.}

1851. Aeolothrips fasciatipennis Blanchard, Hist. fis. y polit. de Chile. Zool. VI, pag. 152 .

"Ae. fuscus; capite brevi, leviter striolato; antennis fuscis, articulis secundo et tertio pallide flavidis; prothorace sat nitido, fere laevi, paullo striolato; alis hyalinis, basi fasciaque media lata pallide fuscis; pedibus testaceo-fuscis, tibiis anticis dilutioribus. Long. $3 / 4$ lin. - Cuerpo pardo, bastante brillante. Cabeza finamente estriolada. Antenas pardas, con sus segundo y tercer articulos de un amarillo claro. Protórax igual, liso, guarnecido solamente de estrias pequenas sumamente delicadas. Alas diáfanas, con su base y una faja ancha mediana de un pardo pálido. Patas de un pardo testáceo, con las piernas anteriores un poco mas pálidas que las otras partes. Abdómen de una gradacion de color tirando á moreno, uniforme, mas clara que la porcion anterior del cuerpo. Esta pequena especie se encuentra en la provincia de Valdivia (Chile)."

\section{FAM. Thripidae. (= STENOPTERA BURM.*))}

Tykadla šesti- až osmičlenná (neb zdánlivě devítičlenná), 7. čl. neb 7. a 8. čl. jejich (stylus) velmi tenké a obyčejně krátké. Makadla maxillarní jsou dvoučlenná, někdy třičlenná; makadla labialní jsou vždy dvoučlenná. Křídla úzká, ostře zakončená. Přední okraj hořejších křídel pravidlem jest opatřen třásněmi, mezi nimiž stojí obyčejnè kratší brvy. Ze žilek podélných $\mathrm{v}$ hořejším křídle vzniká hořejši (hlavní) $\mathrm{z}$ kořene křídla a běži až na konec jeho, kdež zaniká, nespojujíc se s žilkou okružní. Asi pod prvou třetinou její délky vzniká podélná žilka dolejší (vedlejší), která spojuje se s žilkou hlavní šikmou žilkou přiční, více nebo méně zřetelnou (Tab. VI., fig. 97.). Bẽží pak s ní rovnoběžně a též zaniká před koncem kř́dla. Hořejší žilka v jednom případě (u rodu Parthenothrips) jest krátká a spojuje se na konci prvé čtvrtiny délky kř́dla s žilkou okružní. Hlavní žilku spojují s přední částí žilky okružní dvě žilky příčné, sotva znatelné: jedna nedaleko za místem, kde se $\mathrm{k}$ hlavní žilce přikládá žilka vedlejší, druhá za polovinou délky křídla. Dolejší křídlo prostoupeno jest jednou žilkou podélnou (výjimkou dvěma). Kladélko samice jest dolů prohnuté.

Haliday (L. č. 43.) rozdèlil Stenoptera ve tři rody: Heliothrips, Sericothrips a Thrips. Rod Thrips pak opět na pět podrodủ: Chirothrips, Limothrips, Aptinothrips, Thrips s. str. a Belothrips. Všecky ty skupiny druhủ, až na podrod Thrips, jsou přirozené a byly $\mathrm{v}$ naší práci přijaty; Halidayùv podrod Thrips však zahrnuje v sobě tolik různých elementû, že bylo nutno ho znovu rozdèliti. - Burmeister při-

*) = Stenelytra Halid. 


\section{J. UZEL, MONOGRAFIE RÁDU ,THYSANOPTERA“.}

jímá jen rody Halidayovy a zástupce podrodu Aptinothrips považuje za larvy. Amyot a Serville (L. č. 54.) rozdèlují Stenoptera na 10 rodủ. Podržují totiž rody Halidayovy, podrody jeho povyšují na rody, podrod Aptinothrips, právẽ tak jako Burmeister, neuznávají a podrod Halidayùv: Thrips rozdèlují v rody: Odontothrips, Physapus, Thrips, Taeniothrips a Tmetothrips. Oba posledně jmenované rody a rod Odontothrips nejsou rody prìrozenými, poněvadž zakládaji se na znacích vedlejších (viz př́slušné místo v Cásti historické). — R. 1852. rozdèluje Haliday (L. č. 61.) rod svủj Thrips na sedm »Sectiones« (Gymnopterae, Eudactyli, Homopterae, Neogami, Heterogynae, Micropterae, Brachyderi) dle prítomnosti neb nedostatku křídel u jednoho neb obou pohlaví a dle jiných znakủ velmi nepodstatných. (Viz přrislušné místo v Části historické.)

Fühler sechs- bis achtgliedrig (oder scheinbar neungliedrig), ihr 7. Glied, oder das 7. u. 8. (Stylus) sehr dünn und gewöhnlich kurz. Maxillartaster zweigliedrig, manchmal dreigliedrig; Labialtaster immer zweigliedrig. Flügel schmal, scharf zugespitzt. Der Vorderrand der Oberflügel ist regelmässig mit Fransen besetzt, zwischen welchen gewöhnlich kürzere Wimpern stehen. Von den Längsadern im Oberflügel entspringt die obere (Hauptader) aus der Flügelwurzel und läuft bis zu seinem Ende, wo sie sich verliert, ohne sich mit der Ringader zu verbinden. Etwa unter dem ersten Drittel ihrer Länge entsteht die untere Längsader (Nebenader), welche mit der Hauptader mittelst einer schiefen Querader verbunden wird, die mehr oder weniger deutlich ist (Taf. VI, Fig. 97) und der in der Mitte des Oberflügels der Aeolothripiden befindlichen Querader entspricht. Die Nebenader läuft mit der Hauptader parallel und verschwindet auch vor dem Flügelende. Die obere Längsader ist in einem Falle (bei der Gattung Parthenothrips) kurz und verbindet sich am Ende des ersten Viertels der Flügellänge mit der Ringader. Ähnlich wie bei den Aeolothripiden wird auch hier die obere Längsader mit dem vorderen Theil der Ringader durch zwei Queradern verbunden, die jedoch sehr undeutlich sind, und von welchen die eine unweit hinter der Stelle, wo die Nebenader an die Hauptader sich lehnt, zu sehen ist, die andere hinter der Flügelmitte sich befindet. Der Unterflügel wird von einer (ausnahmsweise von zwei) Längsadern durchzogen. Der Legebohrer der Weibchen ist nach unten. gebogen.

\section{GENUS CHIROTHRIPS HALID.*)}

Tèlo zavalité. Hlava jest velmi malá a prodlužuje se před očima ve veliký výběžek o třech cípech, na němż nalézají se tykadla. Očka u samic přitomna, značně do zadu posunuta; u samcủ scházejí. 'Tykadla osmičlenná (stylus dvoučlenný). Druhý článek

*) $\mathrm{X} s i \mathrm{p}=$ ruka, Hand. 


\section{H. UZEL, MONOGRAPHIE DER ORDNUNG THYSANOPTERA.}

jejich prodlužuje se někdy (u druhu manicata) na hořejším vněǰšm rohu $\mathrm{v}$ tupý výběžek. Makadla maxillarní o třech článcích. Prothorax skoro dvakrát tak dlouhỵ jako hlava. V predu není širší než tato, nazad se však značně rozšiřuje, takže na zadním kraji jest dvakrát tak široký jako na předním. Na zadních jeho rozích jest po dvou chlupech smyslových. Nohy zavalité; přední u obou pohlaví nápadně stlustlé. Přední femora velmi značně rozšiřená, na konci vně s krátkým, ostrým zoubkem (nazpět ohrnutý kraj); preední tibie krátké, velmi široké. Přední tarsus úzký. Křídla neobyčejnè úzká, dlouhá (přesahuji konec lěla), trochu prohnutá a hořejší prostoupená dvěma podélnými žilkami, kteréžto se za polovinou jejich délky ztrácejí. Přední část okružní žilky má delší třásně a krátké slabé brvy. Samci jsou bezkřídlí. Desatý čl. abdom. jest nahoře rozčísnutý. Druhy sem náležející pohybují se zvolna a nejsou ke skákání způsobilé.

Körper gedrungen. Kopf sehr klein und vor den Augen in einen dreizipfeligen Fortsatz verlängert, auf dem die Fühler sich befinden. Ocellen bei den Weibchen vorhanden, stark rückwärts verschoben; bei den Männchen fehlend. Fühler achtgliedrig (Stylus zweigliedrig). Ihr zweites Glied manchmal (bei der Art manicata) am äusseren Vordereck mit einem stumpfen Fortsatz. Naxillartaster dreigliedrig. Prothorax fast zweimal so lang als der Kopf, vorne nicht breiter als derselbe, nach hinten jedoch stark erweitert, so dass er am Hinterrande zweimal breiter als am Vorderrande ist. Auf seinen Hinterecken stehen je zwei Sinnesborsten. Beine gedrungen. Die vorderen bei beiden Geschlechtern auffallend verdickt. Die Vorderschenkel bedeutend erweitert, am Ende aussen mit einem scharfen Zahn (der zurückgestïlpte Rand); die Vordertibien kurz und sehr breit. Vordertarsen schmal. Flügel ungewöhnlich schmal, lang (sie überreichen das Körperende), etwas gebogen und die oberen ron zwei Längsadern durchzogen, welche hinter ihrer Nitte sich verlieren. Der vordere Theil der Ringader hat längere Fransen und kurze schwache Wimpern. Die Männchen sind flügellos. Das zehnte Abdominalsegment ist oben aufgeschlitzt. Die her gehörenden Thysanopteren bewegen sich langsam und haben kein springvermögen.

\section{Chirothrips manicata Halid.*)}

Tab. I., fig. 2.; Tab. V., fig. 49.

1836. Thrips (Chirothrips) manicata Haliday, Entomol. Magazine, pag. 444.

1836. - manicata Burmeister, Handb. d. Entomologie, II, pag. 413.

1836. - longipennis Idem, ibidem.

*) Doklad ve sbirce musejní, praep. è. 5. - Sammlung des böhmischen Landesmuseums, Praep. Nr. 5. 


\section{J. UZEL, MONOGRAFIE RADU "THYSANOPTERA“.}

1838. Thrips longipennis Idem, Genera Insectorum. (Kolorované vyobrazení. Colorierte Abbildung.)

1843. Chirothirips manicata Amyot et Serville, Ins. Hémiptères, pag. 642.

1843. - Iongipennis Iidem, ibidem.

1852. Thrips (Chirothrips) manicata Haliday, Walker: Homopt. insects of Brit. Museum, pag. 1106.; tab. VI., fig. 12 .

1878-79 - - - _ Reuter, Diagn. öfv. nya Thysanopt. f. Finland, pag. 5. et 6 .

1883. Chirothrips antennatus Osborn, The Canadian Entomologist, pag. 154. 1887. Thrips (Chirothrips) antennata Lindeman, Bull. Soc. Imp. d. Natur. d. Moscou, pag. 322.; fig. 12.

Barva těla tmavě šedohnědá až černohnědá, zrǐidka černá. Pterothorax bývá někdy šedě červenohnědý neb šedě žlutohnědý. Celé tělo jest na př́ic vrásčité (imbricatum). Tykadla krátká, články jejich velmi zavalité. První čl. jest nejširším a jest šikmo utatý, 2. čl. jest trochu delší než první a prodlužuje se na hořejším vnějším rohu v tupý vỷběžek; 3. čl. jest as tak dlouhý, avšak značně tenčí než druhý, sedí na malinké, velmi tenké stopce a je nepravidelnè kulatý; 4. čl. jest delši a značně širší než 3., jest krátce nepravidelně elliptičný; 5 . čl. jest asi tak veliký jako třetí a má touž podobu, nesedí však na stopce; 6. čl. jest as tak dlouhý jako třetí (někdy trochu delší, někdy trochu kratší), avšak značně užší. Stylus jest dosti dlouhý a tenký, o dvou skoro stejných ěláncích. Třetí a čtvrtý ělánek opatřeny jsou před koncem vně širokým přiostřeným a prủhledným ostnem. Barva tykadel je šedohnědá až černohnědá, 2. čl. na konci a 3. žlutavé, šedě zkalené. Zadní okraj prothoraxu jest četnỵmi krátkými a silnými chloupky opatřen. Pterothorax delší a širši než prothorax. Nohy jsou šedo- až černohnědé a jen tarsy a přední tibie uvnitř jsou žlutavě šedè zkalené. Špička křídla jest krátkými tenkými chloupky pokryta a má podobu kartáčku. Żilka $\mathrm{v}$ hořejším křídle vychází z base jeho a dèlí se asi na konci prvé čtvrtiny délky své (zdánlivě) ve dvě větve. $\mathrm{V}$ prodloužení hlavní žilky jsou 2 chlupy, na vedlejší a v prodloužení jejím nalézáme 4 až 5 chlupů. Hoř. křílla jsou silně žlutavošedě zkalená, na basi světlejší a před basí s podélným ěirým okénkem. Dol. křídlo velmi slabě šedé, skoro čiré. Abdomen ostře přišsičatělý a na konci nedlouhỵ́mi chlupy opatřený. Délka těla $0 \cdot 8-1 \mathrm{~mm}$.

Var. (nov.) adusta. Hlava a thorax tmavě, nèkdy světleji šedohnědé (pterothorax někdy šedě červeno- až žlutohnědý), abdomen světle šedožlutavý, na konci černošedý, aneb hlava a prothorax tmavě šedolınědé, pterothorax červenohnědý, abdomen světle hnědožlutý, na konci černošedý; výjimkou jest celý thorax šedě žlutohnědý. 


\section{H. UZEL, MONOGRAPHIE DER ORDNUNG THYSANOPTERA.}

$$
ð \text { (nově objevený). }
$$

Mnohem menší než q. Barva těla tmavě šedožlutavá neb žlutavohnědá, abdomen pak obyčejnè ke konci černohnědý. (Jeden exempl. mnou nalezený mèl hlavu, prothorax a konec abdomenu žlutavošedé, ostatek žlutavý, nohy a tykadla tmavošedá.) Jindy jest barva těla šedo- až černohnědá a pterothorax bývá šedě červenohnědý. Tykadel 2. a 3. čl. jsou žlutavé, šedě zkalené; 3. a 4. čl. mají také ony průhledné ostny jako samice; jsou však tupé. Nohy šedožlutavé, tarsy všecky a přední tibie uvnitř žlutavé. Pterothorax jest as tak dlouhý jako prothorax. Na 3.-7. čl. abdom. dole nalézá se po jedné brzy menší, brzy větší světlé kruhovité prohlubině. Délka těla $0 \cdot 47-0 \cdot 7 \mathrm{~mm}$. - Veliké množství exempl. nalezeno.

Poznámka. Sameček tohoto druhu jest nejmenši posud známou tráșněnkou.

Žije v květenství trav (ve Spojených státech a u Moskvy zvl. ve Phleum praterse), a to někdy ve velikém množství; též v květenství kukuřice, sítiny, tritiny a v klasech ječmene, žita a pšenice; není však zde u nás nikdy hojnou*). Ojediněle vyskytuje se též v různých květech jiných. Přezimuje v suchých květenstvích trav a v drnu. Var. adusta jest hojná mezi formou typickou. Samce nalézáme po celý rok.

Čechy: Praha. Mukařov. Čerčany (Bubák). Hradec Králové. Třebechovice. Opočno. Turnov (Bubák). Liberec. Milešovka. Písek, Chotěboř, Krucemburk (Vařečka). Jindřich. Hradec (Duda).

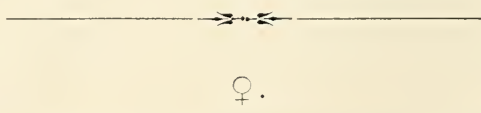

Körperfarbe dunkel graubraun bis schwarzbraun, selten schwarz. Pterothorax manchmal grau rothbraun oder grau gelbbraun. Der ganze Körper ist dachziegelförmig gerunzelt. Fühler kurz, ihre Glieder sehr gedrungen. Das erste Glied ist am breitesten und ist schief abgestutzt, das 2. etwas länger als das 1. und nach aussen oben in einen stumpfen Fortsatz verlängert; das 3. Glied ist etwa so lang, aber bedeutend dünner als das 2.; es sitzt auf einem kleinen, sehr dünnen Stiele und ist unregelmässig rund; das 4. Glied ist länger und bedeutend breiter als das 3 . und ist unregelmässig elliptisch; das 5. ist etwa so gross wie das 3 . und hat dieselbe Gestalt, ist jedoch nicht gestielt; das 6 . ist etwa so lang wie das 4 . (manchmal etwas länger, manchmal etwas kürzer), jedoch viel schmäler. Der zweigliedrige Stylus ist ziemlich lang und dünn. Das 3. und 4. Fühlerglied ist vor der Spitze aussen mit einem scharfen und durchsichtigen Stachel versehen. Die Farbe der Fühler ist graubraun bis schwarzbraun, das 2. Glied am Ende und das 3. gelblich, grau getrübt. Der Hinterrand des Prothorax ist mit zahlreichen kurzen und starken Stachelchen besetzt. Pterothorax länger und breiter als der Prothorax. Die Beine sind grau- bis schwarzbraun und nur

*) U Moskvy nalezl Lindeman tuto třásněnku v žitě a pšenici ve velikém množství, nepozoroval však, že by jim škodila. 


\section{J. UZEL, MONOGRAFIE RADU „THYSANOPTERA“.}

die Tarsen und Vordertibien innen gelblichgrau getrübt. In der Verlängerung der oberen Längsader stehen zwei Borsten; auf der unteren Längsader und in ihrer Verlängerung findet man 4 bis 5 Borsten. Die Oberflügel sind stark gelblichgrau getrübt, am Grunde lichter und vor dem Grunde mit einem klaren länglichen kleinen Fensterfleck. Unterflügel sehr schwach grau, fast klar. Abdomen scharf zugespitzt und am Ende mit ziemlich kurzen Borsten besetzt. Körperlänge $0.8-1 \mathrm{~mm}$.

Var. (nov.) adusta. Kopf und Thorax dunkel, manchmal lichter graubraun (Pterothorax zuweilen grau roth- bis gelbbraun), Abdomen licht graugelblich, am Ende schwarzgrau, oder Kopf und Prothorax dunkel graubraun, Pterothorax rothbraun, Abdomen licht braungelb, am Ende schwarzgrau; ausnahmsweise der ganze Thorax grau gelbbraun.

$$
\delta \text { (neu entdeckt). }
$$

Viel kleiner als das $q$. Körperfarbe dunkel graugelblich oder gelblichbraun, Abdomen dann gewöhnlich gegen das Ende zu schwarzbraun. (Ein Exemplar, welches ich fand, hatte den Kopf, den Prothorax und das Ende des Abdomen gelblichgrau, das Übrige gelblich; Beine und Fühler waren dunkelgrau.) Zuweilen ist die Körperfarbe grau- bis schwarzbraun, und der Pterothorax pflegt grau rothbraun zu sein. Das 2. und 3. Glied der Fühler gelblich, grau getrübt; das 3. u. 4. Glied ebenfalls mit jenen durchsichtigen Stachehn versehen wie das Weibchen; dieselben sind jedoch stumpf. Beine graugelblich, alle Tarsen und die Vordertibien innen gelblich. Pterothorax etwa so lang wie der Prothorax. Am 3.-7. Abdominalsegmente unten befindet sich je eine grössere oder kleinere lichte runde Vertiefung. Körperlänge $0.47-0.7 \mathrm{~mm}$.

Vorkommen: In der warmen Jahreszeit in verschiedenen Grasblüten, oft massenhaft. Vereinzelt auch in anderen Blüten. Überwintert in trockenen Blütenständen und im Rasen. Das $\sigma^{\nearrow}$ findet man das ganze Jahr hindurch. - Fundorte: England (Haliday), Deutschland (Burmeister, Jordan, Bohls), Finnland (Reuter), Russland: Moskau (Lindeman), Nishegoroder Gubernie (Uljanin). Vereinigte Staaten: Delaware, Manchester, Jowa (Osborn), Böhmen.

\section{Chirothrips Dudae nov. sp.*)}

Tab. I., fig. 7.; Tab. V., fig. 50.

Barva těla černohnědá. Tykadla poměrně delši než u druhu předcházejícího, a článkỵ ne tak zavalité. První jest nejširší, a je kratší než 2.; tento přiléhá širokou basí k prvému, jest značně užší; na vnější stranu není prodloužen; 3. čl. jest as tak

*) Dovolil jsem si tento druh nazvati dle pana professora Lad. D udy v Praze. - Doklad ve sbirce inusejní, praep. č. 6 . - Sammlung des böhmischen Landesmuseums, Praep. Nr. 6. 


\section{H. UZEL, MONOGRAPHIE DER ORDNUNG THYSANOPTERA.}

dlouhý jako druhý, má krátkou tenkoü stopku a jest nepravidelně krátce opak vejčitý; 4. čl. as tak dlouhý jako 3. a podobného tvaru, úzká stopka však schází; 5. čl. trochu kratší než 4. a užší; 6. čl. o trochu delší než třetí, ke konci zúžený. Stylus dlouhý, ne př́liš tenký, o dvou asi stejných článcích. Třetí a 4. čl. opatřeny jsou před koncem vně širokým, prohnutým a průhledným ostnem. Barva tykadla černohnědá, 2. čl. na konci a 3 . žluté, slabě šedě zkalené. Zadní okraj prothoraxu opatřen nečetnými krátkými chloupky. Pterothorax delší a širší než prothorax. Přední tibie mají na konci uvnitř dva tupé hrbolky. Nohy jsou černohnědé, všecky tarsy žluté, přední tibie taktéž žluté, na basi a vně černohnèdé. Špička křídla podobným kartáčkem opatřena jako u druhu předcházejícího. V prodloužení hlavní žilky lze viděti dva chlupy. Na vedlejší žilce a v prodloužení jejím nalézáme 6 neb 7 chlupủ. Hořejší křídla jsou silně žlutavošedě zkalená, na basi světlejší a pred basí s podélným čirým okénkem. Dol. kiřídla skoro čirá. Abdomen jest značně přišpičatělý a na konci nedlouhými tenkými chlupy opatřený. Články abdominalní jsou na zadním kraji kol do kola krátkými špičatými přívěsky ozdobeny. Délka těla $1 \mathrm{~mm}$. - Dosti značné množství exempl. nalezeno.

Málo menši než + , jen výjimkou značněji menší. Barva těla černohnědá. Články tykadel jsou poněkud delší než u †. Na 3. a 4. ěl. jsou též ony prủhledné ostny. Prothorax není nazad tou měrou rozšíren. Pterothorax jest jen as tak dloụý jako prothorax. Pr̃ední tibie na knonci uvnitř podobně jako u samic dvěma tupými hrbolky opatřeny. Také abdominalní články mají na zadních krajích dole špičaté príivěsky, které však na hřbetě jsou zakrnělé. Na 3.-7. čl. abdom. dole po jedné veliké, velmi dlouhé, světlé prohlubině. Délka těla $0.9 \mathrm{~mm}$, zirílka $0.75 \mathrm{~mm}$ a jen výjimkou $0.6 \mathrm{~mm}$. Dosti značný počet exempl. nalezen.

Žije v drnu lučním a vỵlézá někdy do květenství trav. Samice nalézal jsem od dubna do června, samce $\mathrm{v}$ dubnu a květnu.

Čechy: Hradec Králové: Na několika místech v okolí.

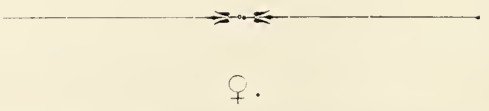

Körperfarbe schwarzbraun. Die Fühler verhältnismässig länger als bei der vorhergehenden Art, ihre Glieder weniger gedrungen. Das 1. ist am breitesten; es ist kürzer als das 2.; dieses sitzt mit breiter Basis auf dem 1., und ist viel schmäler; an der Aussenseite hat es keinen Fortsatz; das 3. Glied ist etwa so lang wie das zweite, hat einen kurzen dünnen Stiel und ist unregelmässig kurz verkehrt eiförmig; das 4. Glied etwa so lang wie das 3. und ähnlich gebildet, jedoch ohne Stiel; das 5. etwas kürzer als das 4. und schmäler; das 6. etwas länger als das 3., gegen das Ende zu verengt. 


\section{J. UZEL. MONOGRAFIE RADU „THYSANOPTERA“.}

Stylus lang. nicht sehr dünn und seine Glieder etwa von gleicher Länge. Das 3. u 4. Glied ist vor dem Ende aussen mit einem breiten, gebogenen und durchsichtigen Stachel versehen. Farbe der Fühler schwarzbraun, das 2. Glied am Ende u. das 3. gelb, schwach grau getrübt. Der Hinterrand des Prothorax mit wenigen kurzen Härchen besetzt. Pterothorax länger und breiter als der Prothorax. Die Vordertibien haben am Ende innen zwei stumpfe Höckerchen. Die Beine sind schwarzbraun, alle Tarsen gelb, die Vordertibien ebenfalls gelb, am Grunde und aussen schwarzbraun. In der Verlängerung der oberen Längsader befinden sich zwei Borsten. Auf der unteren Längsader und in ihrer Verlängerung stehen 6 oder 7 Borsten. Oberflügel stark gelblichgrau getrübt, am Grunde lichter und vor dem Grunde mit einem kleinen länglichen klaren Fensterfleck. Unterflügel fast klar. Abdomen bedeutend zugespitzt und am Ende mit ziemlich kurzen dünnen Borsten besetzt. Abdominalsegmente am Hinterrande ringsherum mit winzigen kurzen spitzigen Anhängseln geziert. Körperlänge $1 \mathrm{~mm}$.

$$
\text { o. }
$$

Nicht viel kleiner als das , nur ausnahmsweise bedeutend kleiner. Körperfarbe schwarzbraun. Fühlerglieder sind etwas länger als beim ๆ. Am 3. u. 4. Gliede befinden sich ebenfalls jene durchsichtigen Stacheln; der Prothorax ist nach hinten nur in geringerem Masse erweitert. Pterothorax nur etwa so lang wie der Prothorax. Vordertibien am Ende innen ähnlich wie bei den Weibchen mit zwei stumpfen Höckerchen versehen. Auch haben die Abdominalsegmente an den Hinterrändern unten spitzige Anhängsel, die jedoch auf der Dorsalseite verkümmern. Am 3.-7. Abdominalsegment unten befindet sich je eine grosse, sehr lange, lichte Vertiefung. Körperlänge $0.9 \mathrm{~mm}$, selten $0.75 \mathrm{~mm}$ und nur ausnahmsweise $0.6 \mathrm{~mm}$.

Vorkommen: Weibchen von April bis Juni, Männchen im April und Mai im Rasen und zuweilen in Grasblüten. - Fundort: Böhmen.

\section{GENUS LIMOTHRIPS HALID.*)}

Tělo mohutné. Hlava delší než širši, nazad rozšírená. Před očima prodlužuje se ve výběžek o třech cípech, na němž se nalézají tykadla. Očka u samic přitomna; u samcủ scházejí. Tykadla osmičlenná (stylus dvoučlenný); třetí článek prodlužuje se u druhu $L$. denticornis na vnější straně v široký trojhranný, do předu namírený výběžek. Makadla maxillarní o dvou (u druhu L. cerealium o třech?) stejně dloulıých článcích. Prothorax trochu kratši ně̌ hlava, nazad trochu rozšiřený, zadní rohy zaokrouhlené a jedním chlupem smyslovým opatřené. Nohy velmi zavalité, přední ještě širší než ostatní, bezbranné. Křídla dosti široká, dvěma podélnými žilkami prostoupená. Přední část okružní

*) $\Lambda$ w. $\delta \xi=$ hlad, Hunger, Hungersnoth. 


\section{H. UZEL, MONOGRAPHIE DER ORDNUNG THYSANOPTERA.}

žilky nese tr̃ásně a mezi nimi kratší silné brvy. Samci jsou bezkřídlí. Desátý článek abdomenu jest u samic trochu delší než 9 ;; ze stran jest značně sploštilý, takže shora vypadá skoro jako rourovitý. Nahoře uprostřed jest rozčísnutý. Poslední články abdomenu opatřeny jsou silnými ostny, z nichž vynikají zvláště dva sbližené, které se nalézají na hřbetní straně 10. článku. Samci mají abdomen na konci široce zaokrouhlený. Devátý článek jeho opatřen jest na zadnich rozich jedním dosti dlouhým ostnem a uprostřed nahoře jedním párem sblížených mohutných trnů, ostře zakončených. Zadní okraj jeho lemován jest (aspoň u druhu L. denticornis) klikatou lištnou. Druhy sem náležející pohybují se zvolna a nejsou způsobilé ke skákání.

Körper mächtig. Kopf mehr lang als breit, nach hinten erweitert und vor den Augen in einen dreizipfeligen Fortsatz verlängert, auf welchem sich die Fühler befinden. Ocellen beim Weibchen vorhanden, beim Männchen fehlend. Fühler achtgliedrig (Stylus zweigliedrig); ihr drittes Glied (bei $L$. denticornis) aussen in einen breiten, dreieckigen, nach vorn gerichteten Fortsatz verlängert. Maxillartaster aus zwei (bei $L$. cerealium drei?) gleichlangen Gliedern bestehend. Prothorax etwas kürzer als der Kopf, nach hinten etwas erweitert, die Hinterecken abgerundet und mit einer Sinnesborste versehen. Beine sehr gedrungen, die vorderen breiter als die übrigen, wehrlos. Flügel ziemlich breit. Der Vorderrand der Ringader trägt Fransen, zwischen denen sich stärkere kurze Wimpern befinden. Männchen flügellos. Das 10. Abdominalsegment ist bei den Weibchen etwas länger als das 9.; von den Seiten ist es bedeutend abgeplattet, so dass es, von oben gesehen, eine röhrige Gestalt hat. Oben ist es der Länge nach aufgeschlitzt. Die lezten Abdominalsegmente mit starken Stacheln versehen, von denen hauptsächlich ein auf der Dorsalseite des 10. Abdominalsegmentes befindliches Paar durch seine Stärke auffällt. Das Abdomenende bei den Männchen breit abgerundet. Das 9. Segment an den Hinterecken mit einem langen Stachel und oben in der Nitte mit einem Paar einander genäherter mächtiger Dornen versehen. Sein Hinterrand mit einer zickzackförmigen Leiste (wenigstens bei L. denticornis) umsäumt. Die her gehörenden Arten bewegen sich langsam und haben kein Springvermögen.

\section{Limothrips denticornis Halid.*)}

Tab. I., fig. 8.; Tab. V. fig. 51.

1836. Thrips (Limothrips) denticomis Haliday, Entomol. Nagazine, pag. 445.

1836. - denticornis Burmeister, Handb. d. Entomologie, II, pag. 414.

1843. Limothrips denticornis Amyot et Serville, Ins. Hémiptères, pag. 642.

*) Doklad ve sbírce musejní, praep. ¿̌. 7. - Sammlung des böhmischen Landesmuseums, Praep. Nr. 7 . 


\section{J. UZEL, MONOGRAFIE Ṙ̉ UUHYSANOPTERA“.}

1852. Thrips (Limothrips) denticomis Haliday, Walker: Homopt. ins. of Brit. Museum, pag. 1106.

1852. - Kollari Heeger, Sitzungsb, d. Akad. d. Wiss., Wien, IX, pag. 485. tab. XXI.

1878-79. - (Limothrips) denticornis Reuter, Diagn. öfv. ny̧a Thys. f. Finland, pag. 6. 1878-79. - - - bidens Idem, ibidem, pag. 12.

1887. - secalina Lindeman, Bull. Soc. Imp. d. Natur. d. Moscou, pag. 308.; pag. 308., fig. 4., pag. 309., fig. 5., pag. 310 , fig. 7 .

$$
q .
$$

Barva těla černá až černohnědá; zř́dka jest abdomen žlutavohnědý, šedě zkalený, ke konci černý. Očka stoji na rozích velmi nízkého trojúhelníka. Články tykadel krátké, 1. šikmý, široký, kratší a trochu širší než 2., tento nesouměrný, šikmě baňkovitý; 2.-5. čl. jsou skoro stejně dlouhé. Vnější strana 3. čl. prodlužuje se v široký trojhranný, do předu namírený výběžek, jenž se zakončuje krátkým prủhledným ostnem. Mezi ním a koncem článku nalézá se ještě jeden osten; 6 . čl. jest nejdelší a na basi a ke konci zúžený. Stỵlus dlouhý, silný, o dvou asi stejných článcích. Barva tykadel: první dva čl. černé, 3. žlutavý, šedě zkalený, ostatní černohnědé, 4. často šedohnědý. Pterothorax delší a silnējší než prothorax. Mesothorax s vyčnívajicimi přednimi rohy. Nohy černohnědé; všecky tarsy a přední tibie žluté, tyto uvnitř úžeji, vně šíre černohnědě zkalené. Hlavní žilka má ve své druhé polovině tři chlupy, z nichž jeden od ostatnich dvou jest oddálen. Vedlejší žilka poseta jest devíti chlupy. Kř́idla silně šedožlutavě zkalená; před basí jest malá část' křídla velmi světlá. Dolejší křídla skoro čirá. Poslední čl. abdomenu jest trochu delší než předposledni a jest ze stran značně sploštilý. Konec abdomenu opatřen jest silnými ostny. Desátý èl. má nahore za polovinou dva velmi silné ostny sbližzené. Délka těla $1.3 \mathrm{~mm}$.

\section{$\sigma^{7}(=L$. bidens Reut. $)$.}

Zbarvení dvou exemplářủ, jež jsem nalezl, lišilo se od sebe velmi značně. U jednoho byly hlava a prothorax šedohnědé, pterothorax světleji šedohnědý; abdomen černý, 1. čl. jeho však jako pterothorax zbarvený. Tykadel 1., 2., 5., 6. čl. a stylus šedohrědé (2. čl. nejtmavší), 3. a 4. bělavé. Nohy černohnědé, všecky tarsy a přední tibie žluté. Tyto vně a uvnitř úzce černohnědé. - U druhého exempláře byly hlava a prothorax šedohnědé, pterothorax a první polovice abdomenu žlutavé, slabě šedě zkalené. druhá polovice abdomenu černohnědá, skoro černá. Tykadel 1., 5., 6. čl. a stylus žlutavošedé, 2. šedohnědý, 3. bělavý, 4. žlutavý, šedě zkalený. Nohy šedo- skoro černohnědé; všecky tarsy a přední tibie žluté, tyto vně a uvnitř úzce černohnědé jako 
u prvého exempláře. - Plerothorax jest u samců jen as tak dlouhý jako prothorax a málo širší. Abdomen široký, vzadu zaokrouhlený. Tykadla jsou jen trochu delší hlavy, a výběžek třetího článku jejich jest více zaokrouhlený než u samice; 5. čl. prǐléhá širokou plochou k široké basi článku 6., kterýžto jest jen o málo delší než onen.

Samice ryskytuji se po celý rok, a to nejvíce v drnu Mučním i lesnim; mnohé nalézáme také $\mathrm{v}$ květenství trav. $\mathrm{V}$ ječných klasech bývá jich veliké množství, $\mathrm{v}$ žitných, pšeničných klasech a v ovse objevují se zî́dka, a nejvíce ještě tehdy, když klasy zmíněné jsou velmi mladé. Dle Lindemana (L. č. 153.) škodí značně žitu, pšenici, ječmenu a trávě Phleum pratense. Časem zdržují se na listech rủzných rostlin (zvl. od Lappa) a dle Heegra (L. č. 63.) způsobuji na rostlinách ve sklenících vadnutí a opadávání listů. Nèkdy navštěvuji také jednotlivě různé květy (zvl. Onobrychis viciaefolia a Hyoscyamus nigev). V zimě ukrývají se v drnu, pod spadaným listím a větvičkami, v mechu a částečně též pod korou. Samci jsou velmi řídcí. Nalezl jsem je koncem června na pšenici.

Čechy: Praha. Hradec Králové. Třebechovice. Opočno. Jaroměř. Krkonoše: Vrchol Sněžky a Vys. Kola (v drnu). Liberec. Milešovka. Peruc. Jind. Hradec (Duda).

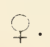

Körperfarbe schwarz bis schwarzbraun; selten ist das Abdomen gelblichbraun, grau getrübt, gegen das Ende zu schwarz. Die Ocellen stehen auf den Ecken eines sehr niedrigen Dreieckes. Fühlerglieder kurz, das 1. schief, breit, kürzer und etwas breiter als das 2., dieses unsymmetrisch, schief napfförmig; das 2.-5. Glied fast gieich lang. Die Aussenseite des 3. Gliedes in einen breiten, dreieckigen, nach vorn gerichteten Fortsatzt verlängert, der am Ende einen kurzen durchsichtigen Stachel trägt. Zwischen demselben und dem Gliedende befindet sich noch ein Stachel; das 6. Glied ist am längsten und ist am Grunde und gegen das Ende zu verengt. Stylus lang, stark, aus zwei etwa gleichen Gliedern zusammengesetzt. Fühlerfärbung: die ersten zwei Glieder schwarz, das 3. gelblich, grau getrübt, die übrigen schwarzbraun, das 4. oft graubraun. Pterothorax länger und stärker als der Prothorax. Mesothorax mit vorragenden Vorderecken. Beine schwarzbraun; alle Tarsen und die, Vordertibien gelb, diese innen schmäler, aussen breiter schwarzbraun getrübt. Die Hauptader trägt in ihrer zweiten Hälfte drei Borsten, von denen eine von den übrigen zwei entfernt ist. Dic Nebenader ist mit neun Borsten besäet. Flügel stark graugelblich getrübt; vor dem Grunde ist ein kleiner Theil des Flügels sehr hell. Unterflügel fast klar. Das letzte Abdominalsegment ist etwas länger als das vorletzte und von den Seiten bedeutend abgeplattet. Das Abdomenende ist mit starken Stacheln versehen. Das letzte Segment trägt oben zwei besonders starke genäherte Stacheln. Körperlänge $1.3 \mathrm{~mm}$. 


\section{ऽ (= L. bidens Reut.).}

Die Färbung der zwei Exemplare, die ich fand, ist sehr verschieden. Bei dem einen ist der Kopf und der Prothorax graubraun, der Pterothorax lichter graubraun; das Abdomen schwarz, sein 1. Segment jedoch wie der Pterothorax gefärbt. Das 1., 2., 5. , 6. Fühlerglied und der Stylus graubraun (das 2. am dunkelsten), das 3. u. 4. weisslich. Beine schwarzbraun, alle Tarsen und die Vordertibien gelb. Diese aussen und innen schmal schwarzbraun. - Bei dem anderen Exemplar ist der Kopf und der Prothorax graubraun, der Pterothorax und die erste Abdomenhälfte gelblich, schwach grau getrübt, die zweite Hälfte des Abdomen schwarzbraun, fast schwarz. Erstes, 5., 6. Fühlerglied und der Stylus gelblichgrau, das 2. graubraun, das 3. weisslich, das 4. gelblich, grau getrübt. Die Beine grau-, fast schwarzbraun, alle Tarsen und die Vordertibien gelb, diese aussen und innen schmal schwarzbraun. - Pterothorax bei den Männchen nur etwa so lang wie der Prothorax und wenig breiter. Abdomen breit, hinten abgerundet. Fühler nur etwas länger als der Kopf, und der Fortsatz ihres 3. Gliedes mohr gerundet als beim Weibchen; das 5. Glied legt sich mit breiter Fläche an die breite Basis des 6 . Gliedes, welches nur wenig länger ist als jenes.

Vorkommen: Die Weibchen das ganze Jahr hindurch im Rasen, jedoch auch in Gras- und einzeln in anderew Blüten. Die Männchen fand ich im Juni. — Fundorte: England (Haliday), Wien (Heeger), Deutschland (Beling, Bohls; bei Berlin Uzel), Moskau (Lindeman), Finnland (Reuter), Böhmen.

\section{Limothrips cerealium Halid.}

1796. Thrips physapus Kirby, Transact. Linn. Soc., pag. 242.

180. - - V - Vassalli-Eandi, Mem. Accad. Sc. di Torino, XVI, LXXVI.

1836. - (Limothrips) cerealium Haliday, Entomol. Magazine, pag. 445.

1836. - cerealium Burmeister, Handb. d. Entomologie, pag. 414.

1837. - - Haliday, Entom. Mag. Additional Notes, pag. 146. (larva).

1843. Limothrips physapus Amyot et Serv., Ins. Hémiptères, pag. 642.

1852. Thrips (Limothrips) cerealium Haliday, Walker: Homopt. ins. etc., pag. 1105.; tab. VI., fig. 4.-6., fig. 15.; tab. VII., fig. 6., fig. 27.-29.

Poznámka. Pozdější údaje, týkající se toho druhu, nejsou určité (viz Část' historickou) a vztahuji se na nejrůznějši druhy, na obilí žijící, které všecky shrnovány bývají pod jménem Thrips cerealium.

Bemerkung. Die späteren Angaben, welche sich auf diese Art beziehen, sind nicht bestimmt, denn es werden in ihnen die verschiedensten auf Getreide lebenden Arten vermengt.

$$
-89-
$$




\section{H. UZEL, MONOGRAPHIE DER ORDNUNG THYSANOPTERA.}

Hali da y (anno 1836.): »Prothorax aequilatus; antenna estylus biarticulatus, articulo sexto brevior; ocelli tres; alae feminae completae, maris nullae. Feminae segmenta posteriora spinosa. - Antennae articulo tertio rotundato. - The larva is yellow; the pupa paler, with long wing-cases."

Haliday (anno 1837.): „The larva is deep yellow, with the greater part of the head, and two spots on the prothorax dusky. The antennae and legs have alternate rings of pale and dusky. The pupa paler yellow, with the antennae, legs, and wing-cases, whitish, the latter reaching to the middle of the abdomen. The eyes are dusky red, and the simple eyes sometimes indicated by red dots."

Halid ay (anno 1852.): " Antenna apicula discreta brevi biarticulata; prothorax apice parum attenuatus; abdomen dorso efoveolatum, segmento fem. extremo biglumi; ocelli 3 ; frons inter oculos impressa; mares apteri (an semper?), abdominis lateribus appendiculatis ante apicem.*

Z výkresư Halidayových z tohoto roku lze ještẽ souditi na následujicí znaky: Tèlo jest velmi úzké a dlouhé. Hlava jest patrně delší než širší, na basi trochu rozšírená. Sosák jest tupý, zaokrouhlenỵ. Makadla maxillarní skládaji se ze tři skoro stejnè dlouhých článkủ. (Tento znak, potvrdi-li se, nenasvědčoval by, že druh cerealium náleží do rodu Limothrips.) Zadní okraj 9. čl. abdomenu samcủ má nahoře uprostřed dva trny a po každé straně těla jeden osten. Desátý čl. abdom. samic má nahoře dva sblížené trny. - V Čechách nebyl druh tento posud objeven.

Aus Halidays Zeichnungen aus dem Jahre 1852 kann man noch folgende Charaktere beifügen: Körper sehr schmal und lang. Saugrüssel stumpf, abgerundet. Maxillartaster aus drei fast gleich langen Gliedern zusammengesetzt. (Dieser Charakter, wenn er sich bewährt, würde die Zugehörigkeit dieser Art zu der Gattung Limothrips stark erschüttern.) Der Hinterrand des 9. Abdominalsegmentes der Männchen hat oben in der Mitte zwei Dornen und auf jeder Seite des Körpers einen Stachel. Das 10. Abdominalsegment der Weibchen oben mit zwei einander genäherten Dornen.

Vorkommen: In Getreideähren. - Fundorte (sichere): England (Haliday), Deutschland (Jordan, Bohls). - In Böhmen lebt diese Art im Getreide nicht.

\section{GENUS SERICOTHRIPS HALID.*)}

Tělo velmi krátké a široké, černé, za živa a za sucha stríbrìitě lesklé, což pochází od nesčishỵch přemalỵch chloupkủ, jimiž jest abdomen poset. Hlava trochu více než dvakrát tak široká jako dlouhá; oči jsou značnou měrou vykoulené. Očka u obou pohlaví prítomna. Tykadla osmičlenná (stylus dvoučlenný). Makadla maxillarní třičlenná. Prothorax skoro dvakrát delši než hlava, s porůznu roztroušenými silnějšími chlupy;

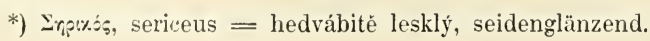


zvláštních delších chlupů smyslových na zadnich jeho rozích není. Nohy bezbranné. Křidla jsou u samic obyčejně, u samcủ vždy zakrnělá. Hořejši jsou na basi široká; na konci prvé třetiny se značně zúžuji a zủstávají zúženými až do konce, kde jsou přišpičatělá. Jimi jde jen jedna žilka, která vychází z base. Přední část’ okružní žilky jest opatrena po celé své délce třásněmi a kratšími ostny. Abdomen značně vyklenutý. Články jeho velmi široké a krátké. Zadní okraje jejich na bríše jsou drobně laločnaté. U samic jest abdomen ke konci velmi zúžen; u samcủ jest celý úzký. Druh sem náležející leze velmi rychle a skáče obratnẽ.

Körper sehr kurz und breit, schwarz, beim lebenden oder getrockneten Thiere silberglänzend, was durch unzählige winzige Härchen bewirkt wird, mit denen das Abdomen besetzt ist. Kopf etwas mehr als zweimal so breit als lang; die Augen stark hervortretend. Ocellen bei beiden Geschlechtern vorhanden. Fühler achtgliedrig (Stylus zweigliedrig). Maxillartaster dreigliedrig. Prothorax fast zweimal so lang als der Kopf, mit zerstreut stehenden stärkeren Borsten; besondere längere Sinnesborsten sind auf seinen Hinterecken nicht vorhanden. Beine wehrlos. Flügel bei den Weibchen gewöhnlich, bei den Männchen immer verkümmert. Die oberen am Grunde breit; am Ende des ersten Drittels verengen sie sich bedeutend und bleiben verengt bis an ihr zugespitztes Ende. Sie werden nur von einer Ader, die aus der Wurzel entspringt, durchzogen. Der vordere Theil der Ringader ist der ganzen Länge nach mit Fransen und kürzeren Wimpern versehen. Abdomen stark gewölbt. Seine Segmente sehr breit und kurz. Ihre Hinterränder am Bauche mit kleinen Anhängseln versehen. Bei den Weibchen ist das Abdomen gegen das Ende zu sehr verengt; bei den Männchen ist es überall schmal. Die her gehörende Art kriecht sehr rasch und springt geläufig.

\section{Sericothrips staphylinus Halid.*)}

Tab. I., fig. 1.; Tab. V., fig. 52.

1836. Sericothrips staphylinus Haliday, Entomol. Magazine, pag. 444.

$\begin{array}{llll}1836 . & - & - & \text { Burmeister, Handb. d. Enlomologie, II, pag. } 413 . \\ 1843 . & - & - & \text { Amyot et Serville, Ins. Hémiptères, pag. } 641 . \\ 1852 . & - & - & \text { Haliday, Walker: Homopt. ins. of Brit. Museum, } \\ \text { pag. } 1103 . ; \text { tab. V., fig. } 14 . \\ 1878-79 . & - & - & \text { Reuter, Diagn. öfv. nya Thysanopt. f. Finland, } \\ & \text { pag. } 11 .\end{array}$

*) Doklad ve sbírce musejní, praep. č. 8. a 9. - Sammlung des böhmischen Landesmuseums, Praep. Nr. 8 u. 9 . 


$$
\text { q. }
$$

První čl. tykadel značně kratši než 2 ., tento podlouhle baňkovitý; 3 . značně delší než druhý, 4. kratší než 3 .; 5 . málo kratší než 4.; 6. trochu kratší než 3.; stylus dosti dlouhý, o dvou článcích, 2. jeho článek delší prvého; 3. a 4. čl. jsou ke konci hrdlovitě zúženy. První čl. tykadla jest žlutý, často na basi slabě šedohnědý, zríídka celý poněkud neb silněji hnědè zkalený; 2. čl. žlutý, 3. čl. žlutý, šedě zkalený, na konci černohnědý; 4., 5., 6. čl. a stylus černé. Zadní tibie jsou na konci dole opatřeny párem ostnů a oba zadní tarsalní články mají dole na konci po jednom ostnu. Všecka femora jsou černá, konce jejich žluté, tibie žluté, střední a zadní někdy kromě konce a zvláště vně slabě (jen výjimkou celé silnēji) hnědě zkalené. Abdomen jest ke konci značně zúžený a konec jeho opatřen jest slabými a krátkými chlupy. Zadní kraje abdom. článkủ dole jsou drobně laločnaté. Délka tèla $0.7-0.9 \mathrm{~mm}$.

\section{$\sigma^{\top}$ (dosud nepopsaný).}

Značně menší a užší ney̌ q; abdomen zúžený, takže šǐ̌ku pterothoraxu nepreesahuje. Poměrné rozmèry hlavy, hrudi, noh, tykadel, barva těla, noh a tykadel, to vše totéž jako u q. Zadní kraje abdominalních článkủ dole jsou také drobně laločnaté. Abdomen má dole na 4. čl. malou, na 5., 6. a 7. čl. vètší světlou prohlubinu.

FORMA MAGROPTERA. (Objevena Halidayem r. 1852.) † i đ. Podélná žilka $\mathrm{v}$ hoř. kř́dle jest po celé délce mnohými silnými chlupy poseta. Zadní křídla jsou úzká a mají jednu silnou žilku. Hoř. kř̌idla jsou červenošedohnědě zkalená a před basí nalézá se široká svěllá bílá stuha. Dol. křídla jsou na basi čirá, jinak velmi slabě šedẽ zkalená. žilka pak jest černošedá. Pterothorax značně širší a delší než prothorax.

FORMA BRACHYPTERA. $\subsetneq$ i $\sigma^{\nearrow}$. Kř́del jen rudimenta, pterothorax nepřesahujicí. Tato rudimenta jsou široká a bílá, na samé basi černohnědě zkalená. Pterothorax as tak dlouhỵ jako prothorax.

Žije v drnu a nalézáme ji v obou pohlavích po celý rok. V létě vylézá někḍ na rùzné rostliny, květû zvláště nevyhledávajíc. Haliday však udává, že nalezl ji četně v květech od Ulex europaea, a Reuter zastihl ji v motýlokvětých. Exempláře, takto neskrytě žijící, bývaji časem okřídlené ( $\sigma^{\nearrow}$ i q). Přezimují v drnu, někdy též pod spadaným listím a v suchých květenstvích. Mezi přezimujícími nalezl jsem koncem listopadu na jednom mistě po dvẽ léta též samičky dlouhokř́ílé.

Čechy: Praha: V Divoké Śárce. Hradec Králové. Třebechovice. Opočno. Prales boubínský. Jind. Hradec (Duda). 


\section{J. UZEL. MONOGRAFIE RADU „THYSANOPTERA“.}

f.

Das erste Fühlerglied bedeutend kürzer als das 2., dieses länglich napfförmig; das 3 . bedeutend länger als das 2., das 4 . kürzer als das 3., das 5 . wenig kürzer als das 4., das 6. etwas kürzer als das 3.; der Stylus ziemlich lang, zweigliedrig, sein 2. Glied länger als das erste; das 3. u. 4. Fühlerglied gegen das Ende halsförmig zusammengezogen. Das erste Fühlerglied gelb, oft am Grunde schwach graubraun, selten ganz schwach oder stärker braun getrübt; das 2. Gl. gelb, das 3. ebenfalls gelb, grau getrübt, am Ende schwarzbraun; das 4., 5., 6. Glied und der Stylus schwarz. Die Hintertibien sind am Ende unten mit einem Paar Stacheln versehen, und die hinteren Tarsenglieder haben unten am Ende je einen ähnlichen Stachel. Alle Schenkel sind schwarz, ihre Enden gelb, Tibien gleichfalls gelb, die mittleren und hinteren manchmal, das Ende ausgenommen, hauptsächlich aussen (nur ausnahmsweise ganz), braun getrübt. Das Abdomen ist gegen das Ende zu bedeutend verengt, und sein Ende ist mit schwachen und kurzen Borsten versehen. Die Hinterränder der Abdominalsegmente sind unten mit kleinen Anhängseln besetzt. Körperlänge $0.7-0.9 \mathrm{~mm}$.

\section{$\sigma^{7}$ (noch unbeschrieben).}

Bedeutend kleiner und schmäler als das $\subsetneq$; Abdomen eng, nicht breiter als der Pterothorax. Dimensionen des Kopfes, des Thorax, der Beine, der Fühler und die Körperund Extremitätenfarbe wie bei dem Weibchen. Die Hinterränder der Abdominalsegmente sind unten ebenfalls mit kleinen Anhängseln versehen. Das Abdomen hat unten am 4. Segmente eine kleine, am 5., 6. u. 7. je eine grössere lichte Vertiefung.

FORMA MACROPTERA. (Von Haliday entdeckt.) $\subsetneq u . \sigma^{\star}$. Die Hauptader ist der ganzen Länge nach mit vielen starken Borsten besetzt. Die Hinterflügel sind schmal und haben eine starke Ader. Die Oberflügel sind rothgraubraun getrübt und vor dem Grunde mit einer breiten lichten Binde versehen. Die Unterflügel sind am Grunde hell, sonst sehr schwach grau getrübt, ihre Ader ist schwarzgrau. Pterothorax bedeutend breiter und länger als der Prothorax.

FORMA BRAchyptera. $\subsetneq u$. $\sigma^{\nwarrow}$. Die Flügel sehr kurz, den Pterothorax nicht überreichend. Die Flügelrudimente sind breit und weiss, am Grunde schwarzbraun getrübt. Pterothorax etwa so lang wie der Prothorax.

Vorkommen: Das ganze Jahr hindurch ( + u. $\left.\sigma^{\pi}\right)$ hauptsächlich im Rasen. Geflügelte Exemplare ( $q$ u. $\left.\sigma^{\nwarrow}\right)$ manchmal auf Büschen und Blumen. - Fundorte: England (Haliday), Finnland (Reuter), Böhmen. 


\section{H. UZEL, MONOGRAPHIE DER ORDNUNG THYSANOPTERA.}

\section{GENUS PHYSOPUS (DEG.) AM. et SERV.*)}

Očka jsou obyčejně prítomna, někdy však více nebo méně zakrñují. Tykadla osmičlenná (stylus dvoučlenný). Nakadla maxillarní třičlenná. Prothorax as tak dlouhý jako hlava neb trochu delší. Na předních jeho rozích nalézáme u druhů: vulgatissima, tenuicomis, pallida, nervosa, robusta a nigriventris po jednom dlouhém chlupu smyslovém, kterého tam u ostatních druhů není. Na zadních rozích jeho po dvou podobných chlupech. Nohy obyčejně bezbranné, u některých druhủ však (phalerata, intermedia a ulicis) opatřeny jsou přední tibie na konci dole silným zubem; u druhủ robusta a inconsequens pak ukončeny jsou přední tarsy na konci dole malým ostrým zoubkem. Kř́dla jsou obyčejnè vyvinutá, někdy však jsou zkrácená, takže pterothorax nepřesahuji (pak i očka více nebo méně zakrňují). Jsou dosti široká a na přední části žilky okružní nalézají se mezi třásněmi silné, dosti dlouhé brvy. U druhû, které mají diouhý smyslový chlup na předních rozích prothoraxu, jsou vždy obě žilky v hoř. křídle po celé délce četnými silnými brvami opatřeny. Hořejší pár bývá někdy světle a tmavẽ stuhovaný. Abdomen dosti silně chlupatý; chlupy na jeho konci tenké a dlouhé; u samců druhů robusta a aspera má 8. čl. po každé straně silný trn. Druhy sem náležející jsou k skákání způsobilé.

Ocellen gewöhnlich vorhanden, zuweilen jedoch mehr oder weniger verkümmert. Fühler achtgliedrig (Stylus zweigliedrig). Maxillartaster dreigliedrig. Prothorax etwa so lang wie der Kopf oder etwas länger. Auf seinen Vorderecken steht bei den Arten: vulgatissima, temuicomis, pallida, nervosa, robusta und nigriventris je eine lange Sinnesborste, welche bei den übrigen Arten dort fehlt. Auf seinen Hinterecken befinden sich je zwei ähnliche Borsten. Beine gewöhnlich wehrlos, bei manchen Arten jedoch (phalerata, intermedia, ulicis) sind die Vordertibien am Ende unten mit einem starken Zahn bewaffnet; bei den Arten robusta und inconsequens sind die Vordertarsen am Ende unten mit einem kleinen scharfen Zahn versehen. Flügel gewöhnlich entwickelt, manchmal jedoch verkürzt, so dass sie den Pterothorax nicht überreichen (in diesem Falle verkümmern auch die Ocellen mehr oder weniger). Sie sind ziemlich breit und am Vorderrande befinden sich zwischen den Fransen starke, ziemlich lange Wimpern. Bei den Arten, die eine lange Borste am Vordereck des Prothorax haben, sind immer beide Längsadern im Oberflügel der ganzen Länge nach mit zahlreichen starken Wimpern besetzt. Die Oberflügel pflegen manchmal licht und dunkel gebändert zu sein. Abdomen ziemlich stark borstig; die Borsten auf seinem Ende dünn und lang; bei den Männchen der Arten robusta und aspera hat das 8. Segment jederseits einen starken Dorn. Die her gehörenden Arten haben ein Springvermögen.

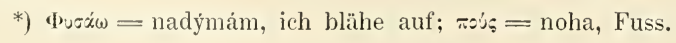




\section{J. UZEL, MONOGRAFIE RADU, "THYSANOPTERA“.}

\section{Physopus vulgatissima Halid.*)}

Tab. V., fig. 53. et 54 .

1744. Physapus ater, alis albis; Degeer, K. Swenska Wetensk. Acad. Handl., V, pag. 6. ; tab. I., fig. 4 .

1773. Thrips atra, alis albis, antennis sexnodiis; Degeer, Mém. p. servir à l'hist. d. Insectes, pag. 6.; tab. I., fig. 1. (Goeze III, pag. 4.).

1776. Thrips, Physapus atra, elytris albidis, conjunctis, fastigatis; Müller, Zoologiae danicae Prodromus, pag. 96.

1777. Thrips physapus Goeze, Entomol. Beyträge, pag. 347.

1836. - vulgatissima Haliday, Entomolog. Magazine, pag. 447.

1836. - - Burmeister, Handb. d. Entomologie, II, pag. 414.

1843. Physapus ater Amyot et Serville, Ins. Hémiptères, pag. 643.

1852. Thrips vulgatissima Haliday, Walker: Homopt. ins. of Brit. Museum, pag. 1110.; tab. VI., fig. 14.

?1852. - - Heeger, Sitzungsb. d. Akad. d. Wiss., Wien, IX, pag. 488.; tab. XXII.

1878-79. - - - Reuter, Diagn. öfv. nya Thysanopt. f. Finland, pag. 6. f.

Barva těla dosti nestálá, tmavě šedohnědá až černohnědá a výjimkou černá; pterothorax jest šedẽ červenohnědý, při světlejších exempl. šedě žlutohnědý; abdomen ke konci černý. Hlava širší než delší, nazad dosti značně zúžená. Z vrásek, jež se na týle nalézají, jest jedna nejpatrnèjši. Očka jsou přítomna. Tykadel 1. ěl. kratší než 2., 3. delší než tento; 3., 4. a 6. skoro stejně dlouhé, 5. značně kratší; stylus dosti dlouhý, ne př́liš tenký, o dvou stejných článcích. Barva tykadel: 1. a 2. čl. tmavo- neb černohnědé (1. ěl. bývá světlejší ně̌ 2. a průsvitavý), 3., 4. a 5. žlutavé, nahoře ke konci velmi slabě šedẽ zkalené (pátý bývá výjimkou skoro celý silnēji zkalenỹ); 6. čl. a stylus černohnědé. Prothorax nepatrně delší hlavy, zadní rohy široce zaokrouhlené. Na předních rozich po jednom dlouhém chlupu, na zadních po dvou. Kromě těchto chlupủ má ještě prothorax na zadním svém okraji po každé straně pět malých chloupkủ, z nichž čtvrtý

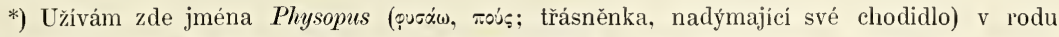
ženském (dle analogie se slovem $\dot{r}_{i}$ ìxírous = bystronohá) z toho dủvodu, aby docílen byl souhlas $\mathrm{v}$ rodu jmen rodových, který jest všude jinde $\mathrm{v}$ tomto řádu ženský.

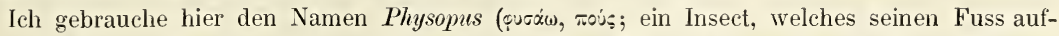

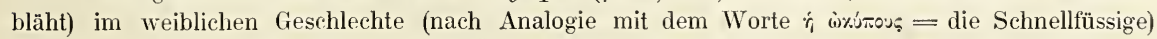
damit eine Übereinstimmung im Geschlechte mit den übrigen Gattungsnamen, die in dieser Ordnung durchgehends weiblich sind, erreicht werde.

Doklad ve sbirce musejni, praep. č. 10. - Sammlung des böhmischen Landesmuseums, Praep. Nr. 10. 


\section{H. UZEL, MONOGRAPHIE DER ORDNUNG THYSANOPTERA.}

jest nejdelši. Pterothorax značně širši a delší než hlava. Nohy bezbranné. Přední femora na konci a uvnitr̃ žlutavá, vně šedohnědá. Střední a zadní femora šedohnědá, na konci žlutavá, tibie prvého páru noh před basi vně slabẽ šedohnědẽ zkalené, střední uprostřed šedohnědé, zadni tibie taktéž šedohnědě zkalené, na samé basi a na konci žlutavé; tarsy žlutavé. Obẽ żilky $\mathrm{v}$ hoř. kř́idlech ěetnými chlupy stejnoměrnè posety. Tato jsou slabě šedožlutě zkalená, ke konci často trochu silněji; dolejši jsou čirá. Abdomen na konci tmavými dlouhými štětinami opatřen. Délka těla $1 \cdot 2 \mathrm{~mm}$.

Var. (nov.) adusta. Hlava a prothorax žlutavé, obyčejně šedě zkalené, někdy světle hnědožluté s šedým náletem. Pterothorax světle hnèdožlutý. více nebo ménẽ šedè zkalený. Výjimkou jest pterothorax šedožlutavý. Abdomen běložlutavý, žlutavý neb velmi světle hnědožlutavý, zpočátku slabě, ke konci pak silněji zkalený a na konci (obyčejně na dvou posledních ěláncích) černošedý. Tykadla a nohy jsou podobně zbarveny, jako u typické formy, ale mnohem bleději. První ěl. tykadel někdy bývá i průsvitavý. Mezi touto varietou a formou typickou existuji mnohé přechody. Množství exemplár̆ů nalezeno.

Var. (nov.) albicornis. Tykadel 1. a 2. čl. šedohnědé, ostatek tykadla bílý. Hlava a abdomen tmavě šedohnědě zbarvené, tento ke konci černohnědý; thorax sedè červenohnědý. Nohy jako u typické formy. - Dva exempl. nalezeny.

Var. (nov.) fulvicornis. Tykadla celá žlutavě šedohnědě zbarvená, 3. čl. trochu světlejší; zbarvení těla jako u typické formy. - Jeden exempl. nalezen.

Var. (nov.) nigropilosa. Barva těla žlutá, thorax trochu tmavější. Nejzazši koneček abdomenu tmavý; chlupy na těle černé. Barva tykadel žlutavá, 2. čl. celý, 3., 4. a 5. čl. na konci velmi slabě šedě zkalené, 6. čl. a stylus černošedé. Nohy žluté, nezkalené. Křídla slabě šedožlutě zkalená, dosti krátká. Dva exempl. nalezeny.

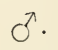

Jest značně menší a užší neż @. Hlava žlutavá, thorax nádherně žlutý, abdomen žlutavý, nahoře slaběji neb silněji, zrídka velmi silně šedě zkalený. Chlupy na těle černé. Tykadel 1. a 2. čl. žlutavé, 3., 4. a 5. čl. taktéž žlutavé, na konci šedè zkalené, 6. čl. tmavošedý, na basi, jindy do polou žlutavý neb jen světlejší, stylus tmavošedý. Kř́dla slabě žlutavě zkalená. Nohy žlutavé, vně někdy slabě (zřídka silněji) šedě zkalené. Dva poslední čl. abdomenu jsou velmi silnými černými zahnutými chlupy opatřeny. Šafránově žlutá varlata prosvítají. Na 3.-7. čl. abdom. dole jsou dlouhé úzké světlé prohlubiny, jež však nelze pro svěllost okolí ziretelně vidèti a jen pròi exemplařích, které mají abdomen i dole trochu zkalený, zřetelněji vystupuji.

Druh tento jest nejhojnęjši třásněnkou vůbec. Samičky lze nalézti po celý rok. Když z jara paprsky sluneční půdu jen trochu rozehřejou a první květy počinají se objevovati, vylézají trásněnky tyto ze svých zimních skrỵš́i a navštěvuji je všecky, nejsouce 


\section{J. UZEL, MONOGRAFIE RADU „THYSANOPTERA“.}

nijak vybíravými. Později žiji ve velikém množství skoro ve všech květech (i na Petısites, která se zdá býti třásněnkám protivnou) a vyskytuji se na nich časem $\mathrm{v}$ prevelikém množství, takže je téměr naplñuji. Takovým zpủsobem obtěžovány bývají vrbové kočičky, vadnouci již kvèty od Galanthus nivalis, dále květy od Onobrychis sativa, Solanum tuberosum, Armeria vulgaris a Colchicum autumnale. Květủm papilionaceí (ve kterých již Haliday je nalézal) dávají přednost' před květy složnokvětých a zvl. okoličnatých. Kromě v květech zdıžují se také na listech různých nízkých rostlin i stromů, zvláště mladých, a ssají jejich štávu. Žijí též na mnohých rostlinách pěstovaných a stávaji se jim škodlivými. Mimo ligrus a brambory, o kterých jsme se již zmínili, navštèvuji hojnè květy od Papaver somniferum, Vicia sativa, Vicia faba, Limum usita tissimum, samči květy kukuřice, četné květy zahradní; mladé výhonky chmelu, květenství cukrovky; méně obývají květy ovocných stromů. Květenstvím travin a klasy obilnými pohrdají. Samci objevuji se v první polovici června a mizejí v řijnu. Vyskytují se někdy v počtu úžasném. Samice přezimuji v drnu, pod spadaným listím a větvičkami, pod korou stromovou a mnohé také $\mathrm{v}$ seschlých květenstvích, a to zvláště květin zahradních, takže si je v zimě snadno v libovolném množství mủžeme ke studiím anatomickým opatřiti. Druh tento pro svou neobyčejnou hojnost' jest velikou svizelí sběratele třásněnek, kterýž jest nucen schytati třásněnky všecky bez rozdílu, nebot' bez ohledání mikroskopického nelze většinu druhủ pro jejich drobnost' rozeznati. Tím již mnoho času přichází na zmar; ještě mnohem více času však vyžaduje oddèlování druhû jiný̛ch, které často jsou jen nepatrným procentem $\mathrm{v}$ zástupech druhu vulgatissima, a jež velmi snadno lze prehlédnouti.

Vyskytuje se všude po Čechách. V Krkonoších jest velmi hojná a dostupuje tam nejvyšších vrcholků. Var. adusta žije mezi typickou formou dosti zhusta. Var. albicornis a var. fulvicornis objeveny na vrcholu Sněžky. Var. nigropilosa nalezena v červnu a srpnu u Mukařova a nedaleko Chotěboře (Vařečka).

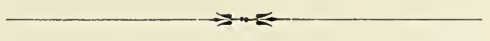

Q.

Körperfarbe ziemlich veränderlich, dunkel graubraun bis schwarzbraun, ausnahmsweise schwarz; Pterothorax grau rothbraun, bei lichteren Exemplaren grau gelbbraun; Abdomen gegen das Ende zu schwarz. Kopf mehr breit als lang, nach hinten bedeutend verengt. Von den am Hinterhaupte befindlichen Runzeln ist eine am auffallendsten. Ocellen vorhanden. Erstes Fühlerglied kürzer als das 2., das 3. länger als das vorhergehende; das 3., 4. u. 6. fast gleich lang, das 5. bedeutend kürzer; der Stylus ziemlich lang, nicht sehr dünn, aus zwei gleichen Gliedern zusammengesetzt. Fühlerfarbe: 1. u. 2. Glied dunkel- oder schwarzbraun (das 1. pflegt lichter zu sein als das 2., und dabei 


\section{H. UZEL, MONOGRAPHIE DER ORDNUNG THYSANOPTERA.}

durchscheinend), das 3., 4. u. 5. gelblich, oben gegen das Ende zu sehr schwach grau getrübt (das 5. pflegt ausnahmsweise gänzlich dunkler getrübt zu sein); das 6. Glied und der Stylus schwarzbraun. Prothorax unbedeutend länger als der Kopf, seine Hinterecken breit abgerundet; auf den Vorderecken ist er mit je einer, auf den Hinterecken mit je zwei langen Borsten versehen. Ausser diesen Borsten hat der Prothorax auf seinem Hinterrande jederseits fünf kleine Härchen, von denen das vierte am längsten ist. Pterothorax bedeutend breiter und länger als der Prothorax. Beine wehrlos. Vorderschenkel am Ende und imnen gelblich, aussen graubraun. Die mittleren und hinteren Schenkel graubraun, am Ende gelblich; die Tibien des ersten Beinpaares gelblich, vor dem Grunde aussen schwach graubraun getrübt, die mittleren gelblich, in der Mitte graubraun, die hinteren graubraun getrübt, am Grunde und am Ende gelblich; Tarsen gelblich. Beide Längsadern im Oberflügel mit zahlreichen Borsten gleichmässig besetzt. Die Oberflügel schwach graugelb getrübt, gegen das Ende zu oft etwas stärker; die Unterflügel sind hell. Abdomen am Ende mit langen dunklen Borsten versehen. Körperlänge $1.2 \mathrm{~mm}$.

Var. (nov.) adusta. Kopf und Prothorax gelblich, gewöhnlich grau getrübt, manchmal licht braungelb mit grauem Anflug. Pterothorax licht braungelb, mehr oder weniger grau getrübt. Ausnahmsweise ist der Pterothorax graugelblich. Abdomen weissgelblich, gelblich oder sehr licht braungelblich, anfangs schwach, gegen das Ende zu jedoch stärker getrübt und am Ende (gewöhnlich die zwei letzten Segmente) schwarzgrau. Fühler und Beine ähnlich wie bei der typischen Form gefärbt, nur viel lichter. Das erste Fühlerglied pflegt auch manchmal durchscheinend zu sein. - Zwischen dieser Varietät und der Stammform existieren viele Übergänge.

Var. (nov.) albicornis. Die ersten zwei Fühlerglieder graubraun, die übrigen weiss. Kopf und Abdomen dunkel graubraun, dieser gegen das Ende zu schwarzbraun; Thorax grau rothbraun. Beine wie bei der Stammform.

Var. (nov.) fulvicornis. Fühler ganz gelblich graubraun, das 3. Glied etwas lichter; Körperfarbe wie bei der Stammform.

Var. (nov.) nigropilosa. Körperfarbe gelb, Thorax etwas dunkler. Das äusserste Abdomenende dunkel; Borsten am Körper schwarz. Fühlerfärbung gelblich, das 2. Glied ganz, das 3., 4. u. 5. am Ende sehr schwach grau getrübt, das 6. Glied und der Stylus schwarzgrau. Beine gelb, nicht getrübt. Flügel ziemlich kurz, schwach graugelb getrübt.

$$
\sigma^{\top}
$$

Bedeutend kleiner und schmäler als das $\uparrow$. Kopf gelblich, Thorax hochgelb, Abdomen gelblich, oben schwächer oder stärker, selten sehr stark grau getrübt. Borsten am Körper schwarz. Die ersten zwei Fühlerglieder gelblich, das 3., 4. u. 5. ebenfalls gelblich, am Ende grau getrübt, das 6. Glied dunkelgrau, am Grunde, manchmal bis zur Hälfte gelblich oder nur heller gefärbt, der Stylus dunkelgrau. Flügel schwach gelblich 
getrübt. Beine gelblich, aussen manchmal schwach (selten stärker) grau getrübt. Die zwei letzten Abdominalsegmente sind mit sehr starken schwarzen gebogenen Borsten versehen. Die safrangelben Hoden scheinen durch. Am 3.-7. Abdominalsegmente befindet sich je eine schmale, lange, lichte Vertiefung, die jedoch wegen der lichten Umgebung nicht deutlich wahrzunehmen ist und nur bei Exemplaren, bei welchen das Abdomen auch unten etwas getrübt ist, deutlicher hervortritt.

Vorkommen: Weibchen das ganze Jahr hindurch überall, nur nicht in Grasund Getreideblüten. Männchen von Juni bis October. - Fundorte: England (Haliday), Wien (Heeger), Finnland (Reuter), Deutschland (Jordan, Bohls; bei Berlin Uzel), Böhmen.

\section{Physopus tenuicornis nov. sp.*)}

Barva těla tmavẽ šedohnědá až černohnědá; pterothorax jest šedě červenohnědý, při světlejších exemplářich šedě žlutohnědý; abdomen ke konci černý. Hlava as tak široká jako dlouhá, s tvářemi nevypouklými; nazad značně zúžená. Z vrásek, jež se na týle nalézají, jest jedna nejpatrnèjší. Tykadla velmi tenká. První čl. kratší než 2., 3. značně delší než tento, 4. trochu kratší než 3 , 5. kratší než 4., 6. článek tak dlouhý jako 3., stylus dlouhý, silný, o dvou skoro stejných článcích. Barva tykadel: 1. a 2. čl. šedohnědé, první trochu světlejší, 3. a 4. žlutavé, 5., 6. čl. a stylus černošedé. Někdy jest 3. ěl. trochu, a výjimkou jen silněji zkalený. Prothorax jest o něco kratší hlavy a zadní rohy nejsou tak široce zaokrouhlené jako u druhu předcházejícího, ani přední tak ostré. Na těchto nalézá se po jednom dlouhém chlupu, na zadních po dvou. Malé chloupky na zadním okraji prothoraxu jsou v témže počtu a téhož tvaru jako u předẹšlého druhu. Pterothorax značně širši a delší než prothorax. Přední nohy trochu stlustlé. Všecka femora šedohnědá, na konci žlutavá. Přední a střední tibie žlutavé, před basí zvláště vně slabě, někdy silněji šedohnědě zkalené, zadní tibie šedohnědé, na samé basi a ke konci žlutavé; tarsy též žlutavé. Obě žilky v hořejším křídle četnými chlupy stejnoměrně posety. Hořejší křídla jsou žlutavě zkalená, na basi skoro ěirá, dolejší čirá. Abdomen na konci tmavými dlouhými štětinami opatřen. Délka těla $1.4 \mathrm{~mm}$.

Var. adusta. Barva hlavy a prothoraxu šedožlutavá, pterothoraxu světle hnědožlutá, šedě zkalená. Abdomen jest žlutavý, slabě šedě zkalený, ke konci tmavější; poslední dva články jeho jsou černošedé až černé. Tykadla a nohy podobně zbarveny jako u typické formy, ale mnohem (zvláště nohy) bleději. První článek tykadel jest průsvitavý.

*) Doklad ve sbirce musejní, praep. ě. 11. - Sammlung des böhmischen Landesmuseums, Praep Nr. 11. 


\section{H. UZEL, IONOGRAPHIE DER ORDNUNG THYSANOPTERA.}

$$
\sigma^{\pi}
$$

Menši a užší než $q$. Hlava, prothorax a abdomen žlutavé; tento nahoře, kromě posledních dvou článkủ, silně zkalený. Pterothorax bývá temnēji žlutavý až světle hnědožlutavý; jest bud taktéž šedě zkalený aneb mívá rovněž tak jako prothorax šedé skvrny kresby tvořicí. Tykadla jsou žlutavá, 5., 6. čl. a stylus však černošedé; často bývají 2. a 4. čl. velmi slabě šedě zkalené. Nohy jsou žlutavé, vně velmi slabě šedě zkalené; konec abdomenu opatřen dosti silnými černými chlupy. Šafránově žlutá varlata prosvítají. Na 3.-7. čl. dole jsou dlouhé úzké prohlubiny, jež však nelze pro svěllost' okolí zřetelně vidèti. - Dosti značné množství exempl. nalezeno.

Vyskytuje se misty hojně $v$ klasech ječných a ovesných. $V$ žitě a $v$ pšenici bývá hostem vzácným. Dále žije nečelně v květech od Papaver somniferum, Cirsium palustre, Panicum miliaceum, v kvètenství trav, na rozličných nízkỹch rostlinách nekvetoucích, na listech kukur̃ice a na listech olšových. Samice žijí po celý rok a přezimuji v drnu. Samci objevují se od června do zárí. Var. adusta vyskytuje se mezi formou typickou pořídku.

Čechy: Praha. Hradec Krrálové. Třebechovice. Opočno. Krrkonoše: Na temeni i na stráních Sněžky v drnu; na temeni Vys. Kola.

$$
\text { P. }
$$

Körperfarbe dunkel graubraun bis schwarzbraun, Pterothorax grau rothbraun, bei lichteren Exemplaren grau gelbbraun; Abdomen gegen das Ende zu schwarz. Kopf etwa so breit wie lang, seine Wangen nicht gewölbt; nach hinten bedeutend verengt. Von den am Hinlerhaupte befindlichen Runzeln ist eine am auffallendsten. Fühler sehr dünn. Erstes Glied kürzer als das 2., das 3. bedeutend länger als jenes, das 4. etwas kürzer als das 3., das 5. kürzer als das 4., das 6. so lang wie das 3., der Stylus lang; stark, aus zwei fast gleichen Gliedern zusammengesetzt. Fühlerfärbung: 1. u. 2. Glied graubraun, das 1. etwas lichter, das 3. u. 4. gelblich, das 5., 6. Glied u. der Stylus schwarzgrau. Manchmal ist das 3. Glied wenig, nur ausnahmsweise stärker getrübt. Prothorax etwas kï̈zer als der Kopf. Auf seinen Hinterecken befinden sich je zwei, auf den Vorderecken je eine lange Borste. Die kleinen Härchen auf seinem Hinterrande gleichen in Zahl und Gestalt jenen der vorhergehenden Art. Pterothorax bedeutend breiter und länger als der Prothorax. Die Vorderbeine etwas verdickt. Alle Schenkel graubraun, am Ende gelblich. Vorder- und Mitteltibien gelblich, vor der Basis besonders aussen schwach, manchmal stärker graubraun getrübt; Hintertibien graubraun, am untersten Grunde und gegen das Ende zu gelblich, Tarsen gelblich. Beide Längsadern im Oberflügel mit zahlreichen, gleichmässig vertheilten Borsten 
besetzt. Die Oberflügel gelblich getrübt, am Grunde fast klar, die Unterflügel ganz klar. Abdomenende mit langen dunklen Borsten versehen. Körperlänge $1.4 \mathrm{~mm}$.

Var. adusta. Farbe des Kopfes und des Prothorax graugelblich, des Pterothorax licht braungelb, grau getrübt. Abdomen gelblich, schwach grau getrübt, gegen das Ende zu dunkler; seine zwei letzten Segmente schwarzgrau bis schwarz. Fühler und Beine ähnlich wie bei der Stammform gefärbt, jedoch (hauptsächlich die Beine) lichter. Erstes Fühlerglied durchscheinend.

\section{$\delta^{7}$}

Kleiner und schmäler als das $\uparrow$. Kopf, Prothorax und Abdomen gelblich; dieses oben, ausser den letzten zwei Segmenten, stark getrübt. Der Pterothorax pflegt dunkler gelblich bis licht braungelblich zu sein; er ist entweder ebenfalls grau getrübt oder hat ähnlich wie der Prothorax graue Flecke, welche Zeichnungen bilden. Fühler gelblich, 5., 6. Glied und der Stylus jedoch schwarzgrau; oft pflegt das 2. u. 4. Glied sehr schwach grau getrübt zu sein. Beine gelblich, aussen sehr schwach grau getrübt; das Abdomenende mit ziemlich starken schwarzen Borsten besetzt. Die safrangelben Hoden scheinen durch. Am 3.-7. Abdominalsegmente unten je eine lange schmale, lichte Vertiefung, die jedoch wegen der lichten Umgebung schwer zu unterscheiden ist.

Vorkommen: Zuweilen häufig in Gersten- und Haferähren, sonst vereinzelt in verschiedenen Blüten. Weibchen findet man das ganze Jahr hinduch; sie überwintern im Rasen. Die Männchen leben von Juni bis September. - Fundort: Böhmen.

\section{Pliysopus pallida nov. sp.*)}

$$
\text { q. }
$$

Hlava a thorax žlutavé, abdomen světle žlutohnědý, slabě šedě zkalený, aneb hlava a abdomen žlutavé, thorax slabě žlutohnědý; celé tělo nahoře slabě šedẽ zkaleno. Hlava širší než delší, nazad trochu zúžená. Tykadla tenká; 1 . čl. jejich značně kratší než 2., 3. trochu delši než tento, ke konci hrdlovitě zúžený, 4. a 6. trochu delší a 5. trochu kratší než 3.; stylus dlouhý, tenký, 2. čl. jeho delší prvého. Barva tykadel: 1 čl. celý žlutavý, 2. čl. žlutavý, slabě šedě zkalený, 3. žlutavý, ke konci slabě šedẽ zkalený, 4. skoro do polou žlutavý, ostatek šedý, 5. žlutavý, od polou nebo na konci šedý; ostatní články tmavošedé. Prothorax as tak dlouhý jako hlava. Na zadních rozích po dvou dlouhých chlupech, na předních po jednom. Pterothorax mnohem silnější a delší než prothorax. Malé chloupky na zadním okraji jeho podobně jako u druhů předešlỵch rozestavené i utvořené. Nohy žlutavé, pr̉ední trochu stlustlé. Krǐídla jsou dosti krátká, hořejší slabě žlutavě šedě zkalená a na bașị.

*) Doklad ve sbírce autorově. 


\section{H. UZEL, MONOGRAPHIE DER ORDNUNG THYSANOPTERA.}

sotva světlejší. Obě žilky jejich jsou stejnoměrně mnohými chlupy posety. Spodní krídla jsou čirá. Délka těla $1 \mathrm{~mm}$. - Dva exempl. nalezeny.

$$
\sigma^{\top} \text {. Nebyl posud objeven. }
$$

Nalezena $\mathrm{v}$ dubnu $\mathrm{v}$ kvètech mochny.

Čechy: Praha: U Sv. Prokopa. Hradec Králové.

q.

Kopf und Thorax gelblich, Abdomen licht gelbbraun, schwach grau getrübt, oder Kopf und Abdomen gelblich. Thorax licht gelbbraun; der ganze Körper oben schwach grau getrübt. Kopf mehr breit als lang, nach hinten etwas verengt. Fühler dünn; ihr 1. Glied bedeutend kürzer als das 2., das 3. etwas länger als jenes, gegen das Ende zu halsförmig verengt, das 4. u. 6. etwas länger und das 5. etwas kürzer als das 3.; der Stylus lang, dünn, sein 2. Glied länger als das erste. Fühlerfärbung: 1. Glied ganz gelblich, das 2. gelblich, schwach grau getrübt, das 3. gelblich, gegen das Ende zu schwach grau getrübt, das 4. fast bis zur Mitte gelblich, übrigens grau, das 5. gelblich, hinter der Mitte oder am Ende grau; die übrigen Glieder dunkelgrau. Prothorax etwa so lang wie der Kopf. Auf seinen Hinterecken je zwei, auf seinen Vorderecken je eine lange Borste. Pterothorax viel stärker und länger als der Prothorax. Die kleinen Härchen auf seinem Hinterrande ähnlich vertheilt und gebildet wie bei der vorhergehenden Art. Beine gelblich, die vorderen etwas verdickt. Die Flügel sind ziemlich kurz, die oberen schwach gelblich grau getrübt und am Grunde kaum lichter. Beide Längsadern derselben gleichmässig mit vielen Borsten besetzt. Die unteren Flügel sind hell. Körperlänge $1 \mathrm{~mm}$.

ơ unbekannt.

Vorkommen: Im April in den Blüten von Potentilla. - Fundort: Böhmen.

\section{Plyssopus nerrosa nov. sp.*)}

$$
\text { q. }
$$

Barva těla černohnědá, pterothorax žlutohnědý. Hlava jen trochu širší než delší, strany její za očima jsou rovnoběžné. Očka od sebe oddálená. Na týle množství parallelních vrásek, z nichž žádná není zvláště vy̧značená. Tykadla tenká, 1. ěl. jejich značně kratší ně̌ 2., 3. trochu delší než předcházející, 3. a 4. čl. skoro stejně dlouhé, Praep. Nr. 12.

Doklad ve sbirce musejni, praep. ¿̌. 12. - Sammlung des böhmischen Landesmuseums, 
5. kratší, 6. delší než 3.; stylus dlouhý, o dvou stejných článcích. Barva tykadel: 1. a 2. čl. černohnědé, první trochu světlejší, 3. a 4. čl. žlutavé, 4. slabě, někdy silněji hnědě zkalený, 5., 6. čl. a stylus černohnědé. Prothorax tak dlouhý jako hlava a málo širší. Na předních jeho rozích po jednom dlouhém chlupu, na zadních po dvou. Malé chloupky na zadním okraji jeho podobně jako u předešlých druhủ rozestavené i utvořené. Pterothorax značně delší a širší než prothorax. Přední nohy jsou trochu stlustlé. Femora tmavě šedohnědá, na basi a zvl. na konci (přední též někdy urnitř) žlutavá, tibie téže barvy a kromé konce nahoře a dole šedohnědě zkalené. Obě žilky podélné v hoř. krǐídle jsou velmi silné a stejnomèrně po celé délce mnohỵmi chlupy poseté. Hoř. křídla jsou Žlutavě neb šedožlutavě zkalená. Abdomen na konci černými dlouhỵ́mi a tenkými chlupy opatřen. Délka těla $1 \mathrm{~mm}$. - Tři exempl, nalezeny.

$$
\text { ơ. Posud nebyl objeven. }
$$

Nalezena v prvních jarních květech; také v drnu, kdež přezimovala. Čechy: Hradec Králové. Turnov: U Rovenska (slč. Aloisie Bubáková).

$$
\text { f. }
$$

Körperfarbe schwarzbraun, Pterothorax gelbbraun. Kopf nur ein wenig mehr breit als lang, seine Wangen parallel. Ocellen weit auseinander stehend. Auf dem Hinterhaupte viele a parallele Runzeln, von denen keine besonders ausgezeichnet ist. Fühler dünn, ihr 1. Glied bedeutend kürzer als das 2., das 3 . etwas länger als das vorhergehende, das 3. und 4. fast gleich lang, das 5. kürzer, das 6. länger als das 3.; der Stylus lang, aus zwei gleichen Gliedern zusammengesetzt. Fühlerfärbung: 1, u. 2. Glied schwarzbraun, das 1. etwas lichter, das 3. u. 4. gelblich, das 4. schwach, manchmal stärker braun getrübt, das 5., 6. Glied und der Stylus schwarzbraun. Prothorax so lang wie der Kopf und wenig breiter. Auf seinen Vorderecken je eine, auf seinen Hinterecken je zwei lange Borsten. Die kleinen, auf seinem Hinterrande befindlichen Härchen ähnlich wie bei den vorhergehenden Arten dislociert und gebildet. Pterothorax bedeutend länger und breiter als der Prothorax. Vorderbeine etwas verdickt. Schenkel dunkel graubraun, am Grunde und hauptsächlich am Ende (die vorderen auch manchmal innen) gelblich; Tibien ebenfalls gelblich und, das Ende ausgenommen, oben und unten graubraun getrübt. Beide Längsadern im Oberflügel sind sehr stark und gleichmässig der ganzen Länge nach mit vielen Borsten besetzt. Die Oberflügel gelblich oder graugelblich getrübt. Abdomen am Ende mit schwarzen langen Borsten versehen. Körperlänge $1 \mathrm{~mm}$.

$$
\text { ơ unbekannt. }
$$

Vorkommen: In den ersten Frühlingsblumen; überwintert im Rasen. - Fund ort: Böhmen. 


\section{H. UZEL, MONOGRAPHIE DER ORDNUNG THYSANOPTERA.}

\section{Physopus robusta nov. sp.*)}

Tab. V., fig. 55. et 56 .

q.

Barva těla černá až černohnědá; postava velmi mohutná. Hlava jen trochu širší než delší, nazad sotva zúžená. První článek tykadel značně kratší a trochu širší než 2 ., 3. mnohem delší než předcházející, 4. kratší než 3 , 5 . kratší než 4., 6. trochu kratší než 3. Stylus silný, a to zvl. jeho první článek, který jest značně kratší druhého. Barva tykadla: 1. a 2. čl., pak 5., 6. čl. a stylus černé, někdy černohnědé, 3. čl. žlutavý, 4. taktéž žlutavý, nahoře hnědě zkalený. Prothorax trochu delší a širší než hlava. Na předních rozich po jednom, na zadních po dvou dlouhých chlupech. Nalé chloupky na zadním okraji jeho podobně jako u předešlých druhủ rozestavené i utvořené. Pterothorax mnohem delší a širši než prothorax. Nohy zavalité, bezbranné; jen na konci tarsu předního nalézá se dole malý ostrý zoubek. Přední femora tlustši než femora ostatních noh. Všecka femora černá; přední tibie žluté, nahoře a dole hnědě zkalené. Ostatní tibie celé černé. Všecky tarsy žluté. Obě žilky $\mathrm{v}$ hoř. kř́idlech stejnoměrně mnohými chlupy poseté. Tato silně hnědošedě zkalená, ke konci světlejší, na basi čirá. Dol. kirídla čirá. Abdomen ke konci zúžený, značně přišpičatělý. Chlupy na konci abdomenu tenké, černé. Osmý čl. jest po obou stranách opatřen širokým, ostře se zakončujícím cípkem, který sice u jiných druhủ jest také prítomen, avšak méně jest patrným. Délka těla $1.4 \mathrm{~mm}$. Dvacet čtyry exempl. nalezeny.

$$
\sigma^{\top}
$$

Menší a slabší než q. Barva těla černohnědá. Tykadel 1. a 2. čl. jsou žlutavé, slabě šedohnědě zkalené; ostatní články jsou podobně zbarveny jako u samice. Také barva nohı jest u obou pohlaví tatáž. Samci mají rovněž přední femora stlustlejší a přední tarsus má též na konci dole malý ostrý zoubek. Osmý čl. abdom. má po obou stranách na místech, kde u samice ostré cípky vystupují, po jednom silném, dosti dlouhém, odstávajícím trnu. Devátý čl. abdomenu jest dlouhý, 3.-7. čl. jeho mají dole u předního okraje po jedné dlouhé, úzké, uprostřed trochu zúžené světlé prohlubině. Pochvy pyje vyzbrojeny jsou před koncem zubem zpětným. - Několik exempl. nalezeno.

Třásněnku tuto sbíral jsem jen $\mathrm{v}$ červnu jednotlivě $\mathrm{v}$ obou pohlavích na rozličny̛ch květech lučních, zvl. na Scabiosa arvensis.

Čechy: Mukařov. Hradec Králové: Na mnoha místech v okolí. Turnov. Solnice: U Skuhrova. Jind. Hradec (Duda).

*) Doklad ve sbirce musejní, praep. č. 13. - Sammlung des böhmischen Landesmuseums, Praep. Nr. 13 
q.

Körperfarbe schwarz bis schwarzbraun, Gestalt sehr mächtig. Kopf nur etwas mehr breit als lang, nach hinten einigermassen verengt. Das 1. Fühlerglied bedeutend kürzer und etwas breiter als das 2., das 3 . viel länger als das vorhergehende, das 4 . kürzer ais das 3., das 5. kürzer als das 4., das 6. etwas kürzer als das 3. Stylus stark, und zwar besonders sein erstes Glied, welches bedeutend kürzer ist als das zweite. Fühlerfärbung: die ersten zwei Glieder, dann das 5., 6. und der Stylus schwarz, manchmal schwarzbraun, das 3. gelblich, das 4. ebenfalls gelblich, oben braun getrübt. Prothorax etwas länger und breiter als der Kopf. Auf seinen Vorderecken je eine, auf seinen Hinterecken je zwei lange Borsten. Die kleinen Härchen auf seinem Hinterrande ähnlich wie bei den vorigen Arten gestellt und gebildet. Pterothorax viel länger und breiter als der Prothorax. Beine gedrungen, wehrlos; nur am Ende des Vordertarsus unten befindet sich ein kleiner scharfer Zahn. Vorderschenkel dicker als die Schenkel der übrigen Beine. Alle Schenkel schwarz. Die Vordertibien gelb, oben und unten braun getrübt, die übrigen Tibien ganz schwarz. Alle Tarsen gelb. Beide Längsadern im Oberflügel gleichmässig mit vielen Borsten besetzt. Die Oberflügel stark braungrau getrübt, gegen das Ende zu lichter, am Grunde hell. Unterflügel hell. Abdomen gegen das Ende zu verengt und bedeutend zugespitzt. Borsten am Ende des Abdomen dünn und schwarz. Das achte Segment ist beiderseits mit einem breiten scharfen Zipfel versehen, welcher wohl auch bei anderen Arten vorkommt, jedoch weniger auffallend ist. Körperlänge $1.4 \mathrm{~mm}$.

$$
\text { o. }
$$

Kleiner und schwächer als das Weibchen. Körperfarbe schwarzbraun. Die ersten zwei Fühlerglieder gelblich, schwach graubraun getrübt; die übrigen Glieder ähnlich gefärbt wie beim Weibchen. Auch die Farbe der Beine ist bei beiden Geschlechtern dieselbe. Die Männchen haben ebenfalls die Vorderfemora verdickt und der Vordertarsus hat auch am Ende unten einen kleinen scharfen Zahn. Das achte Abdominalsegment hat jederseits an der Stelle, wo bei den Weibchen die scharfen Zipfel hervortreten, einen starken. ziemlich langen abstehenden Dorn. Das 9. Abdominalsegment ist lang, sein 3.-7. Glied hat unten beim Vorderrand je eine lange, schmale, in der Mitte etwas verengte lichte Vertiefung. Die Pennisscheiden sind vor dem Ende mit einem rückwärts gerichteten Zahn versehen.

Vorkommen: Im Juni in verschiedenen Blüten. — Fundort: Böhmen.

\section{Physopus aspera Halid.}

1852. Thrips aspera Haliday, Walker: Homopt. ins. of Brit. Museum, pag. 1109. »Alae evolutae; tibiae muticae. - Nigra, hemelytris nigricantibus basi albidis, pedibus fuscis, femorum anticorum et tibiarum basi, tibiis anticis tarsisque et antennarum medio pallidis; abdominis segmento antepenultimo basi utrinque mucronato, mas. - England. « 


\section{H. UZEL, MONOGRAPHIE DER ORDNUNG THYSANOPTERA.}

\section{Physopus nigriventris nov. sp.*)}

$$
\text { ‥ }
$$

Hlava a thorax žlutavé neb žlutohnědé, šedè zkalené; abdomen černohnèdý, někdy šedohnědý. Hlava širší než delši a nazad poněkud zúžená. Mezi rráskami na týle jest jedna nejpatrnèjší. První èl. tykadel značnè kratší než 2.; 2., 3. a 4. čl. postupně delší, 5. kratší než pr̀edcházející; 6 . delší než 3 .; stỵlus dlouhý, tenký, 2. jeho èl. patrně delší než prvý. Barva tykadel: 1. čl. šedožlutý, 2. ěl. tmavošedý, 3. žlutavý, na konci šedý neb žlutošedý, 4. šedý, na basi žlutavý, 5., 6. čl. a stỵlus tmavošedé, 5. čl. někdy v prvé polovici žlutavý. Prothorax trochu delší než hlava. Na předních rozích po jednom, na zadních po dvou dlouhyjch chlupech. Malé chloupky na zadním okraji jeho podobnè jako u předešlỵch druhủ rozestavené i utrořené. Femora tmavě šedožlutá, ke konci Žlutavá, tịbie żlutavé, vnè trochu šedè zkalené. Abdomen na konci s dlouhỵ́mi tenkými chlupy. - Pèt exempl. nalezeno.

FORMA MAGROPTERA. Všecka trì očka ryvinutá. Křídla prítomna, avšak krátká; dosahuji jen k 6 . čl. abdom. Hořejší jsou trochu žlutavè zkalená a mají obě žilky po celé délce opatřené ěetnými chlupy. Délka těla skoro $1 \mathrm{~mm}$.

F ORMA BRACHYPTERA. Jen zadní drě očka jsou prítomna; přední jest zakrmèlé. Kìídel jen rudimenta, nepresahující plerothorax. Tento není patrnè menši než u dlouhokrídlé formy. Délka těla $0.7 \mathrm{~mm}$.

$$
\text { ऊ. Nebyl posud objeren. }
$$

Žije v drnu, kdež i prezimuje.

Čechy: Praha: I Divolé Šárce. Hradec Králové: V lese Oulišti u Piletic. Třebechovice. Opoěno.

$$
\text { Q. }
$$

Kopf und Thorax selblich oder gelbbraun, grau getrübt; Abdomen schwarzbraun manchmal graubraun. Kopf mehr breit als lang und nach hinten einigermassen verengt. Unter den Runzeln auf dem Hinterhaupte ist eine am stärksten. Das erste Fühlerglied bedeutend kürzer als das 2.; das 2., 3. u. 4. Glied immer länger und länger, das 5. kürzer als das vorhergehende; das 6. länger als das 3.; der Stylus lang, dünn, sein 2. Glied deutlich länger als das erste. Fühlerfärbung: 1. Glied graugelb, 2. Glied dunkelgrau, 3. Glied gelblich, am Ende grau oder gelblichgrau, das 4. grau, am Grunde gelblich, das 5., 6. und der Stylus dunkelgrau, das 5. manchmal in der ersten Hälfte gelblich. Prothorax

*) Doklad re sbírce musejní, praep. č. 14. - Sammlung des böhmischen Landesmuseums, Praep. Nr. 14. 
etwas länger als der Kopf. Auf seinen Vorderecken je eine, auf seinen Hinterecken je zwei lange Borsten. Die kleinen Härchen auf seinem Hinterrande sind ähnlich gestellt und ähnlich gebildet, wie bei den vorhergehenden Arten. Schenkel dunkel graugelb, gegen das Ende zu gelblich. Tibien gelblich, aussen etwas grau getrübt. Abdomen am Ende mit langen dünnen Borsten versehen.

FORMA MAGROPTERA. Alle drei Ocellen entwickelt. Flügel vorhanden, jedoch kurz; sie reichen nur bis zum 6. Abdominalsegmente. Die Oberflügel sind etwas gelblich getrübt; ihre beiden Längsadern sind der ganzen Länge nach mit zahlreichen Borsten versehen. Körperlänge fast $1 \mathrm{~mm}$.

FORMA BRAGHYPTERA. Nur die hinteren zwei Ocellen vorhanden; das vordere ist verkümmert. Die Flügelrudimente überragen den Pterothorax nicht. Dieser ist nicht besonders kleiner als bei der langflügeligen Form. Körperlänge $0.7 \mathrm{~mm}$.

$$
\text { ऽ unbekannt. }
$$

Vorkommen: Im Rasen, wo sie auch überwintert. - Fundort: Böhmen.

\section{Physopus atrata Halid.*)}

Tab. I., fig. 6 .

1836. Thrips atrata Haliday, Entomolog. Nagazine, pag. 447.

1843. Physapus atratus Amyot et Serville, Ins. Hémiptères, pag. 643.

1852. Thrips atrata Haliday, Walker: Homopt. ins. of Brit. Nuseum, pag. 1109. 1878-79. - — Reuter, Diagn. öfv. nya Thysanopt. f. Finland, pag. 6.

$$
\text { +. }
$$

Barva těla černohnědá, někdy černá; pterothorax bývá, zvl. po stranách, tmavě červenohnědý. Výjimkou jest barva těla světlejší, a sice jsou hlava a thorax žlutohnědé, silně (zvl. hlava) šedẽ zkalené, abdomen světle šedohnědý. Hlava trochu širší než delší. První čl. tykadel kratší (ne značně) než 2., 3. značně delší než předcházející, 3. a 4. skoro stejně dlouhé, 5. značně kratší než 4., 6. as tak dlouhý jako 3. Stylus dosti dlouhý, tlustý, 2. jeho čl. trochu delší než prvý. Barva tykadel černohnědá, jen 3. ěl. jest na basi šedẽ žlutavý; výjimkou jest celý žlutavý, šedě zkalený. Prothorax as tak dlouhý jako hlava. Na pìedních rozích není dlouhỹch chlupủ, na zadních po dvou. Kromě těchto chlupủ má ještě prothorax na svém zadním okraji po každě stranè tr̃̄i malé chloupky, z nichž třetí jest nejdelší. Pterothorax značně širší a delší než prothorax.

*) Doklad ve sbírce musejní, praep. ě. 15. - Sammlung des böhmischen Landesmuseums, Praep. Nr. 15. 


\section{H. UZEL, MONOGRAPHIE DER ORDNUNG THYSANOPTERA.}

Všecka femora jsou černohnědá. Přední tibie temně žlutavé, nahoře a dole černohnědẽ zkalené, střední a zadní tibie černohnědé, na samém konci temně žlutavé. 'Tarsy žlutavé, šedě zkalené. Za třemi chlupy na hlavní žilce $\mathrm{v}$ hoř. křídle, nalézajícími se nad místem, kde počíná žilka vedlejší, následuje malá mezera, za níž je osm chlupủ (velmi zřídka 7 neb 9) stejnomèrně rozestavených až na konec krídla. Vedlejší žilka jest po celé délce mnohými chlupy opatřena. Hoř. křídlo jest silně žlutošedě zkalené, na basi čiré. Dol. křídlo čiré. Abdomen na konci dlouhými tmavými štětinami opatřen. Délka těla $1.2-1.4 \mathrm{~mm}$.

\section{$\sigma^{\nearrow}$ (dosud nepopsaný).}

Jest značně menší než $q$. Barva těla a barva tykadel tatáž jako u ní. Nohy jsou podobně zbarveny, konec středních a zadních tibií však jest trochu šíre temně žlutavý. Kr̂́íla jsou ke konci trochu světlejší a hlavní žilka má $\mathrm{v}$ druhé polovici někdy jen 5 neb 6 chlupủ. Stylus jest pomèrně trochu kratší než u f. Třetí až 7. čl. abdom. mají dole po jedné podlouhlé, trochu ohnuté, světlé prohlubině. Na 7. čl. jest tato prohlubina trochu menší než na článcích předcházejících.

Var. (nov.) adusta. \&. Hlava a thorax červenohnědé, nahoře tmavošedě zkalené, abdomen světle hnědožlutý s šedým náletem. Konec abdomenu černý. - ơ. Hlava a thorax žlutohnědé, nahoře slabě šedě zkalené, abdomen světle hnědožlutý, konec abdomenu tmavošedý.

Třásněnka tato jest velmi hojnou a obývá již od března nejrúznější květy, avšak zrí́dka kdy v tak velikém množství jako $P h$. vulgatissima. Květy jí zvláště oblíbené jsou především Papaver somniferum, Melandryum pratense, Agrostemma githago, Monotropa hypopitys, Malva alcea, Colchicum autumnale, Solanum tuberosum a mnohé květy zahradní. Mimo to nalézáme ji také na nekvetoucích rostlinách, a to někdy v dosti značném množství. Tak vidèl jsem, jak z jara vyrážející koukol jimi byl téměr̆ obsypán. C̆asem zdržuje se v drnu neb navštěvuje Equisetum arvense. - Nahoře poznali jsme již některé pěstované rostliny, které obývá a jimž zajisté i škodí. Kromě oněch již vyjmenovaných sluší v tom ohledu ještě uvésti květy od Linum usitatissimum, Vicia sativa, Beta vulgaris; hostem, ač řídkým, bývá někdy též v klasech obilných. - Samci objevují se v květnu, ba nèkteří jǐ̌ koncem dubna a mizejí v září. Samice prezimují v drnu, pod mechem, pod korou stromovou, v seschlých květenstvích a pod spadaným listím. - Var. adusta vyskytuje se mezi typickou formou jednotlivẽ. Jest po celých Čechách rozšiřena a objevuje se též všude po Krkonoších, kdež dostupuje nejvyšších vrcholkủ. — Z Rěky byla mi v kvètinách zaslána. V okolí Berlína sbiral jsem ji v zimě. 
f.

Körperfarbe schwarzbraun, manchmal schwarz. Der Pterothorax pflegt, besonders an den Seiten, dunkel rothbraun zu sein. Ausnahmsweise ist die Körperfarbe lichter, und zwar ist der Kopf und der Thorax gelbbraun, stark (hauptsächlich der Kopf) grau getrübt, das Abdomen licht graubraun. Kopf etwas mehr breit als lang. Erstes Fühlerglied etwas kürzer als das 2., das 3. bedeutend länger als das vorhergehende, das 3. u. 4. fast gleich lang, das 5 . bedeutend kürzer als das vorhergehende, das 6 . etwa so lang wie das 3. Der Stylus ziemlich lang, dick, sein 2. Glied etwas länger als das erste. Fühlerfärbung schwarzbraun, nur das 3. Glied am Grunde graugelblich; ausnahmsweise ist es ganz gelblich, grau getrübt. Prothorax etwa so lang wie der Kopf. Auf seinen Vorderecken ohne lange Borsten, auf den Hinterecken mit je zwei solchen. Ausserdem trägt der Prothorax auf seinem Hinterrande jederseits drei kleine Härchen, von denen das dritte am längsten ist. Pterothorax bedeutend breiter und länger als der Prothorax. Alle Schenkel schwarzbraun. Vordertibien düster gelblich, oben und unten schwarzbraun getrübt, Mittel- und Hintertibien schwarzbraun, am äussersten Ende düster gelblich. Tarsen gelblich, grau getrübt. Hinter den drei Borsten, die sich auf der Hauptader im Oberflügel über jener Stelle befinden, wo die Nebenader anfängt, folgt eine kleine Lücke, hinter welcher acht (sehr selten 7 oder 9) Borsten bis zum Ende der Ader gleichmässig auf derselben vertheilt sind. Die Nebenader ist der ganzen Länge nach mit vielen Borsten besetzt. Oberflügel stark gelbgrau getrübt, am Grunde hell. Unterflügel hell. Abdomen am Ende mit langen dünnen Borsten versehen. Körperlänge $1 \cdot 2-1 \cdot 4 \mathrm{~mm}$.

\section{ठ (noch unbeschrieben).}

Bedeutend kleiner als das Weibchen. Körper- und Fühlerfarbe dieselbe. Beine ähnlich gefärbt, das Ende der Mittel- und Hintertibien ist jedoch breiter gelblich. Flügel gegen das Ende zu etwas lichter; die Hauptader hat in ihrer zweiten Hälfte manchmal nur 5 order 6 Borsten. Der Stylus ist verhältnismässig etwas kürzer als beim Weibchen. Das 3.-7. Abdominalsegment haben unten je eine längliche, etwas gebogene, lichte Vertiefung. Auf dem 7. Segmente ist diese Vertiefung etwas kleiner als auf den vorhergehenden.

Var. (nov.) adusta. $\subsetneq$. Kopf und Thorax rothbraun, oben dunkelgrau getrübt, Abdomen licht braungelb mit grauen Anflug. Abdomenende schwarz. - $\sigma^{\top}$. Kopf und Thorax gelbbraun, oben schwach grau getrübt, Abdomen licht braungelb, das Abdomenende dunkelgrau.

Vorkommen: Sehr häufig in den mannigfaltigsten Blüten. Die Weibchen findet man das ganze Jahr hindurch (sie überwintern im Rasen), die Männchen von Ende April bis September. - Fundorte: England (Haliday), Finnland (Reuter), Böhmen, Berlin (Uzel), Fiume. 


\section{Physopus pallipemnis nov. sp.*)}

Tab. V.. fig. 57.

Barva těla tmavě šedohnědá, zřídka černohnědá, pterothorax šedě červenohnědý. Hlava málo širši než delší. Oči trochu vykoulené. Tváře nemnoho vypouklé. První článek tykadel kratší, 3. značně delší než 2., 4. čl. trochu kratší než 3., 5. úzký, kratší než 4., 6. čl. trochu kratši než 3. Stylus krátký, tlustý, o dvou skoro stejných článcích; 3. a 4. čl. jsou ke konci značně zúženy. Barva tykadel jest černá, 2. čl. na konci a třetí jsou žluté; tento jest na konci šedẽ zkalený. Prothorax as tak dlouhý jako hlava, zadní rohy jeho jsou zaokrouhlené; na předních rozích není dlouhých chlupư, na zadních po dvou. Kromě těchto chlupủ má prothorax na zadním svém okraji tři malé chloupky, z nichž třetí jest nejdelší. Femora šedohnèdá, přední na konci žlutá; přední tibie žluté, nahoře a dole úzce šedohnèdé, ostatní tibie šedohnědé, na konci žluté; tarsy žluté. Kř̀dla slabě žlutošedě zkalená, u kořene skoro čirá; dolejší čirá. Hlavní žilka jest v druhé své polovině opatřena třemi chlupy, $\mathrm{z}$ nichž jeden jest od ostatních obou více oddálen. Vedlejši žilka jest po celé délce hustě chlupy poseta. Délka těla $1.3 \mathrm{~mm}$.

Var. adusta. Hlava a thorax světle hnědožluté, hlava silněji, thorax slabě šedẽ zkalený. Hlava a prothorax mívaji slabý zelenavý nálet. Abdomen žlutavý, nahoře sotva, jindy slabě, ke konci silněji šedẽ zkalený; dva poslední články tmavošedé.

\section{ð. Nebyl posud objeven.}

Nalézá se v různých květech (zvl. v blinu) od dubna do srpna v počtu nevelikém. Var. adusta vyskytuje se mezi formou typickou velmi pořídku.

Čechy: Hradec Králové. Třebechovice: U Jenikovic. Opočno. Nová Paka. Pecka. Vrajt. Vrchlabí. Liberec. Písek (Vařečka). V Krrkonoších sbíral jsem ji u Krausových mlýnu, u Spindelmühlu, v Labském důle, v Malém Sněžném březnu, okolo Petermannovy boudy, po stráních nad Malým stavem, u Veliké Úpy a na vrcholu Sněžky (zde var. adusta). Hory Orlické. - Na Helgolandě nalezl jsem ji v srpnu.

$$
f .
$$

Körperfarbe dunkel graubraun, selten schwarzbraun, Pterothorax grau rothbraun. Kopf ein wenig mehr breit als lang. Augen etwas hervorgequollen. Wangen nicht viel gewölbt. Erstes Fühlerglied kürzer, 3. bedeutend länger als das 2., das 4. etwas kürzer als das

*) Doklad ve sbirce musejni, praep. č. 16. - Sammlung des böhmischen Landesmuseums, Praep. Ni. 16. 
3., das 5. schmal, kürzer als das 4., das 6. etwas kürzer als das 3. Stylus liurz, dick, aus zwei fast gleichen Gliedern zusammengesetzt; 3. u. 4. Glied gegen das Ende zu bedeutend verengt. Fühlerfarbe schwarz, 2. Glied am Ende und das 3. gelb, dieses am Ende grau getrübt. Prothorax etwa so lang wie der Kopf, seine Hinterecken abgerundet; auf seinen Vorderecken keine, auf seinen Hinterecken je zwei lange Borsten. Ausserdem ist sein Hinterrand jederseits mit drei kleinen Härchen besetzt, von denen das dritte am längsten ist. Schenkel graubraun, die vorderen am Ende gelb; die Vordertibien gelb, oben und unten schmal graubraun, die übrigen Tibien graubraun, am Ende gelb; Tarsen gelb. Oberflügel schwach gelbgrau getrübt, am Grunde fast hell; Unterflügel hell. Die Hauptader ist in ihrer zweiten Hälfte mit drei Borsten besetzt, von denen die eine von den übrigen zwei entfernt ist. Die Nebenader der ganzen Länge nach dicht mit Borsten besäet. Körperlänge $1.3 \mathrm{~mm}$.

Var. adusta. Kopf und Thorax licht braungelb, jener stärker, dieser schwach grau getrübt. Kopf und Prothorax haben zuweilen einen schwachen grünlichen Anflug. Abdomen gelblich, oben kaum, manchmal schwach, gegen das Ende zu stärker grau getrübt; die zwei letzten Segmente dunkelgrau.

$$
\text { ơ unbekannt. }
$$

Vorkommen: Von April bis August in verschiedenen Blüten, hauptsächlich jedoch in jenen von Hyoscyamus niger. - Fun dorte: Böhmen, Helgoland (Uzel).

Bemerkung. Da diese Art als Halidays vulgatissima aufgefasst werden könnte (wegen der bei der dunklen Körperfarbe auffallend lichten Flügel und wegen der Färbung der Fühler), erlaube ich mir hier einige Betrachtungen anzuführen. Haliday wendet den Namen vulgatissima zuerst im Jahre 1836 an, gibt jedoch von dieser Art keine Beschreibung und identificiert sie nur mit einer gewissen Art Degeers. Er erwähnt, dass sie die bei weitem häufigste sei, das ganze Jahr hindurch in den verschiedensten Gartenblumen vorkomme und im Frühjahre schon mit den Narcissen erscheine. Erst in Walkers Katalog der Homopteren des britischen Museums, der eine Abhandlung über Thysanopteren, nach den Manuscripten Halidays zusammengestellt, enthält, befindet sich folgende Beschreibung: „Nigricans, hemelytris albidis, antennis pedibusque fuscis, antennarum articulo secundo apice, tertio toto, femoribus tibiisque basi et apice tarsisque pallidis, fem. Fusco-testacea, abdomine citra basin nigricante, antennis pedibusque pallidis, antennis apice femoribus tibiisque medio infuscatis, mas." Weil nun Ph. pallipenis stets alle Schenkel (das Ende der rorderen ausgenommen) bis zur Spitze dunkel hat und auch die mittleren und hinteren Tibien vom Grunde an ganz dunkel und nur ihre Enden hell sind, erscheint sie als gut gesonderte Art. Übrigens glaube ich Halidays Art vulgatissima richtig aufgefasst zu haben, obwohl die Fühlerfärbung bei meinen Exemplaren in der Regel abweichend ist. Bei der grossen Mehrzahl meiner Exemplare ist nämlich das 3., 4. u. 5. Glied licht, oben, gegen das Ende zu sehr schwach grau getrübt. Es pflegt jedoch (je nach dem Fundorte) auch das 5. Glied fast ganz grau getrübt zu sein, wobei auch das 4. Glied an Trübung gewinnt: dadurch nähern sich die Fühler der betreffenden Exemplare in Färbung sehr den Halidayschen Exemplaren. Da ich nun auch eine (allerdings sehr seltene) Varietät (fulvicomis) entdeckt habe, bei welcher die ganzen Fühler gelblich graubraun sind, und das. 3. Glied sogar nur etwas lichter ist, bei der Varietät albicornis (auch nur sehr selten) die Fühler im Gegentheil (die ersten zwei Glieder ausgenommen) weiss werden, so ist ersichtlich, dass die Färbung der Fühler Veränderungen unterworfen ist. Viel- 


\section{H. UZEL, MONOGRAPHIE DER ORDNUNG THYSANOPTERA.}

leicht ist es auch nicht bei den sehr knappen Beschreibungen Halidays ganz ausgeschlossen, dass das 4. u. 5. Fühlerglied bei seinen Exemplaren theilweise licht waren, da der Autor möglicherweise nur besonderen Nachdruck auf das helle 3. Glied im Gegensatz zu seiner vorhergehenden Art atrata gibt, bei der hervorgehoben wird, dass das 3. Fühlerglied dunkel ist. Dass ich Hali days Art vulgatissima vor mir habe, beweisen auch die Flügel meiner Exemplare, die im Verhältnis zur Körperfarbe auffallend (noch auffallender als bei pallipennis) licht sind, die Färbung ihrer Beine, die mit Halidays Exemplaren übereinstimmt: weiter ist auch die Verengung des Kopfes nach hinten, welche bei meinen Exemplaren vorkommt, auf Degeers Zeichnung, auf die Haliday hinweist (Mém. p. servir à l'hist. d. Insectes, tab. I., fig. 1.), angedeutet, und endlich ist die betreffende Art bei uns entschieden die gewöhnlichste und bewohnt in Unmassen Blumen überhaupt und auch speciell Gartenblumen, und zwar gleich vom Frühjahre an sehr zahlreich. Was die Männchen, die ich gesammelt habe, anbelangt, so sind ihre Fühler und Beine ähnlich wie bei Halidays Exemplaren gefärbt. Der Körper jedoch ist gewöhulich viel lichter, obwohl er ausnahmsweise auch ähnlich dunkel erscheinen kann, wie es Haliday angibt.

\section{Physopus phalerata Halid.*)}

Tab. I., fig. 5.; Tab. V., fig. 58.-60.

1836. Thrips phalerata Haliday, Entomolog. Magazine, pag. 447.

1836. - - Burmeister, Handb. d. Entomologie, II, pag. 413.

1843. Odontothrips phalerata Amyot et Serville, Ins. Hémiptères, pag. 643.

1852. Thrips phalerata Haliday. Walker: Homopt. ins. of Brit. Museum, pag. 1108. 1852. - - Heeger, Sitzb. d. Akad. d. Wiss., Wien, VIII, pag. 131., tab. XIX. (špatně! - schlecht!).

q.

Barva těla černohnědá až černá. Hlava trochu širší než delší. Tykadel 1. čl. kratší než 2., stejně však široký: Tretí čl. delší než předcházející; 3., 4. a 6. čl. asi stejně dlouhé, 5. značně kratší; 3. a 4. čl. ke konci trochu zúžené. Stỵlus dlouhý; 2. čl. jeho delší než první. K spodní straně 6 . čl. dole přiléllá čirá šupinka, v předu v cípek prodloužená. Celé tykadlo černohnèdé, 2. čl. na konci, 3. článek celý žlutý. Prothorax jest trochu delší nè hlava, na předních jeho rozích není dlouhỵch chlupủ, na zadních po dvou. První pár noh značně stlustlỵ. Všecka femora jsou černohnědá; přední tibie žluté, nahoře a dole úzce šedè zkalené, ostatní tibie celé černohnědé; tarsy všecky žluté. Přední tibie maji na konci dole silný, dlouhý, dolủ zakǐivený zub. Vedle tohoto zubu nalézá se ještě ostrý hrbol, u něhož stoji silná štětinka. Přední tarsus nemá dole žádnỹch hrbolkủ. Hlavní żilka jest po celé své délce stejnoměrně chlupy poseta; jen před dvěma posledními chlupy jest vètši mezera. Vedlejší žilka taktéž celá chlupy posetá. Hořejší křídla bílá, uprostred s vẹmi širokou tmavou stuhou; kořen a konec křidla jsou též

*) Doklad ve sbírce musejní, praep. č. 17. - Sammlung des böhmischen Landesmuseums, Praep Nr. 17. 


\section{J. UZEL, HONOGRAFIE RÁDU, „THYSANOPTERA“.}

tmavě zkalené. Bílá část kî́dla mezi prostřední tmavou stuhou a tmarỵm koncem jest trochu temnèjší než bílá část kríidla na basi. Toto nepatmé zkalení není však nijak na újmu zr̃etelnosti tmarých stuh. Dol. křídla slabě zkalená, ke konei trochu silněji, na basi čirá. Délka těla 1·1 $\mathrm{mm}$.

$$
\text { o (dosud nepopsaný). }
$$

Menši než $q$; tèlo, tykadla, nohy i křídla právě tak zbarvené jako u ní. Přední nohy jsou taktéž stlustlé a mají na předních tibiích podobný zub, jenž však jest trochu tenčí a více zakìivený. Vedle něho jest též u samce ostrỵ hrbol. Články abdom. nemají dole žádných světlých prohlubin; za to prodlužují se 4.-7. čl. dole na zadním kraji uprostred v okrouhlý čípek.

Żije $\mathrm{v}$ drnu. $\mathrm{V}$ krètnu nalezl jsem ji $\mathrm{v}$ obou pohlavích, a to místy hojnè. Jednu samici sbíral jsem také počátkem listopadu. Dle Halida ye žije v krětech od Vicia sativa.

Čechy: Hradec Králové: U Vèkoše. Třebechovice: V lese pod Vysokým Újezdem. Opočno: $V$ háji Chropotíně. Milešovka.

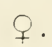

Kiörperfarbe schwarzbraun bis schwarz. Kopf etwas mehr breit als lang. Erstes Fühlerglied kürzer als das 2., jedoch gleich breit. Das 3. Glied länger als das vorhergehende; das 3., 4. u. 6. Glied etwa gleich lang, das 5. bedeutend kürzer; das 3. u. 4. Glied gegen das Ende zu etwas verengt. Stylus lang, sein zweites Glied länger als das erste. An der Unterseite des 6. Gliedes befindet sich eine helle schuppe, welche vorne in einen kleinen Zipfel verlängert ist. Der ganze Fühler schwarzbraun, das 2. Glied am Ende und das 3. ganz gelb. Prothorax etwas länger als der Kopf; auf seinen Vorderecken keine, auf seinen Hinterecken je zwei lange Borsten. Das erste Paar Beine bedeutend rerdickt. Alle Schenkel schwarzbratin; die Vordertibien gelb, oben und unten schmal grau getrübt, die übrigen Tibien ganz schwarzbraun; alle Tarsen gelb. Vordertibien am Ende unten mit einem starken, langen nach unten gekrümmten Zahn versehen. Neben diesem Zahn befindet sich noch ein scharfer Höcker, bei welchem eine kleine starke Borste steht. Vordertarsus unten ohne Höckerchen. Die Hauptader ist der ganzen Länge nach gleichmässig mit Borsten besäet; nur vor den zwei letzten befindet sich eine Lücke. Die Nebenader überall mit Borsten versehen. Oberflügel weiss, inmitten mit einer sehr breiten dunklen Binde; auch die Wurzel und das Ende des Flügels dunkel. Der lichte Theil des Flügels zwischen der dunklen Mittelbinde und dem dunklen Ende ist etwas trüber als der lichte Theil vor der Wurzel. Diese unbedeutende Trübung ist jedoch der Deutlichkeit der dunklen Binden nicht nachtheilig. Unterflügel schwach getrübt, gegen das Ende zu etwas stärker, am Grunde hell. Körperlänge $1 \cdot 1 \mathrm{~mm}$. 
o (noch unbeschrieben).

Kleiner als das $\subsetneq$; Körper, Fühler, Beine und Flügel ebenso gefärbt. Vorderbeine ebenfalls verdickt und die Enden der Vordertibien mit einem ähnlichen Zahn versehen, der jedoch etwas dünner und mehr gekrümmt ist. Neben ihm steht auch hier ein scharfer Höcker. Die Abdominalsegmente haben unten keine lichten Vertiefungen; dafür sind die Hinterränder des 4.-7. Segm. in der Mitte unten mit je einem abgerundeten Zapfen versehen.

Vorkommen: Im Mai wurden Weibchen und Männchen gefunden, im November nur Weibchen. Lebt im Rasen. - Fund orte: England (Haliday), Böhmen.

\section{Physopus intermedia nov. sp.*)}

$$
\text { f. }
$$

Barva těla černá. Pr̀ední tibie mají na konci veliký silný, značně ohnutý zub, vedle něhož stojí hrbolek, štětinou zakončený. Na pr̉edním tarsu není hrbolkủ. Hořejší i dolejší křídla a nohy jsou tak zbarvené jako u druhu předcházejíciho. Chlupatost žilek jest rovněž tatáž jako u druhu phalerata. 'Tvar a zbarvení tykadel však jako u druhu následujícího. Délka tèla $1.5 \mathrm{~mm}$. - Dvanáct exempl. bylo nalezeno.

$$
\sigma^{\pi}
$$

Barva těla černohnědá. Tykadel první článek šedohnědý, 2. žlutavý, slabě hnědě zkalený, 3. žlutavý. 4. dole žlutavý, nahoře ke konci šedohnědý; následujicí články taktéž šedohnědé. Femora černohnědá, pìední na konci žlutavá. Přední tibie žlutavé, střední a zadní černohnědé, na konci žlutavé. Tarsy všecky žlutavé. Přední tibie na konci dole s mohutným zahnutým zubem. Na predním tarsu dole není lirbolků. Kř́dla jsou zbarvena jako u samice. Dole na článcích abdomenu není oněch čípkủ na zadním kraji jako u samců druhu předcházejícího. Délka těla $0.9 \mathrm{~mm}$. - Jediný exempl. nalezen.

Třásněnku tuto sbíral jsem v červnu v obou pohlavích na květech u Piletic, nedaleko Hradce Králové.

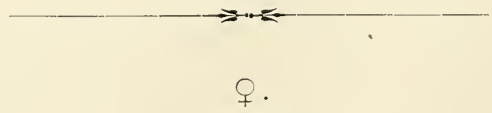

Körperfarbe schwarz. Die Vordertibien haben am Ende einen grossen, starken, bedeutend gekrümmten Zahn, neben welchem ein Höcker steht, auf dessen Ende eine

*) Doklad ve sbírce musejní, praep. č. 18. - Sammlung des böhmischen Landesmuseums, Praep. Nr. 18. 
Borste sich befindet. An den Vordertarsen keine Höckerchen. Beine, Ober- und Unterflügel sind ähnlich wie bei der vorhergehenden Art gefürbt. Die Behaarung der Flügeladern ebenfalls dieselbe wie bei der Art phalerata; Gestalt und Färbung der Fühler jedoch wie bei der folgenden Art. Körperlänge $1.5 \mathrm{~mm}$.

$\delta^{7}$

Körperfarbe schwarzbraun. Erstes Fühlerglied graubraun, 2. gelblich, schwach braun getrübt, 3. gelblich, das 4. unten gelblich, oben gegen das Ende zu graubraun; die folgenden Glieder ebenfalls graubraun. Die Schenkel schwarzbraun, die vorderen am Ende gelblich. Vordertibien gelblich, Nittel- und Hintertibien schwarzbraun, am Ende gelblich. Alle Tarsen gelblich. Vordertibien am Ende unten mit einem mächtigen gekrümmten Zahn versehen. Am Vordertarsus unten keine Höckerchen. Flügel ähnlich wie beim Weibchen gefärbt. Die Abdominalsegmente haben an der Bauchseite keine Zapfen wie bei der vorhergehenden Art. Körperlänge $0.9 \mathrm{~mm}$.

Vorkommen: Im Juni in beiden Geschlechtern auf Blüten. - Fundort: Böhmen.

\section{Physopus ulicis Halid.*)}

Tab. V., fig. 61.

1836. Thrips Ulicis Haliday, Entomolog. Magazine, str. 446.

1836. - - Burmeister, Handb. d. Entomologie, II, pag. 414.

1843. Odontohrips ulicis Amyot et Serville, Ins. Hémiptères, pag. 643.

1852. Thrips - Haliday, Walker: Homopt. ins. of Brit. Museum, pag. 1108.; tab. VII., fig. 43. et 44.

1852. - Loti Idem, ibidem.

1852. - Ulicis Heeger, Sitzungsb. d. Akad. d. Wiss., Wien, VIII, pag. 130.; tab. XVIII. (špatnè! - schlecht!).

1878-79. - basalis Reuter, Diagn. öfv. nya Thysanopt. f. Finland, pag. 13.

$$
\text { q. }
$$

Barva těla černohnědá, často černá. Hlava trochu širší než delší. První čl. tykadel kratši než 2., stejně však široký; 3 . jest delší druhého a ke konci hrdlovitě se zúžuje; 4. jest podobného tvaru, mírnèji však ke konci zúžený; 3., 4. a 6. čl. jsou skoro stejně dlouhé, 5. mnohem kratší než předcházející. Stylus dlouhý, druhý jeho článek delší než prvý. K 6 . čl. přiléhá dole veliká elliptičná, v předu přišpičatělá, světlá šupinka. Tykadlo černohnědé, 2. čl. na konci, 3 čl. celý žlutý, 4. žlutý, slaběji nebo silněji š̃edohnědě zkalený. Prothorax jest delší než hlava. Na zadních rozích jsou dva dlouhé

*) Doklad re sbírce musejní, praep. č. 19. - Sammlung des böhmischen Landesmuseums, Praep. Nr. 19. 


\section{H. UZEL, MONOGRAPHIE DER ORDNUNG THYSANOPTERA.}

chlupy. První pár noh jest značně stlustlý. Přední tibie mají na konci dole silný, dolů zakřivený zub, který však jest menší než u druhu předcházejícího. Ved!e toho zubu nalézá se ještě malý hrbol, zakončujicí se silnou štètinou. Přední tarsus má ke konci dole dva malé ostré hrbolky, těsně vedle sebe stojicí, takže, díváme-li se ze strany, vidíme toliko jeden. V̌secka femora jsou černohnědá; přední tibie žluté, nahoře a dole úzce šedẽ zkalené, ostatní tibie celé černohnědé; tarsy všecky žluté. Žilky v hoř. křídle podobně obrvené jako u druhu předcházejícího, mezera však před posledními dvěma chlupy na žilce hlavní jest značně menší. Hořejši křídla jsou až po začátek spodni žillky bílé, jen kořen jest tmavý; od počatku spodní žilky až na konec jest křídlo silně šedohnědě zkalené. Dol. krìidla čirá a jen ke konci nepatrně zkalená. Délka těla $1.3 \mathrm{~mm}$.

\section{$\sigma^{\top}$ (dosud nepopsaný).}

Menší než f. Tèlo tmavě šedohnědé. Tykadel 1.-3. ěl. žlutavé; první článek bývá trochu hnědě zkalený; 4. někdy celý žlutavý, jindy jen dole žlutavý, nahore však ke konci světle šedohnědý; následující všecky světle šedohnědé. Křídla jsou podobně jako u samičky zbarvena, od polovice však do konce trochu méně zkalená; špička krídla jest opět tmavší. Nohy jsou utvořeny a zbarveny jako u samice. Přední nohy také stlustlé. Zub na koncích tibií jest též zde prritomen, jakož i hrbolek se štětinou na konci vedle něho a dva ostré hrbolky dole před koncem tarsu. Někdy jsou střední a zadní tibie na samém konci žlutavé. Čtvrtý až 7. čl. abdom. dole nemají na zadním kraji uprostřed onoho výběžku jako samci druhu phalerata.

Vyskytuje se v obou pohlavích od května do srpna v drnu. Mimo to žije v různých květech, zvláště v papilionaceích, v kopretině a v jeteli. Někdy nalézáme ji též na nízkých rostlinách nekvetoucích $\mathrm{v}$ počtu dosti značném.

Čechy: Mukařov. Hradec Králové. Třebechovice. Turnov. Jilemnice: U Branné. Liberec: U Habendorfu. Solnice: U Skuhrova. Písek. Chotěboř (Vařečka). Jindř. Hradec (Duda).

$$
q .
$$

Körperfarbe schwarzbraun, oft schwarz. Kopf etwas mehr breit als lang. Erstes Fühlerglied kürzer als das 2., jedoch gleich breit; das 3. ist länger als das 2. und gegen das Ende zu halsförmig verengt; das 4. ähnlich geformt, jedoch mässiger verengt; das 3., 4. u. 6. Glied fast gleich lang, das 5. viel kürzer als das vorhergehende. Stylus lang, sein zweites Glied länger als das erste. Am 6. Gliede unten befindet sich eine grosse elliptische, vorn zugespitzte lichte Schuppe. Fühler schwarzbraun, das 2. Glied am Ende, das 3. ganz gelb, das 4. gelb, schwächer oder stärker graubraun getrübt. Prothorax länger als der Kopf. Auf seinen Hinterecken je zwei lange Borsten. Erstes Beinpaar be- 


\section{J. UZEL, MONOGRAFIE RADU, „THYSANOPTERA“.}

deutend verdickt. Vordertibien am Ende unten mit einem starken, nach unten gekrümmten Zahn bewaffnet, der jedoch kleiner ist als bei der vorhergehenden Art. Neben diesem Zahn befindet sich noch ein kleiner Höcker, auf dessen Spitze eine starke Borste steht. Vordertarsus unten mit zwei kleinen scharfen Höckerchen versehen, welche dicht neben einander stehen, so dass wir, wenn wir sie von der Seite betrachten, nur eins derselben wahrnehmen. Alle Schenkel schwarzbraun; Vordertibien gelb, oben und unten schmal grau getrübt, die übrigen Tibien ganz schwarzbraun; alle Tarsen gelb. Längsadern im Oberflügel ähnlich beborstet wie bei der vorhergehenden Art, jedoch ist die Lücke vor den zwei letzten Borsten auf der Hauptader bedeutend kleiner. Oberflügel bis zum Anfang der Nebenader weiss, die Wurzel selbst jedoch dunkel; vom Anfange der Nebenader bis zum Ende ist der Oberflügel stark graubraun getrübt. Unterflügel hell und nur gegen das Ende zu unbedeutend getrübt. Körperlänge $1.3 \mathrm{~mm}$.

\section{$\sigma^{\top}$ (noch unbeschrieben).}

Kleiner als das $\subsetneq$. Körper dunkel graubraun. Erstes bis 3. Fühlerglied gelblich; erstes Glied oft etwas braun getrübt, das 4. manchmal ganz gelblich, zuweilen nur unten gelblich, oben jedoch gegen das Ende zu licht graubraun; alle folgenden Fühlerglieder licht graubraun. Flügel ähnlich wie beim Weibchen gefärbt, von der Nitte an bis zum Ende jedoch etwas lichter; die Flügelspitze ist wieder dunkler. Gestalt und Farbe der Beine wie beim Weibchen. Vorderbeine ebenfalls verdickt. Auch der Zahn auf den Enden der Vordertibien ist hier vorhanden, ebenso wie der Höcker mit der Borste auf seiner Spitze neben ihm und die zwei scharfen Höckerchen unten am Tarsus. Manchmal sind die Mittel- und Hintertibien am äussersten Ende gelblich. Das 4.-7. Abdominalsegment unten ohne Zapfen wie bei den Männchen der Art plealerata.

Vorkommen: Von Mai bis August in beiden Geschlechtern in Rasen, zuweilen in verschiedenen Blüten. - Fund orte: England (Haliday), Finnland (Reuter), Böhmen.

\section{Physopus inconsequens nov. sp.*)}

$$
\text { q. }
$$

Barva těla žlutošedá až šedohnědá; pterothorax bývá červenohnědý neb temnè žlutohnědý. Při světlejšich exemplářich bývají hlava a konec abdomenu nejtmavšími částmi. Hlava trochu delší než širší. Oči dosti značně vykoulené. První článek tykadel velmi silný a jen trochu kratší než 2., 3. čl. delší a 4. málo kratší než 3., 5. velmi malý, 6. kratší ně̃ 3. Stylus krátký, tlustý, konický, ze dvou stejně dlouhých článkủ

*) Doklad ve sbírce musejni praep. č. 20. - Sammlung des böhmischen Landesmuseums, praep. Nr. 20. 


\section{H. UZEL. MONOGRAPHIE DER ORDNUNG THYSANOPTERA.}

složený. Tykadla šedohnědá, 2. čl. na konci a třetí celý žlutavé. Prothorax hlavy trochu kratší. Na zadních rozích dvě dlouhé štětiny. Nohy šlihlé. Přední tarsus ukončen jest malým, dolủ obráceným zoubkem (podobně jako u druhu robusta). Všecka femora a tibie šedohnědé (u světlỵch exempl. šedožluté); všecky tibie, zvláště přední, na konci kalně žlutavé. Hoř. kř́́dla jsou málo prohnutá. Rozestavení chlupủ na hlavní žilce, které jest u jiných druhů velmi stálé, mění se zde měrou značnou a to nejen u různých individuí, ale též u pravého a levého křídla téhož individua. Pro tuto nestálost zvoleno jméno inconsequens. Na oné části hořejší žilky, pod níž začiná žilka dolejší, a kde u jiných druhû jsou pravidlem 3 chlupy, jsou u druhu tohoto chlupy čtyři (někdy až 6). Za nimi bývá větší neb menší mezera, obyčejně jedním, jindy dvěma chlupy přervaná, a ke konci žilky stávají 2-7 chlupủ. Dolejší žilka stejnoměrně po celé délce chlupy poseta. Hoř. křídla jsou značně žlutošedě zkalena, na basi světlejší, před basí pak nalézá se podélné, někidy dosti nezřetelné, čiré okénko. Kr̂̉́dla dolejšś celá velmi slabě šedě zkalená. Délka tèla $1.3 \mathrm{~mm}$.

\section{ऽ. Nebyl posud objeven.}

Třásněnka tato žije v dubnu a v kiětnu na spodní straně listủ kaštanu koňského, dále $\mathrm{v}$ květech od Acer platanoides a Prmmus cerasus místy v možstrí; r menším počtu pak vyskytuje se $\mathrm{r}$ květech od Anemone nemorosa a Populus tremula.

Čechy: Praha: Jen v Cibulce. Peruc. — Také z Pešti mi byla v květech zaslána.

$$
\text { q. }
$$

Körperfarbe gelbgrau bis graubraun; Pterothorax oft rothbraun oder dunkel gelbbraun. Bei lichteren Exemplaren pflegen der Kopf und das Abdomenende die dunkelsten Theile zu sein. Kopf etwas mehr lang als breit. Augen ziemlich stark hervorgequollen. Erstes Fühlerglied sehr stark und nur etwas kürzer als das 2., das 3. Glied länger, das 4. wenig kürzer als das 3., das 5. sehr. klein, das 6. kürzer als das 3. Stylus kurz, dick, konisch, aus zwei gleich langen Gliedern bestehend. Fühler graubraun, das 2. Glied am Ende und das 3. ganz gelblich. Prothorax etwas kürzer als der Kopf. Auf seinen Hinterecken zwei lange Borsten. Beine schlank. Vordertarsus am äussersten Ende mit einem kleinen, nach unten gewendeten Zähnchen (ähnlich wie bei der Art robusta). Alle Schenkel und Tibien graubraun (bei lichten Exemplaren graugelb), alle Tibien, hauptsächlich die vorderen, am Ende trüb gelblich. Oberflügel wenig gebogen. Die Stellung der Borsten auf der Hauptader, welche bei anderen Arten sehr constant ist, ändert hier ungemein ab, und zwar nicht nur bei verschiedenen Individuen, sondern auch am rechten und linken Flügel desselben Individuum. Wegen dieser Unbeständigkeit wurde der Name inconsequens gewählt. Auf jener Stelle der Hauptader, unter welcher die Nebenader 
ihren Ursprung nimmt, stehen bei dieser Art 4 Borsten (manchmal bis 6), hinter welchen eine grössere oder kleinere Lücke folgt, durch eine oder zwei Borsten unterbrochen; gegen das Ende der Hauptader zu befinden sich noch 2-7 Borsten. Die Nebenader gleichmässig der ganzen Länge nach mit Borsten besäet. Oberflügel bedeutend gelbgrau getrübt, am Grunde lichter. Unterflügel sehr schwach grau angehaucht. Körperlänge 1.3 mm.

ơ unbekannt.

Vorkommen: Im April und Mai auf der Unterseite der Blätter von Aesculus hippocastanum und in verschiedenen Blüten stellenweise zahlleich. - Fundorte: Böhmen, Pest.

\section{Physopus primulae Halid.*)}

Tab. V., fig. 62 .

1836. Thrips Primulae Haliday, Entomolog. Magazine, pag. 449.

1836. - decora Idem, ibidem.

1836. - Primulae Burmeister, Handb. d. Entomologie: II, pag. 415.

1836. - decora Idem, ibidem, pag. 416.

1843. Taeniothrips primulae Amyot et Serville, Ins. Hémiptères, pag. 644.

1843. - decora Idem, ibidem.

1852. Thrips Primulae Haliday, Walker: Homopt. ins. of Brit. Museum, pag. 1109. 1852. - decora Idem, ibidem.

$$
\text { q. }
$$

Barva těla černohnědá až čemá; výjimkou jest pterothorax aneb celé tělo světlejší. Hlava delší než širší, oči značnou měrou vykoulené. Tykadel první čl. velmi silný a jen trochu kratší než 2., 3. mnohem delší než tento, ke konci hrdlovitě se zúžujicí, 4. málo kratší než 3., ke konci méně zúžený, 5. velmi malý, 6. kratší než 3. Stylus dlouhý, tenký, o dvou skoro stejných ěláncích. Barva tykadel: první dva čl. černohnědé, konec druhého a třetí čl. žlutý, 4. od polou šedo- až černohnědý, do polou žlutý až žlutohnědý; ostatní články černohnědé. Prothorax hlavy trochu kratší. Na zadních rozích dvě dlouhé štětiny. Femora černohnědá, přední na konci často žlutá; přední tibie žluté, často z počátku slabě, vždy pak nahoře a dole úzce hnědě zkalené; ostatní tibie černohnědé, na konci a na samé basi žluté. Hoř. křídla jsou za prvni třetinou zúžená a značně nahoru prohnutá, špičatá. Na oné části hlavní žilky, pod níž začíná žilka vedlejší, nalézáme u druhu tohoto, rovněž jako u druhu předcházejícího, čtyři chlupy, kdežto

*) Doklad ve sbírce musejní, praep. č. 21. - Sammlung des böhmischen Landesmuseums, Praep Nr. 21. 


\section{H. UZEL, MONOGRAPHIE DER ORDNUNG THYSANOPTERA.}

u jinỵch třásněnek zde bývají toliko tři. As uprostřed mezi nimi a špičkou křidla jest jeden, na konci žllky pak dva chlupy. Vedlejší žilka jest stejnoměrně po celé délce chlupy poseta. Hoř. křídla jsou od base až k počátku vedlejší žilky bílá, pak šedohnědě zkalená, a to z počátku a ke konci velmi značně, uprostřed mnohem slaběji. Před špičkou nalézá se někdy podélné světlé okénko. Dolejší křídla jsou na basi čirá, pak šedě zkalená, na konci tmavější. Délka těla $1.3-1.5 \mathrm{~mm}$.

Var. (nov.) adusta. Hlava a thorax čeprenohnědé, slabě až silně šedě zkalené, abdomen světle žlutohnědý, se slabým šedým nádechem; dva poslední články černé.

\section{o (dosud nepopsaný).}

Mnohem menši než $q$. Barva těla, tykadel, noh i kř̌idel tatáž jako u ní. Abdomen má na 3.-7. čl. dole po jedné velmi dlouhé, piškotovité, světlé prohlubině.

První květiny jarní lákaji tuto tř̆́sněnku z jejích zimních skrỵ̛̌́i, kiteré si vỵhledává $\mathrm{v}$ drnu a pod spadaný̛m listím. Tak nalézáme často květy od Leucojum vermum jimi četně navštívené. Mimo to žije zvláště četně v květech od Anemone nemorosa, Corydalis cava, Viola, Oxalis acetosella, Stellaria holosericea, Fragaria a Monotropa hypopitys. Samci objevují se v dubnu a obě pohlaví nalézal jsem až do srpna, za něhož mizejí. Var. adusta žije jednotlivě mezi formou typickou.

Čechy: Praha: V lese mezi Krěí a Kundraticemi, u Sv. Prokopa, v Cibulce. Mukařov. Čerčany (Bubák). Hradec Králové. Třebechovice. Opočno. Jaroměř. Turnor (Bubák). Jablonec. Liberec. Milešovka. Peruc. Jind. Hradec (Duda).

\section{q.}

Körperfarbe schwarzbraun bis schwarz; ausnahmsweise der Pterothorax oder der ganze Körper lichter. Kopf mehr lang als breit, Augen stark hervorgequollen. Erstes Fühlerglied sehr stark und nur etwas kürzer als das 2., das 3. viel länger als das rorhergehende, gegen das Ende zu halsförmig verengt, das 4. wenig kürzer als das 3., gegen das Ende zu weniger verengl, das 5. sehr klein, das 6. kürzer als das 3. Stylus lang, dünn, aus zwei fast gleichen Gliedern zusammengesetzt. Fühlerfärbung: die ersten zwei Glieder schwarzbraun, das Ende des 2. u. das 3. gelb, das 4. von der Mitte an graubis schwarzbraun, bis zur Mitte gelb bis gelbbraun; die übrigen Glieder schwarzbraun. Prothorax etwas kürzer als der Kopf. Auf seinen Hinterecken je zwei lange Borsten. Schenkel schwarzbraun, die vorderen am Ende oft gelb; die Vordertibien gelb, anfangs oft schwach, immer jedoch oben und unten schmal braun getrübt; die übrigen Tibien schwarzbraun, am Ende und an der untersten Basis gelb. Oberflügel hinter dem ersten Drittel verengt und bedeutend aufwärts gebogen, spitzig. Auf jener Stelle der Hauptader, 


\section{J. UZEL, MONOGRAFIE ŘÁDU, „THYSANOPTERA“.}

unter welcher die Nebenader ihren Ursprung nimmt, finden wir bei dieser Art, ebenso wie bei der vorhergehenden, vier Borsten, wogegen hier bei anderen Thysanopteren nur 3 Borsten zu sein pflegen. Die Nebenader der ganzen Länge nach mit Borsten besäet. Oberflügel vom Grunde bis zum Anfang der Nebenader weiss, dann graubraun getrübt, und zwar an der Basis und gegen das Ende sehr stark. in der Nitte viel schwächer. Vor der Spilze befindet sich manchmal ein länglicher heller Fensterfleck. Unterflügel am Grunde hell, dann grau getrübt, am Ende noch dunkler. Körperlänge $1.3-1.5 \mathrm{~mm}$.

Var. (nov.) adusta. Kopf und Thorax rothbraun, schwach bis stark grau getrübt, Abdomen licht gelbbraun, mil einem grauen Anflug; die beiden letzten Glieder schwarz.

$$
\sigma^{\top} \text { (noch unbeschrieben). }
$$

Viel kleiner als das $q$. Färbung des Körpers, der Fühler, der Beine und der Flügel dieselbe. Das 3.-7. Abdominalsegment unten mit je einer sehr langen, lichten, in der Mitle verengten Vertiefung.

Vorkommen: Weibchen in den ersten Frühlingsblumen schon im März. Beide Geschlechter bis August. — Fundorte: England (Haliday), Böhmen.

\section{Physopus distincta nov. sp.*)}

$$
\text { P. }
$$

Barva těla úplně černá. Tělo mohutné. Hlava trochu delší než širší, oči značnou měrou vykoulené. Za očima jest hlava trnitá. První ěl. tykadel velmi silný a jen trochu kratší než 2., 3. značně delší než prvé dva články dohromady, úzký, ke konci hrdlovitě se zúžující, 4. trochu kratši než 3., podobného tvaru, 5. krátký, poměrně však delší než u druhů primulae a inconsequens, 6. jen o trochu kratší než 3., stylus dlouhý, 2. čl. jeho tenčí a patrně delši prvého. Barva tykadel: 1. a 2. čl. černohnědé, konec druhého, 3. a 4. žluté, 5. do polou žlutý, od polou černohnědý, 6. černohnědý, na basi žlutý, slylus celý černohnědý. Prothorax hlavy trochu kratší. Na zadních jeho rozích po dvou dlouhých chlupech smyslových. Nohy štíhlé. Všecka femora černá, všecky tibie žluté, vně slabě hnědě zkalené, tarsy žluté. Kǐídla úzká, špičatá. Obě žilky stejnoměrně mnohými chlupy posety. Hoř. křídla na samé basi tmavá, před basí až k počátku vedlejší žilky bílá, ostatní část velmi silně, a to zvl. z počátku a na konci, šedohnědě zkalená. Dolejší s velmi slabým šedohnědým nádechem, na konci trochu silnějším; žilka jejich jest černohnědá. Délka těla $1.3 \mathrm{~mm}$.

*) Doklad ve sbirce autorově. 


\section{H. UZEL, MONOGRAPHIE DER ORDNUNG THYSANOPTERA.}

\section{$\sigma^{7}$. Nebyl posud objeven.}

Jedinou samici toho druhu chytil jsem v srpnu do sítě, smykané po nekvetoucich rostlinách $\mathrm{v}$ lese pod Vys. Újezdem, nedaleko Třebechovic.

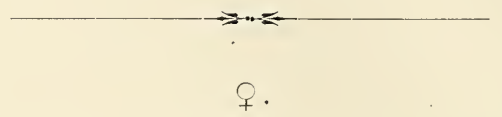

Körper ganz schwarz, mächtig. Kopf elwas mehr lang als breit, die Augen stark hervorgequollen. Hinter den Augen ist der Kopf dornig. Erstes Fühlerglied sehr stark und nur wenig kürzer als das 2., das 3. bedeulend länger als die zwei ersten zusammen, schmal, gegen das Ende zu halsförmig verengt, das 4. elwas kürzer als das 3., ähnlich geformt, das 5. kurz, verhältnismässig jedoch länger als bei den Arten primulae und inconsequens, das 6. nur etwas kürzer als das 3., Stylus lang, sein 2. Glied dünner und deutlich länger als das erste. Fühlerfärbung: 1. u. 2. Glied schwarzbraun, das Ende des 2., das 3. u. 4. gelb, das 5. bis zur Nitte gelb, von der Nitte an schwarzbraun, das 6. schwarzbraun, am Grunde gelb, Stylus gan\% schwarzbraun. Prothorax etwas kürzer als der Kopf. Auf seinen Hinterecken je zwei lange Borsten. Beine schlank. Alle Schenkel schwarz, alle Tibien gelb, aussen schwach braun getrübt, Tarsen gelb. Flügel schmal, spitzig. Beide Längsadern im Oberflügel gleichmässig mit vielen Borsten besetzt. Oberflügel am untersten Grunde dunkel, vor dem Grunde bis zum Anfang der Nebenader weiss, übrigens sehr stark, und zwar besonders anfangs und gegen das Ende, graubraun getrübt. Unterflügel mit einem sehr schwachen graubraunen Ton, am Ende etwas dunkler; ihre Ader schwarzbraun. Körperlänge $1.3 \mathrm{~mm}$.

\section{ठ unbekannt.}

Vorkommen: Im August auf nichtblühenden Pflanzen. — Fundort: Böhmen.

\section{Physopus ulmifoliorum Halid.*)}

Tab. V., fig. 63.

1836. Thrips ulmifoliorum Haliday, Entomol. Magazine, pag. 447.

1843. Physapus - Amyot et Serville, Ins. Hémiptères, pag. 643.

1852. Thrips - Haiday, Walker: Homopt. ins. of Brit. Museum, pag. 1111.

1878-79. - Salicis Reuler, Diagn. öfv. nya Thysanopt. f. Finland, pag. 14. 1886. Futhrips consociata Targioni Tozzetti, Bull. Soc. entom. ital., pag. 425.

*) Doklad ve sbirce musejní, praep. ¿̇. 22. — Sammlung des böhmischen Landesmuseums, Praep. Nr. 22. 
오.

Barva těla žlutá až světle hnědožlutá; prothorax nahoře na discu, pterothorax mezi kř́idly a abdomen nahoře, jen pokud je křídly pokryt, tmavě šedě zkalen, poslední dva kroužky celé, nahoře i dole, černošedé. Hlava jest širší než delši a nazad se trochu zúžuje. Vrásky na týle jsou hustě stěsnány. První čl. tykadel značně kratší druhého, 3. delší než 2. a 4. Pátý čl. jest značnè kratší než předcházející a přiléhá širokou plochou k následujícímu článku, tvoře s ním jaksi celek. Stylus dlouhý, 2. čl. jeho značně delši prvého. Barva tykadel: 1. čl. žlutavý, nèkdy trochu šedě zkalený, 2. šedý, 3. žlutavý a slabè, ke konci silněji šedě zkalený, 4. tmavošedý, na basi světlejší, ostatní černošedé. Prothorax as tak dlouhý jako hlava. Zadní rohy se dvěma dlouhými chlupy. Mimo to nalézaji se na zadním kraji jeho na každé straně ještě dva chlupy: vnější slabší, vnitřní silnější. Nohy żlutavé až světle hnědožluté, femora a tibie vně slabě šedě zkalené, Křídla dosti silně žlutavošedá, na basi sotva světlejší. Žilky bývaji obyčejně nezřetelné, někdy však velmi patrné. Hoř. žilka má na konci dva chlupy, dolejší je po celé délce chlupy poseta. Dva poslední články abdom. mají dlouhé, tuhé a tmavé chlupy. Délka těla $0 \cdot 9-1 \cdot 2 \mathrm{~mm}$.

Var. (nov.) obscura. Celé tělo nahoře i dole hnědošedé. Tykadla celá tmavá, jen 1. a 3. c̀l. (časem i 4.) trochu, někdy sotva světlejší. Jindy jsou 1. a 2. čl. šedé, 3. žlutavý, 4. žlutavý, slabě šedě zkalený, ostatek tykadla černý. Všecka femora a všecky tibie hnědošedé a na konci (zvl. tibie) žlutavé. Kř́dla značně šedě zkalená.

Var. bicolor m. Hlava a celý thorax žlutohnědý, abdomen černý. První čl. tykadel šedý, 2., 5., 6. čl. a stylus černé, 3. čl. žlutavý, 4. žlutavý, slabě šedě zkalený.

Var. (nov.) amnulicornis. Trochu menší než typická forma. Barva těla světle žlutá, nahoře místy velmi slabè šedě zkalená. Tykadel 1. ěl. žlutavý, prosvítavý, druhý světle šedý, ostatní černé, 3., 4. a 5. na basi bilé. Šestý čl. jest na samé basi zúžený, následkem čchož netvoři s pátým článkem celek jako u formy typické.

\section{ठ (novẽ objevený).}

Menší, značně svěllejši ně̌ $q$, žlutavý, nahoře slabě šedě zkalený, abdomen bělavý. Tykadel čl. 1., 2. i 3 . bývají bèlavé, 2. někdy slabě, 3. jen na konci a následující celé šedě zkalené; 4 . bývá světlejší. Šestý čl. tykadla jest poměrně delší než u samice. Zúžení hlavy nazad jest ještě patrnèjši než u ní.

Żije v létě na listech (obyčejně na hořejší straně) vrb, topolu černého, olší, bříz, dle Halidaye jilmů a dle Targ.-Tozzettiho na keřích lískových. Též pod korou vrbovou a olšovou jsem ji zastihl. Samce nalézal jsem v srpnu. Samice přezimují pod korou stromů, na kterýchž $\mathrm{v}$ létě žijí a částečně též $\mathrm{v}$ drnu neb mechu pod nimi. - 


\section{H. UZEL, MONOGRAPHIE DER ORDNUNG THYSANOPERA.}

Var. obscura vyskytuje se dosti zhusta mezi formou typickou. Var. bicolor a ammulicormis nalezeny po jediném exemplári u Hradce Králové (v srpnu).

Čechy: Hradec Králové, Opočno. Jind. Hradec (Duda).

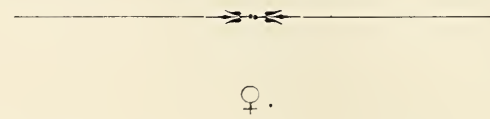

Körperfarbe gelb bis licht braungelb, Prothorax oben auf dem Discus, Pterothorax zwischen den Flügeln und Abdomen oben, nur soweit es von den Flügeln bedeckt ist, dunkel grau getrübt, die letzten zwei Segmente ganz (oben und unten) schwarzgrau. Kopf mehr breit als lang, nach hinten etwas verengt. Die Runzeln auf dem Hinterhaupte dicht gedrängt. Das 1. Fühlerglied bedeutend kürzer als das 2., das 3. länger als das 2. u. 4. Das 5. ist bedeutend kürzer als das vorhergehende und legt sich an das folgende Glied mit breiter Fläche an, so dass es mit ihm ein Ganzes bildet. Stylus lang, sein 2. Glied bedeutend länger als das erste. Fühlerfärbung: 1. Glied gelblich, manchmal etwas grau getrübt, 2. grau, 3. gelblich und schwach, gegen das Ende stärker grau getrübt, das 4. dunkelgrau, am Grunde lichter, die übrigen schwarzgrau. Prothorax etwa so lang wie der Kopf. Seine Hinterecken mit zwei langen Borsten versehen. Ausserdem befinden sich auf seinem Hinterrande jederseits noch zwei Borsten; die äusseren sind schwächer, die inneren stärker. Beine gelblich bis licht braungelb, die Schenkel und die Tibien aussen schwach grau getrübt. Flügel ziemlich stark gelblichgrau, am Grunde kaum lichter. Die Adern pflegen gewöhnlich undeutlich zu sein, zuweilen jedoch kenntlich. Die Hauptader am Ende mit zwei Borsten beselzt, die Nebenader der ganzen Länge nach mit Borsten versehen. Die zwei letzlen Abdominalsegmente mit langen steifen und dunklen Borsten besäet. Körperlänge $0 \cdot 9-1 \cdot 2 \mathrm{~mm}$.

Var. (nov.) obscura. Der ganze Körper oben und unten braungrau. Die Fühler ganz dunkel, nur das 1. u. 3. Glied (zuweilen auch das 4.) etwas, manchmal kaum lichter. Zuweilen ist das 1. u. 2. Glied grau, das 3. gelblich, das 4. gelblich, schwach grau getrübt, die übrigen Glieder schwarz. Alle Schenkel und alle Tibien braungrau und am Ende (lıauptsächlich die Tibien) gelblich. Flügel bedeutend grau getrübt.

Var. bicolor m. Kopf und der ganze Thorax gelblich, Abdomen schwarz. Erstes Fühlerglied grau, 2., 5., 6. Glied und der Stylus schwarz, das 3. Glied gelblich, das 4. gleichfalls gelblich, schwach grau getrübt.

Var. (nov.) annulicornis. Etwas kleiner als die typische Form. Körperfarbe lichtgelb, oben stellenweise sehr schwach grau getrübt. Erstes Fühlerglied gelblich, durchscheinend, das 2. lichtgrau, die übrigen schwarz, das 3., 4. u. 5. am Grunde weiss. Das 6. Glied ist an der Wurzel verengt, so dass es mit dem vorhergehenden kein Ganzes bildet, wie es bei der typischen Form der Fall isl. 


\section{J. UZEL, MONOGRAFIE RÁDU „THYSANOPTERA“.}

ơ (neu entdeckt).

Kleiner, bedeutend lichter als das $\subsetneq$, gelblich, oben schwach grau getrübt, Abdomen weisslich. Erstes, 2. u. 3. Fühlerglied pflegen weisslich zu sein, das 2. manchmal schwach, das 3. nur am Ende und die folgenden ganz grau getrübt; das 4. ist oft lichter. Das 6. Fühlerglied ist verhältnismässig länger als beim Weibchen. Die Verengung des Kopfes rückwärts ist noch deutlicher als beim Weibchen.

Vorkommen: Weibchen während der warmen Jahreszeit auf Blättern (gewöhnlich auf der Oberseite) von Weiden, Schwarzpappeln, Erlen, Birken, nach Haliday auch von Ulmen und nach Targioni-Tozzetti auf Haselnüssen. Männchen im August. Weibchen überwintern unter Baumrinde und theilweise im Rasen und Moos. - Fundorte: England (Haliday), Finnland (Reuter), Sicilien (Targioni-Tozzetti), Böhmen.

\section{Pliysopus pini nov. sp.*)}

$$
\text { q. }
$$

Barva těla tmavě šedohnědá až černohnědá. Hlava trochu širši než delší, na samé basi dosti značně zaškrcená. Tváře vypouklé. První čl. tykadel kratší než 2,, 3. ělánek trochu delší než tento, 3. a 4. ěl. skoro stejně dlouhé, 5. tak široký jako 4., avšak značně kratší; 6 . trochu delší než 3 . Stylus krátký, tlustý, o dvou skoro stejně dlouhých článcích. Tr̀etí a 4. článek jsou ke konci trochu zúžené. Barva tykadla: 1. a 2. článek šedohnědé, 2. na konci žlutavý, 3. žlutavý, nahoře ku konci obyčejně slabě šedohnědě zkalený, 4., 5., 6. ěl. a stỵlus černohnědé, 4. někdy na basi dole žlutarý. Prothorax as tak dlouhý jako hlava, se zadními rohy zaokrouhlenými. Na předních rozích není dlouhých chlupû, na zadních dva. Mímo tyto chlupy má prothorax na svém zadním okraji na každé straně ještě 3 malé chloupky, z nichž tretí jest nejdelší. Přední femora na konci a uvnitř žlutavá, vně šedohnědá, střední a zadní na obou koncích žlutá, uprostřed široce šedohnědá. Všechny tibie žluté, před basí dosti široce slabě šedohnědě zkalené, tarsy žluté. Hlavní žilka má ve druhé polovině tři chlupy, z nichž prvý bývá od ostatních dvou trochu oddálen. Vedlejší žilka po celé své délce jest rídce chlupy poseta. Hoř. křídla jsou slabě žlutavě zkalená, uprostřed ještě světlejší a na basi skoro čirá. Dol. kríidla čirá. Abdomen jest na konci tenkými nedlouhỵmi chlupy opatřen. Délka tèla $0.9 \mathrm{~mm}$. - Třináct exempl. nalezeno.

$$
\text { ऽ. Nebyl posud objeven. }
$$

Třásněnku tuto nalézal jsem od dubna do září na jehličí mladých smrčkủ a mimo to jednotlivě $\mathrm{v}$ různých květech a na nízkých nekvetoucích rostlinách.

Čechy: Hradec Králové. Tr̉ebechovice. Opočno. Vrchlabí. Liberee.

*) Doklad ve sbírce musejni, praep. ě. 23. - Sammlung des böhmischen Landesmuseums, Praep. Nr. 23. 
․

Körperfarbe dunkel graubraun bis schwarzbraun. Kopf etwas mehr breit als lang; hinten ziemlich stark halsförmig eingeschnürt. Die Wangen gewölbt. Erstes Fühlerglied kürzer als das 2., das 3. etwas länger als das vorhergehende, das 4 . fast so lang wie das 3., das 5. so breit wie das 4 ., jedoch bedeulend kürzer; das 6 . etwas länger als das dritte. Stylus kurz, dick, aus zwei fast gleich langen Gliedern zusammengesetzt. Das 3. u. 4. Fühlerglied sind gegen das Ende zu etwas verengt. Fühlerfärbung: 1. u. 2. Glied graubraun, 2. am Ende gelblich, 3. gelblich, oben gegen das Ende gewöhnlich schwach graubraun getrübt, das 4., 5., 6. Glied und der Stylus schwarzbraun, das 4. manchmal an der Basis unten gelblich. Prothorax etwa solang wie der Kopf, mit abgerundeten Hinterecken, welche mit zwei langen Borsten versehen sind (Vorderecken ohne dieselben). Ausserdem ist sein Hinterrand jederseits noch mit drei kleinen Härchen besetzt, von denen das dritte am längsten ist. Die Vorderschenkel am Ende und innen gelblich, aussen graubraun, die mittleren und hinteren auf beiden Enden gelb, in der Mitte breit graubraun. Alle Tibien gelb, vor dem Grunde ziemlich breit schwach graubraun getrübt, die Tarsen gelb. Die Hauptader ist in ihrer zweiten Hälfte mit drei Borsten versehen, von denen die erste von den übrigen zwei etwas entfernt zu sein pflegt. Die Nebenader der ganzen Länge nach spärlich mit Borsten besetzt. Oberflügel schwach gelblich getrübt, inmitten noch lichter, am Grunde fast hell. Unterflügel hell. Abdomen am Ende mit dünnen, nicht langen Borsten besetzt. Körperlänge $0.9 \mathrm{~mm}$.

o unbekannt.

Vorkommen: Selten und einzeln auf jungen Fichtennadeln; vier Exempl. fand ich ausserdem auf Blättern nichtblïhender Pflanzen und drei waren (wohl nur zufällig) auf Blüten. - Fund or I: Böhmen.

\section{Physopus Friči nov. sp.*)}

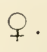

Barva těla šedě olivová, abdomen ke konci tmavši a na konci skoro černohnědý. Jindy jest tělo celé šedohnědé, abdomen ke konci černohnědý. Hlava skoro tak dlouhá jako široká, nazad trochu zúžená. Tykadla poměrně kratši než u předcházejícich druhů. První ěl. jejich značně kratši druhého; 2., 3. a 4. ěl. skoro stejně dlouhé, 5 málo kratší. Stylus dosti dlouhý, 2. čl. jen málo delši prvého. Barva tykadla: 1. čl. žlutavý, šedě zkalený, 2. ěl. tmavošedý, na konci žlutavý, 3. a 4. čl. žluté, velmi slabě šedě zkalené, 5. žlutavý, se slabým šedým náletem, 6. tmavošedý $\mathrm{k}$ oběma koncủm světlejší, stylus tmavošedý. Sosák jest velmi krátký a zaokrouhlený. Prothorax as tak dlouhý jako

*) Dovolil jsem si tento vzácný druh nazvati dle pana Dr. Ant. Friče, professora universitniho v Praze. - Doklad ve sbirce autorovè. 


\section{J. UZEL, MONOGRAFIE RADU, "THYSANOPTERA“.}

hlava. Na jeho zadních rozích po dvou nedlouhých chlupech; na zadním kraji pak po každé straně 4 chloupky, první nejmenší, poslední největší. Pterothorax jest poměrně menší než u druhů předcházejících. Ostny na zadních tibiích jsou mnohem slabší než u ostatních druhủ toho rodu. Femora šedè olivová, jen přední ke konci trochu svěllejší. Přední tibie ̌̌lutavé, po obou stranách slabě šedě zkalené, ostatní tibie šedě olivové, na konci žlutavé. Tarsy žlutavé. Hoř. kî́dla žlutavošedě zkalená. Hlavní žilka $\mathrm{v}$ druhé polovině se třemi chlupy, $z$ nichž první od dvou ostatních jest oddálen. Poslední ċlánky abdomenu opatřeny jsou silnými ostnitými chlupy postranními. Na 8. čl. uprostřed po obou stranách jest hrbolek, který zde, podobně jako u druhu robusta, jest dosti nápadnỵ. Délka těla $0.9 \mathrm{~mm}$. - Dva exempl. nalezeny.

\section{$\sigma^{7}$. Nebyl posud objeren.}

Tř̌śsněnku tuto sbíral jsem $\mathrm{v}$ květnu a v červnu vं květech lesních u Hradce Králové.

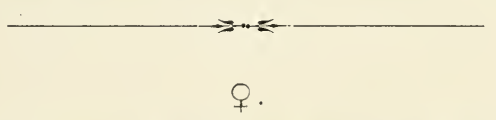

Körperfarbe grau olivengrün, Abdomen gegen das Ende zu dunkler, am Ende fast schwarzbraun. Es kann jedoch der Körper auch ganz graubraun und das Abdomen gegen das Ende zu schwarzbraun sein. Kopf fast so lang wie breit, nach hinten etwas verengt. Fühler verhältnismässig kürzer als bei den vorhergehenden Arten. Ihr erstes Glied bedeutend kürzer als das zweite; dieses, das 3. u. 4. fast gleich lang, das 5. nicht viel kürzer. Stylus ziemlich lang, sein 2. Glied nur wenig länger als das erste. Fühlerfärbung: 1. Glied gelblich, grau getrübt, 2. dunkelgrau, am Ende gelblich, 3. u. 4. Glied gelb, sehr schwach grau angeflogen, das 5. gelblich, ebenfalls mit schwachem grauen Anflug, das 6. dunkelgrau an beiden Enden lichter, der Stylus dunkelgrau. Der Rüssel sehr kurz, abgerundet. Prothorax etwa so lang wie der Kopf. Auf seinen Hinterecken je zwei nicht lange Borsten; ausserdem befinden sich auf seinem Hinterrande jederseits 4 Härchen, von denen das erste am kleinsten, das letzte am grössten ist. Pterothorax verhältnismässig kleiner als bei den vorhergehenden Arten. Die Stachelhaare auf den Hintertibien sind viel schwächer als bei den anderen Arten dieser Gattung. Schenkel grau olivengrün, nur die vorderen am Ende etwas lichter. Vordertibien gelblich, beiderseits schwach grau getrübt, die übrigen Tibien grau olivengrün, am Ende gelblich. Tarsen gelblich. Oberflügel gelblichgrau getrübt. Die Hauptader in ihrer zweiten Hälfte mit drei Borsten, von denen die erste von den beiden anderen entfernt ist. Die letzten Abdominalsegmente sind mit ungewöhnlich starken Seitenborsten besetzt. Auf dem 8. Segmente befindet sich beiderseits (wie bei $P h$.robusta) ein ziemlich auffallender Höcker. Körperlänge $0.9 \mathrm{~mm}$.

$$
\text { ठ unbekannt. }
$$

Vorkommen. Im Nai und Juni in Waldblüten. - Fu ndort: Böhmen. 


\section{H. UZEL, MONOGRAPHIE DER ORDNUNG THYSANOPTERA.}

\section{Physopus frontalis nov. sp.*)}

Tab. V., fig. 64 .

†.

Hlava vzadu tmavohnědá, mezi očima a v předu světle hnědo- až červenožlutá. Thorax tmavohnědý, abdomen černohnědý až leskle ċerný. Hlava trochu širší než delší, do zadu trochu rozšírená. Přední očko jest velmi maličké a zadní stávají se někdy nezřetelnými. Sosák jest veliký. První èl. tykadel velmi silný, trochu silnèjší než druhý a nemnoho kratší; 3. čl. delší než 2. a ke konci hrdlovitě se zúžujicí, 4. as tak dlouhý jako 3., ke konci mírněji hrdlovitě zúžený; 5. čl. kratší, 6. delši než 3. Stylus velmi dlouhý, tenký, 2 čl. jeho delší než první. Barva tỵkadel: 1. a 2. čl. šedohnědé, 1. trochu světlejší než 2., 3. čl. žlutý, ke konci nepatrně šedě zkalený, 4. žlutavý, ke konci neb již od polou šedohnědý, 5. as v prvé třetině žlutý, ostatek šedohnědý; 6. čl. šedohnědý, na basi žlutý, stylus šedohnědý. Chlupy na článcích tykadelních (zvl. na 2. a 3.) velmi silné a černé. Prothorax trochu delši než hlava. Na jeho zadních rozich po dvou dlouhých chlupech smyslových. Pterothorax jen as tak dlouhý jako prothorax. Pr̃ední femora temně žlutohnědá, ostatní černohnědá. Všecky tibie a tarsy žluté. Křídel jen nepatrná rudimenta. Abdomen silně chlupatý, na konci dlouhými tenkými šlětinami opatřený. Délka těla $0.9 \mathrm{~mm}$. — Sedm exemplářù nalezeno.

\section{ð. Nebyl posud objeven.}

Tato tř̌́sněnka žije pořídku v drnu lesním i lučním a přezimuje tamtéž. Čechy: Hradec Králové: na několika místech v okolí. Jind. Hradec (Duda).

q.

Kopf hinten dunkelbraun, zwischen den Augen und vorn licht braun- bis rothgelb. Thorax dunkelbraun, Abdomen schwarzbraun bis glänzend schwarz. Kopf etwas mehr breit als lang, nach hinten etwas erweitert. Das vordere Nebenauge ist winzig und die hinteren werden zuweilen undeutlich. Der Rüssel ist gross. Das erste Fühlerglied sehr stark, etwas dicker als das 2. und nicht viel kürzer; das 3. Glied länger als das 2. und gegen das Ende zu halsförmig verengt, das 4. etwa so lang wie das 3., gegen das Ende zu mässiger verengt; das 5. kürzer, das 6. länger als das 3. Stylus sehr lang, dünn, sein 2. Glied länger als das erste. Fühlerfärbung: 1. und 2. Glied graubraun, das 1. etwas lichter als das 2., das 3. gelb, gegen das Ende zu unbedeutend grau getrübt, das 4. gelblich, gegen das Ende zu oder schon von der Mitte an graubraun, das 5. etwa

*) Doklad ve sbirce musejní, praep. č. 24. - Sammlung des böhmischen Landesmuseums, Praep. Nr. 24 
im ersten Drittel gelb, übrigens graubraun, das 6. graubraun, am Grunde gelb, der Stylus graubraun. Die Borsten auf den Fühlern (hauptsächlich am 2. u. 3. Gliede) sehr stark und schwarz. Prothorax etwas länger als der Kopf. Auf seinen Hinterecken je zwei lange Borsten. Pterothorax nur etwa so lang wie der Prothorax. Vorderschenkel düster gelbbraun, die übrigen schwarzbraun. Alle Tibien und Tarsen gelb. Die Flügel verkümmern zu unbedeutenden Stummeln. Abdomen stark borstig, am Ende mit langen dünnen Haaren besetzt. Körperlänge $0 \cdot 9 \mathrm{~mm}$.

o unbekannt.

Vorkommen: Im Rasen, das ganze Jahr hindurch. - Fundort: Böhmen.

33. Physopus pilosa nov. sp.*)

Tab. V., fig. 65 . ․

Barva těla a noh kalně žlutá, thorax nahoře slabě šedě zkalený. Jindy jest barva těla a noh světle žlutá, prothorax a abdomen ke konci žlutohnědé. Chlupy na těle (zvl. na abdomenu) silné, odstávající a velmi tmavé. Hlava jest širší než delší. Očka velmi zakrnělá. Misto nich nalézáme dvě nebo tr̆i nepravidelné skvrnky červeného pigmentu. První čl. tykadel krátký, 2. čl. mnohem delší, nejširší v celém tykadle, 3. čl. delší ně̌ předcházející, 4. trochu kratší než 3., 5. kratší než 4., 6. as tak dlouhý jako třetí. Stylus dlouhý, tenký, skoro jen o 0.3 kratší než 6. čl.; 2. čl. jeho malinko delší než první. Barva tykadel: První čl. žlutavý, nezkalený, 2. žlutavý, slabě šedẽ zkalený, 3. as do polou žlutavý, od polou šedě zkalený, ostatní černošedé. Prothorax trochu delší než hlava. Na zadních rozích po dvou dlouhých chlupech. Kromě nich má zadní okraj jeho na každé straně trì chloupky, z nichž je prostřední nejdelši. Pterothorax jest kratší než prothorax. Křídel jen rudimenta, pterothorax nepřesahující. Délka těla $0.7 \mathrm{~mm}$. — Dva exempl. nalezeny.

$$
\sigma^{\top}
$$

Barva těla mdle žlutavá. Chlupy na těle čiré a na abdomenu značně odstávající. Očka nelze rozeznati. Tykadla trochu štihlejšś než u samičky; zvl. 6. čl. ke konci značněji zúžen. Barva tykadel: 1. a 2. čl. čiré, 3., 4. a 5. čl. žlutavé, na konci slabě žlutošedě zkalené a na samé basi čiré. Šestý čl. do polou žlutavý, od polou slabě žlutošedẽ zkalený, 7. a 8. čl. żlutošedé. Pterothorax as tak dlouhý jako prothorax, málo širší. Křídel jen velmi nepatrná rudimenta. První čl. abdom. skoro tak dlouhý jako 2. Délka těla $0.6 \mathrm{~mm}$. - Jediný exempl. objeven.

*) Doklad ve sbírce autorovè. 


\section{H. UZEL, MONOGRAPHIE DER ORDNUNG THYSANOPTERA.}

Poznámka. Neni vyloučena možnost', že tento sameček náleži jinému, velmi blízkému druhu, jehož samice posud neznáme.

Třásněnka tato žije velmi pořídku v drnu, kdež i přezimuje. Samce nalezl jsem v květnu.

Čechy: Hradec Králové: Na pokraji lesa u Nového Hradce Král.

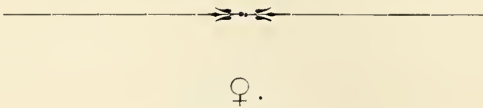

Färbung des Körpers und der Beine trübgelb, Thorax oben schwach grau angeflogen. Auch kann die Farbe des Körpers und der Beine lichtgelb sein, wobei der Prothorax und das Abdomen gegen das Ende zu gelbbraun sind. Borsten am Körper (hauptsächlich am Abdomen) stark, abstehend und sehr dunkel. Kopf mehr breit als lang. Ocellen sehr verkümmert. An ihrer Stelle finden wir zwei oder drei unregelmässige Pigmentfleckchen. Erstes Fühlerglied kurz, 2. Glied viel länger, am breitesten im ganzen Fühler, das 3. länger als das vorhergehende, das 4. etwas kürzer als das 3., das 5. kürzer als das 4., das 6 . etwa so lang wie das dritte. Stylus lang, dünn, fast nur um 0.3 kürzer als das 6. Fühlerglied; sein 2. Glied wenig länger als das erste. Fühlerfärbung: 1. Glied gelblich, nicht getrübt, 2. gelblich, schwach grau getrübt, das 3. etwa bis zur Mitte gelblich, von der Mitte an grau angeflogen, die übrigen Glieder schwarzgrau. Prothorax etwas länger als der Kopf. Auf seinen Hinterecken je zwei lange Borsten. Ausserdem hat sein Hinterrand jederseits drei Härchen, von denen das mittlere am längsten ist. Pterothorax kürzer als der Prothorax: Flügel zu Stummeln verkümmert, die den Plerothorax nicht überragen. Körperlänge $0.7 \mathrm{~mm}$.

$$
\text { ठ’. }
$$

Körperfarbe matt gelblich. Borsten am Körper hell und am Abdomen bedeutend abstehend. Ocellen sind nicht wahrzunehmen. Fühler etwas schlanker als bei dem Weibchen; hauptsächlich ist das 6. Glied gegen das Ende zu mehr verengt. Fühlerfärbung: 1. u. 2. Glied klar, 3., 4. u. 5. gelblich, am Ende schwach gelbgrau getrübt und an der Wurzel klar. Sechstes Glied bis zur Mitte gelblich, von der Mitte an schwach gelbgrau getrübt, das 7. u. 8. Glied gelbgrau. Pterothorax etwa so lang wie der Prothorax und wenig breiter. Die Flügel verkümmern zu unbedeutenden Rudimenten. Erstes Abdominalsegment fast so lang wie das 2. Körperlänge $0.6 \mathrm{~mm}$.

Bemerkung. Möglicherweise gehört dieses Männchen zu einer nahe verwandten Art, deren Weibchen noch nicht bekannt ist.

Vorkommen: Im Rasen, wo die Weibchen auch überwintern. Das Männchen fand ich im Mai. - Fundort: Böhmen. 


\section{J. UZEL, IONOGRAFIE RADU „THYSANOPTERA“.}

\section{GENUS RHAPHIDOTHRIPS. (Nov, gen.)*)}

Očka prítomna. Tỵkadla osmičlenná. Pátý čl. jejich jest $\mathrm{v}$ předu ufatý a priléhá těsně k široké basi šestého článku, takže spolu s ním troři dvoučlenný celek. Stylus o dvou velmi tenkých ěláncích o stejném prûměru a neobyčejně dlouhý, takže délka jeho přesahuje něco málo délku 5. a 6. ěl. dohromady. Makadla maxillarní tř́členná. Prothorax hlavy málo delší, nazad trochu rozšírený; na zadních rozich jeho po dvou chlupech smyslových; na předních rozích není takových chlupů. Nohy bezbranné. Křídla u samic obyčejně, u samcû vždy zakrnělá. Jsou-li u samic prítomna, jsou dosti krátká a maji tvar podobný jako u rodu předcházejícího. Mezi třásněmi na předním okraji hořejších křídel nalézaji se kratši silné brvy.

Ocellen vorhanden. Fühler achtgliedrig. Ihr fünfles Glied ist vorne abgestutzt und legt sich mit breiter Fläche an die breite Basis des folgenden Gliedes an. Beide Glieder bilden demnach zusammen ein zweigliedriges Ganzes. Stylus aus zwei sehr dünnen Gliedern zusammengeselzt und ausserordentlich lang, so dass seine Länge diejenige des 5. und 6 . Gliedes zusammen ein wenig überragt. Maxillartaster dreigliedrig. Prothorax wenig länger als der Kopf, nach hinten etwas erweitert; auf seinen Vorderecken keine, auf seinen Hinterecken je zwei lange Borsten. Beine wehrlos. Flügel bei den Weibchen gewöhnlich, bei den Männchen immer verkümmert. Wenn bei den Weibchen vorhanden, sind sie ziemlich kurz und in Gestalt jenen der vorhergehenden Gattung ähnlich. Zwischen den Fransen am Vorderrande des oberen Flügelpaares befinden sich kürzere, starke Borsten.

\section{Rhaphidothrips longistylosa nov. sp.**)}

Tab. VI., fig. 70 .

+.

Barva těla velmi tmavě červenohnědá. Hlava trochu delši než širší nazad trochu rozšiřená; oči jsou trochu vṿkoulené. Očka tvoří rovnostranný trojúhelník. První článek tykadel kratši než 2., avšak právě tak široký; 2., 3., 4. a 6. čl. vespolek skoro stejně dlouhé; 3. čl. má krátkou úzkou stopku, 4. ěl. a 5. maji stopky velmi krátké a široké, 5. čl. jest značně kratší než 4., jest $\mathrm{v}$ předu utatý a přiléhá těsně $\mathrm{k}$ široké basi šestého článku; tento ke konci poznenáhla se zúžuje. Stylus neobyčejně dlouhý a tenký. Barva tykadel: 1., 2., 5., 6. ěl. a stylus šedě červenohnědé; 5. čl. na basi někdy žlutý; 3. a 4. žluté, nahoře slabě, jindy silněji zkalené. Všecka femora jsou velmi tmavě červenohnědá,

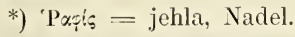

**) Doklad ve sbírce musejni praep. č. 25. - Sammlung des böhmischen Landesmuseums, Praep. Nr. 25. 


\section{H. UZEL. IIONOGRAPHIE DER ORDNUNG THYSANOPTERA.}

přední tibie žluté, rně šíre, uvnitř úžeji tmavě zkalené. Ostalní tibie jsou tmavè cervenohnědé a stávaji se ke konci znenáhla temně žlutými. Tarsy všecky žluté. Abdomen na konci tenkými dlouhými chlupy opatřen. Délka těla $1.1 \mathrm{~mm}$.

FORMA MACROPTERA. Hlavní žilka má v druhé polovinè tř̀i chlupy, v stejných asi vzdálenostech rozestavené. Vedlejší žilka jest po celé délce asi sedmi chlupy poseta. Hoř. kǐídla jsou silně žlutavošedẽ zkalená, na basi úphně čirá, dolejší slabě šedẽ zkalená; žilka těchto jest tmavá. Pterothorax o něco delši a širší než prothorax. Přední rohy mesothoraxu vyčnívající. - Dva exempl. nalezeny.

FORMA BRAGHYPTERA. Kríidel toliko rudimenta pterothorax nepresahující. Poměrné rozmèry pterothoraxu jsou tytéž jako u formy dlouhokrìdlé. - Sedmnáct exempl. nalezeno.

$$
\gamma^{7}
$$

Značně menši než $f$. Tělo, tykadla a nohy stejně zbarveny. Kríidel jen rudimenta pterothorax nepresahujicí. Konec abdomenu dlouhými tenkými chlupy opatren. Tr̉etí až 7. c̀l. má dole po jedné velmi dlouhé, úzké, na koncích rozširǐené, světlé prohlubině. Jediný exempl. nalezen.

Třásněnka talo žije na nekvetoucích rostlinách lučních a $\mathrm{v}$ drnu. Krátkokîrídlou formu nalézal jsem od dubna do srpna. Dlouhokřídlou formu sbíral j:em jen $\mathrm{v}$ srpnu, v kterémžto měsíci i samce jsem zastihl.

Čechy: Hradec Králové. Liberec. Milešovka. Jind. Hradec (Duda).

P.

Köperfarbe sehr dunkel rothbraun. Kopf etwas mehr lang als breit; nach hinten etwas erweitert; Augen einigermassen hervorgequollen. Erstes Fühlerglied kürzer als das 2. und ebenso breit wie dieses; 2., 3., 4. und 6. Glied untereinander fast gleich lang; das 3. Glied ist mit einem kurzen dünnen, das 4. und 5. mit einem kurzen dicken Stiel versehen; das 5. Glied bedeutend kürzer als das 4.; es ist vorne abgestulzt und legt sich dicht an die sehr breite Basis des 6. Gliedes an; dieses wird gegen das Ende zu allmählich schmäler. Stṿlus ausserordentlich lang und dünn. Fühlerfärbung: 1., 2., 5., 6. Glied und der Stylus grau rothbraun; 5. Glied am Grunde manchmal gelb; 3. und 4. Glied gelb, oben schwach, zuweilen stärker getrübt. Alle Schenkel sehr dunkel rothbraun, die Vordertibien gelb, aussen breiter, innen schmäler dunkel getrübl. Die übrigen Tibien dunkel rothbraun; gegen das Ende werden sie allmählich düster gelb. Alle Tarsen gelb. Abdomenende mit dünnen langen Borsten besetzl. Körperlänge $1.1 \mathrm{~mm}$.

FORMA MA GROPTERA. Hauptader in ihrer zweiten Hälfte mit drei etwa gleich von einander entfernten Borsten versehen. Nebenader der ganzen Länge nach etwa mit sieben 


\section{J. UZEL, MONOGRAFIE ṘAU "THYSANOPTERA“.}

Borsten besäet. Oberflügel stark gelblichgrau getrübt, am Grunde vollkommen hell. Unterflügel schwach grau getrübı; ihre Längsader dunkel. Pterothorax etwas länger und breiter als der Prothorax. Vorderecken des Mesothorax vorstehend.

FORMA BRA GHY PTERA. Flügel zu Rudimenten verkümmert, die den Pterothorax nicht überragen. Die Dimensionen des Pterothorax wie bei der langflügeligen Form.

$$
\text { ð. }
$$

Bedeutend kleiner als das $\subsetneq$. Körper, Fühler und Beine ähnlich gefärbt. Flügel rudimentär. Abdomenende mit langen dünnen Borsten versehen. Das 3.-7. Abdominalsegment hat unten je eine sehr lange, dünne, auf den Enden erweiterte lichte Vertiefung.

Vorkommen: Die kurzflügelige Form von April bis August auf nichtblühenden Wiesenpflanzen und im Rasen. Die langflügelige Form und die Männchen im August. Fundort: Böhmen.

\section{GENUS OXYTHRIPS m.*)}

Očka u obou pohlaví prítomna. Tykadla osmičlenná (stylus dvoučlenný), poměrně značně kratši a zavalitější než u rodu Physopus. Stylus jest dosti dlouhý, vždy však značně kratší než 6 . čl. Nakadla maxillarní o třech článcích. Prothorax trochu až značnè delší než hlava; na zadních rozích jeho po jednom neb dvou chlupech smyslových; na předních rozích není takovỵ́ch chlupů. U některých druhủ ukončeny jsou přední tarsy obou pohlaví malým nehyytkem. Kríídla prrítomna, tvaru obvỵklého; jen u druhu firma scházejí u samic často, u samcû vždy. Brvy mezi tř̉ásnèmi na přední části žilky okružní jsou (na rozdíl od rodu Physopus) slabé. Abdomen jest ke konci značně zúžen; u samic druhu hastata jest 10. čl. velmi dlouhý, rourovitý, takže upomíná poněkud na rod Belothrips. Samci mají nahoře na 9. čl. abdomenu dva páry velmi krátkých a obyčejně velmi silnỵch ostnû, z nichž přední jest mohutnější než zadní.

Ocellen bei beiden Geschlechtern vorhanden. Fühler achtgliedrig (Stylus zweigliedrig), verhältnismässig bedeutend kürzer und gedrungener als bei der Gattung Physopus. Stylus ziemlich lang, jedoch bedeutend kürzer als das 6. Glied. Maxillartaster dreigliedrig. Prothorax etwas bis bedeutend länger als der Kopf; auf seinen Vorderecken ohne Borste, auf seinen Hinterecken mit je zwei oder einer langen Borste. Bei manchen Arten sind die Vordertarsen am Ende mit einer kleinen Kralle versehen. Flügel vorhanden, ihre Gestalt wie bei den vorhergehenden zwei Gattungen; nur bei der Art firma fehlen sie bei den Weibchen oft, bei den Männchen immer. Die Wimpern zwischen den Fransen am Vor-

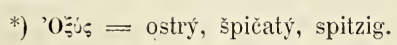




\section{H. UZEL, MONOGRAPHIE DER ORDNUNG THYSANOPTERA.}

derrande der Oberflügel sind (im Gegentheil zu der Gattung Pliysopus) schwach. Abdomen gegen das Ende zu bedeutend verengt; bei den Weibchen der Art hastata ist das 10. Abdominalsegment sehr lang und röhrenförmig, so dass es etwas an die Gattung Belothrips erinnert. Die Nännchen haben auf dem 9. Abdominalsegmente oben zwei Paar sehr kurzer und gewöhnlich sehr starker Dornen, von denen das vordere mächtiger als das hintere ist.

\section{Oxythrips hastata $m . *)$}

Tab. V., fig. 66 .

$$
\text { f. }
$$

Hlava a prothorax žlutavé, pterothorax svělle hnědožlutý, abdomen žlutavý, ke konci hnědošedý. Hlava o trochu širší než delší, do předu se zúžující. První čl. tykadel kratší než 2., tento, pak 3., 4. a 5. čl. vespolek skoro stejně dlouhé. Stylus o 0.4 kratší než 6. ěl. tykadla; druhý čl. stylu značně delši prvého. Barva tykadel: 1. a 2. čl. Žlutavé, 3. žlutavý, nahoře se slabým šedỵm nádechem, ostatní silnè šedě zkalené. Prothorax hlavy patrně delší. Před zadnimi rohy po jedné dlouhé šlětině. Na konci předního tarsu není nehýtku. Nohy žlutavé, někdy všecka femora i tibie vnè trochu šedè zkalené. Hoř. křídla slabě žlulošedě zbarvená. Hlavní žilka v druhé polovinè s pěti chlupy v stejných asi vzdálenostech rozestavenými. Vedlejší žilka má as 13 chlupů. Poslední čl. abdomenu jest velmi dlouhý, rourovitý, skoro třikrát tak dlouhý jako předposlední. Délka těla $0.9 \mathrm{~mm}$.

Var. bicolor Reuter sp. Hlava a thorax žluté se slabým hnědým neb ċerveným nádechem. Celý abdomen černošedý. Barva tykadel: 1.-4. čl. żlutavé, 3. slabě, 4. silně šedě zkalený, ostatní černošedé. Nohy žlutavé, vně se slabỵ́m šedým náletem. Tělo mohutnější; délka jeho $1 \cdot 1 \mathrm{~mm}$.

Poznámka. Reuter (L. č. 113.) radí tuto varietu jakožto druh bicolor (nov. sp.) do rodu Belothrips. Jsem však přesvědčen, že jen vzhledem k zúženému poslednímu článku abdomenu tak učinil, a že druhý znak, kterým rod Belothrips se honosí, totiž neobyčejná délka stylu, který se u tohoto rodu šestému článku skoro vỵrovnává, omylem uvádí u svého (jediného), jak se zdá, usušeného exempláre. Že exemplár̆ Reute r ův bỵl suchý a tudíž nespolehlivý, soudím hlavně z jeho údajủ, týkajicích se rozměrủ hlavy, o níž praví, že je »sotva dvakráte širší než delší (patrně částečně v prothorax vtažená, nebot' ani rod Belothrips nemá tak·širokou hlavu) a z rozměrủ článků abdominalních, z nichž první jest prý patrně delši ně̌ druhỵ. Také není basis posledniho článku chlupy opatřená, nýbrž zadní kraj předposledního článku atd.

*) Doklad ve sbirce musejní, praep. ‘̌. 26. - Sammlung des böhmischen Landesmuseums, Praep. Nr. 26. 


\section{J. UZEL, MONOGRAFIE RÁDU "THYSANOPTERA“.}

\section{$\sigma^{\pi}$ (novẽ objevený).}

Trochu menši než †. Tèlo žlutavé, nahoře slabě šedě zkalené. Nohy żlutavé, všecka femora a ršecky tibie vně trochu šedě zkalené. Tykadla a kîídla zbarvena jako u samice. Uspořádání chlupủ na žilkách totéž. Na 4.-6. čl. abdom. dole po jedné malé, skoro kruhovité, dosti nezretelné prohlubinè.

Nèkolik exemplářủ tohoto druhu nalezl jsem na mladém jehličí smrkovém; po jednom exemplári sbirán $\mathrm{v}$ kvètu borovice (Duda), vstavače a $\mathrm{v}$ drnu. Obě pohlaví přezimuji pod mechem a spadaným listím. - Var. bicolor chytil jsem v nèkolika exempl. na nekveloucích rostlinách $\mathrm{v}$ kvètnu.

Čechy: Praha: V lese mezi Krčí a Kundraticemi. Hradec Králové (zde též var. bicolor). Jind. Hradec (Duda).

\section{+.}

Kopf und Prothorax gelblich, Pterothorax licht braungelb, Abdomen gelblich, gegen das Ende zu braungrau. Kopf etwas mehr breit als lang, nach vorne etwas verengt. Erstes Fühlerglied kürzer als das 2., dieses, das 3., 4. u. 5. untereinander fast gleich lang. Der Stylus um 0.4 kürzer als das 6. Fühlerglied; sein zweites Glied bedeutend länger als das erste. Fühlerfärbung: 1. u. 2. Glied gelblich, das 3. ebenfalls gelblich, oben mit einem schwachen grauen Anflug, die übrigen stark grau getrübt. Prothorax deutlich länger als der Kopf. Vor seinen Hinterecken je eine lange Borste. Vordertarsus am Ende ohne Kralle. Beine gelblich, manchmal alle Schenkel und Tibien aussen etwas grau getrübt. Oberflügel ganz schwach gelbgrau gefärbt. Hauptader in ihrer zweiten Hälfte mit fünf von einander etwa gleich entfernten Borsten versehen. Nebenader mil etwa 13 Borsten besetzt. Das letzte Abdominalsegment sehr lang, röhrenförmig, fast dreimal so lang wie das vorletzte. Körperlänge $0.9 \mathrm{~mm}$.

Var. bicolor Reut. sp. Kopf und Thorax gelb mit schwach braunem oder rothem Ton. Das ganze Abdomen schwarzgrau. Fühlerfärbung: 1.-4. Glied gelblich: 3. schwach. 4. stark grau getrübt, die übrigen schwarzgrau. Beine gelblich, aussen mit schwach grauem Anflug. Körper mächtiger; seine Länge $1.1 \mathrm{~mm}$.

Bemerkung. Reuter (Diagn. öfv. nya Thysanoptera f. Finland, S. 15 u. 16) betrachtet diese Varietät als eine Art der Gattung Belothrips. Ich bin jedoch überzeugt, dass der erwähnte Autor sie nur mit Hinsicht auf das röhrenförmige letzte Abdominalsegment zu jener Gattung brachte, und dass er das zweite Kennzeichen, welches der Gattung Belothrips zukommt, nämlich die ungewöhnliche Länge des Stylus, welche bei dieser Galtung der des sechsten Fühlergliedes fast gleichkommt, nur irrthümlich für sein einziges, wie es scheint, getrocknetes Exemplar angibt. Dass Reuters Exemplar trocken 


\section{H. UZEL. MONOGRAPHIE DER ORDNUNG THYSANOPTERA.}

und daher ziemlich unverlässlich war, glaube ich hauptsächlich aus seiner Angabe schliessen zu dürfen, welche sich auf die Dimensionen des Kopfes bezieht, von dem er sagt, dass er »kaum zweimal mehr breit als lang ist« (jedenfalls war er theilweise in den Prothorax eingezogen; denn es hat auch das Genus Belothrips keinen so breiten liopf).

$$
\text { ơ (neu entdeckt). }
$$

Etwas kleiner als das $q$. Der Körper gelblich, oben schwach grau getrübt. Beine gelblich, alle Schenkel und alle Tibien aussen etwas grau getrübt. Färbung der Fühler und der Flügel wie bcim Weibchen. Die Stellung der Borsten auf den Adern ebenfalls dieselbe. Auf dem 4.-6. Abdominalsegmente unten je eine kleine, fast kreisförmige, ziemlich undeutliche Vertiefung.

Vorkommen: Auf jungen Fichtennadeln, in verschiedenen Blüten und auf nichtblühenden Pflanzen. Beide Geschlechter überwintern unter Moos und abgefallenem Laube. Fundorte: Finnland (Reuter), Böhmen.

\section{Oxythrips ajugae nov. sp.*)}

Tab. V., fig. 67 .

q.

Barva těla běložlutá; pterothorax jest někdy světle hnědožlutý. Abdomen (zrídkia i thorax) bỵvá nahoře slabè sedè zkalen, a to zvl. na posledních dvou článcích. Hlava trochu širší než delší, za očima po obou stranách obloučkem rozšiřená. První ěl. tykadel značně kratši než druhý; 2., 3. a 4. čl. mezi sebou skoro stejně dlouhé. Stỵlus jen as 00.4 kratší než 6 . čl. Jeho druhý ěl. trochu tenčí a značně delší než prvý. Barva tykadel: 1., 2. a 3. čl. jsou žlutavé, 4. a následující hnědo- až černošedé; často však jest již třetí čl., zvl. ke konci, slabě šedě zkalený. Prothorax trochu delší než hlava. Na zadních jeho rozích po jednom dlouhém chlupu. Všecky ostatní chlupy na prothoraxu nepatrné. Nohy žlutavé. Přední tarsy ukončeny jsou malým nehýtkem. Hor̈. křídla slabě žlutavě zkalená. Hlarní žilka má v druhé své polovině trìi chlupy. Vedlejší poseta jest devíti neb desíti chlupy. Poslední článek abdomenu sotva delší než předposlední a mnohem méně zúžený než u druhu předcházejícího. Délka těla $0 \cdot 8 \mathrm{~mm}$. Deset exempl. nalezeno.

Var. bicolor. Hlava a thorax nádherně žluté, abdomen nahore i dole tmavě šedý. (Ve zbarvení těla jest velmi podobná varietẽ bicolor druhu hastata.) Postava mohutnējší než u formy typické. Hoř. kř̌ídla slabě šedožlutavě zkalená. Délka těla $1 \mathrm{~mm}$. Pèt exempl. nalezeno.

*) Doklad ve sbírce musejní, praep. č. 27. - Sammlung des böhmischen Landesmuseums, Praep. Nr. 27. 


\section{J. UZEL, MONOGRAFIE RADU „THYSANOPTERA“.}

$\overbrace{}^{7}$

Menši než $q$, běložlutavý, pterothorax žlutý. Zrídka kdy jest tělo kromě hlavy nahoře velmi slabě šedě zkaleno. Oba páry krátkých ostnủ nahoře na 9. čl. abdom. nejsou tak silné jako u ostatních druhů toho rodu. - Tŕináct exempl. nalezeno.

Třasněnka tato žije obyčejně $\mathrm{v}$ květech zběhovce a výjimkou též na mladém jehličí smrkovém. Samice nalézal jsem (zároveň s var. bicolor) v květnu a èervnu, samce v květnu.

Čechy: Hradec Králové: V lese hradeckém. Opočno: V háji Chropotinè. Peruc.

$$
\text { P. }
$$

Körperfarbe weissgelb; Pterothorax zuweilen licht braungelb. Das Abdomen (selten auch der Thorax) pflegt oben schwach grau getrübt zu sein, und zwar hauptsächlich auf den zwei letzten Segmenten. Kopf etwas mehr breit als lang, hinter den Augen stark gewölbt. Erstes Fühlerglied bedeutend kürzer als das zweite; das 2., 3. u. 4. Glied fast gleich lang. Stylus nur etwa um $0 \cdot 4$ kürzer als das 6. Fühlerglied. Sein zweites Glied etwas dünner und bedeutend länger als das erste. Fühlerfärbung: 1., 2. u. 3. Glied gelblich, das 4. und die folgenden braun- bis schwarzgrau, oft ist jedoch schon das dritte Glied, hauptsächlich gegen das Ende, schwach grau getrübt. Prothorax etwas länger als der Kopf. Auf seinen Hinterecken je eine lange Borste. Alle übrigen Borsten am Prothorax winzig klein. Beine gelblich. Vordertarsen am Ende mit einer kleinen Kralle. Oberflügel schwach gelblich getrübt. Hauptader in ihrer zweiten Hälfte mit drci Borsten. Nebenader mit neun oder zehn Borsten besetzt. Letztes Abdominalsegment kaum länger als das vorletzte und viel weniger verengt als bei der vorhergehenden Art. Körperlänge $0.8 \mathrm{~mm}$.

Var. bicolor. Kopf und 'Thorax hochgelb, Abdomen oben und unten dunkel grau. (In der Färbung sehr ähnlich der Varietät bicolor der Art hastata.) Gestalt mächtiger als die der Stammform. Oberflügel schwach graugelblich getrübt. Körperlänge $1 \mathrm{~mm}$.

$$
\sigma^{x}
$$

Kleiner als das $\subsetneq$, weissgelblich, Pterothorax gelb. Selten ist der Körper, den Kopf ausgenommen, oben sehr schwach grau getrübt. Beide Paare kurzer Dornen oben auf dem 9. Abdominalsegmente sind schwächer als bei den übrigen Arten dieser Gattung.

Vorkommen: Gewöhnlich in den Blüten von Ajuga, einzeln auch auf jungen Fichtennadeln. Die Weibchen im Mai und Juni, die Männchen im Mai. - Fundort: Böhmen. 


\section{H. UZEL. HONOGRAPHIE DER ORDNUNG THYSANOPERA.}

\section{Oxythrips firma nov. sp.*)}

Tab. V., fig. 68. et 69.; Tab. VI., fig. 71.

$$
\text { \&. }
$$

Barva těla leskle černá, někdy černohnědá, pterothorax však tmavohnèdý. Hlava o málo širší než delší, do předu trochu zúźená. Z vrásek na týle jest jedna nejpatrnèjší. Články tykadla krátké, 1. čl. značně kratši druhého; tento jest nejširším článkem v celém tykadle a jest as lak dlouhý jako $3 . ; 4$. čl. delší než 3 ; 5 . čl. značně kratší nez̀ 4.; stylus dlouhý, tenký, 2. čl. jeho delší prvého. Barva tykadel: 1. čl. a 2., tento kromě konce, šedohnědé, 2. na konci a 3. celý žlutavé, 4. žlutavý, šedě zkalený, 5., 6., 7. a 8. čl. tmavošedé. Prostřední článek makadel maxillarních jest neobyčejně krátký. Prothorax značně delší než hlava, $\mathrm{v}$ zadu širší než $\mathrm{v}$ předu a na zadních obou rozich se dvěma dlouhými chlupy. Pr̃ední nohy stlustlé. Přední tarsy na konci s nehýtkem. Femora černohnědá, přední na konci světlejší až žlutá. Přední tibie žluté. vně a uvnitř velmi úzce a slabě zkalené, střední a zadní tibie černohnědé, na konci žluté; všecky tarsy žluté. Délka těla $0.9 \mathrm{~mm}$.

FORMA M A ROPTERA. Křídla úzká, hořejší šedožlutě zkalená, na basi značně světlejší. Obè žilky stejnoměrně mnohỵmi dlouhỵmi chlupy posety. Dolejší křídla světlá, ke konci trochu zkalená. Pterothorax značně delší a širší než prothorax. - Veliké množství exempl. nalezeno.

FORMA BRACHYPTERA. Krídel jen nepatrná rudimenta. Pterothorax jen as tak dlouhý jako prothorax. - Čtyr̆i exempl. sbírány.

$$
\text { o'. }
$$

Mnohem menší než $f$, barva těla, tykadel a noh tatáž. Přední nohy ještě nápadněji stlustlé. Křídel jen nepatrná rudimenta. Pterothorax poměrně kratší a užší než u ૧. Abdomen široký; 3.-7. čl. dole mají po jedné úzké, velmi dlouhé, uprostřed piškotovitě zúžené prohlubině. - Dosti značné množství exempl. sbíráno.

Třásněnku tuto nalézal jsem $\mathrm{v}$ obou pohlavich $\mathrm{v}$ dubnu a zvláště $\mathrm{v}$ květnu mezi drnem na lukách v nejbližšim okolí Hradce Králové.

$$
\text { P. }
$$

Körperfarbe glänzend schwarz, manchmal schwarzbraun, Pterothorax dunkelbraun. Kopf ein wenig mehr breit als lang, nach vorne etwas verengt. Von den Runzeln auf dem Hinterhaupte ist eine am auffallendsten. Fühlerglieder kurz, das 1. bedeutend kürzer

*) Doklad ve sbírce musejní, praep. こ̌. 28. — Sammlung des böhmischen Landesmuseums, Praep. Nr. 28 


\section{J. UZEL, MONOGRAFIE RADU, "THYSANOPTERA“.}

als das 2.; dieses ist das breiteste Glied im ganzen Fühler und is! etwa so lang wie das 3.; das 4. Glied ist länger als das 3.; das 5. Glied bedeutend kürzer als das 4.; der Stylus lang, dünn, sein 2. Glied länger als das erste. Fühlerfärbung: 1. Glied und das 2., dieses mit Ausnahme des Endes, graubraun, das 2. am Ende und das ganze 3. gelblich, das 4. gelblich, grau getrübt, das 5., 6., 7. u. 8. dunkelgrau. Das mittlere Glied der Naxillartaster ist ungewöhnlich kurz. Prothorax bedeutend länger als der Kopf, hinten breiter als vorn und auf den beiden Hinterecken mit je zwei langen Borsten. Vorderbeine verdickt. Vordertarsen am Ende mil einer kleinen Kralle versehen. Schenkel schwarzbraun, die vorderen am Ende lichter bis gelb. Vordertibien gelb, aussen und innen sehr schmal und schwach getrübt, die Mittel- und Hintertibien schwarzbraun, am Ende gelb; alle Tarsen gelb. Körperlänge $0.9 \mathrm{~mm}$.

FORMA MACROPTERA. Flügel schmal, die oberen graugelb getrübt, am Grunde bedeutend lichter. Beide Adern gleichmässig mit vielen langen Borsten besetzt. Unterflügel hell, gegen das Ende zu etwas getrübt. Pterothorax bedeulend länger und breiter als der Prothorax.

FORMA BRACHYPTERA. Flügel rudimentär. Pterothorax nur etwa so lang wie der Prothorax.

$$
\delta^{7}
$$

Viel kleiner als das $q$. Farbe des Körpers, der Fühler und Beine dieselbe. Vorderbeine noch mehr verdickt. Flügel rudimentär. Pterothorax verhältnismässig kürzer und schmäler als beim kurzflügeligen Weibchen. Abdomen breit; sein 3.-7. Segment unten mit je einer schmalen, sehr langen, in der Mitte verengten lichten Vertiefung.

Vorkommen: Im April und Mai im Rasen. - Fundort: Böhmen.

\section{Oxythrips parviceps nov. sp.*)}

Tab. VI., fig. 72.

$$
\text { f. }
$$

Barva těla šedohnědá až žlutohnědá, v tomto pádě šedè zkalená, někdy černohnědá. Pterothorax jest tmavě žlutohnědý s šedým náletem. Hlava velmi malá, značnè širší než delší, nazad zúžená. První ěl. tykadel značně kralší než 2.; 2. a 3. čl. skoro stejně dlouhé, 4. patrně delší; 5. trochu kratší než 3.; 6. èl. trochu delší než 4.; stylus dlouhý, 2. jeho ěl. trochu delší a tenči než prvý. Barva všech článkủ tykadelních černohnědá (ani 3. čl. není světlejší). Prothorax jest značně širší a delší než hlava. Nazad se rozšiřuje. Na zadních jeho rozích po dvou chlupech. Pterothorax jest delší a širši než

*) Doklad ve sbírce musejní, praep. č. 29. - Sammlung des bōhmischen Landesmuseums, Praep. Nr. 29. 


\section{H. UZEL, MONOGRAPHIE DER ORDNUNG THYSANOPTERA.}

prothorax. Femora žlutošedá, přední uvnitř ke konci žlutavá. Přední tibie žlutavé, nahoře a dole úzce šedě zkalenė, prostřední a zadní žiutošedé, na samé basi obyčejně žlutavé neb jen světlejší a ke konci vždy žlutavé. Všecky tarsy světlé. Kř́idla dosti prohnutá. Na hlavní žilce nalézá se nad místem, kde začíná žilka dolejší, pèt (zřídka 4 nebo 6) chlupú; v druhé své polovici má tato žilka tr̆i chlupy, z nichž první od obou ostatních jest značně oddálen. Vedlejši žilka jest po celé délce četnými chlupy poseta. Hořejší krídla jsou celá šedožlutè zkalená; před basí nalézá se čiré okénko. Dolejší krídla jsou celá čirá. Délka těla $0.8 \mathrm{~mm}$.

\section{ऽ. Nebyl posud objeven.}

Třásněnku tuto nalézal jsem od května do počátku listopadu jednotlivě v rủznỵch květech, v množství však $\mathrm{v}$ květech vĩesových.

Čechy: Hradec Králové. Trebechovice. Turnov (Bubák). Vrchlabí. Krkonoše: Na stráních nad Malým stavem. Jindř. Hradec (Duda).

f.

Körperfarbe graubraun bis gelbbraun, in diesem Falle grau getrübt, zuweilen schwarzbraun. Pterothorax dunkel gelbbraun mit grauem Anflug. Kopf sehr klein, bedeutend mehr breit als lang, nach hinten verengt. Erstes Fühlerglied bedeutend kürzer als das 2.; dieses und das 3. fast gleich lang, das 4 . deutlich länger; das 5. etwas kürzer als das 3.; das 6. etwas länger als das 4.; Stylus lang, sein zweites Glied etwas länger und dünner als das erste. Färbung des ganzen Fühlers schwarzbraun. Prothorax bedeutend breiter und länger als der Kopf, nach hinten erweitert. Auf seinen Hinterecken je zwei Borsten. Pterothorax länger und breiter als der Prothorax. Schenkel gelbgrau, die vorderen innen gegen das Ende zu gelblich. Vordertibien gelblich, oben und unten schmal grau getrübt, Nittel- und Hintertibien gelbgrau, an der Wurzel gewöhnlich gelblich oder nur lichter und gegen das Ende zu immer gelblich. Alle Tarsen licht. Flügel ziemlich gebogen. Auf der Hauptader befinden sich auf jener Stelle, unter welcher die Nebenader ihren Ursprung nimmt, fünf (selten 4 oder 6) Borsten; in ihrer zweiten Hälfte stehen drei Borsten, von denen die erste von den übrigen zwei bedeutend entfernt ist. Die Nebenader ist der ganzen Länge nach mit zahlreichen Borsten versehen. Oberflügel ganz graugelb getrübt; vor dem Grunde befindet sich ein kleiner heller Fensterfleck. Unterflügel ganz hell. Körperlänge $0.8 \mathrm{~mm}$.

$$
\text { ठ unbekannt. }
$$

Vorkommen: Von Nai bis Anfang November einzeln in verschiedenen Blüten, häufig jedoch in jenen von Calluma. - Fundort: Böhmen. 


\section{J. UZEL, IIONOGRAFIE RADU „THYSANOPTERA*}

\section{GENUS PACHYTHRIPS $m . *$ )}

Celé tělo, zvl. však abdomen vyniká šiřkou. Oči trochu vygkoulené. Očka scházejí. Tỵkadla osmičlenná, poměrně delší než u rodu předcházejícího. Stylus velmi dlouhý, kratší však než článek šestý. Makadla maxillarní o třech článcích. Prothorax trochu delší než hlava; na zadních jeho rozích po jednom chlupu smyslovém. Plerothorax kratší než prothorax, avšak širší. Nohy zavalité, bezbranné. Kirídel pr̉emalá rudimenta. Prrvní článek abdomenu jest zřetelně od pterothoraxu oddèlen a jest tak široký jako tento. Poslední článek jeho jest značně zúžený a zašpičatělý. Samci mají na devátém článku abdom. nahoře dva páry velmi krátkých, silných ostnủ, z nichž přední jest mohutnější než zadní.

Der ganze Körper, hauptsächlich jedoch das Abdomen durch beträchtliche Breite ausgezeichnet. Augen etwas vorgequollen. Ocellen fehlen. Fühler achtgliedrig, verhältnismässig länger als bei der vorhergehenden Gattung. Stylus sehr lang, jedoch kürzer als das 6. Fühlerglied. Maxillartaster dreigliedrig. Prothorax etwas länger als der Kopf; auf seinen Hinterecken je eine Borste. Pterothorax kürzer als der Prothorax, jedoch breiter. Beine gedrungen, wehrlos. Flügel zu überaus kleinen Rudimenten verkümmert. Das erste Abdominalsegment ist deutlich vom Pterothorax getrennt und ist so breit wie dieser. Das letzte Abdominalsegment ist stark verengt und zugespitzt. Die Männchen haben auf dem 9. Segmente oben zwei Paar sehr kurzer, starker Dornen, von denen das vordere mächtiger ist als das hintere.

\section{Pachythrips subaptera Halid.**)}

Tab. VI., fig. 73 . et 74 .

1836. Thrips subaptera Haliday, Entomolog. Magazine, pag. 450.

1836. - - Burmeister, Handb. d. Entomologie, II, pag. 416.

1843. Tmetothrips subaptera Amyot et Serville, Ins. Hémiptères, pag. 645.

1852. Thrips subaptera Haliday, Walker: Homopt. ins. of Brit. Museum, pag. 1114.

$$
\text { †. }
$$

Barva těla leskle černá, zř́ídka černohnědá. Hlava širší než delší, nazad trochu rozšiřená. Tỵkadla mají články krátké, zavalité. První ělánek jejich kratší než druhý a trochu širší než tento; 3. čl. delší než druhý, 3. a 4. skoro stejně dlouhé, 5. mnohem kratší, 6. čl. delší než třetí, stylus tenký, 2. jeho čl. značně delší prvého. Barva tykadel:

*) IIxœus = tlustý, dick.

**) Doklad ve sbirce musejní, praep. č. 30. - Sammlung des böhmischen Landesmuseums, Praep. Nr. 30. 
1. a 2. čl.. pak 6. čl. a stylus jsou černé, 3., 4. a 5. čl. světle šedohnědé, někdy žluté. šedě (zvl. nahor̀e) zkalené. Všecka femora černá. všecky tibie žluté až (zrrídka) světle hnědožluté, na basi trochu šedohnědě zkalené. Délka těla $1 \cdot 1 \mathrm{~mm}$.

$$
\sigma^{\nearrow} \text { (nově objevený). }
$$

Mnohem menši a slabší ně̌ ‡. Barva těla černá neb černohnědá. Tykadla podobně utvořená a zbarvená jako u samičky. Nohy taktéž bezbranné. Barva noh podobná jako u samičky, přední femora jsou však na konci hnědožlutá. Na 3.-7. čl. abdom. dole nalézá se po jedné úzké, velmi dlouhé svètlé prohlubině. — Dva exempl. nalezeny.

Třásněnka tato żije po celý rok v drnu; na jaře vylézá někdy na nekvetoucí rostlinky. Samci nalezeni v červenci.

Čechy: Hradèc Králové. Na mnoha místech v okolí. Jindř. Hradec (Duda).

$$
\text { f. }
$$

Körperfarbe glänzend schwarz, selten schwarzbraun. Kopf mehr breit als lang, nach hinten etwas erweitert. Fühlerglieder kurz, gedrungen. Das 1. kürzer als das 2. und etwas breiter als dasselbe; das 3. länger als das 2., das 3. u. 4. fast gleich lang, das 5. viel kürzer, das 6. länger als das 3.; Stylus dünn, sein 2. Glied bedeutend länger als das erste. Fühlerfärbung: 1. u. 2. Glied, dann das 6. und der Stylus schwarz, das 3., 4. u. 5. licht graubraun, manchmal gelb, grau getrübt (hauptsächlich oben). Alle Schenkel schwarz, alle Tibien gelb bis (selten) licht braungelb, am Grunde etwas graubraun getrübt. Körperlänge $1.1 \mathrm{~mm}$.

$$
\delta \text { (neu entdeckt). }
$$

Viel kleiner und schwächer als das $\subsetneq$. Körperfarbe schwarz oder schwarzbraun. Fühler ähnlich gebildet und gefärbt wie beim Weibchen. Beine ebenfalls wehrlos. Farbe der Beine ähnlich wie beim Weibchen, Vorderschenkel jedoch am Ende braungelb. Auf dem 3.-7. Abdominalsegmente unten je eine schmale, sehr lange lichte Vertiefung.

Vorkommen: Weibchen das ganze Jahr hindurch im Rasen und nur im Frühjahr manchmal auf nichtblühenden Pflanzen. Männchen im Juli. - Fund orte: England (Halidav), Böhmen.

\section{GENUS ANAPHOTHRIPS $\mathrm{m}^{*}$ )}

Očka prítomna, tèlo jen krátkými chloupky opatřeno; dlouhỵch štětin na prothoraxu a na konci abdomenu není. Tykadla osmičlenná, oba články stylu poměrně dlouhé. U druhu virgo má 6. ěl. tykadla před koncem šikmou přehrádku, takže se tỵkadla zdaji

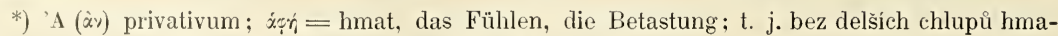
tavých na tẽle; das ist ohne längere Tasthaare am Körper. 


\section{J. UZEL, HONOGRAFIE RADU, "THYSANOPTERA“.}

býti devítičlennými. Makadla maxillarní o tr̉ech ěláncích. Prothorax as tak dlouhý jako hlava. Nohy bezbranné. Křídla pravidlem jsou přítomna. Jen druh virgo jest obyčejně bezkřídlý. Brvy mezi třásnèmi na předním okraji hořejších křídel jsou překrátké. Chloupky na žilkách jsou tenké, obyčejně velmi králké a nepatrné. Chloupky na konci abdomenu jsou velmi slabé a krátké, jen druhy virgo a sordida mají na zadním okraji 9. čl. několik silnỵch krátkỵch chlupû. Samci maji obyčejně nahoře na devátém článku abdom. dva páry velmi krátkỵch, silnỵch ostnủ, z nichž přední jest mohutnèjši než zadní. Druhỵ sem náležejicí nejsou k skákání způsobilé.

Ocellen vorhanden, Körper nur mit kurzen Härchen besetzt; auch am Ende des Abdomen und auf den Hinterecken des Prothorax gibt es keine längeren Borsten. Fühler achtgliedrig, beide Stylusglieder ziemlich lang. Bei der Art virgo hat das sechste Fühlerglied vor dem Ende eine schiefe Querwand, so dass die Fühler neungliedrig zu sein scheinen. Maxillartaster dreigliedrig. Prothorax etwa so lang wie der Kopf. Beine wehrlos. Flügel regelmässig vorhanden. Nur die Art virgo ist gewöhnlich flügellos. Die Wimpern zwischen den Fransen am Vorderrande der Oberflügel sind überaus kurz. Die Borsten auf den Adern sind dünn und gewöhnlich sehr kurz und unscheinbar; ebenfalls sind die Borsten am Abdomenende sehr liurz und dünn; nur bei den Arten virgo und sordida sind die Borsten, welche sich am Hinterrande des 9. Abdominalsegmentes befinden, kurz und stark. Die Männchen haben gewöhnlich auf dem 9. Abdominalsegmente oben zwei Paar sehr kurzer, starker Dornen, von denen das vordere mächtiger als das hintere ist. - Die her gehörenden Arten haben kein Springvermögen.

\section{Anaphothrips ferruginea nov. sp.*)}

$$
\text { ․ }
$$

Barva těla šedẽ žlutohnědá, pterothorax méně šedě zkalený. Hlava trochu širší než delší, před basí náhle ponèkud se rozšiřující. První článek tykadel velmi krátký, 2. značně delší a širší, 3. čl. delší než 2. a 4. Stylus dlouhý, jen o $0 \cdot 4$ kratší než 6 . čl. Druhý čl. stylu delši a tenči než prvý. Barva tykadel: 1. a 2. čl. hnědošedé, 2. na konci žlutavý, 3. žlutavý, někdy ku konci trochu tmavě zkalený, 4., 5., 6., 7. a 8. černošedé, 4. čl. na basi někdy trochu světlejší. Nohy jsou dosti zavalité. Pr̀ední femora jsou žlutavá a vně, kromě konce, šedè zkalená, střední a zadní bud celá žlutošedá, aneb nèkdy ku konci světlejší. Přední tibie žlutavé, vně velmi úzce šedé, střední a zadní žlutavé, po obou stranách, zxl. však vně, šedẽ zkalené, na konci celé žlutavé; tarsy žlutavé.

*) Doklad ve sbírce musejní, praep. č. 31. - Sammlung des böhmischen Landesmuseums, Praep. Nr. 31. 


\section{H. UZEL, MONOGRAPHIE DER ORDNUNG THYSANOPTERA.}

Hořejší křídla slabě žlutavě zkalená. Hlavní žilka má v druhé své polovině tř̆i nepatrné chloupky; vedlejší žilka jich má 6 , někdy 7 . Zvláštností této žilky jest, že v poslední pětině kríidla se ztrácí úplně, kdežto hlavní teprv blízko konce zaniká. Délka tèla 0.9 mm. - Sedm exempl. nalezeno.

$$
\text { ơ. }
$$

Značně menší než q, stejně však zbarvený, jen pterothorax ještě světlejší, skoro hnèdožlutý. Abdomen dosti široký, na konci zaokrouhlený. Na spodní straně článků abdominalních není zřetelných prohlubin. Na vedlejší žilce jsou jen čtyři chlupy. — Čtyři exempl. nalezeny.

Třásněnka tato sbírána u Peruce $\mathrm{v}$ květnu $\mathrm{v}$ obou pohlavích. Několik exempl. nalezl jsem mezi travou lesní a jeden $\mathrm{v}$ kvètnu od Polygala amara.

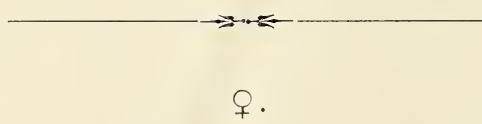

Körperfarbe grau röthlich gelbbraun, Pterothorax weniger grau getrübt. Kopf etwas mehr breit als lang, hinten plötzlich etwas erweitert. Erstes Fühlerglied sehr kurz, das 2. bedeutend länger und breiter, das 3 . länger als das 2. u. 4. Stylus lang, nur um $0 \cdot 4$ kürzer als das 6. Glied. Sein 2. Glied länger und dünner als das erste. Fühlerfärbung: 1. u. 2. Glied braungrau, das 2. am Ende gelblich, das 3. gelblich. manchmal gegen das Ende zu etwas dunkel getrübt, das 4., 5., 6. Glied und der Stylus schwarzgrau. das 4. Glied am Grunde zuweilen etwas lichter. Beine ziemlich gedrungen. Vorderschenkel gelblich und aussen, mit Ausnahme des Endes, grau getrübt, Mittel- und Hinterschenkel entweder ganz gelbgrau, oder manchmal gegen das Ende lichter. Vordertibien gelblich, aussen sehr schmal grau, Mittel- und Hintertibien gelblich, jederseits, besonders jedoch aussen, grau getrübt, am Ende ganz gelblich; Tarsen gelblich. Oberflügel schwach gelblich getrübt. Die Hauptader hat in ihrer zweiten Hälfte drei winzige Borsten; die Nebenader hat 6 , manchmal 7 solche Borsten. Dieselbe verliert sich im letzten Fünftel der Flügellänge, wogegen die Hauptader erst in der Nähe des Flügelendes aufhört Körperlänge $0.9 \mathrm{~mm}$.

$$
\text { d’. }
$$

Bedeutend kleiner als das $q$, jedoch von gleicher Färbung; nur der Pterothorax noch lichter, fast braungelb. Abdomen ziemlich breit, am Ende abgerundet. Auf der Unterseite der Abdominalsegmente keine deutlichen Vertiefungen. Auf der Nebenader nur vier winzige Borsten.

Vorkommen: Im Mai in beiden Geschlechtern zwischen Gras und in den Blüten von Polygala amara. - Fundort: Böhmen. 


\section{Anaphothrips similis nov. sp.*)}

P.

Barva celého těla tmavě šedohnědá. Hlava trochu širší než delší a před basí náhle poněkud se rozšiřující. Tykadla podobná co do tvaru i co do zbarvení tykadlủm druhu predcházejiciho, avšak články jejich jsou zavalitější a 3. i 4. čl. jsou skoro stejně dlouhé. Všecka femora tmavě šedohnědá; přední tibie žlutavé, vně silněji, uvnitř slabě šedě zkalené, ostatní tibie šedohnědé, na konci žlutavé, na samé basi trochu světlejší. Hořejší krídla jsou šedožlutè zkalená, před basí s malým okrouhlým čirým okénkem. Hlavní žilka má v druhé své polovinè tři chlupy, vedlejši po celé své délce 8 chlupů. Chlupy na žilkách jsou silnèjší než u druhu předcházejiciho. Také zde, jako u tohoto, ztrácí se żilka vedlejší v poslední pětině křídla úplně, kdežto hořejší teprv blízko konce zaniká. Délka těla $1 \mathrm{~mm}$. - Jediný exempl. nalezen.

\section{$\sigma^{\top}$. Nebyl posud objeven.}

Třásněnka tato sbirána na vrcholu Milešovky v květnu.

․

Körperfarbe dunkel graubraun. Kopf etwas mehr breit als lang und hinten etwas erweitert. Fühler ähnlich gefärbt und gebildet wie bei der vorhergehenden Art, die Glieder jedoch gedrungener und das 3. u. 4. fast gleich lang. Alle Schenkel dunkel graubraun, Vordertibien gelblich, aussen stärker, innen schwach grau getrübt, die übrigen Tibien graubraun, am Ende gelblich, an der Wurzel etwas lichter. Oberflügel graugelb getrübt. Die Hauptader trägt in ihrer zweiten Hälfte drei Borsten, die Nebenader ihrer ganzen Länge nach 8 Borsten. Die Borsten auf den Adern sind stärker als bei der vorhergehenden Art. Die Nebenader verlierl sich auch hier im letzten Fünftel der Flügellänge. Körperlänge $1 \mathrm{~mm}$.

$$
\text { ơ unbekannt. }
$$

Vorkommen: Im Mai. - Fundort: Böhmen.

\section{Anaphothrips armata nov. sp.**)}

†. Nebyla posud objevena.

$$
\sigma^{\top} \text {. }
$$

Barva těla zelenavě tmavošedá, hlava nejtmavší. Tato jest širší než delší. Články tykadel krátké, zavalité. První čl. jest značně kratší a trochu širší než 2., 3. čl. trochu delší než tento, 4. trochu kratší než 3., 5. kratší než 4., 6. trochu delší než 3. Stỵlus

*) Doklad ve sbirce autorovè. 
dosti dlouhý, tlustý, 2. jeho článek delší než prvý. Barva tykadel: 1. čl. nápadně tmavý, černohnědý, skoro černý; 2., 3., 4. a 5. čl. žlutavé, 2. a 5. slabě šedě zkalené, 6. čl. a stylus černošedé. Přední femora vně tmavošedá, uvnitř žlutavá, střední a zadní tmavošedá, na obou koncích světlejší. Tibie žlutavé, přední vně a uvnitř velmi slabě zkalené, střední a zadní žlutavé, vně a uvnitř trochu více šedě zkalené. Tarsy všecky žlutavé. Kr̂́ídla široká, žilky $\mathrm{v}$ hor̀. kř́ídle velmi slabými krátkỵmi chloupky opatṙeny. Hlavní žilka má ve své druhé polovině 2 neb 3 chlupy, vedlejší žilka po celé své délce 7 neb 8 ; před posledním jest vètší mezera. Hoř. křídla jsou velmi slabě žlutavě zkalená, dolejší čirá. Ostny na 9. čl. abdomenu jsou velmi silné. Na 3.-6. čl. jeho dole nalézá se po jedné veliké, světlé, elliptické prohlubině. Délka těla $0.6 \mathrm{~mm}$.

Jediný exemplár nalezen v květech u Peruce v květnu.

\section{q unbekannt.}

$\sigma^{\lambda}$.

Körperfarbe grünlich dunkelgrau; Kopf der dunkelste Theil. Derselbe ist mehr breit als lang. Fühlerglieder kurz, gedrungen. Erstes Glied bedeutend kürzer und etwas breiter als das 2., das 3. etwas länger als das vorhergehende, das 4. etwas kürzer als das 3., das 5. kürzer als das 4., das 6. etwas länger als das 3. Stylus ziemlich lang, sein zweites Glied länger als das erste. Fühlerfärbung: 1. Glied auffallend dunkel, schwarzbraun, fast schwarz; 2., 3., 4. und 5. Glied gelblich, 2. und 5. schwach grau getrübt, das 6. Glied und der Stylus schwarzgrau. Vorderschenkel aussen dunkelgrau, innen gelblich; Nittel- und Hinterschienen dunkelgrau, auf beiden Enden lichter. Tibien gelblich, die vorderen aussen und innen sehr schwach getrübt, die mittleren und hinteren gelblich, aussen und innen etwas stärker grau getrübt. Alle Tarsen gelblich. Flügel breit, Adern im Oberflügel mit sehr kurzen dünnen Härchen besetzt. Die Hauptader hat in ihrer zweiten Hälfte zwei oder drei Härchen; die Nebenader ihrer ganzen Länge nach 7 oder 8 ; vor dem letzten befindet sich eine grössere Lücke. Oberflügel sehr schwach gelblich getrübt, Unțerflügel hell. Die Dornen oben auf dem 9. Abdominalsegmente sehr stark. Auf dem 3.-6. Segmente unten je eine grosse, lichte, elliptische Vertiefung. Körperlänge $0.6 \mathrm{~mm}$.

Vorkommen: Im Mai in Blüten. - Fundort: Böhmen.

\section{Anaphothrips euphorbiae nov. sp.*)}

$$
\text { q. }
$$

Barva těla tmavè šedě červenohnědá, hlava černohnèdá, zřídka celé tělo černohnědé. Hlava jest širší než delší, nazad trochu se rozšiřujici. Články tykadel dosti krátké,

*) Doklad ve sbirce musejní, praep. č. 32. - Sammlung des böhmischen Landesmuseuins, Praep. Nr. 32. 


\section{J. UZEL, MONOGRAFIE RADU, „THYSANOPTERA“.}

zavalité. První čl. značně kralší než 2., 3. trochu delší než tento, 4. trochu kratší než 3.; 5. jest kratší než 4. a přiléhá dosti širokou plochou k šestému; tento ěl. as tak dlouhý jako 3. Stylus velmi dlouhý, tenký, 2. čl. jeho delši prvého. Barva lykadel: 1. a 2. čl. Imavě šedohnědé, 3. a 4. žlutavé, 5. žlutavý, šedẽ zkalený, 6. čl. a stylus černé. Nohy zavalité. Všecka femora tmavě šedohnědá. Přední tibie žlutavé, nahoře a dole úzce tmavošedé, střední a zadní tmavošedé na obou koncích žlutavé, tarsy žlutavé. Křídla široká. Hlavní žilka má v druhé své polovině 3 chloupky, z nichž jeden jest od obou ostatních oddálen; žilka vedlejší jest po celé délce poseta chlupy, které jsou ke konci řídké. Hor̆. kǐídla slabě žlutošedě zkalená, dolejši čirá. Délka těla $0.9 \mathrm{~mm}$. - Dvacet pět exempl. nalezeno.

$$
\sigma^{\lambda} \text {. }
$$

Značně menši a slabši než †. Barva těla tatáž. Tykadel 1. čl. šedohnědý, 2., 3., 4. a 5. žlutavé, 5. ke konci šedě zkalený, 6. čl. a stylus šedohnědé. Femora šedohnědá; tibie a tarsy žluté, ony vně slabě šedohnědě zkalené. Na 3.—6. čl. abdomenu nalézá se dole po jedné dlouhé, dosti široké, uprostřed trochu stažené, svěllé prohlubině.Jediný exempl. objeven.

Třásněnka tato nalezena $\mathrm{v}$ dubnu a květnu na kvělech od Euphorbia cyparissias a jeden exempl. též na květech od Taraxacum. Samce chytil jsem v květnu. Čechy: Hradec Králové. Třebechovice: V lese pod Vys. Újezdem.

$$
\text { q. }
$$

Körperfarbe dunkel grau rothbraun, Kopf schwarzbraun, selten der ganze Körper schwarzbraun. Kopf mehr breit als lang, nach hinten etwas erweitert. Fühlerglieder ziemlich kurz, gedrungen. Erstes Glied bedeutend kürzer als das 2., das 3. etwas länger als das vorhergehende, das 4. etwas kürzer als das 3.; das 5. ist kürzer als das 4. und legt sich mit ziemlich breiter Fläche an das 6. Glied an; dieses etwa so lang wie das 3. Stylus sehr lang, dünn, sein 2. Glied länger als das erste. Fühlerfärbung: 1. u. 2. Glied dunkel graubraun, das 3. u. 4. gelblich, das 5. gelblich, grau getrübt, das 6. und der Stylus schwarz. Beine gedrungen. Alle Schenkel dunkel graubraun. Vordertibien gelblich, oben und unten schmal dunkelgrau, Mittel- und Hintertibien dunkelgrau, auf beiden Enden gelblich, Tarsen gelblich. Flügel breit. Die Hauptader hat in ihrer zweiten Hälfte 3 kleine Borsten, von denen die erste von den beiden übrigen entfernt ist; die Nebenader der ganzen Länge nach mit Borsten beselzt, welche gegen das Ende zu dünn stehen. Oberflügel schwach gelbgrau getrübt, Unterflügel hell. Körperlänge $0.9 \mathrm{~mm}$.

$$
\sigma \text {. }
$$

Bedeutend kleiner und schwächer als das $\subsetneq$. Körperfarbe dieselbe. Erstes Fühlerglied graubraun, 2., 3., 4. u. 5. gelblich, dieses gegen das Ende grau getrübt, das 6. Glied 


\section{H. UZEL, MONOGRAPHIE DER ORDNUNG THYSANOPTERA.}

und der Stylus graubraun. Schenkel graubraun. Tibien und Tarsen gelb, jene aussen schwach graubraun getrübt. Auf dem 3.-6. Abdominalsegmente unten je eine lange, ziemlich breite, inmitten etwas verengte, lichte Vertiefung.

Vorkommen: Das Weibchen im April und Mai gewölnnlich in den Blüten von Euphorbia cyparissias. Das Nännchen im Nai. - Fundort: Böhmen.

\section{Anaphothrips virgo $\mathrm{m} . *)$}

Tab. Il., fig. 11.; Tab. Vl., fig. 75.-77.

1836. Thrips obscura Haliday, Entom. Magaz., pag. 447.

1843. Physapus obscums Amyot et Serville, Ins. Hémiptères, pag. 643.

1852. Thrips obscura Haliday, Walker: Homopt. ins. of Brit. Museum, pag. 1107.; tab. VI.. fig. 8 .

Haliday uvádí tento druh pod jménem Thrips obscmª Müll., pod kterýmž Müller (L. č. 13.) mèl zcela jiný druh na mỵsli, a sice dle mého presvèdčení onen druh, který Hali da y nazývá $T$. discolor. I odhodlal jsem se, poněradž mimo to jméno obscura nijak na světlý náš druh se nehodi, navrhnouti pro nẽj jméno virgo, pro okolnost, že zajisté parthenogeneticky se rozmnożuje.

$$
\text { f. }
$$

Barva tèla žlulá až svètle hnèdožlutá. Výjimkou jest tèlo barvy žlutohnědé. Hlava as tak dlouhá jako široká, do předu zúžená: mezi očima v tomtéž směru trochu prodloužená. Prrní čl. tykadel značně kratší než 2., 3. delší než predcházející, 4. čl. trochu kratší než 3.. 4. a 5̃. čl. stejně dlouhé, 6. čl. delší než 3. Stylus dlouhý, 2. jeho čl. tenčí a nemnoho delši než prvý. Šestý čl. má na konci třetí čtvrtiny své délky šikmou, vně nižší přehrádku, takže se tỵkadla zdaji bỵti devítičlennými. Barva tykadel: 1. čl. skoro čirý, 2. èl. žlutavý a kromè konce slabě šedẽ zkalený, 3. a 4. Žlutavé, celé slabě šedè zkalené, 4. někdy na konci šedý až tmarošedý, 5. as do polou žlutavý, šedě zkalený, as od polon šedý až černošedý, aneb celý šedý, 6. ěl. a stylus šedé až černošedé. Mesothorax má přední roby vyčnívajicí. Nohy jsou žlutavé, vně slabě až velnii slabě šedè zkalené. Konec abdomenu opatřen nahoře nedlouhỵmi, silnými chlupy. Délka těla as $1 \mathrm{~mm}$.

F O R II A MA GROPTER A. Tèlo jest pravidlem nahoře šedohnèdými skrmami, kresby trorícími, ozdobeno. Kìídla dosti prohnutá. tupá. Chloupky na žilkách hor̀ejšiho křídla jsou sporé, neplatvidelnè rozestavené a velmi nepatrné. Hlavní žilka mívá v druhé své polovině 2 neb 3 clloupky; na vedlejší žilce jest počet jejich větší, avšak velmi nestálý. Oba páry kríclel isou slabě šedožlutavě zkalené.

*) Doklad ve sbírce musejni, praep. č. 33. — Sammlung des böhmischen Landesmuseums, Praep. Nro 33. 


\section{J. UZEL, MONOGRAFIE RADU „THYSANOPTERA“.}

F OR M A B R A C H Y P T ER A. Kìidel jen rudimenta pterothorax nepresahujicí. Jediný exemplář z nalezených mèl kř́ídla přes první články abdominalní prodloužená. Plerothorax není nápadně kratší ně̃ u formy dlouholirídlé.

$$
\sigma^{7} \text {. Nebyl posud objeven. }
$$

Třásněnka tato žije po celý rok hojně $\mathrm{v}$ drnu. $\mathrm{V}$ létě mimo to nalézáme ji často na nekvetoucích nízkých rostlinách, na listech stromů a jednotlivě v různých květech. Také někdy vyskytuje se $\mathrm{v}$ květenstvích trav a $\mathrm{v}$ klasech obilnỵch, ba i na presliěce. Od dubna do řịnna jest valná většina těchto tř́ásněnek opatřena dlouhỵ́mi křídly; přezimující pak skoro všecky jsou krátkokřídlé. Samce nikdy jsem nenalezl. Jest tudíž jisto, že tento druh, jako mnohé jiné, rozmnožuje se v několika generacích po sobě parthenogeneticky.

Čechy: Praha. Hradec Králové. Třebechovice. Opočno. KTrkonoše: Vrchol Sněžky, Malé Sněžné březno, Bouda prince Jindřicha. Liberec. Písek (Vařečka).

P.

Körperfarbe gelb bis licht braungelb, ausnahmsweise gelbbraun. Kopf etwa so lang wie breit, nach vorn verengt, zwischen den Augen in derselben Richtung etwas verlängert. Erstes Fühlerglied bedeutend kürzer als das 2., das 3. länger als das vorhergehende, das 4. etwas kürzer als das 3., das 4. u. 5. gleich lang, das 6. länger als das 3. Stylus lang, sein zweites Glied dünner und nicht viel länger als das erste. Das 6. Glied am Ende des dritten Viertels seiner Länge mit einer schiefen, nach aussen geneigten Scheidewand, so dass die Fühler neungliedrig zu sein scheinen. Fühlerfärbung: erstes Glied hell, 2. Glied gelblich und ausser dem Ende schwach grau getrübt, das 3. und 4. gelblich, schwach grau getrübt, das 4. zuweilen am Ende grau bis dunkelgrau, das 5. etwa bis zur Mitte gelblich, grau getrübt, hinter der Mitte grau bis schwarzgrau, oder ganz grau, das 6. Glied und der Stylus grau bis schwarzgrau. Mesothorax mit vorragenden Vorderecken. Beine gelblich, aussen schwach bis sehr schwach grau getrübt. Abdomen am Ende oben mit nicht langen starken Borsten versehen. Körperlänge etwa $1 \mathrm{~nm}$.

FORMA MACROPTERA. Körper regelmässig oben mit graubraunen Flecken versehen, welche Zeichnungen bilden. Flügel ziemlich gebogen, stumpf. Die Härchen auf den Adern der Oberflügel spärlich, unregelmässig gestellt und winzig. Die Hauptader hat in ihrer zweiten Hälfte 2 oder 3 solche Härchen; auf der Nebenader ist ihre Zahl grösser, jedoch sehr unstät. Beide Flügelpaare sind schwach graugelblich getrübt.

FORMA BRACHYPTERA. Flügel zu Rudimenten verkümmert, welche den Pterothorax nicht überragen; ausnahmsweise sind sie über die ersten Abdominalsegmente verlängert. Pterothorax nicht auffallend kürzer als bei der langflügeligen Art. 


\section{H. UZEL, MONOGRAPHIE DER ORDNUNG THYSANOPTERA.}

ơ unbekannt.

Bemerkung. Haliday führt diese Art unter dem Namen Thrips obscura Müll. an. Müller (Zoologiae danicae Prodromus, S. 96) bezeichnet jedoch mit diesem Namen (Thrips obscura flavescens, elytris pallidis; oculis abdominisque annulis nigris) eine andere, und zwar meiner Meinung nach jene Art, welche Haliday T. discolor nennt. Ich erlaube mir daher für unsere Art den Namen virgo vorzuschlagen, und zwar wegen der bei ihr zweifellos vorkommenden parthenogenetischen Vermehrung, und weil ausserdem der Name obscura auf eine lichte Art keineswegs passt.

Vorkommen: Weibchen das ganze Jahr hindurch häufig im Rasen. Im Sommer oft auf nichtblühenden Gewächsen und einzeln in Blüten. Von April bis October sind fast alle Weibchen langflügelig; die überwinternden Exemplare fast alle kurzflügelig. Kein Männchen unter tausenden von Weibchen! - Fundorte: England (Haliday), Böhmen.

\section{Anaphothrips sordida nov. sp.*)}

$$
\text { f. }
$$

Barva žlutavá; tèlo nahoře velmi slabými, šedými skvrnami, kresby tvořícimi, ozdobeno. Hlava širší než delší, do předu nezúžená, tváře dosti značně vypouklé. První čl. tykadel jest značně kratší než 2., 3. čl. delší než 2., 4. trochu kratší než 3., 5. čl. patrně kratší než 4., 6. delší než 3. a bez přehrádky. Stylus dlouhý, tenký, 2. čl. jeho značně delší než prvý. Barva tykadel: 1. čl. skoro čirý, 2. bělavý neb žlutavý a kromě konce velmi slabě šedě zkalený, 3. hnědošedý, na basi žlutavý, slabě šedě zkalený, 4., 5., 6. čl. a stylus hnědošedé, 4. čl. někdy trochu světlejší. Mesothorax má přední rohy vyčnívajicí. Nohy jsou žlutavé, vně slabě šedožlutě neb jen temněji žlutě zkalené. Chloupky na podélných žilkách hořejšiho křídla jsou sice krátké a slabé, ale mnohem patrnèjší než u druhu předcházejícího. Na konci hoř. žilky jsou 2, na dolejší žilce pak jest jich šest. Hoř. křídla jsou slabě šedožlutavě zkalená, dolejší z počátku čirá, ke konci slabě šedožlutavá. Abdomen opatřen na konci nahoře nedlouhými, silnými chlupy. Druhý až 8. čl. jeho mají nahoře uprostred po dvou krátkých chlupech. Délka těla $0.8 \mathrm{~mm}$. Dosti veliké množství exempl. nalezeno.

$$
0^{x}
$$

Značně menši a slabší než + . Zbarvení tèla totéž. Šafránová varlata prosvítají. Devátý ěl. abdomenu nahore bez ostnủ. - Jediný exempl. objeven.

*) Doklad ve sbirce musejni, praep. ì. 34. - Sammlung des böhmischen Landesmuseums. Pracp. Nr. 34 
Druh tento nalezl jsem $\mathrm{v}$ květnu a červnu $\mathrm{v}$ drnu a několik exempl. (mezi nimi jednoho samce) $\mathrm{v}$ květech.

Čechy: Hradec Králové: U Pouchova a v háji Oulišti u Piletic.

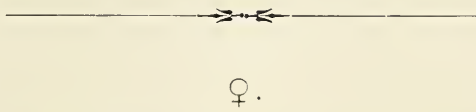

Farbe gelblich; der Körper oben mit sehr blassen, Zeichnungen bildenden Flecken geziert. Kopf mehr breit als lang, nach vorn nicht verengt, Wangen ziemlich gewölbt. Erstes Fühlerglied bedeutend kürzer als das 2., das 3. länger als das vorhergehende, das 4. etwas kürzer als das 3., das 5. deutlich kürzer als das 4., das 6. länger als das 3. und ohne Scheidewand. Stylus lang, dünn, sein zweites Glied bedeutend länger als das erste. Fühlerfärbung: 1. Glied fast klar, das 2. weisslich oder gelblich und, das Ende ausgenommen, sehr schwach grau getrübt, das 3. braungrau, am Grunde gelblich, schwach grau getrübt, das 4., 5., 6. und der Stylus braungrau, das 4. Glied manchmal etwas lichter. Vorderecken des Mesothorax vorstehend. Beine gelblich, aussen schwach graugelb oder nur dunkler gelb getrübt. Die Härchen auf den Adern der Oberflügel sind woh! sehr kurz und dünn, jedoch viel deutlicher als bei der vorhergehenden Art. Am Ende der Hauptader befinden sich zwei solche Härchen, auf der Nebenader sechs. Oberflügel schwach graugelblich getrübt, Unterflügel anfangs hell, gegen das Ende zu schwach graugelblich. Abdomen am Ende mit kurzen starken Borsten versehen. Auf dem 2.-8. Segmente oben in der Mitte je zwei kurze Borsten. Körperlänge $0.8 \mathrm{~mm}$.

$$
\text { ơ. }
$$

Bedeutend kleiner und schwächer als das $\subsetneq$. Körperfarbe dieselbe. Die safrangelben Hoden scheinen durch. Das 9. Abdominalsegment oben ohne Dornen.

Vorkommen: Weibchen im Mai und Juni im Rasen und einzeln in Blüten. Männchen im Juni. — Fundort: Böhmen.

\section{GENUS APTINOTHRIPS HALID.*)}

Tèlo úzké, skoro lysé. Hlava delši než širší, mezi očima do předu v tupý výběžek prodloužená. Oči jsou malé, očka scházejí. Tykadla osmičlenná (stylus dvoučlenný). U variety comnaticornis druhu Apt. rufa schází stylus, takže jest tykadlo jen šestičlenné. Makadla maxillarní o třech článcích, z nichž první jest nejdelší. Prothorax jest kratši než hlava a nazad trochu se rozšiřuje; na zadních rozich jeho není chlupủ smyslových. Nohy jsou krátké. Femora značně rozšířená, tibie na samé basi úzké, načež

*) 'A $A \approx r_{i}$ ' 


\section{H. UZEL, MONOGRAPHIE DER ORDNUNG THYSANOPTERA.}

pojednou velmi značně se rozšiřuji. Tarsy jsou široké. Krídel ani nejmenší rudimenta. Chloupky na konci abdomenu nedlouhé a velmi tenké. Samci mají dle Halidaye na 9. čl. nahoře uprostřed dva ostny. - Druhy sem nálě̌ející pohybuji se zvolna, nejsou způsobilé ku skákání a drážděny byvše hadovitě se svijí.

Poznámka. Gmelin (L. č. 22.), Burmeister i Amyot a Serville domnívali se neprávem, že zástupcové tohoto rodu jsou asi larvy.

Körper schmal, fast kahl. Kopf mehr lang als breit, zwischen den Augen nach vorn in einen stumpfen Fortsal\% verlängert. Augen klein, Ocellen fehlen. Fühler achtgliedrig (Stylus zweigliedrig). Bei der Varietät connaticornis der Art Apt. rufa fehlt der Stylus, so dass der Fühler nur sechsgliedrig erscheint. Maxillartaster aus drei Gliedern zusammengesetzt, von denen das erste an längsten ist. Prothorax kürzer als der Kopf und nach hinten etwas erweitert; auf seinen Hinterecken befinden sich keine Borsten. Beine kurz. Schenkel bedeutend erweitert, Tibien aut dem Grunde sehr schmal, sonst ungewöhnlich breit, Tarsen ebenfalls breit. Flügel vollkommen verkümmert. Die Härchen am Abdomenende kurz und sehr dünn. Die Männchen haben nach Haliday auf dem 9. Segmente oben in der Mitte zwei Dornen. - Die her gehörenden Arten bewegen sich langsam und haben kein Springvermögen; gereizt, winden sie sich schlangenartig.

\section{Aptinothrips rufa Gmel.*)}

Tab. II., fig. 17.; Tab. VI., fig. 78. et 79.

1764. „Der rothe Blasenfuss“ v. Gleichen, Das Neueste aus dem Reiche d. Pflanzen. tab. 16., fig. 6. et 7 .

1788. Thrips rufa Gmelin, Caroli a Linné Systema Nat., pag. 2224.

179 . - - Nicholson, Journ. of Nat. Phil., tab. 8., fig. 1.

1836. - (Aptinothrips) rufa Haliday, Entomol. Magazine, pag. 445.

1852. - - - Haliday, Walker: Homopt. ins. of Brit. Museum. pag. 1103.; tab. V., fig. 5.-11.

1887. Aptinothrips rufa Lindeman, Bull. Soc. Imp. d. Natur. d. Moscou, pag. 319.; pag. 320., fig. 11 .

1894. - stylifera Trybom. Entomol. Tidskrift, pag. 43.

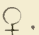

Barva těla světle hnědožlutavá. Nejzazši konec abdomenu jest šedohnědý až černy์: téy̆ konec kužele ústního jest černý. Hlava směrem k basi trochu se rozšiřuje. C̆lánky tykadel

*) Doklad ve sbirce musejni, praep. ¿̌. 35. —. Sammlung des böhmisehen Landesmuseums, Praep. Nr. 35. 


\section{J. UZEL. MONOGRAFIE ṘADU, "THYSANOPTERA“}

jsou velmi krátké, podlouhle kulaté. První čl. velmi široký a nizký, značně kratši než 2., avšak trochu širši, částečně pod výběžkem čelním skirytý, 2. člínek baňkovitý, velmi široký, na úzké stopce. Treti, 4. a 5. čl. asi stejně dlouhé, asi stejně široké, trochu kratši než 2. ěl., na krátkých stopkách; 6. ěl. delší než 2. a užší. Stylus dosti dlouhý, 2. čl. jeho jest tenči a trochu delší než prvý. Tykadla žlutavá, 4. a 5. čl. na konci slabě šedohnědě zkalené, 6. ěl. as do polou nezkalený, od polou šedohnědý, stylus šedohnědý. Velmi zřídka jsou zkaleniny na článcích tykadelních bledé. Výjimkou jest 3. čl. ke konci slabě šedý, 4. čl. kiomě base, 5. celý, 6. celý a stylus šedohnědé až černohnèdé. Pterothorax málo delší než hlava, delší než prothorax a málo širší než tento. Prední rohy mesothoraxu vyčnívající. Délka těla $0.8 \mathrm{~mm}$.

Var. commaticoruis $m$. Šestý čl. tykadla a stylus srủstají $v$ jediný celek. na nẻmž nelze rozeznati hranic článkủ, z nichž se skládá. Spojené tyto tři články jsou na basi žlutavé, jinak šedohnědé.

$\sigma^{\top}$

Dle Halidaye bledě žlutý; abdomenem jeho prosvitají šafránová varlata; předposlední článek abdom. má před koncem uprostred dva ostny.

Druh ten jest jedním z nejhojnějších. Mezi tisíci exempl., které jsem »koumal, nenalezl jsem ani jediného samce; jest tudíž jisto, že rozmnožuje se třásněnka tato pravidlem parthenogeneticky. Žije po celý rok v drnu, mimo to v létě hojně v květenstvích nejrủznějšich trav a někdy i $\mathrm{v}$ klasech obilných (vyjimaje oves). V květech jiných rostlin ji není. - Var. comnaticornis jest hojnějši než forma typická.

Čechy: Praha. Mukařov. Hradec Králové. Třebechovice. Opočno. Turnov. Krkonoše: Po celém hřebenu v mechu a drnu; na vrcholu Sněžky v množství. Jablonec. Liberec. Solnice. Hory Orlické. Milešovka. Peruc. Jind. Hradec (Duda). — Na Helgolandě a $\mathrm{v}$ okolí Berlína prosíval jsem ji z drnu.

\section{q.}

Körperfarbe licht braungelblich. Das äusserste Abdomenende ist graubraun bis schwarz; ebenfalls schwar\% ist die Spitze des Rüssels. Kopf nach hinten etwas erweitert. Fühlerglieder sehr kurz, länglich kugelig. Erstes Glied sehr breit und kurz, bedeutend kürzer als das 2., jedoch etwas breiter, theilweise unter dem Stirnfortsatz verborgen, das 2. Glied napförmig, sehr breit, mit kurzem, schmalem Stiele. Das 3., 4. u. 5. Glied etwa gleich lang, etwas kürzer als das 2., kurz gestielt; das 6. länger und schmäler als das 2. Stylus ziemlich lang, sein zweites Glied dünner und etwas länger als das erste. Fühler gelblich, das 4. u. 5. Glied am Ende schwach graubraun getrübt, das 6. Glied etwa bis zur Mitte licht, von der Mitte an graubraun, Stylus 


\section{H. UZEL, MONOGRAPHIE DER ORDNUNG THYSANOPTERA.}

graubraun. Ausnalısmweise ist das 3. Glied gegen das Ende blassgrau, das 4. Glied mit Ausnahme seines Grundes, das ganze 5., 6. und der Stylus graubraun bis schwarzbraun. Pterothorax wenig länger als der Kopf, länger als der Prothorax und wenig breiter als derselbe, Vorderecken des Nesothorax vorstehend. Körperlänge $0.8 \mathrm{~mm}$.

Var. conuaticoruis m. Das sechste Fühlerglied und der Stylus in ein Ganzes zusammengewachsen, an dem man nicht die Grenzen der Glieder; aus welchen es entstanden ist, unterscheiden kann. Dieser zusammengewachsene Theil ist am Grunde gelblich, übrigens graubraun.

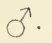

Nach Haliday blassgelb; durch die Abdomenwandungen scheinen die safrangelben Hoden durch; das 9. Abdominalsegment hat oben in der Mitte unweit vom Hinterrande zwei Dornen.

Vorkommen: Sehr häufig im Rasen das ganze Jahr hindurch, im Sommer auch zahlreich in Grasblüten. Var. connaticornis häufiger als die Stammform. Unter vielen Tausenden von Weibchen fand ich kein Männchen. - Fundorte: England (Haliday), Moskau (Lindeman), Böhmen, Berlin, Helgoland (Uzel), Schweden ('Trybom).

\section{Aptinothrips nitidula Haiid.}

1836. Thrips (Aptinothrips) nitidula Haliday, Entomol. Magaz., pag. 446.

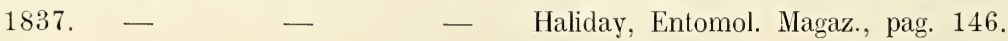

1852. - - - - Haliday, Walker: Homopt. ins. of Brit. Museum, pag. 1105.

Haliday (anno 1836.): "Prothorax aequilatus; ocelli nulli nec alae; antennae articulus 6. apice attenuatus, absque stylo articulato. - Fem. Testacea, abdominis incisuris, etc. fuscis. - One half smaller than Apt. rufa." England.

Haliday (anno 1837.): »Shorter than Thr. $r u f a$, dusky chestnut, with the eyes and incisures of the abdomen darker; the antennae (except the 6th joint) with the shanks and feet paler. «

Haliday (anno 185̃2.) : F Fusco-ferruginea, abdominis incisuris fuscis. Long. ${ }^{1 / 2}$ lin. «

\section{GENUS BELOTHRIPS HALID.*)}

Očka přitomna. Tykadla osmičlenná, oba články stylu neobyčejně dlouhé a tenké. (Celý stylus jen as o 0.2 kratši než 6 . c̀l.) Makadla maxillarní o třech článcích; makadla labialní zakrnělá. Sosák jest úzký a ostrý. Prothorax trochu delší než hlava; na zadních rozích jeho není delších chlupủ smyslovỵch. Nohy bezbranné. Krídla jsou u obou pohlaví prítomna a maji tvar obvyklý, jen dolejší křídla jsou $\mathrm{v}$ poměru $\mathrm{k}$ hořejším velmi

*) Bềos = kopi, Wurfspiess. 


\section{J. UZEL, MONOGRAFIE ŘÁD „THYSANOPTERA“.}

úzká. Brvy mezi třásněmi na předním okraji hořejšiho křídla jsou překrátké (podobně jako u rodu Anaphothrips). Abdomen úzký, 8. čl. se stranami nazad sbíhavými. Dva poslední články abdom. značně zúžené; poslední tvoří dlouhou tenkou rouru. Na konci obou posledních èlánků jsou slaboučké prủhledné chloupky. Samci maji konec tèla tupý.

Ocellen vorhanden. Fühler achtgliedrig, beide Glieder des Stỵlus ungewöhnlich lang und dünn. (Der ganze Stylus nur etwa um $0 \cdot 2$ kürzer als das 6. Glied.) Maxillartaster dreigliedrig; Labialtaster verkümmert. Rüssel schmal und scharf. Prothorax etwas länger als der Kopf; auf seinen Hinterecken keine längeren Borsten. Beine wehrlos. Flügel bei beiden Geschlechtern vorhanden, von üblicher Form, nur die unteren im Verhältnis zu den oberen sehr schmal. Die Wimpern zwischen den Fransen am Vorderrande der Oberflügel winzig (ähnlich wie bei der Gattung Anaphothrips). Abdomen schmal, die Seiten des 8. Segmentes nach hinten convergierend. Die zwei letzlen Abdominalsegmente bedeutend verengt; das letzte bildet eine lange dünne Röhre. Am Ende der zwei letzten Glieder dünne durchsichtige Härchen. Männchen mit stumpfem Abdomenende.

\section{Belothrips acuminata Halid.*)}

Tab. II., fig. 10.; Tab. VI., fig. 80 .

1836. Thrips (Belothrips) acuminata Haliday, Entom. Magazine, ${ }_{n}$ pag. 1115.

1836. - acuminata Burmeister, Handb. d. Entomologie, II, pag. 416.

1843. Belothrips - Amyot et Serville, Ins. Hémiptères, pag. 645.

1852. Thrips (Belothrips) acuminata Haliday, Walker: Homopt. ins. of Brit. Museum, pag. 1115.

$$
\text { q. }
$$

Barva těla tmavě červenohnědá, pterothorax a první články abdomenu mají někdy žlutý odstín. Tèlo jen velmi nepatrnými chloupky opatřenio. Hlava trochu širší než delší, s tvářemi nevỵpouklými. První čl. tỵkadel značně kratší než 2., 3. čl. nejužší v celém tykadle, trochu delší než 2., 4. čl. trochu kratši než třetí, 5. jest značně kratší než 4. a má, jako oba předcházející, krátkou úzkou stopku; na konci jest velmi široký. Šestý článek as tak dlouhý jako 3., široký, na samé basi zúžený. Druhý čl. stylu bývá trochu kratši prvého. Barva tykadel černá, 3. čl. na samé basi žlutavý. Pterothorax delši a širší než prothorax. Přední rohy mesothoraxu vyčnívající. Nohy zavalité, zvláště přední femora a tibie rozšírené; na basi jsou všecky tibie velmi zúžené; tarsy nápadně štíhlé

*) Doklad ve sbírce musejní, praep. ě. 36. - Sammlung des böhmischen Landesmuseums, Praep. Nr. 36. 
a dlouhé. Barva noh jest šedohnědá neb šedě červenohnědá, všecky tarsy a přední tibie jsou temně žlutavé, tỵto vně i uvnitř úzce tmavě zkalené; ostatní tibie pak na konci temně žlutavé. Chloupky na kî̌́dlech jsou dosti slabé a krátké. Hlavní žilka má v druhé polovině tr̆i od sebe značněji vzdálené chloupky; vedl. žilka má as 9 chlupủ po celé délce své rozestavených. Hoř. kříla jsou dosti silně šedožlutavě zkalená, na basi trochu světlejši a tam uprostřed s malỵm, nepravidelným, podloublým, čirým okẹnkem. Dol. křídla slabě šedožlutavě zkalená; żilka jejich jest tmavá. Délka těla $1 \mathrm{~mm}$.

\section{$\sigma^{\top}$}

O něco menši než + , okřídlený a též červenohnèdý; uprostred tèla nahoře má žlutavý odstín. Zbarrení tykadel, noh a kîídel totéż jako u q. Abdomen na konci tupý; na 3.-7. c̀l. abdom. dole po jedné velmi veliké světlé skirnè, která jest $\mathrm{v}$ př̀edu okrouhlá, v zadu pak dosti rovná.

Vzácnou tuto třásněnku, traru podivného, nalezl jsem jen jednou $\mathrm{v}$ polovici k větna u Hradce Králové na lukách za vojenskou plovárnou, a to mezi travou (11 ex.). Dle Halidaye nalézá se r květech od Rosa spinosissima.

$$
\text { Q: }
$$

Körperfarbe dunkel rothbraun, Pterothorax und die ersten Abdominalsegmente manchmal mit gelbem Ton. Der Körper mit nur unbedeulenden Härchen versehen. Kopf etwas mehr breit als lang, mit nicht gewölbten Wangen. Erstes Fühlerglied bedeutend kürzer als das 2., das 3. am schmälsten im ganzen Fühler, etwas länger als das 2, das 4. etwas kürzer als das 3., das 5 . bedeutend kürzer als das 4 . und ebenso wie die zwei vorhergehenden mit kurzem engem Stiele versehen; auf dem Ende ist es sehr breit. Das 6. Glied etwa so lang wie das 3., breit, an der Wurzel verengt. Das 2. Stỵlusglied pflegt unbedeutend kürzer zu sein als das erste. Fühlerfärbung schwarzbraun, 3. Glied an der Wurzel oft gelblich. Plerothorax länger und breiter als der Prothorax. Vorderecken des Mesothorax vorragend. Beine gedrungen, hauplsächlich die Vorderschenkel und Vordertibien erweitert; am Grunde sind alle Tibien sehr verengt; Tarsen auffallenó schlank und lang. Farbe der Beine graubraun oder grau rothbraun, alle Tarsen und die Vordertibien düster gelblich, die letzteren aussen und innen schmal dunkel getrübt; die übrigen Tibien am Ende düster gelblich. Die Härchen auf den Flügeladern sind ziemlich schwach und kurz. Die Hauptader hat in ihrer zweiten Hälfle drei von einander entfernte Härchen, die Nebenader 9, welche ihrer ganzen länge nach z.erstreut sind. Oberflügel ziemlich stark graugelblich getrübt, am Grunde etwas lichter. Unterflügel schwach graugelblich gefärbt; ihre Ader ist dunkel. Körperlänge $1 \mathrm{~mm}$. 
Etwas kleiner als das $\subsetneq$, geflügelt und auch rothbraun; der Körper oben in der Mitte mit gelblichem Ton. Farbe der Fühler, Beine und Flügel dieselbe wie beim Weibchen. Abdomen am Ende stumpf; auf dem 3.- 7. Segmente unten je eine sehr grosse, vorn runde, hinten ziemlich gerade lichte Vertiefung.

Vorkommen: Im Mai zwischen Gras. Nach Haliday in den Blüten von Rosa spinosissima. - Fundorte: England (Haliday), Böhmen.

\section{GENUS DICTYOTHRIPS. (Nov gen.)*)}

Tělo sífkované. Hlava jen trochu širší než, delší, do předu poněkud zúžená. Očka př́tomna. sbližena. Tykadla osmičlenná (stỵlus dvoučlenný). Makadla maxillarní třičlenná. Prothorax as tak dlouhý jako hlava; na zadních rozích jeho není chlupư smyslových, za to však po jedné bradavce. Křídla nedosahují u samic konce těla, u samců však až $\mathrm{k}$ němu se prodlužují. $\mathrm{V}$ první čtvrtině jsou značně rozšířená a zakončují se (na rozdil od druhu následujícího) obvyklým zpủsobem. Žilka okružní dokonale lemuje hor̉ejší krìidlo. Žilka vedlejší odvětvuje se od žilky hlavní asi v prvé třetině její délky. Na obou podélných žilkách hořejšího křídla jsou přemalé chloupky. Přední část žllky okružní ozdobena jest krátkými třásněmi. Brv mezi nimi není. Posledni článek abdomenu jest velmi malý a čtyřmi krátkými, dosti silnými chlupy opatřený; pr̃edposlední článek má čtyři osténky prímo do zadu namírené.

Körper mit netzförmiger Structur. Kopf nur ein wenig mehr breit als lang, nach vorn etwas verengt. Ocellen vorhanden, einander genähert. Fühler achtgliedrig (Stỵlus zweigliedrig). Maxillartaster dreigliedrig. Prothorax etwa so lang wie der Kopf; auf seinen Hinterecken keine Borsten; dafür jederseits eine kleine Warze. Flügel reichen bei den Weibchen nicht bis zum Körperende, bei den Männchen verlängern sie sich jedoch bis $z u$ demselben. Im ersten Viertel ihrer Länge sind sie bedeutend erweitert und enden (im Gegentheil zur folgenden Gattung) auf übliche Weise. Die Ringader umsäumt vollkommen den Oberflügel. Die Nebenader zweigt (manchmal undeutlich) von der Hauptader etwa im ersten Drittel ihrer Länge ab. Die beiden Längsadern des Oberflügels sind mit winzigen Härchen besetzt. Der vordere Theil der Ringader ist mit kurzen Fransen geziert. Wimpern zwischen ihnen nicht vorhanden. Das letzte Abdominalsegment ist sehr klein und mit vier kurzen, ziemlich starken Borsten versehen; das vorletzte Segment hat vier kleine Stachelborsten, welche direct nach hinten gewendet sind.

*) $\Delta$ : : vov $=$ sit, Netz. 


\section{H. UZEL, MONOGRAPHIE DER ORDNUNG THYSANOPTERA.}

\section{Dictyothrips betae nov. sp.*)}

Tab. VI., fig. 81.-83.

q.

Barva tèla žlutá, thorax se slabým červeným odstínem. Všecky tykadelní články jsou hustě kroužkované. První čl. značně kratši a užši než 2., 3. čl. úzký a značně delší neż předcházející, 4. kratší než 3., 5. kratší než 4. Stylus dosti dlouhý, tenký, 2. jeho článek trochu delší ně̌ 1. Barva tykadel: 1. a 2. čl. žlutavé, 3., 4. a 5. taktéž žlutavé, nahoře, zvl. ku konci slabě hnědě zkalené, 6. čl. a stylus černé. Pterothorax jest delší a širši než prothorax. Nohy slabě sítkované. Přední trochu stlustlé. Přední femora maji na konci vně malý zoubek (ohrnutý ostrý okraj). Barva noh jest žlutavá. Hoř. křídla jsou slabě hnědožlutě zkalená, na basi mnohem slaběji, na konci silněji. Abdomen opatřen jest $\mathrm{v}$ zadu ěirými, krátkými a dosti silnými štětinami. Délka těla $0.8 \mathrm{~mm}$. - Jediný exempl. nalezen

$$
\sigma^{x}
$$

Menší než samice, jinak jí velmi podoben tvarem i zbarvením. Jediný exempl. objeven.

Třásněnka tato žije na chřástě cukrovky. - Samici nalezl jsem v srpnu u Jilovice nedaleko Třebechovic, samce $v$ červenci u Pouchova blíže Hradce Králové.

$$
\text { q. }
$$

Körperfarbe gelb, Thorax mit schwachem rothem Ton. Alle Fühlerglieder sind dicht geringelt. Erstes Glied bedeutend kürzer als das 2., das 3. schmal und bedeutend länger als das vorhergehende, das 4. kürzer als das 3., das 5. kürzer als das 4. Stylus ziemlich lang, dünn, sein zweites Glied etwas länger als das erste. Fühlerfärbung: 1. u. 2. Glied gelblich, 3., 4. u. 5. ebenfalls gelblich, oben, besonders gegen das Ende zu, schwach braun getrübt, das 6. Glied und der Stỵlus schwarz. Pterothorax länger und breiter als der Prothorax. Beine mit schwacher netzförmiger Structur. Die vorderen etwas verdickt. Die Vorderschenkel am Ende aussen mit einem kleinen Zahne (der umgebogene scharfe Rand). Farbe der Beine gelblich. Oberflügel schwach braungelb getrübt, am Grunde viel schwächer, am Ende stärker. Körperlänge $0.8 \mathrm{~mm}$.

$$
\text { o. }
$$

Kleiner als das Weibchen, sonst demselben schr ähnlich in Gestalt und in Färbung.

Vorkommen: Im Juli und August auf den Blättern der Runkelrübe. Fundort: Böhmen.

*) Doklad ve sbirce autorově. 


\section{J. UZEL, MONOGRAFIE RADU "THYSANOPTERA“.}

15. GENUS DENDROTHRIPS. (Nov. gen.) *)

Tèlo zavalité, nikoliv sítkované. Hlava $0 \quad 0.4$ až dvakrát širši než delši, oči veliké. do předu značně vyčnívající. Očka u obou pohlaví prítomná, daleko od sebe vzdálená; pred nimi jest hlava prohloubená, pred prohlubinou, t. j. mezi tykadly, opèt zvỵšená. Tykadla nápadně krátká, osmičlenná (stylus dvoučlenný). Šestý článek jejich má obyčejně před koncem šikmou přehrádku, takže tykadla zdaji se býti devítičlennými. Nakadla maxillarní o dvou článcích; makadla labialní velmi krátká. Prothorax asi tak dlouhỵ jako hlava, obyčejně více než dvakrát šírší než delší na zadních rozích jeho po jednom krátkém slabším neb silnějším ostnu. Přední a strední nohy jsou zavalité. Zadní pár jest značně delší než ostatní a k zručnému skákání způsobilý lím, že kyčle jeho opírají se o veliké, uvnitř hrudi umistěné péro. Zadní tibie ukončuji se dole dvěma osténky a zadní tarsy maji jeden krátký silný osten. Úċel těchto ostnủ jest zajisté ten, aby třásněnka při skoku lépe jimi mohla se odrážeti. Kř̌idla jsou velmi dlouhá a presahují konec těla. Hořejší jsou v prvé ětvrtině široká, pak se zúžuji a zûstávaji úzkými až na konec. Dolejší okraj jejich jest př́mý a hořejší ohýbá se $\mathrm{k}$ němu, což jest tvar křídla u třásnènek neobvyklý. Żilka okružní jest tím pamětihodnou, že neobrubuje pr̃ední okraj krídla, nýbrž že běží pod okrajem, nechávajíc úzkou cást jeho přečnívati. Kromẽ žilky okružní jşou tu ještě dvě żilky podélné. Hořejší vychází z base křídla a přibližuje se v místech, kde krídlo počíná se zúžovati, k žilce okružní, načež běží vedle této až do konce. Zúženou části křidla probíhá pod ní ještě jedna slabá žilka, nad niž nalézá se jednoduchá rada bodủ. Přední i zadní okraj křídel jest truasnitý. Na přední části žilky okružní není kratších brv. Na konci předních křídel třásnè scházejí. Přední třásně vycházejí na hořjších křídlech z úzké mezery mezi předni okružní žilkou a hořejší žilkou podélnou. Dolejší křídla jsou velmi úzká a maji jednu hlavní žilku, vycházející z kořene jejich; nedaleko kořene vzniká jiná slabá žilka, která běži nad ní a jest zvláště z počálku málo vyznačená. Poslední článek abdomenu jest velmi malý. Druhý až 8 . čl. jeho opatřeny jsou nahoře uprostřed párem sbližených chlupư; 9. čl. má na zadním okraji čtyřri rovné, dosti dlouhé, silné chlupy. Poslední článek opatr̃en velmi tenkými a krátkými chloupky. Samci jsou menši a světlejší než samice, tvar křídel, žilkování jejich, tvar tykadel, noh i ozbrojení těchto totéž jako u samic.

Körper gedrungen, ohne netzförmige Structur. Kopf um 0.4 bis zweimal mehr breit als lang, Augen gross, nach vorn stark hervorgequollen. Ocellen bei beiden Geschlechtern vorhanden, weit von einander entfernt; vor ihnen ist der Kopf vertieft, vor der Vertiefung, das ist zwischen den Fühlern, erhöht. Fühler auffallend kurz, achtgliedrig (Stylus zweigliedrig). Ihr sechstes Glied hat gewöhnlich vor dem Ende eine schiefe Querwand, so dass der Fühler neungliedrig zu sein scheint. Naxillartaster zweigliedrig;

*) $\Delta \dot{y} y$ s̀pov $=$ strom, Baum. 
Labialtaster sehr kurz. Prothorax etwa so lang wie der Kopf, gewöhnlich mehr als zweimal so breit als lang; auf seinen Hinterecken je ein kurzer dünnerer oder stärkerer Stachel. Vorder- und Mittelbeine gedrungen. Hinterbeine bedeutend länger als die übrigen und durch eine im Thorax liegende Chitinfeder (Taf. VI. Fig. 86), an die sich ihre Hüften stützen, zum gewandten Springen besonders befähigt. Hintertarsen mit einem kurzen starken Stachel versehen. Flügel sehr lang, das Körperende überragend. Oberflügel schmal, im ersten Viertel stark erweitert. Eine bei den Thysanopteren ungewohnte Gestalt erhalten sie dadurch, dass sich ihr Vorderrand am Ende zu dem durchaus gerade verlaufenden Unterrande biegt (Taf. II, Fig. 15). Die Ringader ist dadurch merkwürdig, dass sie einen schmalen Theil des Vorderrandes unumsäumt lässt, indem sie unter ihm verläuft. Zwischen den beiden Längsadern im Oberflügel befindet sich eine Reihe von Punkten. Vorder- und Hinterränder der beiden Flügelpaare sind mit Fransen versehen. Zwischen den Fransen am Vorderrande der Oberflügel befinden sich keine Wimpern. Am Ende der Oberflügel fehlen auch die Fransen. Die vorderen Fransen am Oberflügel entspringen aus der Flügelfläche zwischen dem vorderen Theil der Ringader und der oberen Längsader. Die Unterflügel sind sehr schmal und haben eine Längsader, die aus ihrer Wurzel entspringt; unweit von der Wurzel entsteht eine zweite Längsader, welche über der erwähnten Ader verläuft; sie 'ist hauptsächlich anfangs wenig ausgedrückt. Das letzte Abdominalsegment ist sehr klein. Das 2.-8. Segment ist oben in der Mitte mit je einem Paare nahe an einander stehender Borsten versehen; das 9. Segment hat am Hinterrande vier gerade, ziemlich lange und starke Borsten. Das letzte Segment ist mit sehr dünnen und kurzen Härchen besetzt. Die Männchen sind kleiner und lichter als die Weibchen; die Gestalt der Flügel, der Verlauf der Adern, die Form der Fühler und Beine wie bei denselben.

50. Dendrothrips tiliae nov. $\mathrm{sp} . *)$

Tab. II., fig. 15.; Tab. VI., fig. 84.-86.

? 1773. (T. fasciata L.) Thrips atra, alis fasciis tribus transversis albis; antemis anuulo albo; De Geer, Ném. p. servir à l'hist. d. Insectes (Goeze, III, pag. 11.).

P.

Barva těla černo- až šedohnědá, prothorax bílý s černou kresbou, která obyčejně pozůstává v tom, že zadní kraj lemován jest tmavou stuhou, uprostřed často přervanou, jež vysýlá po každé straně do předu jeden krátký výběžek, před nímž stojí černá skvrnka. Jindy nalézáme na prothoraxu jen dvẽ šikmé stuhy, nazad se rozbíhající. Přes celý ab-

*) Doklad ve sbírce musejní, praep. č. 37. - Sammlung des böhmischen Landesmuseums, Praep. Nr. 37. 
domen jde nahoře uprostřed svěllá stuha, kterou přikrývaji křidla, jsouce složena. Dole jest abdomen světlejší, velmi často šedobělavý. Někdy jsou hlava a plerothorax žlutohnědé, šedě zkalené, a abdomen jest nahoře bělavý, slaběji neb silnēji šedivý. Hlava dvakrát širší než delší. Tykadla jen $0 \quad 0 \cdot 2$ delší než šiřka hlavy; 1 . čl. jejich značně kratší než 2. Tento jest baňkovitý. skoro kulatý; 3., 4. a 5. čl. mezi sebou asi stejně dlouhé, vesměs.trochu kratší a značně užší než 2.; 6. čl. málo delší než predcházející; na basi jest nejširší, načež poznenáhla značně se zížuje; před koncem má šikmou přehrádku; 7. a 8. ěl. dohromady mnohem kratší než 6., mezi sebou skoro stejně dlouhé. Barva tykadel: 1. čl. Imavošedý až černohnědý, 2., 6., 7. a 8. čl. černohnědé, 3.. 4. a 5. čl. žlulé. Pterothorax jest mnohem širší a delší než prothorax. Nohy jsou černošedé, femora zvl. pr̉ední a zadní, na samé basi bílá, všecky tibie, zvl. zadní. ke konci po obou stranách lakléż bílé, všecky tarsy bèlavé. Hor̀. křídla jsou bílá a maji tři černé stuhy, z nichž jedna zaujímá kořen kř́dla, druhá uprostřed něho se nalézá a třetí před koncem; konec pak jest také čený. Jsou-li křídla složena, mají světlé části jejich podobu tří bílých okrouhlých skvrn. Dolejší křídla jsou as uprostřed a ke konci velmi slabě šedẽ zkalená, jinak ěirá. Délka těla $0 \cdot 7 \mathrm{~mm}$.

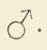

Značně menší $(0 \cdot 5 \mathrm{~mm})$ a světlejší než $\subsetneq$. Barva hlavy žlutošedả, prothorax bílý se slabými kresbami, někdy bez kreseb, pterothorax šedě žlutohnědý, abdomen žlutý neb bělavý, slabě neb silněji šedè zkalený. Stuhy na krídlech slabší. Nohy slabě šedé; femora na basi, tibie ke koncům a tarsy bílé. Tykadla bèlavá, slabě šedě zkalená, 2.. 6. čl. a stylus silněji.

Překrásný tento druh žije od dubna do zárí na liștech kĭovitých líp, a to místy v množství prevelikém. Také na listech olšových a šeříkových časem se zdržuje. Samce nalézal jsem velmi četnẽ $\mathrm{v}$ srpnu a zárí.

Čechỵ: Praha: V Cibulce. Tam zastihl jsem již dne 11. dubna samičku, jež kladla vajíčko. majíc kladélko zapuštěné do listu šeř́kového právě se rozvijejícího. Hradec Králové: V lese hradeckém i novohradeckém a v háji Oulišti u Piletic. Opočno: V bažantnici mochovské v neobyčejném množství. Milešovka.

\section{\&.}

Körperfarbe schwarz- bis graubraun, Prothorax weiss mit einer schwarzen Zeichnung, welche gewöhnlich darin besteht, dass der Hinterrand mit einer dunklen Binde umsäumt ist, die, inmitten oft unterbrochen, beiderseits nach vorn einen kurzen Ausläufer entsendet, vor dem ein schwarzes Fleckchen steht. Zuweilen finden wir auf dem Prothorax nur zwei nach hinten divergierende Streifen. Oben geht über das Abdomen in der Mitte eine lichte Binde, welche die Flügel, wenn sie zusammengelegt sind, bedecken. Unten 


\section{H. UZEL, MONOGRAPHIE DER ORDNUNG THYSANOPTERA.}

ist das Abdomen lichter als oben, sehr oft grauweisslich. Nanchmal ist der Kopf und der Pterothorax gelbbraun, grau getrübt, und das Abdomen oben weisslich, schwächer oder stärker grau angehaucht. Kopf zweimal mehr breit als lang. Fühler nur um $0 \cdot 2$ länger als die Kopfbreite; ihr 1. Glied bedeutend lürzer als das 2. Dieses ist napfförmig, fast rund; das 3., 4. u. 5. Glied untereinander etwa gleich lang und durchgehends etwas kürzer und bedeutend schmäler als das 2.; das 6. Glied wenig länger als das vorhergehende, gegen das Ende zu bedeutend verengt, vor dem Ende mit einer schiefen Querwand; das 7. u. 8. Glied zusammen viel kürzer als das 6., untereinander fast gleich lang. Fühlerfärbung: 1. Glied dunkelgrau bis schwarzbraun, das 2., 6., 7. u. 8. Glied schwarzbraun, das 3., 4. и. 5. gelb. Pterothorax viel breiter und länger als der Prothorax. Beine schwarzgrau. Schenkel, hauptsächlich die vorderen und hinteren, an der Wurzel weiss, alle Tibien (hauptsächlich die hinteren) gegen das Ende zu jederseits ebenfalls weiss, alle Tarsen weisslich. Oberflügel sind weiss und haben drei schwarze Querbinden, von denen die eine die Wurzel des Flügels einnimmt, die andere in seiner Mitte verläuft, und die dritte vor dem Ende sich befindet. Das Flügelende ist ebenfalls schwarz. Wenn die Flügel zusammengelegt sind, bilden ihre lichten Oberflügelpartien drei rundliche weisse Flecke. Die Unterflügel sind etwa in der Mitte und gegen das Ende zu schwach grau getrübt, sonst hell. Körperlänge $0.7 \mathrm{~mm}$.

$$
\text { ð. }
$$

Bedeutend kleiner $(0.5 \mathrm{~mm})$ und lichter als das $q$. Kopf gelbgrau, Prothorax weiss mit schwachen Zeichnungen, welche auch fehlen können, Pterothorax grau gelbbraun, Abdomen gelb oder weisslich, schwach oder stärker grau getrübt. Die Flügelbinden lichter. Beine schwach grau gefärbt; Schenkel am Grunde, Tibien gegen das Ende und Tarsen weiss. Fühler weisslich, schwach grau getrübt, 2., 6. Glied und der Stylus stärker.

Vorkommen: Von April bis September auf Lindenblättern, seltener auf Erlenund Fliederblättern. Männchen im August und September. — Fundort: Böhmen.

\section{Dendrothrips Degeeri nov. sp.*)}

Tab. VI., fig. 87.

$$
\text { ‥ }
$$

Hlava a abdomen šedohnědé, oči bělavě obroubené, prothorax bělavý s šedohnědými kresbami, podobnými kresbám na prothoraxu u druhu předcházejícího, avšak většími. Pterothorax šedě žlutohnědý. Jindy jsou hlava a abdomen šedožlutavé, prothorax žlutavý s šedými kresbami a pterothorax šedě žlutohnědý. Hlava dvakrát širší než delší.

*) Doklad ve sbirce musejni, praep. č. 38. - Sammlung des böhmischen Landesmuseums, Praep. Nro 38. 


\section{J. UZEL, MONOGRAFIE RADU "THYSANOPTERA“.}

Tykadla jen as o 0.2 delší než šírka hlavy, ve tvaru podobná tykadlům druhu předcházejicího (také přehrádka v 6 . čl. jest prítomna), jen $3 ., 4$. a 5. čl. jsou poněkud kratší a tlustší. První, 3., 4. a 5. čl. šedé, 4. z nich nejsvětlejší, 2., 6. článek a stylus černošedé. Barva noh šedohnědá, přední tibie ke konci po obou stranách bělavé, střední tibie na konci dole taktéž bělavé, zadní femora na basi a zadní tibie ke konci bílé. Horejši kî́dla silně žlutošedě zkalená, na basi mnohem svètlejší a zde na předním okraji skoro čirá; šupinka celá ð̌lutošedá. Dolejší kî̌idla slabě šedě zkalená, žilka tmavá. Délka těla $0.8 \mathrm{~mm}$.

$$
\sigma^{\top}
$$

Značně menší a svěllejší než †. Barva těla světle žlutá. Tykadel 1. a 2. článek běložluté, 3.-6. čl. a stỵlus šedé, nèkdy 3., 4. a 5. ěl. bèlavé, jen na konci šedé. Kríídla slabě šedě zikalená. Nohy běložluté. Šafránová varlata prosvítají. Výjimkou jsou tèlo, nohy a první dva články tykadel bílé, ostatek tỵkadla tmavošedý; křídla zủstávají slabě šedě zkalenými.

Třásněnka tato žije po celý rok pod korou stromủ, zvláště vrb, topolủ, dubû, břiz a hrušek; mimo to pak $\mathrm{v}$ létě na listech kaštanu koňského $\mathrm{v}$ počtu někdy značném, dále na listech lípových, olšových, šeríkových a jasanových. Samci vyskytuji se četně v sippnu.

Čechy: Hradec Králové: Ve Věkoši. Opočno: u Mezríiče a v bažantnici Mochovẽ.

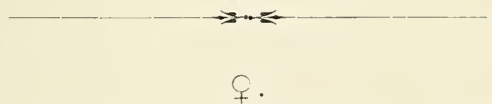

Kopf und Abdomen graubraun, Augen weisslich umsäumt, Prothorax weisslich mit graubraunen Zeichnungen, welche denen der vorhergehenden Art ähnlich sind. Pterothorax grau gelbbraun. Zuweilen ist der Kopf und das Abdomen graugelblich, der Prothorax gelblich, seine Zeichnungen grau; der Pterothorax bleibt grau gelbbraun. Kopl zweimal mehr breit als lang. Fühler nur etwa um 0.2 länger als die Kopfbreite, in der Form ähnlich denjenigen der vorhergehenden Art (auch die Querwand in 6. Glied ist vorhanden), nur ist das 3., 4. u. 5. Glied etwas kürzer und dicker. Das 1., 3., 4. u. 5. Glied grau (das 4. lichter), das 2., 6. Glied und der Stylus schwarzgrau. Farbe der Beine graubraun, Vordertibien gegen das Ende zu beiderseits weisslich, Nitteltibien am Ende unten ebenfalls weisslich, Hinterschenkel am Grunde und Hintertibien gegen das Ende weiss. Oberflügel stark gelbgrau getrübt (ohne Binden), am Grunde viel lichter und hier am Vorderrande fast hell; die Schuppe gänzlich gelbgrau gefärbt. Unterflügel schwach grau getrübt, die Längsader dunkel. Körperlänge $0.8 \mathrm{~mm}$.

$$
\text { 万. }
$$

Bedeutend kleiner und lichter als das $q$. Körperfarbe lichtgelb. Erstes und zweites Fühlerglied weissgelb, die übrigen grau, manchmal das 3., 4. u. 5. Glied 


\section{H. UZEL, MONOGRAPHIE DER ORDNUNG THYSANOPTERA.}

weisslich, nur am Ende grau. Flügel schwach grau getrübt. Beine weissgelb. Die safran gelben Hoden scheinen durch. Ausnahmsweise sind der Körper, die Beine und die ersten zwei Fühlerglieder weiss, die übrigen dunkelgrau.

Vorkommen: Das ganze Jahr hindurch unter der Rinde verschiedener Bäume; ausserdem im Sommer auf verschiedenen Baumblättern, vorzüglich auf denen der Rosskastanie. Männchen im August. -- Fundort: Böhmen.

\section{Dendrothrips saltatrix nov. sp.*)}

Tab. VI., fig. 88 .

q.

Hlava, prothorax a abdomen žlutavobilé, tento ke konci žlutý, pterothorax žlutý, zrídka bčlužlutavý. Nahoře na těle nalézáme šedé kresby, z nichž zvlášlě nápadna jest kresba na prothoraxu, majic více méně podobu koruny. Hlava as o $0 \cdot 4$ širši než delší. Tykadla o 0.5 delši než šî́ka hlavy. Tvar tykadla tentýž jako u druhu tiliae, jen 1. čl. trochu delší, a 6. èl. nemá přehrádky. Barva tykadel: 1., 3. a 4. čl. žlutavé, 2. žlutavý. silně šedě zkalený, 5., 6., 7. čl. a stylus černé. Prothorax as tak dlouhý jako hlava a málem dvakrát širši než delši; na zadních jeho rozích po jednom silném ostnu. Pterothorax značně širši a delši než prothorax. Nohy žlutavé, místy šedẽ zkalené, a sice: všecka femora uprostřed, tibie predni a střední vně a slabě též uvnitř; zadní nohy však jsou skoro nezkalené. Křídla přesahuji konec abdomenu značněji než u obou předcházejících druhủ. Vedlejší žilka $\mathrm{v}$ hoř. krídlech jest nezřetelná. Kr̂̀́dla tato jsou silně žlutošedě zkalená, na konci svěllejší; rozšírená basalní čási jejich jest v přední polovině skoro čirá; také šupinka jest v prvé polovině bezbarvá, v druhé však šedá. Dol. křídla jsou velmi slabě šedě zkalená, hlavní žllka jejich jest tmavá. Délka těla $0.7 \mathrm{~mm}$.

$$
\sigma^{\lambda}
$$

Značně menší než + . Barva lĕla, tykadel a noh tatáž jako u ní, i kresby tỵtéž. Kř̉idla jsou černošedá (kromě na basi $v$ předu, kdež jsou skoro čirá). Šafránová varlata prosvitají.

Tuto třásnènku nalezl jsem $\mathrm{v}$ obou pohlavích $\mathrm{v}$ květnu a $\mathrm{v}$ srpnu na listech olšových, samičky pak též v zimě pod korou nejrůznějšich stromú, zvláště bríz, vrb, švestek a hrušek.

Čechy: Hradec Králové. Opočno: V bažantnici Mochově.

*) Doklad ve sbirce musejni, praep. ċ. 39. —- Sammlung des böhmischen Landesmuseums, Praep. Nr. 39. 


\section{J. U\%EL, MONOGRAFIE RADU "THYSANOPTERA".}

$\uparrow$.

Kopf, Prothorax und Abdomen gelblichweiss, dieses gegen das Ende zu gelb, Pterothorax gelb, selten weissgelblich. Oben auf dem Körper befinden sich graue Zeichnungen, von denen besonders jene auf dem Prothorax auffällt, indem sie mehr oder weniger einer Krone ähnelt. Kopf etwa um $0.4 \mathrm{mehr}$ breit als lang. Fühler um $0 \cdot 5$ länger als die Kopfhreite. Fühlerform dieselbe wie bei der Art tiliae, nur ist das 1. Glied etwas länger, und das 6. Glied hat keine Querwand. Fühlerfärbung: 1., 3. u. 4. Glied gelblich 2. gelblich, stark grau getrübt, das 5., 6., 7. Glied und der Stylus schwarz. Prothorax etwa so lang wie der Kopf und fast zweimal so breit als lang; auf seinen Hinterecken je ein starker Stachel. Pterothorax bedeutend breiter und länger als der Prothorax. Beine gelblich, theilweise grau getrübt, und zwar: alle Schenkel in der Mitte, die Vorder- und die Mitteltibien aussen und schwach auch innen; die Hinterbeine sind fast ungetrübt. Flügel überreichen das Abdomenende bedeutender als bei beiden vorhergehenden Arten. Die Nebenader im Oberflügel ist undeutlich. Die Oberflügel sind stark gelbgrau getrübt, am Ende lichter; ihre erweiterte basale Partie ist in der vorderen Hälfte fast klar; auch die Schuppe ist in der ersten Hälfte klar, in der zweiten jedoch grau. Unterflügel sehr schwach grau getrübt, ihre Hauptader dunkel. Körperlänge $0.7 \mathrm{~mm}$.

\section{$\sigma^{\top}$.}

Bedeutend kleiner als das $q$. Farbe des Körpers, der Fühler und Beine ebenso wie bei demselben, auch ähnliche Zeichnungen sind vorhanden. Flügel dunkelgrau (ausser am Grunde vorn, wo sie hell sind). Die safrangelben Hoden scheinen durch.

Vorkommen: In beiden Geschlechtern im Nlai und August auf Erlenblättern. Im Winter fand ich Weibchen unter der Rinde der verschiedensten Bäume. - F und or t: Böhmen.

\section{GENUS PROSOPOTHRIPS. (Nov. gen.)*)}

Tělo sífkované. Hlava jest širší než delší, za očima vypouklá. Po každé straně její nalézá se malý hrbol s chloupkem. Oči jsou vykoulené. Mezi nimi v předu na hlavě jsou dva hrboly. Očka nejsou př́tomna. Tykadla osmičlenná (stylus dvoučlenný). Makadla maxillarní o třech článcích. Prothorax jest značně delší než hlava. Na zadních rozích jeho není chlupư smyslových. Nohy jsou krátké a velmi zavalité, bezbranné. Kî̌idel ani nejmenši rudimenta. Chloupky na konci těla jsou velmi nepatrné.

Körper mit netzförmiger Structur. Kopf mehr breit als lang, hinter den Augen gewölbt und jederseits mit einem Höcker versehen, an dessen Spitze ein Härchen steht.

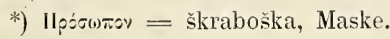




\section{H. UZEL, MONOGRAPHIE DER ORDNUNG THYSANOPTERA.}

Augen hervorgequollen. Zwischen ihnen vorn auf dem Kopfe zwei Höcker. Ocellen fehlen. Fühler achtgliedrig (Stylus zweigliedrig). Maxillartaster dreigliedrig. Prothorax bedeutend länger als der Kopf. Auf seinen Hinterecken keine Sinnesborsten. Beine kurz und sehr gedrungen, wehrlos. Flügel vollkommen fehlend. Härchen am Abdomenende unbedeutend.

\section{Prosopothrips Vejdovskýi nov. sp.*)}

Tab. II., fig. 9.; Tab. VI., fig. 89.

$$
\text { q. }
$$

Hlava, prothorax a mesothorax jsou černé, metathorax a abdomen světle žlutohnèdé. První èl. tykadel jest krátký, značně kratší než 2. a velmi široký, se stranami vypouklými; 2. ěl. jest šikmý, neobyčejně veliký, ke konci zúžený; 3.—5. čl. jsou úzké, mezi sebou skoro stejně dlouhé a stejnè utvořené; 6 . c̀l. jest nejdelším $\mathrm{v}$ celém tykadle a taktéž poněkud šikmý. Barva tykadel: první čl. jest žlutý, více nebo ménè hnědě zkalený až černohnědý, 2. èl. světle žlutohnèdý, 3., 4. a 5. žluté, 6. žlutý, na konci černý, stylus černý. Pterothorax jest kratši a širší ně prothorax. Mesothorax a metathorax jsou velmi zretelnè od sebe oddèleny. Onen jest velmi krátký. Předni femora černá, přední tibie svělle žlutohnědé, na basi vně tmavě zkalené; přední tarsy a stiední i zadní nohy celé žlutohnědé. První čl. abdomenu krátký a 9. čl. jeho daleko do osmého vsunutý. Zadní kraje článkủ abdom. mají nahoře zubatý lem. Délka těla $0 \cdot 8 \mathrm{~mm}$. Dosti značný počet exempl. nalezen.

$$
\text { ऊ. Nebyl posud objeven. }
$$

Tr̀ásněnka tato žije $\mathrm{v}$ létě i $\mathrm{v}$ zimě $\mathrm{v}$ hájich pod drnem.

Čechy: Hradec Králové: Háj Ouliště u Piletic. Tr̉ebechovice: Pod Vys. Újezdem.

$$
\text { Q. }
$$

Kopf, Prothorax und Mesothorax schwarz, Metathorax und Abdomen licht gelbbraun. Erstes Fühlerglied kur\%, bedeutend kürzer als das 2. und sehr breit, mit gewölbten Seiten; 2. Glied schief, ungewöhnlich gross, gegen das Ende zu verengt; das 3.-5. Glied schmal, unlereinander fast gleich lang und gleich gebildet; 'das 6 . ist im ganzen Fühler am längsten und ebenfalls etwas schief. Fühlerfärbung: erstes Glied gelblich, mehr oder weniger braun getrübt bis schwarzbraun, das 2. licht gelbbraun, das 3, 4 . u. 5. gelb, das 6. gelb, am Ende schwarz, der Stylus ebenfalls schwarz. Pterothorax

*) Dovolil jsem si tento druh nazvati dle pana Dr. Frant. Vejdovského, universitního professora v Praze. - Doklad ve sbirce musejni, priep. ě. 40. - Sammlung des böhmischen Landesmuseums, Praep. Nr. 40. 


\section{J. UZEL, MONOGRAFIE RADU, "THYSANOPTERA“.}

kürzer und breiter als der Prothorax. Mesothorax und Metathorax sehr deutlich von einander getrennt. Vorderschenkel schwarz, Vordertibien licht gelbbraun, am Grunde aussen dunkel getrübt; Vordertarsen und die ganzen Mittel- und Hinterbeine gelbbraun. Erstes Abdominalsegment kurz; das 9. Segment weit in das 8. eingeschoben. Hinterränder der Abdominalsegmente oben gezähnt. Körperlänge $0.8 \mathrm{~mm}$.

$$
\text { ơ unbekannt. }
$$

Vorkommen: Das ganze Jahr hindurch im Waldrasen. — Fundort: Böhmen.

\section{GENUS HELIOTHRIPS HALID.*)}

Tělo, zvláště hlava a prothorax silně sittkované. Hlava širši než delší, hrbolatá, do zadu trochu rozšiřená, mezi očima do předu v ostrý hrb prodloužená. Tváře nevypouklé, uprostřed sedlovitě stažené. Oči nevylkoulené, nýbrž jen do předu vyčnívající. Očka přitomna. Tykadla osmičlenná. Stylus dvoučlenny̧, 2. jeho článek mnohem delší než prvý, vlasovitý, as tak dlouhý jako 3. èl. tykadla a na konci ještě tenčím krátkým vláskem opatřený. Na 3,-6. čl. tykadel nalézá se na vnější straně po jednom čípku čichovém. Makadla maxillarní o dvou článcích, z nichž druhý jest mnohem delši prvého. Prothorax značně kratši než „hlava, hrbolatý, uprostřed trochu stažený; na zadních rozích jeho není chlupů ani ostnủ. Nohỵ bezbranné. Kř̌idla prítomna a nesítkovaná. Hořejší silně nahoru prohnutá; na basi jsou široká, za první ětvrtinou se však značně zúžuji a zůstávají zúženými až ke konci, kdež jsou zaokrouhlená. Kromě žilky okružní jest zde podélná žilka, která se rozdèluje na konci prvé třetiny ve dvě větve, z nịchž hořjejši běži až do konce křílla těsně vedle přední části žilky okružní, dolejší pak těsnè vedle její zadní části. Na žilkách jsou krátké, sporé chloupky (tak zvláště na hořejším rameni žilky podélné). Přední okraj hořejších křídel opatřen jest tenkými dosti dlouhými trásněmi; kratšich brv mezi nimi neni. Dolejší krídla jsou úzká a na basi též rozširrená. Chlupy na konci abdomenu jsou velmi slabé a svètlé. Rozmnožování dẽje se obyčejně parthenogeneticky.

Körper, hauptsächlich der Kopf und der Prothorax mit tiefer netzförmiger Structur. Kopf mehr breit als lang, uneben, nach hinten etwas erweitert, zwischen den Augen vorne mit einem scharfen Höcker versehen. Wangen nicht gewölbt, inmitten sattelförmig eingeschnürt. Augen nicht hervorgequollen. sondern nur vorstehend. Ocellen vorhanden. Fühler achtgliedrig. Stylus zweigliedrig, sein 2. Glied viel länger als das 1., haarförmig, etwa so lang wie das 3. Fühlerglied und am Ende mit einem noch dünneren, kurzen Härchen versehen. Am 3.-6. Fühlergliede befindet sich aussen je ein Geruchszapfen.

*) "Hネıs = slunce, Sonne; jméno nevhodné; willkürlich gewählter Name. 
Maxillartaster aus zwei Gliedern zusammengesetzt, von denen das 2. viel länger als das ersle ist. Prothorax kürzer als der Kopf, uneben, inmitten etwas eingeschnürt; auf seinen Hinterecken weder Borsten noch Stacheln. Beine wehrlos. Flügel vorhanden. ohne netzförmige Structur. Die oberen stark aufwärts gebogen, am Grunde breit, vom ersten Viertel an jedoch schmal und am Ende abgerundet. Ausser der Ringader befindet sich hier eine Längsader, welche aus der Flügelwurzel entspringt und sich im ersten Drittel der Flügellänge in zwei Äste gabelförmig theilt. Der obere Ast läuft dicht neben dem vorderen Theil der Ringader, der untere Ast dicht neben ihrem hinteren Theil. Die Adern sind mit Härchen dünn beselzt (so besonders der obere Ast der Längsader). Der Vorderrand der Oberflügel trägt dünne, ziemlich lange Fransen; kürzere Wimpern zwischen denselben sind nicht vorhanden. Die Unterflügel sind schmal und an Grunde ebenfalls erweitert. Die Borsten am Abdomenende sind sehr schwach und licht.

\section{Heliothrips haemorrhoidalis Bouché*)}

Tab. VI., fig. 90.-92.

1833. Thrips haemormoidalis Bouché, Naturg. d. schädl. Garten-Ins., pag. 206. 1836. Heliothrips Adonidum Haliday, Entomolog. Magazine, pag. 443.

1836. - haemorrhoidalis Burmeister, Handb. d. Entomolog., II. pag. 412. 1838. - - - Burmeister, Genera Insectorum. (Kolorované vyobrazení. - Colorierte Abbildung.)

1843. - - - Amyot et Serville, Ins. Hèmiptères, pag. 641.

1852. - - Haliday, Walker: Homopt. ins. of Brit. Museum, pag. 1002.; tab. VI., fig. 13.

1852. - - Heeger, Silzungsb. d. Akad. d. Wiss., Wien, IX, pag. 473.; tab. XVII.

1855. Thrips - $\quad$ Bremi, Stetliner Entomolog. Zeitung, pag. 313.

1882. - - Frič, Prílodopis živočišstva, pag. 113. (vyobrazení).

1886. Heliothrips adonidum Cameron, Transact. Natur. Hist. Soc. Glasgow, pag. 300. 1891. - haemorrhoidalis Reuter, Thysanopt. i finska orangerier, pag. 164. et 165 .

$$
\text { q. }
$$

Barva tèla černohnědá, hlava trochu světlejší, dva poslední články abdomenu červenavě žlutohnědé; 8. čl. jeho jen uprostřed tak zbarvený. Tykadla velmi tenká, dlouhá. První jejich článek jest kratší a užší než 2., tento jest baňkovitý, nemnoho

*) Doklad ve sbirce musejni, praep. è. 41. - Sammlung des böhmischen Landesmuseums, Praep. Nr. 41. 
delši ně̌ širší; 3., 4. a 5. čl. na basi úzké, ku konci však kyjovitě se rozšiřující a postupně kratši a kratší; 6. čl. na basi široký, značně kratší než 3., ano i kratši než 5., 7. čl. tenký, o polovinu kratší než 6. Barva tykadel: 1.--5. čl. žlutavé, první Iva slabě šedohnědẽ zkalené, 6. čl. černošedý, na basi světlý, 7. a 8. ̌̌lutavé, velmi slabě šedè zkalené. Pterothorax značně širší a delší než prothorax. Přední rohy mesothoraxu vyčnívajicí. Nohy zavalité, celé žlutavé. Hoř. krì́dla žlutavá, na basi světlejší. Dolejší krìilla taktéž žlutavá, slabě šedè zkalená, s žilkou tmavou. Devátý čl. abdomenu prodloužený, konický; jest nejdelším článkem vủbec; 10. čl. velmi úzký, značně kratší než předcházející. Délka těla $1.2 \mathrm{~mm}$.

Var. abdominalis Reut. Hlava a thorax černohnědé, abdomen šedě žlutavohnědý. První čl. abdom. celý a 2.-5. po stranách úzce slabè (jen 2. silněji) šedohnědě zkalené.

$$
\text { d. }
$$

Objeven Heegrem (L. č. 63.), avšak nepopsán.

Trásněnka tato byla zavlečena $\mathrm{z}$ cizích krajủ do našich skleníkủ, kdež zdržuje se na spodní straně listủ rủzng̣ch rostlin a někdy značně škodí. Var. abdominalis vyskytuje se dosti zhusta mezi formou typickou.

Čechỵ: Praha (prof. Řezník). Hradec Králové. Hořice.

q.

Körperfarbe schwarzbraun, Kopf etwas lichter, die zwei letzten Abdominalsegmente ganz, und das 8 . in der Nitte röthlich gelbbraun. Fühler sehr dünn u. lang. Ihr erstes Glied kürzer und schmäler als das 2 , dieses napförmig, nicht viel länger als breit; das 3., 4. u. 5. Glied auf dem Grunde schmal, gegen das Ende jedoch keulenförmig erweitert und jedes etwas kürzer als das vorhergehende; das 6. Glied auf dem Grunde breit, bedeutend kürzer als das 3., und sogar etwas kürzer als das 5.; das 7. dünn, um die Hälfte kürzer als das 6. Fühlerfärbung: 1.-5. Glied gelblich, die ersten zwei schwach graubraun getrübt, das 6. schwarzgrau, am Grunde licht, das 7: u. 8. gelblich, sehr schwach grau angeflogen. Pterothorax bedeutend breiter und länger als der Prothorax. Die vorderen Ecken des Mesothorax vorragend. Beine gedrungen, gelblich. Oberflügel gelblich, am Grunde heller. Unterflügel ebenfalls gelblich, schwach grau getrübt, ihre Ader dunkel. Das neunte Abdominalsegment verlängert, konisch, am längsten. Das 10. Segm. sehr schmal, bedeutend kürzer als das vorhergehende. Körperlänge $1 \cdot 2 \mathrm{~mm}$.

Var. abdominalis Reut. Kopf und Thorax schwarzbraun, Abdomen grau gelblichbraun. Erstes Abdominalsegment gan\%, das 2.-5. an den Seiten schmal schwach (nur das 2. stärker) graubraun getrübt. 
Von Heeger entdeckt, jedoch nicht beschrieben.

Vorkommen: Auf der Blattunterseite vieler Pflanzen in unseren Glashäusern (aus fremden Ländern eingeschleppt). — Fund orte: England (Walker, Cameron), Deutschland (Bouché, Burmeister, Bremi, Jordan, Bohls), Wien (Heeger, Löw), Finnland (Reuter), Nordamerika (bei Washington Pergande), Böhmen.

\section{Heliothrips femoralis Reut.}

1891. Heliothrips femoralis Reuter, Thysanoptera i finska orangerier, pag. 165.

»Caput rufo-ferrugineum, thorax fusco-ferrugineus, abdomen, apice excepto, nigropiceum; capite vitta media pone ocellos infuscata; antennis pedibusque rufo-ferrugineis, illis articulo sexto ultimisque fuscis, his femoribus quatuor posterioribus nigro-fuscis; capite longitudine fere ${ }^{1 / 2}$ latiore; oculis ultra latera capitis haud prominulis; antennis utroque articulorum $3-5$ secundo minus quam duplo longiore; pronoto capite $1 / 5$ breviore; mesonoto pronoto dimidio latiore, lateribus fortius rotundato; alis anticis pronoto $2_{i 5}$ angustioribus, abdomine paullo longioribus (in exsiccatis!), linearibus, basi solum leviter dilatatis, nigricantibus, basi albida, apice extremo fasciolaque supra quartam apicalem partem pallidis, margine externo (antico) dense et longe ciliatis, ciliis marginis interni (postici) adhuc longioribus; venis parum elevatis, setosis, longitudinali in tertia basali parte bifurcata, venis apicalibus parallelis; vena brevi basali interiore in marginem internum exeunte. Long. $1^{2 / 5}-1^{1 / 2} \mathrm{~mm}$.

\section{GENUS PARTHENOTHRIPS m.*)}

Tèlo, zvl. hlava a prothorax, silně sitkované. Hlava širší než delší, mezi očima do předu v hrbol prodloužená, vzadu v krček zúžená. Oči značně vỵkoulené. Tráře vypouklé. Očka přitomna. Tykadla sedmičlenná, kromě prvých dvou článkủ velmi tenká. Stylus jednočlenný, vlasovitý, tak dlouhý jako 6. čl. tykadla a na konci ještě tenčím vláskem stejné délky opatřený. $\mathrm{Na}$ 3.-6. článku po dvou od sebe oddèlených čípcích čichových. Makadla maxillarní o dvou článcích, z nichž druhý jest značně delší než prvý. Prothorax valně kratší než hlava; hrbolatý, do zadu se rozširujuící, na zadních svých rozích po jednom nedlouhém kríidlatém ostnu. Nohy bezbranné. Kř́dla jsou velmi široká a velmi dlouhá, takže přesahuji konec abdomenu. Hořejší mají podobu kuchyňského nože, jsou sítkovaná a mají kromě žilky okružní jen jednu žilku podélnou. Tato rysyylá za prvou čtvrtinou své délky krátké, šikmé rameno k přední části žilky okružní, sama pak ohýbá se k spodnímu okraji kǐídla a běží rovnoběžně s ním. Tato žilka jest po

*) П[xpó̂̀s = panna, Jungfrau; vzhledem k parthenogenetickému rozmnožováni se; im Bezug auf die parthenogenetische Vermehrung. 
celé délce chlupy poseta. Pr̃ední část żilky okružní jest opatrena silnými, krátkỵmi brvami; třásní mezi nimi není. Zadní okraj křídla ozdoben jest dlouhými tr̉ásněmi. Za onou krátkou, šikmou žilkou jsou hořejší kǐídla náhle trochu stažená. Dolejší křídla jsou ke konci nahoru prohnutá. Dva poslední články abdomenu jsou u samic značně zížené. Chlupy na konci abdomenu jsou slabé a svěllé. Druh sem náležejíci jest k skákáni zpủsobilý.

Der Körper, hauptsächlich der Kopf und der Prothorax, mit tiefer netzförmiger Structur. Kopf mehr breit als lang, zwischen den Augen vorn mit einem Höcker; ganz hinten halsförmig verengt. Die Augen bedeutend hervorgequollen. Die Wangen gewölbt. Ocellen vorhanden. Fühler siebengliedrig, ausser den ersten zwei Gliedern sehr dünn. Stylus eingliedrig, haarförmig, so lang wie das 6. Fühlerglied und am Ende mit einem noch dünneren Härchen von gleicher Länge versehen. Am 3.-6. Gliede je zwei von einander getrennte Geruchszapfen. Maxillartaster zweigliedrig, ihr zweites Glied bedeutend länger als das erste. Prothorax bedeutend kürzer als der Kopf, uneben, nach hinten erweitert, auf seinen Hinterecken mit je einem nicht langen geflügelten Stachel. Beine wehrlos. Flügel sehr breit und sehr lang, so dass sie das Abdomenende überragen. Die oberen haben die Form eines Küchenmessers, ihre Structur ist netzförmig, und sie besitzen ausser der Ringader nur eine Längsader. Dieselbe entsendet hinter dem ersten Viertel ihrer Länge einen kurzen schiefen Ast zum vorderen Theil der Ringader, wendet sich nachher zum Hinterrand des Flügels und läuft parallel mit ihm. Diese Ader ist der ganzen Länge nach mit Borsten besetzt. Der Vorderrand des Flügels ist mit kurzen starken Wimpern versehen; Fransen sind hier nicht vorhanden. Hinter jenem kurzen schiefen Ast ist der Oberflügel plötzlich etwas zusammengezogen. Die Unterflügel sind gegen das Ende zu aufwärts gebogen. Die zwei letzten Abdominalsegmente sind bei den Weibchen bedeutend verengt. Die Borsten am Abdomenende sind schwach und licht. Die her gehörige Art hat ein Springvermögen.

\section{Parthenothrips dracaenae. Heeg.*)}

Tab. II., fig. 12.-14.; Tab. Vl., fig. 93.

1852. Heliothrips Draccıence Heeger, Sitzungsb. d. Akad. d. Wiss., Wien, pag. 365. (V separatním otisku pag. 3.; tab. I. Separatabdruck: pag. 3 ; tab. I.)

1858. Thrips - Regel, Bull. phys.-math. Acad. St. Petersb., pag. 632.; fig. 4. et 5 .

1888. Heliothrips - Jordan, Zeitschr. f. wiss. Zool., 47. Jahrg.

1891. - - Reuter, Thysanopt. i finska orangerier, pag. 166.

*) Doklad ve sbirce musejni, praep. č. 42. - Sammlung des böhmischen Landesmuseums, Praep. Nr. 42. 
․

Hlava a thorax hnědožlutavé, s postranní tmavou čarou, někdy šedẽ zkalené. Abdomen černolınědý, poslední tř̀i články žlulohnědé. Očka v předu na hlavě blízko vedle sebe seskupená. První čl. tykadel umístěn jest $\mathrm{v}$ nízké mističce a jest kratší a užši než 2.. lento jest baňkovitý, nemnoho delší než širší, 3. a 4. čl. velıni úzké, z tenké base ke konci poznenáhla kyjovitě se rozšiřujicí, v poslední asi čtvrtině zase zúžené. mezi sebou skoro stejně dlouhé, kroužkované; 5. čl. trochu kratší, taktéž z úzkẻ base ke konci se rozširující, na konci však nezúžený, též kroužkovaný; 6. čl. značně kralší než třetí. Barva tỵkadla žlutavá, 6. a 7. čl. šedohnědé, onen na basi trochu svètlejší. Pterothorax značně širší a delší než prothorax. Nohy jsou sitkované. Přední femora slabě hnědožlutavá, uprostřed poněkud šedě zkalená. Střední a zadní černohnědá, na basi a na konci slabě hnědožlutavá. všecky tibie a tarsy světle hnědožlutavé. Hoř. křídla jsou bílá a mají dvě tmavé přičné stuhy. Prvá jest silnèjší a nalézá se za vidlicí, t. j. na konci prvé třetiny křridla. Druhá, šikmá, dosti neurěitá, jest na konci druhé třeliny jeho. Mezi druhou stuhou a koncem křídla znamenáme ješlě na předním kraji slabou skvrnu. Žilky jsou na oněch částech, kde leží ve stuhách neb ve skvrnè, černošedé. Pod onou skvrnou na hořejším okraji křídla, trochu stranou, bývá žilka podélná i okružní na malém místě dosti Imavá. Délka těla $1 \mathrm{~mm}$.

Var. (nov.) concolor. Barva celého těla, i abdomenu, slaběji neb silněji hnědožlutavá, hlava a thorax po stranách taktéž s tmavou čaṛou.

$$
\sigma^{x} .
$$

Dle Heegra (L. ̌̌. 66.) žlutolınědý.

Tr̉ásněnka tato byla do našich skleníků rosllinami z cizích zemí zavlečena. Žije zde na spodní stranè listů nejrůznějšich rosllin a škodí někdy značně. Var. concolor nalezena mezi formou typickou v několika exemplárích.

Čechy: Praha (prof. Řezník). Hradec Králové. Jind. Hradec (Duda).

$$
\text { †. }
$$

Kopf und Thorax braungelblich mit einer dunklen Seitenlinie, manchmal grau getrübt. Abdomen dunkel- bis schwarzbraun, die letzten drei Segmente gelbbraun. Ocellen einander sehr genähert. Das 1. Fühlerglied sitzt in einem seichten Napfe und ist kürzer und schmäler als das 2., dieses ist napfförmig, nicht viel länger als breit, das 3. u. 4. Glied sehr schmal, auf dem Grunde dünn, gegen das Ende allmählich keulenförmig erweitert, im letzten Viertel wieder verengt, untereinander fast gleich lang, geringelt; das 5. Glied etwas kürzer, ebenfalls auf dem Grunde dünn und gegen das Ende zu erweitert, jedoch auf dern Ende selbst nicht wieder so verengt, auch geringelt; das 6. Glied bedeutend kürzer als das 
dritle. Fühlerfärbung gelhlich, das 6. u. 7. Glied graubraun, jenes am Gr unde etwas lichter. Pterothorax bedeutend breiler und länger als der Prothorax. Beine mit netzförmiger Structur. Vorderschenkel schwach braungelblich, in der Mitte etwas grau getrübt. Mittelund Hinterschenkel schwarzbraun, am Grunde und am Ende schwach braungelblich, alle Tibien und Tarsen ebenfalls licht braungelblich. Die Oberflügel sind weiss und haben zwei dunkle Querbinden. Die erste ist stärker und befindet sich hinter der Gabel, d. i. am Ende des ersten Drittels der Flügellänge. Die zweite Querbinde ist schief, ziemlich undeutlich und liegt am Ende ihres zweiten Drittels. Zwischen der zweiten Binde und dem Flügelende nehmen wir am Vorderrande noch einen schwachen Fleck wahr, und schief unter ihm eine Trübung der Längs- und Ringader. Körperlänge $1 \mathrm{~mm}$.

Var. (nov.) concolor. Farbe des ganzen Körpers lichter oder dunkler braungelblich (die letzten Abdominalsegmente ebenso gefärbt), Kopf und Thorax an den Seiten ebenfalls mit einem schwarzen Strich.

Nach Heeger gelbbraun.

Vorkommen: In unseren Glashäusern auf der Blattunterseite vieler Pflanzen, aus fremden Ländern verschleppt. Schaden manchmal bedeutend. - Fundorte: Wien (Heeger, v. Frauenfeld), Finnland (Reuter), St. Petersburg (Regel), Deutschland (Jordan, Bohls), Nordamerika (bei Washington Pergande), Böhmen.

\section{GENUS THRIPS (L.).*)}

Očka prítomna. Tykadla sedmičlenná (stylus jednočlenny̧). Makadla maxillarní o třech článcích. Prothorax pravidlem o něco delší hlavy; na zadních jeho rozích po dvou dlouhỵch smyslových chlupech. Přední nohy jsou pravidlem bezbranné; jen u druhu calcarata opatřeny jsou přední tarsy dlouhỵm, tenkým, ohnutým zubem. Kř́ídla obyčejnè prítomna, jen někdy scházejí; jsou dosti široká, a žilka okružní na předním kraji křídla jest opatřena dlouhỵmi třásněmi a kratšími tuhỵmi brvami. Druhy sem náležejíci jsou k skákání způsobilé.

Angen vorhanden. Fühler siebengliedrig (Stylus eingliedrig). Maxillartaster dreigliedrig. Prothorax regelmässig etwas länger als der Kopf; auf seinen Hinterecken je zwei lange Borsten. Vorderbeine regelmässig wehrlos; nur bei der Art calcarata sind die Vordertarsen mit einem langen, dünnen, gebogenen Zahn bewaffnet. Flügel gewöhnlich vorhanden; sie sind ziemlich breit und ihr Vorderrand ist mit langen Fransen besetzt, zwischen denen sich kürzere steife Borsten befinden. Die her gehörenden Arten haben ein Springvermögen.

*) Opị, červ ve drevě žijicí, Holzwurm (bei Theophrast). 
H. UZEL, MONOGRAPHIE DER ORDNUNG THYSANOPTERA.

\section{Thrips physopus L.*)}

Tab. VI., fig. 94.-99.; Tab. X., fig. 172.

1746. Thrips elytris glaucis, corpore atro; Linné, Fauna Svecica. Editio I., pag. 220. 1761. Thrips physapus Linné, Fauna Svecica, pag. 266.

1764. Thrips elytris glaucis, corpore atro; Geoffroy, Histoire abrégée d. Ins., pag. 385. 1767. Thrips physapus Linné, Systema Naturae, pag. 743.

1776. Thrips fusca, nigricans, elylvis glaucis; Müller, Zoologiae danicae Prodromus, pag. 96 .

1780. Thrips physapus Schäffer, Elementa entomologica, pag. 127.

1781. - - Schrank, Enumeratio Ins. Austriae indig., pag. 296. et 298.

1781. - - Fabricius, Species Insectorum, pag. 396.

1787. - - Fabricius, Mantissa Insectorum, pag. 320.

1788. - - Gmelin, Caroli a Linné Systema Nat., pag. 2222.

1789. - - Berkenhout, Synopsis of Nat. Hist. of Gr. Britain and Ireland, pag. 122.

$\begin{array}{llll}\text { 1789. } & - & - & \text { de Villers, Car. Linnaei Entomologia. } \\ 1794 . & - & - & \text { Fabricius, Entomologia Systematica, pag. } 228 . \\ 1802 . & - & - & \text { Stew, Elements of Nat. Hist., pag. 114. } \\ 1803 . & - & - & \text { Fabricius, Systema Rhyngotorum, pag. } 313 . \\ 1806 . & - & - & \text { Turton, A General System of Nature, pag. } 716 . \\ 1806 . & - & - & \text { Shaw, General Zoology, pag. 199.; tab. 63. } \\ 1821 . & - & - & \text { Wood, Illustr. of the Linn. Genera of Ins., pag. 118.; tab. } 42 . \\ 1836 . & - & - & \text { Haliday, Entomological Magazine, pag. 448. } \\ 1836 . & - & - & \text { Burmeister, Handb. d. Entomologie, II, pag. 415. } \\ 1843 . & - & - & \text { Amyot et Serville, Ins. Hémiptères, pag. 644. } \\ \text { ?1852. } & - & - & \text { Haliday, Walker: Homopt. ins. of Brit. Museum, pag 1111.; }\end{array}$ tab. V1., fig. 7.-11.**)

1878-79. - - Reuter, Diagn. öfv. nya Thysanopt. f. Finland, pag. 6.***) f.

Barva těla černohnědá, pterothorax však často tmavě žlutohnědý. Hlava širší ně̌ delší, nazad patrně zúžená. První čl. tykadel značně kratší než druhỹ; 3. a 4. čl. mezi sebou skoro stejně dlouhé, 5. značně kratší. Barva tykadel: 1. a 2. čl. šedohnědé, 3.

*) Doklad ve sbirce musejni, pritep. ¿̌. 43. - Sammlung des böhmischen Landesmuseums. Praep. Nr. 43.

**) Výkresy vztahuji se najisto na druh $T$. physopus. - Die Zeichnungen beziehen sich sicher auf die Art T. physopus.

***) Poukázali jsme jen na popisy stars̀i a na dủležitèjsi. - Von den überaus zahlreichen Beschreibungen dieser Art wurden nur die älteren und die wichtigeren berücksichtigt. 
4. a 5. čl. žlutavé, 5. obyčejně na samém konci trochu zkalený, 6. do polou žlutavý, od polou černohnědý, 7. černohnědý. Výjimkou jest 4. a zvl. 5. čl. ke konci tmavý a 6. čl. jen na basi světlý. Prothorax nepatrně delši hlavy; na jeho zadním okraji nalézají se kromẽ dlouhých chlupủ smỵslových ještẽ na každé straně čtyríi malé chloupky. Nohy černohnẽdé, všecky tarsy a přední tibie běložlutavé, tyto z počátku po obou stranách, zvl. vně, trochu hnědě zkalené. Hlavní žilka $v$ hořejším kř́idle ke konci se třemi chlupy stejně od sebe vzdálenými anebo s prvním trochu oddálenỵm. Vedlejší s četnými chlupy. Hořejši křídla silně šedě neb šedohnědě zkalená, na basi světlejšś a před samou vidlicí s velikým čirým místem. Dolejší křídla jsou dosti čirá. Délka těla $1.2 \mathrm{~mm}$.

Var. (nov.) adusta. Hlava a thorax jsou žlutohnědé, více nebo méně šedě zkalené. Abdomen světle šedožlutý, na konci černý.

\section{$\sigma^{\nearrow}$ (dosud nepopsaný).}

Značně menši než $q$. Barva tèla bud černohnědá aneb běložlutavá, pǐ̀i čemž jest thorax žlutý. U tmavých samců jsou tykadla a nohy podobnẽ zbarveny jako u samic; u svẻtlých jsou první tr̃i články tykadel celé žlutavé, 4. a 5. taktéž žlutavé, na samém konci však tmavé, 6. do polou žlutavý, od polou tmavošedý, 7. tmavošedý, nohy celé žlutavé. Kr̂́idla prítomna. U tmavỵch nalézá se na spodni straně 3.—7. čl. abdom. po jedné bílé podélné prohlubině. U svẽtlých jsou tỵto prohlubiny ještě delší a uprostřed trochu staženy; na světlé půdě však nejsou tak zřetelnými.

Třás̉něnka tato žije od jara do podzimu $\mathrm{v}$ nejrùznějších květech a jest po druhu Physopus vulgatissima nejhojnējší. Vyskytuje se někdy v úžasném množství. Tak nalezl jsem květy od Tragopogon pratensis v háji mezi Krěí a Kundraticemi jimi téměr̆ naplněné. Kromě květů lučních a lesních obývá také kvẽty zahradní, avšak nikdy ve větším počtu. Pokud se jiných pěstovaných rostlin týče, vyskytuje se, ač ne hojně, v květech jabloní, lnu a brambor. Na obilí je řídká; nalezl jsem jen několik exemplár̉ủ v klasech pšeničných. Přezimuje pod spadaným listím, $v$ seschlých květenstvích a v drnu. Samce nalezl jsem od počátku dubna aż do polovice listopadu, a sice světlé i tmavé v stejném asi množství. Var. adusta nalézá se dosti zhusta mezi formou typickou.

Vyskytuje se po celé naší vlasti a stoupá až na vrchol Sněžky, kdež dosti hojně žije $\mathrm{v}$ sporých květech. Kromě toho zvláště hojně nalezl jsem ji $\mathrm{v}$ květech $\mathrm{v}$ Nalém Sněžném breznu, okolo Boudy prince Jindřicha, na stráních nad Malỵ́m stavem a kolem Obři boudy. - Z Pešti mi byla s květinami zaslána.

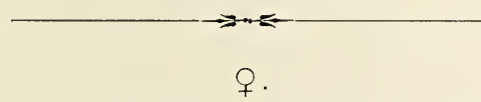

Körperfarbe schwarzbraun, Pterothorax jedoch oft dunkel gelbbraun. Kopf mehr breit als lang, nach hinten deutlich verengt. Erstes Fühlerglied bedeutend kürzer als das zweite; das 3. u. 4. untereinander fast gleich lang, das 5. bedeutend kürzer. Fühler- 
färbung: 1. u. 2. Glied graubraun, 3., 4. 1. 5. Glied gelblich, das 5. gewöhnlich am äussersten Ende etwas getrübt, das 6. bis zur Mitte gelblich, von der Mitte an schwarzbraun, das 7. schwarzbraun. Ausnahmsweise ist das 4. und hauptsächlich das 5. Glied gegen das Ende dunkel und das 6. nur am Grunde licht. Prothorax unbedeutend länger als der Kopf; auf seinem Hinterrande befinden sich ausser den langen Sinnesborsten noch jederseits vier kleine Härchen. Beine schwarzbraun, alle Tarsen und die Vordertibien weissgelblich, diese anfangs jederseits, hauptsächlich aussen, etwas braun getrübt. Die Hauptader im Oberflügel gegen das Ende zu mit drei Borsten, die von einander etwa gleich entfernt sind, oder die erste etwas weiter von den übrigen abstehend. Die Nebenader mit zahlreichen Borsten besetzt. Oberflügel stark grau oder graubraun getrübt, am Grunde lichter. Unterflügel ziemlich hell. Körperlänge $1 \cdot 2 \mathrm{~mm}$.

Var. (nov.) adusta. Koopf und Thorax gelbbraun, mehr oder weniger grau getrübt. Abdomen licht graugelb, am Ende schwarz.

$$
\sigma^{\nearrow} \text { (noch unbeschrieben). }
$$

Bedeutend kleiner als das $\mathcal{f}$. Körperfarbe entweder schwarzbraun oder weissgelblich, wobei der Thorax gelb ist. Bei den dunklen Männchen sind die Fühler und die Beine ähnlich wie bei den Weibchen gefärbt; bei den lichten Männchen sind die ersten drei Fühlerglieder gelblich, dis 4. und 5. ebenfalls gelblich, am äussersten Ende jedoch dunkel, das 6. bis zur Mitte gelblich, von der Mitte an dunkelgrau, das 7. dunkelgrau, die Beine gelblich. Flügel vorhanden. Auf der Unterseite des 3.-7. Abdominalsegmentes befindet sich je eine weisse längliche Vertiefung. Bei den lichten Männchen sind diese Vertiefungen etwas länger als bei den dunklen, jedoch viel weniger deutlich.

Vorkom in en: Die ganze warme Jahreszeit hindurch in allerlei Blüten in beiden Geschlechtern. Die dunklen Männchen ebenso häufig wie die lichten. Die Weibchen überwintern unter abgefallenem Laub, in trockenen Blütenständen und im Rasen. - - Fundorte: (alle Localitäten anzuführen, wo diese Art angeblich gefunden wurde, ist unrathsam, da sehr oft die verchiedensten Arten unter dem Namen Thrips plyysapus angefïhrt werden): England (Haliday), Finnland (Reuter), Deutschland (Bohls), Böhmen, Pest.

\section{Thrips communis nov. sp.*)}

Tab. VI., fig. 100 .

$$
\text { q. }
$$

Barva tèla bledẽ žlutá, žlutošedá neb žlutozelená až svètle šedohnědá, zirídka bilí neb bělošedá. Hrud jest pravidlem silnèji žlutě zbarvena. Chlupy nả tèle jsou tmavé.

*) Doklad ve sbirce musejni, praep. ¿̇. 44. a 45. - Sammlung des böhmischen Landesinuseums, Praep. Nr. 44 и. 45. 
Hlava trochu širši než deiší, se stranami vypouklými, nazad nezúžená. První čl. tykadel kratší než druhý, tento článek, pak 3. a 4. mezi sebou skoro stejně dlouhé, 5. čl. jen trochu kratší neż 4., 7. ěl. krátký, na basi široký, často tupý. Tykadla jsou u bledỵch exemplár̊ủ následovně zbarvena: 1. ěl. ěirý; ostatní kalně žlutavé; 3. (ne vždy), 4. a 5. ke konci, 6. a 7. celé šedě zkalené. Čím tmavší se stává tělo. tím jsou také tmavši tykadla, při ċem̌̆ se i první čl. trochu zakaluje, ač zn̉stává stále prủsvitným; druhý pak a 6. i 7. jsou nejtemnèjšími. Na zadním okraji prothoraxu nalézáme kromě dlouhých chlupủ smyslových na každé straně (podobně jako u následujicích osmi druhủ) ještě tři malé chloupky. Barva noh jest při exemplárích nejsvěllejších bělavá, bez místních zkalenin. Cím tmavši se však barva těla stává, tím tmavšími též jsou nohy, a tím ziretelněji lze na nich pozorovati místní zkaleniny, které jsou následujici: přední femora jsou v zadu uprostred zkalená; střední a zadní jsou zkalená celá, kromě špičky, přední tibie pak po obou stranách, střední a zadní v první polovině, kromě base. Hlavní žilka má v druhé své polovině pravidlem čtyři chlupy, z nichž první dva a poslední dva jsou sblíženy. U bledých exempláỉ̛u jsou hor̉ejší křídla velmi slabě žlutavě zkalená; u tmavších prìistupuje slabé šedé zkalení, $\mathrm{k}$ němuž ještě slabý neb silnější hnědý nádech se přidává. U kořene jsou hořejší křídla vždy značně světlejší, ne však čirá. Délka těla $08 \mathrm{~mm}$.

Var. annulicornis. Zkalení 3.-5. čl. tykadla na konci jest velmi silné a náhlé, takže tykadlo uprostřed zdá se býti kroužkovaným.

Var. pulla. Abdomen stává se u této variety tmavším a tmavšim, až úplně zčerná; po něm ztmaví poznenáhla hlava a posléze prothorax, ano tyto části nabývají barvy tmavohnědé až černohnědé. Pterothorax při tom pravidlem jest žlutohnèdý. Mistní zkaleniny noh, jak u formy typické jsou udány, vystupuji zde velmi patrně; někdy však, a to u nejtmavšich exemplářu, ztmavějí celé nohy. První čl. tykadel jest nejsvětlejší, šedý, nepatrně prủsvitný, ostatní černošedé, jen třetí kromě konce a ětvrtý na basi žlutavé. Hořejší kiridla jsou kromě světlejši base hnědošedá neb šedohnědá. Sedmý článek tykadla jest delší, ostřejší a na basi užši než u formy typické, čímž bliží se druhu následujicímu. Hlavní žilka má v druhé své polovici obyčejně tři chlupy.

Hlava a abdomen žlutobílé, thorax žlutý. První dva články tykadel bílé, 3., 4. a 5. světlé, na konci šedě (3. velmi slabè) zkalené, 6. čl. jest šedý, na basi aneb do polou bílý, 7. jest celý šedý. Křídla prítomna.

Třásněnka talo žije od března do listopadu v nejrủznějšich květech, obyčejně jednotlivě. Některé kvěly však obzvláště miluje, a tam nalézáme ji v množství někdy preevelikém. Jsou to predevšim květy lilkovitých (Solanum tuberosum, dulcamaia, nigrum, Lycium barbarum, Hyoscyamus niger) a květy většiny okoličnatých, pak Erythraea centaurium, Eupatorium camuabinum, Valeviana officinalis a kvètenství cukrovky 
i lebedy. Složnokvěté za to navštivuje zríldka. Mimo to vyskytuje se v květenství rủzných trav; I malém počtu též v klasech obilných a na listech různých rostlin nízkỵch (zvi. na bramborové nati) i stromů. - Kromè na uvedeny̧ch rostlinách pěstovaných žije ještě $\checkmark$ krĕtech od Papaver somniferum, Onobrychis sativa, Limum usitatissimum, Vicia satiea, na květinách zahradních, na mladých výnoncích pěstovaného chınelu a na karfiolu. - Samci objevuji se od dubna do ríjna, v tomto měsíci však i v predcházejícím pořídku. Samice pr̀ezimují v seschlỵch květenstvích, pod spadaným listím a v drnu. Nalézá se všude po Čechách. Také po celých Krkonoších, i na nejryšších temenech. Z Pešti a Rěliy poslána mi byla v květech. Na Helgolandě vyskytuje se četně. - Var. ammulicornis jest hojná na krkonoších. Var. pulla vyskytuje se všude po Čechách mezi formou typickou a také po celých Krkonoších. Na nejvyššich vrcholcích však jest značně ridší.

\section{q.}

Körperfarbe blassgelb, gelbgrau oder gelbgrün bis licht graubraun, selten weiss oder weissgrau. Thorax regelmässig stärker gelb gefärbt. Die Borsten am Körper sind dunkel. Kopf etwas mehr breit als lang, mit gewölbten Wangen, nach hinten nicht verengt. Erstes Fühlerglied kürzer als das 2., dieses, ditnn das 3. u. 4. untereinander fast gleich

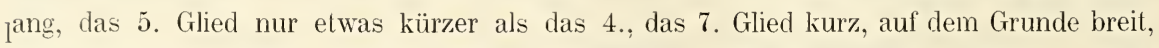
oft stumpf. Die Fühler sind bei lichten Exemplaren folgendermassen gefärbt: 1. Glied hell, die übrigen trüb gelblich, das 3. (nicht immer), das 4. u. 5. gegen das Ende, das 6. u. 7. ganz grau getrübt. Je dunkler der Körper wird, desto dunkler werden auch die Fühler, wobei sich auch das erste Glied etwas trübt, obwohl es immer durchscheinend bleibt; das 2., 6. u. 7. Glied sind dann am dunkelsten. Am Hinterrande des Prothorax befinden sich ausser den langen Borsten noch jederseits (ebenso wie bei den folgenden acht Arten) drei kleine Härchen. Die Farbe der Beine ist bei den lichtesten Exemplaren weisslich, ohne locale Trübungen. Je dunkler jedoch die Körperfärbung wird, desto dunkler werden auch die Beine, und desto deutlicher treten die localen Trübungen hervor. Es sind dann die Vorderschenkel hinten in der Mitte dunkel, die Mittel- und Hinterschenkel bis auf die lichte Spitze stark getrübt, die Vordertibien jederseits, die Mittel- und Hintertibien in ihrer ersten Hälfte mit Ausnahme der Basis dunkel. Die Hauptader im Oberflügel ist in ihrer zweiten Hälfte regelmässig mit vier Borsten versehen, von denen die ersten zwei und die letzten zwei einander genähert sind. Bei lichten Exemplaren sind die Oberflügel sehr schwach gelblich getrübt; bei den dunkleren tritt eine schwache graue Trübung hinzu, der sich noch ein schwächerer oder slärkerer brauner Ton zugesellt. Am Grunde sind die Oberflügel immer viel lichter, jedoch nicht hell. Körperlänge $0.8 \mathrm{~mm}$.

Var. annulicornis. Die Trübung des 3.-5. Fühlergliedes am Ende ist sehr stark und plötzlich, so dass der Fühler in der Mitte geringelt erscheint. 


\section{J. UZEL, MONOGRAFIE RADU, "THYSANOPTERA“.}

Var. pulla. Das Abdomen trübt sich bei dieser Varietät immer mehr und mehr, bis es vollkommen schwarz wird; nachher werden auch der Kopf und endlich der Prothorax immer mehr dunkel bis dunkelbraun und schwarzbraun. Der Pterothorax ist dabei regelmässig gelbbraun. Die localen Trübungen der Beine treten hier, so wie sie bei der Stammform angegeben wurden, sehr deutlich hervor; zuweilen werden jedoch, bei sehr dunklen Exemplaren, die ganzen Beine ebenfalls dunkel. Erstes Fühlerglied am lichtesten, grau, wenig durchscheinend, die übrigen schwarzgrau, nur das dritte ausser dem Ende und das vierte am Grunde gelblich. Die Oberflügel sind ausser dem lichteren Grunde braungrau oder graubraun. Das 7. Fühlerglied ist länger, schärfer und am Grunde schmäler als bei der Stammform, wodurch diese Varietät sich der folgenden Art nähert. Die Hauptader hat in ihrer zweiten Hälfte gewöhnlich drei Borsten.

$$
\text { o. }
$$

Kopf und Abdomen gelbweiss, Thorax gelb. Die ersten zwei Fühlerglieder weiss, das 3. auf dem Ende sehr schwach, das 4. u. 5. stärker grau getrübt, das 6 . ist grau, auf dem Grunde oder bis zur Mitte weiss, das 7. ganz grau. Flügel vorhanden.

Vorkommen: Die Weibchen von März bis November in den verschiedensten Blüten, hauptsächlich jedoch in jenen der Solanaceen und der Umbelliferen. Die Männchen von April bis August häufig, im September und October selten. Die Weibchen überwintern in trockenen Blütenständen, unter abgefallenem Laube und im Rasen. - Fundorte: Böhmen, Helgoland (Uzel), Fiume, Pest.

\section{Thrips major nov. sp.*)}

$$
\text { q. }
$$

Podobá se druhu předcházejícímu, a to zvl. tmavé jeho varietě. Postava její jest však značně mohutnější, zbarvení těla vždy velmi tmavé, zbarvení noh a křídel světlejší, tykadla štíhlejší, 7. čl. jejich ještě delší a tenčí; hlavní žilka pak má v druhé své polovině vždy jen tři chlupy. - Barva těla černohnědá. Hlava trochu širší než delší se stranami vypouklými, nazad nezúžená. Pátý ěl. tykadel jen o něco málo kratší než 4.; dva prvé články tykadel tmavé, 3. světlý, 4. ke konci zkalený, 5. kromě base tmavý, 6. a 7 taktéž tmavé. Nohy jsou dosti světlé; femora žlutavá, vně uprostřed zkalená, zadní tmavá, na obou koncích světlejší; predni tibie obỵčejně celé světlé, střední a zvl. zadní vně uprostřed zkalené. Jindy jsou všecka femora tmavá, na obou koncích světlejší. Tarsy jsou světlé. Kř́dla světlá, na basi skoro čirá. Délka těla $1 \mathrm{~mm}$.

*) major, vztahem $\mathrm{k}$ druhu předcházejícimu. - major, in Bezug auf die vorhergehende Art. - Doklad ve sbírce musejni, praep. ¿̇. 46. - Sammlung des böhmischen Landesmuseums, Praep. Nr. 46. 
Var. adusta. Hlava, prothorax a abdomen jsou žlutavé, slabě šedẽ zkalené; abdomen má poslední dva články tmavošedé; pterothorax jest slabě žlutavohnědě zbarvený. Tỵkadla jsou žlutavá, dva první články, 4. čl. ke konci, pak 5., 6. čl. a stylus šedě zkalené.

Var. gracilicornis. Tykadla jsou útlejší a tenčí než u formỵ typické. Nohy velmi svěllé. Hoř. kî́ídla jsou dosti temně zkalená, na basi však značně světlejší.

$$
\text { ð. }
$$

Malý, bledý a velmi podobný samci druhu communis, dobře však od něho liši se znaky u samice udanými. Kř́dla taktéž prítomna.

Třảsněnka tato žije hojněji jen $\mathrm{v}$ krajinách výše položených, a sice od května do záríí v různých květech, zvl. od Sambucus nigra, Senecio nemorensis, Eupatorium cannabinum a na listech od Solanum dulcamara, jež značnè poškozuje. Samci objevuji se od června do záríi. Samice prezimuji $\mathrm{v}$ suchých květenstvích a pod korou stromovou.

Čechy: Hradec Králové. Třebechovice. Opočno. Trutnov. Vrajt. Maršov. V Krkonoších hojně; tak zvl, na vrcholu Sněžky, v Malém Sněžném březnu, na stráních nad Malým stavem a pod Labským slapem. Liberec. Častolovice. Solnice: u Skuhrova. Milešovka. Prachatice: U Kubern. Prales boubínský (velmi hojně v květech od Senecio nemorensis). Var adusta nalezena (1 ex.) na Sněžce v záŕí; var. gracilicornis (6 ex.) u Turnova (Bubák) a u Peruce.

$$
\text { P. }
$$

Der vorigen Art, hauptsächlich ihrer dunklen Varietät, ähnlich. Ihre Gestalt ist jedoch bedeutend mächtiger, die Körperfarbe immer sehr dunkel, die Färbung der Beine und der Flügel lichter, die Fühler schlanker, ihr 7. Glied noch länger und dünner; die Hauptader im Oberflügel hat in ihrer zweiten Hälfte immer nur drei Borsten. - Körperfarbe schwarzbraun. Kopf etwas mehr breit als lang, seine Wangen gewölbt; nach hinten ist er nicht verschmälert. Das 5. Fühlerglied nur wenig kürzer als das 4.; die ersten zwei Glieder dunkel, das 3. u. 4. licht, letzteres gegen das Ende zu getrübt, das 5. aușser dem Grunde dunkel, das 6. u. 7. dunkel. Beine ziemlich licht; Schenkel gelblich, aussen in der Mitte getrübt, die hinteren dunkel, an beiden Enden lichter; Vordertibien gewöhnlich licht, die Mittel- und hauptsächlich die Hintertibien aussen in der Mitte getrübt. Zuweilen sind alle Schenkel dunkel und an beiden Enden lichter. Die Tarsen sind hell. Flügel licht, auf dem Grunde fast klar. Körperlänge $1 \mathrm{~mm}$.

Var. adusta. Kopf, Prothorax und Abdomen gelblich, schwach grau getrübt; die zwei letzten Abdominalsegmente dunkelgrau; Pterothorax schwach gelblichbraun. Fühler gelblich, die zwei ersten Glieder, das 4. gegen das Ende, dann das 5., 6. und der Stylus grau getrübt. 


\section{J. UZEL, MONOGRAFIE RADU, „THYSANOPTERA“.}

Var. gracilicornis. Fühler dünner als bei der Stammform. Beine sehr licht. Oberflügel ziemlich dunkel getrübt, auf dem Grunde bedeutend heller.

$$
\text { đa. }
$$

Klein, blass und sehr ähnlich dem Nännchen der Art communis, jedoch leicht nach den beim Weibchen angegebenen Kennzeichen zu unterscheiden.

Vorkommen: In verschiedenen Blüten und auf der Unterseite der Blätter von Solamum dulcamara. Weibchen von Mai bis September, Männchen von Juni an. Die Weibchen überwintern in trockenen Blütenständen und unter Baumrinde. - Fundort: Böhmen.

\section{Thrips sambuci Heeg. $\left.{ }^{*}\right)$}

1854. Thrips Sambuci Heeger, Sitzungsb. d. Akad. d. Wiss., Wien, pag. 369. (V separatním otisku str. 7.; tab. II. - Separatabdruck: S. 7 , Taf. II.)

$$
\text { ๆ. }
$$

Podobá se druhu předcházejicímu, od něhož ji lze ihned rozeznati dle světlého 5. čl. tykadla a dle stehen tmavých. - Barva těla žlutohnědá. Hlava jest trochu širší než delší, se stranami vypouklými, nazad nezúžená. Pátý čl. tykadel tak dlouhý jako čtvrtý. Dva první čl. jsou tmavé, 3., 4. a 5. žluté, tento ke konci velmi slabě zkalený, 6 . a 7. trnavé. Femora jsou celá tmavá, přední a strední tibie bělavé. na basi tmavé, zadní tibie tmavé, ke konci bèlavé, všeckỵ tarsy bèlavé. Hlavní žilka v hoř. křídle má ke konci obyčejně 2 chlupy, někdy tři. Hořejši křídla jsou temnēji zkalená než u druhu předcházejícího, basis jejich jest čirá. Chlupy na konci abdomenu jsou slabší. Délka těla $1 \mathrm{~mm}$.

$$
\text { ơ. }
$$

Velmi světlý. Pruní ěl. tykadel čirý, 2. bilý, 3.-5. Žlutavé, 6. šedý, na basi světlejší. Hlavni žilka na konci pravidelně se třemi chlupy. - Podobá se značnẻ samcủm druhu communis, rozeznává se však od nich třetím až pátým článkem tykadelním nezkalenỵm, sedmỵm ostrým i tenkým a třemi chlupy (ne čtyřmi) na konci hlavní žilky.

Třásněnka tato žije od počátku dubna až do září na listech od Sambucus nigra; jednou nalezl jsem ji též na Samb. racemosa. Dle Jordana vyskytuje se také na listech lípových a jasanových. Samce sbíral jsem v záríi. Samice přezimují pod spadaným listím a ve skulinách kủry.

*) Doklad ve sbirce musejní, praep. č. 47. - Sammlung des böhmischen Landesmuseums, Praep. Nro 47. 


\section{H. UZEL, MONOGRAPHIE DER ORDNUNG THYSANOPTERA.}

Čechy: Praha: Zahrada v bývalém Museu na Pr̉ikopech (Prof. Dr. Frič), na Štvanici. Hradec Králové: V hradbách pevnostních.

f.

Der vorhergehenden Art ähnlich, von der sie jedoch sogleich nach dem hellen 5. Fühlerglied und nach den dunklen Schenkeln zu unterscheiden ist. - Körperfarbe gelbbraun. Kopf etwas mehr breit als lang, nach hinten nicht verengt; seine Wangen sind gewölbt. Fünftes Fühlerglied so lang wie das vierte. Die zwei ersten Fühlerglieder sind dunkel, das 3., 4. u. 5. gelb, dieses gegen das Ende zu sehr schwach getrübt, das 6. u. 7. dunkel. Alle Schenkel dunkel, die Vorder- und Mitteltibien weisslich, am Grunde dunkel, die Hintertibien dunkel, gegen das Ende zu weisslich, alle Tarsen weisslich. Die Hauptader gegen das Ende gewöhnlich mit zwei, zuweilen mit drei Borsten. Die Oberflügel mehr als bei der vorhergehenden Art getrübt, am Grunde klar. Die Borsten am Abdomenende schwächer. Körperlänge $1 \mathrm{~mm}$.

$$
\sigma^{2} .
$$

Sehr licht. Erstes Fühlerglied klar, das 2. weiss, das 3.-5. gelblich, das 6. grau, am Grunde lichter. Die Hauptader am Ende regelmässig mit drei Borsten. - Ähnelt stark den Männchen der Art communis, unterscheidet sich jedoch von ihnen durch das ganz helle dritte bis fünfte Fühlerglied, durch das scharfe und dünne 7. Glied und durch drei (nicht vier) Borsten am Ende der Hauptader.

Vorkommen: Die Weibchen von Anfang April bis September hauptsächlich an den Blättern von Sambucus nigra. Die Männchen im September. Die Weibchen überwintern unter abgefallenem Laube und unter Baumrinde. - Fundorte: Wien (Heeger), Deutschland (Jordan), Böhmen, Helgoland (Uzel).

\section{Thrips salicaria nov. sp.*)}<smiles>[CH]1[CH]C1</smiles>

Podobá se poněkud druhu predcházejícimu, lze ji však ihned rozeznati dle zbarveni těla odchylného a dle tmavého 5. čl. tykadla. - Barva těla černohnědá. Hlava trochu širší ně̌ delší, se stranami vypouklými, nazad nezúžená. Vrásky na týle jsou rovnoběžné a nevbíhají tak často do sebe jako u druhu sambuci. Pátý článek tykadel jen o něco málo kratší než čtvrtý, v předu ulatý. Barva tykadel: první dva články černé, 3. žlutý, 4. ̌̌lutý, velmi slabě zkalený, 5. černý, na samé basi světlý, 6. a 7. černé. Nohy poněkud zavalitējší a mnohem určitěji zbarvené než u druhu předcházejícího. Všechna femora černohnědá, přední tibie ̌̌luté, po obou stranách velmi slabě šedohnědě zkalené, střední

*) Doklad ve sbirce musejní, praep. ě. 48. - Sammlung des böhmischen Landesmuseums, Praep. Nr. 48 
a zadní tibie černohnědé, na konci žluté, všecky tarsy žluté. Hlavní žilka ke konci vždy se třemi chlupy. Hoř. kǐídlo tmavě zkaleno, zvl. hned za koncem prvé třetiny a ke konci. Basis jeho skoro úplně čirá. Chlupy na konci abdomenu jsou mohutnější a tmarší než u druhu sambuci. Délka tèla $1 \cdot 1 \mathrm{~mm}$.

$$
\sigma^{\star} \text {. Nebyl posud objeren. }
$$

Třásnènku tuto nalezl jsem v zimních mèsících hlavnè pod korou vrb, zirídka též pod korou břiz, moruší a švestek; v dubnu pak zastihl jsem jediný exemplár̆ na mladých rýhoncích divokého chmelu.

Čechy: Hradec Králové: Na několika mistech r okolí.

$$
\text { f. }
$$

Ähnelt etwas der vorhergehenden Art; man unterscheidet sie jedoch von ihr nach der abweichenden Körperfarbe und nach dem dunklen 5. Fühlergliede (von $T$. major nach der abweichenden Beine- u. Flügelfarbe). - Körperfarbe schwarzbraun. Kopf etwas mehr breit als lang, seine Wangen gewölbt; nach hinten ist er nicht verengt. Die Runzeln auf dem Hinterhaupte sind parallel und verbinden sich nicht so oft miteinander wie bei der Art sambuci. Das 5. Fühlerglied nur um wenig kürzer als das vierte, vorn abgestutzt. Fühlerfärbung: die ersten zwei Glieder schwarz, das 3. gelb, das 4. ebenfalls gelb, sehr schwach getrübt. das 5. schwarz, an der Wurzel hell, das 6. u. 7. schwar\%. Beine etwas gedrungener und viel bestimmter gefärbt als bei der vorhergehenden Art. Alle Schenkel schwarzbraun, die Vordertibien gelb, aussen und innen sehr schwach graubraun getrübt, die Mitlel- und Hintertibien schwarzbraun, am Ende gelb, alle 'Sarsen gelb. Die Hauptader gegen das Ende immer mit drei Borsten besetzt. Oberflügel dunkel getrübt, hauptsächlich im Anfang des zweiten Drittels seiner Länge und gegen das Ende zu. Auf dem Grunde fast vollkommen klar. Die Borsten am Abdomenende sind slärker und dunkler als bei der Art sambuci. Körperlänge $1.1 \mathrm{~mm}$.

$$
\text { đั unbekannt. }
$$

Vorkommen: Im Winter hauptsächlich unter Weidenrinde. Im April fand ich ein Exemplar auf jungen Trieben des wilden Hopfens. - Fundort: Böhmen.

\section{Thrips valida nov. sp.*)}<smiles>[CH-]</smiles>

Jest podobná obèma druhum předcházejícím, od nichž se však na první pohled rozeznává pátým článkem tỵkadla, jenž jest malinký, značnē kratší než ětvrtý, a tělem

*) Doklad ve sbirce musejni, praep. č. 49. - Sammlung des böhmischen Landesmuseums, Praep. Nr. 49. 


\section{H. UZEL, MONOGRAPHIE DER ORDNUNG THYSANOPTERA.}

mnohem mohutnějším. - Barva těla černohnèdá, dva poslední články abdom. nejsou tmavší než ostatní tělo. Hlava patrně širší než delší, se stranami vypouklými, nazad nezúžená. Tykadla jsou poněkud zavalitá První článek jejich jest tmavý, druhý světlý, na basi však a po obou stranách úzce zkalený, 3. světlý, 4. taktéž světlý, ke konci zkalený, 5. do polou světlý, od polou zkalený, 6. tmavý, na basi světlejší, 7. tmavý. Všecka femora tmavě zbarvená, přední často na samém konci světlejši. Přední tibie světlé, po obou stranách trochu zkalené, střední a zadní tmavé, ke konci světlejší. Všecky tarsy světlé. Hlavní žilka ke konci se třemi chlupy. Horejší křídla jsou trochu zkalená, a to na počátku druhé třetiny a ke konci značněji. Na basi jsou světlejší. Dolejši kr̂̌idla jsou na konci nepatrně zkalená. Poslední článek abdom. značně zúžený. Délka těla $1 \cdot 2 \mathrm{~mm}$.

$$
c^{7}
$$

Menši a trochu světlejší než q. - Barva těla tmavě žlutohnèdá, dva poslední články abdom. nejsou nápadně tmavšími. Kř̀dla přítomna. Na 3.-7., čl. abdom. dole po jednom malém bilém okrouhlém puntíku. Čtvrtý a 5 . čl. tykadel jsou jen slabẽ zkaleny; 6. čl. skoro do polou světlý.

Tr̉ásněnka tato žije od května do zárí v rủzných květech a časem i v drnu. Samce nalezl jsem $v$ červnu.

Čechy: Praha. Mukařov. Hradec Králové. Tr̉ebechovice. Stará Paka. Vrajt. Jablonec. Liberec. Solnice: U Skuhrova. Pisek (Vareecka). Prales boubínský.

\section{+.}

Ähnlich den beiden vorhergehenden Arten, von denen man sie jedoch sofort nach dem winzigen 5. Fühlerglied, welches viel kürzer ist als das vorhergehende, und nach der mächtigeren Körpergestalt unterscheiden kann. - Körperfarbe schwarzbraun, die zwei letzten Abdominalsegmente nicht dunkler als der übrige Körper. Kopf deutlich mehr breit als lang, nach hinten nicht verengt; seine Wangen sind gewölbt. Fühler etwas gedrungen. Ihr erstes Glied dunkel, das 2. licht, am Grunde jedoch und beiderseits schmal getrübt, das 3. licht, das 4. ebenfalls licht, gegen das Ende zu getrübt, das 5 . bis zur Mitte licht, von der Mitte an getrübt, das 6. dunkel, am Grunde lichter, dạs 7. dunkel. Alle Schenkel dunkel, die vorderen oft am äussersten Ende lichter. Die Vordertibien licht, jederseits etwas getrübt, die Mittel- und Hinterlibien dunkel, gegen das Ende zu lichter. Alle Tarsen licht. Die Hauptader gegen das Ende zu mit drei Borsten. Oberflügel etwas getrübt, und zwar im Anfang des zweiten Drittels und gegen das Ende zu bedeutender. Am Grunde sind sie lichter. Unterflügel am Ende unbedeutend getrübt. Das letzte Abdominalsegment schmal. Körperlänge $1.2 \mathrm{~mm}$. 
ð.

Kleiner und etwas lichter als das $\subsetneq$. - Körperfarbe dunkel gelbbraun, die zwei letzten Abdominalsegmente sind nicht auffallend dunkler. Flügel vorhanden. Auf dem 3.-7. Abdominalsegmente unten je ein kleiner weisser Punkt. Das 4. u. 5. Fühlerglied nur schwach getrübt; das 6. Glied fast bis zur Nitte licht.

Vorkommen: Weibchen von Mai bis September in verschiedenen Blüten und zuweilen auch im Rasen. Männchen im Juni. - Fundort: Böhmen.

\section{Thrips adusta nov. sp.*)}

$$
\text { T. }
$$

Rozeznává se od druhu předcházejíciho ihned dvěma posledními články abdomenu, které mají černou barvu, kdežto tělo jinak je hnědožluté neb žlutohnědé. Také postava jest značně menší. - Hlava trochu širší než delší, se stranami vypouklými, nazad nezúžená. Pátý čl. tykadla malinký, značně kratší než čtvrtý. Barva tykadel: první dva články tmavé, 2. na konci světlý, 3. celý žlutavý, 4. žlutavý, v poslední třetině (zvl. nahoře) tmavý, 5. do polou žlutavý, od polou tmavý, 6. a 7 . tmavé, onen na basi světlejší. Všecka femora ke knnci pravidlem světlejší, přední tibie žlutavé, jen vně šedě zkalené, strední tibie na samé basi a v druhé polovici, zadní tibie na samé basi a ke konci světlé. Hlavní žilka ke konci se třemi chlupy. Hoř. křídla jsou tmavěji zkalená než u druhu předcházejicího, a to zvl. ke konci. Basis kř́dla jest dosti čirá. Délka těla $1 \mathrm{~mm}$.

Var. nigra. Hlava a abdomen jsou černé, pterothorax černohnèdý. Tykadla jsou podobně zbarvena jako $u$ formy typické. Všecka femora a střední i zadní tibie černé. Všecky tarsy a přední tibie žlutavé, tyto vně šedě zkalené. - Jediný exempl. nalezen.

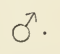

Sotva svètlejší než samice, dva poslední články abdomenu tmavé. Křrídla př́itomna Na 3.-7. čl. abdom. dole po jednom malém bílém okrouhlém puntíku.

Třásněnka tato jest hojna od dubna do června v obou pohlavích v rủzných květech, zvláště v květech od Ranunculus ficaria a Taraxacum officinale.

Čechy: Praha. Čerčany (Bubák). Hradec Král. Opoěno. Jaroměř. Turnov. Jablonec. Milešovka. Peruc. Slané. Unhošt (Vařečka). Prachatice. Prales boubínský.

*) Doklad ve sbirce musejní, praep. ě. 50. - Sammlung des böhmischen Landesmuseums, Praep. Nr. 50. 
q.

Von der vorigen Art sofort zu unterscheiden nach den zwei letzten Abdominalsegmenten, welche schwarz sind, wogegen der übrige Körper braungelb oder gelbbraun ist. Auch die Gestalt ist bedeutend kleiner. - Kopf etwas mehr breit als lang, nach hinten nicht verengt; seine Wangen sind gewölbt. Das 5. Fühlerglied winzig, bedeutend kürzer als das vierte. Fühlerfärbung: die ersten zwei Glieder dunkel, das 2. am Ende licht, das 3. ganz gelblich, das 4. gelblich, im letzten Drittel (hauptsächlich oben) dunkel, das 5. bis zur Mitte gelblich, von der Mitte an dunkel, das 6. u. 7. dunkel, jenes am Grunde lichter. Alle Schenkel gegen das Ende zu regelmässig lichter, die Vordertibien gelblich, nur aussen grau getrübt, die Mitteltibien an der Wurzel und in der zweiten Hälfte, die Hintertibien an der Wurzel und gegen das Ende zu licht. Die Hauptader in ihrer zweiten Hälfte mit drei Borsten. Die Oberflügel sind dunkler getrübt als bei der vorhergehenden Art, und zwar hauptsächlich gegen die Spitze zu. Ibre Basis ist ziemlich hell. Körperlänge $1 \mathrm{~mm}$.

Var. nigra. Kopf und Abdomen schwarz, Pterothorax schwarzbraun. Fühler ähnlich gefärbt wie bei der Stammform. Alle Schenkel und die Mittel- und Hintertibien schwarz. Alle Tarsen und die Vordertibien gelblich, diese aussen grau getrübt.

$$
\text { ð. }
$$

Kaum lichter als das Weibchen, die zwei letzten Abdominalsegmente dunkel. Flügel vorhanden. Auf dem 3.-7. Abdominalsegmente unten je ein kleiner weisser Punkt.

Vork o mmen: Häufig von April bis Juni in beiden Geschlechtern in verschiedenen Blüten und hauptsächlich in jenen von Ramunculus ficaria und Taraxacum officinale. - Fundort: Böhmen.

\section{Thrips flava Schr.*)}

177. Thrips flava, alis albidis; Schrank, Beyträge zur Naturgesch., pag. 31.; tab. I., fig. 25 . et 26.

1781. Thrips flava Schrank, Enumeratio Ins. Austriae indig., pag. 297.

1781. - melanopa Idem, ibidem, pag. 298.

1781. - Urticae Fabricius, Species Insectorum, pag. 397.

1787. - - Fabricius, Mantissa Insectorum, pag. 320.

1788. - - Gmelin, Caroli a Linné Systema Nat., pag. 2223.

1789. - - de Villers, C. Linnaei Entomologia.

*) Doklad ve sbirce musejní, praep. ¿̌. 51. a 52. - Sammlung des böhmischen Landesmuseums, Praep. Nr. 51 u. 52. 


\section{J. UZEL, MONOGRAFIE RÁDU, „THYSANOPTERA“.}

1794. Thrips Urticae Fabricius, Entomologia Systematica, pag. 229.

1803. - - Fabricius, Systema Rhyngotorum, pag. 313.

1806. - - Turton, A General System of Nature, pag. 716.

1836. - - Haliday, Entomolog. Magazine, pag. 448.

1836. - - Burmeister, Handb. d. Entomologie, pag. 415.

1843. - - Amyot et Serville, Ins. Hémiptères, pag. 644.

1852. - - Haliday, Walker: Homopt. ins. of Brit. Museum, pag. 1113.; tab. VII., fig. 7 , et 8 .

1878-79. - - Reuter, Diagn. öfv. nya Thysanopt. f. Finland, pag. 6.

1882. - Solanacearum (Widgalm), Portschinsky. (Překlad [Übersetzung] jeho práce v časop.: Revue Mens. d'Ent. St. Pétersb., pag. 44.)

q.

Tělo nádherně žluté, thorax (někdy celé tělo) s odstínem do červena. Chlupy na těle a křídlech velmi tmavé. Hlava trochu širší než,delší, se stranami vypouklými, nazad nezúžená. První čl. tykadel kratši než 2., 3. a 4. stejně mezi sebou dlouhé, 5. článek značně kratší než předcházející, směrem k basi se zúžující. Barva tykadel: první tři čl. běložluté, 3. často na konci slabě šedě zkalený, 4. čl. as do polou běložlutý, od polou silně šedě až černošedě zkalený, 5. čl. skoro do dvou třetin běložlutý, v poslední třetině náhle černošedý (velmi charakteristické!), 6. a 7. čl. černošedé, onen na basi světlejší a někdy zde až žlutavý. Nohy celé bèložluté, nijak nezkalené. Hlavní žilka v hoř. křídle má v druhé své polovici tř̀i chlupy, z nichž prvý jest od ostatních dvou oddálen. Hor̀. křídla jsou slabě žlutavošedě zkalená, na basi svètlejší. Délka těla $1.2 \mathrm{~mm}$.

Var. (nov.) obsoleta. Rozměry těla menší než u formy typické, zbarvení její jest však podobné, jen bledší thorax i abdomen jsou kromě toho často nahoře slabě šedě zkaleny a chlupy na těle a křídlech jsou světlejší. Tykadla podobně zbarvená jako u formy typické. Varieta tato blǐ̌̌ se typické formě druhu communis, rozeznává se ršak od ní štíhlejším a poměrně delšim tělem a zvl. štíhlejšími tykadly, pátým článkem jejich značně kratším než čtvrtý a sedmým článkem na basi ne tak širokým, dále vždy jen třemi chlupy na druhé polovině hlavní žilky v hořejším kř́dle a také barvou těla obyčejně světlejší.

$\sigma^{7}$

Bělavý, thorax slabounce žlutavý; tykadla podobně zbarvená jako u q. Křídla přitomna. Chlupy na těle svěllé. Dole na několika článcích abdom. nalézají se velmi nezřetelné piškotovité prohlubiny.

Třásněnka tato žije $\mathrm{v}$ obou pohlavích od dubna do záñí $\mathrm{v}$ nejrủznějších květech a objevuje se časem ve velikém množství; tak v kvělech od Cormus mas (kvetoucí 


\section{H. UZEL, MUNOGRAPHIE DER ORDNUNG THYSANOPTERA.}

keře dřinové u Sv. Prokopa jimi bývaji přeplněny), Monotropa hypopitys, Pulsatilla pratensis, Vicia faba, Calluna vulgaris, Epilobium angustifolium, Humulus lupulus (plodni šišky). Mimo to vyskytuje se též časem v květenství trav (zvl. Seslevia coerulea) a někdy též na listech rủzných nízkých rostlin i stromů. Kromě na uvedených rostlinách pěstovaných žije ještě $\mathrm{v}$ květech třešní, brambor, ligrusu, máku a někdy velmi četně na květinách zahradních. Že by zvláště žlutým květům prednost dávala, jak Haliday tvrdí, nemohl bych potvrditi (viz o tòm príslušné místo v Části biologické).

Jest rozšiřena po celých Čechách. Na Krkonoších žije sice všude (dostupuje též nejvyššich vrcholkủ), avšak jen ojediněle.

$$
\text { Q. }
$$

Körper hochgelb, der Thorax (manchmal der ganze Körper) mit rothem Ton. Die Borsten am Körper und auf den Flügeln sehr dunkel. Kopf etwas mehr breit als lang, mit gewölbten Wangen; nach hinten ist er nicht verengt. Erstes Fühlerglied kürzer als das 2., das 3. u. 4. untereinander gleichlang, das 5. bedeutend kürzer als das vorhergehende, gegen die Basis zu verengt. Fühlerfärbung: die ersten drei Glieder weissgelb, das 3. oft auf dem Ende schwach grau getrübt, das 4. Glied etwa bis zur Mitte weissgelb, von der Mitte an stark grau bis schwarzgrau getrübt, das 5. Glied fast bis zum zweiten Drittel seiner Länge weissgelb, im letzten Drittel plötzlich schwarzgrau (sehr charakteristisch!), das 6. u. 7. schwarzgrau, jenes auf dem Grunde lichter bis gelblich. Die ganzen Beine weissgelb. nicht getrübt. Die Hauptader in ihrer zweiten Hälfte mit drei Borsten besetzt, von denen die erste von den beiden übrigen entfernt ist. Die Oberflügel schwach gelblichgrau getrübt, auf dem Grunde lichter. Körperlänge $1 \cdot 2 \mathrm{~mm}$.

Var. (nov.) obsoleta. Körperdimensionen kleiner als bei der typischen Form, die Färbung jedoch ähnlich, nur blasser; der Thorax und das Abdomen sind ausserdem oft oben schwach grau getrübt, und die Borsten auf dem Körper und den Flügeln sind lichter. Die Fühler ähnlich gelärbt wie bei der Stammform. Diese Varietät nähert sich auch der Stammform der Art communis, unterscheidet sich jedoch von ihr durch einen schlankeren und verhältnismässig längeren Körper und besonders durch schlankere Fühler, durch das 5. Fühlerglied, welches bedeutend kürzer ist als das 4., und durch das 7. Glied, welches aut dem Grunde weniger breit ist, weiter durch immer nur drei Borsten in der zweiten Hälfte der Hauptader und endlich auch durch die gewöhnlich lichtere Körperfarbe.

$$
\sigma^{x}
$$

Weisslich, der Thorax sehr schwach gelblich; die Fühler ähnlich wie beim $q$ gefärbt. Flügel vorhanden. Borsten auf dem Körper licht. Auf einigen Abdominalsegmenten unten befindet sich je eine längliche, in der Mitte verengte, sehr undeutliche Vertiefung. 


\section{J. UZEL, MONOGRAFIE RADU "THYSANOPTERA“.}

Vorkommen: In beiden Geschlechtern von April bis September in den verschiedensten Blüten, zeitweise in grossen Mengen. Zuweilen auch in Grasähren und auf Blättern. - Fundorte: England (Haliday), Finnland (Reuter), Deutschland (Jordan), bei Berlin (Uzel), Böhmen. Var. obsoleta: Böhmen, Pest.

\section{5. 'Thrips alni nov. sp. *)}

$$
\text { q. }
$$

Tělo světle zelenavě žluté, chlupy na těle a na křidlech velmi tmavé. Hlava trochu širši než delší, se stranami vypouklými, nazad nezúžená. První čl. tykadel kratší než 2., 4. čl. nepatrně kratší než 3., 5. čl. kratši než předcházející, v předu utatý, takže přiléhá širokou plochou k článku šestému; 7. čl. poměrně delší než u druhu předcházejícího. První tři články tykadla jsou běložluté, ostatní celé černé; třetí bývá někdy na konci nahoře velmi slabě šedě zkalený. Nohy celé žlutavé. nezkalené. Hlavní žilka v hoř. krídle má v druhé své polovině tři chlupy skoro stejně od sebe vzdálené. Hoř. kr̂ídla jsou slabě žlutavošedě zkalená, na basi světlejší. Chlupy na abdomenu, zvláště na jeho konci, mohutnější než u druhu předcházejícího. Délka těla $0.8 \mathrm{~mm}$. - Dvacet sedm exempl. nalezeno.

$$
0^{\pi}
$$

Zelenavě žlutavý; tykadla právě tak zbarvená jako u samice. Kř́ídla prítomna. Chlupy na těle tmavé. - Čtyřri exempl. nalezeny.

Třásněnka tato zdržuje se na mladých listech olšových. Sbírána v srpnu v obou pohlavích. - Čechy: Opočno: V bažantnici Mochově.

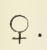

Körper licht grünlichgelb, die Borsten auf ihm und auf den Flügeln sehr dunkel. Kopf etwas mehr breit als lang, mit gewölbten Wangen; nach hinten ist er nicht verengt. Erstes Fühlerglied kürzer als das 2., das 4. Glied unbedeutend kürzer als das 3., das 5. kürzer als das vorhergehende, vorn breit und abgestutzt, so dass es sich mit breiter Fläche an das 6. Glied anlegt; 7. Glied verhältnismässig länger als bei der vorhergehenden Art. Die ersten drei Fühlerglieder sind weissgelb, die übrigen schwarz, das 3. pflegt zuweilen auf dem Ende oben sehr schwach grau getrübt zu sein. Beine gelblich, ungetrübt. Die Hauptader hat in ihrer zweiten Hälfte drei Borsten, welche fast gleich von einander entfernt sind. Die Oberflügel sind schwach gelblichgrau getrübt, auf dem Grunde lichter.

*) Doklad ve sbírce musejní, praep. ě. 53. - Sammlung des böhmischen Landesmuseums, Praep. Nr. 53. 


\section{H. UZEL, MONOGRAPHIE DER ORDNUNG THYSANOPTERA.}

Die Borsten auf dem Abdomen, hauptsächlich auf seinem Ende, mächtiger als bei der vorhergehenden Art. Körperlänge $0.8 \mathrm{~mm}$.

$$
0
$$

Grünlichgelb; die Fühler ebenso wie beim Weibchen gefärbt. Flügel vorhanden. Borsten auf dem Körper dunkel.

Vorkommen: Im August auf jungen Erlenblättern in beiden Geschlechtern. Fund ort: Böhmen.

\section{Thrips albopilosa nov. sp.*)}

$$
\text { q. }
$$

Celé tělo žlutavé, velmi slabě šedě zkalené, chlupy na těle i na kirídlech bílé. Hlava trochu širší než delší, se stranami sotva vypouklými, nazad nezúžená. Články tykadel zavalitějši než u druhu flava. První čl. jejich kratší než 2., 4. patrně kratší než 3., 5. jen trochu kratší než předcházejicí, v předu utatý, takže prriléhá dosti širokou plochou k článku šestému; 7. čl. poměrně delší než u druhu předcházejícího a poměrně značně delší než u druhu flava. První a třetí čl. žlutavé, 2. žlutavý, slabě šedě zkalený, 4. žlutavý, na konci velmi slabě šedý, 5. do polou žlutavý, od polou tmavošedý, 6. a 7. tmavošedé, 6. někdy skoro do polou žlutavý. Nohy celé žlutavé, nezkalené. Hlavní žilka v hoř. kríídle má v druhé polovici tr̆i chlupy, z nichž jest proní od obou ostatních velmi značně oddálen. Hor̀. křídla jsou velmi slabě žlutavě zkalená. Chlupy na konci abdomenu nedlouhé, velmi tenké, bílé. Délka těla $0.9 \mathrm{~mm}$. — Osm exempl. nalezeno.

$$
\text { ऊ. Nebyl posud objeven. }
$$

Čechy: Hradec Králové.

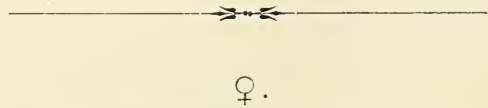

Der ganze Körper gelblich, sehr schwach grau getrübt, Borsten auf dem Körper und den Flügeln weiss. Kopf etwas mehr breit als lang, seine Wangen kaum gewölbt; nach hinten ist er nicht verengt. Fühlerglieder gedrungener als bei der Art flava. Ihr erstes Glied kürzer als das 2., das 4. deutlich kürzer als das 3., das 5. nur etwas kürzer als das vorhergehende, vorn abgestutzt, so dass es sich mit ziemlich breiter Fläche an das 6. Glied anlegt; das 7. Glied verhältnismässig länger als bei der vorhergehenden Art und verhältnismässig bedeutend länger als bei der Art flava. Erstes und drittes Glied

*) Doklad ve sbirce musejni, praep. ě. 54. - Sammlung des böhmischen Landesmuseums, Praep. Nr. 54. 


\section{J. UZEL, MONOGRAFIE RÁD U „THYSANOP TERA“.}

gelblich, das 2. gelblich, schwach grau getrübt, das 4. gelblich, auf dem Ende sehr schwach grau, das 5. bis zur Mitte gelblich, von der Mitte an dunkelgrau, das 6. u. 7. dunkelgrau, jenes manchmal fast bis zur Hälfte gelblich. Beine gelblich, nicht getrübt. Die Hauptader ist in ihrer zweiten Hälfte mit drei Borsten versehen, von denen die erste von den übrigen zwei sehr stark entfernt ist. Die Oberflügel sind sehr schwach gelblich gefärbt. Die Borsten am Abdomenende sind nicht lang, sehr dünn und weiss. Körperlänge $0.9 \mathrm{~mm}$.

$$
\text { ơ unbekannt. }
$$

Fund ort: Böhmen.

\section{Thrips angusticeps nov. sp.*)}

Tab. VI., fig. 101. et 102 .

$$
\text { †. }
$$

Barva těla šedohnědá až černohnědá, pterothorax světlejši. Hlava malá, asi tak dlouhá jako široká, s tvářemi sotva vypouklými, do předu nepatrně zúžená. První čl. tykadel trochu kratší než 2., avšak asi tak široký, 2., 3. a 4. čl. skoro stejně dlouhé, 3. a 4. trochu vřetenovilé, 6. ěl. rozšiřený, 7. čl. velmi krátký, na basi široký. V barvě jsou tykadla proměnlivá. První čl. jest vždy tmavý, 2. ěl. někdy žlutavý, jindy na basi a po obou stranách šedẽ zkalený neb kromě konce celý tmavý, 3. světlý, žlutavý, 4., 5., 6. a 7. často černošedé neb tmavošedé, 4. čl. a někdy i 5. bývaji šedožlutavé. Nohy šedohnědé, přední tibie žluté, na basi zkalené, ostatní tibie šedohnědé, jen na konci více neb méně světlé, tarsy žlutavé. Prothorax má na zadním okraji kromě dlouhých chlupů smyslových ještě 4 malé chloupky na každé straně. Délka těla $0.9 \mathrm{~mm}$.

FORMA MA GROPTERA. Hoř. křídla žlutavě zkalená, na basi světlejší. Hlavní žilka má $\mathrm{v}$ druhé své polovici obyčejně pět, někdy šest chlupů; vedlejší žilka jest po celé délce chlupy opatřená.

F ORM A B R A G H Y P TERA. Křídel jen rudimenta pterothorax nepřesahující aneb jen málo přesahujicí. Tento jest poměrně kratší než u formy dlouhokríídlé.

$$
\delta^{x}
$$

Trochu menší než samice a jen málo světlejší. Na spodní straně 3., 5., 6. a 7 . čl. abdom. nalézá se po jedné podélné bílé prohlubině; na 4. čl. jest uprostřed dole jen malinká bílá tečka. Kř́dla jsou prítomna.

Třásněnka tato žije v květech od Trifolium pratense, Armoracia rusticana, Centaurea cyanus, Melandryum pratense, Agrostemma githago, Linum usitatissimum. Také na pšenici a ječmeni jsem ji zastihl, ač velmi pořídku. Pan prof. Duda

*) Doklad ve sbirce musejni, praep. ě. 5็. - Sammlung des böhmischen Landesmuseums, Praep. Nr. 55. 


\section{H. UZEL, MONOGRAPHIE DER ORDNUNG THYSANOPTERA.}

sbíral ji na listech bramborových. V dubnu a květnu nalézal jsem samice formy krátkokřídlé. V červnu a v červenci samice formy dlouhokřídlé. Samci objevuji se v červnu. Čechy: Praha: U Krče. Hradec Král. Třebechovice. Turnov. Postoloprty (Bubák). Unhošt: U Hájku; Písek (Vařečka). Jindřichův Hradec (Duda).

\section{오.}

Körperfarbe graubraun bis schwarzbraun, Pterothorax lichter. Kopf klein, etwa so lang als breit, seine Wangen kaum gewölbt. Das 1. Fühlerglied etwas kürzer als das 2. und etwa gleich breit, das 2., 3. u. 4. Glied untereinander fast gleich lang, das 3. u. 4. etwas spindelförmig, das 6. erweitert, das 7. sehr kurz, auf dem Grunde breit. Die Fühlerfärbung veränderlich. Erstes Glied immer dunkel, das 2. manchmal gelblich, zuweilen am Grunde und beiderseits grau getrübt, oder ganz dunkel, das Ende ausgenommen, das 3. Glied licht, gelblich, das 4., 5., 6. u. 7. oft schwarzgrau oder dunkelgrau, das 4. Glied und manchmal auch das 5. pflegen graugelblich zu sein. Die Beine graubraun, die Vordertibien gelb, auf dem Grunde getrübt, die übrigen Tibien graubraun, nur auf dem Ende mehr oder weniger licht, die Tarsen gelblich. Der Prothorax ist auf seinem Hinterrande ausser mit den langen Sinnesborsten noch jederseits mit vier kleinen Härchen besetzt. Körperlänge $0.9 \mathrm{~mm}$.

F O R A MA GR O P TERA. Oberflügel gelblich, auf dem Grunde lichter. Die Hauptader ist in ihrer zweiten Hälfte gewöhnlich mit fünf, manchmal mit sechs Borsten versehen; die Nebenader ist der ganzen Länge nach mit Borsten besäet.

FORMA BRAGHYPTERA. Flügel zu Rudimenten verkümmert, die den Pterothorax nicht oder wenig überragen. Dieser verhältnismässig kürzer als bei der langflügeligen Art.

$$
\text { ○’. }
$$

Etwas kleiner als das $q$ und nur wenig lichter. Auf der Unterseite des 3., 5., 6. u. 7. Abdominalsegmentes je eine längliche weisse Vertiefung, auf dem 4. Segmente in der Mitte nur ein winziger weisser Punkt. Flügel vorhanden.

Vorkommen: In verschiedenen Blüten, und zwar die kurzflügeligen Weibchen im April und Mai, die langflügeligen im Juni und Juli, die Männchen im Juni. - F und ort: Böhmen.

\section{Thrips linaria nov sp.*)}

$$
\text { ㅇ. }
$$

Barva tèla černošedá až skoro černá. Hlava patrně širši než delší. Články tykadel krátké; první čl. kratší než 2., 3. a 4. skoro slejně dlouhé, 5. kratší než 4., 6. ke konci

*) Doklad ve sbirce musejní, praep. č. 5̌6. - Sammlung des böhmischen Landesmuseums, Praep. Nr. 56.

$$
-192-
$$




\section{J. UZEL, MONOGRAFIE RADU, „THYSANOPTERA“.}

značně zúžený, 7. dosti dlouhý a priı̌šičatělý. Barva tykadel černošedá, 2. čl. ke konci a třetí celý bělavý. Prothorax patrně delší než hlava. Na zadním okraji jeho nalézají se kromẽ chlupủ smyslových ještè na každé straně tř̀i malé chloupky. Nohy tmavší než tělo, černé, jen přední tibie žlutavé, vně tmavě zkalené; všecky tarsy žlutavé. Hlavní žilka v hoř. křídle na konci se třemi chlupy, vedlejší s mnohými. Hoř. křídla dosti silně šedohnědě zkalená, u kořene trochu světlejší. Před basí uprostřed s podélným čirým okénkem. Dolejši křídla na basi a na konci slabĕ zkalená. Délka těla $0.9 \mathrm{~mm}$. — Šest exempl. nalezeno.

$$
\text { ð. Nebyl posud objeven. }
$$

Třásněnka tato žije $\mathrm{v}$ červenci a $\mathrm{v}$ srpnu nehojně na květech lnu. Čechy: Hradec Králové: U Malšovic. Třebechovice: U Jilovice.

q.

Körperfarbe schwarzgrau bis fast schwarz. Kopf deutlich mehr breit als lang. Fühlerglieder kurz; das 1. Glied kürzer als das 2., das 3. u. 4. fast gleich lang, das 5. kürzer als das 4., das 6. gegen das Ende zu bedeutend verengt, das 7. ziemlich lang und zugespitzt. Fühlerfärbung schwarzgrau, das 2. Glied gegen das Ende zu und das dritte ganz weisslich. Prothorax deutlich länger als der Kopf. Auf seinem Hinterrande befinden sich ausser den langen Sinnesborsten noch jederseits drei kleine Härchen. Beine dunkler als der Körper, schwarz, nur die Vordertibien gelblich, aussen dunkel getrübt; alle Tarsen gelblich. Die Hauptader auf ihrer zweiten Hälfte mit drei, die Nebenader der ganzen Länge nach mit vielen Borsten bėsetzt. Die Oberflügel ziemlich stark graubraun getrübt, auf dem Grunde etwas lichter. Die Unterflügel auf dem Grunde und auf dem Ende schwach getrübt. Körperlänge $0.9 \mathrm{~mm}$.

$$
\text { ơ unbekannt. }
$$

Vorkommen: In Flachsblüten nicht häufig im Juli und August. - Fundort: Böhmen.

\section{Thrips minutissima L. *)}

Tab. VI., fig. 103.

1761. Thrips minutissima Linné, Fauna Svecica, pag. 266.

1767. - - L Linné, Systema Naturae, pag. 743.

1776. - - Müller, Zoologiae danicae Prodromus, pag. 96.

1781. - - Schrank, Enumeratio Ins. Austriae indig., pag. 297.

*) Doklad ve sbirce musejní, praep. è. 57. - Sammlung des böhmischen Landesmuseums, Praep. Nr. 57. 


\section{H. UZEL, MONOGRAPHIE DER ORDNUNG THYSANOPTERA.}

1781. Thrips minutissima Fabricius, Species Insectorum, pag. 396.

$\begin{array}{lll}1787 . & - & - \\ 1788 . & - & - \\ 1794 . & - & - \\ 1802 . & - & - \\ 1803 . & - & - \\ 1806 . & - & - \\ 1836 . & - & - \\ 1843 . & - & - \\ 1852 . & - & -\end{array}$

Fabricius, Mantissa Insectorum, pag. 320.

Gmelin, Caroli a Linné Systema Nat., pag. 2222.

Fabricius, Entomologia Systematica, pag. 229.

Stew. Elements of Nat. Hist., pag. 114.

Fabricius, Systema Rhyngotorum, pag. 314.

Turton, A General System of Nature, pag. 717.

Haliday, Entomolog. Nagazine, pag. 449.

Amyot et Serville, Ins. Hémiptères, pag. 644.

Haliday, Walker: Hornopt. ins. of Brit. Museum, pag. 1112.

$$
\text { †. }
$$

Barva těla šedožlutavá, pterothorax žlutohnědý; někdy jest celé tělo tmavější. Hlava o něco širší než delší, nazad trochu rozšířená, strany její značně vypouklé. Články tỵkadel krátké, zavalité; první čl. značně kratší než druhý, 3. a 4. mezi sebou skoro stejně dlouhé, 4. širší než predcházející, 5. značně kratší; 7. velmi krátký, na basi široký. Barva tykadel: 1., 2. a 3. čl. žlutavé, někdy 3. čl. na konci nahor̀e trochu temněji zkalený; 4., 5., 6. a 7. šedohnědé. Prothorax jen málo delši hlavy. Femora šedožlutá, přední na konci a uvnitr̆ běložlutá, ostatní na konci trochu světlejší, strední a zadní tibie šedožluté, na konci běložluté, přední tibie běložluté, vně zpočátku šedẽ zkalené. Hlavní žilka má v druhé své polovině obyčejně osm chlupů; vedlejší jest po celé své délce chlupy poseta. Hoř. křídla slabě šedožlutě zkalená, ke konci silněji; u kořene dosti čirá. Délka těla $0.9 \mathrm{~mm}$.

$$
\text { ठౌ. (novẽ objevený). }
$$

Ninohem menší a světlejší než ф́. Kř́idla přítomna. Na 2. --. 7. čl. abdom. dole po jeduś ízké, dlouhé, světlé prohlubině.

Tato malá třásněnka žije $\mathrm{v}$ květech od Fragaria vesca a Prumus cerasus; ojedinèle též v jiných květech (ku př. od Pirus malus). Ve větším počtu nalezl jsem ji též na spodní straně listů od Aesculus hippocastamum. Dle Hali da ye zdržuje se také v obilí a dle Jordana na spodní straně listủ bramborových. Samice i samci objevují se $\mathrm{v}$ dubnu a květnu.

Čechy: Praha: Na Cibulce. Třebechovice: U Vys. Újezda. Vrchol Milešovky. Peruc. Unhošt: U Hájku (Vařečka)

$$
\text { f. }
$$

Kopf und Abdomen graugelblich, Pterothorax gelbbraun; zuweilen ist der ganze Körper dunkler. Kopf um etwas mehr breit als lang; nach hinten etwas erweitert, seine 
Wangen bedeutend gewölbt. Fühlerglieder kurz, gedrungen: erstes Glied bedeutend kürzer als das 2., das 3. u. 4. untereinander fast gleich lang, das 4. breiter als das vorhergehende, das 5. bedeutend kürzer; das 7. sehr kurz, auf dem Grunde breit. Fühlerfärbung: 1., 2. u. 3. Glied gelblich, manchmal das 3. auf dem Ende oben etwas dunkler getrübt; das 4., 5., 6. u. 7. graubraun. Prothorax nur wenig länger als der Kopf. Schenkel graugelb, die vorderen auf dem Ende und innen weissgelb, die übrigen auf dem Ende etwas lichter, die Mittel- und Hintertibien graugelb, auf dem Ende weissgelb, die Vordertibien weissgelb, anfangs aussen grau getrübt. Die Hauptader ist in ihrer zweiten Hälfte gewöhnlich mit acht Borsten besetzt; die Nebenader ist der ganzen Länge nach mit Borsten besäet. Die Oberflügel schwach graugelb getrübt, gegen das Ende zu stärker; auf dem Grunde ziemlich klar. Körperlänge $0.9 \mathrm{~mm}$.

$$
\sigma^{7} \text { (neu entdeckt). }
$$

Viel kleiner und lichter als das q. Flügel vorhanden. Auf dem 2.-7. Abdominalsegmente unten je eine lange, schmale, lichte Vertiefung.

Vorkommen: Beide Geschlechter im April und Nai in einigen Blütenarten, zuweilen auf der Unterseite von Blättern, und nach Haliday auch im Getreide. Fundorte: England (Haliday), Deutschland (Jordan), Böhmen.

\section{0. 'Thrips calcarata nov. sp.*)}

Tab. VI., fig. 104.

$$
\text { q. }
$$

Barva těla šedožlutá, pterothorax někdy šedohnědý. Hlava tak dlouhá jako široká, S tvářemi vỵpouklými, nazad nerozšiřená. Oči vykoulené. První čl. tykadel mohutný, tak dlouhý a trochu širší než 2., 3. čl. trochu delší než tento, 4. a 5. čl. postupně kratší, 6. čl. široký. Barva tykadel: 1. a 2. čl. tmavé, 2. na konci světlejší, 3. světlyy, 4. trochv zkalený, 5., 6. a 7. tmavošedé. Prostřední článek makadel maxillarních jest nejkratším. Přední tarsy mají dlouhý, tenký, ohnutý zub. Zadní nohy jsou velmi dlouhé. Všecka femora, kromě konců, tmavá; tibie přední světlé, po obou stranách s tmavou čarou, ostatní tibie, kromě konce a samé base, tmavě zkalené; tarsy světlé. Hlavní žilka ke konci se třemi chlupy, z nichž první od obou ostatních jest oddálen. Vedlejší žilka s četnými chlupy. Hoř. křídla jsou trochu žlutošedě zkalená, na basi čirá. Délka těla 0.9 mm. - Šest exempl. nalezeno.

*) Doklad ve sbirce musejni, praep. č. 58. - Sammlung des böhmischen Landesmuseums, Praep. Nr. 58 . 


$$
\text { ð. Nebyl posud objeven. }
$$

Vzácný tento druh nalezl jsem v květnu na kvètech od Mercurialis perennis a Sesleria coerulea.

Čechy: Vrchol Milešovky. Peruc.

$$
\text { q. }
$$

Körperfarbe graugelb, Pterothorax zuweilen graubraun. Kopf so lang wie breit, nach hinten nicht erweitert, seine Wangen gewölbt. Augen hervorgequollen. Erstes Fühlerglied mächtig, so lang und etwas breiter als das 2., das 3. etwas länger als das vorhergehende, das 4. u. 5. stufenweise kürzer, das 6. breit. Fühlerfärbung: 1. u. 2. Glied dunkel, dieses auf dem Ende lichter, das 3. licht, das 4. etwas getrübt, das 5., 6. u. 7. dunkelgrau. Das mittlere Glied der Maxillartaster am kürzesten. Vordertarsen mit einem langen, dünnen, gebogenen Zahn bewaffnet. Hinterbeine sehr lang. Alle Schenkel, die Enden ausgenommen, dunkel; die Vordertibien licht, jederseits mit einem schwarzen Strich, die übrigen Tibien, ausser auf dem Ende und ganz auf der Wurzel, dunkel getrübt; die Tarsen licht. Die Hauptader in ihrer zweiten Hälfte mit drei, die Nebenader ihrer ganzen Länge nach mit vielen Borsten besetzt. Die Oberflügel etwas gelbgrau getrübt. auf dem Grunde hell. Körperlänge $0.9 \mathrm{~mm}$.

$$
\text { ð] unbekannt. }
$$

Vorkommen: Im Mai in den Blüten von Mercurialis peremis und Sesleria coerulea. - Fundort: Böhmen.

\section{Thrips viminalis nov. sp.*)}

q.

- Barva těla černohnědá. Hlava as tak dlouhá jako široká, se stranami vypouklými. První čl. tykadel velmi krátký, tak široký jako 2., 3. a 4. čl. skoro stejně dlouhé, 5. jen trochu kratší než předcházející článek, 7. poměrně dlouhý. Barva tykadel: 1. a 2. čl. černošedé, tento ke konci světlejší, 3. žlutavý, 4. žlutavỵ, ke konci slabě zkalený, 5. černošedý, na basi žlutavý, 6. a 7. taktéž černošedé. Prothorax delší než hlava. Všecka femora černohnědá, přední na samém konci světlejší, někdy žlutavá, střední a zadní na samé basi světlá. Přední tibie žlutavé, po obou stranách trochu zkalené, střední a zadní černohnèdé, často na samé basi trochu světlejší, ke konci světle žlutavé. Tarsy taktéžžlutavé. Hlavni

*) Doklad ve sbírce musejní, praep. ‘̌. 59. - Sammlung des böhmischen Landesmuseums, Praep. Nr. 59. 
žilka ve druhé své polovině se třemi chlupy, z nichž první jest od obou ostatních oddálen. Hoř. křídla značně šedohnědě zkalená, na počátku druhé třetiny a ke konci ještě silněji, na basi čirả. Délka tèla $0.9 \mathrm{~mm}$.

$$
\sigma^{x}
$$

Menší než $\nmid$, sotva světlejší, hoř. krîídla jeho bledši. Na spodni stranè $3 .-6$. čl. abdom. po jedné světlé okrouhlé prohlubině.

Třásnènka tato žije na listech vrbových a topolových (Populus nigra), a to misty v značném množství. Také zdržuje se pod korou vrbovou. Samice i samci nalezeni v srpnu.

Čechy: Třebechovice: Pod Vys. Újezdem. Opočno: U Mezříče.

\section{q.}

Körperfarbe schwarzbraun. Kopf etwa so lang wie breil, seine Wangen gewölbt. Das erste Fühlerglied sehr kurz, so breit wie das 2., das 3. u. 4. untereinander fast gleich lang, das 5. nur etwas kürzer als das vorhergehende, das 7. verhältnismässig lang. Fühlerfärbung: 1. u. 2. Glied schwarzgrau, dieses gegen das Ende zu lichter, das dritte gelblich, das 4 . ebenfalls gelblich, gegen das Ende zu schwach getrübt, das 5 . schwarzgrau, am Grunde gelblich, das 6. u. 7. ebenfalls schwarzgrau. Prothorax länger als der Kopf. Alle Schenkel schwarzbraun, die vorderen am äussersten Ende lichter, manchmal gelblich, die mittleren und hinteren ganz auf der Wurzel licht. Die Vordertibien gelblich, jederseits etwas getrübt, die Mittel- und Hintertibien schwarzbraun, oft ganz auf der Wurzel etwas lichter, gegen das Ende zu licht gelblich. Die Tarsen ebenfalls gelblich. Die Hauptader in ihrer zweilen Hälfte mit drei Borsten versehen, von denen die erste von den übrigen zwei entfernt ist. Die Oberflügel bedeutend graubraun getrübt, am Anfang des zweiten Drittels und gegen das Ende zu noch stärker, am Grunde klar. Körperlänge $0.9 \mathrm{~mm}$.

$$
\delta^{7} \text {. }
$$

Kleiner als das $q$, kaum lichter, seine Oberflügel blasser. Auf der Unterseite des 3.-6. Abdominalsegmentes befindet sich je eine lichte runde Vertiefung.

Vorkommen: Im August in beiden Geschlechtern auf Weiden- und auch auf Schwarzpappelblättern. - Fund ort: Böhmen.

\section{Thrips longicollis nov. sp.*)}

?.

Tělo menší a slabší než u druhu předcházejícího. Barva těla šedohnědá. Hlạva as tak dlouhá jako široká, se stranami značně vypouklými. Tykadla mají dosti krátké

*) Doklad ve sbirce autorově. 


\section{H. UZEL, MONOGRAPHIE DER ORDNUNG THYSANOPTERA.}

a široké články. První jest velmi krátký a tak široký jako 2., 3. a 4. čl. mezi sebou skoro stejně dlouhé, 5. značně kratší, 7. čl. poměrně dlouhý. Barva tykadel: 1. a 2. čl. žlutošedé, 3. a 4. žluté, 5. taktéž žlutý, slabě šedě zkalený, zvl. ke konci, 6. a 7. žlutošedé. Prothorax v poměru $k$ hlavě o něco delší než obyčejně. Nohy šedohnědé, tarsy a přední tibie celé, přední femora na samém konci žlutavé. Hlavní žilka $\mathrm{v}$ druhé své polovině se třemi chlupy, $\mathrm{z}$ nichž první jest od obou ostatních oddálen; vedlejší po celé své délce s četnými chlupy. Hoř. křídla celá šedohnědě zkalená, jen na basi se světlým mistem. Délka tèla $0 \cdot 7 \mathrm{~mm}$.

$$
\sigma^{7} \text {. Nebyl posud objeven. }
$$

Jediný exemplár̆, který mám, prosiván z drnu v srpnu u Vys. Újezda nedaleko Tr̉ebechovic.

†.

Körper kleiner und schwächer als bei der vorhergehenden Art. Körperfarbe graubraun. Kopf etwa so lang wie breit, seine Wangen bedeutend gewölbt. Fühlerglieder ziemlich kurz und breit. Das 1. ist sehr kurz und so breit wie das 2., das 3. u. 4. untereinander fast gleich lang, das 5 . bedeutend kürzer, das 7. verhältnismässig lang. Fühlerfärbung: 1. u. 2. Glied gelbgrau, 3. u. 4. gelb, das 5. ebenfalls gelb, schwach grau getrübt, hauptsächlich gegen das Ende zu, das 6. u. 7. gelbgrau. Prothorax im Verhältnis zum Kopfe etwas länger als gewöhnlich. Beine graubraun, die 'Tarsen und die Vordertibien ganz, die Vorderschenkel am äussersten Ende gelblich. Die Hauptader in ihrer zweiten Hälfte mit drei Borsten, von denen die erste von den beiden übrigen entfernt ist; die Nebenader ihrer ganzen Länge nach mit zahlreichen Borsten besetzt. Die ganzen Oberflügel graubraun getrübt, nur auf dem Grunde mit einem hellen Fleck. Körperlänge $0.7 \mathrm{~mm}$.

$$
\text { ठ unbekannt. }
$$

Vorkommen: Im August im Rasen. - Fundort: Böhmen.

\section{Thrips nigropilosa nov. sp.*)}

Tab. VI., fig. 105. et 106 .

$$
\text { ․ }
$$

Barva tèla i celých noh žlutá. Výjimkou jest celé tělo více nebo méně šedě zkaleno. Veškeré chlupy na těle jsou dlouhé, silné a černé. Hlava o něco širší než delší. První čl. tykadel trochu kratší a slabší než 2., tento mohutný, 3. a 4. mezi sebou Praep. Nr. 60.

*) Doklad ve sbírce musejní, praep. č. 60. - Sammlung des böhmischen Landesmuseums, 


\section{J. UZEL, MONOGRAFIE RADU, "THYSANOPTERA“.}

skoro stejně dlouhé; 5. málo kratší, 7. čl. poměrně dlouhý. Barva tykadel: 1. ěl. čirý, 2. žlutavý, 3. taktéž žlutavý, více nebo méně šedẽ zkalený, na konci silněji, 4 . silně šedẽ zkalený, na basi slaběji, 5., 6. a 7. černošedé. Prothorax o něco hlavy delší. Délka těla $0 \cdot 8 \mathrm{~mm}$.

FORMA MA GROPTERA. Hor̃. kǐídla slabě žlutavě zkalená. Hlavní żilka má v druhé své polovině dva chlupy.

F ORMA BRA CHY P TERA. Kř́dla jsou bud tak zkrácená, že nepřesahují pterothorax, nebo dosahuji jen ětvrtého čl. abdom. Pterothorax jest trochu kratší než u formy dlouhokrídlé.

Var. laevior. Nahoře na abdomenu jsou chlupy velmi slabé. Křídla jsou zkrácená a sahají jen až ke čtvrtému čl. abdom.

$\sigma^{\top}$

Značně menší než + , 1.-3. čl. tykadel světlé, 4., 5. a 6 . šedé, na basi světlé. Kř́del jen rudimenta pterothorax nepřesahující. Na 3.-7. čl. abdom. dole po jedné piškotovité, dosti nezřetelné prohlubině.

Třásněnka tato žije po celý rok v drnu luc̀ním i lesním. V zimě vyskytuje se jen forma krátkokríidlá, mezi níž jsou jednotlivé exempláře, jichž rudimenta křidel dosahuji až k čtvrtému čl. abdom. Od dubna do listopadu vylézaji mnohé exempláře na rozličné rostliny nekvetoucí, a též jednotlivě v květech se vyskytují. Mezi nimi již od dubna nalézáme některé dlouhokřídlé, jichž počet značně vzroste $v$ měsíci srpnu, načež rỵchle mizejí, takže počátkem září zaniknou úplně, a přes zimu do dubna zase jen krátkokrídlé samice se objevují. Samce nalezl jsem ve dvou exempl., a sice jednoho v polovici srpna a druhého 18. zárín.

Čechy: Praha: V Divoké Šáree. Hradec Králové. Třebechovice. Opočno. Jaromẹr. Krkonoše: Na Sněžce nedaleko Obří boudy. Liberec.

\section{ㅇ.}

Farbe des Körpers und der Beine gelb. Ausnahmsweise ist der ganze Körper mehr oder weniger grau getrübt. Alle Borsten auf dem Körper sind lang, stark und schwarz. Kopf etwas mehr breit als lang. Erstes Glied etwas kürzer und dünner als das 2.; dieses mächtig; das 3. u. 4. untereinander fast gleich lang, das 5. wenig kürzer, das 7. verhältnismässig lang. Fühlerfärbung: 1. Glied klar; das 2. gelblich, das 3. ebenfalls gelblich, mehr oder weniger grau getrübt, am Ende stärker, das 4. stark grau getrübt, am Grunde schwächer, das 5., 6. u. 7. schwarzgrau. Prothorax etwas länger als der Kopf. Körperlänge $0.8 \mathrm{~mm}$.

FORMA MAGROPTERA. Die Oberflügel schwach gelblich getrübt. Die Hauptader in ihrer zweiten Hälfte mit zwei Borsten. 
FORMA BRACHY PTERA. Flügel entweder so verkürzt, dass sie den Pterothorax nicht überragen, oder sie reichen nur bis zum 4. Abdominalsegment. Pterothorax etwas kürzer als bei der langflügeligen Form.

Var. laevior. Die Borsten oben auf dem Abdomen sehr schwach. Die Flügel reichen bis zum 4. Abdominalsegment.

$\sigma^{7}$

Bedeutend kleiner als das $\subsetneq ;$ 1.-3. Fühlerglied licht, 4., 5. u. 6. grau, am Grunde lichter. Die Flügel zu Rudimenten verkümmert, die den Pterothorax nicht überragen. Auf dem 3.-7. Abdominalsegmente unten je eine ziemlich lange, in der Mitte verengte, undeutliche Vertiefung.

Vorkommen: Weibchen das ganze Jahr hindurch im Rasen. In der warmen Jahreszeit viele Exemplare auch auf verschiedenen nichtblühenden Pflanzen und einzeln in Blüten. Darunter einige (die meisten im August) langflügelig. Männchen im August und September. - Fund ort: Böhmen.

\section{Thrips discolor Halid.*)}

1776. Thrips obscura flavescens, elytris pallidis; oculis abdominisque ammulis nigris; Müller, Zoologiae danicae Prodromus, pag. 96.

1788. - - Gmelin, Caroli a Linné Systema Nat., pag. 2223.

1836. - discolor Haliday, Entomolog. Nagazine, pag. 449.

1836. - pallens Idem, ibidem, pag. 450.

- 1836. - - Burmeister, Handb. d. Entomologie, II, pag. 416.

1843. - discolor Amyot et Serville, Ins. Hémiptères, pag. 644.

1843. Tmetothrips pallens Iidem, ibidem, pag. 645 .

1852. Thrips discolor Haliday, Walker: Homopt. ins. of Brit. Museum, pag. 1112.

1852. - pallens Idem, ibidem, pag. 1115.

$$
\text { ?. }
$$

Hlava a thorax ochrové až hnědožluté, celý abdomen leskle černý. Hlava sotva širší než delší. Očka sice prítomna, avšak bez pigmentu a tudiž nezřetelná. První čl. tykadel dosti mohutný, kratší než druhý, tento, pak 3. a 4. mezi sebou skoro stejně dlouhé; 7. čl. poměrně dlouhý. Barva tykadel: 1. čl. světlý, někdy se slabým šedým náletem, 2. tmavý, na konci světlý, 3. svètlý, s šedým nádechem, zvl. ke konci, 4. šedý, 5. tmavý, na basi světlejší, 6. a 7. tmavé. Prothorax nepatrně hlavy delší. Barva noh Praep. Nr.61.

*) Doklad ve sbírce musejní, praep. ě. 61. - Sammlung des böhmischen Landesmuseums, 
bývá skoro stejnoměrně žlutavá, často však jsou femora před basí, a to zvl. zadní, šířeji neb úžeji šedě zkalená. Délka tèla $0.8 \mathrm{~mm}$.

FORMA MAGROPTERA (= T. discolor Halid.). Horejší krídla trochu prohnutá. Hlavní žilka se čtyřmi chlupy nad místem kde začíná žilka vedlejší, a se dvèma na svém konci. Vedlejší jest stejnoměrnè po celé své délce chlupy posetá. Hoř. krìidla jsou slabẽ žlutavě zkalená.

FORMA BRA GHYPTERA ( $=T$. pallens Halid.). Krídel jen rudimenta pterothorax nepresahujicí. Tento značně kratší a užší než u formy dlouhokrídlé.

$$
\text { J. }
$$

Dle Halidaye světlejší ně̌ samice.

Forma krátkokřídlá této lǐ̌ásněnky žije $\mathrm{v}$ drnu, kdež jsem ji nalézal $\mathrm{v}$ květnu, srpnu a listopadu. V srpnu sbíral jsem též formu dlouhokřídlou. Tato dle Halidaye vyskytuje se na křižokvětých (asi náhodou).

Čechy: Hradec Králové. Třebechovice. Opočno: V háji Chropotíně.

\section{q.}

Kopf und Thorax ocher- bis braungelb, das ganze Abdomen glänzend schwarz. Kopf kaum mehr breit als lang. Ocellen wohl vorhanden, jedoch ohne Pigment und infolge dessen undeutlich. Das erste Fühlerglied ziemlich mächtig, kürzer als das zweite, dieses, dann das 3. u. 4. untereinander fast gleich lang, das 7. verhältnismässig lang. Fühlerfärbung: 1. Glied licht, manchmal schwach grau angehaucht, das 2. dunkel. am Ende licht, das 3. licht, mit grauem Anflug, hauptsächlich gegen das Ende zu, das 4. grau, das 5. dunkel, am Grunde lichter, das 6. und 7. dunkel. Prothorax unbedeutend länger als der Kopf. Die Färbung der Beine pflegt fast gleichmässig gelblich zu sein; oft sind jedoch die Schenkel, und zwar hauptsächlich die hinteren, breiter oder schmäler grau getrübt. Körperlänge $0.8 \mathrm{~mm}$.

FORMA MA CROPTERA (=T. discolor Halid.). Die Oberflügel etwas gebogen. Die Hauptader über der Stelle, wo die Nebenader ihren Ursprung hat, mil vier, und am Ende mil zwei Borsten besetzt. Die Nebenader ist gleichmässig der ganzen Länge nach mil Borsten versehen. Die Oberflügel sind schwach gelblich getrübt.

FORMA BRAciYPterA ( $T$. pallens Halid.). Die Flügel zu Rudimenten verkümmert, die den Pterothorax nicht überragen. Dieser bedeutend kürzer und schmäler als bei der langflügeligen Form.

Nach Haliday lichter als das Weibchen. 


\section{H. UZEL, MONOGRAPHIE DER ORDNUNG THYSANOPERA.}

V or k ommen: lm Rasen. Die kurzflügelige Form fand ich im Mai, August und November, die langflügelige Form im August. - Fundorte: Dänemark (Müller), England (Haliday), Böhmen.

\section{Thrips dilatata nov. sp.*)}

†.

Barva těla černá, pterothorax tmavohnědý. Chlupy na těle silné a dlouhé. Hlaviı širší než delši. Oči trochu vykoulené. Pruní čl. tykadel kratší než 2., skoro právě tak silný, 2., 3. a 4. čl. mezi sebou asi stejnẽ dlouhé. Barva tykadel šedohnědá, 3. čl. žlutavý. Femora černohnědá, předni tibie žlutavé, po obou stranách tmavě zkalené, ostatni tibie černohnědé, na konci žlutavé; tarsy celé žlutavé. Abdomen široký, nejširši v tomto rodu. Délka těla $0.9-1 \mathrm{~mm}$.

FOR MA MA GR OPTERA. Hoř. kríila šedohnědě zkalená, na basi čirá, ke konci poznenáhla světlejší. Hlavní žilka ke konci se třemi chlupy, od sebe skoro stejnè vzdálenv́mi.

F O R M A BR A GH Y P TER A. Kř́ídel jen rudimenta pterothorax nepresahujicí. Tento poměmě liratši a užší než u formy dlouhokirídlé.

$$
\sigma^{x}
$$

Menší než f a sotva světlejši. Kř́idel jen rudimenla. Pterothorax krátký. Na 3. až 7. čl. abdom. na spodní straně po jedné piškotovité bílé prohlubině.

Třásněnka tato žije $\mathrm{v}$ drnu lesním a zdržuje se nèkdy $\mathrm{v}$ květech, tak zvl. od Pedicularis palustris. Formu krátkokřídlou nalezl jsem $\mathrm{v}$ květnu a červnu, formu dlouhokříllou v kvělnu a záŕí. Samce sbíral jsem v červnu a srpnu.

Čechy: Hradec Királové: Na Obické. Tr̉ebechovice: U Vys. Újezda. Vrchlabí: U Hackelsdorfu. Jindri. Hradec: V oboře (Duda).

$$
\text { Q. }
$$

Farbe des lioples, des Prothorax und des Abdomen schwarz, der Pterothorax dunkelbraun. Borsten auf dem Körper stark und lang. Kopf mehr breit als lang. Augen etwas hervorgequollen. Erstes Fühlerglied kürzer als das 2., fast ebenso stark, das 2., 3. und 4. Glied untereinander fast gleich lang. Fühlerfärbung graubraun, das 3. Glied gelblich. Schenkel schwarzbraun, die Vordertibien gelblich, jederseits dunkel getrübt, die übrigen

*) Doklad ve sbirce musejní, praep. č. 62. - Sammlung des böhmischen Landesmuseums, Praep. Ni. 62. 


\section{J. UZEL, MONOGRAFIE RADU, „THYSANOPTERA“.}

Tibien schwarzbraun, am Ende gelblich; die Tarsen gelblich. Abdomen breit, am breitesten im ganzen Genus. Körperlänge $0.9-1 \mathrm{~mm}$.

FORMA MACROPTERA. Die Oberflügel graubraun getrübt, auf dem Grunde klar, gegen das Ende zu allmählich lichter. Die Hauptader in ihrer zweiten Hälfte mit drei Borsten, welche von einander fast gleich entfernt sind.

F ORMA BRA CHY P TERA. Flügel zu Rudimenten verkümmert, die den Pterothorax nicht überragen. Dieser ist verhältnismässig kürzer und schmäler als bei der langflügeligen Form.

Kleiner als das $\subsetneq$ und kaum lichter. Flügel rudimentär. Pterothorax kurz. Auf dem 3.-7. Abdominalsegmente unten je eine lange, in der Mitte zusammengezogene, weisse Vertiefung.

Vorkommen: Im Waldrasen und zuweilen in Blüten (hauptsächlich von Pedicularis palustris). Kurzflügelige Weibchen fand ich im Nai und Juni, Jangflügelige im Mai und September, Männchen im Juni und August. - Fundort: Böhmen.

\section{Thrips Klapáleki nov. sp.*)}

Tab. VI., fig. 107.

$$
\text { +. }
$$

Tělo mohutné, barvy černé. Hlava trochu delší než širší oči vykoulené. Tykadla silná a dlouhá. První dva články jejich skoro stejné délky, první článek však širší než 2.; 3. a 4. čl. taktéž mezi sebou skoro stejně dlouhé, na basi a na konci zúžené, 5. nejslabší, značně kratší než předcházející, 7. poměrně dlouhý. Barva tykadel: 1. a 2. čl. černohnědé, 2. na konci žlutavý, 3. také žlutavý, někdy, zvl. nahoře, šedě zkalený, 4.-7. šedohnědé, 4. na basi a na konci světlý. Prothorax jest o něco kratší než hlava. Pterothorax poměrně kratší než u ostatních zástupcủ tohoto rodu. Femora čemohnědá. Pr̉ední tibie žlutavé, na samé basi a po stranách trochu tmavě zkalené, střední as do polou černohnědé, od polou žlutavé, zadní celé černohnědé, jen špička jejich žlutavá. Tarsy celé žlutavé. Křídla jsou krátká, prohnutá, hořejši značnè šedohnědě zkalená, na basi čirá. Hlavní žilka má ke konci tři chlupy, z nichž jeden jest od obou ostatních více vzdálen; vedl. žilka s četnými chlupy. Abdomen na konci značně zúžený. Dálka těla $1.3 \mathrm{~mm}$. -- Šest exempl. nalezeno.

$$
\sigma^{7} \text {. Nebyl posud objeven. }
$$

Vzácný ten druh sbíral jsem $\mathrm{v}$ květnu na lukách, rozkládajicích se na úpatí Milešovky, a to $\mathrm{v}$ květech od Orchis sambucina.

*) Dovolil jsem si nazvati tento druh dle pana professora Fr. Klapálka v Treboni. Doklad ve sbirce musejni, praep. ¿. 63. - Sammlung des böhmischen Landesmuseums, Praep. Nr. 63. 


$$
f .
$$

Körper mächtig, schwarz. Kopf etwas mehr lang als breit; Augen hervorgequollen. Fühler stark und lang. Ihre ersten zwei Glieder fast gleich lang, das erste jedoch breiter als das 2., das 3. u. 4. untereinander ebenfalls fast gleich lang, auf dem Grunde und auf dem Ende verengt, das 5. am schwächsten. bedeutend kürzer als das vorhergehende, das 7. verhältnismässig lang. Fühlerfärbung: 1. u. 2. Glied schwarzbraun, das 2. am Ende gelblich, das 3. ebenfalls gelblich, manchmal, hauptsächlich oben, die beiden Enden ausgenommen, grau getrübt, das 4.-7. graubraun, das 4. am Grunde und am Ende licht. Prothorax um etwas kürzer als der Kopf. Pterothorax verhältnismässig kürzer als bei den übrigen Arten dieses Genus. Schenkel schwarzbraun. Die Vordertibien gelblich, an der Wurzel und an den Seiten etwas dunkel getrübt, die Mitteltibien etwa bis zur Mitte schwarzbraun, von der Mitte an gelblich, die Hintertibien ganz schwarzbraun, nur ihre Spitze gelblich. Die Tarsen gelblich. Flügel kurz, gebogen, die oberen bedeutend graubraun getrübt, auf dem Grunde klar. Die Hauptader gegen ihr Ende zu mit drei Borsten besetzt, von denen die erste von den übrigen zwei entfernt ist; die Nebenader mit zahlreichen Borsten versehen. Abdomen auf dem Ende bedeutend verengt. Körperlänge $1.3 \mathrm{~mm}$.

$$
\text { ठ unbekannt. }
$$

Vorkommen: Im Mai in den Blüten von Orchis sambucina. - Fundort: Böhmen.

\section{Thrips fuscipennis Halid.}

1836. Thrips fuscipemis Haliday. Entom. Magazine, pag. 446. (bez popisu ohne Beschreibung).

1852. - - Haliday, Walker: Homopt. insects of Brit. Museum, pag. 1111 .

Haliday (anno 1852.): „Fusca vel fusco-testacea, abdomine citra basin obscuriore, antennis basi, tibiis apice tarsisque pallidioribus, hemelytris fuscanis basi albida. Oculis glabris, fem. (Nas minor, pallidior, abdominis incisuris fuscis, hemelytris pallidis?) Hab. in gramine pascuorum Julio mense frequens, in Rumice etc."

\section{GENUS BALIOTHRIPS Halid.*)}

Očka prítomna. Tyliadla sedmičlenná; 5. c̀l. jejich na konci utatý, takže těsně přiléhá $\mathrm{k}$ šestému; stỵlus jest jednočlennỵ. Makadla maxillarní o dvou článcích. Prothorax o málo delší než hılava, vzadu o trochu širši než $\mathbf{v}$ předu; na zadních rozích po dvou

*) Bàisz = pestrý, bunt. 


\section{J. UZEL, MONOGRAFIE RADU, "THYSANOPTERA“.}

dlouhých smyslových chlupech. Pr̉ední nohy bezbranné. Krídla prítomna, přední naprìčc černě stuhovaná, ostatně jako u rodu předcházejícího utvořená. Samci dle Halidaye jsou bezkřídlí.

Augen vorhanden. Fühler siebengliedrig; ihr 5. Glied auf dem Ende abgestutzt, so dass es sich mit breiter Fläche an das 6. Glied anlegt; der Stylus ist eingliedrig. Maxillartaster zweigliedrig. Prothorax wenig länger als der Kopf, hinten etwas breiter als vorn; auf seinen Hinterecken je zwei lange Sinnesborsten. Vorderbeine wehrlos. Flügel vorhanden, die vorderen schwarz gebändert, übrigens wie bei dem vorhergehenden Genus. Die Männchen sind nach Haliday flügellos.

\section{Baliothrips dispar Halid.*)}

Tab. VII., fig. 108. et 109 .

1836. Thrips dispar Haliday, Entomol. Magazine, pag. 449.

1836. - brevicornis Idem, ibidem.

1836. - dispar Burmeister, Handb. d. Entomologie, II, pag. 416.

1836. - brevicornis Idem, ibidem.

1843. Taeniothrips dispar Amyol et Serville, Ins. Hémiptères, pag. 644.

1843. - brevicornis Iidem, ibidem.

1852. Thrips dispar Haliday, Walker: Homopt. ins. of Brit. Museum, pag. 1113.

$$
\text { q. }
$$

Barva tèla černá. pterothorax hnědý. Hlava jen trochu širší než delší. Oči poněkud vykoulené. První čl. tykadel kratši než 2., 4. a 5. mezi sebou skoro stejně dlouhé, 3. trochu delší. Barva tykadel: 1. a 2. čl. černé, 2. ke konci světlejší, 3. světlý, 4. šedè zkalený, 5., 6. a 7. černé. Všecka femora černá. Tibie žlutavé. na basi, zadní skoro do polou, černé. Tarsy žlutavé. Hlavní žilka ke konci se třemi chlupy. z nichž proní jest více nebo ménè od ostatních vzdálen; žilka vedlejší četnými chlupy stejnoměrně poseta. Hoř. křídla jsou světlá, $\mathrm{v}$ druhé a v poslední čtvrtině tmavẽ zkalená; před špičkou nalézá se někdy na tmavé půdẽ podélné více nebo méně světlé místo. Dolejší kîídla jsou čirá a v druhé a poslední ětvrtině slabě zkalená. Abdomen vzadu značněji zúžený a zašpičatělý. Délka těla $0.9 \mathrm{~mm}$.

$$
\sigma^{\top} .
$$

Barva těla dle Ha lid a ye černohnědá; tykadla bledá, na basi a na konci tmavá, nohy bledé, přední a střední femora na basi a zadní, kromě koncủ, tmavá; kř́idel jen rudimenta.

*) Doklad ve sbirce musejní, praep. ě. 64. - Sammlung des böhmischen Landesmuseums, Praep. Nr. 64. 


\section{H. UZEL, MONOGRAPHIE DER ORDNUNG THYSANOPTERA.}

Třásněnku tuto chytil jsem (10 exempl.) v sıpnu u Opočna do vlečné sítě, kterou smykal jsem po nekvetoucích rostlinách. Dle Halidaye nalézá se v klasech od Festuca fluitaus a jiných travin na podzim.

$$
\text { P. }
$$

Kopf, Prothorax und Abdomen schwarz, Pterothorax braun. Kopf nur etwas mehr breit als lang. Augen etwas hervorgequollen. Erstes Fühlerglied kürzer als das 2., das 4. u. 5. untereinander fast gleich lang, das 3. etwas länger. Fühlerfärbung: 1. u. 2. Glied schwarz, das 2. gegen das Ende lichter, das 3. licht, das 4. grau getrübt, das 5., 6. u. 7. schwarz. Alle Schenkel schwarz. Tibien gelblich, am Grunde, die hinteren fast bis zur Hälfte, schwarz. Tarsen gelblich. Die Hauptader gegen das Ende zu mit drei Borsten besetzt, von denen die erste von den übrigen zwei mehr oder weniger entfernt ist; die Nebenader mit zahlreichen Borsten gleichmässig besetzt. Die Oberflügel licht, in dem zweiten und letzlen Viertel dunkel; vor der Spitze befindet sich manchmal auf dunklem Boden ein mehr oder weniger lichter länglicher Fleck. Die Unterflügel hell, im zweiten und letzten Viertel schwach getrübt. Abdomen hinten ziemlich stark verengt und zugespitzt. Körperlänge $0.9 \mathrm{~mm}$.

$$
\sigma^{\top}
$$

Körperfarbe nach Haliday schwarzbraun; Fühler blass, am Grunde und am Ende dunkel; Beine blass, die Vorder- und Mittelschenkel am Grunde und die Hinterschenkel, das Ende ausgenommen, dunkel; Flügel rudimentär.

Vorkommen: Im August auf nichtblühenden Pflanzen. In England nach Haliday im Herbst auf Festuca fluitans und anderen Grasarten. Fundorte: England (Haliday), Böhmen.

\section{1. (GENUS SMINYOTHRIPS. (Nov gen.)*)}

Očka přitomna. Tykadla sedmičlenná, stylus jednočlenný. Makadla maxillarní o třech článcích. Lištna, obrubující nahoře zadní okraj hlavy, jest uprostřed přerušena. Prothorax o něco delší ně̌ hlava; na zadních rozích jeho po dvou chloupcích smyslových. Přední tibie u obou pohlaví na konci dole se dvẽma ohnutými zuby opatřené. Kř́íla u samic a samcu prítomna, podobnè utvořená jako u rodu Thrips, jen brvy na predním okraji hořejších křídel, mezi třásněmi se nalézající, jsou slabé, a to zvl. ty, které stoji na vnẹjší její polovici.

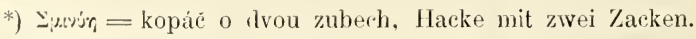




\section{J. UZEL, MONOGRAFIE RADU, "THYSANOPTERA“.}

Ocellen vorhanden. Fühler siebengliedrig (Stylus eingliedrig). . Naxillartaster dreigliedrig. Die Leiste, welche den Hinterrand des Kopfes oben umsäumt, ist in der Mitte unterbrochen. Prothorax etwas länger als der Kopf; auf seinen Hinterecken je zwei Sinnesborsten. Vordertibien am Ende unten bei beiden Geschlechtern mit zwei gebogenen Zähnen bewaffnet. Flügel beim Weibchen und beim Männchen vorhanden, ähnlich wie bei dem Genus Thrips gebildet, nur sind die Wimpern, welche sich am Vorderrande der Oberflügel zwischen den Fransen befinden, schwach, und zwar hauptsächlich jene, welche auf seiner äusseren Hälfte stehen.

\section{Sminyothrips biuncinata nov. sp.*)}

Tab. VII., fig. 110.

$$
\text { †. }
$$

Barva těla šedožlutá, hlava někdy tmavší. Tato skoro právě tak dlouhá jako široká, se stranami dosti rovnými. Očka všecka skoro stejně veliká. Druhý čl. tykadel sotva delší než $1 ., 3$. trochu delší než 2 ., 4. trochu kratší než předcházející, 5. kratší než 4., na konci utatý. Barva tykadel žlutavá, 1., 2. a 4. čl. slaběji, 5., 6. a 7. silně šedě zkalené. Druhỵ článek jest na konci žlutavý; vỹjimkou jest celý žlutý a jen na basi trochu šedè zkalený. Přední tibie na konci dole se dvěma krátkými zoubky vedle sebe. Tyto jsou v předu před koncem chloupkem opatřeny. Nohy kromě tarsû, předních tibií a konců tibií ostatních žlutošedé, tmavší než tělo. Přední tibie žlutavé, vně značněji, uvnitĩ slaběji šedě zkalené; konce tibií ostatních a tarsy żlutavé. Chlupy na žilkách slaboučké. Hlavní žilka má ke konci tři chloupky, z nichž první jest od obou ostatních oddálen. Vedlejší žilka jest četnými chloupky posetá. Hořejši křídla jsou slabě žlutavě zkalená. Abdomen jest ke konci značně zúžený. Délka těla $0.8 \mathrm{~mm}$. - Sedm exempl. nalezeno.

$$
\sigma^{\pi}
$$

Trochu menši než $q$, téže barvy. Na břišní straně 3.-7. čl. abdom. nalézá se po jedné elliptické světlé prohlubině. Druhý čl. tykadla jest skoro celý žlutavý, jen na basi slabě šedě zkalený. - Jediný exempl. objeven. v květnu.

Trìáněnka tato nalezena $\mathrm{v}$ kvẽtech pryšcových na lukách královéhradeckỵch

$$
\text { †. }
$$

Körperfarbe graugelb, Kopf manchmal dunkler. Dieser fast ebenso lang wie breit, seine Wangen kaum gewölbt. Alle Ocellen fast gleich gross. Das 2. Fühlerglied kaum

*) Doklad ve sbirce musejní, praep. č. 65. — Sammlung des böhmischen Landesmuseums, Praep. Nr. 65. 
länger als das 1., das 3 . etwas länger als das vorhergehende und das folgende, das 5 . kürzer als das 4., auf dem Ende abgestutzt. Fühlerfärbung gelblich, 1., 2. u. 4. Glied schwächer, 5., 6. u. 7. stärker grau getrübt. Das 2. Glied ist am Ende gelblich, ausnahmsweise ist es ganz gelblich und nur am Grunde etwas grau getrübt. Vordertibien am Ende unten mit zwei kurzen Zähnchen, die nebeneinander stehen. bewalfnet. Dieselben sind vorn vor dem Ende mit einem Härchen versehen. Beine, die Tarsen, die Vordertibien und die Enden der übrigen Tibien ausgenommen, gelbgrau, dunkler als der Körper. Die Vordertibien gelblich, aussen stärker, innen schwächer grau getrübt; die Enden der übrigen Tibien und die Tarsen gelblich. Die Borsten auf den Adern sehr schwach. Die Hauptader hat in ihrer zweiten Hälfte drei kleine Borsten, von denen die erste von den übrigen zwei entfernt ist. Die Nebenader mit vielen Borsten besäet. Die Oberflügel schwach gelblich getrübt. Ahdomen gegen das Ende zu verengt. Körperlänge $0.8 \mathrm{~mm}$.

$$
\delta .
$$

Etwas kleiner als das $q$ und ebenso gefärbt. Auf der Bauchseite des 3.-7. Abdominalsegmentes befindet sich je eine elliptische lichte Vertiefung. Das 2. Fühlerglied immer fast ganz gelblich, nur am Grunde schwach grau getrübt.

Vorkommen: Im Nai in den Blüten von Euphorbia. - Fundort: Böhmen.

\section{Sminyothrips biumcata nov. sp.*)}

Tab. VII., fig. 111.

$$
\text { f. }
$$

Barva těla tmavě žlutošedá; chlupy na něm silnější než u druhu předcházejícího. Hlava trochu širší ně̌ delší, se stranami poněkud vypouklými. Přední očko o polovinu menší ně̌ zadní. Tykadla s články krátkými, okrouhlými; 1. a 2. čl. mezi sebou skoro stejně dlouhé; 3. as tak dlouhý jako 2. i 4. Barva tykadel: 1. čl. a 4. žlutošedé, 5., 6. a 7.černošedé, 2. nejsvětlejší, žlutavý, jen na basi a po obou stranách velmi slabě šedě zkalený, tr̉etí žlutavý s šedým náletem. Prothorax trochu delší než u druhu předcházejícího. Přední tibie na konci dole se dvěma dosti silnými, ohnutými zuby, jež jsou chloupkem $\mathrm{v}$ předu před koncem opatřeny. Všecky tarsy a přední tibie žlutavé, tyto po obou stranách trochu šedě zkalené. Přední femora žlutošedá, ostatní femora a střední i zadní tibie skoro černošedé. Chlupy na žilkách dosti silné. Hlavní žilka ke konci se třemi chlujy, z nichž první jest od obou ostatních oddálen. Vedl. žilka četnýıni chlupy poseta. Hoř. kríidla žlutošedě zkalená, na basi světlejší. Abdomen není ke konci nápadně zúżen. Délka tèla $1 \mathrm{~mm}$. - Jediný exempl. nalezen.

\footnotetext{
*) Doklarl ve sbíree autorovè.
} 
J. UZEL, MONOGRAFIE RADU "THYSANOPTERA".

万. Nebyl posud objeven.

Trásnènku tuto nalezl jsem $\mathrm{v}$ květnu mezi travou na Milešovce.

q.

Körperfarbe dunkel gelbgrau; die Borsten auf dem Körper stärker als bei der vorhergehenden Art. Kopf etwas mehr breit als lang, seine Wangen etwas gewölbt. Das vordere Nebenauge um die Hälfte kleiner als die beiden hinteren. Fühlerglieder kurz, rundlich; 1. u. 2. Glied fast gleich lang; das 3. etwa so lang wie das 2. u. 4. Fühlerfarbe: 1. u. 4. Glied gelbgrau, das 5., 6. u. 7. schwarzgrau, das 2. am lichtesten, gelblich, nur am Grunde und jederseits sehr schwach grau getrübt, das 3. gelblich mit grauem Auflug. Prothorax etwas. länger als bei der vorhergehenden Art. Die Vordertibien auf dem Ende unten mit zwei ziemlich starken, gebogenen Zähnen bewaffnet, welche vorn vor dem Ende mit einem Härchen versehen sind. Alle Tarsen und die Vordertibien gelblich, diese jederseits etwas grau getrübt. Vorderschenkel gelbgrau, die übrigen und die Mittel- u. Hintertibien fast schwarzgrau. Die Oberflügel gelbgrau getrübt, am Grunde lichter. Die Borsten auf den Adern ziemlich stark. Die Hauptader in ihrer zweiten Hälfte init drei Borsten besetzt, von denen die erste von den beiden übrigen entfernt ist. Die Nebenader mit zahlreichen Borsten versehen. Körperlänge $1 \mathrm{~mm}$.

$$
\delta^{\pi} \text { unbekannt. }
$$

Vorkommen: Im Nai in Rasen. - Fundort: Böhmen.

\section{GENUS STENOTHRIPS. (Nov. gen.)*)}

Tělo velmi úzké. Hlava o čtvrtinu delší než širší. Očka př́itomna. Tykadla sedmičlenná (stylus jednočlenný). Nakadla maxillarní o dvou článcích, z nichž druhý jest skoro dvakrát delší prvého; je zřejmo, že povstal srủstem dvou článkủ. Prothorax as tak dlouhý jako hlava, na zadních jeho rozích po dvou chlupech smyslovỹch. Nohy bezbranné. Kř́dla podobně utvořená jako u rodu Thrips, jen o něco užší; u obou pohlaví přítomná. Desátý čl. abdom. jest nahoře rozčisnutý.

Körper sehr schmal. Kopl' um ein Viertel mehr lang als breit. Ocellen vorhanden. Fühler siebengliedrig (Stylus eingliedrig). Maxillartaster zweigliedrig; ihr zweites Glied fast zweimal so lang als das erste und offenbar aus zwei ursprünglichen Gliedern zu-

*) บ̌svós $=$ úzký, schmal. 


\section{H. UZEL, MONOGRAPHIE DER ORDNUNG THYSANOPTERA.}

sammengewachsen. Prothorax etwa so lang wie der Kopf; auf seinen Hinterecken je zwei Borsten. Beine wehrlos. Flügel ähnlich denjenigen der Gattung Thrips, nur etwas schmäler; bei beiden Geschlechtern vorhanden. Das 10. Abdominalsegment oben aufgeschlitzt.

\section{Stenothrips graminum nov. sp.*)}

Tab. II., fig. 16 .<smiles>[CH]1[CH-]C1</smiles>

Barva těla žlutavošedá až světle šedohnědá; hlava a konec abdomenu jsou tmavší, často dosti silně šedohnědé. Hlava má na týle velmi četné husté vrásky. První čl. tykadel kratší a slabší než druhý, 3. a 4. čl. mezi sebou skoro stejně dlouhé, 5. trochu kratší, 7. čl. dosti dlouhý, často tupý. Barva tykadel: dva první články žlutavé, slabě šedě zkalené, třetí žlutavý, nezkalený, 4., 5., 6. a 7. černošedé, 4. dole nèkdy trochu světlejší. Na zadním okraji prothoraxu nalézá se kromě delších chlupủ smyslových na každé straně ještě pět malých chloupků. Femora žlutavošedá, tibie žlutavé, střední a zadní na basi trochu šedě zkalené, tarsy žlutavé. Hořejší křídla slabě žlutošedẽ zkalená, na basi sotva světlejší a před kořenem uprostřed s podélným čirým okénkem. Hlavní žilka má v druhé své polovině tr̆i chlupy, z nichž jeden od ostatních dvou jest oddálen; vedlejši žilka jest po celé své délce četnými chlupy poseta. Na konci abdomenu jsou slabé chlupy. Délka těla $0.9 \mathrm{~mm}$.

$$
\delta^{x}
$$

Menší než $\subsetneq$; barva těla a noh světlejší; hlava a konec abdomenu jsou nejtmavšími částmi. Na spodní straně 3.-7. čl. abdom. nalézá se po jedné okrouhlé, světlé prohlubinè.

Poznámka. Tento druh celým svým vzhledem upomíná ponèkud na Halida y ủ v druh Limothrips cerealium, rozeznává se však od něho hlavně tykadly sedmičlennými (stylus jest jednočlenný), samci vždy okřídlenými, koncem abdomenu u obou pohlaví netrnitým a neostnitým.

Třásněnka tato žije $\mathrm{v}$ květenství trav lučních a $\mathrm{v}$ klasech obilných. $\mathrm{V}$ ječmeni vyskytuje se někdy $\mathrm{v}$ převelikém množství; také na ovse jest časem hojná; $\mathrm{r}$ pšenici a v žitě jí bývá poskrovnu. Samice i samce nalezl jsem v červnu a v červenci.

Čechy: Praha. Mukařov. Hradec Králové. Třebechovice. Jindř. Hradec (Duda).

*) Doklad ve sbirce musejní, praep. č. 66. - Sammlung des böhmischen Landesmuseums, Praep. Nr. 66. 


\section{J. UZEL, MONOGRAFIE RADU „THYSANOPTERA“.}

f.

Körperfarbe gelblichgrau bis licht graubraun; der Kopf und das Abdomenende dunkler, oft ziemlich stark graubraun. Das Hinterhaupt ist mit zahlreichen, dicht gedrängten Runzeln versehen. Erstes Fühlerglied kürzer und schwächer als das 2., das 3. u. 4. untereinander fast gleich lang, das 5. etwas kürzer, das 7. ziemlich lang, oft stumpf. Fühlerfärbung: die ersten zwei Glieder gelblich, schwach grau getrübt, das dritte gelblich. ungetrübt, das 4., 5., 6. u 7. schwarzgrau, das 4. unten manchmal etwas lichter. Am Hinterrande des Prothorax befinden sich ausser den längeren Borsten jederseits noch fünf kleine Härchen. Schenkel gelblichgrau, Tibien gelblich, die mittleren und die hinteren am Grunde etwas grau getrübt, Tarsen gelblich. Die Oberflügel schwach gelbgrau getrübt, am Grunde kaum heller. Die Hauptader in ihrer zweiten Hälfte mit drei Borsten versehen, von denen die erste von den übrigen zwei entfernt ist; die Nebenader ihrer ganzen Länge nach mit zahlreichen Borsten besetzı. Auf dem Abdomenende schwáche Borsten. Körperlänge $0.9 \mathrm{~mm}$.

$$
ð .
$$

Kleiner als das $q$; die Farbe des Körpers und der Beine lichter, der Kopf und das Abdomenende am dunkelsten. Auf der Unterseite des 3.-7. Abdominalsegmentes befindet sich je eine rundliche, lichte Vertiefung.

Bemerkung. Diese Art erinnert durch ihre Gestalt etwas an Halidays Limothrips cerealium, unterscheidet sich jedoch von ihr hauptsächlich durch siebengliedrige Fühler (der Stylus ist eingliedrig), durch stets geflügelte Männchen und durch ein unbedorntes Abdomenende bei beiden Geschlechtern.

Vorkommen: Beide Geschlechter im Juni und Juli in den Blütenständen der Wiesengräser und in Getreideähren. In der Gerste manchmal in überaus grosser Menge, auch im Hafer zeitweise häufig; im Weizen und Korn selten. - Fundort: Böhmen.

\section{GENUS BOLACOTHRIPS. (Nov. gen.)*)}

Tělo úzké. Hlava delší než širší, mezi očima do předu prodloužená. Očka jsou velmi zakrnělá aneb scházejí úplně. Tykadla sedmičlenná (stylus jednočlenný). Makadla o třech článcích. Sosák jest tupý, dolejší pysk na konci zaokrouhlený. Prothorax as tak dlouhý jako hlava, na zadních rozích po dvou chlupech smyslových. Nohy bezbranné, krátké a široké. Křidel ani nejmenší rudimenta. Abdomen opatřen jest v druhé polovici po stranách dosti dlouhými chlupy; na konci abdomenu jsou tyto chlupy velmi tenké a dlouhé. Druh sem náležejíci není k skákání zpủsobilý.

*) $\mathbf{B} \omega \dot{\alpha} \alpha \div=$ drn, Rasen. 


\section{H. UZEL, MONOGRAPHIE DER ORDNUNG THYSANOPTERA.}

Körper schmal. Kopf mehr lang als breit, zwischen den Augen nach vorne erweitert. Ocellen sehr verkümmert oder ganz fehlend. Fühler siebengliedrig (Stylus eingliedrig). Maxillartaster dreigliedrig. Rüssel stumpf, die Unterlippe auf dem Ende gerundet. Prothorax etwa so lang wie der Kopf, auf seinen Hinterecken je zwei Borsten. Beine wehrlos, kurz und breit. Flügel vollkommen fehlend. Abdomen in seiner zweiten Hälfte mit ziemlich langen Borsten besetzt; auf dem Abdomenende sind diese Borsten sehr dünn und lang. Die her gehörende Art hat kein Springvermögen.

\section{Bolacothrips Jordani nov. sp.*)}

Tab. VII., fig. 112.

$$
\text { †. }
$$

Barva tèla světle žlutá; 10. čl. abdom. kromè base černošedý. Chlupy na těle svètlé. První čl. tykadel kratši než 2., právě tak široký jako tento, 3. čl. o trochu delši než pr̀edcházející, 4. as tak dlouhý jako 3., 7. čl. pomèrně dlouhý. Barva tykadel: 1. čl. čirý, 2. žlutý, 3. a 4. žluté, na samém konci tmavošedè zkalené, 3. nèkdy celý žlutý, 5. taktéž žlutý, v poslední třetině zkalený, 6. tmavošedý, na basi aneb do polou žlutý, 7. tmavošedý. Nohy celé světle žluté. Délka tèla $0.9 \mathrm{~mm}$. - Jedenáct exempl. nalezeno.

$$
\text { ठ. Nebyl posud objeren. }
$$

Třásněnka tato żije jednotlivè po celý rok $\mathrm{v}$ drnu lučním i lesním.

Čechy: Hradec Králové: Na několika místech v okolí.

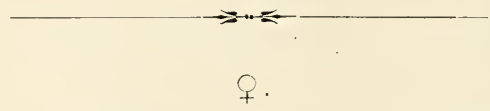

Körperfarbe lichtgelb, das äusserste Abdomenende schwarzgrau. Die Borsten auf dem Körper licht. Erstes Fühlerglied kürzer als das 2., jedoch ebenso breit, das 3. Glied etwas länger als das vorhergehende und etwa so lang wie das folgende, das 7 . verhältnismässig lang. Fühlerfärbung: 1. Glied klar, das 2. gelb, das 3. u. 4. ebenfalls gelb, am äussersten Ende dunkelgrau getrübt, das 3. zuweilen ganz gelb, das 5. im letzten Drittel dunkel, sonst gelb, das 6. dunkelgrau, am Grunde oder bis zur Hälfte gelb, das 7. dunkelgrau. Die ganzen Beine lichtgelb. Körperlänge $0.9 \mathrm{~mm}$.

$$
\text { c) unbekannt. }
$$

Vorkommen: Das ganze Jahr hindurch einzeln im Wiesen- und Waldrasen. Fundort: Böhmen.

*) Dorolil jsem si nazvati tento druh dle pana prof. Dr. Karla Jordana. - Doklad ve sbirce musejni, praep. ¿̇. 67. - Sammlung des böhmischen Landesmuseums, Praep. Nr. 67. 


\section{J. UZEL, MONOGRAFIERADU, THYSANOPTERA“.}

\section{4. (EENUS DREPANOTHRIPS. (Nov. gen.)*)}

Očka př́tomna. Tỵkadla jen šestičlenná, poněvadž hranice mezi šestým a sedmým článkem jejich není zretelná. Makadla maxillarní o třech článcích. Sosák jest dosti ostrý. Prothorax o málo delši než hlava; na zadních rozích jeho po drou chlupech smyslovỵ́ch. Nohy bezbranné. Křídla prítomna a tvaru obvyklého. Chloupky na konci abdomenu jsou slabé a krátké. U samcủ jest 9. článek abdomenu ozbrojen na každé straně velmi dlouhým, srpovitẽ prohnutým černým přivẽskem; 10. čl. jeho má podobu krátké roury.

Ocellen vorhanden. Fühler nur sechsgliedrig, weil die Gränze zwichen dem 6 . Glied und dem Stylus undeutlich ist. Maxillartaster dreigliedrig. Der Rüssel ziemlich scharf. Prothorax wenig länger als der Kopf; auf seinen Hinterecken je zwei Borsten. Beine wehrlos. Flügel vorhanden und von üblicher Form. Auf dem Abdomenende schwache und kurze Härchen. Das 9. Abdominalsegment bei den Männchen jederseits mit einem langen, sichelförmig gebogenen schwarzen Chitinanhang bewaffnet; das 10. Segment ist kurz, röhrenförmig.

\section{Drepanothrips Reuteri nov. sp.*)}

Tab. VII., fig. 113. et 114 .

$$
\text { f. }
$$

Barva tẽla bledẽ žlutá neb běložlutá, pterothorax svètle hnèdožlutý neb žlutavý, nohy běložluté, celé tělo mimo to nahoře slabè šedě skvrnité. Hlava trochu širší než delší, oči dosti rỵkoulené. První čl. tykadla kratši než 2., tento, pak 3. a 4. mezi sebou skoro stejně dlouhé, 5. trochu delší. Barva tykadel: 1. čl. čirý, 2. a 3. světlé, 4., 5. a 6. tmavošedé. Pterothorax málo širši než prothorax. Hor̆. křídla slabě žlutošedě zkalená. Hlavní žilka v druhé polovině se třemi chlupy od sebe skoro stejně vzdálenými; vedlejší po celé své délce jen čtyr̀mi chlupy opatřená. Délka těla $0.6 \mathrm{~mm}$. — Dosti značné množství exempl. nalezeno.

$$
\delta^{7} \text {. }
$$

Trochu menší než $\nmid$. Na 9 . čl. abdom. dva srpovité přívěsky; 10. čl. má podobu krátké rourky.

Třásnènka tato žije na listech stromových, zvl. lísek, dubủ a bukû. Samice nalezl jsem v srpnu a záríí, jediného samce v září.

Čechy: Hradec Králové. Tr̀ebechovice: Pod Vys. Újezdem.

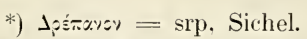

**) Dovolil jsem si druh tento nazvati dle pana prof. Dr. O. M. Re uter a v Helsingforse. Doklad ve sbirce musejni, praep. č. 68. - Sammlung des böhmischen Landesmuseums, Praep. Nr. 68. 
q.

Kopf, Prothórax und Abdomen blassgelb oder weissgelb, Pterothorax licht braungelb oder gelblich, Beine weissgelb. der ganze Körper ausserdem oben schwach graufleckig. Kopf etwas mehr breit als lang, die Augen ziemlich hervorgequollen. Erstes Fühlerglied kürzer als das 2., dieses, dann das 3. u. 4. untereinander fast gleich lang, das 5. etwas länger. Fühlerfärbung: 1. Glied klar, das 2. u. 3. licht, das 4., 5. u. 6. dunkelgrau. Pterothorax wenig breiter als der Prothorax. Oberflügel schwach gelbgrau getrübt. Die Hauptader in ihrer zweiten Hälfte mit drei Borsten versehen, die von einander fast gleich entfernt sind; die Nebenader im ganzen nur mit vier Borsten besetzt. Körperlänge $0.6 \mathrm{~mm}$.

$$
\sigma^{3}
$$

Etwas kleiner als das $\uparrow$. Am 9. Abdominalsegmente zwei sichelförmige Anhänge; das 10. Segment kurz, röhrenförmig.

Vorkommen: Auf den Blättern verschiedener Bäume, hauptsächlich der Eiche, der Buche und der Haselnuss. Weibchen im August und September, Männchen im September. - Fundort: Böhmen.

\section{GENUS PLATYTHRIPS $\left.\mathrm{m} . *^{*}\right)$}

Tělo velmi široké. Očka scházejí. Tykadla sedmičlenná (stylus jednočlennỹ). Makadla maxillarní o dvou článcích. Prothorax as tak dlouhý jako hlava; na zadních rozích jeho po dvou chlupech smyslových. Nohy bezbranné. Kř́del ani nejmenší rudimenta. Abdomen mnohými velmi tuhými chlupy opatřen. Desátý jeho článek jest nahoře rozčísnutý.

Körper sehr breit. Ocellen fehlend. Fühler siebengliedrig (Stylus eingliedrig). Maxillartaster zweigliedrig. Prothorax etwa so lang wie der Kopf; auf seinen Hinterecken je zwei Sinnesborsten. Beine wehrlos. Flügel vollkommen fehlend. Abdomen mit vielen sehr steifen Borsten besetzt. Sein zehntes Segment oben aufgeschlitzt.

\section{Platythrips tunicata Halid.**)}

Tab. III., fig. 21.

1852. Thrips tunicata Haliday, Walker: Homopt. insects of Brit. Museum. pag. 1115 .

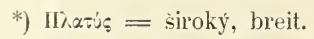

**) Doklad ve sbirce musejni, praep. ‘̌. 69. - Sammlung des böhmischen Landesmuseums, Praep. Nr. 69. 


\section{J. UZEL. IONOGRAFIE RÁDU "THYSANOPTERA".}

q.

Hlava, thorax a poslední dva články abdomenu hnědožluté; ostatní články abdominalní černé. Výjimkou jest proní z nich světlejší. Hlava širší než delší, mezi očima do předu prodloužená. První čl. tykadel značnè kratší než druhý, avšak právě tak široký, 3. a 4. čl. k oběma koncům zúžené, mezi sebou skoro stejně dlouhé, 5. na konci jen nepatrně se zúžující, málo kratší. Tỵkadla tmavošedá, 1. čl. a 2., aneb jen konec tohoto, žlutohnědé, slabě šedẽ zkalené. Nohy hnědožluté, přední bud nezkalené, aneb jejich femora vně a tibie z počátku se slabým šedým nádechem; střední femora kromě obou koncủ a střední tibie kromě konce slabě hnědě zkalené; zadní nohy nejtmarší: femora tmavohnědá až černohnnědá, tibie světle hnědé, ke konci žlutohnědé. Dle Halidaye jsou někdy zadní nohy celé hnědé. Délka těla $0.8-1 \mathrm{~mm}$. - Značné množství exempl. nalezeno.

\section{$\sigma^{\top}$. Nebyl posud objeven.}

Třásněnka tato žije $\mathrm{v}$ létě $\mathrm{v}$ krětech lesních, zvl. od Galium (také Haliday nalezl ji na Galium mollugo) a prezimuje v drnu.

Čechy: Hradec Králové. Jind. Hradec: Za židovským hřbitovem (Duda).

$$
\text { Q. }
$$

Kopf, Thorax und die letzten zwei Abdominalsegmente braungelb; die übrigen Segmente schwarz. Ausnahmsweise ist das erste Abdominalsegment lichter. Kopf mehr breit als lang, zwischen den Augen nach vorn erweitert. Das erste Fühlerglied bedeutend kürzer als das zweite, jedoch ebenso breit, das 3. u. 4. Glied gegen beide Enden zu verdünnt, untereinander fast gleich lang, das 5. auf dem Ende nur unbedeutend verengt, wenig kürzer. Fühler dunkelgrau, das 1. u. 2. Glied, oder nur sein Ende, gelbbraun, schwach grau getrübt. Beine braungelb, die vorderen entweder nicht getrübt, oder ihre Schenkel aussen und ihre Tibien am Grunde mit schwachem grauem Anflug; die Nittelschenkel, die beiden Enden ausgenommen, und die Mitteltibien, ausser dem Ende, schwach grau getrübt; die Hinterbeine am dunkelsten: die Schenkel dunkelbraun bis schwarzbraun, die Tibien lichtbraun, gegen das Ende zu gelbbraun. Nach Haliday sind die Hinterbeine manchmal ganz braun. Körperlänge $0.8-1 \mathrm{~mm}$.

$$
\text { ऽ unbekannt. }
$$

Vorkommen: Im Sommer in Waldblumen, hauptsächlich in Galium (schon Haliday), im Winter in Rasen. - Fundorte: England (Haliday), Deutschland (Bohls), Böhmen. 
H. UZEL, NONOGRAPHIE DER ORDNUNG THYSANOPTERA.

\section{POPISY DRUHU TEREBRANTIÍ, JICH\%̆ PŘÍSLUŠNOSŤT RODOVOU NEBYLO LZE STANOVITI. \\ BESCHREIBUNGEN DER TEREBRANTIENARTEN, DEREN GATTUNGS- ZUSTÄNDIGKEIT NICHT FESTGESTELLT WERDEN KONNTE.}

U následujicích druhủ terebrantií nemohl jsem př́slušnost’ rodovou zjistiti, poněvadž jsem nemèl př́ležitost' je ohledati, a poněvadž v popisech jejich není zmínky o znacích, charakterisujících jednotlivé rody. Uvádím je tedy pod jménem rodovým Thrips s. 1.

Die folgenden Terebrantienarten konnte ich nicht in die angeführten Gattungen einreihen, weil ich nicht Gelegenheit hatte, sie selbst zu untersuchen, und weil in ihren Beschreibungen keine Erwähnung von den Charakteren, welche jene Gattungen kennzeichnen, geschieht. Ich zähle sie infolge dessen unter dem Gattungsnamen Thrips s. l. auf.

\section{Thrips ericae Halid.}

1836. Thrips Ericae Haliday, Entomol. Nagazine, pag. 448.

1852. - - Haliday, Walker: Homopt. ins. of Brit. Museum, pag. 1114.

Halid a y (anno 1852.): » Mares apteri, ocellis nullis; feminae alatae; antennae apicula biarticulata. Vasa hepatica rufescentia, quod in hac familia fere singulare. - Nigra, abdomine piceo, hemelytris fuscanis et fusco-ciliatis, tibiis tarsisque ferruginosis, illis margine, his puncto apicali fuscis, fem., aut crocea, antennis basi dempta oculisque fuscis, abdominis glandulis rufis perlucentibus, segmento penultimo biglumi, mas. Long. ${ }^{2 / 3}$ lin. Var. fem. piceo-rufa (immatura). Etiam in varietate antennae nigro-fuscae, et inde corpore obscuriores sunt. Hab. in floribus Ericae Tetralix in montosis; larva simul lecta pinguis lutea . England.

Zdá se, že sameček náleží jinému druhu. - Es scheint, dass das Männchen einer anderen Art angehört.

\section{Thrips striaticeps Blanch.}

1851. Thrips striaticeps Blanchard, Hist. fis. y polit. de Chile. Zool. VI. pag. 149.; tab. 2., fig. 12 .

»T. niger, capite elongato, transversim striolato; antennis fuscis, articulo tertio flavido, apice infuscato, quarto testaceo-fusco; alis paulo infuscatis, basi flavidis; pedibus nigris, tibiis anticis fuscis. Long. 1 lin. - Cuerpo enteramente negro, cabeza una vez 


\section{J. UZEL, MONOGRAFIE RADU „THYSANOPTERA“.}

mas larga que ancha, guarnecida de estrias transversales muy pronunciadas las unas contra las otras. Antenas con sus dos primeros articulos pardos; el tercero amarillo, pero un poco mas oscurecido en su extremidad; el cuarto de un testáceo tirando á moreno, y los siguientes enteramente pardos como los primeros. Protórax un poco convexo, muy finamente estriolado transversalmente. Alas levemente ahumadas, poco transparentes, con un pequeño viso de amarillo en su base. Patas negras finamente pestanadas, con las piernas anteriores solas de un testáceo tirando á moreno, los muslos muy poco hinchados. Abdómen medianamente ensanchado, negro y guarnecido lateralmente de pelos largos y tiesos. - Esta especie se encuentra en las plantas en las cordilleras de Ovalle.

\section{Thrips rugicollis Blanch.}

1851. Thrips rugicollis Blanchard, Hist. fis. y polit. de Chile. Zool. VI, pag. 149.

»T. niger, capite striolato; antennis fuscis; prothorace striolato, profunde lateque transversim sulcato; alis infuscatis, longis, fimbriatis; pedibus nigris, tibiis anticis fuscis. Long. 1 lin. ${ }^{1 / 4}$. - Cuerpo ancho, enteramente negro. Cabeza larga estriada transversalmente, pero con las estrias menos apretadas que en la especie precedente ( $T$. striaticeps). Antenas tirando á moreno. Protórax ancho estriolado transversalmente, y que presenta un hondo sulco irregular que le hace parecer divido en tres rodetes. Alas muy ahumadas guarnecidas de franjas sumamente largas. Patas negras un poco peludas, con las piernas anteriores pardas. Abdómen muy ancho y velludo. - Esta especie difiere notablemente de la precedente por su protórax, por la anchura de su abdómen y por las alas mas ahumadas, los muslos anteriores mas hinchados. Parece encontrarse en las mismas localidades."

\section{8. 'Thrips femoralis Blanch.}

1851. Thrips femoralis Blanchard, Hist. fis. y polit. de Chile. Zool. VI, pag. 150.

»T. sat angustus, niger, capite striolato, areolato; antennis fuscis; prothorace laevi, nitido, vix striolato, medio foveolato posticeque sulcato; alis infuscatis; pedibus nigris, tibiis anticis flavo-rufis, femoribus valde inflatis. Long. 1 lin. 1/5. - Cuerpo bastante angosto, enteramente negro y brillante. Cabeza muy estriada, formando las estrias un enrejado areolado. Antenas que tiran á moreno. Protórax espeso, convexo, delicadamente estriolado, brillante, con un hoyuelo ancho en el medio, y atras un sulco transversal. Alas ahumadas franjeadas. Patas negras, muslos anteriores muy gruesos, muy hinchados, piernas anteriores de un amarillo tirando á encarnado. Abdómen alargado, parallelo, poco ensanchado, ciliado lateralmente. - Esta especie se distingue fácilmente de las precedentes ( $T$. striaticeps, $T$. rugicollis) por su coselete mas estrecho, mas 


\section{H. UZEL, MONOGRAPHIE DER ORDNUNG THYSANOPTERA.}

convexo, mas brillante y marcado de impresiones diferentes, y sobre todo por lo grueso de los muslos anteriores. Se encuentra en la provincia de Valdivia (Chile). *

\section{Thrips annulicornis Blanch.}

1851. Thrips ammulicornis Blanchard, Hist. fis. y polit. de Chile. Zool. VI, pag. 150.

»T. niger, laevis, sat nitidus; capite elongato, striato; antennis fuscis, articulo tertio flavo, apice fusco; prothorace convexo, lateribus foveolato; pedibus fuscis, femoribus anticis valde incrassatis, nigris, tibiis flavidis. Long. 1 lin. ${ }^{1 / 4}-1$ lin. ${ }^{1 / 2} .-$ Cuerpo negro, liso y brillante. Cabeza larga fuertemente estriada transversalmente. Antenas pardas ciliadas, guarnecidas de pelos tiesos, con todos sus articulos muy adelgazados en su base. El tercero solo amarillo con su estremidad parda. Protórax muy combado, medianamente ancho, muy finamente estriado, presentando de cada lado un hoyuelo longitudinal, alargado. Alas completamente rudimentales. Patas de un pardo marchitado con las piernas anteriores muy gruesas, mas negras, con sus patas tirando á moreno. Abdomen negro pestanado. - Esta especie fué hallada sobre plantas en Calbuco (Chile). No la conocemos ma que en estado áptero."

\section{Thrips tibialis Blanch.}

1851. Thrips tibialis Blanchard, Hist. fis. y polit. de Chile. Zool. VI, pag. 151.

»T. niger, antennis nigris articulo secundo toto tertioque apice excepto flavidis; prothorace transversim sulcato; pedibus nigris, tibiis anticis totis, mediis et posticis basi excepta pallide testaceis. Long. 1 lin. - Cuerpo negro. Cabeza estriada. Antenas negras peludas con su segundo articulo en totalidad y el tercero, con escepcion de la estremidad, de un amarillo pálido. Protórax muy ensanchado de delante atras, desigual por encima y sulcado transversalmente. Alas nulas, patas con muslos hinchados, sobre todo las anteriores, negras con las piernas anteriores en totalidad, y las piernas intermedias y posteriores, con esception de su origen, de un color testáceo bastante claro. - Tampoco conocemos este insecto mas que en estado áptero. Se halla en Valdivia (Chile).«

Zdá se, že tato třásněnka náleži do rodu Chirothrips. - Es scheint, dass diese Art der Gattung Chirothrips angehört.

\section{Thrips laevicollis Blanch.}

1851. Thrips laevicollis Blanchard, Hist. fis. y polit. de Chile. Zool. VI, pag. 151.

T. niger, capite valde elongato; antennis fuscis, articulis secundo, tertio ultimisque testaceis; prothorace laevi, convexo, postice depresso, striolato; pedibus piceis, tibiis tes- 


\section{J. UZEL, MONOGRAFIE RADU, „THYSANOPTERA“.}

taceis. Long. 1 lin. - Esta especie se parece mucho á la precedente ( $T$. tibialis), pero se distingue fácilmente de ella por la coloracion de sus antenas y de sus patas, y sobre todo por el conselete. Cabeza estrecha, muy larga, estriada transversalmente. Antenas pardas con su segundo artículo, la mayor parte del tercero y los tres últimos testáceos. Protórax convexo, muy liso por debajo con borde posterior rebajado, aplastado y delicadamente estriado. Alas nulas. Patas de un pardo negruzco con todos los muslos hinchados. pero sobre todo las anteriores. Las piernas testáceas, las anteriores provistas de una espina corta junto á su estremidad. - Esta especie fué hallada en San Carlos de Chiloé (Chile). «

\section{Thrips Benseleri v. Frauenf.}

1836. Thrips Benseleri v. Frauenfeld, Verhandl. Zool.-bot. Gesellsch., Wien, pag. 800 .

»Ganz bleich lehmfarbig. Kopf sammt Vorderbrust etwas länger als der Theil, woran die Flügel sitzen, schmäler als letzterer, besonders nach vorne zu. Die Fühler 6-, respective 8gliedrig, da das oberste zugespitzte Glied 2 deutliche Trennungslinien zeigt. 1. und 2. verkehrt, kuglich abgestutzt. 1. gleich lang wie breit, 2. fast 2 Mal so lang als das 1 , das 3 . fast $1^{3 / 4}$ so lang als das 2 , , unten dünn, im letzten Drittel stark gebaucht, dann wieder dünner, 4. und 5. gleich lang, kaum kürzer als das 3., mitten verdickt, das 6. am Grunde angeschwollen, fast doppelt so lang als das vorhergehende, endet spitz, und ist 2 Mal abgetheilt. Fühler und Thorax sind gross beborstet. Augen dunkel. Die schmalen schwertförmigen Oberflügel haben an der Wurzel, etwas vor der Nitte und am letzten Drittel ihrer Länge einen rundlichen schwarzen, zusammen also 3 Paar Flecken. Der Aussenrand ist mit einer Reihe weitschichtiger Borsten besetzt, die Flügelfläche mit 2 Reihen. Am Innenrande stehen doppelt so lange dichte steife Haare. Länge $1.2 \mathrm{~mm}$. Auf im Garten im Freien gebautem Kukuruz. Wien.

\section{Thrips flavicornis Reut.}

1878-79. Thrips flavicornis Reuter, Diagn. öfv. nya Thysanopt. f. Finland, pag. 13 .

»Piceus, nitidulus; capite longitudine duplo latius, oculis magnis fortiter granulatis; antennis capiti et pronoto aeque longis, totis dilute flavis, articulo secundo crasso. tertio-sexto inter se sub-aequalibus, sexto quinto haud latiore et stylo distincte longiore, hoc distincte bi-articulato; pronoto capite parum latiore, lateribus leviter rotundatis, disco postice bifoveolato; mesonoto pronoto latiore et hoc duplo breviore; alis anticis griseis, margine antico triseriatim ciliatis. serie nempe pilarum longarum, alia mediocrium et adhuc alia pallidarum breviorum, margine postico longe ciliatis, disco 
vonis duabus longitudinalibus elevatis piliferis; alis posticis anticis paullo longioribus, margine postico longe ciliatis; pedibus piceis, anticis totis tarsisque omnibus pallide flavis. Long. $1-1^{1} \% \mathrm{~mm}$. In paroecia Pargas (Fenia) inventa. A Thr. vulgatissima Halid. corpore minore, antennis pallidioribus, totis usque in apicem flavis, colore pedum, hemelytris obscurioribus etc. divergens; a Thr. physapode Linn. statura multo minore, corpore piceo, antennarum articulo secundo toto flavo pedumque anticorum colore mox distinguenda. «

\section{Thrips tritici Osborn.}

1883. Thrips tritici Osborn, The Canadian Entomologist, pag. 156.

» Male, length .75-.80 mm.; width .20 mm. Female, length $1.10-1.20 \mathrm{~mm}$; width $.25 \mathrm{~mm}$. Color yellow, thorax tinted with orange; antennae with dusky annulations. Head from above nearly square, eyes occupying anterior angles. Antennae approximate at base, joint 2 , apical half of 4 , and 6 , dusky; joints 3 and 5 dusky at apex, the antennae appearing annulated under low power of microscope. Head, thorax and abdomen with few stiff hairs. Legs concolorous with body, all the tibiae with two spines at distal end, distal joint of tarsi a little dusky, proximal joint of hind tarsi with two spines. Wings narrow, hyaline, fringes whitish; anterior wings have costal fringe of shorter ciliae than posterior ones, and the ciliae are intermixed with shorter, stiffer, spiny hairs, which at base replace the fringe; two rows of blackish spines on upper surface of wing corresponding to subcostal and median veins. Posterior wings with no discal spines; ciliae of anterior edge shorter and more spiny than those of posterior. Both wings have numerous rows of very minute hairs on the surface. The males are shorter and smaller than females, with wings reaching beyond the tip of the abdomen instead of nearly to it, and there are some strong spines near the tip of the abdomen. United States.

Třásněnka tato nemá se soujmenným druhem Fitchovým (L. č. 69.) nic společného, podobá se však značně evropskému druhu Thrips flava Schr. - Osborns Art hat mit Fitchs gleichnamiger Art nichts gemeinschaftliches, ähnelt jedoch bedeutend der europäischen Thrips flava Schr.

\section{Thrips striata Osborn.}

1883. Thrips striata Osborn, The Canadian Entomologist, pag. 155.

»Female. Length $1.15 \mathrm{~mm}$. Width .25 $\mathrm{mm}$. Whitish with yellow and blackish markings. Head rounded in front, appears marked wilh transverse striae and dusky border posteriorly; antennae approximate, whitish at base, gradually becoming more dusky toward the apex, where they are nearly black. Eyes large; ocelli near together and well 
upon vertex. Thorax with elongated dusky patches forming a broken subdorsal stripe each side; on the prothorax these extend latero-cephaled and are broken into spots; abdominal segments 1-6 are dusky on tergum, except at the sides, seventh has dusky spot in centre, apex slightly dusky and surrounded with black spines; thorax and abdomen tinged with yellow at the sides. Hairs scarce and fine, except at end of abdomen. Legs concolorous with body, with dusky patches on dorsal aspect of femora and tibiae, sparsely seet with fine hairs. Wings unmarked, fringe and spines wanting at base of costal border, no discal spines; both wings covered with very minute hairs. " United States (Ames, Jowa). 


\section{Subordo TUBULIFERA Halid.}

Tykadla vždy osmičlenná. Makadla maxillarní i labialní jsou o dvou článcích, z nichž první jest velmi krátký. Očka scházejí jen druhům Trichothrips caespitis i semicaeca a bezkř́ldé formě druhu Trichothrips pedicularia. Prothorax do předu značně se zúžuje, takže má tvar lichoběžníku. Přední femora samcủ často velmi rozšířená a ploská. Oba páry kǐídel skoro stejně veliké, tence blánité, doužkující a na okraji kolkolem stejnoměrně tenkými dlouhými třásněmi ozdobené. Obyčejně jsou křídla bez žilek; někdy však jde středem prvé jejich poloviny tenká holá žilka. V klidu jsou všecka čtyři křídla na abdomenu složena tak, že ve druhé polovici své délky pr̃esně jedno leži pod druhým; i vidíme toliko celý povrch jediného křídla (Tab. VII., fig. 142.). Mnohé druhy jsou pravidlem bezkřŕdlé. Poslední článek abdomenu (tubus apicalis) má podobu rourovitou, a to u samcûv i samic. Otvor pohlavní nalézá se dole mezi devátým a desátým článkem. Samice nemaji zvláštního kladélka. Tělo jest sploštilé, abdomen široký, na basi nezúžený. $\mathrm{K}$ tomuto podřádu náležejí největší ze známých třásněnek. Pohyby tubulifer jsou velmi volné. Neskáčou nikdy. Žijí obyčejně pod korou a v drnu, zřídka v květech.

Poznámka. Samce rozeznáváme od samice dle postavy menší a užší, dle předních stehen obyčejně rozšiřenějších, dle pravidlem většich zubủ na předním tarsu, někdy dle zvláštních výrostků na ěláncích abdominalních a konečně velmi spolehlivě dle velikého výkrojku, který se nalézá pod otvorem genitalním na basi desátého čl. abdomenu dole (Tab. VII., fig. 140.). Samici, jež toho výkrojku nemá, poznáme neomylně dle malé chitinové tyčinky, jež stojí kolmo (rovnoběžně s osou těla) na zadním dolejším okraji devátého čl. abdom. uprostřed (Tab. VII., fig. 139.).

Fühler immer achtgliedrig. Naxillar- und Labialtaster zweigliedrig; ihr erstes Glied sehr kurz. Ocellen fehlen nur den Arten Trichothrips caespitis, T. semicaeca und der flügellosen Form von $T$. pedicularia. Prothorax nach vorn bedeutend verengt, trapezförmig. Die Vorderschenkel der Männchen oft sehr erweitert, flach. Beide Flügelpaare fast gleich gross, dünnhäutig, irisirend, an den Rändern ringsum mit langen dünnen Fransen gleichmässig besetzt. Gewöhnlich sind Adern nicht vorhanden, zuweilen durchzieht jedoch ihre erste Hälfte eine solche. In der Ruhe sind alle vier Flügel so zusam- 
mengelegt, dass sie sich in der zweiten Hälfte ihrer Länge vollkommen decken, und man infolge dessen nur die ganze Fläche eines einzigen Flügels wahrnimmt (Taf. VII, Fig. 142). Viele Arten sind regelmässig flügellos. Das letzte Abdominalsegment (tubus apicalis) ist röhrenförmig, und zwar bei beiden Geschlechtern. Die Genitalöffnung befindet sich unten zwischen dem neunten und zehnten Segmente. Die Weibchen haben keine besondere Legeröhre. Der Körper ist platt, das Abdomen breit, auf dem Grunde nicht verengt. Zu dieser Unterordnung gehören die grössten der bekannten Thysanopteren. Die Bewegungen der Tubulifera sind sehr langsam. Sie springen nie. Ihr Leben fristen sie gewöhnlich unter Rinde oder im Rasen, ausnahmsweise (secundär, nachdem sich ihr Körper dem Leben unter Rinde etc. angepasst hat) in Blüten.

Bemerkung. Die Männchen unterscheiden sich von den Weibchen durch kleinere und schmälere Gestalt, durch gewöhnlich sehr erweiterte Vorderschenkel, durch in der Regel grössere Zähne auf dem Vordertarsus und manchmal durch besondere Anhängsel der Abdominalsegmente; endlich erkennt man sie sehr verlässlich nach einem grossen halbkreisförmigen Ausschnitt, welcher sich unter der Genitalöffnung auf dem Grunde des 10. Abdominalsegmentes unten befindet (Taf. VII, Fig. 140). Die Weibchen, welche keinen solchen Ausschnitt besitzen, erkennen wir leicht nach einem kleinen Chitinstäbchen, welches vertical (parallel mit der Körperachse) auf der Mitte des Hinterrandes der Ventralseite des

9. Abdominalsegmentes steht (Taf. VII, Fig. 139).

\section{FAM. Phloeothripidae. (= TUBULIFERA HALID.)}

A myot a Serville (L. č. 54.) rozdèlili čeled Tubulifera na tři rody, totiž na Hoplothrips, Haplothrips a Phloeothrips. Prvé dva rody nelze zachovati, poněvadż zakládají se na omylech. Rod Moplothrips jest takto charakterisován: "Strany hlavy rovnoběžné, přední stehna ozbrojena zubem na vnitřní straně. « Z druhủ, které sem jsou zařaděny, má však toliko jeden takový zub. Znaky pro rod Haplothrips jsou: »Strany hlavy rovnoběžné, přední nohy neozbrojené. * Sem náleži toliko druh Burmeisterủv albipenuis (= Anthothrips statices Halid.), u něhož, jak jsem přesvědčen, B u rmeister malinký zoubek (u samice), na předním tarsu se nalézající, přehlédl. - Také Ha li da yo vo rozdělení (L. č. 61.) této čeledi na Apterae (očka a kǐídla scházeji) a na Ileteropterae (očka prítomna, křídla scházeji aneb jsou přitomna) jest nevhodné, poněvadž jeden a tentýž druh (Trichothrips pedicularia) mủže někdy očka a křídla míti, jindy pak obojích postrádati. - I Heegrovo rozdèlení její v Aptera a Elyoptera z podobných důvodủ jest nevhodné.

Naše Tubulifera tvoří, pokud jsem je sám zkoumal, dohromady jednotnou čeled: Myslil jsem dř́ve, že nutno rozeznávati rody, jichž druhy maji sosák v předu široce 


\section{H. UZEL, NONOGRAPHIE DER ORDNUNG THYSANOPTERA.}

zaokrouhlený a makadla maxillarní zavalitá (Tab. IV., fig. 31.), a jiné rody, utvořené druhy, jejichž dlouhý sosák jest ke konci značně zúžený, a jejichž makadla maxillarní jsou štíhlá (Tab. IV., fig. 30.). Objeviv však druh Zygothrips mimuta, poznal jsem, že by rozdělení to bylo umělým, poněvađ̃z druh zmíněný tykadly svými i křídly uprostřed zúženými upomíná na rod Anthothrips (jehož sosák jest krátký a v předu široce zaokrouhlený), má však sosák značně zúžený; ač tento jest velmi krátký. Tím tvoří přechod mezi oběma zminěnými skupinami rodủ. Také rody Cephalothrips a Trichothrips již poněkud kloní se $\mathrm{k}$ skupině druhé, ježto hořejší pysk jest špičatý a koncem svỵm přesahuje široce zaokrouhlený pysk dolejší.

Unsere Tubulifera bilden zusammen eine einheitliche Familie. Man kann wohl zwei Gruppen von Arten unterscheiden, nämlich die, deren Rüssel auf dem Ende breit gerundet ist, und deren Maxillartaster gedrungen sind (Megalothrips, Cryptothips, Authothrips, Cephalothrips, Trichothrips) und jene, deren Rüssel lang und gegen das Ende zu bedeutend verengt ist, und deren Maxillartaster schlank sind (Plloeothrips, Acanthothrips, Liothrips, Poecilothrips). Die Gattung Zygothrips verbindet jedoch beide Gruppen, indem ihre Fühler und Flügel denjenigen der Gattung Anthothrips (der ersten Gruppe angehörend) sehr ähnehn, obwohl ihr Vertreter einen zwar sehr kurzen, jedoch bedeutend verengten Rüssel besitzt. Die Gattungen Cephalothrips und Trichothrips neigen sich ebenfalls etwas zu der anderen Gruppe hin, da ihre Oberlippe in eine kurze Spitze verlängert ist, welche die breit gerundete Unterlippe überragt.

\section{GENUS MEGALOTHRIPS m.*)}

Postava mohutná. Samec jest užší než samice a má na 6. čl. abdom. dlouhý, na stranu odstávajicí, rourovitý príivěsek. Hlava skoro dvakrát delší než širší, válcovitá. Sosák jest krátký, sahá do tří čtvrtin prosterna, jest v předu široce zaokrouhlený a má tupý hořejší pysk. Makadla maxillarní opatrena jsou dvěma dloühými čípky smyslovými a třemi kratšími chloupky hmatavými. Nakadla labialní mají taktéž dva čípky smyslové (čichové). Prothorax as o polovinu hlavy kratší. Kř́idla bud prítomna aneb scházejí. Vyznamenávají se tím, že jsou v prvé polovině užšími než v druhé, dále tím, že mají poměrně dosti krátké třásně, a že prvou polovici jejich prostupuje tenká žilka. Nohy jsou štíhlé, přední femora u obou pohlaví sotva neb jen málo stlustlá. Tarsy nejsou ani u samic ani u samcủ ozbrojeny. Tubus jest as tak dlouhỵ jako hlava, u samcủ na basi obklopen z každé strany přiléhajícím lupénkem.

*) $\|_{\varepsilon} \dot{\alpha} \dot{\alpha i n}=$ veliká, die Grosse. 
Gestalt mächtig. Das Männchen schmäler als das Weibchen; sein 6. Abdominalsegment ist mit einem langen, seitwärts abstehenden, röhrenförmigen Anhang versehen. Kopf fast zweimal so lang als breit, walzenförmig. Rüssel kurz, bis zum Ende des 2. Drittels des Prosternum reichend, vorn breit gerundet; die Oberlippe stumpf. Maxillartaster mit zwei langen Sinneszapfen und drei kürzeren Tastborsten versehen. Labialtaster ebenfalls mit zwei Geruchszapfen ausgestattet. Prothorax etwa um die Hälfte kür'zer als der Kopf. Flügel entweder vorhanden oder fehlend. Dieselben zeichnen sich dadurch aus, dass sie in ihrer ersten Hälfte schmäler sind als in der zweiten, weiler durch verhältnismässig ziemlich kurze Fransen und durch eine dünne Ader, welche von der Wurzel bis zur Hälfte läuft. Beine schlank, Vorderschenkel bei beiden Geschlechtern kaum oder nur wenig verdickt. Tarsen bei Männchen und Weibchen wehrlos. Tubus etwa so lang wie der Kopf, bei den Männchen am Grunde jederseits mit einer anliegenden Schuppe.

\section{Megalothrips lativentris Heeg.*)}

Tab. III., fig. 20., 22. et 23.; Tab. VII., fig. 115.-117.

1852. Phloeothrips lativentris Heeger, Sitzungsb. d. Akad. d. Wiss., Wien, IX, pag. 479.; tab. XVIII.**)

1878-79. - longispina Reuter, Diagn. öfv. nya Thysanopt. f. Finland, pag. 8. 1878-79. - tibialis Idem, ibidem, pag. 9.

1880. - longispina Reuter, Thysanoptera fennica, pag. 8.

1880. - tibialis Idem, ibidem, pag. 10.

*) Doklad ve sbírce musejní, praep. č. 70. - Sammlung des böhmischen Landesmuseums, Praep. Nr. 70.

**) Popis a obraz tohoto druhu jest rovněž tak jako ostatni popisy a obrazy Heegrovy nepřesný. Tykadla, hlava a tubus jinak zde popsány jsou a jinak vykresleny. Rourovité prínèsky na abdomenu samců udány jsou na ětvrtém segmentu (v pravdě nalézaji se na s̀estém). Omyl tento vysvětluje se tím, že Heeger čitá první malý segment abdominalní k mesothoraxu a druhý segment abdom. že má za metathorax.

Wie die Beschreibungen und Abbildungen der Thysanopteren von Heeger überhaupt ungenau sind, so ist es auch die Beschreibung und die Abbildung dieser Art. Die Ungenauigkeit ist hier sogleich daraus zu erkennen, dass Heeger die Form und Farbe der Fühler anders beschreibt und anders abbildet, dass er neun (anstatt acht) Glieder im Fühler beschreibt und zeichnet, dass er den Kopf als „beinahe walzig“ und den Tubus als „fast walzig, nur gegen das Ende etwas verschmälert" beschreibt, sie jedoch beide vor dem Ende recht beträchtlich erweitert abbildet etc. Was die röhrenförmigen Anhänge, angeblich auf dem vierten Abdominalsegmente, anbelangt, so ist die falsche Angabe und Zeichnung ihrer Lage darauf zurückzuführen, dass Heeger die kleine Rückenschiene des ersten Abdominalsegmentes als Theil des Mesothorax und das zweite Abdominalsegment als Metathorax betrachtet, so dass ihm dadurch das 6. Segment, welches die Anhänge trägt, zum vierten wird. Dass er die grossen Zipfel auf dem 4. (anstatt auf dem 3.) und die kleinen auf dem 5. (anstatt auf dem 4.) Abdominalsegmente, vom hinteren Ende gezählt (den Tubus mitgerechnet), zeichnet, ist leicht daraus erklärlich, dass er die Schuppen, welche sich beiderseits auf der Basis des Tubus befinden, als ein besonderes Segment angesehen hat. Um die 10 Abdominalsegmente, welche er bei anderen Thysanopteren sah, zu erreichen, schaltet er ein Segnent zwischen das mit den Anhängen und das mit den kleinen Zipfeln versehené fälschlich ein. 


\section{H. UZEL, MONOGRAPHIE DER ORDNUNG THYSANOPTERA.}

\section{q (= Phl. tibialis Reut.).}

Barva těla černá. Hlava o $0 \cdot 7$ delši než širši*). Za očima a na basi jest zúžená. Oči jsou malé, očka přitomna, avšak nezřetelná. Tỵkadla skoro dvakrát hlavy delší. Tretí ěl. jejich •o 0.4 delší než první dva dohromady, na konci kvjovitě sllustlý, 4 . čl. kyjovitý, o 0.4 kratší než třetí, 5. článek kyjovilý, trochu kratši než předcházející, 6 . na basi zúžený, 7. a 8. asi stejné mezi sebou délky, 8. velmi tenký. Barva tykadel: 1. a 2. čl. černé, 3. hnèdožlutý, na konci slabě zkalený, 4 téže barvy, na konci ršak tmavý, 5. do polou hnědožlutý, od polou ěerný, 6. černý. na samé basi hnědožlutý, 7. a 8. celé černé. Prothorax o $0 \cdot 4$ hlavy kratší. Nohy dlouhé, štíhlé. Prední femora nepatrně stlustlá; zadni velmi dlouhá. Tarsus předních noh bez zubu. Všecky tibie a tarsy hnědožluté; přední femora celá černá, středni a zvláště zadní na basi šíreji, na samém konci jen trochu hnědožlutá. Tubus skoro o $0 \cdot 1$ delší než hlava; na povrchu opatren jest tenkými chloupky. Délka těla $2 \cdot 5-3 \mathrm{~mm}$.

FORMA MACROPTERA (nově objevená). liřídla úplně vyvinutá.

FORMA BRAGHYPTERA. Kř́del jen rudimenta, pterothorax nepresahující.

$$
\sigma^{\top} \text { (= Phl. longispina Reut.). }
$$

Trochu menší než q. Křidla zakrnèlá. Na 6. čl. abdom. nahoře na kraji po obou stranách velmi dlouhý, od tèla nahoru a trochu na stranu odstávajicí rourovitý vỵ́rostek, zakončený malým chloupkem. Sedmý čl. abdom. opatren jest po obou stranách uprostred ostrỵm malým cípkem; 8. článek má cípky podobné, ale větší. Tubus tak dlouhý jako u samice; v první čtvrtině obklopen jest po obou stranách jedním lupínkem, príivěskem to devátého článku abdomenu.

Třásněnka tato vyskytuje se po celý rok pod spadaným listim, rostlinnými odpadky a mechem ve svèlyých hájích. Forma dlouhokřídlá jest velmi vzácná.

Čechy: Praha: V lese mezi Krči a Kundraticemi. Hradec Králové: V háji na Zámečku ěetně. Holice: Chıojno. Jindř. Hradec (Duda).

$$
\text { f (= Plll. tibialis Reut.). }
$$

Körperfarbe schwarz. Kopf um 0.7 mehr lang als breit**), hinter den Augen und am Grunde ein wenig verengt. Augen klein, Ocellen vorhanden, jedoch undeutlich. Fühler fast zweimal länger als der Kopf. Ihr 3. Glied um $0 \cdot 4$ länger als die beiden ersten zusammen, am Fnde keulenförmig verdickt, das 4. Glied keulenförmig, um 0.4 kür»er als das

*) Délka hlavy mèrena vždy od předniho okraje oči k týlnimu okraji jejimu.

**) Die Kopflänge ist stets vom Vorderrande der Augen bis zum Hinterhauptrande gemessen. 
3., das 5. keulenförmig, etwas kürzer als das vorhergehende, das 6. am Grunde verengt, das 7. u. 8. untereinander etwa gleich lang, dieses sehr dünn. Fühlerfärbung: 1. u. 2. Glied schwarz, das 3. braungelb, am Ende schwach getrübt, das 4. ebenso gefärbt, am Ende jedoch dunkel, das 5. bis zur Hälfte braungelb, von der Hälfte an schwarz, das 6. schwarz, an der Wurzel braungelb, das 7. u. 8. schwarz. Prothorax um 0.4 kürzer als der Kopf. Beine lang und schlank. Vorderschenkel unbedeutend verdickt; Hinterschenkel sehr lang. Vordertarsus zahnlos. Alle Tibien und Tarsen braungelb; die Vorderschenkel ganz schwarz, die Mittel- und hauptsächlich die Hinterschenkel am Grunde breiter, am äussersten Ende nur schmal braungelb. Tubus fast um $0^{\cdot} 1$ länger als der Kopf, mit zahlreichen dünnen Härchen besetzt. Körperlänge $2 \cdot 5-3 \mathrm{~mm}$.

FORMA MAGROPTERA (neu entdeckt). Flügel vollkommen entwickelt.

FOR IA BRACHYPTERA. Flügel zu Rudimenten verkümmert, die den Pterothorax nicht überragen.

$$
\text { ऽ゙ (= Phl. longispina Reut.). }
$$

Etwas kleiner als das $q$. Flügel rudimentär. Am 6. Abdominalsegmente oben am Vorderrande beiderseits ein sehr langer, vom Körper abstehender, röhrenförmiger Anhang, auf dessen Ende ein kleines Härchen steht. Das 7. Abdominalsegment ist jederseits in der Mitte mit einem kleineren, das 8. daselbst mit einem grösseren scharfen Zipfel versehen. Tubus ebenso lang wie beim Weibchen; an seiner Basis jederseits mit einer anliegenden Schuppe versehen, welche ein Anhängsel des 9. Abdominalsegmentes ist und bis zum ersten Viertel der Tubuslänge reicht.

Vorkommen: Das ganze Jahr hindurch unter abgefallenem Laubwerk, Pflanzenabfällen und Moos in lichten Hainen. - Fundorte: Wien (im J. 1818 Ritter v. Goldegg, später Heeger), Finnland (Reuter), Böhmen.

\section{Megalothrips Bonannii nov. sp.*)}

Tab. III., fig. 19.

․ Nebyla posud objevena.

$$
\sigma^{7} \text {. }
$$

Barva těla černá. Hlava málem o 0.8 delší než širší se stranami skoro rovnoběžnými, jen uprostřed trochu vypouklá. Oči malé. Očka př́tomna, avšak těžko spatřitelná. Tykadla o 0.6 delší než hlava. První dva články skoro stejně dlouhé, třetí trochu delší než první dva dohromady, kyjovitý, 4. taktéž kyjovitý, o $0 \cdot 2$ kratší než 3. 8. na basi zúžený. Barva tykadel: 1., 2., 6., 7. a 8. článek černé, 3. žlutý, ıla samém konci černohnèdý, 4. žlutý, za polovinou černý, 5. černý, na basi žlutý. Prothorax asi

*) Doklad ve sbírce autorovẽ. 


\section{H. UZEL, MONOGRAPHIE DER ORDNUNG THYSANOPTERA.}

o polovinu kratši než hlava. Nohy velmi dlouhé, štíhlé. Pr̉ední femora trochu stlustlá. Barva noh černá, tarsy Imavošedé. Kríídla úplně vyvinutá, trochu žlutavě zkalená. Pátý čl. abdom. uprostred náhle rozšiřený: 6. čl. opatřen jest nahoře na předním okraji po obou stranách velmi dlouhým, od tèła nahoru a trochu na stranu odstávajicím, rourovitým výrostkem, zakončeným malým hrbolkem; 7. čl. má po obou stranách před koncem malý ostrý cípek. Tubus asi o $0 \cdot 2$ kratši hlavy, na basi asi o 0.7 širší než před koncem; na samém konci náhle více zúżený; na povichu jeho roztroušeny jsou tenké chloupky. Délka těla $4 \mathrm{~mm}$; jest tudiž lato tr̆ísněnka největším dosud známým evropským druhem.

Jediný exemplár tohoto druhu nalezen v prosinci pod zpuchřelou korou vrbovou. Čechy: Hradec Králové: U Slezského Pr̃edměstí.

q unbekannt.

$\sigma^{\top}$.

Körperfarbe schwarz. Kopf last um 0.8 mehr lang als breit. Wangen fast parallel, nur in der Mitte etwas gewölbt. Augen klein. Ocellen vorhanden, jedoch schwer wahrnehmbar. Fühler um 0.6 länger als der Kopf. Die ersten zwei Glieder fast gleich lang. das 3. ctwas länger als die ersten zwei zusammen, keulenförmig; das 4. ebenfalls keulenförmig, um 0.2 kürzer als das 3 . das 8 . am Grunde verengt. Fühlerfarbe: 1.. 2., 6 ., 7. u. 8. Glied schwarz, das 3. gelb, auf der äussersten Spitze schwarzbraun, das 4. gelb, hinter der Nitte schwar\%, das 5. schwarz, am Grunde gelb. Prothorax etwa um die Hälfte kürzer als der Kopf. Beine sehr lang und schlank. Vorderschenkel etwas verdickt. Farbe der Beine schwar\%, die Tarsen dunkelgrau. Flügel vollkommen entwickelt, etwas gelblich getrübt. Fünftes Abdominalsegment in der Mitte plötzlich erweitert; das 6. Segment ist oben am Vorderrande jederseits mit einem sehr langen, vom Körper seitwärts und etwas nach oben abstehenden, röhrenförmigen Anhang versehen, welcher auf dem Ende ein winziges Höckerchen trägt; das 7. Segment ist jederseits ror dem Ende in einen kleinen scharfen Zipfel erweitert. Tubus etwa um $0 \cdot 2$ kürzer als der Kopf, am Grunde ungefähr um 0.7 breiter als vor dem Ende; auf der Spitze selbst plötzlich mehr verdünnt; seine ganze Oberfläche mit zerstreuten dünnen Härchen besetzt. Körperlänge $4 \mathrm{~mm}$; somit ist diese Art die grösste unter allen bekamnten europäischen Thysanopteren.

Vorkommen: Das einzige Exemplar, welches ich besitze, habe ich im December aus morscher Weidenrinde gesiebt. - Fundort: Böhmen.

\section{GENUS CRYPTOTHRIPS $\mathrm{m} . *$ )}

Hlava $00 \cdot 2$ až $0 \cdot 5$, výjimkou dvakrát (C. migripes Reut.) delší než širší. Sosák jest králký, sahá as do poloviny prosterna, jest $\mathrm{r}$ předu široce zaokrouhlený a má tupý

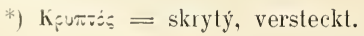




\section{J. UZEL, MONOGRAFIE RADU "THYSANOPTERA“.}

hořejši pysk. Makadla maxillarní jsou opatřena čtyřmi chlupy hmatavými různé délky. Makadla labialní mají jeden neb dva čípy čichové a několik krátkỵch chloupkủ hmatavých. Prothorax 00.2 až 0.5 kratší než hlava. Krí́dla jsou u samic téhož druhu někdy prítomna, obycčejně však scházejí. Jsou v prvé polovině užší než v druhé. Samci jsou vždy bezkǐídlí. Přední femora u samcủ značně stlustlá. Přední tarsy jsou u samic bezbranné, u samců však ozbrojené șilným zubem. Tubus jest u samců na basi obklopen z každé strauy jedním lupinkem.

Kopf um 0.2 bis 0.5 , ausnahmsweise zweimal (C. nigripes Reut.) mehr lang als breit. Rüssel kurz, bis zur Mitte des Prosternum reichend, vorn breit gerundet; die Oberlippe stumpf. Maxillartaster mit vier Tastborsten von verschiedener Länge versehen. Labialtaster mit einem oder zwei Geruchszapfen und einigen kurzen Tastborsten besetzt. Prothorax um 0.2 bis 0.5 kürzer als der Kopf. Flügel bei den Weibchen derselben Art manchmal vorhanden (feminae disseminantes), gewöhnlich jedoch fehlend. Dieselben sind in der ersten L ifte schmäler als in der zweiten. Männchen immer flügellos. Vorderschenkel bei den Männchen bedeutend verdickt. Vordertarsen bei den Weibchen wehrlos, bei den Männchen jedoch mit einem starken Zahne bewaffnet. Tubus der Männchen am Grunde jederseits mit einer anliegenden Schuppe versehen.

\section{Cryptothrips nigripes Reut.}

1880. Phloeothrips nigripes Reuter, Thysanoptera fennica, pag. 11.

$\gg$ Nigra, nitida; capite latitudine duplo longiore, praesertim postice transversim convexo; oculis sub-rotundis; antennis nigris, articulis tertio-sexto oblongo-triangularibus, illo quarto vix longiore el tribus ultimis conjunctis sat multo breviore, pallide flavente; pedibus totis nigris. Long. $2 \mathrm{~mm}$. - Caput latitudine circiter duplo longius, praesertim basin versus transversim convexum et apicem versus leniter declive, lateribus rectis, parallelis, seriebus duabus pilarum brevium e granulis omnium minutissimis nascentibus, disco transversim subtiliter aciculato-strigosum. Oculi superne visi sub-rotundati, quartam partem anticam laterum capitis vix occupantes. Ocelli tres. Antennae albido-pubescentes, capile tantum paullo longiores, nigrae; articulo primo parvulo capitis latitudine fere $4 / 5$ breviore, secundo crasso primo paullo longiore, apice picescente; tertio secundo circiter dimidio longiore et latitudine capitis interoculari fere aeque longo, oblongo-triangulari, pallide luteo-flavo, articulo quarto tertio vix breviore, quinto et sexto sensim brevioribus, duobus ultimis conjunctis huic longitudine aequalibus, septimo sexto circiter ${ }^{1 / 3}$ angustiore, octavo septimo aeque longo gracillimo. Pronotum capite fere duplo brevius, trapeziforme, apice basique marginatum, basi longitudine duplo latius, disco utrinque prope latera foveolis duabus, anteriore et posteriore, hac majore, angulisque posticis impressis, margine 


\section{H. UZEL, IONOGRAPHIE DER ORDNUNG THYSANOPTERA.}

laterali pilis duabus exsertis, antica brevi. Pterygonotum pronoto haud longius basique ejus distincte latius, basi freno instructum, disco planiusculum, sub-laeve, utrinque fovea impressa. Alae completae apicem tubi apicalis attingentes, nitidae, longe fusco-ciliatae. Abdomen latius ovatum, medio pronoti basi circiter duplo latius, segmentis longitudine subaequalibus, utrinque punctis pilam pallidam emittentibus biseriatim impressis, tubo apicali segmentis tribus praecedentibus longitudine aequali, apice longe albicanti-piloso. Pedes toti nigri, femoribus anticis reliquis paullo crassioribus. - Unicum individuum volitantem $\mathrm{m}$. Julii 1879 in paroecia Pargas invenit Lina Reuter.»

\section{Cryptothrips lata nov. sp.*)}

Tab. III., fig. 24.; Tab. VII., fig. 118.-122.

$$
\text { ‥ }
$$

Barva těla černá. Hlava o 0.4 delší neě širší; tváře její rovnoběžné, jen vzadu nepatrně se rozšiřující. Oči malé, v předu vyčnívající. Očka velmi tèžko spatřitelná. Tykadla jsou o 0.6 delší než hlava. První dva články jejich jsou mezi sebou skoro stejně dlouhé; 3 čl. as tak dlouhý jako prvé dva dohromady, od base ke konci se rozšiřujicí, na konci náhle zúžený; 4. čl. trochu kratši než 3. Barva tykadel černá, 3. čl. celý žlutý neb na samém konci trochu zkalený, 4. černohnědý. Makadla maxillarní jsou opatřena čtyřmi hmatavými chlupy. Makadla labialní mají krátký čípek čichový, který nedaleko base jejich vyrůstá, a $\mathrm{k}$ nim prìléhá; mimo to nalézáme zde tři hmatavé chlupy. První pár kusadel ukončen dvěma výběžky, z nichž delši jest na vnitřní straně prejemně zubatý. Prothorax skoro o 0.5 kratší než hlava. Přední femora jsou roztroušenými, dosti dlouhými chlupy opatřena. Barva noh černá, jen tarsy černohnědé. Abdomen široký. Tubus o $0 \cdot 3$ kratší než hlava, na konci náhle značněji zúžený, na basi as o $0 \cdot 5$ širší než před koncem. Délka těla $1.7 \mathrm{~mm}$. - Čtyři exempl. nalezeny.

FORMA MAGROPTERA. Kř́dla jsou úphě vyvinuta.

FORMA BRAGHYPTERA. Křídel jen rudimenta, pterothorax nepřesahující.

$$
\delta^{7}
$$

Trochu menší než + . Přední femora stlustlejší než u této, a přední tarsus opatřen silným zubem. - Dva exempl. nalezeny.

Třásněnku tuto sbíral jsem v zimě pod korou švestkovou, vrbovou a morušovou. Čechy: Hradec Králové: Na několika místech v okolí.

*) Doklad ve sbírce musejní, praep. ě. 71. - Sammlung des böhmischen Landesmuseums, Praep. Nr. 71. 


\section{J. UZEL. MONOGRAFIE RADU "THYSANOPTERA“.}

$$
\text { 千. }
$$

Körperfarbe schwarz. Kopt um 0.4 mehr lang als breit; seine Wangen parallel, nur hinten unbedeutend gewölbt. Augen klein, vorstehend. Ocellen sehr schwer wahrnehmbar. Fühler um $0 \cdot 6$ länger als der Kopf. Ihre ersten zwei Glieder untereinander fast gleich lang; das 3. Glied etwa so lang wie die ersten zwei zusammen, von der Basis an gegen das Ende zu erweitert, am Ende jedoch plölzlich verengt; das 4. Glied etwas kürzer als das 3. Fühlerfärbung schwarz, das 3. Glied ganz gelb oder am aüssersten Ende etwas getrübt, das 4. schwarzbraun. Maxillartaster mit vier Tastborsten. Labialtaster mit einem kurzen Geruchszapfen, welcher unweit von seiner Basis steht und an denselben sich anlehnt; ausserdem befinden sich hier noch drei Tastborsten. Die Mandibeln haben am Ende zwei Fortsätze, von denen der längere auf der Innenseite überaus fein gezähnt ist. Prothorax fast um 0.5 kürzer als der Kopf. Die Vorderschenkel mit zerstreuten, ziemlich langen Borsten besetzt. Farbe der Beine schwarz, nur die Tarsen schwarzbraun. Abdomen breit. Tubus um 0.3 kürzer als der Kopf, am Ende plötzlich bedeutender verengt; am Grunde etwa um 0.5 breiter als vor dem Ende. Körperlänge $1.7 \mathrm{~mm}$.

FORMA MACROPTERA. Flügel vollkommen entwickelt.

F OR M A B R A CHY P TER A. Flügel zu Rudimenten verkümmert, die den Pterothorax nicht überragen.

$$
\sigma^{x}
$$

Etwas kleiner als das $q$. Die Vorderschenkel mehr verdickt, und der Vordertarsus mit einem starken Zahn versehen.

Vorkommen: Im Winter unter Pflaumen-, Weiden- und Maulbeerrinde; Sommeraufenthalt unbekannt. - Fundort: Böhmen.

100. Cryptothrips angusta nov. sp. *)

Tab. VII., fig. 123. et 124 .

$$
\text { †. }
$$

Barva tèla černá. Toto užší než u ostatních zástupcủ tohoto rodu. Hlava skoro o 0.5 delší než širší, na basi krkovitě zúžená. Tỵkadla dvakrát delši hlavy. Třetí článek o 0.3 kratší než prvé dva dohromady, velmi slabý, 4. čl. o 0.3 delší než předcházející. 5. as tak dlouhý jako 4. Tykadlo černé, 3. čl. žlutohnědý, šedě zkalený. Prothorax o 0.4 kratší hlavy. Pterothorax jen trochu delší než prothorax. Přední femora zcela nepatrně stlustlá, bez delších chlupů. Nohy černé, všecky tarsy a nejzazší konce všech tibií (i predních) žluté. Tibie jsou mimo to na samé basi trochu světlejší. Krî́del jen rudimenta. Tubus o $0 \cdot 4$ kratší hlavy, na basi skoro dvakrát širší než na konci. Délka tèla $1 \cdot 6 \mathrm{~mm}$.

*) Doklad ve sbirce autorovè. 


$$
\text { ऽ. Nebyl posud objeven. }
$$

Trúśněnka tato nalezena $\mathrm{v}$ jediném exemplár̆i v srpnu pod korou vrbovou. Čechỵ: Třebechovice: Pod Vys. Újezdem.

$$
\text { q. }
$$

Körperfarbe schwarz. Der Körper schmäler als bei den übrigen Arten dieser Gattung. Kopf fast um 0.5 mehr lang als breit, am Grunde halsförmig verengt. Fühler zweimal länger als der Kopf. Das 3. Glied um 0.3 kürzer als die ersten zwei Glieder zusammen, sehr schwach, das 4. Glied um 0.3 länger als das vorhergehende, das 5 . etwa so lang wie das 4. Die Fühler schwarz, das 3. Glied gelbbraun, grau getrübt. Prothorax um 0.4 kürzer als der Kopf. Pterothorax nur etwas länger als der Prothorax. Die Vorderschenkel unbedeutend verdickt, ohne längere Haare. Beine schwarz, alle Tarsen und die äussersten Enden aller Tibien (auch der vorderen) gelb. Die Tibien ausserdem an der Wurzel etwas lichter. Flügel rudimentär. Tubus um $0 \cdot 4$ kürzer als der Kopf, am Grunde fast zweimal breiter als am Ende. Körperlänge $1.6 \mathrm{~mm}$.

$$
\text { ऽ unbekannt. }
$$

Vorkommen: Im August unter Weidenrinde. - Fundort: Böhmen.

\section{Cryptothrips Icarus nov. sp.*)}

Tab. VIl., fig. 125. et 126 .

$$
\text { q. }
$$

Barva tèla tmavohnědá až černohnědá. Hlava o $0 \cdot 3$ delši než širší, za očima a vzadu trochu zúžená. Tykadla dvakrát delší hlavy. Druhý čl. trochu delší než prvý, 3. skoro tak dlouhý jako prvé dva dohromady, z úzké base poznenáhla se rozšiřující, 4. skoro tak dlouhý jako 3., více kyjovitý. Barva tykadel: 1. čl. černohnědý, 2. na basi tmavý, jinak žlutý, 3. a 4. žluté, tento na konci zkalený, 5. hnèdošedý kromè samé base, 6., 7. a 8. taktéž hnědošedé. Makadla labialní opatřena jsou jedním dosti dlouhým, mohutným čípkem čichovým a čtyřmi kratšími chlupy hmatavými. Prothorax o $0 \cdot 3$ hlavy kratší. Pr̃ední femora dosti stlustlá a roztroušenými, delšími chlupy opatřená. Nohy všecky tmavohnědé, tarsy celé a femora i tibie ke konci světlejší. Křridla úphně scházejí. Abdomen před koncem znaèněji rozšiřený. Tubus o 0.3 kratší než hlava, na basi dvakráte širší ně̌ na konci. Délka těla $2-2 \cdot 1 \mathrm{~mm}$.

*) Doklad ve sbírce musejni, praep. è. 72. - Sammlung des bỏhmischen Landesmuseums, Praep. Nr. 72. 
$\sigma^{\top}$

Menši než samice. Přední femora nejsou více stlustlá než u ní. Na předním tarsu tenký zub. Nohy tmarěji zbarveny. Lupínky obklopují z obou stran asi první třetinu tubu.

Var. pallipes. $\subsetneq$. Nohy mnohem světlejši než u typické formy, žluté, femora a tibie velmi slabě, zřídka silněji hnědě zkalené, ke konci světlé. - $\sigma^{7}$. Přední femora více stlustlá než u $q$. Přední nohy hnědožluté, střední a zadní žluté, femora nezkalená, tibie přes prvou polovinu hnědě zkalené.

Třásněnka tato žije po celý rok $\mathrm{v}$ obou pohlavích na lukách i $\mathrm{v}$ lesích $\mathrm{v}$ drmu. Samci jsou řídci. Var. palllipes vyskytuje se po různu mezi formou typickou.

Čechy: Praha. Liberec. Hradec Král. Třebechovice. Opočno. Jindř. Hradec (Duda).

q.

Körperfarbe dunkelbraun bis schwarzbraun. Kopf um 0.3 mehr lang als breit, hinter den Augen und am Grunde etwas verengt. Fühler zweimal länger als der Kopf. Ihr 2. Glied etwas länger als das 1., das 3. fast ebenso lang wie die ersten zwei zusammen, vom engen Grunde an gegen das Ende zu allmählich erweitert, das 4. fast von gleicher Länge, mehr keulenförmig. Fühlerfärbung: 1. Glied schwarzbraun, das 2. am Grunde dunkel, sonst gelb, das 3. u. 4. gelb, dieses am Ende getrübt, das 5. braungrau, die lichte Wurzel ausgenommen, das 6., 7. u. 8. ebenfalls braungrau. Labialtaster mit einem ziemlich langen und mächtigen Geruchszapfen und mit vier kürzeren Tastborsten versehen. Prothorax um $0 \cdot 3$ kürzer als der Kopf. Vorderschenkel ziemlich erweitert und mit zerstreuten längeren dünnen Borsten besetzt. Alle Beine dunkelbraun, die ganzen Tarsen und die Schenkel u. Tibien gegen das Ende zu lichter. Die Flägel fehlen vollkommen. Das Abdomen vor seinem Ende erweitert. Tubus um 0.3 kürzer als der Kopf, am Grunde zweimal breiter als am Ende. Körperlänge 2-2.1 $\mathrm{mm}$.

$$
\sigma^{\top}
$$

Kleiner als das Weibchen. Vorderschenkel nicht mehr erweitert als bei demselben. Am Vordertarsus ein dünner Zahn. Beine dunkler gefärbt. Die Schuppen am Grunde des Tubus reichen etwa bis zu seinem ersten Drittel.

Var. pallipes. + . Beine viel lichter als bei der Stammform, gelb, Schenkel und Tibien sehr schwach, selten etwas stärker braun getrübt, gegen das Ende zu licht. ð. Vorderschenkel mehr erweitert als beim Weibchen. Vorderbeine braungelb, Mittelund Hinterbeine gelb, ihre Schenkel nicht getrübt, ihre Tibien bis hinter die erste Hälfte braun getrübt.

Vorkommen: Das ganze Jahr hindurch in beiden Geschlechtern im Wald- und Wiesenrasen. - Fundort: Böhmen. 


\section{H. UZEL, MONOGRAPHIE DER ORDNUNG THYSANOPTERA.}

\section{Cryptothrips dentipes Reut.*)}

Tab. IV., fig. 31. et 33.; Tab. VII., fig. 127 .

1880. Phloeothrips dentipes Reuter, Thysanoptera fennica, pag. 12.<smiles>[CH]=[CH]</smiles>

Barva těla cerná. Hlava as o 0.2 delší než širší, nazad se zúžující a na basi krkovitě stažená. Mezi očima jest do předu dosti značně prodloužena. Tỵto jsou trochu sploštilé, vykoulené. Tykadla drakrát tak dlouhá jako hlava. První čl. jejich mohutný, 3. ěl. od base ke konci poznenáhla rozšírený; právě tak dlouhý jako prvé dva články dohromady, 4. a 5. trochu kratši než třetí. Barva tỵkadel černá, 2. čl. kromě base a 3. čl. kromě samé špičky žluté. Nakadla maxillarní mají jeden ze čtyř chlupú hmatavých značně stlustlý a průsvitný. Makadla labialní opatřena jsou dvěma krátkými, na konci zakrìvenými čípky čichovými. Prothorax o 0.3 kratší hlavy, úzký. Přední femora značně stlustlá, bez delších chlupů; jsou černohnědá, na konci a uvnitř hnědožlutá; přední tibie hnědožluté, rně kromě konce tmavě zkalené; přední tarsy žluté; střední a zadní nohy černé, base a konečky tibii a tarsy hnědožluté. Tubus tak dlouhý jako hlava, na basi skoro dvakrát tak široký jako na konci. Délka tèla $2 \cdot 1 \mathrm{~mm}$.

FORMA MAGROPTERA (novẽ objevená). Ǩríila úplně vyvinutá.

FORMA APTERA. Křídla zakrñují docela. Pterothorax zĩetelně užší než u formy okìídlené.

$$
\text { ¿ౌ (nově objevený). }
$$

Trochu menši než $\subsetneq$. Na předním tarsu dosti silný, trochu ohnutý zub. Přední femora značně stlustlá, tmavší než u samice, střední a zadní tibie na samém kořenu a nejzazší špičce temně hnědožluté. Jinak jsou nohy podobně jako u samic zbarveny.

Tr̉ásněnka tato žije $\mathrm{v}$ mechu. $\mathrm{v}$ rašelinnicich a $\mathrm{v}$ drnu na lukách $\mathrm{i}$ v lesích po celý rok.

Čechy: Hradec Králové. Soběslav, Jindř. Hradec (Duda).

P.

Körperfarbe schwarz. Kopf etwa um 0.2 mehr lang als breit, nach hinten verengt, am Grunde halsförmig eingeschnürt, zwischen den Augen nach vorn ziemlich bedeutend erweitert. Diese sind etwas abgeplattet und hervorgequollen. Fühler zweimal so lang als der Kopf. Ihr 1. Glied ist mächtig, das 3. vom Grunde gegen das Ende allmählich erweitert, ebenso lang wie die ersten zwei Glieder zusammen, das 4 . und 5 . Praep. Nr. 73

*) Doklad ve sbirce musejní, praep. é. 73. — Sammlung des böhmischen Landesmuseums, 
etwas kürzer als das 3. Fühlerfärbung schwarz, das 2. Glied, den Grund ausgenommen und das 3., mit Ausnahme der äussersten Spitze, gelb. Von den auf den Maxillartastern befindlichen Tastborsten ist eine bedeutend verdickt und durchsichtig. Labialtaster mit zwei kurzen, am Ende gekrümmten Geruchszapfen versehen. Prothorax um $0 \cdot 3$ kürzer als der Kopf. Die Vorderschenkel bedeutend erweitert, ohne längere Borsten, schwarzbraun, am Ende und innen braungelb; die Vordertibien braungelb, aussen, das Ende ausgenommen, dunkel getrübt, die Vordertarsen gelb; die Nittel- und Hinterbeine schwarz, die Wurzeln und Spitzen ihrer Tibien und ihre Tarsen braungelb. Tubus so lang wie der Kopf, am Grunde fast zweimal so breil als am Ende. Körperlänge $2 \cdot 1 \mathrm{~mm}$.

FORMA MAGROPTERA (neu entdeckt). Flügel vollkommen entwickelt.

FOR I A APTERA. Flügel vollständig verkümmert. Pterothorax deutlich schmäler als bei der geflügelten Form.

$$
\text { ð (neu entdeckt). }
$$

Etwas kleiner als das $\nmid$. Am Vordertarsus ein ziemlich starker, etwas gebogener Zahn. Vorderschenkel bedeutend erweitert. dunkler als beim Weibchen; die Mittel- und Hintertibien an der Wurzel und an der äussersten Spitze düster braungelb. Sonst sind die Beine ähnlich wie beim Weibchen gefärbt.

Vorkommen: Das ganze Jahr hindurch im Moos und im Rasen in Wäldern und auf Wiesen. - Fundorte: Finnland (Reuter), Böhmen.

\section{Cryptothrips bicolor Heeg.*)}

1852. Phloeothrips bicolor Heeger, Sitzungsb. d. Akad. d. Wiss., Wien, IX, pag. 477.; tab. XVIII.

1889. - - Uzel, Vesmír, ročník XVIII., str. 259.

$$
\text { †. }
$$

Barva těla černá, jen prothorax jest hnědožlutý. Hlava skoro $0 \quad 0 \cdot 2$ delší než širši, do zadu se zúžující a na basi krkovitě stažená; má vủbec podobu hlavy druhu předcházejícího. Tykadla dvakrát delši hlavy, ve tvaru taktéž podobná tykadlùm druhu předešlého. Tretí ěl. jejich od tenké base ke konci poznenáhla se rozšiřuje a jest 00.2 kratši ně̌ prvé dva dohromady, 4. i 5. skoro tak dlouhé jako 3. a podobného tvaru. Barva tykadel: 1. čl. cernohnèdý, 2.-5. žluté, tento ke konci tmavě zkalený, 6., 7. a 8. černé. Makadla labialní opatřena jsou jedním dosti dlouhým, mohutným čípkem čichovỵ́m a člyřmi kratšími chlupy hmatavými. Prothorax as o 0.2 kratší než hlava. Přední femora

*) Doklar ve sbirce musejni, praep. č. 74. - Sammlung des böhmischen Landesmuseums. Praep. Nr. 74. 
stlustlá, s roztroušenými delšími chlupy. Nohy všecky hnědožluté. Tubus jest skoro o $0 \cdot 2$ kratší hlavy; směrem k basi velmi značně se rozšiřuje, takže před ní jest skoro třikrát šrší než na konci. Na basi samé opět jest trochu zúžený. Délka těla $2 \cdot 1 \mathrm{~mm}$.

F O M A M A G ROPTER A (nově objevená). Kî́dla jsou úphě vyvinuta.

FORMA BRAGHYPTERA. Kř́del jen rudimenta, pterothorax nepresahující.

$$
\text { đ’ (nově objevený). }
$$

Menší $(1 \cdot 7 \mathrm{~mm})$ a slabší než $\mathcal{~}$. U některých exempl. jsou přední femora velice rozšírená, u jiných nejsou širši než u samiček. Přední tarsus opatřen velikým ohnutým zubem. Lupínky na basi tubu se nalézající sahají až přes prvou třetinu jeho.

Třásněnka tato žije po celý rok v obou pohlavích v drnu lučním i lesním. V srpnu nalezl jsem jeden exempl. okirídlené formy (femina disseminans) na květu lučním.

Čechy: Hradec Králové.

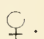

lïorperfarbe schwar\%, nur der Prothorax ist braungelb. Kopf fast um $0.2 \mathrm{mehr}$ lang als breit, nach hinten verengt und am Grunde halsförmig zusammengezogen; er hat grosse Ähnlichkeit mit demjenigen der vorhergehenden Art. Fühler zweimal länger als der Kopf, in Gestalt gleichfalls ähnlich denjenigen der vorigen Art. Ihr 3. Glied von dünner Basis an gegen das Ende zu allmählich erweitert und um 0.2 kürzer als die ersten zwei Glieder" zusammen, das 4. und auch das 5. fast ebenso lang wie das 3. und ähnlich geformt. Fühlerfärbung: 1. Glied schwarzbraun, das 2.-5. gelb, dieses gegen das Ende zu dunkel getrübt, das 6., 7. u. 8. schwarz. Labialtaster mit einem ziemlich langen, mächtigen Geruchszapfen und mit vier kürzeren Tastborsten versehen. Prothorax etwa um 0.2 kürzer als der Kopf. Die Vorderschenkel erweitert, mit längeren zerstreuten Borsten besetzt. Alle Beine braungelb. Tubus fast um 0.2 kürzer als der Kopf; gegen die Basis zu ist er sehr stark erweitert, so dass er vor derselben fast dreimal breiter ist als am Ende. Auf der Basis selbst ist er wieder etwas verschmälert. Körperlänge $2 \cdot 1 \mathrm{~mm}$.

FORMA MAGROPTERA (neu entdeckt). Flügel vollkommen entwickelt.

FORMA BRA CHYPTERA. Flügel rudimenlär.

$$
\sigma^{7} \text { (neu entdeckt). }
$$

Kleiner $(1.7 \mathrm{~mm})$ und schwächer als das . Bei manchen Exemplaren sind die Vorderschenkel sehr erweitert, bei anderen jedoch nicht in grösserem Masse als beim Weibchen. Die Vordertarsen mit einem grossen gebogenen Zahne versehen. 
Vorkommen: Das ganze Jahr hindurch in beiden Geschlechtern im Waldund Wiesenrasen. Im August fand ich ein geflügelles Weibchen (femina disseminans) auf einer Blüte. - Fundorte: Wien (im J. 1808 Ritter v. Goldegg, später Heeger), Böhmen.

\section{GENUS ANTHOTHRIPS m.*)}

Hlava nemnoho delší než širší. Tykadla nezcela dvakiát tak dlouhá jako hlava. Sosák jest krátký, sahá do poloviny prosterna a jest v předu široce zaokrouhleny; hořejší pysk jest tupý. Makadla maxillarní jsou opatrena ětyr̃mi chlupy hmatavými. Makadla labialní s jedním dlouhým zakřiveným čípkem čichovým. Prothorax tak dlouhý jako hlava. Kiřídla jsou u obou pohlaví vždy přítomna a vyznamenávají se tím. že jsou uprostřed značně zúžená, čimž nabývají podoby protáhlé podešve. Přední femora u samců značně stlustlá. Přední tarsy jsou u samic ozbrojeny velmi malỵm zoubkem, u samců pak zubem mohutným a jen výjimkou malým. Tubus nemá u samcu na basi lupínkû.

Kopf nicht viel mehr lang als breit. Fühler nicht ganz zweimal so lang wie der Kopf. Rüssel kurz, bis zur Mitte des Prosternum reichend, vorn breit gerundet; die Oberlippe ist stumpf. Maxillartaster mit vier Tastborsten, Labialtaster mit einem langen gebogenen Geruchszapfen versehen. Prothorax so lang wie der Kopf. Flügel bei beiden Geschlechtern immer vorhanden ünd dadurch ausgezeichnet, dass sie in der Nitte bedeutend verengt sind und somit gestreckten Sohlen ähnlich werden. Vorderschenkel bei den Männchen bedeutend erweitert. Vordertarsen bei den Weibchen mit einem sehr kleinen, bei den Männchen mit einem mächtigen und nur ausnahmsweise kleinen Zahn bewaffnet. Die Basis des Tubus bei den Männchen ohne Schuppen.

104. Anthothrips statices Halid.**)

Tab. III., fig. 26.; Tab. VII., fig. 128.-130.

1691. (Bez jména. - Ohne Namen.) Bonanni, Observ. circa viventia etc. I, pag. 384.; tab. XII., fig. 38 .

1836. Phloeothrips statices Haliday, Entomol. Magazine, pag. 442.

1836. - - Burmeister, Handb. d. Entom., II, pag. 409.

1843. Hoplothrips - Amyot et Serville, Ins. Hémiptères, pag. 640.

1852. Phloeothrips - Haliday, Walker: Homopt. ins. of Brit. Museum, pag. 1099.; tab. VIll., fig. 7.

*) "Aข0ss = krèt, Blüte.

**) Doklad re sbirce musejni, praep. ¿̇. 75. - Sammlung des böhmischen Landesmuseums, Praep. Nr. 75. 


\section{H. UZEL, MONOGRAPHIE DER ORDNUNG THYSANOPTERA.}

1852. Phloeothrips flavipes Heeger, Sitzungsh. d. Akad. d. Wiss., Wien, IX pag. 127.; tab. XVI. (Auf Grund der Abbildung her gerechnet.)

1852. - statices Idem, ibidem, pag. 128.; tab. XVII.

1880. - - Reuter, Thysanoptera fennica, pag. 22.

1887. - armata Lindeman, Bull. Soc. Imp. Nat. Moscou, pag. 335.

$$
\text { †. }
$$

Barva těla leskle černá, mezi kroužky červená. Hlava o $0 \cdot 2$ delší než širší, se stranami dosti parallelními, na basi trochu krkovitě zúžená. Tykadla o 0.75 delší hlavy. Články jejich zavalité, krátké. Třetí čl. kratší než prvé dva dohromady a asi tak dlouhý jako 4. Tento jest zakulacený a je nejširším článkem vủbec. Barva tykadel šedočerná až černá, jen 3. čl. žlutavý, na konci tmavý, a někdy též basis čtvrtého světlá. Přední femora trochu stlustlá, přední tarsy s malým zoublem. Nohy černé; přední tarsy a přední tibie ke konci a po stranách temně šedožluté, střední a zadní tarsy tmavší až šedočerné. Křídla někdy kromě samých koncủ celá šedohnědě zkalená, jindy ke konci čirá. Tubus o 0.2 kratši hlavy, skoro všude se slejným prủměrem, válcovitý, jen na samé basi sesilený. Délka těla $1 \cdot 6-1.8 \mathrm{~mm}$.

$$
\sigma^{7}
$$

O málo menší samice. Přední femora velmi značně stlustlá, zub na tarsu mohutný. Přední tibie, kromě tmavé base, žluté.

Třásněnka tato žije $\mathrm{v}$ létě $\mathrm{v}$ nejrủznèjších kvělech lučnich a lesních; nejvíce v květech od Chrysanthemum leucanthemum a (dle Halidaye) v květech od Armeria maritima, které bývaji třásněnkou tou naplnèny. V zimě nalezl jsem ji jednou pod spadaným listím a po druhé pod zpuchřelou korou. Samci objevují se od května do července.

Čechy: Po celém království v množství rozširiena a také na květnatých paloucích krkonošských všude přitomna. Nejvýše sbíral jsem ji na stráních Malého Sněžného března, okolo Boudy prince Jindřicha a na stráních nad Malým stavem. — Z Pešti mi byla s květinami zaslána.

$$
\text { Q. }
$$

Körperfarbe glänzend schwarz, die Verbindungshäute roth. Kopf um $0 \cdot 2$ mehr lang als breit, seine Wangen ziemlich parallel, am Grunde etwas halsförmig verengt. Fühler um 0.75 länger als der Kopf. Thre Glieder gedrungen. Das 3. Glied kürzer als die ersten zwei zusammen und etwa so lang wie das 4. Dieses ist gerundet und unter allen am breitesten. Fühlerfärbung grauschwarz bis schwarz, nur das 3. Glied ist gelblich, am Ende dunkel, und manchmal das 4. am Grunde licht. Vorderschenkel etwas erweitert, 


\section{J. UZEL, MONOGRAFIE RADU, "THYSANOPTERA“.}

Vordertarsen mit einem kleinen Zähnchen bewaffnet. Beine schwarz, die Vordertarsen und die Vordertibien gegen das Fnde zu und beiderseits düster graugelb, die Nittel- und Hintertarsen dunkler bis grauschwarz. Flügel graubraun getrübt, gegen das Ende zu oder nur an den Spitzen klar. Tubus um $0 \cdot 2$ kürzer als der Kopf, walzenförmig, nur an der Wurzel etwas verdickt. Körperlänge $1.6-1.8 \mathrm{~mm}$.

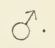

Wenig kleiner als das Weibchen. Vorderschenkel bedeutend erweitert, der Zahn am Vordertarsus mächtig. Vordertibien, ausser dem dunklen Grunde, gelb.

Vorkommen: Im Sommer in allerlei Wiesen- und Waldblüten; oft massenhaft in jenen von Chrysanthemum leucanthemum und (nach Haliday) von Armeria maritima. Überwinternde Weibchen fand ich unter abgefallenem Laube und morscher Rinde. Die Nännchèn leben im Mai, Juni und Juli. - Fundorte: England (Haliday), Wien (Heeger), Finnland (Reuter), Moskau (Lindeman), Deutschland (Jordan, Bohls; bei Berlin Uzel), Böhmen, Pest.

\section{Anthothrips distinguenda nov. sp.*)}<smiles>[CH-]</smiles>

Na priní pohled podoben druhu předcházejícímu. - Barva těla leskle černá. Hlava jest trochu kratší a zavalitější než u druhu statices, v předu nejširší, takřka utatá, se stranami již od očí obloučkem do zadu sbíhavými. Tykadla utvořená podobně jako u druhu předcházejícího. Barva jejich jest černá, 3. čl. celý a 4., 5. a 6 . do prvé třetiny ěistě žluté. Čl. 4., 5. a 6 . jsou mimo to ke konci trochu světlejší než uprostřed. Přední femora poněkud více stlustlá než u druhu statices; přední tarsy s malým zoubkem. Nohy černé, střední a zadní tarsy šedožluté neb čistě žluté, přední tarsy celé a přední tibie ke konci a na stranách čistě žluté. Křŕdla úplně čirá, jen na samé basi hnědě zkalená. Tubus o 0.26 kratši hlavy, konický, na basi skoro o 0.8 silnèjší než na konci. Délka těla $1.6-1.8 \mathrm{~mm}$.

$$
\text { ऽ. Nebyl posud objeven. }
$$

Třásnènka tato žije $\mathrm{v}$ létě $\mathrm{v}$ květech, $\mathrm{v}$ zimě ukrývá se pod korou.

Čechy: Jind. Hradec, v srpnu na květech od Scabiosa arvensis 12 exempl. (Duda). Hradec Királové: U Farářství, v prosinci pod korou vrbovou (2 exempl.).

*) Doklad ve sbirce musejní, praep. č. 76. - Sammlung des böhmischen Landesmuseums, Praep. Nr. 76. 


$$
\text { . }
$$

Körperfarbe glänzend schwarz. Kopf etwas kürzer und gedrungener als bei der vorhergehenden Art, vorn am breitesten, sozusagen abgestutzt, seine Wangen etwas gewölbt und schon von den Augen an nach hinten convergierend. Fühler ähnlich gebildet wie bei der vorigen Art. Thre Farbe schwarz, das 3. Glied ganz, das 4., 5. u. 6. im ersten Drittel rein gelb. Das 4., 5. u. 6. Glied ausserdem gegen das Ende zu etwas lichter. Vorderschenkel ein wenig mehr erweitert als bei der Art statices; die Vordertarsen mit einem kleinen Zähnchen bewaffnet. Beine schwarz, die Mittel- und Hintertarsen graugelb oder rein gelb, die Vordertarsen ganz und die Vordertibien gegen das Ende $z u$ und an den Seiten rein gelb. Flügel vollkommen klar, nur an der Wurzel braun getrübt. Tubus um 0.26 kürzer als der Kopf, konisch, am Grunde um 0.8 stärker als am Ende. Körperlänge $1.6-1.8 \mathrm{~mm}$.

$$
\text { ơ unbekannt. }
$$

Vorkommen: Im Sommer in Blüten, im Winter unter Rinde. - Fundort: Böhmen.

\section{Anthothrips aculeata Fabr. *)}

Tab. VII., fig. 131.

1803. Thrips aculeata Fabricius, Systema Rhyngotorum, pag. 312.

1836. Phloeothrips aculeatı Haliday, Entomol. Magazine, pag. 441.

1836. - - Burmeister, Handb. d. Entom., II, pag. 409.

1836. - albipenuis Idem, ibidem, pag. 410.

1843. Hoplothrips aculeata Amyot et Serville, Ins. Hémiptères, pag. 640.

1843. Haplothrips albipennis Iidem, ibidem, pag. 640.

1852. Pleloeothrips - Haliday, Walker: Homopt. ins. of Brit. Museum, pag. 1100 .

1852. - aculeata Heeger, Sitzungsb. d. Akad. d. Wiss., Wien, VIII, pag. 124.; tab. XIV.

1872. Thrips frumentarius Beling, Verhandl. Zool.-bot. Gesellsch., Wien, XXII, pag. 651 .

1876. - - - Szaniszló, Erdélyi gazda. Koloszvár. 24.

1878-79. Phloeothrips pallicomis Reuter, Diagn. öfv. nya Thysanopt. f. Finland, pag. 10 .

1880. Thrips frumentarius Szaniszló, Verhandl. Zool.-bot. Gesellsch., Wien, XXIX. 1880. Phloeothrips pallicomis Reuter, Thysanoptera fennica, pag. 23.

*) Doklad ve sbirce musejní, praep. č. 77. - Sammlung des böhmischen Landesmuseums, 


\section{J. UZEL, HONOGRAFIE RADU, „THYSANOPTERA“.}

1885. Thrips frumentarius Werner: Körnicke u. Werner, Handb. d. Getreidebaues, Bonn.

1887. Phloeothrips frumentaria Lindeman, Bull. Soc. Imp. Nat. Moscou, pag. 325.; pag. 329., fig. 15 , et 16 .

Q.

Barva těla černohnědá až červenohnědá, zřídka černá. Tělo menši a slabší než u obou druhủ předcházejicích. Tvar hlavy jako u druhu statices. Tykadla o $0^{\cdot} 75$ delší hlavy a tvaru podobného jako u zmínèného druhu, jen 4. čl. jest zde obyčejnè zretelně delší než třetí a ne tak široce zaokrouhlený. Zbarvení tykadel promènlivé: 1. čl. černý, 2. šedohnědý až černý, na konci žlutavý, 3. žlutavý, na konci tmavý (zřídka celý žlutý), někdy též basis jednoho nebo dvou následujicich světlá, jinak tỵkadlo světle šedé, šedohnědé až černošedé. Časem bývají články: 3., 4. a 5. celé šedožlutavé, a výjimkou bývá 6 . jen o něco tmavší. Za živa aneb na suchých exempl. jsou tỵkadla v celku světlejší. Přední femora nemnoho stlustlá a přední tarsy s malým, nèkdy přemalým zoubkem. Nohy tmavé, všecky tarsy, pak přední tibie kromè base šedožluté až čistě žluté. Kǐridla zcela ěirá, jen na samé basi hnědě zkalená. Tubus o 0.4 kratši hlavy, smèrem k basi vždy širši a širši, na samé pak basi náhle ještě rozširený a tam o 0.8 širš́i než na konci. Délka tèla $1.4 \mathrm{~mm}$.

$$
\sigma^{\top}
$$

O málo menší samice. Pr̉ední femora velmi značnè stlustlá, zub na tarsu mohutný, výjimkou jen malý.

Třásněnka tato žije $\mathrm{v}$ létě ve velikém množství v nejrůznējších květech lučních, lesních i zahradních, v kvètenství nejrủznéjších trav, zvl. v kukurìici, tritině a v bojínku; též na žitè, pšenici, ječmeni a ovse $\mathrm{v}$ počtu často úžasném se vyskytuje; dále objevuje se na mladých větvičkách smrkủ, jednotlivẽ také $\mathrm{v}$ drnu, na listech rozličných rostlin a stromů, i na houbách kloboukatých, výjimkou též někdy pod zpuchřelou korou. V zimě zalézá pod kûru, do suchỵch květenství nejrủznèjších rostlin, do drnu, mechu a pod spadané listí. Samci objevují se pořídku v červnu a počátkem července.

Čechy: Po celém királovstrí ve veliliém množství rozšiřena. Také všude po Kirkonoších lze ji v kvètech nalézti. Na vrcholu Sněžky žije $\mathrm{v}$ drnu.

$$
\text { P. }
$$

Körperfarbe schwarzbraun bis rothbraun. selten schwarz. Körper kleiner und schwächer als bei den zwei vorhergehenden Arten. Form des Kopfes wie bei der Art statices. Fühler um 0.75 länger als der Kopf und ähnlich gestaltet wie bei der eben erwähnten Art, nur ist das 4. Glied gewöhnlich deutlich länger als das 3, und nicht so 


\section{H. UZEL, MONOGRAPHIE DER ORDNUNG THYSANOPTERA.}

brcil gerundet. Fühlerfärbung veränderlich: das 1. Glied schwarz, das 2. graubraun bis schwarz, am Ende gelblich, das 3. gelblich, am Ende dunkel (selten ganz gelb), manchmal auch die Basis eines oder zweier folgenden Glieder licht; sonst ist der Fühler lichtgrau. graubraun bis schwarzgrau. Zuweilen pflegen das 3., 4. u. 5. Glied ganz graugelblich zu sein; das 6. Glied ist ausnahmsweise nur etwas dunkler. Beim lebenden oder trockenen Thiere sind die Fühler im ganzen lichter. Die Vorderschenkel nicht viel erweitert und die Vordertarsen mit einem kleinen, manchmal winzigen Zähnchen bewaffnet. Beine dunkel, alle Tarsen, dann die Vordertibien, ausser am Grunde, graugelb bis rein gelb. Flügel vollkommen klar, nur an der Wurzel braun getrübl. Tubus um 0.4 kürzer als der Kopf, gegen seinen Grund zu immer breiter und breiter, am Grunde selbst noch plötzlich erweitert und hier um 0.8 breiter als am Ende. Körperlänge $1.4 \mathrm{~mm}$.

$$
\sigma^{3} .
$$

Wenig kleiner als das Weibchen. Vorderschenkel bedeutend erweitert, der Zahn an Vordertarsus mächtig, nur ausnahmsweise klein.

Vorkommen: Im Sommer in den manigfaltigsten Blüten; auch in Grasblüten. In Getreideähren oft zahllos. Im Winter (nur q) unter Rinde, in trockenen Blülenständen, im Rasen, Moos und unter abgetallenem Laube. Männchen selten im Juni und anfangs Juli. - Fundorte: England (Haliday), Wien (Heeger), Finnland (Reuter), Russland: Moskau, Kiew, Tamboff (Lindeman), Deutschland (Burmeister, Beling, Jordan, Bohls), Bölımen.

\section{Anthothrips nigra Osborn.}

1883. Phloeothrips nigra Osborn, The Canadian Entomologist, pag. 154.

»Length $1.75-1.80 \mathrm{~mm}$. Width $.37 \mathrm{~mm}$. Black, distal portion of anterior tibiae, proximal joint of all tarsi and joints 3 with base of 4 , sometimes $3-5$, of antennae, vellowish. Head from above quadrangular, longer than broad, front convex with lateral angles obtusely rounded. Antennae sub-approximate, third joint yellowish and the two following ones more or less pale, especially at base; joints nearly equal, 8th short and small, sparsely set with hairs. Prothorax short, broad, lateral borders converging toward the head; meso and metathorax together as long as broad, converging slightly toward the abdomen; abdomen tapering, caudal segments sparsely fringed with hairs; tube fringed at end. Anterior legs larger than the others, with tibiae and tarsi yellowish, set with a few very minule hairs; posterior tibiae with spines at the distal extremity. Wings without veins, perfectly membranous, no minute hairs on the surfaces; anterior pair with a row of three spines near the costal border at the base; fringe at base wating; very long on both borders and at apical portion of posterior border composed of two rows, the additional one of finer ciliae. - Collected from heads of red clover. United Slates: Ames, Jowa.« 


\section{J. UZEL. IONOGRAFIE RADU "THYSANOPTERA“.}

Tato třásnènka podobá se značně našemu druhu statices, není-li s ním totožna. - Diese Art ähnelt sehr unserer $A$. statices, und ist vielleicht mit ihr identisch.

\section{GENUS ZYGOTHRIPS. (Nov. gen.)*)}

Hlava velmi málo delši než širši. Tỵkadla as dvakrát hlavy delší. Sosák sahá do poloviny prosterna; hořejší i dolejší pysk jsou ke konci zúžené a tupé. Makadla maxillarní dlouhá, šlíhlá a opatřená ělyřmi chlupy hmatavými. Prothorax skoro $0 \quad 0 \cdot 4$ kratší než hlava. Kř́idla jsou u samic přítomna a mají, uprostřed jsouce znaěně zúžena, podobu protáhlé podešve; u samců jssou zakrnělá. Přední femora u obou pohlaví sotva stlustlá. Přední tarsy u samic bezzubé, u samcủ s malým ostrým zoubkem. Tubus jest na basi u samcu z každé strany obklopen lupínkem.

Kopf nur sehr wenig mehr lang als breit. Fühler etwa zweimal länger als der Kopf. Der Rüsscl reicht bis zur Nitte des Prosternum; Ober- und Unterlippe gegen das Ende zu verengt, stumpf. Maxillartaster lang, schlank und mit vier Tasthaaren besetzt. Prothorax fast um 0.4 kürzer als der Kopf. Flügel bei den Weibchen vorhanden, in der Mitte verengt und infolge dessen gestreckt sohlenförmig; bei den Männchen verkümmert. Vorderschenkel bei beiden Geschlechtern kaum erweitert. Vordertarsen bei den Weibchen wehrlos, bei den Männchen mit einem kleinen scharfen Zähnchen bewaffnet. Tubus bei den Männchen am Grunde jederseits mit einer anliegenden Schuppe versehen.

\section{8. 'Zygothrips minuta nov. sp.**)}

Tab. VII., fig. 132 , et 133 .

$$
\text { P. }
$$

Barva tèla černá. Hlava nazad trochu zúžená. Tykadla as dvakrát delší hlavỵ. První čl. kratši druhého, 3. as tak dlouhý jako předcházejicí, slaboučký, 4. značnè silnější, široce zaokrouhlený, 8. na basi velmi široký. Barva tykadel: 1. čl. ěernohnědý, 2. žlutý, na basi a po obou stranách tmavý, 3. žlutavý, následujicí všechny šedožlutavé, 7. a 8. poněkud tmavě zkalené. Makadla labialní mají jeden dlouhý zakrìivený a jeden velmi krátký ě́pek smyslový. Všecka femora černohnědá, všecky tarsy žluté; tibie taktéž žluté, přední však na basi, střední as do polou a zadní do dvou třetin silněji nebo slaběji hnědě zkalené. Kirídla ěirá, jen na samé basi zkalená. Tubus as o $0 \cdot 3$ kratší hlavy, na basi skoro dvakráte tak silný jako na konci. Délka těla $1 \cdot 1 \mathrm{~mm}$.

*) Zưó̀ = článek spojovací, Verbindungsglied.

**) Doklad ve sbírce autorovè. 


\section{H. UZEL, MONOGRAPHIE DER ORDNUNG THYSANOPTERA.}

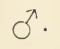

Křídla zakrnělá. Tubus na basi z každé strany obklopen jedním lupínkem, přesahujicím prvou jeho třetinu.

Ze tř̉i exempl. této tř́ásněnky, které mám, nalezen jeden v létẽ pod korou vrbovou, druhý v zimě pod korou lípovou a třeti na kvètu od Sorbus aucuparia.

Čechy: Liberec: U Habendorfu. Hradec Králové. Tr̉ebechovice: U Jilovice.

$$
\text { q. }
$$

Körperiarbe schwarz. Kopf nach hinten etwas verengt. Fühler etwa zweimal so lang als der Kopf. Das erste Glied kürzer als das zweite, das 3. etwa so lang wie das vorhergehende, schwächlich, in seiner ersten Hälfte verengt, das 4. bedeutend stärker, breit gerundet, das 8. am Grunde sehr breit. Fühlerfärbung: 1. Glied schwarzbraun, das 2. gelb, am Grunde und jederseits dunkel, das 3. gelblich, alle folgenden graugelblich, das 7. u. 8. schwach dunkel getrübt. Labialtaster mit einem langen gekrümmten und einem sehr kurzen Sinneszapfen versehen. Alle Schenkel schwarzbraun, alle Tarsen gelb; die Tibien ebenfalls gelb, die vorderen jedoch am Grunde, die mittleren etwa bis zur Mitte und die hinteren in den ersten zwei Dritteln stärker oder schwächer braun getrübt. Flügel klar, nur an der Wurzel getrübt. Tubus etwa um 0.3 kürzer als der Kopf, am Grunde fast zweimal so stark als am Ende. Körperlänge 1.1 mm.

$$
\text { đ. }
$$

Flügel verkümmert. Tubus am Grunde jederseits mit einer anliegenden Schuppe, die sein erstes Drittel überragt, versehen.

Vorkommen: Im Sommer fand ich ein Exempl. unter Rinde und ein Exempl. auf einer Blüte von Sorbus aucuparia. Im Winter unter Rinde. - Fundort: Böhmen.

\section{GENUS CEPHALOTHRIPS m.*)}

Hlava značnè delší než širší, tlustá, o mnoho delší neż prothorax. Sosák jest krátký a sahá asi do poloviny prosterna; hoř. pysk ukoněen krátkým tupým hrotem, presahujicím široký zaokrouhlený pysk dolejší. Makadla maxillarní se čtyřmi chlupy hmatavými. Kř́idla scházeji úplně. Nohy krátké, zavalilé. Předni larsy u samiček opatřeny premalým zoubkem.

*) $\mathrm{K}$ equiki $=$ hlava, Kopf. 


\section{J. UZEL, MONOGRAFIE RADU "THYSANOP'TERA“.}

Kopf bedeutend mehr lang als breit, dick, viel länger als der Prothorax. Rüssel kurz, bis zur Mitte des Prosternum reichend; Oberlippe in eine kurze stumpfe Spitze auslaufend, welche die breit gerundete Unterlippe überragt. Maxillartaster mit vier Tastborsten besetzt. Flügel vollkommen fehlend. Beine kurz, gedrungen. Vordertarsen bei den Weibchen mit einem winzigen Zähnchen versehen.

\section{Cephalothrips monilicornis Reut.*)}

Tab. VII., fig. 134. et 135 .

1880. Phloeothrips monilicomis Reuter, Thysanoptera fennica, pag. 21.

$$
\text { P. }
$$

Barva tèla černá. Hlava skoro o $0 \cdot 4$ delši než širši, velmi zavalitá, uprostred trochu rozšírená, k oběma koncủm poznenáhla poněkud se zúžující. Oči veliké. Tykadla jsou jen $0 \quad 0.5$ delší než hlava. Třetí čl. jejich trochu kratší a slabší než 2. ., 4. trochu delší a mocnējší ně̌ třetí, 5. skoro téže délky jako $3 . ; 6 ., 7$. a 8 . tvoři dohromady celek. Barva tykadel: 1. a 2. cl. černé, 6., 7. a 8. černohnědé, 3., 4. a 5. žlutohnědé, na obou koncich žlutavé. Makadla labiahni mají jeden dlouhý a jeden krátký čípek smyslový. Prothorax o 0.4 kratši hlavy, velmi úzký, i v zadu jen o malinko širší než tato. Pterothorax jest jen tak široký jako hlava a trochu delší než prothorax; nazad se poněkud zúžuje. Přední femora poněkud stlustlá. Barva noh černá, konce tibií a tarsy žluté. Tubus o 0.4 kratši hlavy. Délka těla $1 \cdot 1 \mathrm{~mm}$.

$$
ð \text {. Nebyl posud objeven. }
$$

Čechỵ: Jind. Hradec: V lese nad Skrejchovem (Duda).

$$
\text { q. }
$$

Körperfarbe schwarz. Kopf fast um 0.4 mehr lang als breit, sehr gedrungen, in der Mitte ein wenig erweitert, nach vorn und hinten allmählich etwas verengt. Augen gross. Fühler nur um 0.5 länger als der Kopf. Ihr 3. Glied etwas kürzer und schwächer als das 2., das 4. etwas länger und mächtiger als das vorhergehende, das 5. fast ebenso lang wie das 3., das 6., 7. u. 8. bilden zusammen ein Ganzes. Fühlerfärbung: 1. u. 2. Glied schwarz, das 6., 7. u. 8. schwarzbraun, das 3., 4. u. 5. gelbbraun, an beiden Eıden gelblich. Labialtaster mit einem langen und einem kurzen Sinneszapfen versehen. Prothorax um 0.4 kürzer als der Kopf, sehr schmal, auch hinten nur wenig breiter als der Kopf. Pterothorax nur so breit wie der Kopf und etwas länger als der Prothorax;

*) Doklad ve sbirce autorovẽ. 


\section{H. UZEL, MONOGRAPHIE DER ORDNUNG THYSANOPTERA.}

nach hinten ein wenig verengt. Vorderschenkel etwas erweitert. Farbe der Beine schwarz, die Enden der Tibien und die Tarsen gelb. 'Tubus um $0 \cdot 4$ kürzer als der Kopf. Körperlänge $1 \cdot 1 \mathrm{~mm}$.

$$
\text { ठ unbekannt. }
$$

Fundorte: Finnland (Reuter), Böhmen (Duda).

\section{GENUS TRICHOTHRIPS m.*)}

Hlava as tak široká jako dlouhá, v pr̉edu nejširší. Hor̉. pysk jest ve hrot prodloužen a přesahuje spodní pysk, který jest široce zaokrouhlený. Makadla maxillarní maji čtyři chlupy himatavé různé délky. Nakadla labialní jsou na vnitřní straně opatřena jedním ěípkem cichovým, na vnèjši pak dvěma delšími chlupy hmatavými. Oči jsou velmi malé. Očka často scházejí. Křídla někdy prítomna, jindy úplně zakrñují. Př̀ední femora u samiček značně. u samcủ pak měrou ještě větší stlustlá. Přední tarsy jsou u obou pohlaví zubem ozbrojeny. Tubus nemá u samců na basi žádných lupínkủ. Chlupy na těle, zvl. na zadní polovině abdomenu, neobyčejně dlouhé a tenké. Nymfỵ mají tykadla přiloželıí ke stranám hlary.

Kopf elwa ebenso breit wie lang, vorn am breilesten. Oberlippe in eine Spitze verlängert, welche die breil gerundete Unterlippe überragt. Naxillartaster mit vier ungleich langen Tastborsten besetzl. Labialtaster an der Innenseite mit einem Geruchskolben, an der Aussenseile mit zwei längeren Tasthorsten versehen. Augen sehr kicin. Ocellen oft fehlend. Flügel manchmal vorhanden, gewöhnlich jedoch vollkommen verkümmerl. Vorderschenkel bei den Weibchen bedeutend, bei den Männchen in noch grösserem Masse erweitert. Vordertarsen bei beiden Geschlechtern mit einem Zahn bewaffnet. Tubus bei den Männchen am Grunde ohne Schuppen. Die Borsten auf dem Körper, hauptsächlich auf der hinleren Hälfte des Abdomen. mgewöhnlich dünn und lang. Die Fühler der Nymphen an den Kopfseiten anliegend.

\section{Trichothrips pedicularia Halid. **)}

Tab. II., fig. 18.; Tab. VII., fig. 136. et 137 .

1836. Phloeothrips pedicularia Haliday, Entomol. Magazine, pag. 441.

1836. - flavipes Idem, ibidem, pag. 442.

1836. - pedicularia Burmeister. Handb. d. Entomol., II, pag. 408.

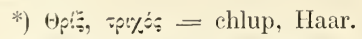

**) Doklad ve sbirce musejní, praep. ¿̌. 78. - Sammlung des böhmischen Landesmuseums, Praep. Ni. 78. 


\section{J. UZEL, NONOGRAFIE RADU "THYSANOPTERA“.}

1836. Phloeothrips flavipes Idem, ibidem, pag. 409.

1843. Hoplothrips - Amyot et Serville, Ins. Hémiptères, pag. 640.

1852. Phlocothrips pedicularia Haliday, Walker: Homopt. ins. of Brit. Museum, pag. 1098.

1880. - apicalis Reuter, Thysanoptera fennica, pag. 25.

$$
\text { ․ }
$$

Tělo velmi široké. Tykadla trochu více než dvakrát hlavy delší. První článek nejmohutnější, 2. as tak dlouhý jako první, 3. čl. as o 0.3 kratší než prvé dva dohromady, od velmi úzké base ke konci značně rozšiřený, na konci opět náhle zúžený, 4. as tak dlouhý jako predcházejicí, 8. na basi zúžený. Sosák dosahuje zadniho okraje prosterna. Prothorax delší než hlava. Nohy krátké. Pr̃ední femora značně stlustlá, přední tarsy s dlouhým tenkým zubem. Barva noh žlutá. Prední femora někdy na basi s šedým nádechem, střední a zadní často šedě zkalená, na konci neb ke konci světlá. Tubus jest trochu kratší než hlava a často basí vězí v 9. c̀l. abdom., jsa zde ještě jednou tak tlustý jako na konci. Délka tẻla as $1.4 \mathrm{~mm}$.

$$
\text { 万. }
$$

Nemnoho menší samice. Přední femora velice stlustlá, někdy ǎ̌ tak široká jako hlava. Přední tarsus s dlouhým silným zubem.

FORMA MAGROPTERA. $\subsetneq$ i $\sigma^{\pi}$. - Křídla úplně vyvinutá. Tèlo červenohnědé. Hlava hnědošedá, konec abdomenu žlutý. Tykadla žlutavá, kromě dvou prvních článkû (a někídy i 1., zř́ídka 2.) šedě až tmavošedẽ zkalená. Očka zřetelná. Hoř. kř́ídla šedožlutě zkalená, před basí světlá. Tubus jest žlutý, před kořenem však úžeji nebo širreji hnèdošedě zkalený.

FORMA APTERA. † i đ. - Kř́del ani nejmenši rudimenta. Tělo červenohnědé. Hlava žlutá až červenožlutá, abdomen ke konci žlutý. Tykadla světlejší než u formy okřidlené. Oči menší. Očka obyčejně nezřetelná. Tubus zbarven jako u předcházející formy.

Třásněnka tato žije ve společnostech pod zpuchřelou korou různých stromủ, zvláště bř́z, topolủ, jeřábů, a ráda zdržuje se $\mathrm{v}$ okolí polyporů.

Čechy: Praha: V Cibulce. Peruc. Čerčany: V lese u Lštění (Bubák).

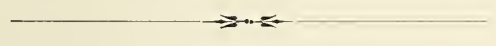

P.

Körper sehr breit. Fühler etwas mehr als zweimal so lang als der Kopf. Das 1. Glied am mächtigsten, das 2. etwa so lang wie das 1., das 3 . etwa um 0.3 kürzer als die ersten zwei zusammen, von sehr dünner Basis gegen das Ende zu bedeutend er- 


\section{H. UZEL, MONOGRAPHIE DER ORDNUNG THYSANOPTERA.}

weitert, am Ende jedoch wieder plötzlich verengt, das 4. etwa so lang wie das vorhergehende, das 8. am Grunde verengt. Der Rüssel reicht zum Hinterrande des Prosternum. Prothorax länger als der Kopf. Beine kurz. Vorderschenkel bedeutend erweitert, Vordertarsen mit einem langen dünnen Zahne bewaffnet. Farbe der Beine gelb; Vorderschenkel manchmal am Grunde mit grauem Anflug. Mittel- und Hinterschenkel oft grau getrübt, am Ende oder gegen das Ende licht. Tubus etwas kürzer als der Kopf und oft in das 9. Abdominalsegment etwas eingeschoben; am Grunde noch einmal so dick als am Ende. Körperlänge etwa $1.4 \mathrm{~mm}$.

$$
\text { o. }
$$

Nicht viel kleiner als das Weibchen. Die Vorderschenkel ungewöhnlich erweitert, manchmal so breit wie der Kopf. Vordertarsen mit einem langen starken Zahn bewaffnet,

FORMA MAGROPTERA. \& u. $\sigma^{\nwarrow}$. - Flügel vollkommen entwickelt. Körper rothbraun. Kopf braungrau, das Abdomenende gelb. Fühler gelblich, die zwei ersten Glieder ausgenommen (und zuweilen auch das 1., selten das 2.), grau bis dunkelgrau getrübt. Ocellen deutlich. Oberflügel graugelb angehaucht, am Grunde licht. Tubus gelb, vor der Wurzel jedoch schmäler oder breiter braungrau getrübt.

FORMA APTERA. † u. $\sigma^{\nearrow}$. - Flügel vollkommen verkümmert. Körper rothbraun, Kopf gelb bis rothgelb, Abdomen gegen das Ende zu gelb. Fühler lichter als bei der geflügelten Form. Augen kleiner. Ocellen gewöhnlich undeutlich. Tubus so gefärbt wie bei der vorhergehenden Form.

Vorkommen: In Gesellschaften unter morscher Rinde verschiedener Bäume (besonders Birken, Pappeln und Vogelbeeren), und zwar mit Vorliebe in der Nähe von Polyporen. - Fundorte: England (Haliday), Finnland (Sahlberg), Böhmen.

\section{Trichothrips caespitis nov. sp.*)}

$$
\text { f. }
$$

Barva těla tmavohnědá, jen hlava jest žlutá. Tvar těla jest mnohem štihlejší než u druhu pedicularia. Tvar hlavy jako u druhu tohoto. Také tykadla jsou podobně utvořena a zbarvena; 8. čl. jejich jest však na basi značně širši. Očka jsou nezřetelná. Sosák dosahuje jen as $\mathrm{k}$ polovině prosterna. Prothorax o něco delší hlavy. Přední femora málo stlustlá; zub na předních tarsech jest malý a tenký. Křídla scházejí úplně. Tubus trochu kratší než hlava. Délka tèla $0.9 \mathrm{~mm}$. - Čtyři exempl. nalezeny.

*) Doklad ve sbirce musejní, praep. ¿̌. 79. - Sammlung des böhmischen Landesmuseums, Praep. Nr. 79. 


\section{J. UZEL, HONOGRAFIE RADU, "THYSANOPTERA".}

$\sigma^{\pi}$.

Trochu užši a menši než †, přední femora o něco více stlustlá než u této. Kíídla scházeji taktéž úplně. - Jeden exempl. nalezen.

Třásněnku tuto prosíval jsem $\mathrm{v}$ zimě z drnu na pasekách lesních.

Ċechy: Hradec Králové: V lese hradeckém i novohradeckém.

$$
\text { ?. }
$$

Körperfarbe dunkelbraun, nur der Kopf gelb. Körpergestalt viel schlanker als bei der Art pedicularia. Die Form des Kopfes und der Fühler, sowie die Farbe der letzteren ähnlich wie bei derselben; nur ist das 8 . Fühlerglied am Grunde breiter. Ocellen undeutlich. Der Rüssel reicht nur etwa bis zur Mitte des Prosternum. Prothorax etwas länger als der Kopf. Vorderschenkel wenig erweitert; der Zahn auf den Vordertarsen klein und dünn. Flügel vollkommen fehlend. Tubus etwas kürzer als der Kopf. Körperlänge $0.9 \mathrm{~mm}$.

$$
\sigma^{7} .
$$

Etwas schmäler und kleiner als das $\uparrow$, die Vorderschenkel ein wenig mehr als bei demselben erweitert. Flügel ebenfalls vollkommen fehlend.

Vorkommen: Im Winter im Waldrasen: hier olıne Zweifel auch im Sommer. Fundort: Böhmen.

\section{Trichothrips semicaeca nov. sp.*)}

‥

Barva těla šedě žlutavá, prothorax c̀ernohnědý neb šedohnědý a tubus kromẽ světlé base černý. Oči velmi malé, poměrně nejmenší mezi všemi třásněnkami vůbec. Očka scházejí úplnè. Tỵkadla více než dvakrát hlavy delší. První až 3. čl. jejich žlutavé, ostatní hnědočerné. Sosák dosahuje k zadnímu okraji prosterna. Prothorax delši hlavy. Pìední femora značně rozšírená, na předních tarsech dlouhý tenký zub. Nohy žlutavé, ršecka femora slabě šedě zkalená. Křídla scházejí úplně. Tubus právě tak dlouhý jako hlava, na basi ješlě jednou tak široký jako na špičce. Délka těla $1.3 \mathrm{~mm}$. — Sedm exempl. nalezeno.

రె.

Menší $(0 \cdot 9-1 \cdot 1 \mathrm{~mm})$ a zavalitější než $q$. Též bezkřídlý a bez oček. Přední femora jsou nezkalená a více rozšiřená než u ní, a zub na předních tarsech jest mohutnèjší. - Tři exempl. sbírány.

Třásněnka tato nalezena $\mathrm{v}$ březnu pod korou březovou u Věkoše, nedaleko Hradce Králové.

*) Doklad ve sbirce musejní, praep. ě. 80. - Sammlung des böhmischen Landesmuseums, Praep. Nr. 80. 
†.

Körperfarbe grau gelblich, Prothorax schwarzbraun oder graubraun und der Tubus, den lichten Grund ausgenommen, schwarz. Augen sehr klein, verhältnismässig die kleinsten unter allen Thysanopteren. Ocellen vollkommen fehlend. Fühler mehr als zweimal länger als der Kopf. Das 1.-3. Glied gelblich, die übrigen braunschwarz. Der Rüssel reicht bis zum Hinterrande des Prosternum. Prothorax länger als der Kopf. Die Vorderschenkel bedeutend erweitert, auf den Vordertar:en ein langer dünner Zahn. Beine gelblich, alle Schenkel schwach grau getrübt. Flügel vollkommen fehlend. Tubus ebenso lang wie der Kopf, am Grunde nochmal so breit als am Ende. Körperlänge $1 \cdot 3 \mathrm{~mm}$.

$$
\sigma^{3}
$$

Kleiner $(0 \cdot 9-1 \cdot 1 \mathrm{~mm})$ und gedrungener als das $\subsetneq$. Ebenfalls flügellos und ohne Ocellen. Die Vorderschenkel sind nicht getrübt und mehr erweitert als bei demselben, und der Zahn auf den Vordertarsen ist mächtiger.

Vorkommen: Unter Birkenrinde. - Fundort: Böhmen.

\section{Trichothrips ulmi Fabr.}

1781. Thrips ulmi Fabricius, Species Ins., pag. 396.

1787. - - Fabricius, Mantissa Ins., pag. 320.

1788. - - Linné (Gmelin), Systema Naturae. Ed. XlII., pag. 2223.

1794. - - Fabricius, Entomol. System., pag. 229.

1803. - - Fabricius, Systema Rhyngotorum, pag 313.

1806. - - Turton, A General System of Nature, pag. 716.

1836. Phloeothrips Ulmi Haliday, Entomol. Magazine, pag. 441.

1836. - - Burmeister, Handb. d. Entomol., II, pag. 409.

1837. - - Haliday, Entom. Magaz. Additional Notes, pag. 145.

1852. - - Haliday, Walker: Homopt. ins. of Brit. Museum, pag. 1098.; tab. V., fig. 1.-4.; tab. VI., fig. 1.

Haliday (anno 1836.): „Ocellis tribus. - Capitis lateribus parallelis. - Piceonigra, antennarum articulo 3tio toto, sequentibus basi flavo-pallidis; tibiis basi apiceque, anticis totis tarsisque ferrugineis; femoribus anticis incrassatis; pollice in utroque sexu

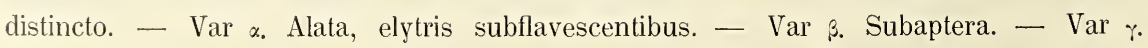
Subaptera fusco-castanea. - The male is much shorter than the female, with the fore thighs twice as large, and the thumb, or tooth, on the inside of the fore foot, common to all of this genus, very thick. - Inhabits under the bark of old trees feeding on mucor.» 


\section{J. UZEL. MONOGRAFIE RADU „THYSANOPTERA“.}

Haliday (anno 1837.): "Larva much depressed, white; the head, a bilobed spot on the prothorax, the last two segments of the abdomen and a lateral spot on the preceding one, black. A few black dots on the thorax. Antennae black, with the base pale. Pupa white, with a few red dots on the thorax, and in the place of the simple eves. Sometimes a faint reddish tinge in parts of the abdomen "

Halida y (anno 1852.): »Subabtera, nigro-picea, pectore dilutius piceo, antennarum articulo tertio tolo. sequentibus basi pallide flavis, tibiis basi et apice, anticis totis tarsisque ferrugineis, $\sigma^{\nearrow}$, $\subsetneq$. Tum fem. alata, alis anticis extus laevissime flavicantibus. Larva depressa alba, capite, antennis, prothoracis macula biloba, abdominis apice nigris. Hab. sub cortice arborum exsiccato, praesertim Ulmi, gregaria. Long. fem. $1^{1 / 2}$ lin., mar. 1. lin. England. «

\section{Trichothrips pini Halid.}

1837. Phloeothrips Pini Haliday, Entom. Magaz. Additional Notes, pag. 145. 1839. Thrips aptera Dufour, Annales d. Scienc. Nat., 11, tab. VIII., fig. 8. 1840. - Fungi Zetterstedt, Ins. lapponica, pag. 312.

1852. Phloeothrips Pini Haliday, Walker: Homopt. ins. of Brit. Museum, pag. 1099.; tab. VIII., fig. 33.

Haliday (anno 1837.): »Phl. Ulmi simillima, sed magis elongata. Mas subapterus; fem. subaptera, vel alata, elytris extrorsum infumatis. - The eggs are milky, or bluish white, about $\frac{x}{50}$ of an inch in length, by $\frac{3}{400}$ diameter. They are cylindric, with each end equally rounded, thus differing from those of Plll. statices. They are attached in loose clusters to the bark, and hardened by a gummy wash, soluble in water, by the application of which they are detached, and become flaccid. The larva is longer and less depressed than that of Phl. Ulmi; of a red flesh colour, with the head and feet paler; the body is thickly freckled with bright red on a paler ground, which produces the general tint. The last two segments of the abdomen are black; also the antennae, which have the base pale. Very young larvae are of a dirty watery tint, with the antennae and lail black. The antennae are then proportionally larger; the abdomen small and attenuate, the hairs of the body very long and conspicuous. The pupa is very pale flesh colour, the red dots being fewer; the head whitish, with a reddish patch in the middle; the legs and last two segments of the abdomen white; the fore-thighs very little thickened. The pterothecae were very small in those examined, which would probably have produced subapterous individuals, these being the most numerous. The perfect insect exceedingly resembles the last species ( $P h l$. Ulmi), but is longer, a female of Pll. Ulmi measuring $\frac{\mathrm{xt}}{\mathrm{roo}}$ of an inch in length, by $\frac{2}{100}$ in breadth; while one of Phl. Pini, scarcely so broad, was $\frac{r_{4}}{\text { Ioo }}$ in length. The fore-thighs, besides, are less thickened, which difference is particularly observable in comparing the males. The winged females 


\section{H. UZEL, MONOGRAPHIE DER ORDNUNG THYSANOPTERA.}

evidently differ by the darker colour of their wings, the upper pair being brown in the outer half, with the hind margin paler, and the lower having that margin alone brown. Inhabits under the bark of old pine stumps in profusion.

Haliday (anno 1852.): »Subaptera, nigro-picea, pectore dilutius piceo, antennarum articulo tertio toto, sequentibus basi pallide flavis, tibiis basi apiceque, anticis totis tarsisque ferrugineis, $\delta^{\nearrow}, q$. Tum fem. alata, alis extrorsum infumatis. Larva elongata, incarnata, abdominis apice et antennis dilutius nigricantibus. Hab. sub cortice arborum emortuarum, et praecipue Pini sylvestris, gregaria. Long. fem. $1 \frac{2}{3}$ lin. Praecedenti (Pll. Ulmi) simillima, modo longior; alata laeviore opere dignoscenda."

\section{Trichothrips copiosa nov. sp.*)}

Tab. IV., fig. 32.; Tab. VII., fig. 138.-140.

q.

Barva těla šedohnědá, hlava nejtmavší, pterothorax nahoře a celý thorax dole žlutavohnědé. Tykadla skoro dvakrát hlavy delši, zavalitá. Třetí ěl. jejich jest as $00 \cdot 2$ kratší než prvé dva dohromady, 4. as tak dlouhý jako 3., avšak trochu silnější; 3.—6. ěl. jsou krátce zavalitě kyjovité. Barva tykadel: 1. čl. černohnědý, někdy šedohnědý, 2. žlutý, na samé basi a po obou stranách úzce tmavẽ zkalený, 3. žlutý, 4., 5. a 6. taktéž žluté, v druhé polovině však trochu šedě zkalené, 6. a 7. veskrz šedé. Někdy jest celé tykadlo od článku čtvrtého dosti silně šedě zkaleno. Sosák dosahuje jen as k polovině prosterna. Prothorax jest právè tak dlouhỵ jako hlava. Přední femora značně rozšsiřená, na předních tarsech velmi dlouhý tenký zub. Femora všecka šedohnědá, tibie a tarsy všecky žluté. Tubus právẽ tak dlouhý jako hlava, na basi ještě jednou tak široký jako na špičce a na obou koncích trochu svěllejši. Délka těla $2 \cdot 1 \mathrm{~mm}$. - Larvy jsou bílé, jemně červeně kropenaté. Hlava a dvě skvrny na předohrudi jsou slabě šedě zkalené, poslední dva články abdomenu tmavošedé. Nymfy jsou průsvitavě bělavé, spořeji červeně kropenaté a lezou právě tak jako larvy.

FORMA IIAGOPTERA. Krídla úplně vyvinutá. Středem jejich jde obyčejně Žlutohnědý podélný pruh; hořejší jsou mimo to v poslední čtvrtině celá žlutohnědě zkalená.

FORMA APTERA. Kǐ́del ani nejmenši rudimenta.

$$
\text { or. }
$$

Vždy bezkřídlý. Menší a zavalitější než q; přední femora mnohem více rozšířená a zub na předních tarsech mohutnější. Konce předních stehen jsou žlutohnědé.

*) Doklad ve sbirce musejni, praep. č. 81. - Sammlung des böhmischen Landesmuseums, Praep. Nr. 81. 


\section{J. UZEL, MONOGRAFIE RADU, „THYSANOPTERA“.}

Poznámka. Trich. copiosa rozeznává se od obou předcházejicích druhủ na proní pohled svými žlutými tibiemi, od druhu Trich. Ulmi mimo to zvl. larvou bílou a červeně kropenatou.

Třásněnka tato žije po celý rok $\mathrm{v}$ obou pohlavích ve velikých společnostech pod zpuchřelou korou vrb, švestek, bříz a olši. Forma okřidlená vyskytuje se ojediněle mezi formou bezkǐídlou.

Čechy: Hradec Králové: Na několika mistech v okolí. - Nezi různỵ́m hmỵzem, panu prof. Dudovi z Laponska zaslaným, byl též jeden exempl. druhu tohoto.

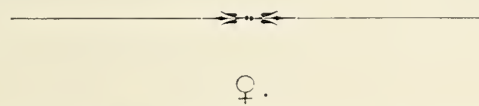

Körperfarbe graubraun, der Kopf am dunkelsten, der Pterothorax oben und der ganze Thorax unten gelblichbraun. Fühler fast zweimal länger als der Kopf, gedrungen. Das 3. Glied etwa um $0 \cdot 2$ kürzer als die ersten zwei zusammen, das 4. etwa so lang wie das 3., jedoch etwas stärker; das 3.-6. Glied gedrungen keulenförmig. Fühlerfärbung: 1. Glied schwarzbraun, manchmal graubraun, das 2. gelb, an der Wurzel und zu beiden Seiten schmal dunkel getrübt, das 3. gelb, das 4., 5. u. 6. ebenfalls gelb, in ihrer zweiten Hälfte jedoch etwas grau getrübt, das 6. u. 7. ganz grau. Zuweilen ist der ganze Fühler vom 4. Glied an ziemlich stark grau getrübt. Der Rüssel reicht nur bis zur Nitte des Prosternum. Prothorax ebenso lang wie der Kopf. Vorderschenkel bedeutend erweitert, auf den Vordertarsen ein sehr langer dünner Zahn. Alle Schenkel graubraun, alle Tibien und Tarsen gelb. Tubus ebenso lang wie der Kopf, am Grunde nochmal so breit als an der Spitze, seine beiden Enden lichter gefärbt. Körperlänge $2.1 \mathrm{~mm}$. - Larven weiss, fein roth gesprenkelt. Kopf und zwei Flecke auf dem Prothorax schwach grau getrübt; die letzten zwei Abdominalsegmente dunkelgrau. Die Nymphen durchscheinend weisslich und sparsam roth gesprenkelt. Sie kriechen ebenso wie die Larven.

F O R M A II A CR OP T E R A. Flügel vollkommen entwickelt. Durch ihre Mitte zieht sich gewöhnlich ein gelbbrauner Längsstreif; die Oberflügel sind ausserdem im letzten Viertel ganz getrübt.

FORMA APTERA. Flügel vollkommen verkümmert.

$$
\sigma^{\pi}
$$

Kleiner und gedrungener als das $\subsetneq$, immer flügellos, seine Vorderschenkel viel mehr erweitert und der Zahn auf den Vordertarsen mächtiger. Die Enden der Vorderschenkel gelbbraun.

Bemerkung: Trich. copiosa unterscheidet sich von den beiden vorhergehenden Arten auf den ersten Blick durch ihre ganz gelben Tibien, von der Art Ulmi ausserdem durch ihre weissen, roth gesprenkelten Larven. 


\section{H. UZEL, MONOGRAPHIE DER ORDNUNG THYSANOPTERA.}

Vorkommen: Das ganze Jahr hindurch in beiden Geschlechtern in grossen Gesellschaften unter morscher Weiden-, Pflaumen-, Birken- und Erlenrinde. Die geflügelte Form kommt nur vereinzelt vor. - Fund orte: Böhmen, Lappland.

\section{GENUS PHLOEOTHRIPS HALID.*)}

Hlava trochu delší než šiší, na stranách s několika malými bradavkami, z nichž každá jest osténkem ukončena; v predu se zúžuje. Tykadla dvakrát delši hlavy. Sosák jest špičatý a skoro se mesosterna dotýlḱ. Hor̆. pysk jest hrotem zakončen. Makadla maxillarní jsou dlouhá a dosti štíhlá. Ze čtyr̃ chlupủ hmatavých, na nich se nalézajících, jest jeden velmi krátký. Nakadla labialní nedlouhým, na vnější stranu ohnutým čípkem opatřena, kolem něhož jsou rozestaveny trì delší chlupy hmatavé. Kríidla u samcủv i samic vždy přitomna. Přední tarsy u obou pohlaví ozbrojeny zubem. Tubus nemá u samcủ na basi lupínkủ.

Kopf etwas mehr lang als breit, auf seinen Wangen mit einigen sehr kleinen Wärzchen, von denen jedes mit einem winzigen Stachel rersehen ist; vorn ist er verengt. Fühler zweimal länger als der Kopf. Der Rüssel spitzig und fast bis zum Vorderrand des Mesosternum reichend. Die Oberlippe in einen Stachel verlängert. Maxillartaster lang und ziemlich schlank. Von den vier auf ihnen befindlichen Tastborsten ist eine sehr kurz. Labialtaster mit einem nicht langen, nach aussen gebogenen Geruchskolben versehen, um welchen drei längere Tastborsten herumstehen. Flügel bei Männchen und Weibchen immer vorhanden. Vordertarsen bei beiden Geschlechtern mit einem Zahn bewaffnet. Tubus bei den Männchen am Grunde ohne Schuppen.

\section{Phloeothrips coriacea Halid.**)}

Tab. IV., fig. 29.; Tab. VII., fig. 141. et 142.

1836. Phloeothrips coriacea Haliday, Entomol. Magazine, pag. 442.

1836. - - Burmeister, Handb. d. Entom., II. pag. 410.

1843. - - Amyot et Serville, Ins. Hémiptères, pag. 640.

1852. - - Haliday, Walker: Homopt. ins. of Brit. Museum, pag. 1100.; tab. VI., fig. 2.

1852. - Ulmi Heeger, Sitzungsb. d. Akad. d. Wiss., Wien, VIII, pag. 126.; lab. XV.

1852. - - Idem, ibidem, IX, pag. 481.

1880. - simillima Reuter, Thysanoptera fennica, pag. 18.

*) Фiotós $=$ kůra, Rinde.

**) Doklad ve sbirce musejní, praep. č. 82. - Sammlung des böhmischen Landesmuseums, Praep. Nr. 82. 
q.

Hlava $o \quad 0 \cdot 2$ delši než širší, $\mathrm{v}$ předu nepatrně zúžená, $\mathrm{v}$ zadu značně krkovitě stažená. Oči veliké, jen o $0 \cdot 6$ kratši než hlava. Třetí ěl. tykadel dlouhý, kvjovitý, skoro o 0.2 delší než prvé dva dohromady a skoro o třetinu delší čtvrtého; tento a 5 . i 6 . vřetenovité. Barva tykadel: 1. čl. černý, 2. _mavéji nebo světleji (zvl. ke konci) hnědý, 3. hnědožlutý, na konci někdy velmi slabě zkalený, následujici tmavé, na basi vždy úžeji a úžeji hnědožluté, jen osmý celý tmavý. Prothorax as o 0.2 hlavy kratši. Prední femora krátká, značně stlustlá. Přední tarsy opatřeny silným zubem, který však ve velikosti poněkud kolísá. Všecka femora černohnědá, všecky tarsy a předni tibie hnědoŽluté, tyto obyčejně na samé basi a zř̃́dka též uprostřed vně slabě hnědě zkalené, střední a zadní tibie černohnědé, na obou koncích hnědožluté. Hořejší krí́dla jsou slabě žlutavě zkalená a mají před polovinou svělle šedohnědou skvrnu; dolejší na zadním okraji s velmi slabým šedým nádechem. Tubus tak dlouhý jako hlava, na samé basi as o 0.7 širší než na konci. Délka těla $2 \cdot 3$ až skoro $3 \mathrm{~mm}$.

$$
\sigma^{\nearrow} \text { (nově objevený). }
$$

Trochu menši a slabši než q a nemá stlustlejších přednich stehen. Zuby na tarsech jsou v celku větši než u samice, avšak též ve velikosti kolísaji. Prothorax jest trochu kratší než u ní.

Třásněnka tato žije ve velikých společnostech pod korou hrušek, topolủ, vrb, jabloní, olší, dubủ, bukủ, moruší, břiz, švestek a též jehličnatỵch stromủ. Samci jsou velmi řídcí, avšak vyskytuji se po celý rok.

Čechy: Hradec Králové. Jind. Hradec (Duda).

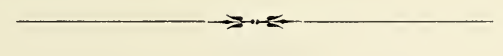

$$
\text { q. }
$$

Kopf um 0.2 mehr lang als breit, vorn unbedeutend verengt, hinten halsförmig zusammengezogen. Augen sehr gross. Das dritte Fühlerglied lang, keulenförmig, beinahe um 0.2 länger als die ersten zwei zusammen und fast um ein Drittel länger als das 4., dieses und das 5. spindelförmig. Fühlerfärbung: 1. Glied schwarz, das 2. dunkler oder lichter (hauptsächlich gegen das Ende) braun, das 3. braungelb, am Ende manchmal sehr schwach getrübt, die folgenden dunkel, am Grunde immer schmäler und schmäler braungelb, nur das 8. ganz dunkel. Prothorax etwa um 0.2 kürzer als der Kopf. Vorderschenkel kurz, bedeutend erweitert. Vordertarsen mit einem starken Zahn bewaffnet, welcher jedoch in der Grösse etwas variiert. Alle Schenkel schwarzbraun, alle Tarsen und die Vordertibien braungelb, die letzteren gewöhnlich an der Wurzel und selten auch aussen in der Mitte schwach braun getrübt, die Mittel- und Hintertibien 


\section{J. UZEL. MONOGRAFIE Ṙ́DU „THYSANOPTERA“.}

schwarzbraun, auf beiden Enden braungelb. Oberflügel schwach gelblich getrübt und vor der Mitte mit einem lichten graubraunen Fleck versehen. Unterflügel am Hinterrande mit sehr schwachem grauem Anflug. Tubus so lang wie der Kopf, auf der Wurzel etwa um 0.7 breiler als am Ende. Körperlänge 2.3 bis fast $3 \mathrm{~mm}$.

$$
\sigma^{\nearrow} \text { (neu entdeckit). }
$$

Etwas kleiner und schwächer als das $f$; seine Vorderschenkel nicht breiter als bei demselben. Die Zähne auf den Vordertarsen sind im ganzen mächtiger, variieren jedoch in der Grösse ebenfalls. Prothorax verhältnismässig etwas kürzer.

Vorkommen: In grossen Gesellschaften unter Birnen-, Pappeln-, Weiden-, Apfel-, Erlen-, Buchen-, Maulbeer-, Birken-, Pflaumenrinde. Männchen sehr selten, jedoch das ganze Jahr hindurch. - Fundorte: England (Haliday), Wien (Heeger), Finnland (Schulman), Böhmen.

117. Phloeothrips minor nov. sp.*)

Tab. VII., fig. 143.

$$
\text { q. }
$$

Barva tèla černohnèdá. Hlava zavalitá, podobná hlavě druhu následujícího, o $0 \cdot 1$ jen delší než širší, v předu málo zúžená, na basi krkovitě stažená. Na stranách hlavy jsou v malém počtu roztroušeny bradavky, na nichž stoji slabý ostének, kiterý jest tak dlouhý jako bradavka sama. Třetí čl. tykadel patrně delší než prvé dva dohromady, kyjovitý, 4. o 0.3 kratši třetího, rovněž jako 5. vřetenovitý, 7. skoro téže délky jako předcházející. První dva články tykadel černé, druhý na konci žlutý, všecky ostatní žlutošedé, jen 3. na basi světlejší. Prothorax as o $0 * 4$ kratší hlavy. Přední femora stlustlá, tarsy předních noh s velmi malỵm ostrỵm zoubkem. Barva noh černohnědá, konce všech tibií a tarsy žluté. Hor̀ejší kríf́la na zadním liraji uprostřed velmi slabě šedožlutẽ zkalená. Tubus sotva o $0 \cdot 1$ kratši hlavy. skoro všude se stejným prủměrem. Délka těla $1.7 \mathrm{~mm}$.

$$
\text { ๘. Nebyl posud objeven. }
$$

Jediný exemplár̆, který mám, nalezen v únoru pod zpuchřelou korou vrbovou. Čechy: Hradec Králové: U Věkoše.

\section{․}

Körperfarbe schwarzbraun. Kopf gedrungen, in Gestalt ähnlich demjenigen der folgenden Art, nur um 0.1 mehr lang als breit, vorn wenig verengt, am Grunde halsförmig zusammengezogen. Auf den Wangen befindet sich eine geringe Anzahl kleiner

*) Doklad ve sbirce autorově. 


\section{J. UZEL, MONOGRAFIE LAADU, „THYSANOPTERA".}

Wärzchen, von denen jedes mit einem gleich langen kleinen Stachelchen versehen ist. Das 3. Fühlerglied deutlich länger als die ersten zwei zusammen, keulenförmig, das 4. um 0.3 kürzer als das 3. und sowie das 5. spindelförmig. Die ersten zwei Fühlerglieder schwarz, das 2. am Ende gelb, alle übrigen gelbgrau, nur das 3. am Grunde lichter. Prothorax etwa um 0.4 kürzer als der Kiopf. Vorderchenkel verdickt, Vordertarsen mit einem sehr kleinen scharfen Zahne bewaffnel. Farbe der Beine schwarzbraun, die Enden aller Tibien und die Tarsen gelb. Oberflügel an Hinterrande in der Mitte sehr schwach graugelb getrübt. Tubus kaum um $0 \cdot 1$ kürzer als der Kopf, mit fast überall gleichem Durchmesser. Körperlänge $1.7 \mathrm{~mm}$.

$$
\text { ð unbekannt. }
$$

Vorkommen: Das einzige Exemplar, welches ich besitze, wurde im Feber unter morscher Weidenrinde gesammelt. — Fundort: Böhmen.

\section{Phloeothrips parva nov. sp.*)}

Tab. III., fig. 27.; Tab. VIl., fig. 144.

+.

Barva těla hnědočerná. Hlava zavalitá, sotva $0 \quad 0 \cdot 2$ delší než širši, do předu i do zadu poněkud zúžená a na basi trochu krkovitě stažená. Na stranách jejich jsou porủznu roztroušeny malé bradavky, prodlužujicí se v silný ostének, jenž jest delší než bradavky samy. Tr̉etí článek tykadel jest sotva kratší než první dva dohromady; z velmi úzké base značnè se rozširuje, na konci ršak zase náhle se úži; 4. čl. jest tak dlouhý a podobně utvořený jako předcházejicí. Barva tykadel: 1. a 2. čl. černé, 3.-6. šedohnědé, na basi žluté, 3. a 4. též na konci trochu svètlejší, 7. a 8. celé tmavé. Prothorax o 0.35 hlavy kratší. Přední femora značně stlustlá, přední tarsy velmi malým zoubkem ozbrojeny. Všecka femora černohnědá, tarsy žluté, tibie taktéž žluté, střední a zadní kromě obou koncủ šedè zkalené. Krrídla se slabým žlutohnědým nádechem, ke konci čirá. Tubus as $\quad 0.3$ hlavy kratší, na basi značně rozšírený. Délka těla $1.3 \mathrm{~mm}$.

$$
\sigma^{\top} \text {. Nebyl posud objeven. }
$$

Jediný exemplár̆, který mám, sesmykán s nekvetoucích rostlin. Čechy: Třebechovice: Pod Vys. Újezdem.

$$
\text { q. }
$$

Körperfarbe braunschwarz. Kopf gedrungen, kaum um $0.2 \mathrm{mehr}$ lang als breit, nach vorn und nach hinten etwas verengt und am Grunde etwas halsförmig zusammen-

*) Doklad ve sbírce autorovè. 


\section{H. UZEL, MONOGRAPHIE DER ORDNUNG THYSANOPTERA.}

gezogen. Seine Wangen mit einigen zerstreuten Wärzchen besetzt, von denen jedes mit einem etwas längeren starken Stachelchen versehen ist. Das 3. Fühlerglied kaum kürzer als die ersten zwei zusammen; am Grunde sehr eng, dann bedeutend erweitert, am Ende jedoch wieder plötzlich verengt; das 4 . Glied ebenso lang und ähnlich geformt wie das vorhergehende. Fühlerfärbung: 1. u. 2. Glied schwarz, das 3.-6. graubraun, am Grunde gelb, das 3. u. 4. ebenfalls am Ende etwas lichter, das 7. u. 8. ganz dunkel. Prothorax um 0.35 kürzer als der Kopf. Vorderschenkel bedeutend verdickt, Vordertarsen mit einem sehr kleinen Zahne bewaffnet. Alle Schenkel schwarzbraun, die Tarsen gelb, die Tibien ebenfalls gelb, die mittleren und hinteren, die beiden Enden ausgenommen, grau getrübt. Flügel schwach gelbbraun angehaucht, gegen das Ende zu klar. Tubus etwa um 0.3 kürzer als der Kopf, am Grunde bedeutend erweitert. Körperlänge $1.3 \mathrm{~mm}$.

ơ unbekannt.

Vorkommen: Das einzige Exemplar, welches ich besitze, wurde von nichtblühenden Pflanzen geketschert. - Fundort: Böhmen.

\section{Phloeothrips anmulipes Reut.}

1880. Phloeothrips ammlipes Reuter, Thysanoptera fennica, pag. 19.

»Nigra, sat nitida, supra cum femoribus sub-laevis; capite latitudine tantum paullo magis quam ${ }^{1 / 4}$ longiore, deplanato, lateribus sub-muricatis, antice nonnihil angustato; oculis ovalibus; antennis capite et pronoto brevioribus, articulis sat brevibus, tertio secundo tantum circiter $2 / 5$ longiore, obconico, duobus ultimis simul sumtis vix longiore, secundo apice, tertio dimidio basali, quarto et quinto basi, hoc angustissime. pallidius flavo-testaceis; femoribus totis nigris, tibiis piceo-nigris, basi et apice sat late nec non tarsis basi flavotestaceis. Long. $1^{3 / 5} \mathrm{~mm}$. - Caput latitudine vix magis quam ${ }^{1 / 4}$ longius, deplanatum, - lateribus levissime rotundatis apicem versus leviter angustatum, pilis lateralibus brevibus, rigidis, paucis, e granulis parvulis nonnihil exsertis nascentibus; disco nitidum, subtilius transversim aciculatum. Oculi oblongiusculi, fere $2 / 5$ anticas laterum capitis occupantes. Antennae capite cum pronoto breviores, nigrae, articulo secundo apice anguste testaceo, tertio obconico et secundo tantum circiter $2 / 5$ longiore, quarto etiam obconico, tertio paullo breviore, sed apice hoc distincte latiore, quinto quarto paullulum breviore, subovali, sexto huic fere aequali, duobus ultimis conjunctis secundo longitudine aequalibus, ultimo gracili, acuminato, penultimo fere aeque longo; articulo tertio dimidio basali, quarto parte basali quarta, quinto et etiam sexto basi angustissime flavo-testaceis, articulis omnibus pilis fuscis ciliatis. Pronotum trapeziforme, capite circiter $1 / 3$ brevius, angulis basalibus setis duabus rigidis instructis; disco sub-laevi. Pterygonotum pronoti basi parum latius. Alae explicatae, obscure hyalinae, punctatae, fusco-fimbriatae. Abdomen lateribus aequaliter ro- 


\section{J. UZEL. HONOGRAFIE RADU "THYSANOPTERA“.}

tundalum, tubo apicali segmentis tribus praecedentibus simul sumtis longiludine subaequali, angulis apicalibus segmenti octavi flavo-testaceis; segmentis $1-7$ utrinque setis biseriatis pallidis sat longis instructis, quarum setis series interioris ad discum dorsi vergentibus. Pedes piceo-nigri, femoribus anticis sat incrassatis, muticis*), tibiis omnibus basi et apice sat late pallidius flavo testaceis, tarsis testaceis, apice picescentibus. - Tantum individuum unicum D. Schulman in sacellanio Artsjö paroeciae Orimattila invenit."

\section{GENUS ACANTHOTHRIPS $m . * *)$}

Hlavai značně delši než širší; na stranách jejích nalézá se několik malých bradavek, z nichž každá krảtkým, do pr̉edu namíreným osténkem je opatřena. Tỵkadla skoro dvakrát hlavy delši, čípky smyslové na nich velmi dlouhé. Sosák jest špičatý a skoro se mesosterna dotýká; hoř. pysk hrotem zakončen. Nakadla maxillarní dlouhá a štíhlá. Makadla labialní s velmi krátkým, na vnèjší stranu ohnutým čípkem smyslorým, kolem něhož jsou rozestaveny tr̆i delši chlupy hmatavé. Křídla u obou pohlaví vždy prítomna. Přední femora u samcûv i samic pr̉ed koncem uvnitř s ostrým zubem***), jenž jest u oněch menší, u tèchto větší. U samcủ nejsou přední femora širší než u samic. Na předním tarsu u samic silný, u samců slabši zub (úkaz to u třásněnek neobvỵliý). Tubus nemá u samců na basi lupínki̊.

Kopf bedeutend melır lang als breit; auf seinen Wangen befinden sich einige zerstreute kleine Wärzchen. von denen jedes mit einem kurzen, nach vorn gerichteten Stachelchen versehen ist. Fühler fast zweimal so lang als der Kopf, die Sinneskolben auf ihren Gliedern sehr lang. Der Rüssel ist spitzig und erreicht fast den Vorderrand des Mesosternum; die Oberlippe ist in einen Stachel verlängert. Naxillartaster lang und schlank. Labialtaster mit einem sehr kurzen, nach aussen gebogenen Sinneskolben, um den herum drei längere Tastborsten stehen. Flügel bei beiden Geschlechtern immer vorhanden. Die Vorderschenkel bei den Männchen und Weibchen vor dem Ende innen mit einem $\dagger$ ) scharfen Zahne bewaffnel, der bei jenen kleiner, bei diesen grösser ist. Bei den Männchen sind die Vorderschenkel nicht mehr erweitert als bei den Weibchen. Die Vordertarsen bei den Weibchen mit einem starken, bei den Männchen mit einem schwachen Zahne versehen. Der Tubus bei den Männchen am Grunde ohne Schuppen.

*) Velmi malý zoubek byl asi u jediného objevenèho exempláře přehlédnut. — Der sehr kleine Zahn wurde wohl bei dem einzigen untersuchten Exemplar übersehen.

**) $" \mathrm{~A} \% \alpha \mathrm{v}(1 \alpha=\operatorname{trn}$, Dorn.

***) Burmeister udává, že přední femora maji dva zuby. I počitá zajisté vnitřní ostré zakončení stehen za zub druhý.

$\dagger$ ) Nach Burmeister befinden sich auf den Vorderschenkeln zwei Zähne. Somit fasst dieser Autor das innere scharfe Vorderschenkelende als zweiten Zahn auf. 
H. UZEL, MONOGRAPHIE DER ORDNUNG THYSANOPTERA.

\section{Acanthothrips nodicornis Reut.*)}

Tab. IV., fig. 28.; Tab. VII., fig. 145.

1836. Phloeothrips Ulmi Burmeister, Handb. d. Entomol., II, pag. 409.

1839. - coriacea Burmeister, Genera Insectorum. (Kolorované vyobrazení. - Colorierte Abbildung.)

1843. Hoplothrips corticis Amyot et Serville, Ins. Hémiptères, pag. 640. 1880. Phloeothrips nodicomis Reuter, Thysanoptera fennica, pag. 16.

$$
\text { P. }
$$

Barva těla černá. Na 3.-8. ěl. abdom. nahoře na předních rozích po jedné bílé skvrně. Hlava o 0.4 delší než širší, se stranami skoro rovnoběžnými a jen na samé basi trochu krkovitě zúžená. Na stranách hlavy nalézají se mezi bradavkami, osténky ukončenými, četná zrníčka bez chloupkủ. Tr̉etí čl. tykadel jest $00 \cdot 2$ delší než prvé dva dohromady, kyjovitý, 4. čl. taktéž kyjovitý, oba na konci však zase značně zúžené, 5. a 6. čl. vřetenovité. Čtvrtỵ a pátý čl. mezi sebou skoro stejně dlouhé; oba trochu kratší než třetí. Barva tykadel: 1., 2., 7. a 8 . èl. černé, 3. żlutý, před koncem (na stlustlé části) více nebo méně zkalený, 4., 5. a 6. tmavé, na basi a na konci hnědožluté. Prothorax as o $0 \cdot 3$ hlavy kratší. Přední femora značně rozširrená. Všecka femora černá, přední tibie hnědožluté, kromě samé base a poslední třetiny vně černohnědě zkalené, střední a zadní černé, na konci a na samé basi hnědožluté. Tarsy všecky hnědožluté. Hořejší kř̌idla velice slabě žlutavě zkalená, jen výjimkou uprostřed trochu silněji; dolejší čirá. Tubus as 00.1 kratší než hlava, na basi skoro dvakrát širší než na konci. Délka těla $2 \cdot 4 \mathrm{~mm}$.

$$
\sigma^{\nearrow} \text { (nově objevený). }
$$

Menší a slabší ně̌ †. Zrníčka u samic, mezi bradavkami na hlavě se nalézající, scházejí. Zuby na předních stehnech a tarsech jsou slabší. Přední tibie jsou černé, jen na konci žlutohnědé.

Třásněnka tato žije ojediněle pod zpuchřelou korou vrb, osyk, topolů, bríiz, švestek, hrušek, olší. Jednou nalezena na květu od Solanum dulcamara, jindy (Reuterem) na listu lípovém. Samci objevují se velmi pořídku.

Čechy: Hradec Králové. Jind. Hradec (Duda).

$$
\text { †. }
$$

Körperfarbe schwarz. Auf den Vorderecken des 3.-8. Abdominalsegmentes oben je ein weisser Fleck. Der Kopf um 0.4 mehr lang als breit, seine Wangen parallel und

*) Doklad ve sbírce musejní, praep. č. 83. - Sammlung des böhmischen Landesmuseums, Praep. Nr. 83. 


\section{J. UZEL, MONOGRAFIE RADU, „THYSANOPTERA“.}

nur ganz am Grunde etwas halsförmig zusammengezogen. Auf den Seiten des Kopfes befinden sich zwischen den mit kleinen Stacheln versehenen Wärzchen zahlreiche Körnchen. Das 3. Fühlerglied um 0.2 länger als die ersten zwei zusammen, keulenförmig, das 4. ebenfalls keulenförmig, beide am Ende jedoch wieder bedeutend verengt, das 5. und 6 . spindelförmig, ihre Enden abgestutzt. Das 4. u. 5. Glied untereinander fast gleich lang; beide etwas kürzer als das 3. Fühlerfärbung: das 1., 2., 7. u. 8. Glied schwarz, das 3. gelb, vor seinem Ende (auf dem verdickten Theile) mehr oder weniger getrübt, das 4 ., 5. u. 6. dunkel, am Grunde und am Ende braungelb. Prothorax etwa um 0.3 kürzer als der Kopf. Vorderschenkel bedeutend erweitert. Alle Schenkel schwarz, die Vordertibien braungelb, die Wurzel und das letzte Drittel ausgenommen, aussen schwarzbraun getrübt, die Nittel- und Hntertibien schwarz, am Ende und an der Wurzel braungelb. Alle Tarsen braungelb. Oberflügel sehr schwach gelblich getrübt, ausnahmsweise inmitten etwas stärker; Unterflügel klar. Tubus etwa um $0 \cdot 1$ kürzer als der Kopf, am Grunde fast zweimal so breit als am Ende. Körperlänge $2 \cdot 4 \mathrm{~mm}$.

$$
\sigma^{\pi} \text { (neu entdeckt). }
$$

Kleiner und schwächer als das q. Die Körnchen, welche sich bei den Weibchen zwischen den Wärzchen am Kopfe befinden, fehlen. Die Zähne auf den Vorderschenkeln und Vordertarsen sind schwächer. Vordertibien schwarz und am Ende gelbbraun.

Vorkommen: Einzeln unter morscher Weiden-, Zitterpappel-, Schwarzpappel-, Birken-, Pflaumen-, Birnen- und Erlenrinde. Männchen selten. - Fundorte: Deutschland (Burmeister), Finnland (Reuter), Böhmen.

\section{GENUS LIOTHRIPS m.*)}

Hlava 00.2 až 0.3 delší než širší; strany jeji bez bradavek. Tykadla as dvakrát delši hlavy. Sosák jest špičatý a skoro se mesosterna dotýká; hoř. pysk hrotem zakončen. Makadla maxillarní jsou dlouhá, štíhlá a mají čtyři chlupy hmatavé. Makadla labialní opatřena jedním kratším, tupým a jedním delším, ostrým čípkem smyslovým. Krídla prítomna. Přední tarsus u samic bezzubý.

Kopf um 0.2 bis 0.3 mehr lang als breit; seine Wangen ohne Wärzchen. Fühler etwa zweimal so lang als der Kopf. Der Rüssel ist spitzig und erreicht fast den Vorderrand des Mesosternum; die Oberlippe in einen Stachel verlängert. Maxillartaster lang, schlank und mit vier Tastborsten besetzt. Labialtaster mit einem kürzeren, stumpfen und einem längeren, scharfen Sinneszapfen versehen. Flügel vorhanden. Vordertarsen bei den Weibchen wehrlos. Wangen.

*) $\Lambda$ iós = hladký, nedrsný. totiž na stranách hlavy; glatt, nicht rauh, nämlich auf den 


\section{H. UZEL, MONOGRAPHIE DER ORDNUNG THYSANOPTERA}

\section{Liothrips hradecensis nov. sp.*)}

Tab. VII., fig. 146

․

Barva těla černá. Hlava málem o 0.3 delší než širší, se stranami skoro rovnoběžnými. Tykadla skoro dvakrát hlavy delší. Tretí článek jejich tenký, as tak dlouhý jako prvé dva dohromady; na basi jest velmi úzký a ke konci poznenáhla se rozšiřuje; 4. čl. trochu kratší a silnèjší než předcházející. Barva tykadel: 1: a 2. čl. čemé. tento na samém konci žlutý, 3. celý žlutý, 4. a 5. taktéž žluté, na konci slabẽ hnèdè zkalené, 6. as do polou žlutý, od polou tmavohnédý, 7. a 8. černé. Prothorax as 00.3 hlavy kratší. Přední femora dosti dlouhá, sotva stlustlá. Všecka femora černá, přední tibie celé žluté, střední a zadní černé, na konci náhle žluté, všecky tarsy żluté. Tubus as o 0.2 kratší než hlava. Délka těla $2 \cdot 1 \mathrm{~mm}$.

\section{ऽ. Nebyl posud objeven.}

Jediný exemplár̆, který mám, nalezen v zárí na spodní straně listu od Heracleum sphondylium.

Čechỵ: Hradec Králové: Na hradbách pevnostních.

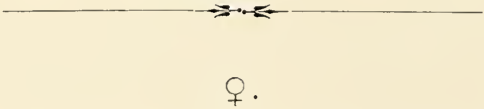

Körperfarbe schwarz. Kopf fast um 0.3 mehr lang als breit, seine Wangen beinahe parallel. Fühler fast zweimal so lang als der Kopf. Ihr 3. Glied etwa so lang wie die zwei ersten zusammen, am Grunde sehr dünn, gegen das Ende zu allmählich erweitert, das 4. Glied etwas kürzer und stärker als das vorhergehende. Fühlerfärbung: 1. u. 2. Glied schwarz, dieses an der Spitze gelb, das 3. ganz gelb, das 4. u. 5. ebenfalls gelb, am Ende schwach braun getrübt, das 6. etwa bis zur Mitte gelb, von der Mitte an dunkelbraun, das 7. u. 8. schwarz. Prothorax etwa um 0.3 kürzer als der Kopf. Vorderschenkel ziemlich lang, kaum verdickt. Alle Schenkel schwarz, die Vordertibien ganz gelb, die Mittel- und Hintertibien schwarz, am Ende plötzlich gelb. Alle Tarsen gelb. Tubus etwa um 0.2 kürzer als der Kopf. Körperlänge $2.1 \mathrm{~mm}$.

$$
\sigma^{\pi} \text { unbekannt. }
$$

Vorkommen: Das einzige Exemplar, welches ich besitze, habe ich im September auf der Unterseite eines Blattes von Heracleum sphondylium gefunden. - Fundort: Böhmen.

*) Doklad ve sbírce autorově. 


\section{J. UZEL, MONOGRAFIE ṘADU, „THYSANOPTERA“.}

\section{Liothrips setinodis Reut.}

Tab. VII., fig. 147 .

1880. Phloeothrips setinodis Reuter, The Scottish Naturalist, V, pag. 310.

$$
\text { ․ }
$$

Barva těla černá. Hlava $0 \quad 0 \cdot 2$ delší ne ž širší, se stranami skoro parallelními. Tykadla dvakrát hlavy delší, podobná tykadlùm druhu předcházejicího. Třetí čl. jejich tenký, as tak dlouhý jako prvé dva dohromady, na basi velmi úzký, ke konci poznenáhla se rozšiřující, 4. kratší a silnèjší než třetí, 8. neobyčejně krátký; 4.-6. ěl. na konci stlustlé. Barva tykadel žlutá, 1. ěl. však černý, 2. na basi černohnědý a 8. hnědý. Prothorax o 0.3 hlavy kratší. Přední femora dosti stlustlá, kratší než u druhu předcházejíciho. Všecka femora černá, přední tibie a všecky tarsy žluté, střední a zadní tibie černé, na konci žluté. Kř́íla čirá, hořejší na samé basi zkalená. Tubus skoro o $0 \cdot 2$ kratší než hlava, na basi skoro dvakrát tak široký jaku na konci. Délka těla $2^{1 / 2}-2^{2} / 3 \mathrm{~mm}$.

Var. (nov.) pragensis. Postava menší, délka těla jen 1.5-1.8 mm. Druhý článek tykadel celý žlutý a osmý obyčejně slabě hnědošedě zkalený, někdy však tmavohnědý. Všecky tibie po celé své délce čistě žluté. Jinak jako forma typická. - Třináct exempl. nalezeno.

$$
\sigma^{\nearrow} \text {. Nebyl posud objeven. }
$$

V Čechách sbíral jsem jen varietu toho druhu (v lese mezi Krěí a Kundraticemi u Prahy), a sice v létě na spodní straně listủ dubových, v zimě pod mechem.

$$
\text { †. }
$$

Körperfarbe schwarz. Kopf um 0.2 mehr lang als breit, seine Wangen fast parallel. Fühler zweimal länger als der Kopf, ähnlich denjenigen der vorhergehenden Art. Ihr 3. Glied dünn, etwa so lang wie die zwei ersten zusammen, am Grunde sehr schmal, gegen das Ende zu allmählich erweitert, das 4. kürzer und stärker als das 3.; das 4.—6. Glied am Ende verdickt. Fühlerfärbung gelb, das 1. Glied jedoch schwarz, das 2. am Grunde schwarzbraun und das 8. braun. Prothorax um 0.3 kürzer als der Kopf. Vorderschenkel ziemlich verdickt und kürzer als bei der vorhergehenden Art. Alle Schenkel schwarzbraun, die Vordertibien und alle Tarsen gelb. die Nittel- und Hintertibien schwarz, am Ende gelb. Flügel hell, die oberen am Grunde getrübt. Tubus fast um $0 \cdot 2$ kürzer als der Kopf: am Grunde beinahe zweimal so breit als am Ende. Körperlänge $2^{1 / 2}-2^{2 / 3} \mathrm{~mm}$.

*) Doklad ve sbirce musejni, praep. ¿̇. 84 . - Simmlung des böhmischen Landesmuseums, Praep. Nr. 84. 


\section{H. UZEL, MONOGRAPHIE DER ORDNUNG THYSANOPTERA.}

Var. (nov.) pragensis. Gestalt kleiner, Körperlänge nur $1.5-1.8 \mathrm{~mm}$. Das zweite Fühlerglied ganz gelb und das achte gewöhnlich schwach braungrau getrübt, manchmal jedoch dunkelbraun. Alle Tibien ihrer ganzen Länge nach rein gelb. Übrigens wie die Stammform.

$$
\text { ð unbekannt. }
$$

Vorkommen: Im Sommer auf der Unterseite der Eichenblätter, im Winter im Moos (in Bönmen). Fundorte: Schottland: Aberdeen, Morayshire (Reuter), Böhmen (hier nur var. pragensis).

\section{GENUS POECILOTHRIPS. (Nov. gen.)*)}

Hlava značně delší než širší, mnohem delši neż úzký prothorax. Tỵkadla jsou jen o 0.5 delší než hlava. Sosák jest velmi špičatý a tak dlouhý, že dotýká se mesosterna. Hoř. pysk zakončen hrotem. Makadla maxillarní jsou dlouhá, štíhlá a mají 4 chlupy hmatavé. Makadla labialní s velmi kirátkým, na vnèjší stranu ohnutým čípkem smyslovým, kolem nèhož rozestaveny jsou tř̀ delši chlupy hmatavé. Křídel jen nepatrná rudimenta. Pr̉ední tarsus u samiček bezzubý.

Kopf viel mehr lang als breit, bedeutend länger als der schmale Prothorax. Fühler nur um 0.5 länger als der Kopf. Der Rüssel sehr verengt und so lang, dass er den Vorderrand des Mesosternum erreicht. Die Oberlippe in einen Stachel verlängert. Maxillartaster lang, schlank und mit vier Tastborsten besetzt. Labialtaster mit einem sehr kurzen, nach aussen gebogenen Sinneszapfen versehen, um den herum drei längere Tasthaare stehen. Flügel rudimentär. Vordertarsen bei den Weibchen wehrlos.

\section{Poecilothrips albopicta nov. sp.**)}

Tab. IlI., fig. 25.; Tab. IV., fig. 30.

$$
\text { ㅇ. }
$$

Barva těla červenohnědá. Nahoře na stranách celé hrudi a dvou prvních článkû abdominalních vine se často přerývaná, klikatá, sněhobílá stuha; mimo to jsou zadní rohy hlavy světlé a na $4 .-8$. čl. abdom. nalézá se $\mathrm{v}$ předních rozích po jedné sněhobílé skvrně; na 3 . čl. abdom. jest tato skvrna nezřetelná. Hlava as o 0.35 delší než širší, nazad trochu zúžená. Třelí čl. tykadel trochu delší než 2., na basi úzký, ke konci značně se rozširujujicí a na konci zase zúžený, 4. čl. trochu kratší než 3 . C̆lánky tỵkadla

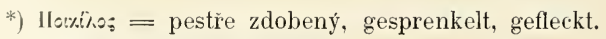

**) Doklad ve sbirce autorovè. 


\section{J. UZEL, MONOGRAFIE RÁDU, „THYSANOPTERA“.}

vủbec zavalité. Prvni čl. jest černý, ostatni kromě třetího černošedé, tretí celý a 4., 5. i 6. na basi žlutavé. Prothorax o $0 \cdot 4$ hlavy kratší. Přední femora trochu stlustlá. Všecka femora černá, tibie taktéž černé, na basi a na konci žlutavé, všecky tarsy žluté. Tubus o 0.4 hlavy kratší, na basi o 0.5 širší než na konci. Délka těla $1.3 \mathrm{~mm}$.

$$
\text { ð. Nebyl posud objeven. }
$$

Jediný exemplár̆ této třásněnky, který mám, nalezen v lednu pod zpuchřelou korou lipovou.

Čechy: Hradec Králové: Ve stromořadí kolem města.

‥

Körperfarbe rothbraun. Oben auf den Seiten des Thorax und der ersten zwei Abdominalsegmente zieht sich ein schneeweisses, oft unterbrochenes Band; ausserdem sind die Hinterecken des Kopfes weiss und am 4.-8. Abdominalsegmente befindet sich in den Vorderecken je ein schneeweisser Fleck; am 3. Abdominalsegmente sind diese Flecke undeutlich. Kopf etwa um 0.35 mehr lang als breit, nach hinten etwas verengt. Das 3. Fühlerglied etwas länger als das 2., am Grunde eng, gegen das Ende zu bedeutend erweitert und am Ende selbst wieder verengt, das 4. etwas kürzer als das 3. Fühlerglieder im allgemeinen gedrungen. Erstes Glied schwarz, die übrigen, das dritte ausgenommen, schwarzgrau, dieses ganz und das 4., 5. u. 6. am Grunde gelblich. Prothorax um 0.4 kürzer als der Kopf. Vorderschenkel etwas verdickt. Alle Schenkel schwarz, die Tibien ebenfalls schwarz, am Grunde und am Ende gelblich, alle Tarsen gelb. Tubus um 0.4 kürzer als der Kopf, am Grunde um 0.5 breiter als am Ende. Körperlänge $1 \cdot 3 \mathrm{~mm}$.

$$
\text { ठ unbekannt. }
$$

Vorkommen: Das einzige Exemplar, welches ich besitze, entdeckte ich im Jänner unter morscher Lindenrinde. - Fundort: Böhmen.

\section{GENUS IDOLOTHRiPS Halid.*)}

Haliday (anno 1852.): »Ocellus anterior remotus ab basi antennarum; haustellum basim prosterni attingens; palpi labiales papilliformes; alae anticae vena unica obsoletiore dimidiata, aut abbreviata. Caput longissimum teres; abdomen excavatum. Antennae graciles, thoracis latitudinem triplo aut quadruplo superantes; prothorax inaequalis tuberculatus; metatarsi inermes. Statura procera; trilinearis et ultra.

*) Eì̀wiov = obraz, mlhavá (příserná) podoba mrtvého; Bild, ein (gespenstiges) Schattenbild eines Todten. 


\section{H. UZEL, MONOGRAPHIE DER ORDNUNG THYSANOPTERA.}

\section{Idolothrips marginata Halid.}

1852. Idolothrips marginata Haliday, Walker: Homopt. ins. of Brit. Museum, pag. 1096.

»Abdomen segmentis posterioribus tam longitudinis quam latitudinis ratione decrescentibus, lateribus fere muticum. - Nigra; abdominis maculis lateralibus thoracisque punctis sanguineis; antennis albidis, articulis apice, interioribus et extremis totis, nigris; pedibus pallide ferrugineis fusco-cingulatis, femoribus anlicis nigris, vel basi plaga sanguinea." - New-Holland (Darwin). — Nach Haliday vielleicht ein $q$.

\section{Idolothrips spectrum Halid.}

1852. Idolothrips spectrum Haliday. Walker: Homopt. ins. of Brit. Museum, pag. 1097.; tab. VI., fig. 3 .

»Abdomen longissimum, segmentis penultimis oblongis, lateribus denticulatum, tubulo basi gibbulo et muricato. - Abdominis lateribus valide 7 -dentatis, denticulis spina, 3. et 4. seta tantum, terminatis; segmento penultimo gibbere apicali bispinoso; maxima quam vidi in hoc genere, ideoque inter Physapoda facile princeps. Long. 4 lin. et ultra. — New-Holland (D a r win). — Druh tento jest největší dosud známou třásněnkou. Nach Haliday vielleicht ein $\sigma$. Die grösste bekannte Art (fast $1 \mathrm{~cm}$ lang!).

\section{Idolothrips lacertina Halid.}

1852. Idolothrips lacertina Haliday, Walker: Homopt. ins. of Brit. Museum, pag. 1097.

Abdomen longissimum, segmentis penultimis oblongis, lateribus denticulatum, tubulo basi gibbulo et muricato. - Abdominis lateribus subtilius denticulatis. denticulis intermediis pluribus muticis. segmento penultimo apice biseto. Praecedente (Id.spectrum) fere duplo minor; long. 3 lin. « - New-Holland (Da r w in). - Nach Halid a y vielleicht ein $\sigma^{7}$.

\section{Idolothrips schotti Heeg.}

1852. Thrips Schottii Heeger, Sitzungsb. d. Akad. d. Wiss., Wien, VIII, pag. 139.; tab. XXIII.

Thr. Schottii ater, oculis luteis; antennis 8-articulatis filiformibus, alis ensiformibus. Schwarz, glänzend, sehr gestreckt, Fühler fadenförmig achtgliederig; Augen nicht vorne, sondern an den Seiten, vor der Mitte des Kopfes, gelb; schmale, gleichbreite, ganz umfranste Flügel. $1^{3 / 4^{\prime \prime \prime}}$ lang. Kopf stumpf kegelförmig, nochma! so lang, am Hinterrande halb so breit als der Vorderbrust-Abschnitt; Augen, vor der Nitte an den Seiten eingefügt, gelb, rund, 
erhoben, mit grossen Pusteln, fast 1/5 so lang als der Kopf; Nebenaugen keine. Fühler fein fadenförmig, unbehaart, achtgliederig, nochmal so lång als der Kopf; erstes und zweites Glied gleich, kurz, so kurz als das achte; drittes und viertes, jedes viermal so lang als das zweite; fünftes und sechstes ${ }^{1}{ }_{4}$ kürzer als das vierte; siebentes nur halb, achtes nur $1 / 3$ so lang als das sechste. Vorderbrust-Abschnitt fast glockenförmig gewölbt, halb so lang, am Vorderrande $1 / 4$ breiter als der Kopf, abgerundet, Hinterrand gerade, um die Hälfte breiter als der vordere; Mittelbrust-Abschnitt $1 / 6$ breiter, $1 / 3$ so lang als voriger, der Hinterrand flach gebogen, an den Seiten zur Spitze verschmälert; Hinterbrust-Abschnitt fast nur so lang als die Schienen und so breit als lang; an den Seiten des Vorderrandes. sind die zwei halbrunden dünnhornigen Platten, so lang als der Kopf breit, gegen den Hinterrand eine schildchenartige, hinten ausgebogene schwache Erhöhung, und der Hinterrand gerade abgeschnitten. Flügel: die vorderen halb so lang als Brustkasten und Hinterleib zusammen, alle sehr schmal, kaum ${ }^{1 / 10}$ so breit als lang, gleichbreit, gerade, blass, bräunlich gelb, nicht dicht, aber sehr fein behaart, ganz mit Haaren umfranset, welche doppelt so lang als die Flügel breit sind; aus der Wurzel ziehet sich eine gerade Längsader bis gegen die Mitte der Flügellänge, wo sie in eine Spitze ausläuft. Die Hinterflügel fast nur halb so lang als der Hinterleib, $1 / 5$ kürzer als die Vorderflügel. Beine schwarz mit rothbraunen Borsten besetzt, nur die Fussglieder dunkelbraun, Vorder- und Hinterbeine gleichlang, halb so lang als der Hinterleib, die mittleren aber 1/4 kürzer; Schenkel der Vorderbeine nur halb so lang als das ganze Bein, verkehrt keulenförmig, an der Wurzel $1 / 3$ so dick als lang, am Knie kaum $1 / 3$ so breit als die Keule: innen gerade, aussen am Knie eingebogen; Schienen 1/6 kürzer als die Schenkel, spindelförmig, am Vorderrande nach innen mit einem langen, dünnen, gebogenen Dorn bewaffnet; Füsse nur 1/4 so lang als die Schienen, halb so dick als lang; Schenkel der Mittelbeine 1/4 kürzer als die vorderen, gegen die Mitte verdickt, 1/6 so dick als lang; die Schenkel der Hinterbeine, der Form nach, den mittleren gleich, nur $1 / 3$ länger und verhältnissmässig stärker; Schienen beider Paare an Grösse wenig unterschieden, an Form gleich, fast spindelförmig gegen die Mitte verdickt, Vorderrand gerade und etwas erweitert; Füsse $1 / 6$ so lang als die Schienen, halb so dick als lang. Hinterleib, wie oben bemerkt, nochmal so lang als die Hinterflügel, gegen die Mitte $1 / 6$ so dick als lang, glatt, spindelförmig, mit wenigen Borsten; erster bis dritter Abschnitt wenig unterschieden, fast $1 \frac{1}{3}$ kürzer als breit, vierter und fünfter um ${ }^{r_{4}^{\prime \prime}}$, sechster um $1 / 3$ länger als der dritte; siebenter und achter halb so lang als der sechste, neunter nur halb so lang als der dritte, fünfter bis neunter allmählich bis. zur Afterröhre verschmälert; Afterröhre so lang als der sechste Abschnitt, schmal kegelförmig, 1/6 so dick als lang, mit vier Borsten am Hinterrand.« Brasilien (Schott).

\section{Idolothrips Halidayi Newm.}

1856. Idolothrips Halidayi Newman, Transact. of the Entomol. Soc. London, III. pag. 265 . 


\section{H. UZEL, MONOGRAPHIE DER ORDNUNG THYSANOPTERA.}

"Nigerrima, glaberrima; antennis gracilibus, flavis, basi apiceque nigris; capite elongato, cylindraceo, nigro-piceo; alis fuliginoso-hyalinis, eradiis, nigro-ciliatis; tarsis laete flavis; abdomine valde elongato, pedetentim attenuato, segmento apicali cylindraceo. longissimo. Corp. long. 25 unc. Alarum dilat. 2 unc. - Head three times as long as broad, cylindrical, pitchy black; eyes large, lateral, oblong, seated at the anterior extremity of the head; antennae very slender, 8-jointed; the first and second joints robust, slightly incrassated exteriorly, black, the apex of the second tinged with yellow; the third very slender, longer than those next following and pale yellow; fourth, fifth and sixth slender, slightly incrassated externally, and pale transparent yellow, tipped with black; seventh rather shorter, subfusiform, and entirely black; eighth extremely slender, fusiform, very acute, and entirely black. Prothorax broader than long, anterior and posterior margins straight, anterior as broad as the head, posterior double that breadth, lateral margins sloped diagonally from the anterior margin half way to the posterior, but, as regards their posterior half, straight and parallel; pronotum impressed with wide irregular foveae; meso- and metathorax uniform in breadth with the base of the prothorax. Abdomen very long, gradually tapering to an acule point, which is armed with a few bristles; the thoracic segments and abdomen are black and shining. Wings nearly transparent, but with a slightly smoky tinge; at the base they have a median ray. which seems almost immediately to divide, and to be lost in the costal and posterior margins, which are fringed with long silky black hairs. Legs rather short; femora very slightly incrassated externally, black and shining; tibiae bright yellow; tarsi 2-jointed, basal joint moderately long, the apical joint short, obtuse, brown. - Hab. Mysore (Hamilton); feeds on the leaves of a species of Anacardium."

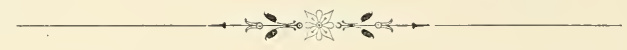

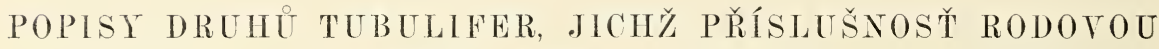 NEBYLO LZE STANOVITI. \\ BESCIREIBUNGEN DER TUBULIFERENARTEN, DEREN GATTUNGS- ZUSTÄNDIGKEIT NICHT FESTGESTELLT WERDEN KONNTE.}

U následujících druhů tubulifer nemohl jsem př́slušnost' rodovou zjistiti, poněvadž jsem neměl príležitosti je ohledati, a poněradž v popisech jejich není zmínky o znacích, charakterisujících jednotlivé naše rody. Uvádím je tedy pod jménem rodovým Phloeothrips s. 1 .

Die folgenden Tubuliferenarten konnte ich nicht in die angeführten Gattungen einreihen, weil ich nicht Gelegenheit hatte, sie selbst zu untersuchen, und weil in ihren 


\section{J. UZEL, NONOGRAFIE RADU „THYSANOPTERA“.}

Beschreibungen keine Erwähnung von den Charakteren, welche die fixierten Gattungen kennzeichnen, geschieht. Ich zähle sie infolge dessen unter dem Gattungsnamen Phloeothrips s. 1. auf.

\section{Phloeothrips anmulicornis Halid.}

1836. Phloeothrips ammulicomis Haliday, Entomol. Magazine, pag. 443.

1836 .

1843.

1852.

1860.
Burmeister, Handb. d. Entom., II, pag. 410.

Amyot et Serville, Ins. Hémiptères, pag. 640.

Haliday, Walker, Homopt. ins of Brit. Museum, pag. 1101.

Haliday (anno 1836.): »Ocellis tribus. - Capitis lateribus antrorsum convergentibus, inermibus. - In the general proportions, intermediate between Pll. Ulmi and Phl. Statices. The antennae short; the intermediate joints pale, but all tipped with brown; the fore shanks and the feet dull ferruginous; the fore thighs thick, and the thumb as in Phl. Ulmi, fem." Long. 1 lin.

\section{Phloeothrips subtilissima Halid.}

1852. Phloeothrips subtilissima Haliday, Walker: Homopt. ins of Brit. Museum, pag. 1100 .

"Metatarsus anticus muticus (in fem.?). - Nigra, antennarum flagello nisi apice tarsisque pallide ferrugineis. tibiis anticis nisi basi ferrugineis, alis subhyalinis; fem.? Phl. Statices aequalis satis distincta. Caput antice magis rotundato-attenuatum, postice tanlum subtilissime transversim aciculatum, inter oculos laevissimum; antennae medio haud crassiores; alae dimidio interiore laevius flavicante ciliis vix fuscis nisi cum congesto visantur. Tubus analis paulo brevior videtur. Long $2 / 3-3 / 4$ lin. - Hab. sub cortice, sat agilis; in gallis Quercus. England (F. Walker).»

\section{Phlocothrips anacardii Newm.}

1855. Phloeothrips Anacardii Newman, Transact. of the Entomol. Soc. London, III, pag. 266.

"Nigerrima, glaberrima; capite paullum elongato, cylindraceo, piceo ; antennis gracilibus: stramineis, basi apiceque nigris; -abdomine vix elongato, lateribus rectis, fere ad apicem parallelis, tunc obliquis, in segmento apicali brevi, cylindraceo, desinientibus; alis diaphanis, eradiis, fusco-ciliatis; femoribus perpaullum incrassatis; tarsis stramineis. Corp. long. $\cdot 175$ - unc. Alar. dilat. 15 unc. - Head more than twice as long as broad, cylindrical, 


\section{H. UZEL, MONOGRAPHIE DER ORDNUNG THYSANOPTERA.}

pitchy black. having at its anterior extremity two very conspicuous bright ocelli seated between the large lateral, oblong, compound eyes; antennae very slender, 8-jointed, the first and second joints robust, and distinctly restricted at the base, incrassated at the apex, the apex of the second yellow; third extremely slender, twice as long as the second, and pale straw-coloured; fourth, fifth and sixth of equal length, but all rather shorter than the third, elongate, pyriform, straw-coloured, tinged with brown externally; seventh long-ovate, shorter than the preceding three, black; eighth short, slender, black. Thoracic segments nearly as described in Idolothrips Halidayi. Abdomen rather robust, its sides parallel to near the apex, when it diminishes, rapidly terminating in a short cylindrical apical segment. Wings without rays, hyaline, with long brown cilia. Legs black, with straw-coloured tarsi; all other parts black and shining. - Hab. Mysore (Hamilton), feeds on the leaves of a species of Anacardium."

\section{Phloeothrips stenomelas Wlk.}

1859. Phloeothrips stenomelas Walker, Annals and Mag. of Nat. Hist., pag. 224.

»Ater, antennis concoloribus, capite glabro, thorace striis transversis, abdomine lineari apice lanceolato. - Deep black. Antennae submoniliform. Head smooth, nearly as long as the thorax, which is transversely striated. Abdomen linear, lanceolate at the tip. Fore legs thick. Length $1^{3 / 4}$ lin. « Ceylon.

\section{Phloeothrips parvipennis Reut.}

1880. Phloeothrips parvipennis Reuter, Thysanoptera fennica, pag. 14.

"Castaneo-fusca, nitida, sublaevis; capite pronoto vix longiore et latitudine circiter $2 / 5$ longiore, lateribus setis fortiter rigidis instructis; oculis subrotundis, circiter quartam partem anticam capitis occupantibus; antennis pilosis articulis tertio-quinto apicem versus sensim clavatis, tantum tertio apice nonnihil constricto, hoc articulo ut etiam secundo totis flavo-testaceis, quarto et quinto piceis, basi flavo-testaceis, tertio duobus ultimis conjunctis longitudine sub-aequali; pronoto angulis basalibus, pterygonotis disco, angulis omnibus basalibus segmentorum abdominalium, femoribus apice tibiis tarsisque flavoferrugineis, tibiis posterioribus medio piceis; tarsis anticis articulo primo apice intrinsecus uncinato; femoribus anticis crassissimis, posterioribus sat gracilibus. Long. circiter $2^{1 / 2}$ mm. - Corpus castaneo-fuscum, laeve, nitidum. Caput latitudine parum magis quam $1 / 3$ longius, praesertim posterius deplanatum ibique confertim subtiliter punctulatum, lateribus apicem versus sub-ampliatum, setis lateralibus fortiter rigidis, spatio interoculari oculo latiore, spatio postoculari utrinque prope marginem et paullo pone oculum seta longa instructo. Oculi superne visi sub-rotundi, deplanati, granulati, circiter quartam 


\section{J. UZEL, MONOGRAFIE RADU „THYSANOPTERA“.}

partem apicalem laterum capitis occupantes. Ocelli tres. Antennae capiti et pronoto simul sumtis longitudine aequales, articulo primo nigro, secundo hoc paullo graciliore et breviore, flavo-testaceo, tertio toto testaceo, spatio interoculari parum breviore, a basi gracili apicem versus clavato-incrassato, ipso apice sub-constricto, ejus clava articulo secundo aeque crasso; articulis quarto et quinto etiam obconicis, piceis, quarto dimidio et quinto triente basali flavo-testaceis, articulo sexto basin versus leviter gracilescente, ipsissima basi testacea, septimo ovali, ultimo aciculato-acuminato; quarto tertio aeque longo, quinto et sexto sensim paullo brevioribus, septimo sexto circiter $1 / 4$ breviore, octavo septimo etiam circiter ${ }^{1 / 4}$ breviore; articulis $3-8$ densius pallido-ciliatis. Pronotum capitis fere longitudine, trapeziforme, lateribus leviter rotundatum, disco apicem versus sat declive, posterius medio foveola oblonga instructum, sublaeve, castaneo-fuscum, angulis posticis testaceis (an specimen immaturum ?). Pterygonotum pronoti longitudine, laeve, castaneum, disco medio latius flavo-ferrugineum. Alae anticae brevissime squamiformes, ferrugineae, pterygonoto magis quam duplo breviores, posticae vix distinguendae. Abdomen laeve, lateribus aequaliter rotundatis, segmento secundo tertio longiore, reliquis longitudine subaequalibus, tubo apicali segmentis duobus ultimis longitudine aequali, apice setoso; limbo abdominis seriebus duabus setarum albidarum, quarum interna pilis versus discum vergentibus; abdomen castaneo-fuscum, angulis omnium segmentorum basalibus latissime apiceque tubi apicalis flavo-ferrugineis. Femora picea, apice flavo-ferruginea, antica crassissima, crassitie capitis latitudini posticae sub-aequali, inermia; posteriora gracilia, postica capiti vix aeque longa, intermedia his circiter ${ }^{1 / 4}$ breviora. Tibiae flavo-ferrugineae, anticae unicolores, posteriores medio picescentes. Tarsi toti flavo-ferruginei, anticorum articulo primo intrinsecus fortiter uncinato. - Unicum individuum in paroecia Yläne legit Dr. J. Sahlber g. «

\section{Phloeothrips albosignata Reut.}

1883. Phloeothrips bigemmata Costa, Geo-fauna sarda (2), pag. 71. (bez popisu ohne Beschreibung).

1884. - albosigmata Reuter, Revue d'Entomol., III, pag. 290.

1885. - - - Costa, Geo-fauna sarda (4), pag. 12.

Reuter (anno 1884.): »Nigra, nitida, margine apicali metanoti fasciaque basali segmenti primi dorsalis ad angulos retrorsum dilatata nec non macula laterali triangulari segmenti quinti dorsalis abdominis albis; anntennis articulo tertio ipso apice excepto, quarto ultra medium basique quinti albido-flaventibus; tarsis basi obscure ferrugineis; capite longissimo, versus apicem angustato, mutico; antennarum articulo tertio tribus sequientibus simul sumtis parum breviore; alis nullis; tarsis anticis maris intrinsecus articulo primo valide dentato-producto. Long. ठ $3 \mathrm{~mm}$, $\subsetneq 3 \% \mathrm{~mm}$. - Corpus nigrum, nitidum. Caput thorace, segmento primo dimidioque secundo abdominalibus simul sumtis 


\section{H. UZEL, MONOGRAPHIE DER ORDNUNG THYSANOPTERA.}

longitudine aequale, latitudine maxima circiter duplo et dimidio vel fere $2^{2 / 3}$ longius, lateribus convexum, versus apicem leviter angustatum, marginibus lateralibus muticum, spatio interoculari oculo nonnihil latiore, disco praecipue antice dense subtiliter transversim aciculato. Oculi superne visi subovati. Antennae capitis longitudine, articulo primo et secundo nigris, aeque longis, hoc ipso apice nonnihil pallidiore, tertio latitudine capitis postoculari paullulum longiore, albido-flavente, ipso apice nigricante, quarto obconico, tertio circiter duplo breviore, albido-flavente, tertia apicali parte nïgra, quinto oblique obconico, quarto $1 / 3$ breviore, nigro, basi albido-flavente, reliquis nigris, sexto quinto paullo breviore, duobus ultimis simul sumtis sexto longitudine aequalibus. Pronotum capite fere duplo brevius, antice annulo laevi, cetero dense subtiliter coriaceo-punctatum, subaenescens, feminae ante basin impressionibus duabus transversis sat levibus. Mesonotum lineare, angulis basalibus dentato-prominentibus. Metanotum subtiliter coriaceum, ipso margine apicali albo. Dorsum abdominis laeve, segmento primo fascia dimidium basalem occupante et lateribus retrorsum in angulos basales segmenti secundi dilatata alba, segmento secundo primo metanotoque simul sumtis longitudine aequali, tertio secundo paullo breviore, quarto - octavo longitudine subaequalibus, nono octavo paullo breviore, sexto - nono versus apicem sensim distinctius angustatis, omnibus utrinque linea longitudinali percurrenti impressis, decimo tubuliformi duobus praecedentibus simul sumtis longitudine aequali; quinque ultimis lateribus pilis longioribus exsertis, praecedentibus pilis lateralibus parum distinctis, brevissimis; segmento quinto utrinque macula marginali triangulari alba. Pedes nigri, femoribus anticis incrassatis capite circiter $2 / 5(q)$ vel solum circiter $1 / 4\left(\delta^{\top}\right)$ brevioribus, tibiis femoribus brevioribus, femoribus intermediis anticis sat multo brevioribus, posticis anticis fere aeque longis, sed multo gracilioribus, tibiis posterioribus femoribus vix longioribus, tarsis omnibus articulo primo obscure ferrugineo, hoc articulo tarsorum anticorum maris intrinsecus valide dentato-producto.

Sardinia (Costa). Algeria: Tlemcen (Marmotton).

\section{Phloeothrips angustifrons Bergroth.}

1888. Phloeothrips angustifrons Bergroth, Comptes rend. Soc. Entomol. Belg., pag. XXX.

»Elongatus, nitidus, niger; caput cylindricum, compressum, latitudine paulo magis quam duplo longius, lateribus praesertim antice transversim strigosum, paulo pone oculos seta brevi nigra rigida utrinque instructum, e latere visum longitudinaliter leviter convexum, spatio interoculari praecipue superne perangusto, oculis vix quartam partem laterum capitis occupantibus, antennis tenuibus, capite distincte longioribus, septemarticulatis, articulis duobus primis brevibus, tertio et quarto apice pilis pauculis longiusculis obscuris praeditis, tertio quarto dimidio longiore, apice clavato, quarto e basi apicem 
versus sensim incrassato, dein nonnihil attenuato, articulis quinto sexto imprimisque septimo subadpresse longiuscule argenteo-pilosis, fusiformibus, quinto quarto longitudine subaequali, sexto quinto paulo breviore, septimo quinto subaequilongo; pronotum trapeziforme, dimidia longitudine capitis paulo brevius apice capite haud latius, lateribus subrectis, prope apicem et basin setis nigris paucissimis munitis, disco paulo inaequali; mesonotum pronoto plus quam duplo brevius, disco subtiliter transverse rugoso, tuberculis duobus obtusis et inter haec fovea impressa praedito; alae ensiformes, nervo crasso medio longitudinali percurrente instructae, fimbriis fusco-testaceis, alis anticis dilute luteoalbidis, fasciis duabus indeterminate fuscis notatis, nervo fuscescente in dimidio basali pilas tres validas erectas crassas capitulatas e papillis nascentes inter se longius distantes gerente, alis posticis albidis, nervo obscuriore; abdomen lineare, e segmento octavo apicem versus attenuatum, segmentis longitudine subaequalibus, ultimo tamen penultimo distincte breviore, tribus ultimis prope angulum apicalem parce longiuscule pilosis, ultimo praeterea ibidem pilis perpaucis ceteris multo longioribus et apicem tubi apicalis longe superantibus ornato, tubo apicali segmento antecedenti dimidio longiore, apice longe parce piloso; femora antica valde incrassata. Long. $3 \mathrm{~mm}$. - Patria: Brazilia meridionalis (Blumenau, in provincia Sanctae Catharinae: Dr. Fritz Müller).« 


\section{PRIIVËSE K. ANHANG.}

$\mathrm{V}$ následujicím sestaveny jsou ony druhy třásnènek, které byly od jednotlivých autorů nedostatečně popsány, także není možno je opěl poznati. Následkem toho dovoluji si navrhnouti, aby byly přiště ignorovány.

Im Folgenden hat der Verfasser jene Arten zusammengestellt, welche von den einzelnen Autoren ungenügend beschrieben wurden, so dass es nicht möglich ist, sie wieder zu erkennen. Infolge dessen erlaubt er sich anzutragen, sie fernerhin zu ignorieren.

\section{Thrips juniperina $L$.}

1744. Plysapus fuscus, alis albicantibus; De Geer, K. Swenska Wetensk. Acad. Handl., V, pag. 3.; tab. I., fig. 2.

1746. Thrips elytris niveis, corpore fusco; Linné, Fauna Svecica. Editio I., pag. 221.

1761. Thrips juniperina Linné, Fauna Svecica, pag. 266.

1767. - - Linné, Systema Naturae, pag. 743 .

1773. Thrips griseo-fusca oculis nigris, alis albescentibus; De Geer, Mém. p. servir à l'hist. d. Insectes, pag. 10., tab. I., fig. 5. (Goeze, III. pag. 7.)

1777. Thrips juniperina Goeze, Entomol. Beyträge, pag. 348.

1781. - - Schrank, Enumeratio Ins. Austriae indig., pag. 298.

1781. - - - Fabricius, Species Insectorum, pag. 396.

1787. - - Fabricius, Mantissa Insectorum, pag. 320.

1788. - - - Gmelin, Caroli a Linné Systema Nat., pag. 2223

1789. - - Berkenhout, Synopsis of Nat. Hist. of Gr. Britain and Ireland, pag. 122. 


\section{J. UZEL, MONOGRAFIE RÁDU "THYSANOPTERA“.}

1789. Thrips juniperina de Villers, Car. Linnaei Entomologia.
1794
Fabricius, Entomologia Systematica, pag. 228.
1802. - - Stew, Elements of Nat. Hist., pag. 114.
1803. - - Fabricius, Systema Rhyngotorum, pag. 313.
1806. - - - Turton, A General System of Nature pag. 716 .

Linné (anno 1761.): »Thrips elỵtris niveis, corpore fusco.»

\section{Thrips paradoxa $L$.}

175 . Thrips paradoxa Linné, Amoenitales academicae, 6, pag. 401.

1767. - - Linné, Systema Naturae, pag. 743.

1781. - - Schrank, Enumeratio Ins. Austriae indig., pag. 298.

1788. - - Gmelin, Caroli a Linné, Systema Nat., pag. 2222.

Linné (anno 1767.): »T. fusca, alis abbreviatis, antennis pectinatis, fissilibus, aliformibus. Insectum valde singulare. Habitat in China."

\section{Thrips ranunculi Schr.}

1763. (Bez jména. - Ohne Namen.) Scopoli, Entomologia Carniolica, pag. 141.

1781. Thrips Ranunculi Schrank, Enumeratio Ins. Austriae indig., pag. 298.

Schrank: »Thrips Ranunculi, nigra, alis albidis, segmentis abdominalibus margine rufis. «

\section{Thrips variegata Gmel.}

1764. Thrips variegata v. Gleichen, Das Neueste aus dem Reiche d. Pflanzen, pag. 22.; tab. 21., fig. 6. et 7. (1788, Gmelin, Syst. Nat., pag. 2224.).

\section{Thrips leucanthemi Schr.}

1763. (Bez jména. - Ohne Namen.) Scopoli, Entomologia Carniolica, pag. 141.

1781. Thrips leucanthemi Schrank, Enum. Ins. Austriae indig., pag. 298.

Scopoli: "In flore Bellidis majoris, copiosissima, nigra tota; antennarum articulis basi albidis; tibiis anticis crassioribus, compressis.

Schrank: »Breitfüssiger Blasenfuss. Thrips nigra, alis albidis; tibiis anticis compressis dilatatis albis." 
H. UZEL, MONOGRAPHIE DER ORDNUNG THYSANOPTERA.

\section{Thrips conica Fabr.}

1803. Thrips conica Fabricius, Systema Rhyngotorum, pag. 312.

Fabricius: »T. atra nitida alis ciliatis albis, abdomine conico. Habitat in America meridionali (Dom. Smidt). Magna in hoc genere. Antennae fere moniliformes. Corpus atrum, pilosum, abdomine aculo, conico. Alae ciliatae, albidae. Pedes atri femoribus anticis incrassatis."

\section{'Thrips cynorrhodi Halid.}

1836. Thrips cynorrhodi Haliday, Entomolog. Magazine, pag. 448.

1843. Physapus - Amygt et Serville, Ins. Hémiptères, pag. 643.

1852. Thrips - Haliday, Walker: Homopt. insects of Brit. Museum, pag. 1110 .

Haliday (anno 1836.): »Tibiae et tarsi inermes. - Elytra linearia, unicolora, basi tantum pallidiora. - Antennae stylus filiformis distincte biarticulatus. - Smaller and paller than T. vulgatissima; the style of antennae shorter. - Common in the flowers of wild roses."

\section{Thrips grossulariae Halid.}

1836. Thrips grossulariae Haliday, Entomolog. Magazine, pag. 448.

Haliday: "Tibiae et tarsi inermes. - Elytra linearia, unicolora, basi tantum pallidiora. - Antennae stylus perbrevis, articulis vix discretis. - Elytra fusca. - Common in the flowers of gooseberries in spring. «

\section{Thrips corymbiferorum Halid.}

1836. Thrips corymbiferarum Haliday, Entom. Magazine, pag. 449.

1843. - corymbiferorum Amyot et Serville, Ins. Hémiptères, pag. 644.

1852. - corymbiferarum Haliday, Walker: Homopt. ins. of Brit. Museum, pag. 1112.

Haliday (anno 1836.): »Tibiae et tarsi inermes. - Elytra linearia, unicolora, basi tantum pallidiora. - Antennae stylus perbrevis, articulis vix discretis. - Elytra pallida. In the flowers of Corymbiferae, with a white border, in the Botanical garden at Glassnevin, near Dublin. «

Haliday (anno 1852.): »Ferruginea, abdominis incisuris et antennarum apice obscuris, ocellis rubris, hemelytris albidis, fem. Silacea mas." 


\section{J. UZEL, MONOGRAFIE RADDU „THYSANOPTERA“.}

\section{Thrips livida Halid.}

1836. Thrips livida Haliday, Entomological Magazine, pag. 449.

Haliday: »Tibiae et tarsi inermes. - Elytra linearia, unicolora, basi tantum pallidiora. - Antennae stylus perbrevis, articulis vix discretis. - Elytra testacea (aut pallida?). - In flowers of Ulex Europaea, very rare."

\section{Thrips persicae Halid.}

1837. Thrips Persicae Haliday, Entomolog. Magazine, pag. 146.

Haliday: »The larva is entirely light yellow, not unlike that of Thr. ulmifoliorum, but without the small spines at the tail. - A small species, found on the diseased leaves of peach-trees."

\section{Thrips ochracea Westw.}

1839. Thrips ochraceus Westwood, Introduction to the modern classific. of Insects, II.

\section{Thrips picipes Zett.}

1840. Thrips picipes Zetterstedt, Insecta lapponica, pag. 313.

Zetterstedt: "Nigra. nitida; hemelytris subulatis fuscis, basi albidis, pedibus rufo-piceis, tarsis pallidis. Long. ${ }_{1 / 3}$ lin. - Ninutissima, vix ${ }_{1 / 2}$ lin. longa. Antennae breviusculae, filiformes, pubescentes, nigrae, basi pallidae. Corpus nigrum, nitidissimum, glabrum. Abdomen subconvexum, lateribus parum pilosum. Anus acutus, stylo vero parum elongato, parce piloso, apice vix setigero. Hemelytra longitudine abdominis, subulata, margine ciliata, tota fuscata, basi alba. Alae angustissimae, albidae. Pedes validi, rufescentes, femoribus suturatioribus, tarsis pallidis. Femora antica reliquis non crassiora. - Habitat in Lapponia boreali rarissime. In floribus pratensibus Lapponiae meridionalis passim inventa.«

\section{Thrips olivaria Tamburin.}

1842. Thrips olivarius Tamburin, Mémoire sur le Thrips oliv. etc., Draguignan.

\section{Phloeothrips tristis Halid.}

1852. Phloeothrips tristis Haliday, Walker: Homopt. ins. of Brit. Museum, pag. 1098.

Haliday: » Alae et ocelli desunt. - Nigra, nitida, antennarum articulo tertio albido, metatarso mutico. Long. 1 lin.« 


\section{H. UZEL, MONOGRAPHIE DER ORDNUNG THYSANOPTERA.}

\section{Phloeothrips mali Fitch.}

1856. Plloeothrips Mali Fitch, Report on the noxious insects of New-York, pag. 104.

Fitch: »This insect measures only six hundredths of an inch in length and one hundreth in width. It is polished and shining; and of a blackish purple color. Its antennae which are rather longer than the head and composed of eight nearly equal joints, have the third joint of a white color. The abdomen is concave on its upper side, and is furnished with a conical tube at its tip which has a hew bristles projecting from its apex. The wings when folded are linear, silvery white, and as long as the abdomen; they are pressed closely upon the back, spreading asunder at their bases, and appear like an elongated white Y-shaped mark. Viewed from above, the head is of a square form, longer than wide. The first segment of the thorax is well separated from the second, is broadest at its base, and gradually tapers to its anterior end, where it is as wide as the head. The following segment is the broadest part of the body and square, with its length and breadth equal. United States: New-York. — Gouging into young apples?

\section{Thrips tritici Fitch.}

1856. Thrips Tritici Fitch, Report on the noxious ins. of New-York, pag. 304. et pag. 308., fig. a-f.

Dle výkresů jest patrno, že tu spleten jest jakýsi zástupce tubulifer s nẽjakou třásněnkou terebrantialní.

Aus den Zeichnungen geht hervor, dass hier ein Vertreter der Tubuliferen mit einem der Terebrantien vermengt wurde.

\section{Aeolothrips trifasciata Fitch.}

1856. Coleothrips trifasciata Fitch, Report on the nox. insects of New-York, pag. 308.; fig. g.

Fitch: »Length 0.07. - It is of a black color, polished and shining, with the third joint of its antennae white, and its wings black or dark smoky brown, with three broad white bands, whereof one is upon the base, another across the middle, and the third, which is somewhat narrower, upon the tip. The wings show two longitudinal veins, but no transverse ones were noticed upon them (?), nor could I discover any fringe upon either their outer or inner (?) margin. The fore legs are larger than the others, and the antennae instead of arising far apart as in most of the species I have examined, come out from the front of the head close together (!), and are composed of only five 


\section{J. UZEL, MONOGRAFIE RADU, "THYSANOPTERA".}

principal joints, of which the two first are short, and a third thicker than the others, which are long and cylindrical, the last one gradually tapering to a slender point, its apical portion being divided into small indistinct segments. - This species is common upon wheat. - New-York.

\section{Phloeothrips caryae Fitch.}

1857. Phloeothrips caryae Fitch, Report (II.) on the noxious ins. of New-York, pag. 127.

In hickory galls, food?

\section{Limothrips poaphagus Comstock.}

1875. Limothrips poaphagus Comstock, A Syllabus of a Course of Lectures etc. Nominalni druh. - Nominalart.

\section{Phloeothrips*) fasciata Butler.}

1876. Aptinothrips (!!) fasciatus Butler, Annals and Mag. of Nat. Hist. No. 101., pag. 412 .

Butler: »Blackish piceous, glabrous; wings hyaline; bases of antennal joints, eyes, ocelli, and five broad abdominal bands crystalline white; frons fulvous; antennae 7-jointed, basal joint conical, the second to fourth obconical, fifth to seventh fusiform; the terminal joint terminating in an acute point; head rounded, truncate in front and behind, with a central obtuse carina and an oblique stria behind each eye. Length 3 millims. Rodriguez; coll. by Gulliver."

\section{Thrips lini Ladureau.}

1877. Thrips lini Ladureau, Assoc. franç. p. l' avanc. d. Sciences, pag. 953., fig. 99. Znaky vytknuté týkají se třásněnek vůbec.

Die angeführten Kennzeichen beziehen sich auf die Thysanopteren überhaupt.

\section{Thrips croceicollis Costa.}

1884. Thrips croceicollis Costa, Geo-fauna sarda (2), pag. 71.

Nominalní druh. - Nominalart.

*) s. 1. 
H. UZEL, MONOGRAPHIE DER ORDNUNG THYSANOPTERA.

Phloeothrips brumnea Jordan.

1888. Phloeothrips brumea Jordan, Zeitschr. f. wiss. Zool., 47.

Thrips asperulae Jordan.

1888. Thrips asperulae Jordan, Zeitschr. f. wiss. Zool., 47.

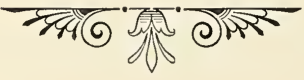




\section{ZÁVĚREČNÉ POZNÁMKY. SCHLUSSBEMERKUNGEN.}

Chceme-li studovati třásněnky, je nutno, jak již na str. 15. řec̀eno, zkoumati je r praeparatu mikroskopickém. Připojime zde ještě nèkteré pokyny. T'ekutina, v niz tř́snènky mikroskopem výhodnè ohledáváme, jest glycerin nebo lih (tento však rychle se vypařuje, proče\% musi býti během zkoımáni ustavičnè pipetou nahrazován). - Kryci skličko nesmi tuze těsnè ke sklu objektivnímu přiléhati, aby jenná tato zviŕátka uebyla smáčknuta a deformována. Toho uvarujeme se, kdyz̀ por skličko to s jedné strany vsuneme s̀pendlik, jimž snadno mìzeme tlak jeho regulovati.

Rozmèry jednotlivých části tèla je naprosto nutno mèriti mikıometrem ( $v$ okuláru), ponèvadž odhad okem mủže velmi klamati P’ì mérení lılavy musime vždy přihližcti $\mathrm{k}$ tomu, zda-li není vtažena do předohrudi, a při měreni článkûv abdominalních se přesvèděiti, zda-li není vsunut èástečnè jeden do druhého. což se nèkdy vclikou mèrou stává. Pravidelnè vs̀ak se tèlo tr̉ásnènek po snurti v líhu rozestoupenim se jednotlivých c̀lánkû znac̀nè prodlouži, pìi ċemž se svètlé spojovací blány objevi. Odměřujice délku tèła, musíme k tomuto nepìirozenému prodlonžení jeho miti zǐetel. Spolehlivè mohou býti měreny jen żivé tìásnènky umèle ochlazené (aby se nepohybovaly), což hodlám príśtè provádèti, abych nabytými pìesnými ěsly nahraditi mohl přibližné délky tèla, v této monografii udané.

Trar a strukturu křidel, tykadel a noh můzeme jen tenkrát spolehlivè posuzovati, když je oddèlime od těla a ohledáváme je pod jistým tlakem (aby všecky části pìis̀ly do jedné roviny). Chceme-li ústroje ústní a makadla přesnè zkoumati, musime hlavu zviřete jehlami pozorně ordejmouti, čímż se sosák, který na hlavě zůstává viseti, stává zrakûm našiin př́stupným. Ocka uhlidáme nèkdy teprve tenkrát, kdy̌ jsme byli hlavu v silném roztoku drasla žiravého vaìili, co\% té\% velmi se odporučuje ke studiu jemných struktur chitinu.

Konečnè podotýkám ještè, ̌̌e milerád zodpovím dotazyketr̃ásnènkám se vztahnjicí, a že určim material mi zaslaný.

Will man verlässlich Thysanopteren bestimmen, so ist es nothwendig, wie schon auf S. 16 erwähnt wurde, sie in einem Tropfen Glycerin auf dem Objectträger unter dem Mikroskope zu untersuchen. Man kann wohl auch Spiritus dazu verwenden, ist jedoch gezwungen ihn im Laufe der Beobachtung, weil er stark verdünstet, fortwährend mit Hilfe einer Pipette zu erneuern. Natürlich muss man über den Tropfen Flüssigkeit, in dem sich die kleinen Insecten befinden, ein Deckgläschen legen, dasselbe jedoch gehörig stützen, damit es sich nicht allzu eng an den Objecttrüger anlegt und dadurch das Object breitdrückt. Vor diesem Umstande ist sehr zu warnen, denn es werden dadurch die Formen des Körpers stark verändert. Hingegen ist ein seh" schwacher Druck, den man durch eine von einer Seite unter das Deckglas geschobene Nadel regulieren kann, recht zweckmässig, ja sogar erforderlich, da er den Körper ziemlich in eine Ebene bringt, olme ihn zu deformieren. Die Dimensionen der einzelnen Theile sind unbedingt mit dem Ocularmikiometer zu messen, da ein Abschätzen mit dem Auge zu grossen Irrthümern führen kann. - Die rerhältnismässigen Längen werden nach folgendem Beispiel angegeben. Ist der Kopf 12 Tlıeile lang' 


\section{H. UZEL. MONOGRAPHIE DER ORINUNG THYSANOPTERA.}

und der Tubus 7 Theile, so heisst es: Der Kopf ist um $0 \cdot 7$ länger als der Tubus $(12: 7=1 \cdot 7$ : $1 \cdot 7-1=0 \cdot 7)$, oder : Der Tubus ist um $0 \cdot 42$ kürzer als der Kopf $(7: 12=0.58: 1-0 \cdot 58=0 \cdot 42)$. Beim Messen der Dimensionen des Kopfes und der einzelnen Abdominalsegmente ist darauf wohl zu achten. ob nicht jener theilweise in den Prothorax eingezogen und diese nicht ineinander hineingeschoben wurden, weil dies zuveilen in hohem Grade bei todten Thieren geschieht. Regelmässig erfolgt jedoch nach dem Tode in Spiritus eine sehr beträchtliche, manchmal eine erstaunliche Verlängerung des ganzen Insectes, weil die einzelnen Segmente auseinanderweichen. Dabei werden die weissen Verbindungshäute zwischen Kopf und Prothorax, zwischen diesem ınd dem Pterothorax, hauptsächlich jedoch die sehr breiten Häute zwischen den einzelnen Abdominalsegmenten mehr oder weniger sichtbar. Ein aufgelegtes Deckgläschen trägt zur unnatïrlichen Verlängerung des Körpers sehr stark bei. Um nun die annähernd genaue Körperłänge zu erfahren, muss man alle Abschnitte des Körpers mit dem Mikrometer einzeln messen und die gewonnenen Zahlen addieren, dabei jedoch ja nicht vergessen, dass beim lebenden Thiere die Abdominalsegmente ineinandergeschoben sind, und dass bei ihnen auch der Kopf und ('ventuell der Tubus etwas eingezogen ist. Man sollte daher die Körperlänge nach lebenden Thieren von Durchschnittsgrösse (mit dem Mikrometer) bestimmen, was jedoch wegen ihrer Bewegungeı sehr selten gelingt. Nur eine starke Abkühlung der Luft (durch ein Stück Eis, welches man unle! eine Metallplatte legt, anf der sich das durch ein umgekehrtes Uhrglas zurückgehaltene Thier befindet) vermag ihı'e Bewegungen zu sistieren. Ich beabsichtige nächstens lebende, auf solehe WVeise zur Ruhe gebrachte Thiere zu messen, um die in vorliegender Monographie nur provisorisch ang egebenen annähernden Körperlängen durch die gewonnenen genauen Zalılen nach und nach ersetzen zu können. In Betracht der Schwierigkeiten, welche mit den genauen Messen del Körperlänge der Thysanopteren verbunden sind. ist es sehr begreiflich, wenn dieselbr von den Autoren öfters zu gross angegeben wird.

Die Flügel. Fühler und Beine kann man nur dann verlässlich beurtheilen, wenn sie, vom Körper abgetrennt, unter einem gewissen Drucke beobachtet werden. Will man Mundwerkzeuge und Palpen genau betrachten, so muss man den Kopf der Insecten voun Leibe vorsichtig init Nadeln abtrennen. un den daran hängen gebliebenen Rüssel untersuchen zu können. Ocellen sieht naul zuweilen erst dann. wenn man den Kopf in einer starken Lösung von Ätzkali gekocht hat. was auch sonst zum Studium der feinen Structuren des Cihitins sehr zu empfehlen ist.

Ich habe in meiner Monographie durchgehends den Namen Thysanoptera (Thysanopteren) gebraucht, welcher dem Namen Physopoda (Physopoden) vorzuziehen ist. da jener die Priorität hat, indem er für unsere Ordnung von Haliday früher verwendet wurde. Das Wort Physopoda bildete Burmeister nach D unérils französischem Vamen Physapodes (der sich auf den Degeerschen Namen Physapus bezieht). Dum éril gebraucht gleichzeitig auch noch den Namen Vésitarses, und da seine Benennungen französisclı uncl doppelt sind, können dieselben auf Priorität keinen Anspruch machen. Dem lateinischen Namen Thysanoptera würde der deutsche Fransenflïgler entsprechen, daher erlaube ich mir als Ersatz für den Namen Blasenfüsse den Namen Fransenfliegen (Gäıtner nennen diese Insecten „schwarze Fliegen“) anzutragen.

Endlich will ichnoch erwähnen, dass ich gernebereit bin, jedermann Auskünfte über den hier behandelten Gegenstand zu ertheilen und das mir zugeschickte Material zu bestimmen*).

*) Aufenthaltsort des Verfassers: Königgrät\%, Nr. 12. (Böhmen.) 


$$
\begin{gathered}
\text { II. ĆÁST' } \\
\text { PALAEONTOLOGICKÁ. }
\end{gathered}
$$

\section{PALAEONTOLOGISCHER THEIL.}





\section{Ú VODNÍ POZNÁM KY. EINLEITENDE BEMERKUNGEN.}

Fossilní trásnènky posud nalezeny byly pouze v útvaru třetihornim. Ze starších vrstev útvaru tohoto popsáno bylo několik druhû Oustaletem (L. č. 103.) a jedna dávno před tím Heerem, a to z lomủ u Aix v jižní Francii, jejichž sádrovce náležejí do vỵššího eocénu a vyznamenávají se bohatou zkamenělou florou. Tři druhy dále popsány byly Mengem z jantaru (do spodního oligocénu počitaného), smůly to dávnověkých konifer. které rostly v lesích skandinavských, odkudž k jižním břelıủm moře baltického splaveny byly. V mladším útvaru třetihorním nalezeny byly četné zbytky vymřelých třásněnek v dolech hnědouhelných u Rottu, nedaleko Bonnu, vrstvách to, náležejících do stupně aquitanského (dle K. Ma yera) a dle staršího rozdèlení do svrchního oligocénu. Z naleziště tohoto popsal v. Schlechtendal 12 druhù. Ze stupně tortonského ëi öningenského (dř́ve do hořejšího miocénu počítaného) popsáno několik druhủ od Öningen v jižním Badensku, kteréžto místo přebohatou faunou hmyzủ z nejrủznějšich řádů se vyznamenává. Konečně známy jsou také fossilní třásněnky ze severoamerického útvaru třetihorního (Utah, Fossil Cañon, Chagrin Valley), z něhož Scudder (L. č. 88. a 100.) popsal tr̃i druhy. Ač posud nám jsou třásněnky jen z třetihor známy, není pochybnosti, že již dávno před tím vyvinuty byly. Ba jest možno, že již v prvohorách (aspoñ v útvaru kamenouhelném) byly differencovány, nebot tenkráte z předkủ našeho hmyzu rovnokřídlého již homoptera se byla vyvinula, jak z nalezených křisů a svítilek nepopíratelně na jevo vychází. Víme pak, že třásněnky z těch přechodních tvarủ mezi orthoptery a homoptery se odvozují (viz Část' systematickou), jež sice mají již znaky, valnou většinou homopterủm. náležející, avšak přece některé vlastnosti orthopter si zachovaly (zvl. v ústrojích ústních). Že nenalezli jsme posud třásnènek jinde než $\mathrm{v}$ třetihorách, jest snadno pochopitelno, uvážíme-li, že hmyz vůbec ve vrstvách zemských velmi pořídku se zachoval, poněvadž žije většinou na suchu, kde mrtvoly jeho setlely neb jinými živočichy sežrány byly, a že jen tenkráte zbytky jejich udržeti se mohly, když dostaly se do bahna, kde ihned novou vrstvou jeho pokryty byly. Jen velikou náhodou dostává se pak petrefakt ten do rukou znalce, který nad to velmi snadno přehlédne hmyz tak drobný jako jsou třásněnky. Proto tedy jen z několika málo nalezišt jsou známy, ač snad na květnatých luzích 


\section{H. UZEL, MONOGRAPHIE DER ORDNUNG THYSANOPTERA.}

mladšich period geologickị́ch četnè se vyskytovaly. Jest pravdẽpodobno, že bỵchom mnohé fossilní třásněnkỵ objevili, kdỵbychom byslreji $k$ nejmenším čárkám na lupcích usazenin sladkovolních prihliželi, a to zvláště na tèch nalezišlích, kde inístní pomèry zachování zbỵtkủ hmyzových velmi príżnivy byly (kromè vyjmenovaných lokalit jsou to zvláště: Commentry. Schambelem, Solenhofen. Sézanne, Auvergne, Radoboj). Snad i v Čechách nalezneme během času fossilní třásnènky. Vzhledem $k$ nim upozorñoval bych na vrstvy hnědouhelné u Starého Sedla a Kučlina a na starší předčedičové hnèdé uhlí vůbec, při jehož tvorení se snad podobně príznivé poměry $k$ zachování zbytkú trrásněnek vládly jako $\mathrm{v}$ soudobỵcch vrstvách (stupeň aquitanský) u nepríiliš vzdáleného Rottu, kdež četně se vyskytují.

\section{O FOSSILNÍCH DRUZÍCH TŘÁSNĚNEK. ÜBER FOSSILE THYSANOPTERENARTEN.}

Fossilní druhy dosud popsané jsou jednak zástupcové rodủ vymirelých, a sice rodu Palaeothrips Sc., Lithadothrips Sc. a Calothrips Sc., aneb vraděny byly do rodû Melanothrips, Thrips, Heliothrips a Phloeothrips, jejichž druhy posud žijí.

Rod Palaeothrips, Scudderem ze Sev. Ameriky popsaný (L. č. 88. a 100.), patrí, jak tento sám poznal, mezi Coleoptrata. Hlava jeho jest okrouhlá, do predu trochu se zúžujicí. Tykadla jsou štíhlá, o sedmi válcovitých ċláncích. Poslední z nich jest právẽ tak dlouhý jako dva priedcházejicí, a nelze na nèm poznati, že by byl srostl z menších částí. Prostřední články tỵkadel jsou na konci trochu rozšírené. Prothorax značně širší než hlava a Irochu širši než delší. Přední femora neobyčejně tlustá, sotva více než dvakrát tak dlouhá jako široká; přední tibie taktéž stlustlé, o něco delší než femora; ostatní nohy jsou mírnēji stlustlé a tak dlouhé, że dosahuji konce abdomenu. Pr̉ední krídla neobyčejně široká, na konci nejširší. Zde jest jejich šiřka o něco větší než čtvrtina délky. Hořejšími krìidly jdou dvẽ podélné žilky, které rozdèluji plochu jejich na tři skoro stejné části. Uprostred náhle $k$ sobě se trochu sbližuji a spojují se príčnou žilkou. Na samém konci od sebe se vadalují. S oběma okraji spojeny jsou jinými priı̌nými žilkami, které nalézají se v prvé a druhé lřelinè délky krrídla. Obẽ př̀ǐné žilky dolejší třetiny křídel jsou o poznání dále $\mathrm{v}$ před posunuty než odpovídajicí žilky $\mathrm{v}$ hořejší třetině. Tr̉ásně na zadním okraji křídel jsou asi třikrát delši než na předním. Nejen žilka okružní, nỵbrž i žilky podélné jsou chlupaté. Dolejší křídla jsou bez žilek a skoro tak dlouhá a široká jako hořejší. Abdomen jest llustý. Jediný druh $P$. fossilis jest $1.6-1.8 \mathrm{~mm}$ dlouhý. Obraz jeho. Scudderem provedený, nalezneme v Zitlelovẽ: Handbuch der Palaeontologie, I. Abth., 2. Bd., na str. 784. (fig. 999.). - Křídla rodu Palaeothrips, jak je Scudder popisuje, jsou úplnè shodna s kř́ldỵ recentního rodu Melanothrips (Tab. V., fig. 39.). Tykadla pak jsou podobnè utvořena jako u recentniho rodu Rhipidothrips nov. gen. (Tab. V., fig. 43.). Zde ovšem lze na poslednim článku poznati, že porstal 


\section{J. UZEL, MONOGRAFIE RADU ,THYSANOPTERA“.}

srủstem tři menších částí, což však při zkamenělém objektu müze snadno státi se nezřetelným. Místo rodu Palaeothrips jest tedy v soustavě mezi obẻma jmenovany̆mi rody recentními.

Rod Lithadothrips, límtéž autorem ze Sev. Ameriky popsaný, má hlavu širokou, okrouhlou, oči veliké. Tykadla jeho jsou štíhlá, osmi- neb devítičlenná; články jejich válcovilé. Prothorax tak široký jako hlava. Křridla jsou špatně zachována, avšak přece tak, že na zákiladè jich mủže přislušenství toho rodu do skupiny Coleoptrata býti zjištěno. Nohy jsou šlihlé a podobné nohám rodu Palaeothrips; zdá se, že byly hojně chlupy opalřeny. Jediný druh $L$. vetusta jest $1.7 \mathrm{~mm}$ dlouhý. — Scudder nalezl dva exempláre toho druhu a praví, że rozeznávají se od sebe značně ve tvaru abdomenu. Tento jest prý u jednoho široký a vřetenovitý, na konci trochu prodloužený a tam několika chlupy opatřený. Druhý má strany abdomenu rovné a konec jeho široce zaokrouhlený. Patrně jest prvý exemplář samice. druhý samec.

K recentnímu rodu Melanothrips radi Scudder jistý druh třásněnek, jehož zbytky jsou velmi neúplnè zachované, a jejž jmenuje $M$. extincta. Praví o nèm, že má hlavu malou, napřed zúženou, a že jeho tỵkadla jsou velmi dlouhá. Z křídla zachovala se jen přední část žilky okružní, nesoucí podobné chlupy jako druh Palceothrips fossilis, a část' jedné \% žilek podélných. Délka těla obnášela $2 \cdot 2 \mathrm{~mm}$.

Ostatni třásněnky fossilní vřaděny byly do recentních rodủ Phloeothrips, Thrips a Heliothrips. Z těch hodláme věnovati větší pozornost druhủm, jež v. Sch lechtendal z hnědého uhlí u Rottu popsal, poněvadž, jak již praveno, máme tytéž vrstvy v Čechách, a tudǐ̌ tytéž druhy by zde nalezeny býti mohly. Kromě toho pak lze druhy v. Schlechtendalovy dobr̀e posuzovati, ježto jsou podrobně popsány a pečlivě vykresleny.

Zbytky třxásněnek z naleziště toho jsou dosti dobře zachovány, jak ukazují vyobrazení jejich, z nichž některá jsem vybral a v Obraz 1. sestavil. — Schlechtendal popsal v celku dvanáct druhů, z nichž jeden zar̆aduje do rodu Plıloeotlırips, sedm do rodu Thrips v šir. slova smyslu a čtyri do rodu Heliothrips. Pokud se tohoto posledního rodu týče, dálo se přiřadění některých třásněnek $k$ němu jen ohledem na jejich mřižkovanou strukturu chitinu, což zdá se autoru samému znakem nepodstatným býti, a to tím více, poněvadž neni vyloučena možnost', že zmíněná struktura povstala teprv při zkamenění. - Všecky druhy byly okřídlené a křídla jejich zachovala se zvláště tenkrát dobře, když nebyla přiložená $k$ tělu třásněnky, nýbrž volně ve vrstvě ležela. Tykadla celkem zachovala se špatně, takže, jak autor praví, jen v málo př́padech mohou popisy jejich poněkud nároky činiti na správnost'. Tím také vysvětlují se bizarní tvary některých vykreslených tykadel (Obr. 1., fig. 6. a 7.). Očka lze spatřiti jen zř́lka a vždy jen nedokonale. Metascutellum čítá v. Schlechtendal mylně k středohrudi, čímž vykládá se jeho tvrzení, že metathorax jest slaběji vyvinut než mesothorax. — Výlkresy v. Schlechtendalovy představuji skoro vesměs samice (jen druh clypeata jest snad sameček), což snadno si vysvětlíme, povážíme-li, že je u třásněnek vždy mnohem více 
samic než samců. - Presné pozorování delailú těchto malých, jen $0 \cdot 9-2 \cdot 3 \mathrm{~mm}$ dlouhỹch zvir̉ảtek valně jest znesnadněno tím, že nemožno užiti prì napadajícím jen světle, při něm\%̆ zkoumání jejich toliko diti se müže, větších zvětšení.

Prvni z tr̉ásněnek v. Schlechlendalových jest Phloeothrips (s. l.) Pohligi (Obr. 1., fig. 1.). Hlava jeho jest as tak dlouhá jako široká, nazad značně zúžená. Očka prítomna. Prothorax má podobu lichoběžníka a jest dvakrát kratší hlavy. Pr̉ední femora nejsou stlustlá. Krídla velmi nedokonale zachována. Poslední článek abdomenu (tubus) jest o něco kratší hlavy, na basi trochu širší než na konci. Délka těla $2 \cdot 3 \mathrm{~mm}$. Kromě toholo druhu nalezl autor ješlě zbytky dvou jiných druhủ, do téhož rodu náležejících, jež však jsou velmi neúplné a tudiž popsány nebyly.

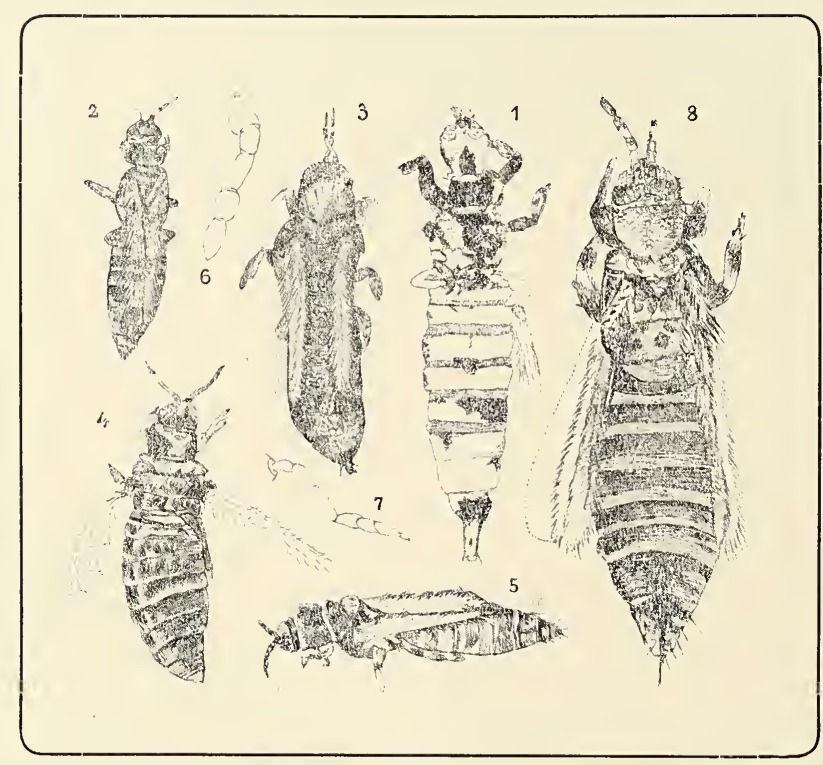

Obtaz 1. FOSSILNI TŔS NÉNKY. (Dle v. Schlechtendala.)*) - 1. Phloeothrips Pohligi. 2. Thrips pygmaea. 3. Thrips clypeata. 4. Thrips Freehi. 5. Thrips exeellens. 6. Cást tykadla druhu Thrips mimima. 7. Tykadlo druhu Thrips breviventris. 8. Lithadothrips cueullata.

Druhá třásnènka, Thrips (s. I.) excellens (Obr. 1., fig. 5.) měla hlavu zaokrouhlenou, skoro dvakrát širši než delší. Tykadla, dvakrát tak dlouhá jako hlava, podobala se prý tykadlům druhu Thrips sambuci. Prothorax byl asi o $1 / 3$ širši než delší a měl

*) FOSSILE THYSANOPTEREN. (Nach v. Schlechtendal.) - 1. Ploloothrips Pohligi. 2. Thrips mygmaea. 3. Thrips elypeata. 4. Thrips Frechi. 5. Thrips exeellens. 6. Ein Theil des Fühler's der Art Thrips minima. 7. Fühler der Art Thrips breviventris. 8. Lithadothrips cuenllata. 


\section{J. UZEL, MONOGRAFIE RADU „THYSANOPTERA“.}

rohy zakulacené. Zadní okraj mesosculella tvořil nízký oblouk. Druhý až osmý èl. abdomenu opatreny byly po každé straně nahoře okrouhlou jamkou a zřetelnou rýhou pod předním okrajem. Poslední články na zadním kraji brvité. Kladélko zřetelné. Přední femora byla trochu stlustlá. Kr̂́ídla dosti široká a opatrená, je-li pozorování správno, dvěma porélnými žilkami, celým křídlem se táhnoucími. Délka těla $1.8 \mathrm{~mm}$. Zdá se, że tento druh byl svého času velmi hojným.

Thrips (s. l.) longula měla dle v. Schlechtendala tělo dlouhé, štíhlé a hlavu tak širokou jako dlouhou. Prothorax byl o málo širší než delší a v délce asi hlavě se vyrovnával; nazad trochu zúžený. Mesosculellüm malé, jeho zadni okraj tvořil vysoký oblouk, do pr̉edu otevřený. Pterothorax veliký. Poslední ělánky abdomenu byly vzadu brvité. Prohlubin na ěláncích abdominalních nebylo. Délka těla $1.8 \mathrm{~mm}$.

Thrips (s. l.) pemifera měla hlavu o dvě třetiny širši než delší, v předu zaokrouhlenou, nazad se rozšiřujicí. Prothorax byl značně širší než hlava a skoro dvakrát širši než delší. Zadní okraj mesoscutella rovný. Kríilla velmi úzká a do kola dlouze třásnitá. Tykadla byla štihlá, nepripouštěji však, jak autor praví, žádné určité predstavy; jen tolik lze poznati, že jejich 4. čl. byl mnohem delší než 2., jenž byl právě tak dlouhý jako článek třetí. Délka těla $1 \cdot 3-1 \cdot 5 \mathrm{~mm}$.

Thrips (s. l.) breviventris měla hlavu podoby polokoule. Tykadla (Obr. 1., fig. 7.) skládala se ze sedmi článkủ, z nichy̌ mèly 2. a 4. stejnou délku a bỵly kratší než 3. Články tykadla utrpèly asi značných deformací při zkameněni. Prothorax byl delší než hlava a do předu trochu se rozšiřoval. Přední jeho rohy ostré a zadní, na nichž nalézalo se po dvou dlouhých chlupech, zaokrouhlené. Zadní okraj mesoscutella tvořil oblouk. Abdomen byl zavalitý a sotva delší než hlava a thorax dohromady. Kř́idla byla úzká, krátká a velmi ř́dkými, dosti dlouhými trásnèmi opatřená. Délka tèla as $1 \mathrm{~mm}$.

Thrips (s. l.) minima měla tělo malé a úzké. Hlava a prothorax dohromady prý tvořily dosti pravidelný kruh (myslím, že jest to asi deformace tlakem způsobená). Abdomen byl úzký. Dlouhá křídla taktéž velmi úzká. Nohy byly krátké a zavalité. Z tykadel (Obr. 1., fig. 6.) zachovalo se jen prvých pět článkủ. První, 2., 4. a 5. čl. byly mezi sebou stejně dlouhé a každý z nich kratší než článek třetí. První článek stál v prohloubeném na konci výstupku hlavy a mèl podobu pohárovitou; 4. čl. byl neobyčejně stlustlý. Délka těla $0.9 \mathrm{~mm}$.

Thrips (s. l.) pygmaea (Obr. 1., fig. 2.) měla hlavu okrouhlou, o $1 / 3-^{1 / 2}$ širší než delší. Prothorax byl tak dlouhý jako hlava a mèl snad nahoře uprostřed podélnou rýhu. Cást zadního okraje mesoscutella, mezi kořeny křídel se nalézající, měla podobu vysokého oblouku. Kořeny hor̉ejšího a dolejšího páru křídel byly od sebe značně vzdáleny. Abdomen jen o málo delší než hlava a thorax dohromady. Hořejší křídla měla dvě žilky podélné, z nichž, dle výkresu, každá celé kríídlo prostupovala. Délka těla as $1.2 \mathrm{~mm}$. 


\section{H. UZEL, MONOGRAPHIE DER ORDNUNG THYSANOPTERA.}

Thrips (s. 1.) capito mèla hlavu skoro tak dlouhou jako širokou. Bezprostředně za očima nalézala se př́čná čára. Tykadla byla jen o málo delší než hlava. Prothorax o polovici kratší než tato a více než drakrát tak široký jako dlouhý. Mesothorax byl svou velikostí velmi nápadný, nebot byl delší než prothorax a skoro téže délky jako metathorax. Mesoscutellum vzadu třikrát vykrojeno. Kior̀eny hor̉ejších krídel byly následkem neobỵcejných rozměrủ středohrudi značně do zadu posunuty. Abdomen dlouhý. Druhý až 7. čl. jeho měly nahoře na každé straně okrouhlou jamku a oblouček, jenž obě jamky spojoval. Zadní kraje článků abdominalních byly uprostred obloukovitě rykrojeny. Kladélko patrné. Délka těla $1.4 \mathrm{~mm}$.

Lithadothrips cucullata (Obr. 1., fig. 8.), v. Schlechtendalem neprárem (viz nahoře) k rodu Heliothrips priiřaděná, vyznamenávala se následujícími znaky. Hlava mèla skoro podobu polokoule; oči byly veliké. Prothorax vzadu zaokrouhlen, predni okraj pronota pokrývala prý týlní část hlary (proto jméno cucullata), což, jak myslim, jen tím povstalo, že hlava se částečně do předohırudi vtáhla, jak to u třásněnek po smrti často se děje. Pronotum bylo na okrajích do kola a částečně též na povrchu krátkými chloupky poseto. Nad pr̃edními kyčlemi stály prý ještě tři délkou svou se vyznamenávající chlupy. Zadní okraj mesoscutella trořil mezi kořeny krídel nevysoký oblouček, k němuž prý přiléhal trojhranný štítek. Abdomen byl široký. Přední a střední nohy dosti krátké, jejich femora stlustlá, assi dvakrát tak dlouhá jako široká; jejich tibie ke konci rozšírené. Zadní nohy dosti silně chlupaté, delší a štíhlejší než ostatní. Druhý čl. tarsu byl opatřen »dvěma malými tělísky, které jeví brzy tvar kulatý, brzy podlouhlý, a jejichž význam nemohl býti určen pro drobnost předmětu, jejichž přítomnost však není nijak nahodilým zjevem, ponèvadž je lze spatroovati na tomtéž místě tarsu jak u samcủ, tak u samic. "Tento ústroj, v. Schlechtendale m pozorovaný, odpovídá jistě oněm zoubkům, jež u recentních některých druhủ coleoptrat se na tomtéž mistẽ objevují (Tab. V.. fig. 47.,e). Tykadla zdají se býti osmičlennými; tvar jednotlivých článkủ nelze již spolehlirě popsati. Délka těla 1.4-1.6 mm. - Myslím, že jsem nechybil, přiřadiv tento druh ke Scudderovu rodu Lithadothrips, a sice vzhledem na jeho prothorax, který jest tak široký jako okrouhlá hlava, vzhledem na veliké oči, na štíhlá jeho tykadla a jejich válcovité články a na poměrně dosti štíhlé nohy, hojně chlupy opatřené. Křídla charakterisují tento druh na první pohled jakožto zástupce coleoptrat, nebof jsou velmi široká, na konci široce zaokrouhlená a mají na přední části žilky okružní velmi krátké tuhé chloupky, na zadní části její pak dlouhé tŕ̛ásnè. Kromě toho lze rozeznati na výkresu v. Schlechtendalovè dvě żilky podélné. $Z$ žilek př́ičných je patrná jedna, a to sice ta, jež spojuje hořejší žilku podélnou $v$ druhé třetině jeji délky s prední částí žilky okružní. Také tr̆i chlupy na predních kyčlích jsou znakem coleoptrat. - Exemplár považovaný za samce nezdá se jím bỵti.

Palcothrips longipes, v. Schlechtendalem taktéž, a sice neprávem k rodu Heliothrips pocítaná, mèla hlavu v predu zaokrouhlenou a za očima príčnou čarou 


\section{J. UZEL, IONOGRAFIE SIADU, "THYSANOPTERA".}

opatřenou. Prothorax není dosti dobre zachován; prece však na něın lze rozeznati. že byl širší než hlava a trochu širší než delší. Abdomen velmi široký. Tykadla pozûstávala ze dvou krátkých článkủ basalnich, z nichž byl proní miskovitý a veimi krátký, druhý pak více baňkovitý. Následujicí článkỵ, jichž počet nedá se přesně určiti, byly dlouhé a válcovilé. Prostrední clánky na konci trochu rozšířené. Přední femora neobyčejně stlustlá, prední tibie taktéž stlustlé. Strední femora tak dlouhá jako přední, méně však rozšírená. Zadní nohy neobyčejně dlouhé, takže délkou skoro abdomenu se vyrovnávaly; jejich stlustlá tehna dvakrát delši stehen stredních. Z kř̀del zbylo jen několik chlupủ. Délka těla $1.8 \mathrm{~mm}$. - Pŕístušnos: toho druhu ke Scudderově rodu Palaeothrips pokládal již v. Schlechtendal za pravdēpodobnou, a toliko okolnost, że kř́dla se nezachovala, bránila mu v přiradèni jeho k rodu zmíněnému. - Já sám pevně přesvědčen jsem, že druh v. Schlechtendalův palrí mezi Coleoptrata, a to sice pro tvar tèla, pro tvar noh i pro tvar tykadel, a že tudíz i křídla, která scházejí. zajisté měla podobu obvyklou u této čeledi.

Thrips (s. l.) clypeata (Obr. 1.. fig. 3.), v. Schlechtendalem opèt neprávem k rodu Heliothrips prìradèná, mèla bezpochỵby hlavu ǎ̃ po oči pokrylou prodlouženou piredohrudí, jež byla silně klenulá, a jejǐz přední rohy byly zaokrouhlené a zadní v osten vybíhající. Zadni okraj prodlužoval se mimo to uprostřed v trojhranný cíp. Pronotum bylo na disku i na okrajích chlupy poseto. Mesothorax dosti mohutně vyvinut. Jeho zadní okraj nalıore dvakrát hluboce vykrojen; ve výlirojcích nalézaly se kořeny horejšiho páru krídel. Abdomen mèl strany rovnoběžné. Dle toho zdá se býti exemplář objevený samečkem, a to tím spiše, že nelze spatriti stopy po kladélku. Kǐridla jsou dlouhá, dvěma žilkami podélnými prostoupená. Nolıy krátké. Na tykadlech nelze ničeho určitého poznati. Délka těla $1.7 \mathrm{~mm}$.

Thrips (s. 1.) Frechi (Obr. 1., fig. 4.), v. Schlechtendalem v rod Heliothrips zaràaěná, měla hlavu širši než delší. Prothorax byl taktéž značně širší než delši a o málo delší než hlava. Tykadla trochu delší pronota a skládala se \% osmi velmi zavalitých a širokých článků. Poslední dva (stylus) byly velmi malé a tenké. U tohoto druhu jest abdomen tak dobre zachován, že lze na něm rozeznati všech deset článků, z nichž prvý jest z polovice v zadohrudi skrytý. Hořejši krídla prostoupena byla dvèma žilkami podélnými, chloupky posázenými. Přední jejich okraj opatřen krátkými třásnèmi, zadní delšími. Nohy krátké a dosti zavalité. Délka těla $1.4 \mathrm{~mm}$.

Ukončivše výpočet podstatných znaků druhů v. Schlechtendalových, podotýkáme, že tvar hlavy a předohrudi jest velmi tèžko u fossilních druhủ spolehlivě popsati; nebot éásti tyto mohou tlakem značně býti deformovány, jak to nejlépe vidime u třásněnek $\mathrm{v}$ praeparatech mikroskopických, na než jsme neopatrně prìtlačili krycí sklo. - Ještě sluši vytknouti, že maji druhy od Rottu popsané úplně ráz recentních, v Evropě žijicích třásněnek; jen Thrips capito a T. clypeata se od nich odchỵlují, 
H. UZEL, MONOGRAPHIE DER ORDNUNG THYSANOPTERA.

a sice první mohutnou svou středohrudi, jež zatlačuje kořeny křídel neobyčejně nazad, a prohlubinami na článcích abdominalních, obloučkem spojenými, druhý pak zvláštním tvarem předonıudi, $u$ evropských druhủ úplně neobvyklým. Podobné pomèry snad nalezneme časem u druhů exotických.

Tím dokoněujeme Cást palaeontologickou s vroucím př̉ánim, aby řádky tyto vzbudily u nás zájem pro tr̃ásněnky dob minulých.

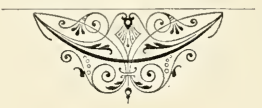




\section{Résumé des palaeontologischen Theils.}

In diesem Theile hat der Verfasser die wichtigsten der bis jetzt bekannt gewordenen Thatsachen über fossile Thysanopteren zusammengefasst und kritische Bemerkungen beigefügt.

Fossile Thysanopteren wurden bis jetzt nur aus den verschiedenen Tertiärbildungen von Heer, Oustalet, Menge, Scudder und v. Schlechtendal beschrieben, und zwar aus den Gypsen von Aix in Süd-Frankreich, aus dem preussischen Bernstein, den Süsswassermergeln von Oeningen, aus den Brüchen von Utah, Fossil Canon und Chagrin Valley in Nord-Amerika und aus dem Braunkohlengebirge von Rott bei Bonn.

Die bis jetzt bekannten fossilen Arten gehören den beiden Unterordnungen der recenten Thysanopteren an und sind einestheils Vertreter ausgestorbener Gattungen ( $\mathrm{Pa}$ lacothrips, Lithadothrips und Calothrips), anderestheils wurden sie zu den recenten Gattungen Plloeothrips, Melanothrips, Thrips und Meliothrips gereiht.

Die von Scudder aus Nord-Amerika beschriebene Gattung Palaeothrips zeichnet sich durch Flügel, welche vollkommen jenen der recenten Gattung Melanothrips (Taf. V, Fig. 39) ähneln, aus. Ihre Fühler sind jedoch ähnlich wie bei der recenten Gattung Rhipidothrips nov. gen. (Taf. V. Fig. 43) gebildet.

Von der Art Lithadothrips vetusta (welche ebenso wie die Gattung Palaeothrips zu der Familie Aeolothripidae gehört) beschreibt Scudder zwei Exemplare und bemerkt, dass sie sich von einander bedeutend in der Form des Abdomens unterscheiden. Dieser ist bei dem einen Exemplar breit, spindelförmig, auf dem Ende etwas verlängert und hier mit einigen Haaren besetzt. Das andere Exemplar hat die Seiten des Abdomens parallel und sein Ende breit gerundet. Ohne Zweifel war das erste Exemplar ein Weibchen, das zweite ein Männchen.

Den ersten Vertreter der Familie Phloeothripidae beschrieb v. Schlechtendal aus der oben erwähnten Rotter Braunkohle. Die übrigen 11 fossilen Arten, welche er von dort beschreibt, rechnet er einestheils zu der Gattung Thrips, anderestheils zu der Gattung Heliothrips.

Wir erlauben uns hier einige Bemerkungen über die Arbeit v. Schlechtendals (Nr. 156) zu machen; auch nahmen wir uns die Freiheit, einige seiner sorgfältig ausgeführten Zeichnungen im 2. Textbild auf Seite 288 wiederzugeben.*)

*) Für die Erlaubnis, diese Abbildungen aufnehmen zu dürfen, bin ich der Redaction der Zeitschrift für Naturwissenschaften in Halle a S., in welcher v. Schlechtendals Abhandlung über fossile Thysanopteren erschienen ist, zu besonderem Dank verpflichtet. 


\section{H. UZEL, MONOGRAPHIE DER ORDNUNG THYSANOPTERA.}

Was die Gattung Heliothrips anbelangt, so gründet sich die Einreihung einiger Arten in dieselbe einzig und allein auf die netzförmige Structur des Chitins, welche jedoch dem Autor selbst ein unwesentlicher Charakter zu sein scheint, umsomehr als, wie er bemerkt, die Möglichkeit nicht ausgeschlossen ist, dass die erwähnte Structur erst durch den Versteinerungsprocess herbeigeführt wurde. Es wird dies auch wirklich wohl der Fall sein, denn auch Vertreter fossiler Aeolothripiden zeigen diese Structur, welche man bei den recenten Vertretern dieser Familie nie antrifft.

Alle die von v. Schlechtendal beschriebenen Arlen waren geflügelt, und ihre Flügel erhielten sich hauptsächlich dann ziemlich gut, wenn sie frei im Gestein lagen. Die Fühler sind im ganzen schlecht erhalten, so dass sie »nur in selteneren Fällen eine Darstellung zulassen, welche einigermassen auf Genauigkeit Anspruch machen kann«. Dadurch werden die bizarren Formen mancher aufgezeichneten Fühler genügend erklärt (sieh Fig. 6 u. 7 des 1. Textbildes auf S. 288 der vorliegenden Monographie). Auch die ursprüngliche Form des Kopfes und des Prothorax lässt sich bei fossilen Thysanopleren sehr schwer beurtheilen; denn diese Theile können durch Druck sehr deformiert werden (sieh \%. B. Fig. 16 u. 17 auf Taf. IV der v. Schlechtendalschen Arbeit), wie wir es am hesten bei Thieren in mikroskopischen Präparaten, auf die wir unvorsichtig das Deckglas drückten, beobachten können. - Das Metascutellum (der vordere der beiden Schilder des Metanotum) zählt v. Schlechtendal irrthümlich zum Nesothorax, wodurch seine Behauptung, dass bei seinen fossilen Thysanopleren der Metalhorax meistens kürzer als der Mesothorax sei und wenig entwickelt erscheine, leicht erklärt wird. - Die Zeichnungen v. Schlechtendals stellen fast durchgehends Weibchen dar, welchen Umstand man sehr begreiflich finden wird, wenı man erwägt, dass es bei den Thysanopteren in der Regel viel mehr Weibchen als Männchen gibt.

Herm v. Schlechtendals Arten Thrips excellens und Thrips Frechi zeigen nach dessen Zeichnungen (Taf. III, Fig. 6; Taf. IV, Fig. 25 b) zivei den ganzen Oberflügel durchlaufende Adern. Dieses Merkmal würde auf ursprüngliche Verhältnisse hinweisen. (Vergleiche meinen Artikel: »Über die Gestalt der ursprünglichen Thysanopteren« auf S. $20-23$.)

Die Art Heliothrips cucullata v. Schlechtendal gehört meiner Meinung nach zu Scudders Gattung Lithadothrips, und zwar wegen der Form des Prothorax*), der ebenso breit ist wie der rundliche Kopf, wegen der grossen Augen, der schlanken Fühler und ihrer walzenförmigen Glieder und endlich wegen ihrer verhältnismässig ziemlich schlanken Beine, welche reich behaart sind. Die Flügel charakterisieren diese Art auf den ersten Blick als einen Vertreter der Aeolothripiden, denn sie sind sehr breit, auf dem Ende breit gerundet und tragen am Vorderrande sehr kurze steife Wimpern,

*) Der Kopf dürfte wohl bei v. Schlechtendals Exemplaren, wie es bei todten Thysanopteren sehr oft vorkommt, theilweise in den Prothorax eingezogen worden sein, so dass letzterer nach vorn kapuzenartig verlängert erscheint (daher der Namen cuculluta). 


\section{J. UZEL. MONOGRAFIE RADU, "THYSANOPTERA“.}

am Hinterrande jedoch lange Fransen. Ausserdem kann man auf v. Schlechtendals Zeichnung zwei Längsadern erkennen. Von den Queradern ist nur eine (undeutlich) zu sehen, und zwar jene, welche die vordere Längsader mil dem vorderen Theil der Ringader verbindet. Die »zwei kleinen. bald rund, bald länglich erscheinenden Körperchen «, welche v. Schlechtendal auf dem zweiten Tarsalglied findet, und deren Bedeutung er nicht feststellen konnte, sind offenbar die bei den recenten Gattungen Rhipidothrips und Aeolothrips auf derselben Stelle bei beiden Geschlechtern vorkommenden Gebilde (Taf. V, Fig. 47,e).

Herrn v. Schlechtendals Art Heliothrips longipes gehört zur Gattung Palaeothrips, wie derselbe selbst vermuthet. Obwohl die Flügel sich nicht erhiellen, lässt sich doch die Zuständigkeit dieser Art zu den Aeolothripiden behaupten, und zwar wegen der allgemeinen Körperform und wegen der Form der Beine und der Fühler. Fast alle aus der Rotter Braunkohle beschriebenen Thysanopteren haben vollkommen den Charakter der recenten in Europa lebenden Arten; nur ist zu bemerken, dass ihr Körper durchschnittlich etwas grösser war. Die Arten Thrips capito und Thrips clypeata allein weichen von der gewohnten Form ab, und zwar die erste durch den mächtigen Mesothorax, welcher die Fühlerwurzeln ungewöhnlich nach hinten verdrängt, und durch zwei auffallend starke, mit einem Bogen untereinander verbundene Vertiefungen oben auf jedem Abdominalsegmente, die zweite durch eine besondere Gestalt des Prothorax, die den europäischen Arten vollkommen fremd ist. Ähnliche Verhältnisse werden wir vielleicht mit der Zeit bei exotischen Arten wiederfinden.

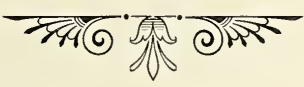





\section{III. ĆÁS'T A NATOMICKÁ.}

\section{ANATOMISCHER THEIL.}





\section{ÚVODNÍ POZNÁMKY. EINLEITENDE BEMERKUNGEN.}

I této části podávám obraz anatomie tr̉ásnènek, spojiv výsledky svých prací anatomických s udaji staršími. Druhy, na nichž jsem hlavně poměry anatomické sledoval, jsou z coleoptrat Aeolothrips fasciata, ze stenopter Thrips ploysopus, T. flava, Plıysopus vulgatissima, z tubulifer Trichothrips copiosa nov. sp. a Anthothrips aculeata i statices. Pr̆i pracích těch použival jsem také methody r̀ezủ seriových, a to zvláště k sestrojení nervové soustavy $\mathrm{v}$ hlavě a v hrudi, k sestrojení ženskỵch ústrojů pohlavních s receptaculem a žlazou mazovou, částečně také ke studiu ústrojủ ústních, kladélka a kostry chitinové. Pr̃i studiu soustavy vzdušnic dobrých služeb prokázal mi glycerin, do něhož jsem zviře za živa ponořil. Konečně podotýkám, že všecka fakta, u nichž není jméno nějakého pozorovatele výslovně uvedeno, jsou podána na základè vlastních zkušeností. - K jednotlivỵm článkủm pr̃ipojil jsem udaje historické.

\section{INTEGUMENT. \\ DAS INTEGUMENT.}

Pancî́ chitinový jest u třásněnek poměrně pevný. Povrch jeho jest obyčejně přejemnými rovnoběžnými vráskami opatřen, které více nebo méně spolu splývají. Na týle bỵvají tỵto vrásky zvláště zr̃etelné, a čašto bývá z nich jedna hlubší, tudíž značně patrnèjší ně̌ ostatní (Tab. V., fig. 53.). Jindy tvoří sit, která nejvíce vyniká na hlavě, na hrudi a na nohách. Rody, jichž druhy mají sítkovaný a následkem toho nelesklý chitin jsou: Heliothrips, Parthenothrips, Prosopothrips a Dictyothrips. - Blány, které spojuji panciře chitinové, jsou obyčejně sesílené přejemnými a velmi četny̧mi body chitinovými. neb krafoučkými, $v$ řadách postavenỵmi lištničkami, aneb konečně, a to zvl. na hrudi tubulifer, drobnými, mnohobokými, chitinovými ploškami.

Zbarvení chitinu jest obyčejně tmavé, zríídka světlé. Barva hnědá a její rủzné světlejší a tmavější odstíny a rủzné kombinace se žlutou, červenou a černou barvou převládají. C̆asto nalézáme též barvu žlutou v nejrủznějších odstínech, mnohdy, a to zvl. na pterothoraxu, s odstínem červeným. Také barva bílá u některých samcủ se objevuje. Tito bỵvají vủbec bledšími než samice, ač to není nikterak pravidlem. Někdy jsou tmavšimi 


\section{H. U/EL, MONOGRAPHIE DER ORDNUNG THYSANOPTERA.}

neb světlejšími jen některé části těla; tak časem prothorax jest ěervený, kdežto celé ostatní tělo jest černé; jindy stává se tělo ke konci značně světlejším (Heliothrips haemorhoidalis, Platythrips tunicata, Aeolothrips albocincta), častěji však značně tmavším a\%̆ černým (Thrips adusta a četné variety nejrůznèjších třásněnek); jindy opět jsou 2. a 3. čl. abdom. bílé, ač všecky sousední jsou černé (Aeolothrips albocincta); jindy zase jest hlava a hrud' svètlá, abdomen však velmi tmavỵ (Platythrips tunicata, Oxythrips hastata var. bicolor, O. ajugae var. bicolor). U tmavých druhủ bývá pterothorax o něco světlejší, u světlých o něco tmavší. Světlé druhy jsou velmi často více nebo méně šedě zkaleny, a lo zvl. nahoře na těle; jindy mívají odstín zelenavý (Thrips communis i alui). Modrá barva schází úplně. - Tykadla bỵ́vají uprostřed světlá, na počátku a ke konci tmavá. Jsou-li zcela tmavá, bývá aspoñ 3. čl. o nèco světlejší. Zřídka jsou tykadla v prvé polovinè svèllá, v druhé tmavá (Thrips mimutissima, $T$. alni). Často bývají jednotlivé články tykadelní na basi světlé a ke konci (nèkdy velmi náhle) tmavé. Zcela světlá tykadla jsou vzácností ( $T$. flavicor uis), rovněž jako tykadla jen na basi tmavá (Physopus vulgatissima var. albicornis). - Nohy jsou rủzně abarveny. U tmavých druhû bývaji někídy celé černé (Megalothrips Bonamuii, Cryptothrips lata, C. nigripes); obyčejně však jsou prední tibie, konce a někdy i basis streedních a zadních tibii a všecky tarsy světlé. Také přední femora ke konci bývají světlejší. Výjimkou jsou u tmavých třásněnek nohy celé svètle zbarvené (Cryptothrips Icarus var. pallipes a Trichothrips pedicularia). U světlých druhủ jsou nohy taktéž světlé a nikdy nestávají se tmavšími než tělo.

Na pancî́i chitinovém nalézaji se porủznu rozestavené delši a kratši chlupy a osténky. O chlupech na tykadlech, o čipcích ěichových na nich, dále o chlupech a triásních na křídlech promluvíme na př́islušném místě. - Hlava má nahoře mezi očima obyčejně dva delší chlupy, za očima pak vždy věnec krátkých osténkú. Prothorax má v předu krátké, do pr̉edu namírené chloupky a na předních rozích někdy (ku pr̃. u Physopus vulgatissima a Melanothrips fusca) dlouhé chlupy smyslové. Na jeho zadních rozích nalézáme obyčejně po dvou podobných chlupech, zrídka po jednom, jenž nahrazen bývá někdy jedním osténkem neb bradavkou. Mezi těmito chlupy smyslovými nalézáıne na zadním okraji prothoraxu větší neb menší počet kratších chloupků neb osténkủ. Zadní kraje článkủ abdominalních jsou vždy delšími neb kratšími chlupy opatreny a na dvou posledních jsou tyto chlupy obyčejně nejdelší a nejsilnèjší. U tubulifer zakončuji se často smyslové chlupy na těle, a to zvl. na prothoraxu, malou paličkou. V jednom připadè (u druhu Sericothrips staphylinus) jest abdomen velice hustě pokryt přejemnými bílými chloupky, které mu dodávají lesku hedvábitého. Šupin nikde nenalézáme.

HLAVA. - Tvar hlavy (Tab. VlII., fig. 148.) jest význačný tím, že nemá dva otvory: jeden v předu, totǐ otvor ústní, druhý vzadu, totiž otvor, jímž prikládá se k hrudi, jak bývá u jiného hmy̧zu, nỵbrž otvor toliko jediný, zadní. Hlava má tudíz 
podobu nádoby, jejiž okraj utvořen jest okrajem týlním a okrajem čelním. Zvláštní té podoby dosáhla hlava okolností, že plocha čelní ohnula se pres prední její okraj na dolejší její stranu a tlačila kužel ústní pred sebou, až jej více nebo méně pod prothorax zatlačila. Hrdelní plocha, za ústroji ústnimi u jiného hmyzu se nalézající, zakrnèla, takže z ní nezbylo více než premalá spojovací blána mezi kuželem ústním a prosternem (Tab. VIII., fig. 148., g). Na prednim okraji hlavy, to jest na rozhraní mezi plochou temenní a čelní, nalézají se facettované oči. Mezi nimi umístněna jsou tykadla, jichž základní články od sebe odděluje malá vyvýšenina předního okraje hlavy o dvou cípcích. Obě tváre prodlužují se do zadu v malou trojhrannou plošku, jež jest od nich silnou chitinovou lištnou oddělena (Tab. IX.. fig. 161., u). Stlustlý čelní okraj hlavy vchlipuje se u terebrantií na každé straně dovnitr̆, a to směrem k oku. U některých druhủ dosahuje levá vchlípenina zadního okraje jeho (Tab. IX., fig. 161., s), pravá pak dospěje sice někdy až k oku, ztrácí však vždy souvislost's okrajem čelním (t). U tubulifer mají tỵto vchlípeniny podobu malých chitinových kliček, a pozorujeme je vždy as uprostred mezi okem a okrajem čela. Kromě těchto vchlípenin nalézáme ještẽ jiné, které s okrajem tímto souvisí, a o které základní kus štětinovitých kusadel prvého páru se opírá. Tỵto výtvory třásněnkám terebrantialním scházeji. Okraj čelní jest u tubulifer symmetrický, u terebrantií však vybíhá na levé straně do předu v ostrý úhel, jenž směruje k oku a na svém hrotu má nahoře popsanou vchlípeninu (Tab. IX., fig. 161., $r$ ).

IIRU D̃. - Prothorax jest volně pohyblivý; mesothorax a metathorax spolu srůstají; celku ř́káme pterothorax. - Prothorax přiléhá v předu těsně $k$ hlavẽ; jest pravidlem širši než tato a obyčejně asi tak dlouhỵ neb jen málo delší; v řídkých jen př́padech přesahuje délka jeho značnè délku hlavy, jako ku pr̃. u zástupcủ rodu Chirothrips. U toholo rodu a u všech tubulifer rozširuje se prothorax čím dále do zadu tím více, takže vzadu jest znaěně širši než hlava. V tomto pî́padẽ tedy má tvar lichoběžníku. Jinak má však tvar čtyrúhelníku s rohy zaokrouhlenými. Po obou stranách za prostředkem vchlipuje se často chitinový panciŕ, takže povstávají krátlé ostré bodce, dovnitř prothoraxu namiřené, kiteré slouži k upevnění svalủ. Také zadní okraj má někdy po každé straně takový bodec; jindy pak jen střed jeho chitinovou vchlípeninou jest opatren. Spodní strana prothoraxu (prosternum) má první pár noh a jest u terebrantií blánitá, u tubulifer však má tenké chitinové pláty (Tab. VIII., fig. 148., $i$ ). - Pterothorax jest u okríídlených druhủ terebrantií značně delší a širší než prothorax; u bezkřidlých pak jest často jen as tak dlouhý a sotva širší. Jsou-li samci nějakého druhu, jehož samice jsou dlouhokríidlé, krátkokřídlí: mají pterothorax značně užší a kratší něs tyto; nelze tedy souditi ze zmenšeného pterothoraxu krátkokřídého samce na krátkost kríidel samice, jak Jordan se domnívá. Když však samice jest, byt i jen výjimkou neokřídlená, scházeji křídla pravidlem také samci. Výjimkou v tom ohledu jest jen druh Sericothrips staphylinus, u něhož nalézáme kromě krátkokríídlých samců též některé okřídlené. Tito ovšem odpovídaji samicim okřídleným, 


\section{H. UZEL, MONOGRAPHIE DER ORDNUNG THYSANOPTERA.}

které mezi neokřídlenými jednotlivě se objevuji. Vyskytuji-li se od jednoho a téhoz̀ druhu samice dlouhokřídlé a krátkokřídlé, jak to velmi zhusta se prrihází, maji tỵto obyčejně pterothorax značně menši a užši než ony. Výjimky od toho pravidla jsou rídké (ku př. Rhaphidothrips longistylosa). Z tubulifer mají druhy, jejichž krííla vždy úplnè jsou vyvinutá, též pterothorax u obou pohlaví značně delši a širši než prothorax. U drulıu však, u nichž samice mají křídla pravidlem zakrnělá, jest i pterothorax u obou pohlarí zkrácen. Mají-li tyto druhy výjimkou (jen samice) krídla úplná, zůstává pterothorax zkráceným, jest však vždy o něco širší než u druhủ krátkokîídlỵch. Má-li tedy některý samec tubulifer křídla zakrnělá a tudíž krátký pterothorax, nelze ani zde souditi, že též jeho samice jest vždy krátkokirídlou. - Hořejši část pterothoraxu troří mesonotum (Tab. VIII., fig. 148., $j$; fig. 149., a) a metanotum (Tab. VIII., fig. 148., l; fig. 149., b, c), dolejší část jeho tvorí mesosternum (Tab. VIIl., figg. 148., $k$; fig. 151., $m$ ) a metasternum (Tab. VIll., fig. 148., $\boldsymbol{m}$; fig. 151., o). Nesonotum jest proti metanotu velmi úzlié, dosahujef jen as poloviny délky jeho. Mesosternum ršak jest pravidlem tak dlouhé jako metasternum. Mesonotum obrnèno nahor̉e deskou, která sluje mesoscutellum. 'Sato deska vchlipuje se uprostřeđ na zadnim svém okraji dovnitr. Kromě toho zdá se, jakoby celý zadní okraj byl ohnut dovnitr̃ těla. Tato zdánlivě ohnutá část' (t. zv. diaphragma), která má uprostřed bodec do zadu směr̀ujicí, utvořena jest chitinovými konci svalū, které se na okraj př̀ikládají. Mesosternum jest podobně jako mesoscutellum na zadním okraji uprostřed dovnitř vtaženo. K této vtaženině, která bývá dvouramenná, prìikládají se taktéž konce svalủ. U druhu Aeolothrips fasciata posunuta jest více do prostred mesostema (Tab. VIII., fig. 151., u). Toto jest někdy tak veliké, že ohnutými okraji svými zạahuje až na hořejši stranu těla (u druhu Parthenothrips dracaenae). Obyčejně však jest obmezeno jen na ventrahni stranu mesothoraxu, a mezi ním a mesonotem leži pak pláty postranní (pleuralie). U mnohých třásněnek terebrantiahních jest po každé stranè jeden takový molıutný postranní plát (Tab. VIII., fig. 150., d). U tubulifer nalézáme po každé straně čtyrìi destičky, z nichž na Tab. III., obr. 20., lze viděli obě hořejší. - Metanotum pokryto jest obyčejnè dvèma panciíri, z nichž prední jest silnẹšsi a sluje metascutellum (Tab. VIII., fig. 149.,b). U hezkridllỵch druhú pokrývá melanolum jen jediná, velmi široká deska (Tab. VIII., fig. 148., l). Melascutellum jest na předním okraji stlustlé. Na tento okraj prìkládaji se četné svaly. Metasternum má uprostřed zadního okraje (u rodu Acolothrips však [Tab. VIII., fig. 151., $p$ ] dále do předu posunutou) vchlípeninu chitinovou, podobnou oné na mesosternu. U nèkterých bezkřidlých tubulifer však jest ta vtaženina zakrnèlá, a nalézáme pak na každé straně melasterna jen jednu stlušlěninu, které vespolek nesouvisí. Mezi metasternem a metanotem leží dlouhỵ postranní plátek, který jest obyčejnè přirostlý k metasternu (Tab. VIII., fig. 149., g; fig. 150,, g). Kromě plátů postranních, jež jsme až dosud poznali, nalézají se ještě mezi mesothoraxem a metathoraxem nad pánvemi středních noh obycènně dvě destičky (fig. 150.,e, é). Pánve zadního páru noh umístněny jsou na zadním olraji metasterna. - Hořejši křidla přiklá- 


\section{J. UZEL, MONOGRAFIE RADU, "THYSANOPTERA“.}

dají se k hrudi na stranách mesoscutella, dolejši křídla pak̉ na stranách metascutella. Zadní kraj metasterna jest dále nazad posunut než zadní kraj metanota. Zbývajicí ěást metathoraxu pokrývá dorsalni deska prvého článku abdominalního, kdežto spodní jeho deska jest obyčejně velmi úzká (Tab. VIII., fig. 151., 1') aneb daleko pod metasternum posunutá (Tab. VIII., fig. 148., 1'). K dorsalní desce přrirůstá obyčejně z každé strany malá ploška (Tab. VIII., fig. 149., h), která odpovídá postranním destičkám článkủ následujících.

A BD O IEN. - Tento skládá se z desíti kroužkủ. Dorsalní deska prvního kroužku, jak již řečeno, přilirývá vzadu hrud. Kroužek ten jest obyčejně kratším než druhý. U samcủ coleoptrat jest však velmi prodloužený a značně delši než článck druhý. Tento a následujících pět ělánkủ bývají skoro stejné délky a stejně utvořeny. Poslední tři články abdomenu jsou ke konci vždy užší a užší. U tubulifer a velmi zrrídka též u terebrantii (Oxythrips hastata [Tab. V., fig. 66.] a Belothrips acuminata 「Tab. II., fig. 10.]) jest poslední článek abdom. rourovitý. U tubulifer spojuje se hořejší deska kroužků s deskou dolejší úzkou blanou. Postrannich destiček tu není. U tř́ásněněk terebrantialních nalézáme obyčejně dvě (Tab. X.. fig. 170.. g), někdy též trĭi destičky postranní, které jsou často na zadním okraji zoubkované, a někdy částečně mezi sebou neb s deskou hřbetní srůstaji. U samic třásněnek terebrantialních schází třem posledním článkủm deska břišní, poněvadž tam kladélko se nalézá. Zadní okraj 8. čl. abdom. bývá u terebrantií často krátce a velmi hustě obrvený. Jindy jsou zadní okraje článkủ abdominalních na břiše (u Sericothrips staphylinus) neb na hr̉betě (u Prosopothrips Vejdovskýi) vykrajovaně zubaté. Poslední ělánek břišní jest u některých rodủ (Limothrips, Chirothrips, Stenothrips, Platythrips) nahoře rozčísnut. Rûzné prrívěsky na abdomenu tr̉ásněnek maji význam sekundernich charakterủ pohlavních, a promluvíme o nich na príslušném místě. - $Z$ chlupủ, na abdomenu se nalézajících, často vynikají, jak již praveno, svou délkou a mohutností ty. které se na posledních dvou článcích nalézají. U tubulifer jest nahoře na článcích abdominalních po každé straně jeden silný chlup, ke středu článku směrující, který slouži k upevnění kǐídel, na hřbetě složených. Podobný účel maji u některých druhủ terebrantií dva sbližené chlupy uprostřed hr̈betní strany jednotlivých článkủ abdom. (tak u druhủ rodu Dendrothrips [Tab. II., obr. 15.], Dictyothrips atd.).

\section{ÚSTROJE POHYBU. ORGANE DER LOCOMOTION. \\ NOHY. BEINE.}

Noha třásněnek (Tab. V., fig. 38.) skládá se ze silné kyčle, z jednočlenného př̀kyčlí (trochanter; Tab. VIII., fig. 151., t), ze silného stehna, z tibie a z tarsu, pravidlem dvoučlenného. Přední nohy jsou o něco kratší, zadní o něco delší než střední. Pĩední 


\section{H. UZEL, MONOGRAPHIE DER ORDNUNG THYSANOPTERA}

kyčle jsou zveličené a uzavírají mezi sebou kužel ústní, k prosternu prìložený. Pr̃ední femora bývají často stlustlá, a to měrou někidy velmi značnou. U mnohỵch samců tubulifer dosahuje stluštění to míry nejrětší (Tab. II., fig. 18.). Způsobeno jest hromaděním se cetných svalủ ve stehnu, jež předním nohám zjednávaji potřebnou sílu, aby mohly tèlo protahovati úzkými skulinami kủry. $\mathrm{V}$ jednom př́padè (u druhu Acanthothrips nodicormis) opatřena jsou femora prvého páru noh před koncem uvnitř silnỵm krátkỵm bodcem (Tab. IV., fig. 31.), jindy pak (u druhu rodu Chirothrips [Tab. I., fig. 2.; fig. 7.] a poněkud též u druhu Dictyothrips reticulata) jest okraj jejich na konci vně ohrnut a tvoři odstávajicí zub. Tibie. nebỵvají delší než femora, vždy však o něco slabší. Výjimkou jen jsou .značnou měrou rozšírené (zvl. u druhu Aptinothıips rufa [Tab. II., fig. 17.] a též u rodu Belothrips); v tom prípadè však jsou vždy na basi velmi úzké. Prední tibie opatřeny u některých tubulifer, jichž tarsus jest aspoñ u jednoho pohlaví ozubený. krátkým, ostrým, k tarsu prìléhajícím zubem. Z třásněnek terebrantialních maji druhové rodu Sminyothrips na konci předních tibií dva zuby vedle sebe stojicí, druhové: Physopus phalerata, intermedia a ulicis jediný. Na konci předních a středních tibii stávají někdy dva krátké pohy̧blivé ostny. Zadní tibie mají obyčejně na konci taktéž dva ostny a před nimi na vnitřní straně dvě řady podobnỵch ostnů. První článek tarsu jest velmi krátký a na konci šikmè utatý. Druhý článek jest značně delší. Oba jsou válcovité. Tubulifera maji na předních nohách jednočlenný tarsus, který často u obou pohlaví, jindy jen u samcí na vnitřní straně zubem jest opatřen. U triásněnek terebrantialních má přední tarsus druhu Plyysopus ulicis na dolejši straně u obou pohlaví dva malé ostré hrbolky, vedle sebe stojící. a zakončuje u druhû Pliysopus robusta a inconsequens malỷm, dolů obráceným zoubkem, u druhủ Oxythrips ajugae a $O$. firma dosti silnỵm nehýtkem. Thrips calcarata má na nèm dlouhý tenký zub. U druhủ rodủ Rhipidothrips a Aeolothrips opatr̃en jest přední tarsus jak samcủ tak samic malým drouzubým ústrojem. Druhý článek tarsu zadních noh ozbrojen jest u druhủ rodu Deudrothrips silným tupým ostnem. Na konci má tarsus třásněnek dva pohyblivé drápky, které jsou pevnè prịrostlé k laloku kožnímu, jenž mezi nimi se nalézá.

Chtějice bliže poznati ukončení nohỵ tr̃ásnènek, zvolíme si nejvhodnēji larvu něliterého velikého druhu, do čeledi tubulifer náležejicího. Larvy mají totǐ̌ pro pozorování naše tu vỵhodu, že ršecky části nohy jsou prủhledné a protož předměty i uvnitr̀ se nalézajicí zřejmé. Na Tab. VIII., fig̣. 152.-15う̃. vidíme konec nohy larry druhu Trichothrips copiosa nov. sp. Mezi obèma drápky (b) nalézá se lalok kožní (a). Drápky nejsou celou plochou k němu pr̃irostlé, nỵbrž na konci volné. Kořeny jejich jsou vespolek sblížené a spočivaji na hákovité stluštěnině chitinové (e). k níž jsou připevněny tak. že mohou se do jisté míry volně kolem ní pohybovati. Ke kořenủm jejich připojuje se z každé strany chitinová obruč (f). Obě obruče jsou na druhé straně nohy připevněny na chitinovou tỵč $(g)$, celou tibii se táhnoucí, a mimo to jsou pevnè přirostlé ke kưži, pod níž leži. Představíme-li si nyní, že zviíe svalem onu chitinovou tyč trochu stáhne 


\section{J. UZEL, MONOGRAFIE RÁDU „THYSANOPTERA“.}

do zadu (na obr. 153. ve směru šípky), pohne zajisté v tom př́padě oběma rameny obruče, které jsou ke kưži prrirostlé, a tudiž rozevrou se i drápky, kleré také s kůží jsou v tèsném spojení, a kolem pevného bodu (e) se otáčejí. Čím pak toto zatáhnutí jest silnējši, tím více se drápky rozevrou, a tím více roztáhne se kožní lalok, mezi drápky se nalézající. Zároveñ pak vnikne do laloku toho množství jisté tekutiny a napne ho tak, že vezme na sebe podobu mèchýrìu vodou naplněného. 'T'ento měchýřek má na konci prohlubinu (fig. 155., a), kterouž přissává se k předmělủm, na něž byl vtlačen. Tekutinu vylučuje veliká žláza, nalézající se částečně v holeni, částečně v stehnu (fig. 156.). Když jest tarsus nečinný (fig. 152.), vyteče veškerá tekutina z váčku. a tento se do vrásek složí. - Jordan, který poměry ty sledoval u larvy svého druhu Phloeothrips brummea, tvrdí, že každá obruč přikládá se jedním koncem na vỵběžek drápku $(d)$, čímž prímo drápky obručemi prý se rozevírají (ač také poznamenává, že se to kromè toho děje též prostřednictvím kủže, $\mathrm{k}$ níž jak konec tyče chitinové, tak i drápky jsou prìrostlé). To zajisté jest malý omyl, který snadno lze vysvětliti z fig. 153. Tam totiž zdá se skutečně, jakoby obruče na výběžek drápkiu se upevnovaly. Pohled však se strany (fig 154.) snadno nás přesvědčí o pravém stavu věci. Tekutinu váček naplñující považuje Jordan za krev, ač i prripouští, že by mohla býti výměškem nějaké žlázy; tu však nenalezl. - U dospělých třásněnek jsou poměry tytéž jako u larev, jen méně zřetelné. Chitinová tyč rozšiřuje se tu obyčejně v chitinovou plošku, z níž jde mnoho chitinových vláken do laloku kožního.

Ke konci dlužno zminiti se ještě o zvláštním péru u rodu Dendrothrips, v pterothoraxu ukrỵtém (Tab. VI., fig. 86.), o něż zadní nohy při skoku se opírají.

Již Bonanni (L. č. 1.) pozoroval, že třásněnky mají nohy zakončené průhledným měchýríkem, jejž přitlačují, rozšírivše ho, na předměty, po kterých lezou a tak na nich lpějí. Degeer pak (L. č. 2.) soudil, že měchyyíek onen vylučuje nějakou lepkavou hmotu; někdy však zdálo se mu prý, že vidí vydutou blanku, která jeví brzy menší, hrzy větší prohlubinu, dle toho, jestliže slabèji neb silněji na povrch předmètủ je tlačena. R. 1761 . právem tvrdil Sulzer (L. č. 5.), že noha třásnènek zakončena jest kromě měchýřkem ještě dvěma drápky. R. 1764. praví Ge offroy (L. č. 9.), že chodidlo třásněnek skládá se ze dvou článkủ, z nichž druhý proměněn jest v puchýřek. R. 1773. opakuje De geer (L. č. 11.) svoje pozorování dřivější a dodává, že vydutý měchýřek snad lpí na předmẹtech podobnỵm způsobem jako bañka $k$ pouštění krve na kủži lidské. R. 1780. praví Goeze (L. č. 18.) v jedné z poznámek, které přidává k překladu práce Degeerovy z r. 1773., že měchýřek třásněnek působí právě tak jako mèchýřek na nohách roztočů, Acarus coleoptratorum zvaných. jímž se tato zvírátka přissávají k hladkému povrchu brouků, na nichž cizopasí. R. 1836. považuje Burmeister (L. č. 45.) měchýŕek třásnènek za príssavku. R. 1838. (L. č. 50.) vyobrazuje tentýž autor mèchýřek ten od druhủ Heliothrips haemorrhoidalis, Chirothrips manicata (u toho kreslí dva drápky k mèchýrìu prìložené), Thrips plyysopus a Acanthothrips nodicornis a nazyvá ho a reola, plan- 


\section{H. UZEL, MONOGRAPHIE DER ORDNUNG THYSANOPTERA.}

tula neb acetabulum suctorium, nekreslí ho však nikde správně. R. 1874. vyobrazuje Uljanin (L. č. 98.) nohu s měchýřkem od druhu Thrips physopus a vkresluje též drápky k měchýríku príléhající. R. 1888. konečně podal Jordan (L. č. 162.) pravdě dosti přiměrený popis chodidla třásněnek i jeho funkcí, zvoliv k tomu druh Aeolothrips fasciata a druh Phloeothrips brumnea i larvy jeho.

\section{K ŘI DLA. \\ FLÜGEL.}

Kríídla trásněnek jsou velmi úzká a dlouhá. U terebrantií jsou hořejši krídla značně tužší a o něco delší než krídla dolejší; u tubulifer jsou oba páry velmi tenké, blánité. Tubulifera a coleoptrata mají krídla po celé své délce skoro stejně široká a na konci zaokrouhlená. Některé rody tubulifer (zvl. rod Anthothrips) mají oba páry kr̂́ídel uprostřed zúžené, takže podoby podešve nabývaji. Třásněnky terebrantialní vykazuji křidla na basi dosti široká; nedaleko za basí se však zúžuji a zůstávají v tom stavu až do přiostřeného konce. Jediný rod Parthenothrips má kî́illa po celé délce skoro stejně široká. Hor̀ejší i dolejší křidla všech třásněnek mají na basi pravidlem malou šupinku, od plochy křidla oddělenou (Tab. VI., fig. 97., h).

Žilky v křídlech jsou u třásněnek velmi sporé. Hořejší křídla mají u terebrantií kromě žilky okružni, obrubující je kol do kola, ještě dvě žilky podélné a nejvýše pět žilek príčných. - U coleoptrat (Tab. V., fig. 39.) vycházejí obě žilky podélné z base a běži vedle sebe až do konce křídla, kdež každá zvlášț vyústuje do žilky okružní. Tyto dvě žilky spojuje as uprostřed křídla krátká žilka přiční. Hořejši žilku podélnou spojuji s přední částí žilky okružní dvě žilky přičné, a to na konci prvé a druhé třetiny délky křídla. Dolejší žilku podélnou spojuji se zadní částí žilky okružní u rodu Melanothrips taktéž dvě žilky přičné, právě pod přičnými žillami hořejšími stojící. U ostatních rodů coleoptrat však jest jen žilka $\mathrm{v}$ druhé třetině se nalézající patrná. Zadní pár krí́del nemá okružní žilky. Z jediné podélné žilky nalézáme u coleoptrat někdy jen zbytek na basi křídla. - U stenopter (Tab. VI., fig. 97.) vychází hořejší (hlavní) žilka taktéž z kořene křídla, dolejší (vedlejší) však vzniká teprv asi v prvé třetině délky jeho a přikládá se k ní více nebo méně zřetelnè pomocí šikmé žilky přičné. Obě žilky podélné běži pak rovnoběžně obyčejně až před konec kř́lda, kdež se ztrácejí, nikdy s žilkou okružní se nespojujice. U druhu Parthenothrips dracaenae (Tab. II., fig. 12.) ohýbá se hlavní žilka nedaleko za místem, kde se k ní prìkládá žilka vedlejší, nahoru a spojuje se s žilkou okružní. U drubu Heliothrips haemorrhoidalis rozděluje se žilka podélná, vycházející z kořene, na konci prvé třetiny ve dvě větve, z nichž hořejší běží až do konce kř́dla těsně vedle přední části žilky okružní, dolejší pak těsně vedle zadní její části. U druhu Sericothrips staphylinus jest jen hlavní žilka vyvinutá (Tab. V., fig. 52.). Príčné žilky jsou v kř́dle stenopter vủbec velmi nezretelné. Jedna z nich spojuje hlavní žilku s prední částí 


\section{J. UZEL. MONOGRAFIE RADU „THYSANOPTERA*}

žilky okružní as v prvé třetině délky kǐídla a druhá za jeho polovinou (Tab. VI., fig. 97., $f, g$ ). O třetí jsme se již nahoře zmínili. Dolejší kř́dla nemaji žilky okružní a pravidlem probíhá je toliko jedna žilka podélná; jen u rodu Dendrothrips dvě, z nichž hořejší jest slabá. — Tubulifera nemaji žilek okružních na křídlech vủhec; na basi hořejšího i dolejšiho jejich páru nalézáme jen zbytek jediné žilky podélné, který však někdy až poloviny kî̃ídla dosahuje (u Megalothrips Bonamii a Idolothrips Schotti i angustifrons). — Šupinka na basi kř́del tř̌́sněnek terebrantialních, o níž jsme se jiz̀ zmínili, jest na předním páru opatřena žilkou, která ji obrubuje kol do kola. Vedle vnitřní části této žilky běži mělká rýha. Na šupince zadních křídel mizí žilka ji lemující obyčejnẻ docela, takže šupinka jen rýhou od plochy křídla jest oddělena. U tubulifer mění se šupinka na zadních křidlech $\mathrm{v}$ přívěsný lalůček.

Okraje křídel třásněnek vyznamenávají se tím, že ozdobeny jsou dlouhými tenkými třásněmi. U tubulifer jsou oba páry křídel na obou okrajích stejnoměrně hustými třásnèmi posety; před koncem zadního okraje hořejších křídel stoji třásnè ty ve dvou řadách. U stenopter jsou zadní okraje křídel velmi dlouze třásnité; u hořejších křídel jsou třásně po dvou sbližené. Přední okraje lıořejších kríidel opatřeny jsou třásněmi o něco kratšími, mezi nimiž obyčejně stoji krátké tuhé brvy. Na dolejších kǐrídlech jest přední okraj poset u všech terebrantií krátkými řídkými třásněmi. U coleoptrat scházejí třásně na předním okraji hořejších kríidel docela; u rodủ Melanothrips a Rhipidothrips nalézáme tam jen tuhé brvy. U lubulifer vycházeji třásně z plochy křídla pod okrajem, u terebrantií však stojí na žilce okružní. Jen u rodu Dendrothrips vycházejí z mezery mezi žilkou okružni (která však zde běží pod předním okrajem) a hořejší žilkou podélnou. Třásně zajisté slouži $\mathrm{k}$ tomu, aby povrch křídla zvětšily a tím při letu měrou větší o vzduch opríti se mu pomáhaly. V klidu nezaujímají velikého místa, jsouce vedle křídel složeny.

Žilky podélné jsou v hořejších křidlech krátkými, tuhými, jen výjimkou přemalými chlupy opatřeny, a sice tak pravidelně, že rozestavení a počtu jejich lze užiti za znak systematický. Obyčejně jest hlavní žilka u stenopter opatrena na onom místě, pod nímž vzniká žilka vedlejší, lřemi chlupy (velmi zřídka čtyřmi neb pěti), které jsou od chlupủ sousedních v pravo i v levo mezerou odděleny. Hlavní žilka bývá pak až ke konci křidla někdy stejnoměrně chlupy poseta, obyčejně však má uprostřed jeden a ke konci dva chlupy (výjimkou jen dva neb čtyři). Vedlejši žilka bývá po celé své délce chlupy poseta. Podélná žilka $\mathrm{v}$ krídlech dolejších jest jen na basi několika chlupy opatřena. Coleoptrata mají obě žilky podélné tuhými chlupy posety. Žilky přičné jsou nahé.

Porovnání žilek $\mathrm{v}$ křídlech třásněnek $\mathrm{s}$ žilkami jiného hmyzu nemủže ještě správně provedeno bỹti, poněvaď̆ neznáme téměř žádných z přečetnỵ́ch dle mého domnění rodủ krajin mimoevropských, které zajisté rozvětvením svých žilek odchylným ukážou nám snad časem cestu, kterou se v tom ohledu bráti máme. Red ten ba cher a Jor d a n tvrdí, że hořejší žilka podélná v křidle rodu Aeolothrips odpovídá žilce v křídle šídel, jež sluje mediana. a dolejší žilce rovnokĩídlých, která se nazývá vena interno-media. 


\section{H. UZEL. MONOGRAPHIE DER ORDNUNG THYSANOPTERA.}

O žilce, která běží na vnitřní straně šupinky, zdá se, že opravdu odpovídá žilce rovnokřídlých, zvané vena analis.

Celý povrch křídel u všech třásněnek terebrantialních jest pokryt velice hustě přejemnými jehličkami. U druhu Parthenothrips dracaenae jsou křílla podobně sítkovaná jako povrch jeho těla. - Také sluší zmíniti se zde o háčkovitém přístroji, na basi dolejšího křídla u některỵch třásněnek se vyskỵtujícím, jenž slouži k zachycení křídla hořejšího za tím účelem, aby obě krídla príi letu vespolek pevně souvisela. U rodu Aeolothrips nalézá se nad kořenem hořejšího křídla silná šupinka chitinová, která př́lišnému ohrnutí jeho zabrañuje.

V klidu jsou křídla u terebrantií složena tak, že hořejší leží na těle vedle sebe, často ke konci od sebe se vzdalujíce; pod každým pak křídlem hořejším leží prrislušné křídlo dolejši. U tubulifer leži všecka čtyřri křídla $\mathrm{v}$ klidu tak, že ve druhé polovici své délky přesně jedno druhým jest krỵto (Tab. VII., fig. 142.).

$U$ některých druhů zakrñují krídla $v$ jednom neb obou pohlavích tou mèrou, že pterothorax nepřesahují aneb jen málo, velmi zř́dka až k člvrtému článku abdom., jej přerủstaji. Takové pahỵlky křídel zobrazeny jsou na Tab. VI., fig. 105. a 106. Na hořejším takto zakrnělém křídle lze spatriti šupinku úplně vyvinutou a též žilku okružní, pahýlek obrubujicí. U malého poměrně počtu druhủ scházeji křídla úplně, takže ani nejmenších zbytkủ nelze spatríti. Tak ku př. u rodů Aptinothrips, Prosopothrips a u bezkřídlé formy druhu Aeolothrips albocincta.

\section{SVALY. MUSCULATUR.}

Celé tělo prostoupeno jest četnými svaly, z nichž zvláště mnohé jsou umístněny $\mathrm{v}$ hrudi, kdež slouži k pohybu noh a bud prímo neb neprímo k pohybu křídel. Mnohé z nich usazují se na konce vchlípenin chitinových, o nichž jsme nahoře promluvili, a na zadní okraj mesoscutella, kdež jejich chitinové konce tvoří tak zvané diaphragma. Mezi tímto a předním okrajem mesoscutella napnuty jsou dle Jordana dva páry neprímých svalů létacích: vnitřní mohutnější a vnější slabší. $V$ metathoraxu svaly ty zakrňují. Jiné svaly prostupují hrud' ve směru kolmém. V abdomenu vynikají zvláště četné, krátké svaly, které spojují vždy dva za sebou následujicí články a vtahování jednoho do druhého umožñují. Také kladélko samiček jest mnohými svaly opatřeno, jež většinou umístněny jsou $\mathrm{v}$ předposledním článku abdominalním.

\section{SOUSTAVA NERVOVÁ. NERVENSYSTEM.}

Soustava nervová jest $u$ třásněnek velmi koncentrovaná, a to sice $u$ tubulifer měrou ještě větši než $u$ terebrantií. U tèchto studována byla Jordanem na druhu 


\section{J. UZEL, MONOGRAFIE RADU, „THYSANOPTERA“.}

Parthenothrips dracaenae. Já sám pak zvolil jsem si z tubuliter druh Trichothrips copiosa, jehož soustavu nervovou $\mathrm{v}$ následujících řádcích popissi, a vytknu pak rozdily mezi obèma zmíněnými druhy. zástupci to obou podřádủ třásněnek.

Trichothrips copiosa má poměrně veliký mozek (Tab. VIII., fig. 157., b) tvaru podlouhlého, který $\mathrm{v}$ předu vysýlá dvě mohutné krátké větve $\mathrm{k}$ očím ( $a$ ), nahoře tři krátké tenké větve ke třem očkủm a dole dvě větve $\mathrm{k}$ tykadlủm. Vzadu vycházejí z něho dvě commissury, které mezi sebou uzavíraji jícen a tvoři tak kruh jícnový. Dále vcházeji do zauzliny podjícnové, která však zde tvoří se zauzlinou prothorakalní jedinou hmotu $(d)$. Tato má tvar hruškovitý a vysýlá v predu po jednom nervu (e) do prvého páru noh. Ze zauzliny prothorakalní vychází jediná lichá velmi krátká a stlustlá commissura. Zauzlina mesothorakalní $(f)$ jest značně kratši ně̌ prothorakalní, má tvar sploštilý, jest napřed vykroužená a vysýlá $\mathrm{v}$ předu na každé straně po jednom nervu do hor̀ejších křídel $(g)$ a uprostřed po jednom do druhého páru noh $(\boldsymbol{l})$. Zauzlina metathorakalní $(i)$ jest asi tak dlouhá jako předcházející, avšak o něco hmotnější, a přikládá se k ní širokou plochou, takže commissury mezi obèma zauzlinami není. As uprostřed vychází z ní na každé straně jeden nerv, který jde do dolejších křídel (j) a vzadu na každé straně jiný, jdoucí do zadního páru noh $(k)$. Následující objemná zauzlina $(l)$ povstala srủstem všech zauzlin abdominalních a posunula se do hrudi, kdež velmi širokou plochou přiléhá k zauzlině metathorakalní, tvoříc takto s ní a se zauzlinou mesothorakalní jedinou hmotu nervovou, na kteréž meze tř́ velikých zauzlin, z nichž povstala, jen zaškrcením se prozrazují. Ze zauzliny abdominalní vycházejí po každé straně dva sblížené nervy a vzadu tlustý provazec nervový, který se táhne celým abdomenem až na konec těla, před nímž se dèlí ve dvẽ vẽtve. Provazec ten vysyylá v rủzných mezi sebou vzdálenostech po každé straně sedm nervủ, které brzy dèlí se ve dví. Nervy pravé strany vycházejí z provazce poněkud níže ně̌ nervy na straně levé. Obě větve pak, ve které se provazec před koncem rozděluje, vysýlají jeden nerv na vnitřní stranu (9), a pokud jsem mohl pozorovati, dva $(10,11)$ na stranu vnější.

Soustava nervová třásněnek terebrantialních liši se od téže soustavy tubulifer především tím, že koncentrace její není tak veliká. Zauzlina metathorakalní spojena jest se zauzlinou mesothorakalní, jakož i se zauzlinou abdominalní krátkou commissurou. Zauzlina abdominalní pak neleží v hrudi, nýbrž v prvých třech článcích zadku. Jiný rozdíl spočívá v tom, že provazec nervový, vycházející ze zauzliny abdominalní, táhne se až na konec těla, nerozdèliv se ve dvě větve a stávaje se čím dál tím užším. V stejných vzdálenostech mimo to vysýlá $\mathrm{v}$ každém článku abdominalním po jednom páru nervů.

R. 1852. vidèl Haliday (L. č. 61.) poprve soustavu nervovou třásněnek a píše o ní, že skládá se ze čtyř stěsnaných zauzlin a z jednoduchého snad provazce nervového. Výkres soustavy nervové druhu Phloeothrips (= Trichothrips) pini, jejž Haliday podává (Tab. VIII., fig. 1.), jest maličký a velmi nejasný. Lze tu spatřovati šest stěsnaných zauzlin a lichý provazec nervový. 


\section{ÚSTROJE SMYSLOVÉ.}

\section{SINNESORGANE.}

\section{ÚSTROJE HMATU.}

TASTWERKZEUGE UND TASTORGANE.

Ke hmalu slouži trásněnkám tykadla, makadla a chlupy hmatavé, na ústrojích ústnich a porůznu na těle rozestavené.

Tykadla třásněnek, obyčejně as tak dlouhá jako hlava a prothorax dohromady, směřují do předu. Ċlánky jejich jsou dosti štíhlé, jen prvé dva, zvláště pak druhỵ́, jsou zejména $u$ třásněnek terebrantialních zavalitější, širší a pravidlem kratší než následujicí. Počet článkủ tykadelních kolísá mezi šesti až deviti. - Tubulifera maji tỵkadla vždy osmičlenná. Třetí článek jejich bỵvá c̀asto nejdelším v celém tykadle. Sedmý článek jest vždy liratším a vždy aspoň o něco užším než články předcházející. Poslední jest přišpičatělý a vždy kratší a značně užši než sedmý; jest nejmenším článkem v celém tỵkadle. U druhu Ceplualothrips monilicornis tvoři poslední tři článkị dohromady jakỵsi celek (Tab. VII., figg. 135.). — Stenoptera mají tykadla šesti- až osmičlenná. Rody Parthenothrips, Thrips, Baliothrips, Sminyothrips, Stenothrips. Bolacothrips a Platythrips mají tykadla sedmičlenná. Sedmý élánek jejich jest mnohem kratši a užši než předcházejíci a sluje stylus. Šestý článek bývá nejdelšim z celého tỵkadla, takže sedmý článek jen jako malý apicalní prívěsek se jeví. Jen u rodu Purthenothrips jest 6. čl. mnohem kratši ně̌ pátý (Tab. VI., fig. 93), a také 7. čl. v délce značně ho překonává. U rodu Drepanothrips zmizela hranice mezi sedmỵm článkem a šestým (Tab. VII., fig. 113.), takže tỵkadlo jest jen šestičlennỵm, s šestým článkem mohutnỵ́m, přišpičatèlým. Rody Chirothrips, Limothrips, Sericothrips, Physopus, Rhaphidothrips, Oxythrips, Pachythrips, Anaphothrips, Aptinothrips, Belothrips, Dictyothrips, Dendrothrips, Prosopothrips a Heliothrips mají tỵkadla osmičlenná. Dva poslední články jejich jsou mnohem užši a obyčejnè kratši než předcházejíci a troři dohrumady tak zvanỵ stylus. Šestý c̀lánek býrá také u tèchto třásněnek nejdelším z celého tỵkadla a má u druhu Anaphothrips virgo (Tab. V1., fig. 75.). Dendrothrips tiliae a D. Degeeri před koncem zřetelnou šikmou přehrádku, takže u nich tykadlo zdá se býti devítičlennỵm. U variety comaticomis druhu Aptinothrips rufa scházi stylus úplně (Tab. VI., fig. 79.), a tykadlo stává se šestičlenným, s šestým článkem velikỵm, přišpičalèlỵ́m. Neoby̌čejnè dlouhý a tenký stylus maji rody Rhaphidothrips (Tab. VI., fig. 70.), Heliothrips (Tab. VI., fig. 91.) a Belothrips (Tab. VI., fig. 80.). U rodu poslednè jmenovaného jest stylus skoro tak dlouhý jako článek šestý. U rodu Ieliothrips jest druhý článek stylu značně prodloužen, takže délkou svou skoro se vyrovnává nejdelšimu článku třetímu. U rodu Rhaphidothrips pak stylus dokonce značně přesalıuje délku pátého a šestého článku dohromady. Tỵto dva články prikládaji se zde k sobè širokou plochou a troři tak respolek jakýsi celek. Podobné 


\section{J. UZEL, NONOGRAFIE ṘAU „THYSANOPTERA“.}

těsné spojení pátého a šestého článku nalézáme též u druhủ Physopus ulmifoliorum a Baliothrips dispar (Tab. VII., fig. 108.). Pokud se tvarủ článkủ týče, sluší ještě poznamenati, že u druhu Chirothrips manicata prodlužuje se druhý článek na vnẹjší stranu v trojhranný široký zub (Tab. V., fig. 49.); u druhu Limothrips denticornis podobně utvořen jest článek tr̉etí (Tab. I., fig. 8.). - Coleoptrata mají tykadla devítičlenná. U rodu Melanothrips (Tab. V., fig. 35.) jsou všecky články v délce ne př́liš rozdílné. Poslední dva jsou nejkratšími a nejužšími. U rodu Rhipidothrips (Tab. V., figg. 43.) jest tretí článek nejdelším $\mathrm{z}$ celého tykadla, a poslední tr̆i srůstaji $\mathrm{v}$ jediný celek, na němž však zřetelně lze spatroovati hranice článkủ, z nichž se skládá. U rodu Aeolothrips (Tab. V., fig. 46.) jsou třetí a čtvrtý článek neobyčejně dlouhé, válcovité, a pět posledních článkủ srủstá v mohutný celek se zr̀etelnými hranicemi jednotlivých částí, z nichž pruní jest as tak dlouhá jako ostatní dohromady. - Nepravidelnosti v tvaru článkủ tykadelních jsou velmi hojné. Často srủstají na tykadle jedné strany dva až tři články v jedinou objemnou hmotu, jindy mění se dvoučlenný stylus v malý nečlánkovaný prívěsek. U druhủ Aeolothrips fasciata a albocincta jest úplný srůst posledních pěti článkủ dosti obycejný.

Vlastuími ústroji hmatavými na tykadlech jsou celné chlupy, kleré bud' jsou porủznu na nich rozestaveny, aneb tvoři před koncem jednotlivých článkủ kruh. U rodủ Parthenothrips a Heliothrips prodlužuje se konec stylu v neobyčejně dlouhý hmatavý vlásek. U rodu Dendrothrips nalézá se na šestém článku jeden ohnutý silný a dlouhý chlup hmatavý, který dosahuje skoro konce tykadla.

Po tykadlech jsou hlavním sídlem hmatu makadla. Makadla maxillarní jsou vždy značně delší než makadla labialní, kterážto u rodu Dendrothrips a Belothrips skoro úplně zakrňují. U tubulifer jsou oba páry makadel dvoučlenné. První článek jejich jest velmi krátký. U terebrantií jsou makadla maxillarní dvou- neb třičlenná, makadla labialní pravidlem dvou-, a jen u rodủ Aeolothrips a Rhipidothrips čtyřčlenná. Trúćlenná makadla maxillarní mají rody: Chirothrips, Sericothrips, Physopus, Raphidothrips, Oxythrips, Pachythrips, Ancophothrips, Aptinothrips, Belothrips, Dictyothrips, Prosopothrips, Thrips, Sminyothrips, Bolacothrips, Drepanothrips a všecka coleoptrata; dvoučlenná makadla maji rody: Limothrips, Dendrothrips, Heliothrips, Parthenothrips, Baliothrips, Stenothrips a Platythrips. Je-li makadlo trojčlenným, bývaji obyčejně všechny tř́ články stejně dlouhé. U rodu Aptinothrips jest první článek značně delší než ostatní dva, a u druhu Oxythrips firma jest prostřední neobyčejně malý. Makadlo maxillarní dvoučlenné má u rodủ Limothrips a Dendrothrips oba články asi stejně dlouhé; u rodů Heliothrips, Parthenothrips, Baliothrips, Stenothrips a Platythrips jest však druhý článek značně delší než prvý, a zřejmě na něm lze znamenati, že povstal srůstem dvou článkủ. Tubulifera maji druhý ělánek makadel maxillarních na konci pravidlem čtyřmi chlupy hmatavými opatřený; u terebrantií stojí pak na konci jejieh tři až pět, zř́dka více takových chlupủ. Kromė toho nalézá se ještě na basi posledního jejich 


\section{H. UZEL, MONOGRAPHIE DER ORDNUNG THYSANOPTERA.}

článku aneb nedaleko base jeden chlup hmatavý. Velmi dlouhý chlup toho druhu stoji u třásněnky Aeolothrips fasciata na konci prvého ělánku makadla maxillarního. Makadla labialní jsou u všech tř́śněnek ukončena několika nedlouhỵ́mi podobnými chlupy.

Z chlupů hmatavých, na ústrojich ústních se nalézajících, vynikají ty. které umístněny jsou na hořejším pysku. Jest jich obyčejně šest, někdy i více. Spodní pysk opatřen jest též několika takovými chlupy. I maxilly maji nèkteré ojedinělé. — Na samém konci dolejšiho pysku stojí u terebrantií po každé straně otvoru ústního větši počet prủhledných trichomủ (Tab. IX., fig. 161.), které se dle Bohlse (L. č. 167.) prodlužují dovnitr̃ pysku v chitinovou rourku. Snad také tyto útvory slouži ku hmatu, nebof mají podobu hmatavých ústrojủ, jež na rypáku much nalézáme, a jež Leydig zobrazil*).

Také ostatní tẽlo třásněnek jest opatreno značnỵm počtem chlupủ hmatavị́ch; tak mezi očima, na zadním a někdy i na předním okraji prothoraxu a na konci těla. Mnohé \% těchto chlupủ bývají u některých druhủ tubulifer paličkami ukončeny (Tab. III., fig. 20.; Tab. IV., fig. 28.). Podobně chlupy na těle i okončinách larev (Tab. II., fig. 13.) a nymf (fig. 14.) jsou často paličkami nebo trychtýřky zakončené, a dlužno je za hmatavé chlupy považovati.

\section{ÚSTROJE CHUTI. GESCHMACKSORGANE.}

Bohls (L. č. 167.) nalezl na spodní (vnitřni) straně hořejšiho pyskiu príǐnou řadu, pozûstávající z osmi šikmých prohlubin $\mathrm{v}$ chitinu, z nichž v každé trčí průhledný čípek. Č́pky ty jsou ve spojení s vlákny nervovými, vycházejícími ze dvou malých ganglii, jež pod mozkem se nalézaj: O tomto ústroji myslí zmínèný autor, že by snad mohl bỵti ústrojem chuti. což jest velmi pravdẻpodobno.

\section{ÚSTROJE ČıCHU. GERUCHSORGANE.}

Sídlem čichu jssou tykadla a makadla. U tubulifer nalézáme na třetím až šestém článku tykadelním po každé straně před koncem jeden ohnutý průhledný čípek, který za ěichový dlužno považovati. Největšími jsou tyto čípky u druhu Acanthothrips nodicornis (Tab. VII., fig. 145., a). Z třásněnek terebrantialních má rod Chirothrips na vnèjší straně třetího a čtvrtého ělánku (Tab. V.. fig. 49.; fig. 50.) a rod Heliothrips na třetím až šestém článku po jednom takovém čípku. Vètšina ostatních rodů má na třetím až šestém článku tykadla po jednom dvouramenném průhledném čípku ěichovém, kterýžto sedí na

*) Les sens et l'instinct chez les animaux et principalement chez les insectes. Par Sir John Lubbock. Paris 1891, str. 18., fig. 24. 


\section{J. UZEL, MONOGRAFIE RADU, „THYSANOPTERA“.}

prekrátké tlusté stopce ve světlé prohlubině nedaleko konce jednollivých článkủ. Na tr̉etím a ětvrtém ělánku jsou tỵto čípky nepoměrnè většími než na následujících dvou. Na tretím nalézá se útvor ten na hořejší straně jeho, na čtvrtém dole. Největší takové čípky má druh Thrips Klapáleki (Tab. VI., fig. 107.). Rod Parthenothrips opatřen jest podobně jako tubulifera čípky ěichovými od sebe oddělenými. Coleoptrata čípkû těch nemají. Nakadla maxillarní jsou jen u některých tubulifer a u rodu Aeolothrips na konci čípky čichovými opatřena. U rodu Megalothrips jsou dva takové ěípky (Tab. VII., fig. 115.), u druhu Cryptothrips dentipes jeden. U rodu Aeolothrips stoji na konci makadla maxillarního taktéž jen jeden, a to velmi krátký čípek čichový (Tab. IX., fig. 161.). Na makadlech labialních vyskytují se čípky tỵto ěastēji. Všecka tubulifera mají po jednom ('Tab. VII., fig. 120.) nebo dvou (Tab. VII., fig. 116.) takových ěípcích, kteréžto jsou často zakřivené (Tab. IV., fig. 30.). Rod Aeolothrips má taktéž dva, a sice velmi krátké (Tab. IX., fig. 161.); rodu Melanothrips-scházeji. Stenoptera nemají, pokud vím, na makadlech žádných čípkủ ěichovỵch.

\section{ÚSTROJE ZRAKU. SEHORGANE.}

Oči nalézají se v pr̉edu na hlavě na hraně mezi temenem a čelem. Jen výjimkou (u rodủ Chirothrips a Idolothrips) bývají více do zadu posunuty. Mají podobu bud kulatou, nebo ledvinitou (na př. u rodu Megalothrips). U rodu Aeolothrips sahají dadaleko na spodní stranu hlavy (Tab. IX., fig. 161.). Skládají se z četných složitých oček, jichž rohovky jsou značně vypouklé, takže oko má vzhled maliny. Jednotlivá složitá očka nejsou v celém oku vždy tak těsně směstnána, že tvorí šestiboká políčka, nýbrž stávají se někdy na pokraji oka a v dolejší části jeho, která nalézá se na čele, řídčmi, takže se mezi sebou ani nedotýkají (Tab. IX., obr. 161.) U nèkterých druhủ (tak zvl. u Sericothrips staphylinus, Physopus primulae, distincta, inconsequens a Parthenothrips dracaenae) jsou oči značnè vykoulené. U rodu Trichothrips, a to zvláště u druhu semicaeca, jsou velmi malé a jen z nepatrného počtu oček složitých se skládají. Úplně slepých třásnènek není.

Očka jednoduchá jsou obyčejně prítomna a nalézají se na temeni hlavy mezi očima na rozích trojúhelníka, jehož vrchol jest obrácen do předu. Jsou opatřena množstvím červeného pigmentu, který nahromaděn jest na straně obrácené ke středu trojúhelníka. U rodů Aptinothrips, Prosopothrips, Platythrips, u druhu Trichothrips semicaeca, dále u samcủ rodủ Chirothrips a Limothrips scházejí úplnè. U ostatních druhủ rodu Trichothrips a u druhủ Physopus nigriventris, frontalis, pilosa a Bolacothrips Jordani více nebo méně zakrñuji. Někdy, když již rohovka očka jednoduchého zmizela úplně, nalézáme ještě zbytky pigmentu. Pozoruhodno jest, že všude tam, kde očka scházejí aneb kde jsou zakrnèlá, není křídel. 
H. UZEL, MONOGRAPHIE DER ORDNUNG THYSANOPTERA.

\section{ÚSTROJE SMYSLOVÉ NEZNÁMÉHO ÚČELU. SINNESORGANE VON UNBEKANNTER FUNCTION.}

Takovým ústrojem je dlouhá čirá šupinka, která jedním okrajem přiléhá na spodní stranu šestého článku tykadla a v předu v cípek je prodloužena. Nalézá se u druhů Physopus ulicis a phalerata (Tab. V., fig. 58., a). Jiný záhadný ústroj smyslorý spatřujeme u rodu Acolothrips. Na třetím a čtvrtém článku tykadehním jest totiž v druhé polovině dlouhá hluboká rỵha, chitinu prostá a pokrỵtá světlou blankou. U téhož rodu nalézá se ještě na šestém článku tykadla malé okrouhlé světlé místo. — Konečně nalezl Bohls (L. ě. 167.) u tubulifer dvè rourovité prohlubiny na jazyku, z nichž v každé nalézá se dlouhá světlá štětina, která na každé straně z cípku jazyka ryčnivá. Účel tohoto prístroje nedovede si vysvětliti.

\section{ÚSTROJE ZAŽÍVACÍ. VERDAUUNGSORGANE.}

Zažívaci roura počíná ústy, která leži na vrchole kužele ústního a konči řití na špičce posledního článku abdominalního. Rozeznáváme na ní tř̀ části. totiž střevo přední (jícen), střevo prostřední (žaludek) a střevo zadní.

Počátek střeva predního leži v kuželu ústním, který utvořen jest ústroji ústními. O ústrojich těchto hodláme obšírně pojednati, poněvadž právě ony nejvice charakterisuji hmy̧z třásnokrídlý jakožlo ř̉d a velmi zajímavými se stáraji tím, že na nich lépe ně̆ kdekoli jinde sledovati múžeme postup, kterým ústroje ssavé vznikají z kousavých; spojujit totiž třásněnky oba ty druhy kusadel v jedno. - Nejprre popíšeme krátce, $\mathrm{k}$ vủli všeobecné orientaci, podobu ústrojủ ústních, načež přikročíme $\mathrm{k}$ dủkladnějšímu ohledávání jednotlivỵch části*).

Sosák třásnènek neboli kužel ústní, jak jej pro jeho podobu kuželovitou nazýváme, nalézá se, jak již dříve praveno, více nebo ménè, někdy úphně pod předohrudí, takže zdá se býti přivěskem této. Tak je tomu u tubulifer (Tab. VIII.. fig. 148.). V klidu jest sosák prittlačen k prosternu a leži mezi kyčlemi prvého páru noh, u tubulifer v prohlubině jeho. Délka sosáku u jednotlivých rodủ značnou měrou se mění. Obyčejně sahá jen do poloviny prosterna; zřídka dosahuje konce jeho, jakž tomu jest ku př. u rodu Poecilothrips. Též tvar jeho jest rozdilný. U většiny rodủ třásněnek terebrantialních jest sosák široký a tupý, u jiných (ku pr̃. u rodu Aeolothrips a Rhipidothrips) tenký a ostrý. U tubulifer maji taktéž některé rody krátký, široký a tupý sosák (Megalothrips, Cryptotherips, Anthothrips, Zygothrips, Cephalothrips a Trichothrips); u jiných pak jest úzký, dlouhý a ostrý (Phloeothrips, Acanthothrips, Liothrips, Poecilothrips). V èas prijjímání potravy jest kužel ústní pomocí svalủ skoro kolmo na osu těla postaven.

*) Druhy námi v tom ohledu zkoumané jsou zvláštè Aeolothrips fasciata, Trichothrips copiosa a pedicularia, Anthothrips statices, Cryptothips dentipes a Poecilothrips albopicta. 


\section{J. UZEL, MONOGRAFIE RADU, "THYSANOPTERA“.}

Velikou pohyblivost' sosáku umožn̆uje měkká světlá blána (Tab. VIII., fig. 148.,d; Tab. IX., fig. 161., bl), která na basi jeho se rozprostírá a spojuje ho s chitinovou kostrou částí sousedních, a to $\mathrm{v}$ předu s okrajem cela $(\boldsymbol{r})$, po stranách s okrajem prodloužených tvárí (u) a vzadu s prosternem. Plášt kužele ústního složen jest ze čtyř částí. V předu (když sosák je vzpřimen) nalézá se trojhranný hořejší pysk (a), po každé jeho stranè široká kusadla druhého páru (maxillae, $b$ ) s jedním párem makadel, a dole široký spodní pysk (labium) s druhým párem makadel. Spodní pysk ze všech částí mèrou nejvètší zúčastňuje se při tvorbě pláště. Na konci rypáku nalézá se otvor ústní, kterým mohou vymrštěna býti kusadla prvního páru (mandibulae, $j$ ), jež u třásněnek leži uvnitř pláště, a jež mají podobu velmi dlouhých štètin. Kromě toho nalézá se ještě $v$ dutině pláště jeden lichý, velmi silný bodec $(\boldsymbol{m})$, který leži na její levé straně a na své basi se rozširuje v desku (u). Tento útvor, jenž bodcem ústním budeme nazývati, jest pro třásněnky velmi charakteristický, nebot nevyskytuje se u žádného jiného hmyzu. - Poznavše tak povšechně podobu sosáku, obratme se již $\mathrm{k}$ dủkladnějšímu popisu částí, z kterých se skládá.

Hořejši pysk (labrum, Tab. IX., fig. 161., a) má podobu vysokého trojúhelníka a pamětihodným jest tím, že basis jeho jest nesymmetrickou. U tř́sněnek terebrantialních prodlužuje se totiž pravá její strana skoro až $\mathrm{k}$ okraji čela, kdežto levá od něho se oddaluje. U tubulifer pak (Tab. IV., fig. 30., fig. 31.), kde celá basis hořejšího pysku jest mnohem bližši okraji čelnímu než u podřádu druhého, nesouměrnost jeví se tím, że roh na levé straně base jest hluboce vykrojen. Ke konci se labrum značnè zúžuje a konči bud tupě (u všech terebrantii a z tubulifer u rodủ Megalothrips, Cryptothrips, Anthothrips a Zygothrips), aneb ohýbají se okraje jeho do zadu a tvoři tak dlouhý, dutý, na konci otevřený hrot (Tab. IV., fig. 30.). Krátce před koncem jest pysk u terebrantií na malou vzdálenost po celé šiřce blánitým a světlým, na konci pak má úzkou blánitou obrubu (Tab. IX., fig. 161.).

Druhý pár kusadel (maxillae, Tab. IX., fig. 161., b) přikládá se ke stranám hořejšího pysku, s nimiž jest pevně spojen. Každé kusadlo má tvar trojúhelníka. Blána, která jeho basi spojuje s prodlouženinou tváře, jest velmi úzká. Maxilly nedosahují konce hoŕ. pysku, nýbrž ztrácejí se před ním z povrchu kužele ústního a vnikají do jeho dutiny, kdež dle Bohls e pevně se spojuji se stranami jazyka (glossa). Nedaleko base kusadla a rovnoběžně s ní táhne se někdy zřetelná přičná rýha, kterou Jordan považuje za hranici mezi dvěma částmi, které u kusadel druhého páru hmyzủ jiných jsou zĩetelně odděleny. Cáasti ty sluji cardo a stipes. Malae, třetí to část kusadla, zakrňuji zde úplně. As uprostřed má každá maxilla své makadlo, které stojí na okrouhlém blánitém světlém místě (Tab. IV., fig. 30.), jež u terebrantií prodlužuje se až k basi kusadla (Tab. IX., fig. 161.).

Spodní pysk (labrum) tvoří zadní stěnu pláště kužele ústního a ohnutými kraji svými pevně prìléhá $\mathrm{k}$ okrajům druhého páru kusadel. Nelze na nèm spatrovati již stop, které by poukazovaly k tomu, že srostl z levé a pravé strany. Za to hranicemi od sebe 


\section{H. UZEL, MONOGRAPHIE DER ORDNUNG THYSANOPTERA.}

odděleny jsou části jeho: submentum (Tab. IV., fig. 30., c), mentum (Tab. IV., fig. 30., d; Tab. 1X., fig. 161., e) a ligula (Tab. IX., fig. 161., i). Tyto hraníce jsou nejpatrnějšími u rodu Aeolothrips, kdež pozůstávají ze světlých a poměrně širokých spojovacích blan (d). Mentum má na svém konci, a sice často na světlém blánitém místě (Tab. IX., fig. 161., g) druhý pár makadel (h). U rodu Aeolothrips prodlužuje se nahor̀e po každé straně v tenký dlouhý výběžek $(f)$, kterỵ prìkládá se na okraj otvoru ústního. Ligula skládá se ze dvou části. Vnější z nich, jež jest na konci blánitá (i), obklopuje otvor ústní ze zadu a ze stran a přikládá se nahoře okraji svými na konec hořejšího pysku. Tuto část považuje Bohls za srostlé přivěsky jazyka (vnější sanice, paraglossae), které uvnitř uprostřed na zadní stěně před otvorem ústním mají podlouhlý chitinový útvor, jenž dle Bohlse někdy na konci jest dvouklanný. Tento útvor jest dle téhož spisovatele jazyk (srostlé vnitřní sanice, glossa). Dvouklanný konec jeho ukazuje na srůst z pravé a z levé poloviny. Jazyk má nahoře uprostred podélný žlábek, který prý tvorí spodní polovinu roury, do níž ústí se žlázy slinné, - Ještě sluší podotknouti, že dolejší pysk má právě tak jako hořejší mimo vnější také vnitřní stěnu (jaksi drojité dno), kteráž jest $u$ onoho blánitou, $u$ tohoto chitinovou.

Prostor, který uzavírají mezi sebou ústroje ústní, plášt kužele trořicí, vyplnèn jest dle Bohls e velikým čtyřhranným chitinovým roubíkem, jehož přední stěna přechází v zadní stěnu jícnu a zadní ve vnitřní stěnu spodního pysku. Jest to tak zvaný hypopharynx. Zúžený konec jeho sahá skoro až k otvoru ústnímu. Pr̉ední jeho plocha má, dle zmíněného autora, dlouhý žlábek, který pokryt jest vnitřní plochou hořejšího pysku. takže tvoři uzavrenou rourku, jež prímo souvisí s jícnem, a jest počátkem roury zažívací. Konečně pokrývá dle Bohlse část zadní plochy hypopharynxu jazyk a troří tak ze žlábku, na jazyku se nalézajícím, taktéž rourku, jež prodlužuje se až k místu, kde zadní plocha hypopharynxu přechází ve rnitřní stěnu dolejšího pysku. Tam, dle popisu Bohlsova, ústí se do zmínèné roury lichý vỵ́vod žláz slinnỵch, a sice skrze malý dutý chitinový výtvor, jehož světlost' svaly se bud otevíá neb uzavírá. Slinná rourka končí, hypopharynxem jsouc tvořena, zároveň s ním nedaleko preed ústy.

První pár kusadel (Tab. IX., fig. 161., j) proměněn jest u třásněnek $\mathrm{r}$ bodavé štětiny, podobně jako u mnohého jiného hmyzu. Každá z těchto štětin skládá se ze dvou kusù: z basalní chitinové páky (l) a z vlastní štětiny bodavé ( $j$ ). Chitinorá páka jest u terebrantií jedním koncem pohyblirě spojena s okrajem prodloužené části tráře. u tubulifer pak vkloubena jest na špičce úzkého výrostlu stlustlého okraje čelního. Na druhém konci nese stlustlý kor̀en $(k)$ štětiny bodavé. $V$ klidu jest páka zmíněná do předu namírena. I terebrantií jest krátká a nepřesahuje mnoho okraj čela; u tubulifer v̌sak jest prodloužena až pod oči. Bodavé šlětiny běží u terebrantií hned od své base nízkým obloukem pod hořejším pyskem nedaleko jeho postrannich okrajủ k ústủm a končí krátce před nimi. U tubulifer jsou pomèry jiné. Tam ohỵbají se velmi dlouhé štětiny bodavé na dorsalní stranu hlavy a běži pod stènou týlní, jsouce více nebo méně $k$ sobẽ 


\section{J. UZEL, MONOGRAFIE RÁDU, „THYSANOPTERA“.}

přiblížené*), načež se do kužele ústního stáčejí. Když třásněnka štětiny ty vỵmrští, postaví se dle Bohlse chitinové páky kolmo na stěnu čelní, takže tvoří se štětinami bodavými úhel pravý. Dle téhož autora netvoři chitinová páka a štětina dohromady morfologický celek, což jest zřejným, uvážíme-li, že u všech ostatních hmyzủ skládá se první pár kusadel jen z jediného kusu. Páku dlužno považovati za dlouhou vchlípeninu chitinové kostry vnèjší, ač kloubem s ní spojena jest. Jakožto přesvědčivý důkaz, že páka není částí kusadla, uvádí Bohls prítomnost některých svalủ, které ji spojují s druhým párem kusadel. Mezi jednotlivými kusadly za sebou následujícími však u žádného hmyzu nemáme príkladu takového spojení. - Bodavé štětiny mají po celé své délce hluboký žlábek, a sice na straně vnitřní. Když štětiny ty z otvoru ústního vysstoupí (což děje se za pomoci svalů, jdoucích k basalní páce), přiloží se dle Halidaye a Bohlse jedna na druhou a żlábky jejich vytvoři uzavřenou rourku ssavou. Každá z obou štětin bodavých pohybuje se dle posledně jmenovaného autora $\mathrm{v}$ dlouhé rourovité dutinè, vzniklé vchlípením ektodermu. U tubulifer jsou obě roury následkem značnè prodloužených štětin taktéž velmi dlouhé; podepřeny jsou u některých druhů pod týlem silnou prričkou chitinovou, která obě roury spojuje. Přička ta jest zvláště u rodu Authothrips velmi patrnou. $\mathrm{V}$ kuželu ústním přikládají se zmíněné roury $\mathrm{k}$ pravé a levé stranè hypopharynxu.

Bodec ústní (epipharynx, Tab. IX., fig. 161., $m$; fig. 162.). Velmi silný tento bodavỹ nástroj hmyzu třásnokřídlého zaviňuje nesouměrnost jejich ústrojů ústních. Leží totiž na levé straně $v$ dutině pláště a jest $u$ obou podřádú třásněnek jinak utvořen. U terebrantií připevňuje se jeho kořen, $\mathrm{v}$ dutou desku rozšířený, pomocí ostrého přivěsku na okraj čela tam, kde vzniká vchlípenina chitinová, směřující k levému oku (o). Ty poměry lze dobře pozorovati skrze prủsvitavou blánu spojovací $(b l)$, pod níž basis bodce ústního leží. Celý ústroj stáči șe pak v nízkém oblouku k otvoru ústnímu, v němž se dosti tupou špičkou zakončuje. Nedaleko za rozšiirenou částí basalní přikládá se bodec ústní k Jevé straně požeráku, jenž dle Bohls e přijímá ho do zvláštní hluboké vchlípeniny. Když minul požerák, přikládají se $\mathrm{k}$ němu, obklopujíce jej: hořejši pysk, levé kusadlo druhého páru a hypopharynx. Basalní rozšířenina má okrouhlý otvor (Tab. IX., fig. 162., c), jímž vstupuje do ní mohutný sval (na fig. 161. vynechaný). - U tubulifer zúčastn̆uje se tato rozšiřenina při tvorbě pláště kužele (Tab. IV., fig. 30, a), vkládajíc se do vykroužené části na levé straně kořenu hořejšiho pysku. Od vnitřní strany této desky ohýbá se bodec nejdříve do předu, načež za krátko v oblouku stáčí se směrem k ústům. Konec bodce vỵstoupí z úst jednak tím, že celý rypák zatlačí se do zadu, což následkem blánité jeho base jest snadným, a jednak tím, že zakřivení jeho dle Bohlse tlakem požeráku se vyrovnává. - Jordan vším právem považuje bodec ústní za epịharynx,

*) U rodů Megalothrips, Cryptothrips i Anthothrips jsou bodavé štětiny na týle dosti oddálené; u rodů Trichothrips, Phlooothrips, Acanthothrips velmi sbližené. Pozoruhodno jest, že prrá skupina má hořejši pysk veskrze tupý, druhá skupina veskrze ostrý. 


\section{H. UZEL, MONOGRAPHIE DER ORDNUNG THYSANOPTERA.}

nebot pozoroval, že u dospělých zárodkủ basalní deska jeho souvisí s hor̉ejším pyskem a jícnem.

Zbývá nám ještě promluviti o požeráku, jehož zadní stěna jest proměněna $\mathrm{v}$ silnou desku chitinovou, do níž přechází, jak již nahoře řečeno, přední stěna hypopharynxı. Přední stěna požeráku jest značně tenčí a přechází ve vnitřní (zadní) stěnu hořejšího pysku. Na ústroj ten přikládá se dle Bohlse jeden pár mohutných svalů, jejichž drulıý konec připevňuje se na zadním okraji očí. Smrštěním těchto svalủ staví se celý kužel ústní kolmo na podélnou osu tèla.

Ssání děje se následujícím způsobem. Třásněnka, vyhledavši vhodné místo pomocí trichomů hmatavých na dolejším pysku a čípkủ čichových na makadlech, navrtá je bodcem ústním. Do otvoru takto vzniklého zapustí ohě štětiny bodavé, żlábky na sebe přilożené. Tak povstane rourka, kterou vystupuje štáva do otvoru ústního již tak zvanou kapillaritou. Odtud pak požerákem čerpá se do počátku zaživací roury. Přední tenká stěna požeráku opatřena jest totiž (dle Bohlse) mohutným svalem, který smrštěním světlost jeho značně rozšírí, čímž vzduch se zředí; následkem toho vystupuje tam tekutina, puzena jsouc větším tlakem vzduchu okolního. Hermetického uzavření dosáhne počátek zaživací roury (ústa), že měkké části, ukončujicí hořejší i dolejší pysk, pevně k povrchu potravy se prìikádají. Za požerákem pak uzavírá se roura zažívací dle Bohlse v okamžiku ssání skupinou svalů.

$\mathrm{V}$ následujicích rădcích vytkneme cestu, kterou se bralo studium ústrojủ ústních třásněnek od počátku. - R. 1761. viděl Sulzer (L. č. 5.) na spodní straně hlavy třásněnek, zvětšiv je slunečním mikroskopem na šest stop, dvě vejčité vyvýšeniny (bezpochyby přední kyčle) a mezi nimi hluboký žlábek. Dvě léta později viděl Scopoli (L. č. 6.) zajisté již rypáček trásněnek, nebot' počitá je do svého řádu Proboscidea, jenž vyznamenává se ohnutým sosákem. R. 1764. mluví Ge off roy (L. č. 9.) o malé podélné skulině, dole na hlavě se nalézající, ve které by prý mohla kusadla ukryta býli. R. 1767 . praví Linné (L. č. 10.), že třásněnky mají rypáček k hrudi přiložený. R. 1773. pozoroval Degeer (L. č. 11.), že hlava dole prodlužuje se pod předohrud, a že má na konci této prodlouženiny krátký, kuželovitý, tupý rypáček, na němž stoji několik malých, z článkủ složených makadel, a který někdy až k předním nohám zasahuje. Na konci rypákü vidèl též malou špičatou část, což zajisté byl konec bodce ústního. R. 1829. rozeznal StraussDürkheim (L. č. 38.) na rypáku třásněnek maxilly, avšak myslil, že jsou volně pohyblivé. R. 1836. uvádí Haliday (L. č. 43.), následující pozorování: Ústroje ústní třásnènek tvoří masitý rypáček, který není zatažitelný, a jehož části jsou vespolek srostlé. Spodní pysk tvoři zadní ěást rypáčku a lze na něm rozeznati submentum, dlouhé mentum a část zvanou ligula. Palpi labialní stojí mezi mentem a ligulou na úzkém blánitém místè. Naxilly jsou ploché, trojhranné, a mũžeme na nich již rozeznati části, z nichž porstaly. Za polovinou své délky nesou makadla, která jsou delší než makadla spodního pysku. IT terebrantii jsou makadla maxillarní tríčlenná, u tubulifer dvoučlenná, s prvým článkem 


\section{J. UZEL. MONOGRAFIE RADU "THYSANOPTERA“.}

relmi krátkým. Hořejší pysk má podobu klínu, aneb jest trojhranný. Mandibulae jsou štětinovité a opatřené na své basi nadureninou; zdá se, že spojují se s cípkem maxill, pod nimiž leží ke konci přikládají se $\mathrm{k}$ sobě a tvoří rourku o dvou chlopních. - Haliday také již pozoroval, že okraj čelni jest nesouměrný. Burmeister téhož roku (L. č. 45.) potvrzuje mnohé udaje Halidayovy a mylně soudi, že makadla labialní u tubulifer spojena jsou vespolek blanou. Blána tato jsou paraglossae, které mezi oněmi makadly leží, s nimi však nesrủstají. R. 1839. prostudoval tentýž autor (L. ě. 500.) ústroje ústní druhủ Chirothrips manicata, Heliothrips haemorrhoidalis a Acanthothrips nodicornis a podává četná vyobrazení, předmětu toho se týkající. V celku nepíše však nic nového, co by jakousi důležitost' mělo. Nesouměrnost' ústrojů ństních nepozoroval. Domnèlé kusadlo prvého páru, jež kreslí, jest všude lichý bodec ústní. Nesprávný svůj dřivější názor o makadlech labialních tubulifer, blanou srostlých, výkresem opravuje. R. 1852. objasnil Haliday (L. č. 61.) své dřívější výklady o ústrojích ústních třás-

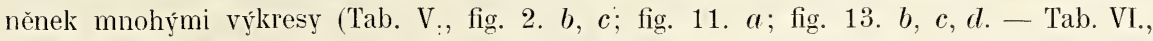
fig. 1. $a-h$; fig. 13. $a$; fig. 14. $a-g$; fig. $15 . a, b, c, h, i, k .-$ Tab. VII., fig. 31.-37. - Tab. VIII., fig. 23.—35.), které jsou však maličké a nezretelné. O tubuliferech poznamenává, že kusadla prvého páru jsou do předu stočená, a že mohou býti dále vymrštěna než u terebrantií. Pozoruhodno je, že bodec ústní, neznaje jeho asymmetrickou polohu, považuje za jazyk (lingua). R. 1888. popsal Jordan ústroje ústní v celku dosti správně a četnými výkresy, druhů Parthenothrips dracaence a Idolothrips brunnea se týkajících, výklad svůj objasnil. R. 1891. prostudoval Bohls ústroje tyto a na základẽ řezú seriových doplnil neb opravil leckteré udaje Jordanovy, týkající se hlavně hypopharynxu, slinné rourky a požeráku, a vzájemnou polohu jednotlivých částí $\mathrm{v}$ rypáku dobře vyložil. V téže době napsal též Angličan Garman o ústrojech ústních třásněnek velmi krátkou zprávu, $\mathrm{k}$ níž připojil jeden rýkres.

Dalši prủběh roury zaživací popíšeme pro každý z obou podřádů třásněnek zvláště, poněvadž v tom ohledu poněkud mezi sebou se liší.

U tubulifer sahá jícen (Tab. IX., fig. 163., a) až do počátku zadohrudi, jest tenkostěnný, bledý, a okraje jeho podélných řas jsou zkadeřené; ke konci trochu se rozšiřuje $(b)$. - Střevo prostřední čili žaludek skládá se ze dvou odstavcủ. Přední odstavec $(c)$ jest nejhmotnější částí $\mathrm{v}$ celém střevě a bývá u některých druhủ jen as dvakrát delší než širší, u jiných však délka jeho vyrovná se skoro pateronásobné šiřce. Jest bud tvaru vejčitého, aneb jest válcovitý a $\mathrm{k}$ oběma koncủm zúžený. Vzadu prodlužuje se $\mathrm{v}$ krátkou stopku. Druhý odstavec středního str̀eva $(d)$ jest na počátku as tak široký jako přední odstavec uprostřed $(e)$; v předu však jest značně prohlouben. Za rozšířeným počátkem dosti náhle se zúžuje, ke konci pak poznenáhla opět dosti značně jest rozšíren $(f)$. - Zadní střevo počíná malou kulatou naduřeninou $(g)$, do které ústí se žlázy malpighické $(\boldsymbol{h})$. Tenké střevo (i) jest velmi krátké, jen as tři- až 


\section{H. UZEL, MONOGRAPHIE DER ORDNUNG THYSANOPTERA.}

čtyřikrát delší než širší. Tlusté střevo (j) jest velmi objemné, vretenovité a velmi úzkou rourkou zakončené.

U terebrantií jest jícen (Tab. IX., fig. 164., $a$ ) delši a sahá až do počátku abdomenu. Jest podobně vytvořený jako $u$ skupiny předcházející; jen na konci jest o něco více rozšírený $(b)$. Střední střevo jeví se poměrně značně delším než u tubulifer. Přední odstavec jeho $(c)$ jest u některých druhủ (Aeolothrips) velmi zřetelnè od zadního oddělen, jest nejširši částí celého střeva a má podobu protáhlého zámotku bource hedvábného. U jiných druhů (Thrips flava a Parthenothrips dracaenae) jest $\mathrm{v}$ predu nejširším, nazad pak více a více se zúžuje a pǐechází poznenáhla do odstavce druhého, jenž vždy po celé délce má stejný pruměr $(d)$ a jen na konci trochu se rozšiřuje $(e)$. Zadní strevo má u některých druhů (Thrips a Parthenothrips) na samém počátku slabou stluštěninu, do níž ústí se žlázy malpighické; u jiných druhů (Aeolothrips) takové stluštěniny není. Tenké střevo jest $u$ některých druhů poměrně o něco delši než $u$ tubulifer (u rodủ Aeolothrips [h] a Thrips), u jiných rovněž velmi krátké. Tlusté střevo $(t)$ jest objemný vak, ke konci velmi značně zúžený.

U obou podřádủ jest střevo tak dlouhé, že musí se $\mathrm{v}$ kličku složiti. U tubulifer tvoři zadní odstavec středního střeva malou zatáčku. Tentýž odstavec u terebrantií ohýbá se do předu až $\mathrm{k}$ basi abdomenu, načež teprv přimo $\mathrm{k}$ řiti se obrací. Konečník u živých tr̃ásněnek neustále čile se stahuje a roztahuje.

R. 1852. popisuje Haliday prvý střevo třásněnek a praví, že tubulifera mají střední střevo od předního (jícnu) hlubokou rýhou odškrcené, že přední část' téhož střeva ("proventriculus«) jest hruškovitá a zřetelnè od zadní části oddělená, a že tenké střevo jest sotva delši svého prủmèru. U terebrantií pak, že přechází přední část stredniho střeva poznenáhla $\mathrm{v}$ zadní jeho část, a že tenké střevo jest mnohokráte svého průmèru delší. Haliday také již udává, že střevo tubulifer jest o polovici delší než tělo, střevo terebrantií však dvakrát delší než toto. K popisu přidává výkresy střeva druhů: Aptinothrips rufa (Tab. VII., fig. 19.), Thrips (= Physopus) vulgatissima (Tab. VII., fig. 20. a 21.), Thrips obscura (= Anaphothrips virgo; Tab. VII., fig. 26.), Limothrips cerealium (Tab. VII., fig. 24.), Sericothrips staphylimus (Tab. VII., fig. 22.) a rodı Phloeothrips (= Trichothrips?; Tab. VIII., fig. 6.).

Do duliny ústní vcházejí vývody slinných žláz. U samic tubulifer a též u terebrantií nalézáme dva páry těchto žláz, u samcủ tubulifer tr̆i. Vètší z obou párů má u samic tubulifer tvar váčku (Tab. IX., fig. 163.. k; Tab. VIIl., fig. 158.). Obsah jejich jest velmi jemně zrnitý, a zbarvíme-li je, vyniknou četná veliká jádra. Vývod žláz tohoto páru obklopen jest na basi velikými buňkami, zr̃etelnými jádry opatřenými. Druhý pár (Tab. IX., fig. 163., $l$; Tab. VIII., fig. 159.) jest značně menší, podlouhlý. Uprostred žláz těchto nalézá se veliká dutina v jednotlivé sklípky rozdèlená. Stěny jejich jsou jemnẽ zrnité a mají jednotlivá veliká jádra. Kolem vývodu nalézá se několik větších a několik menších kulatých a bledých buňek (Tab. VIII, fig. 159., c). Obě žlázy ukončeny jsou 
tenkou nitkou $(d)$. U samcủ druhu Trichothrips copiosa nov. sp. nalezl jsem kromè těchto žláz ještě jeden pár (Tab. IX., fig. 163., $m$ ), ze všech nejdelší, válcovitý, směrem k ústí poznenáhla se zúžujicí. Obsah těchto žláz jest prostoupen jemnějšimi a hrubšími zrnky a rozdělen patrnými hranicemi na veliké buňkỵ, z nichž každá obsahuje mimo jmenovaná zrnka veliké jádro (Tab. VIII., fig. 160.). Středem ð̌lázy táhne se dutina velmi nepravidelně zašlkrcovaná a naplněná čirou látkou, neobyčejně silně světlo lámající.

U terebrantií jsou oba páry žláz slinných mezi sebou velmi rozdílné. Kratši z nich (Tab. IX., fig. 164., l) podobá se u některých druhủ (Acolothrips) značnè vètšimu páru žláz u samic tubulifer, konec jejich jest však zašpičatělý. Druhý pár (i) jest velice dlouhý a tenký a sahá až do druhé poloviny abdomenu, kdež pr̃ipevñuje se k stènám předního odstavce žaludku $(k)$. Touto žlazou po celé délce jeji táhne se jemný kanálek, který v malé stluštěnině ̌̌lázy $(j)$ před ústím jejím trochu se rozšiřuje. U jiných druhủ (Thrips flava. Parthenothrips dracaenae) nalézáme sice také tyto dlouhé nitkovité žlázy slinné. koncem $\mathrm{k}$ žaludku prirostlé, prvý pár však má jiný tvar. Kolem ústřední dutiny rozestaveno jest totiž několik velikých buněk s velikými jádry, která tvoři krátký měchýrek, jenž umistněn jest bud na konci hrudi neb na počátku abdomenu. Tenký, nitkovitý vývod jeho jest následkem toho velmi dlouhý.

Vývody obou párů slinných žláz jedné strany spojují se v jednu chodbičku, která opèt splyne dle Bohlse přẹ samým ústím do chitinové slinné baňky s chodbičkou, vytvořenou vývody obou žláz strany druhé.

R. 1852. viděl Haliday poprve žlázy slinné u třásněnek a píše o nich, že skládaji se ze dvou tvarem různých párů, jejichž vývody jsou nitkovité. Výkresy jeho, které se žláz těchto týkaji (Tab. VII., fig. 16.; fig. 19. $h$, $i$; fig. $22 . h$; fig. 25 ; fig. $26 . h$. Tab. VIII., fig. 17. $m$; fig. 18.-22.), jsou částečně neurčitými.

\section{ÚSTROJE OBĚHU KRVE. KREISLAUFSORGANE.}

Srdce jest u třásněnek velmi krátké a má podobu malého váčku, k oběma koncům zúženého. Leži bud celé v osmém článku abdominalním, aneb jednou polovinou v článku sedmém, druhou v osmém. Jest jen as tak dlouhé jako jediný článek zadku. $V$ předu vystupuje z něho aorta, kterou Jor d a n sledoval až do hrudi. Pozorujeme-li nějakou třásněnku pod mikroskopem v glycerinu, lze velmi dobře rychlỵ tlukot přemalého srdečka pozorovati.

Haliday r. 1836. udává, že krev larev i dospělého hmyzu druhu Anthothrips statices jest červená. To však jest omỵl. Červený pigment, který ho klamal, leží u mnohých larev tubulifer i dospělého hmyzu v tělese tukovém, v němž sám Haliday r. 1852. nalezl více neb méně četná, v klubička shluklá zrnka barvy krvavé. Já pozoroval jsem také světlé kuličky tukového tělesa poseté nesčíslnými, přemalými, červenými zrníčky, která jevila čilý brownický pohyb. 


\section{H. UZEL, MUNOGRAPHIE DER ORDNENG THYSANOPTERA.}

\section{ÚSTROJE DYCHACÍ. \\ ATHMUNGSORGANE.}

Rozvětvená sif wzdušnic u lřásněnek jest ve spojeni se světem vnějším vždy ètyřmi páry otvoru dychacích (stigmata). Proní pár (Tab. X., fig. 172., 1) nalézá se na předních rozích středohrudi, druhý (2) na zadohrudi hned za kořenem dolejších kirídel (Jordanem u terebrantii přehlédnut), tretí (3) pár na próm článku a ètrrtý (f́) na osmém článku abdominalním. - V následujicich řádcích sledovati budeme pruběh vzdušnic u bílých samcú druhu Thrips physopus, kteři k tomu pro prủsvitnost svého chitinu nejlépe se hodí (Tab. X., fig. 172.). Od otvoru dychacího, na pr̉edním rohu středohrudi se nalézajíciho (1), jde do predu těla silná vzdušnice $(a)$. směřujicí prímo ke kořenu tykadla. Tato vzdušnice vysýlá as uprostred předohrudi věter do prední nohy (b). Hned na to vychází na její vnitřní straně tenká vzdušnice $(c)$, klerá spojuje se na rozhrani mezi předohrudí a hlavou se svou symmetrickou větvičkou druhé strany. Společně ubíraji se pak př́mo $\mathrm{k}$ prednímu očku. kdež se zase rozvětvují. Vzdušnice obou stran spojeny jsou mezi sebou príččou $(d)$, jež nalézá se za prostředkem predohrudi, a jež ústí se do větve, jdouci do předních noh $(b)$, nedaleko base jeji. Také obě stigmata středohrudi spojuje silná přičč (e), kiterá prìiéhá k mesosternu. Jeji zadní stěna opatrena jest velmi četnými, tenkými a krátkými větvičkami. Nazad vysýlá stigma stredohrudi silnou vzdušnici, ktera tvor̂i pủlkruh dovnitr̃ vypouklý $(f)$. Druhý jeji konec ústí se do dỵchaciho otvoru středohrudi (2). Zvláštností toho oblouku jest. že uprostred na vnèjší straně má velmi krátký př̉iěsek $\left(f^{\prime}\right)$, za nímž náhle značně se zúžuje. Konečně vysỵlá stigma středohrudi ještě tenkou dlouhou věter do druhého páru noh $(g)$, která krátkị́m ramenem $(h)$ s otvorem dychacim zadohrudi souvisí. Stigma zadohrudi (2) spojuje se se stigmem druhé strany př̀ickou $(i)$, přiléhajicí $k$ metasternu. Také tato príčcka má na své zadní straně množství velmi lenkỵch a krátlị̂ch větviček. Stigma zmíněné vysýlá dlouhou, stočenou vzdušnici $(j)$ do otvoru dychacího prvního ělánku abdominalního (3). z. níž větev vchází do zadní nohy. Od otvoru dychacího, posledně jmenovaného, jde do hrudi velmi silná vzdušnice $(k)$, která dosti náhle dvěma větvičkami se zakončuje právě před oním přivěskem $\left(f^{\prime}\right)$ oblouku, spojujicího stigma stredohrudi se stigmem zadohrudi, o němž jsme nahoře se zmínili. Jest pravděpodobno, že tato vělev s prední, silnou číslí oblouku byla v dřívējšich stadiích vỹvoje ve spojení. Nazad vyssýlá stigma prvého článku abdomenu dvě dlouhé větve, které ústí se do otvoru dychacího na osmém élánku jeho (4). Z těch větví běží silnější (l) dorsalně a lateralně, slabši pak ventralně $(m)$ a bliží se strední éáre. Paměthodno jest. že dorsalní větev v každém èlánku rysýlá králké silné rameno na vnější stranu (u). jež slepě se zakončuje*). Do koncù všech těchto slepých ramen (v 2.-7. čl. abdom.) ústí se tenká vètev (v). vycházející taktéž v každém článku ze vzdušnice ventrahní. V třelím, čtvrtém a pátém ělánku abdominahnín pak

*) Srovnej té\% rýktes Halidayúr z t. 1×52. (L. е̌. 61.: Tab. VII., fig. 30.)! 
přijímá ono slepé rameno na konci ještè velmi krátkou a tenkou, samostatnou vzdušnici (u), kterou také Jordan již viděl. Zde máme dobrou př́ležitost zastihnouti př́rodu takřka v tvoření. Není vše hotové v těle živočichủ, mnohé se mění; ovšem poznenáhla, během tisíciletí. Tak i zde před námi leži práce nedokončená. Patrně vedly jednou slepá ramena $\mathrm{i}$ obě vzdušnice $\mathrm{k}$ otvorủm dychacím, na dotyčných ěláncích abdominalních se nalézajicím, které však již se nezachovaly. - Otvor dychací na osmém ělánku abdominalním (4) vysýlá nazad vzdušnici (ž), která v obou posledních ěláncích tèla značně se rozvětvuje. Obè stigmata toho článku spojena jsou přičckou $(z)$, která opisuje oblouk do předu ohnutý. U nèkterých tubulifer nejsou obè stigmata přičkou spojena, ny̛brž obě hlavní větre vzdušnic v článku sedmém.

Stigmata jsou obyčejnẻ okrouhlá a mají na svém povrchu množství svètlejšich skvrn, z nichž každá opatřena jest dirkou. Skvrny zmíněné pocházejí dle Jordana od malých dutin, dirkou se světem zevnějším spojených. Iprosřed pak nalézá se otvor hlavní, kterỵm otvírá se vzdušnice na venek. Vakủ vzduchovy̧ch u třásněnek není, jak to již Haliday r. 1852. poznamenává.

\section{ÚSTROJE VYMĚŠOVACÍ. EXCRETIONSORGANE.}

Žláz malpighických, ústrojủ to vyměšovacích hmyzủ, nalézáme u tr̉ásněnek dva páry, jak již Haliday r. 1852. poznal. U tubulifer a stenopter ústí se každá ze čtyř żláz malpighických do střeva samostatně. U coleoptral (Aeolothrips) ršak (Tab. IX.; fig. 164.) spojuji se obě žlázy jedné strany $(f), v$ jediné prímce ležící, ve společný vỹvod (g), na prímku tu kolmý. Průběh žláz malpighických má zde tedy podobu písmena $H$. U tubulifer (Tab. IX., fig. 163.) jsou obě přední žlázy obyčejně o něco kratší než obě zadní. Oba páry bývaji mělkými zaškrceninami rozděleny v ěetné komůrky. Obsah žláz malpighických naplněn jest množstvím malých hnědých zrníček, produktủ to vyměšování. Stredem jejich po celé délce vine se úzká chodbička.

\section{ÚSTROJE POHLAVNÍ. GESCHLECHTSORGANE.}

Ústroje tyto jsou u obou podřádủ třásnènek dosti rủzně vytvořeny, a bude tudíz vhodno popsati je pro každý zvláště.

Samčí ústroje tubulifer (Tab. IX., fig. 165.) skládaji se ze dvou varlat $(a)$ a dvou párủ žláz prídavných $(e, f)$. Každé varle jest celistvou hmotou, k obèma koncům zúženou. V zrnitém obsahu jeho vidíme jednotlivé buňky, z nichž se tvoři chámy, jež naplñují střed varlete, kdež jsou seskupeny ve svazky. Vývod každého varlete (vas deferens, $b$ ) jest as dvakrát delší než toto a nedaleko za svou basí $(c)$ a před koncem $(d)$ se rozšiřuje. Světlost' jeho 


\section{H. UZEL, MONOGRAPHIE DER ORDNUNG THYSANOPTERA.}

naplněna jest svazky chámù, které zvláštẽ v oněch stluštěninách se nahromadují. Vývody varlat spojuji se ve společnỵ chámovod (ductus ejaculatorius. i), do jehož base, poněkud rozšírené, ústí se oba páry žláz přídavných. Žlázy vnitřního páru (e) jsou podlouhlé, zaokroublené a i se svým rývodem, v nèjž znenáhla procházejí, as tak dlouhé jako varle. Svěllost jejich, naplněná tmavou zrnitou hmotou, obklopena jest malỵmi velmi četnými buňkami se zřetelným jádrem. Vývod těchto žláz má asi délku żlázy samé a jest uprostřed trochu rozšířeny̦. Žlázy vnějšího páru $(f)$ jsuu i s vỵ́vodem o trochu delši než žlázy vnitr̉ní. Obsab těchto žláz je světlý a obklopený dosti velikými buñkami s jádrem velmi zřetelným. Vývod jejich začiná náhle a má všude skoro stejný prủměr. Jen před koncem najednou se poněkud zúžuje; za zúženinou pak rozšiřuje se v malou baňku $(g)$, jež se ústí do lichého chámovodu (i). Tento má na své basi nevelikou vedlejší dutinku podoby polokoule (h) a vcházi do pyje, nalézající se mezi devátým a desátým kroužkem abdominalním. Pỵj má u rûznỵch druhû tubulifer rũznou podobu. U jednèch (tak u Trichothrips copiosa nov. sp. a Phloeothrips brmmea Jordan) představuje nám krátký lalok o dvou cípech, jehož basis obklopena jest r̀asnatým límcem. U jiných (u Anthothrips statices a aculeata) vidíme na konci vychlípené části společného chámovodu, mající podobu váčku (Tab. VIl., fig. 130., a) dvè tenké, tèsnè vedle sebe stojící chitinové tyčinky (b). - Chám má podobu priedlouhé tenké nitkỵ. — Haliday r. 1852. již udává, že tubulifera maji mimo varlata dva párỵ žláz prídavných a kreslí ústroje samcí od rodı Phloeothrips (= Trichothrips? - Tab. VIII.. fig. 9.-11.).

Samičí ústroje tubulifer (Tab. X.. fig. 167.) skládají se ze dvou raječníkủ, z nichž každý pozủstává ze ětyř rourek vaječných $(a)$. Y těch na distalním konci vylvořuji se vajičcka, jež čím dále tím vice vzrủstaji. takže væ̌dy poslední jest největším a nejzralejším (b). Vaječné rourky ústí se na každé stranè do pohárovité rozšireniny vejcovodu (d). Vejcovody obou stran $(c)$ spojují se r lichý vejcovod $(e)$, tak zvanou dèlohu, jejíz konec, pochva, ústí se na venek, rovněž jako ústroje pohlavní u samcú, mezi 9. a 10. ěl. abdom. Lichý vejcovod opalren jest zásobárnou chámu (receptaculum seminis), která u druhu Trichothrips copiosa nov. sp. zcela jinak je utvořena ně̆ dotyčný ústroj, Jo rdanem od druhu Plloeothrips brumea popisovanỵ. Zásobárna chámu jest u druhu Trichothrips copiosa velmi ozdobnou a podobá se loutce. majic hlaričku $(f)$, krček (g) a těličko $(h)$. Tolo pokryto jest mnohými velikými žlaznatými buňkami se zr̉etelným jádrem, skrze něž prosvítaji svazky nahromaděného chámu ( $j$ ). Chodba, jdoncí krěkem, jest dokola obklopena jednou vrstvou velikých buněk. Hlavička pak má velmi tenké stěny, jedinou vrstvou malých buněk utvořené. Prostranná dutina jeji jakož i chodba v krčku bỵvají taktéž chámem naphněny. Do dutiny hlavičkỵ vchází přetenká a velmi dlouhá rourka (i), jež druhým koncem jest ve spojení s lichỵ́n rejcovodem. Místo, kde se tato rourka s ním spojuje, jest vyznačeno žlutým pigmenten. Rourka pak sama opatřena jest na samém ústí dvěma velmi krátkỵmi chitinovỵmi tyčinkami, které srètlost jeji drží olevrienou. Hlavičkia zásobárny chámové leži v těle tř̀asněnky dotyčné mezi šestým 


\section{J. UZEL, MONOGRAFIE RADU, "THYSANOPTERA“.}

a sedmým kiłoužkem abdominahním. Žlázy mazové tubulifera nemaji. U některých druhû (ku príkladu Trichothrips copiosa, Acauthothrips nodicornis atd.) jsou vždy dvè a dvě rourky vaječné distalním koncem $\mathrm{k}$ sobě přirostlé. $Z$ toho společného zakončení vychází po jedné tenké nitce (Endfaden; Tab. X., fig. 167., k), která brzy spojuje se s nitkou sousedního páru rourek vaječných. Společná nitka (l) připevĩuje se na zadní konec většího z obou párủ žláz slinnỵch $(m)$, jak to již Haliday r. 1852. (L. č 61.; Tab. VII., figg. 16.) poznal. Nilkami těmi, jádry sem tam opatřenými, navzájem drží se tedy slinné žlázy i vaječníky $\mathrm{v}$ poloze stálé. U jiných druhů (Anthothrips statices a aculeata) jsou všecky čtyrìi rourky vaječné každého vaječníku distalními konci spojeny. Z tohoto společného místa pak vỵchází jen jediná nitka. - R. 1852. praví již Haliday, že vaječníky tr̉ásněnek vủbec jsou prstovitě rozložené, a že mají po čtyrech rourkách vaječných o mnohỵch komůrkách; kreslí je od druhủ Phloeothrips (= Anthothrips) statices a Phloeothrips (= Trichothrips) pini (Tab. VIII., fig. 12. a 13.).

Samči ústroje terebrantií (v tom ohledu zkoumal jsem zvl. druhy: Thrips physopus, Physopus vulgatissima a Aeolothrips fasciata) složeny jsou ze dvou varlat (Tab. IX., fig. 166., a) a jen z jednoho páru žláz př́davných (f), jak již Haliday r. 1852. poznal a od druhu Limothrips cerealium vykreslil (Tab. VII., fig. 1., 4. a 5.). Varlata mají bud podobu protáhle hruškovitou, aneb jsou k oběma koncum zúžená. Barva jejich jest hnědá až pomerančová, následkem čehož prosvítají abdomenem. Vývod jejich (b) jest bud jen tak dlouhý jako varle samo, aneb o něco delší. Na konci někdy (u Thrips physopus, $c$ ) dosti značně se rozšiřuje. Ductus ejaculatorius (e), do něhož vývody varlat se ústí, jest na basi značně, někdy neobyčejně rozšířený $(d)$. Do této rozšíreniny jeho ústí se jediný pár žláz přídavných $(f)$, které svou velikostí často překonávají varlata. Tvar jejich jest podlouhle vejčitý. Kolem ústřední jejich dutiny jest rozestavena jedna vrstva velmi objemných buněk žlaznatých. Vývod těchto žláz jest velice krátký. Ductus ejaculatorius ústí se do apparatu pyjového, jenž jest mezi oběma posledními články abdominalními vychlípitelný. Pyj jest chitinový osten, $\mathrm{k}$ němuž se z každé strany prrikládá jedna chitinová pochva ('Tab. V., fig. 54., a). Všechny tři části běží, jsou-li vychlípeny, pod posledním článkem abdomenu (který nemá desky bř̉šní) až na špičku jeho, kdež koncem srým nahoru jsou ohnuty. Pochvy pyje jsou někdy háčkem zakončeny (tak u druhu Plıysopus robusta; Tab. V., fig. 56., a). Jordan míní, že výtok chámu nedèje se pyjí, nýbrž vychlípitelným lichým chámorodem, a že pyj i jeho pochvy slouži jen $\mathrm{k}$ vedení tohoto ústroje.

Samičí ústroje terebrantií (Tab. X., fig. 168.) jsou podobně vytrořeny jako u tubulifer. Také zde pozủstává každý vaječník ze čtyř rourek vaječnỵch $(\alpha)$, které na každé straně úslí se do vejcovodu $(c)$, na konci pohárovitě rozšíreného $(d)$. Oba vejcovody spojuji se brzy v lichỵ vejcovod $(e)$, jenž vchází do kladélka, vyčnívajícího mezi osmým a devátým článkem abdominalním. Rourky vaječné nesrůstají nikdy distalními srými 
konci. Kað̌dá \% nich zakončena jest svou vlastní nitkou (k). Do lichého vejcovodu ústí se zásobárna chámová. Tento ústroj skládá se u druhu Aeolothrips fasciata z malé baňky $(f)$ podoby vejčité, která však na jedné straně jest značněji vypouklá než na druhé. Ústrední dutina jeji obklopena jest četnỵmi zřetelnými buňkami. Z této zásobárny vychází dlouhá, velmi úzká chodbička (g): jež pr̉ed svým ústím se rozšiřuje ( $h$ ). U jiných třásněnek (na př. u druhu Plıysopus atrata; Tab. X., fig. 169.) má dutina baňky (c) a jeji vývod (b), někdy na príic jemně linkovaný, podobu křivule, jak ji k fysikalním pokusủm užíváme. Opět u jiných (na pr̃. u druhủ Thrips physopus a communis) má baňka podobu hlemýždě o jednom závitu. Kromě zásobárny chámové vcházi do lichého vejcovodu ještě krátký vývod objemné žlázy mazové (Tab. X., fig. 168., i, j), která pravidlem jest hnědě neb červenavě až pomerančově zbarvená a $\mathrm{v}$ sedmém článku abdom. se nalézá.

Ústí pohlavních ústroju samičich obklopeno jest, jak již praveno, kladélkem (Tab. X., fig. 170.). Toto pozůstává ze čtyr̃ do oblouku zahnutých, velmi ostře se zakončujících chlopní, z nichž obě přední z ventralní části osmého článku se vyvinuly, obě zadní pak z ventralní části deválého. Oba páry chlopní jsou vespolek $\mathrm{k}$ sobě přiloženy tak, że uzavírají prostor, jímž právě vajičko mủže procházeti. Obě přední chlopně (Tab. X., fig. 171., $a, b$ ) jsou na okraji, kterým prìléhají $\mathrm{k}$ sobě, ostře a drobně zubaté. Vedle těchto zubủ má každá chlopeñ as uprostřed ještě řadu šikmo ležících chitinových lišten. ostře zakončených, počtem obyčejně sedm (Tab. X., fig. 170., c; fig. 171., c). Přední a zadní pár chlopní spojuje se pomocí značnè stlustlých svých okrajủ (Tab. X., fig. $170 ., b, e)$ velmi pevně tím zpủsobem, že okraje zminěné opatřeny jsou u chlopní hořejších po celé délce své žlábkem nahor̀e zúženým, do něhož zapadají lištny, na okraji chlopní dolejších se nalézajicí. 'Tim stává se odchlípení se jedněch od druhých (ve smèru přičném) nemožným, ač prì tom volnému podélnému pohybu jejich těsně podle sebe vpred i vzad zařízení to není nikterak na závadu. Zadní chlopně (Tab. X., fig. 170., d) jsou na zadním svém okraji, kterým prìléhají k sobè, ostře vroubkovány. Přední stlustlý okraj zadního páru chlopní (Tab. X., fig. 171., e) jest vklouben do mèlkého vyyřezu silné chitinové desky $(g)$, která na druhé straně taktéž kloubem spojuje se se silnou chitinovou oporou $(h)$, na konci vykrouženou. Zadní stlustlý okraj předního páru chlopní $(d)$ má na svém konci silný sval, který pomocí chitinového svazu $(f)$ k nèmu přiléhá. Přední okraje předního páru chlopní zakončují se protáhlým pohárovitým výtvorem $(i)$, který má na konci dvě mělké jamky, jež přikrývá malý poklop $(j)$ podoby střevíčku, jedním koncem na okraj pohárku připevněný. Pohárek dotýká se jakési tenké chitinové desky $(k)$, která se opírá o širokou chitinovou páku ( $l$ ). Za onou chitinovou deskou nalézá se dlouhá chitinová tyčinka $(m)$, která se svou družkou \% protější strany slouži asi k tomu, aby dutinu pochvy držely otevřenou. Celé kladélko $\mathrm{v}$ klidu ukryto jest $\mathrm{v}$ hluboké rýze, nalézajicí se na ventralní straně dvou posledních článkủ abdominalních (Tab. X., fig. 170., f), které nemaji desek břišních. 


\section{J. LZEL, HONOGRAFIE RADU, „THYSANOPTERA“.}

Chce-li tr̃ásněuka polożiti vajičko do dužninỵ listoré, vychlipi své kladélko, které pak na osu těla skoro kolmo stojí, a tlači je ostrou špičkou proti povrchu listu. Tím vznikne otvor, kiterým proniká kladélko vždy hloubèji, rydatnè prìi tom si pomáhajíc svými ostre jako pila ozubenými chlopnèmi, kleré svaly se uvádèji v pohyb strídarè vpred a vzad. Pr̀edním párem hỵbá sval na konci slluštěniny zadního okraje přednich chlopní se nalézajíci (fig. 171.,f). Kảyž tento sval se smrští, pohybuji se dotyčné chlopně vzad, kdy̌̌ popustí, vpřed. U zadních chlopní jsou poměry jiné. Když zde smrští se svaly, jež jimi hỵbají, a jež se přiliádají na konec vnējšího sllustlého okraje silné desky (g), nahoře popsané, tu pủsobí deska tato jako páka, jejǐz podpưrný bod jest tam, kde spočívá ve vykroužené chitinové opore, tlačic vkloubený do ní přední okraj zadního páru chlopní vpr̉ed. Zpětný pohyyb dēje se zvláště svalem (proti svalu, o němž právě byla řeč, púsobícím). který prìkládá se na konec vnitřního (nestlustlého) okraje oné desky, př̀i čem̌̆ zase deska chitinová jako páka působí. - Ještě sluší podotknouti, že kladélko stenopler jest prohnuto dolů. kladélko coleoptrat nahoru.

R. 1836. vidèl Haliday poprvé kladélko terebrantií. Praví, že je sploštilé, že skládá se ze čtyr̃ chlopní, že je ukryto ve skulině devátého a desátého článku abdomenu, a \%̆ osmý článek tohoto jest dole rozčísnut. Téhož roku Burmeister právem podotýká, že jest \&. čl. abdominalní dole jen vykrojený. Tenty̌z̆ autor podává r. 1839. (L. č. 50.) ryobrazení kladélka a jeho ěástí od druhủ Heliothrips haemorrhoidalis a Chirothrips manicata. Poznal již, že obě předni chlopně vycházejí z osmého článku abdom.. obè zadní pak z devátého, že chlopnè jedné strany spolu sice pevně souvisí, že však podle sebe mohou se pohybovati. Také již vidèl chitinové opory kladélka, avšak nezretelnè. R. 1854. vyobrazil Heeger (L. č. 66.) kladélko druhu Parthenothrips dracaenae, avšak ne dosti správně. Kíreslí již chitinovou desku, s níž na jedné straně spojen jest stlustlý okraj dolejši chlopnè, a jě̌ na druhé stranè prìiéhá kloubem $\mathrm{k}$ dlouhé chitinové opor̀e. R. 188s. vyobrazuje Jordan kladélko od Parthenothrips dracciencie.

\section{SEKUNDARNÍ ZNAKY POHLAVNÍ. SECUNDÄRE GESCHLECHTSCHARAKTERE.}

Samci trásnènek terebrantialních liši se od samiček prederším nedostatkem kladélka, rozměry tèla menšimi, zadkem všude stejně širokým a tupě zakončeným, zbarvením často svètlejším a pohyby čilejšími. Zuby, které u několika druhủ podřádu tohoto na konci predních tibií stojí, jsou u obou pohlaví stejnè vyvinuty. Také stlustlá prední stehna, jak je u některých druhù nalézáme, nejsou výhradným majelkem jednoho pohlaví. U mnohỵch druhủ. jejicȟ̌ samice jsou dlouhokřídlé, jsou samci opatreni jen rudimenty krídel. pterothorax nepřesahujicími. U třásněnek terebrantialních platí rovněz jako u tubulifer pravidlo, že druhy, které vykazují samice nèkdy dlouhokîídlé, jindy krátkokřídlé. mají samce vždy krátkokirídlé. Jedinou rýjimkou u terebrantií jest Serico- 
thrips staphylinus, a u tubulifer Trichothrips pedicularia, u nichž obě pohlaví maji někdy křídla úphně vyvinutá, kdežto jindy jsou u obou zkrácená, resp. úplnẽ zakrnèlá. Samci rodû Chirothrips a Limothrips liši se od svỵch samic tím, že nemaji oček. Největší počet sekundarních znaků pohlavních mají samci na abdomenu. U rodû Chirothrips, Sericothrips, u většiny druhủ rodu Physopus, dále u rodủ Rhaphidothrips, Oxythrips, Pachythrips, Anaphothrips. Belothrips a Thrips mají obyčejně 3.-7. (zirídka 4.-6., 4.-7. neb 3.-6.) článek abdominalní dole po jedné svěllé prohlubině (Tab. VI., fig. 99.), která jest bud' okrouhlá neb elliptičná aneb piškotovitě napríč protáhlá. Samcům druhu Physopus phalerata scházeji na článcích abdominalních dole světlé prohlubiny, za to však prodlužuje se 4.-7. čl. na zadním kraji na břišní straně uprostřed v malý okrouhlý čípek (Tab. V., fig. 60.). U druhủ Plyysopus robusta (Tab. V., figg. 56., b) a aspera mají samci na osmém čláuku abdominalním na obou stranách po jednom silném, dosti dlouhém, odstávajícím trnu. Samci rodů Oxythrips (Tab. VI., fig. 71., a), Pachythrips a Auaphothrips jsou opatreni na devátém článku abdominalním dvéma páry velmi kirátkých, silných ostnủ, * nich\%̆ přední jest mohutnější než zadní. Rod Drepanothrips má samečky ozbrojené na devátém článku abdomenu na každé straně velmi dlouhỵm. srpovitě prohnutým, černỵm príivěskem (Tab. VII., fig. 114., a). Desátý článek jeho má podobu krátké roury. Samci druhu Limothrips denticornis jsou na zadních rozich devátého článku abdom. opatreni jedním dosti dlouhỵm ostnem a uprostred nahoře jedním párem sbliženỵch mohutnỵch trnů, ostře zakončených (Tab. VI., fig. 51.) Zadní okraj téhož článku jest lemován klikatou lištnou. — Samci coleoptrat mají prvý článek abdomenu značně prodloužený a nahore dvěma podélnými kýly opatřený (Tab. V., fiğ. 40.). U rodu Melamothrips jest tento článek skoro sedmkrát delší než následujici. U druhu Acolothrips fasciata má samec nahoře na devátém článku abdom. černou trojhrannou desku (Tab. V., fig. 48., (l), po obou stranách téhož článku dvouhrotý vỵ́tvor pridržovací (e) a na 4. a 5. čl. abdom. nahoře po dvou malých lalůčcích $(b, c)$; u druhu Rhipidothrips gratiosa nalézáme na místě dvouhrotého výtvoru na každé straně devátého článku jen nepatrný hrbolek. Konec abdomenu jest u samcú terebrantií vždỵ tupý, což zvláštè nápadno jest u těch druhư, jichž samice mají konec těla značně prodloužený, jako rod Pachythrips. Oxythrips (zvl. druh hastata) a predevšim rod Belothrips. U druhů Physopus vulgatissima (Tab. V., fig. 54.) a temuicornis jest konec abdomenu u samcův opatřen velmi tuhými chlupy, kdežto u samcův ostatnich terebrantií jsou chlupy ty slabé.

Samci tubulifer liší se od svých samic postavou menší a užší. Přední stehna samcủ jsou obyčejně značně širší (u rodủ Megalothrips, Zygothrips a Acanthothrips jsou přední stehna u obou pohlaví stejně široká; u druhı Phl. coriacea jsou u samce sotva více stlustlá ně̌ u samice) a zub na předním tarsu jest ponejvíce mohutnější (u rodu Acanthothrips jest naopak zub na předním tarsu u samcủ slabší než u samic). U nèkterých rodů (Cryptothrips a Zygothrips), u kterých samice na předním tarsu 


\section{J. UZEL. WONOGRAFIE RADU „THYSANOPTERA“.}

nemaji zubu, jest tento u samcû př́tomen. Samci rodu Megalothrips maji na šestém článku abdominalním nahoře na kraji po obou stranách velmi dlouhý, od těla nahoru a trochu na stranu odstávající, rourovitý výrostek, zakončený hrboulkem neb chloupkem (Tab. III., fig. 19., fig. 22.). Mimo to jest u samcủ druhu Megalothrips Bonannii pátý kroužek abdomenu na stranách uprostřed náhle rozšiřený, a sedmý opatřen jest po obou stranách malým ostrým cípkem (Tab. IIl., fig. 19.). Tento cípek nalézá se také u samců druhu Megalothrips lativentris (fig. 22.), u nichž mimo to ještẽ osmý článek má podobný cípek, větší. U rodủ Megalothrips, Cryptothrips a Zygothrips prìkládá se u samců $\mathrm{k}$ desátému článku abdominalnímu (tubus) na basi po každé straně jeden lupínek (fig. 22, b), který sahá as do prvé třetiny jeho délky. Samce všech tubulifer poznáme konečně velmi spolehlivě dle velikého výkrojku, který se nalézá pod otvorem genitalním na basi desátého článku abdominalního dole (Tab. VII., fig. 140., a), a o nèmž Jor dan mylně se domnívá, że u obou pohlaví se nalézá. Samice poznáme tedy dle nedostatku onoho rýkrojku a pak ještě neomylně dle malé chitinové tyčinky, jež stojí kolmo na zadním dolejšim okraji devátého čl. abdom. uprostřed (Tab. VIl., fig. 139., a).

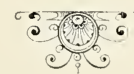




\section{Résumé des anatomischen Theiles.}

In diesem Theile entwarf ich ein Bild der Anatomie der Thysanopteren, indem ich die älteren Entdeckungen (von deren Richtigkeit ich mich durch eigene Studien zu überzeugen suchte), hauptsächlich jene Halidays, Jordans und (was die Mundwerkzeuge anbelangt) Bohls mit den Resultaten meiner eigenen Untersuchungen verband. Das Ganze vervollständigte ich mit geschichtlichen Daten, welche ich den einzelnen wichtigeren Organen beifügte.

Ein übersichtliches Bild der Anatomie dieser Ordnung verschaffen die Abbildungen der vorliegenden Monographie, hauptsächlich auf Taf. VIII, IX u. X; ich weise auf dieselben und auf ihre deutschen Erklärungen hin. Besonders erlaube ich mir aufmerksam zu machen auf das stark concentrierte Nervensystem der Phloeothripiden (Taf. VIIl, Fig. 157), auf die Drüse im Vorderbeine, welche wohl die nöthige Flüssigkeit zum Anfüllen der Haftblase liefert (Taf. VIIl, Fig. 156), auf das dritte (äusserste) Paar von Speicheldrüsen, welches nur bei Männchen von Plloeothripiden (bis jetzt fand ich es nur bei Trichothrips copiosa) vorkommt, den Weibchen jedoch fehlt (Taf. IX, Fig. 163, m), auf die eigenthümliche Form der Malpighischen Gefässe von Aeolothrips (Taf. IX, Fig. 164), auf das Receptaculum seminis von Phloeothripiden (welches von Jor d an anders gezeichnet wird; Taf. X, Fig. 167), auf die vier Paar Stigmen bei den Terebrantien (von denen jenes auf dem Metahorax bis jetzt übersehen wurde; Taf. X, Fig. 172, 2), auf das Tracheensystem der Terebrantien (Taf. X, Fig. 172) und endlich auf die zwei Queradern im Oberflügel der Thripiden, welche die vordere Längsader mit dem vorderen Theil der Ringader verbinden (Taf. VI, Fig. 97, $f, g$ ) und bis jetzt unberücksichtigt blieben. 


$$
\begin{gathered}
\text { IV. CAST } \\
\text { VYVOJEPISNA. } \\
\text { IV. ENTWICKLUNGS= } \\
\text { GESCHICHTLICHER THEIL. }
\end{gathered}
$$





\section{VAJÍČKO.}

EI.

Vajička terebrantií mají obyčejně tvar bobovitý neb ledvinitý, jak již Haliday r. 1852. (L. č. 61.) poznamenává a od druhu Thrips (= Physopus) atrata kreslí (Tab. VIl., fig. 17.). Tak utvořena jsou ku přikladu vajička druhu Thrips physopus, která poprvé vidèl Uljanin (L. č. 98.). Vajička některých druhủ jsou podélně kulatá (druhu Heliothrips haemorrhoidalis dle Heegra), neb podélně vejčitá (druhu Parthenothrips dracaenae dle téhož autora; L. č. 66.), neb skoro válcovitá (Thrips sambuci, tamtéž). Vajička druhu Aeolothrips fasciata jsou bobovitá, na dolejším konci však trochu stlustlejší a na hořejším šikmě ufatá. Již komủrky rourek vaječných u tohoto druhu maji podobný tvar (Tab. X., fig. 168.). Barva vajiček terebrantií jest zelenavě, žlutavě neb čistè bílá, a chorion jejich jest velmi tenký a prủhledný. Zvláštní dirky ku vnikání chámu (micropyle) tu není. Délka těchto vajiček kolisá obyčejně mezi $0 \cdot 2$ a $0.3 \mathrm{~mm}$.

Vajička tubulifer první vidèl r. 1836. taktéž Haliday (L. č. 43.). Authothrips statices má dle něho vajička válcovitá, na jednom konci zaokrouhlená a na druhém knofličkem opatřená. Vajička podobného tvaru viděl též Jordan (L. č. 162.) u jiných druhủ a nalezl v onom knofličku dirku (micropyle). Vajička ostatních tubulifer, pokud jsou známa, jsou sice téhož tvaru, knofličku však nemaji. Tak jest tomu u druhu Trichothrips pini dle Halidaye (L. č. 46.), u druhu Phl. coriacea dle Heegra (L. č. 63.) a u druhu Trichothrips copiosa nov. sp. Barva vajiček tubulifer bývá hnědá neb žlutohnědá (dle Jordana), jindy bělavá (tak u druhu Trichothrips copiosa) neb modravě bílá (dle Halidaye). Phl. coriacea má dle Heegra z počátku barvu červenavě bílou a později světle červenou. - Chorion jejich jest dosti silný a málo (u Trichothrips pedicularia dle Uljanina více) prủhledný. Délka vajiček vètších druhủ jest as (u Trichothrips copiosa) $0.54 \mathrm{~mm}$. a šir̉ka jejich $0.2 \mathrm{~mm}$.

Pod chorionem vajička třásněnek rozprostirá se dle Uljanina tenká a těžko spatřitelná blanka žloutková (Obr. 2., $A, b$.ž), tvořící vak naplnèný kuličkami žloutkovými (జ̈.) šedé barvy. Na vajíčkich z těla mateǐského vyñatých vidíme jádro v podobě světlé skvrny (u.). 


\section{VÝVOJ VAJÍČKA. EMBRYONALENTWICKLUNG.}

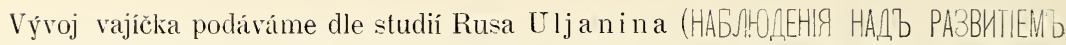
KOSBGHOTHXZ HACBKKOMbXX3. 1874). Obrázky. které pr̃ipojujeme, vỵnali jsme z tabulek týmž autorem nakreslených. Abỵ jim však snáze porozumèno bỵlo. schemalisovali jsme je, takže by̧lo možno často drě neb tr̆i figury Uljaninovy shrnouli v jedinou.

První změna, kterou Uljanin na vajičku tř̌́sněnek (druhu Thrips physopus, jehož se i výkresy tỵkaji) pozoroval, bỵlo zaniknutí jádra a objevení se řady svěllých malỵch bunèk na zadním konci vajička (Obr. 2., B,bl.). Buňky ty vznikly následujícím způsobem. Když vajičko bylo oplozeno, kdy̧z totiž prvojádro mužské spojilo se s prvojádrem ženským, povstalo tím tak zvané jádro rỵhovací. které se rozrýhovalo na množství malých buněk, jež v souvislosti, čile se dělíce, znenáhla postupovaly žloutkem k povrchu vejce, kde pod blankou žloutkovou se usazovaly. Bun̆ky, které Uljanin vidèl, jsou první, které na své místo dospèly. Za nimi následují ostatní, ustavičně se dělíce, takže brzy

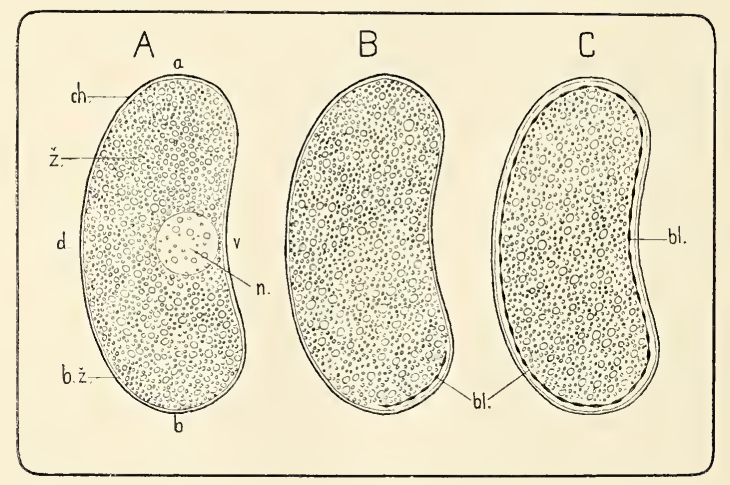

Obraz 2. VYYVOJ VAJICKA TR̆ ÁSNENEK. I. (Schematisováno dle výkresû Uljaninový( h.) *) - $a$, předni konec, $b$, zadni konec vajička, $v$, ventralni, $d$, dorsalní strana jeho, ch., chorion, b. ž.. blanka žloutkorá, ž., žloutek, $u$., nucleus, bl., blastoderm.

obklopen jest celý žloutek jednou vrstrou průsvitných těchto buniček - blastodermem $(C, b l.) . \mathrm{V}$ následujicím stadiu zmohutní na brišñí straně vzadu na podélném mistě blastoderm (Obr. 3., D, d.b.), a to. jak Uljan in pozoroval, vylvořením několika vrstev, čímž povstane tak zvaná deska břišní (Bauchplatte), záliad to proužky zárodečné (Kéeimstreif). Tato deska počíná se na jednom míslě bliže zadního konce vajíčka vchlipovati dovnitř žloutku $(E, v c h$.). I porstane dutina. I. zv. dutina amnionoví $(F$, d. c.), jejǐz dorsalní

*) EMBRYONALENT WICKLUNG DER THYSA NOPTEREN. I. (Schematisiert nach Uljanins Zeichnungen.) - a, vorderes. b, hinteres Ende des Eies, $v$, ventrale, $d$, dorsale Seite desselben. ch., Chorion, 7. ž. Dotterhäutchen. ž. Dotter, n., Nucleus, bl., Blastoderm. 


\section{J. UZEL, IONOGRAFIE RADU, "THYSANOPTERA“.}

tenká stěna pozủstává \% plochỵch bunèk a sluje amnion $(a m$.), a jejiž ventralní stlustlá stèna představuje nám proužku zárodečnou ( $p . z$.$) , z níz během času tẽlo hmyzu se vy-$ vine. Tato proužka vchlipuje se čím dál tím více dovnitř žloutku (Obr. 4., G), až dostane se do něho celá, načež přeroste otvor, kterỵm vchlipování se dálo, blastodermem, a amnion tvoři pak s proužkou zárodečnou uzaviený vak, tak zvaný vak amnionový $(H, v$, a $m$.).

Nezi vchlipováním dèly se na proužce zárodečné samé dủležité zmèny. Nejprve objevila se podélná rỷha, táhnoucí se středem proužky a dèlící tuto na dvě soumèrné části. Tato rýha není nic jiného než ústí velice protáhlého blastoporu. Střední úzké pole proužky zárodečné klesá tolì po celé své délce pod niveau svého okolí; když pak dosáhlo určité hloubky, zavrou se nad ním sousedni vrstvy, takže pole se vchlípivší objeví se vespod. Tato část vchlípená jest základem entodermu a mesodermu, kdežto vrstva ji pokrývající jest základem ectodermu.

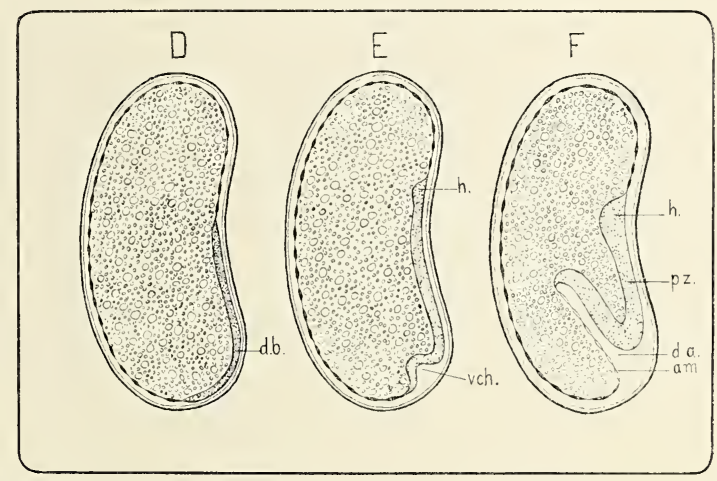

Obraz 3. VIVOJ VAJÍC̆KA TŔŚSNENEK. II. (Schenatisováno dle výkresủ Uljaninových.)*) - d.b., deska břišni, vch., vehlípenina jeji, h., laloky hlavové, d.a., dutina amnionová, um., annion. p.z., proùka zárodečná.

Na pỉedním konci proužky zárodečné, hlavè budoucího zárodku odpovídajicím, jeví se již záhy postranni výrủstky, tak zvané hlavové laloky (Obr. 3., E, $F, h$.). Těsně za nimi po čase začíná tvor̀ení se tykadel (Obr. $4 ., G, t)$ a dále za nimi spatřiti lze již základy tří párủ kusadel $\left(m \boldsymbol{c} l ., m x_{1}, m x_{2}\right)$. Na budouci hrudi pak znamenáme tr̆i páry malých, rỵchle však vzrủslajících prívěskủ, základy to noh. - V tu dobu počíná se jeviti na předním konci vajička stloustnutí blastodermu neboli serosy (jak jej po uzavření se duliny amnionové jmenujeme). kleré záleži v tom. že jednotlivé buňky mění svou podobu, stávajice se \% ploských kulatými $(G, s . s$.).

* EMBRIONALENTWICKLUNG DER THYSANOPTEREN. II. (Schematisiert nach Uljanins Zeichnungen.) - d.b., Bauchplatte, rh., Einstülpung derselben, h., Koptlappen, d.a., Amnionhöhle, am., Amnion, p.z., Keimstreif. 


\section{H. UZEL, MONOGRAPHIE DER ORDNENG THYSANOPTERA.}

Bèhem těchto zmèn roste celé vajičko, takže chorion nemûże již vydržeti tlak vnitřni a praskne podélnou skulinou $(H$, o.ch.) nad stluštèninou blastodermu. Skulina se čím dále tím více rozšiřuje, takže vajičko předním koncem vyčnívá. Ǩdy̌̌ byly ústroje ústní a tykadla i nohy dosáhly jakési velikosti, a když se byl obsah vajičcka od obou koncu jeho dosti značně odchlípil $(H, d, d)$, nastane ve vajičku změna velmi památná, totiž obrat zárodku. Vchlipováním desky brìšní dostala se totiž proužka zárodečná vzhledem k poloze pozdējši do polohy obrácené, takže ventralni její strana jest obrácena $k$ doralní stranè vajička*).

Převrat zárodku děje se zpussobem následujícím. Na onom místě $(\boldsymbol{H}$., $\boldsymbol{z}$.$) , kde se$ dříve dálo vchlipování desky břišní, tedy nyní nedaleko hlavy zárodku, př̀iloži se amnion

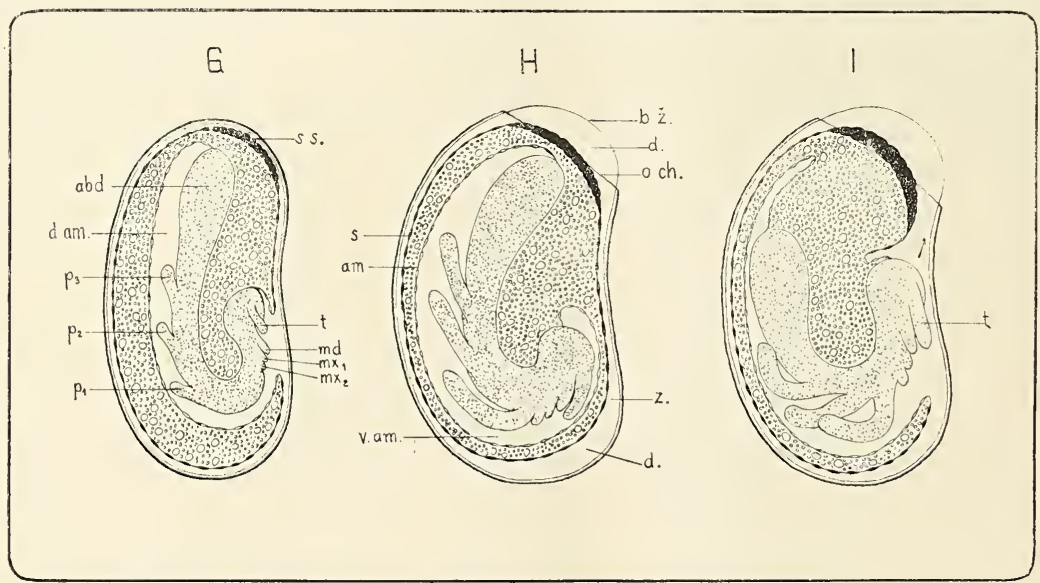

Obraz 4. VÝVOJ VAJIČKA TR̆ÁSNĖNEK. III. (Schematisováno de výkresú Uljanin ových.) **) — d. am., dutina amnionová, $t$, základy tykadel, $m d$, základy prvého, $m x_{1}$, druhèho, $m x_{2}$, třetílı páru (spodního pysku) kusadel, $p_{1}, p_{2}, p_{3}$, základy noh, $a b d$., abdomen, am., amnion, v.am., vak amnionový, s., serosa, s.s., stluštěnina serosy, o.ch., okraj prasklćho chorionu, $b$, ž., blanka žloutková. $d, d$, oba konce vajička. od nichž se jeho obsah odchlipil, z., misto, kde amnionový vak se protrhne.

a serosa těsně na sebe a protrhnou se, takže amnionový vak poznovu se na renek otevře. Tímto otvorem vystoupi nejdřive hlava a pak následujicí články proužky záro-

*) Sluši podotknouti, že předni konec těla zárodku jest u třásněnek (soudě dle obrazů Uljaninovych) vйdy poněkud do předu stočen, kdežto u jiných hmyzů před obratem přmo nazad směruje.

**) EMBRYONALENTWIGKLUNG DER THYSANOPTEREN. III. (Schematisiert nach Uljanins Zeichnungen.) - $d$. am.. $v$. am., Amnionhöhle, $t$, Anlage des Fühlers, $m d$, Anlage der Mandibel, $m x_{1}$, Anlage der Maxille, $m x_{2}$, Anlage der Unterlippe, $p_{1}, p_{2}, p_{3}$, Anlagen der Beine, abd., Abdomen, am., Amnion. s., Serosa, s. s., Verdickung derselben, o. ch., Rand des geplatzten Chorion. $b . z_{\text {. }}$. Dotterhăutchen. $d, d$., beide Enden des Eies, von denen sich dessen Inhalt entfernt hat, z., Stelle, wo die Amnionhöble nach aussen sich öffnen und der Embryo heraustreten wird. 


\section{J. UZEL, MONUGRAFIE RADU, THYSANOPTERA“.}

dečné. Hlava ubírá se $k$ přednímu konci vajička, a pronžka zarodečnả príloži se k ventralni straně jeho. Amnionová dutina stává se tím menší a menši (Obr. $5 ., J$, z.d. a.), až zmizí docela. Obrat zárodliu dèje se velmi rychle, lakže za 10-15 minut jest dokonán.

Amnion a seroșa ohraničují nyní dohromady v podobě vaku žloulek, na hřbetě zárodku se nalézajíci. Serosa mezi tím se poznenảhla zliracuje, její stluštěnina, o níž dríve promluveno, stává se vělši a větši $(H, J)$, načě̌ se však rỵchle resorbuje $(K, r, s$, $L, z . s$.$) . Zbylá část serosy a amnion zúčcistnují se dle Uljanina na trorbě hřbetní$ části těla. Spíše však zdá se, dle analogie s hmyzem jinỵm, že serosa a amnion jsou jen provisorními prikıłývkami hr̉betu, a ze později zanikají. Hr̉betní stranu vytvorí si

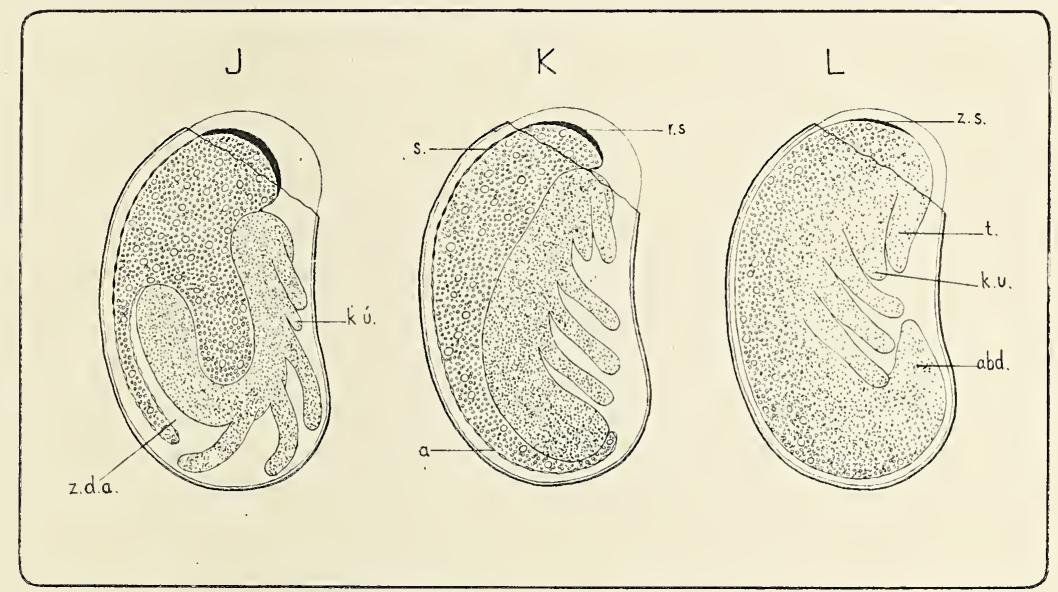

Obraz 5. VÝVOJ VAJÍĊKA TŘÁSNĚNEK. IV. (Schematisováno dile výkresủ Ulja-

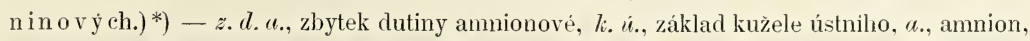
$s$. , serosa, r. s.. resorbujicí se stluštěnina serosy, z. s., zbytek její, $t$., tykadlo, abd., abdomen.

pak proužka zárodečná sama, kidyž byla tak se rozšírila, že kraje její na hirbetní straně se setkají. Tim celý zbývající žloutek dostává se dovnitř embrya $(L)$, a sice do vyvíjejícího se prostredního střeva.

Postupem dalšiho rozvoje tvoři se na povrchu zárodku tenká pokožka**) (Obr. 6., $M, p . e$.$) , těsnè k tèlu prìléhajicí. Zvlášlností její jest, že vytroří na místě, pod nímž$

*) EMBRYONALENTWIGKLUNG DER THYSANOPTEREN. IV. (Schematisiert nach Uljanins Zeichnungen.) - z.d.a., Rest der Amnionhöhle, $k_{\text {. }}$ i., Anlage des Mundkegels, $a$. , Amnion, s., Serosa, ${ }^{\prime} . s$. , die abnehmende Verdickung der Serosa, z. s., Rest derselben, $t$., Fühler, abd., Abdomen.

**) Podobnè jako u roztočủ (zvl. svilušek), kdež ona pokožka sluje a p o derm a neb (Cla pa rè de) deutovum. Také Sommer nalezl tuto pokoz̀ku zuby opatřenou u olovnènky: Macrotoma plumbea (Linn.) Tullb. (Zeitschr. f. wiss. Zool., Bd. XLI, pag. 709).

$$
-337-
$$




\section{H. UZEL, MONOGRAPHIE DER ORDNUNG THYSANOPTERA.}

tykadla zárodku leži, řadu dlouhých a ostrých zubů (z.), ježto přiléhají na onu ěást žloutkové blanky, která z prasklého chorionu vyčnívá. Tato embryonalní pokožka se brzo od zárodku odchlipuje, a tèlo jeho i s údy, na nichž už první členitost se jeví. pokrỴvají se pokožkou novou, tak zvanou larvovou. Zárodek vězí tedy ve čtyrech obalech: $\mathrm{v}$ pokožce larvové, $\mathrm{v}$ pokožce embrỵonalní, v blance žloutkové a $\mathrm{v}$ chorionu.

$\mathrm{V}$ tuto dobu rozvoje objevují se jak první stopy základů očí $(M, o)$ a zauzliny mozkové $(g)$, tak i první pohyby zárodku. Tyto zále\%̌ejí v ohýbání predního a zadnílı konce tèla. Následkem toho pohy̧bu jest, że ony zuby, na pokožce embryonalní se nalézající, protrhnou blanku žloutkovou, a zárodek vytlačuje se tím, že se vzpřimuje, znenáhla ven $(N)$, obklopen jsa ještě pokožkou embryonalní. Konečně zárodek také tuto protrhne, kidyž rozčlenění údủ a těla dosáhlo svého konce, a mladá larva se úplně uvolní, zůstavujic chorion, blanku žloutkovou a pokožku embrỵonalní.

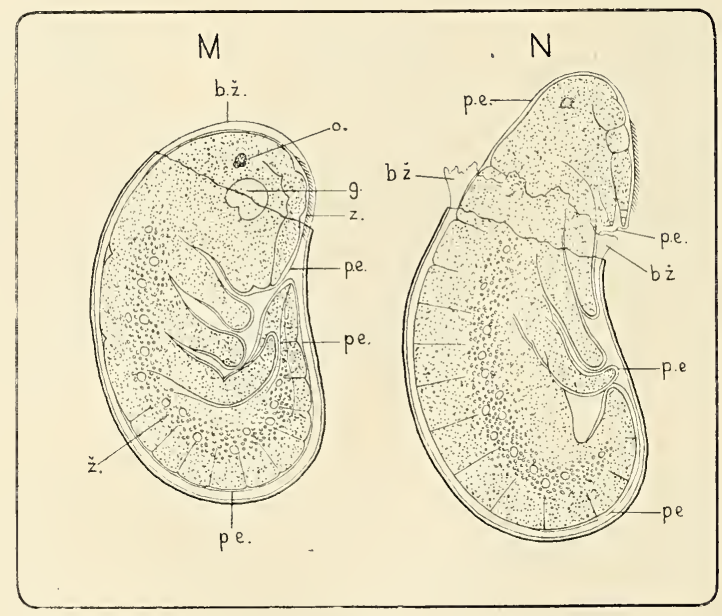

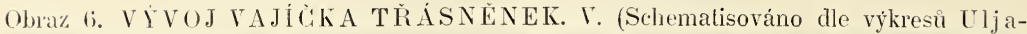

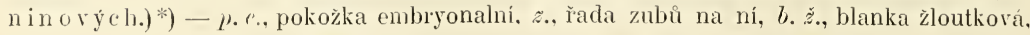
o., základ oka, y., zakklad zauzliny mozkové, ž.. żloutek.

Od položení vajičkia až do vylíhnutí se larvy uplyne dle Heegra u terebranlií prủměrně asi doba devíti dnú; u tubulifer dle Heegra o něco delší, dle Jo rdana taláz.

Dle téhož typu jako u tř́śsenek (dle něhož se proužka zárodečná vchlipuje dovnitř vajíčka [invaginovaná proužka zárodečná]) děje se embryonalní vỵvoj též u čmelů (Mallophluga), u polokî́dlỵch (Rhymchota) a u šídel. U parthenogeneticḳ se vyvijejicích

*) EIBRYONALENTWICKLUNG DER THYSANOPTEREN. V. (Schematisiert nach Üljanins Zeichmungen.) - p.e., Embryonalcuticula. z.. Reihe von Zähnen auf derselben, b. ž.. Dotterhäutchen. o.. Anlage des Auges, g., Anlage des Gehirns, ž., Dotler. 


\section{J. UZEL, MONOGRAFIE RADU, "THYSANOPTERA".}

vajíček mšic nastaly některé modifikace. Bylo by velmi zajímavo zvěděti, zda podobné modifikace též objevují se u vajiček oněch třásněnek, jež pravidlem parthenogeneticky se rozmnožaji (Parthenothrips dracaenae, Heliothrips haemorrhoidalis, Anaphothrips virgo, Prosopothrips Vejdovskiyi etc.) Embryonalní vývoj třásněnek poukazuje k tomu. že jest príbuznost jejich s rhỵnchoty značně vètši než s orthoptery. Orthoptera totiž, rovněž jako Trichoptera, Lepidoptera, Diptera a Hymenoptera, mají embryonalní vývoj svůj zařizený dle typu jiného, dle něhož proužka zárodečná dostává se dovnitr̆ vajička nikoliv vchlípením, nýbr\%̆ tím, že přerostou ji rasy amnionové.

\section{LARVA.}

\section{LARVE}

Larvy tr̆ásnènek jsou v celku podobny hmyzu dospělému. Hlava jejich jest pomèrnè velmi malá. Oči jsou taktéž malé a mají jen skrovný počet oček, klerá dle Jordana teprv po prvém svlékání se objevují. Oček jednoduchých larvy nemají. Tykadla jejich jsou volná, do předu namiřená a maji vždy menší počet článkủ než u hmyzu dospèlého. U larev tubulifer skládají se ze se sedmi v délce nepríliš rozdílných článkủ. Larvy coleoptrat mají v tykadle taktéž sedm článkủ. U larev druhu Aeolothrips fasciata jsou prvé dva články krátké, 3. a 4. velmi dlouhé, 5. čl. taktéž dlouhý a na konci značně stlustlý; 6. a $\mathbf{7}$. čl. velmi krátké. U larev stenopter jsou tykadla šestičlenná; první a druhý článek jsou krátké, třetí o něco delší, 4. a 5 tvoří dohromady mohutný a dlouhý celek, 6. čl. jest velmi úzký a krátký. Ústroje ústní jsou podobně utvořeny jako u dospělého hmyzu; jsou též k ssání přizpůsobeny. Nandibulae stáčejí se u larev tubulifer taktéž do předu až $\mathrm{k}$ očím, a bodec ústní jest u larev terebrantií také již prìpevněn na okraj čelní. Makadla maxillarní a labialní nemají často hranice mezi jednotlivými články tak zřetelné jako u hmyzu dokonalého. Pozoruhodno jest, že makadla maxillarní larvy druhu Aeolothrips fasciata mají všecky tři články asi stejně dlouhé (jak to již Haliday r. 1836. pozoroval), kdežto u dospělého zviŕete jest třetí článek jejich velice zkrácený. Kužel ústní nedá se u larev rodu Aeolothrips, dle Halidaye, přiložiti k hrudi; larvy druhu Parthenothrips dracaenae však mohou, dle Heegra (L. č. 66.), tak učiniti.

Hrud’ larev třásnènek skládá se ze tří od sebe velmi zřetelnè oddělených kroužkiu, z nichž mesothorax a metathorax jsou velmi mohutné. Prothorax jest slabší a pravidlem nazad rozšírený. Nohy jsou králké, zavalité a nemají ani na tibiích, ani na tarsech zubủ, kleré u dospělého hmỵzu často nalézáme. Také přední jejich femora nikdy nejsou stlustlá. Tarsus je vždy jednočlenným, a mèchýřek, na jeho konci se nalézajicí, jakož i chitinové páky a podpory uvnitř tarsu jsou podobnè vỵtvořeny jakio u dokonalého zvir̉ete; jen drápky, po obou stranách mèchýriku stojící, jsou u tohoto obyčejně celou plochou k němu přirostlé, kdežto u larev konce jejich volně odstávají. 


\section{H. UZEL, MONOGRAPHIE DER ORDNUNG THYSANOPTERA.}

Abdomen larer skládá se z desíli kroužkủ, z nichž prvý jest o něco kratši než následujicí a má takléž ventralní část úphě vyvinulou. Poslední dva článkỵ jsou u tubulifer a coleoptral značně 'zúžnỵ.

Kostra chitinová jest u larev relmi měkká a světlá, takže neliší se valně od svých blan spojovacích. Povrch její jest často hladký a lesklý (u tubulifer), jindy velmi drobnỵ́mi zrnky neb lupỵmi hrbolky posetý neb vrásčitý (u stenopter), jindy opèt (u coleoptrat) nesčislnými přejemnỵmi jehličkami pokrylý. Celé tělo opatreno jest chlupy, které json obyčejně ostře zakončené; jindy ršak na samém konci poněkud jsou stlustlé. nebo se ukončuijí paličkou. U larev tubulifer nalézá se takový paličkou ukončený chlup na konci všech tibí. Zvlášñ druh chlupư pokrỵvá tèlo larev druhu Parthenothsips dracaenae (Tab. II., fig. 13.). Tam toliž rozširuje se každỵ chlup na konci v trỵchtýřek, jehož otvor je pokiṿt rypouklou blankou. Slěny trỵchtýrikủ jsou na vnějši straně podepreny několika tyčinkami. Chlupy ty porstaly dle Jordana z chlupú paličkou ukončených tak, že tato značně vzrostla a horejší éást jeji se sploštila, načež slěny části dolejší vỵtvờily podpůrné tyčinky. Na predposledním článku abdominalním bỵvají někdy nahoře člyr̆i silné ostny, na rysokỵch bradarkách slojicí. Tak jest tomu u slaršich larev rodu Aeolothrips, kdežlo u mladšch zde jsou jen obycejné chlupy. Jindỵ opalřen jest poslední článek abdomenu nahore na konci dvèma podobnými ostny, kolmo slojicími.

Barva larev jest dosli pestrá. Larvy lubulifer jsou často krvavě červené (ku pr̀. u rodu Authothrips), jindy pak jsou bilé a poseté četnými. velmi malými červenými skvinkami (ku př. larvy druhu Trichothrips pedicularia a copiosa), neb ozdobené krvavě červe-

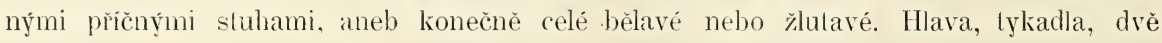
reliké skvrny na pỉedohrudi, jeden nebo dva poslední články abdomenu a nohy jsou při tom často černošedé. Velmi mladé larvy tubulifer bývají bezbarvé. - Terebrantia maji larvy čistě bílé, žlulavé. zelenavé, červenavé neb svètle pomerančové a někdy šedè zkalené. Na předohrudi bývaji u některých druhủ také dvě tmavší skvrny.

Pohỵby larev jsou v celku volnèjší než pohyby dospělého hmyzu. Sulzerovo Ivrzení, žc larvy skáčou (L. ě. 14.) jest mylné.

Larvy stékaji svou pokožkiu během svého vzrůstu trij- neb ělyrìikrále. Heeger (L. č. 63. a 66.) pozoroval vzhledem k tomu larvy druhủ Heliothrips haemorhoidalis, Phloeothrips coriacea, Limothrips denticornis, Parthenothrips dracaenae a Thrips sambuci a trrdí, že se prûmèrnè za 9 dní po vylíhnutí se larva poprvé svléká, načež ve stejných thủtách ješlè dvakráte odvrhuje svoji pokožku. Jordan naproti tomu udává, że larva druhu Parthenothrips dracaenae ětyrìkráte se svléká. Králce před každým svlékáním vidíme pod prủhlednou, starou, od tèla kolem odslávající pokožkou již následujíci stadium, coz poskyluje pohled velmi zvláštní.

Vnitrní ístroje larvy jsou dosti podobně vytrořeny jako u hmỵzu dospèlého. Sonstava vzdušnic v tom jest odchylná, že na těle larvy nalézáme vždy jen tři párỵ otrorủ dỵchacich: jrovni na prednich rozich středohrudi. druhỵ na druhém, třelí na osmém 


\section{J. UZEL. MONOGRAFIE RADU, "THYSANOPTERA".}

článku abdomenu. Larvy maji tedy o jeden pár otvoru dychacích méně než dospělý hmyz. a prọ́ článek abdominalní nemá stigmat jako u tohoto. za to však článek druhý. Proní, kdo larvu třásněnky vidèl, bỵl Linné, a to r. 1746. (L. č. 3.). Byyla to asi larva druhu Anthothrips statices, nebot mèla barvu nachovou, hlavu, nohy a tykadla černavá, a velmi ěetně vyskytovala se v květech, "vyłkračujíc si tam, jakoby dokonalým byla zvírátkem«. R. 1836. popisuje Haliday larvu třásněnek, pravě, že podobá se dospělému hmyzu, že má ršak měkké tēlo. se stredohrudí a zadohrudí oddělenou, ústroje ústní že jsou skoro tỵtéž, tykadla a nohỵ kratší. jednoduchých oček že neni, a oči že jsou zastoupeny očky složeny̧mi, jednotlivě rozestavenými. R. 1839. podávají Dufour (L. č. 49.) a Burmeister (L. č 50.) prvá vỵobrazení larev: Dufour od druhu Thrips aptera (= Phloeothrips ulmi), Burmeister od druhu Heliothrips haemorhoidalis. Tento autor kreslí mimo to hlavu této larvy s kusadly. R. 1852. kresli Haliday (L. č. 61.) larvy druhu Phloeothrips (= Trichothrips) ulmi, Aptinothrips mifa. Melanthrips obesa (= Melanothrips fusca), Limothrips cerealium a rûzné části larev druhû vyjmenovanỵch i nékterỵch jinỵ́ch. R. 1852. a 1854. vyobrazuje Heeger larvy druhu Phloeothrips coriacea, Parthenothrips dracaenae a Thrips sambuci. R. 1s74. kreslí Uljanin (L. č. 98.) jednu velmi mladou a jednu ryrostlou larvu druhu Thrips physopus a tvrdí neprávem, že prodèlávají larvy třásnènek mnohonásobná svlékání. R. 1887. zobrazuje Lindeman (L. č. 153.) larvu druhu Thrips secalina nov. sp. (= Limothrips denticornis Halid.) a druhu Phloeothrips fromentaria Beling (= Authothrips aculeata Fabr.). Tretí larvu, kterou vyobrazuje, a o které mỵslí, že by mohla bỵti larvou druhu Chirothrips antemuatus Osborn (=Ch. manicata Halid.), jest larva druhu Aeolothrips fasciata L.

\section{N Y M FA. NYMPHE.}

Po tr̉etím neb čtvrtém svlékání stává se larva nymfou, která vyznamenává se pochvami kirídelnými. Nymfa má dvě rozdílná mezi sebou stadia, z nichž mladší nazýváme pronỵmfou a slarší nỵmfou $\mathrm{v}$ užším slova smyslu.

PRONYMFA. - Toto sladium jest larvě dosti podobno; tím však zvláště od ní se liší, že na hrudi počínají vyrážeti malé pahýlky, které poznenáhla rostou do délky a dosáhnou $\mathrm{v}$ tomto stadiu as třetího clánku abdominalního. Jsou to pochvy, v nichž v následujícím stadiu kǐidla se utvoří. Tykadla jsou, podobně jako u larvy, volně pohybblivá a do předu namírená. Mezi obèma posledními články abdomenu dole povstane dle Jordana malá prohlubina. V níž lze pozorovati tři nádory. V prostredním z nich rytroìi se bĕhem času pỵj a v postrannich obě jeho pochvy. U pronymf, z nichz̆ samice se vyvinou. pozorovati lze na osmém a devátém článku abdominalním dole po dvou pahỵ́lcích, v nichž pozdèji ělỵĭi chlopně kladélka se utvoří. Pohyby pronymfy nejsou 


\section{H. UZEL, MONOGRAPHIE DER ORDNUNG THYSANOPTERA.}

ještě volnější než pohyby larvy. Taktéž mohou třásněnky v tomto stadiu potravu prìjímati, ač to dle Jordana není naprosto nutným. Svléknuvši pokožku stává se pronymfa nymfou.

Burmeister byl r. 1839. (L. č. 50.) pronim, který pronymfu vidèl, a to sice od druhu Heliothrips haemorrhoidalis. Haliday r. 1852. (L. č. 61.) nazývá toto stadium propupou a kresli ho (zároveň se silněji zvètšenými detaily) od druhủ Phloeothrips (= Trichothrips) ulmi, Aptinothrips rufa a Limothrips cerealium. He eger toho stadia nezná.

NY MFA. - Tato vyznamenává se pochvami křídelnými, které již asi do dvou třetin abdomenu se prodlužují a k stranám jeho přiloženy jsou. Dolejší pár těchto pochev lě̌i bud přesně pod hořejším párem aneb poněkud stranou. $\mathrm{V}$ jejich vnitřku lze již

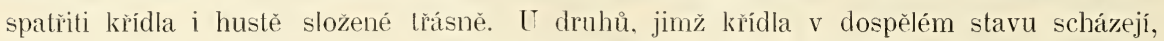
nemá ovšem ani nymfa pochev křídelných. Zvláštní změna udála se s tykadly. Ohnuvše se nazpèt, přiléhaji u tubulifer $\mathrm{k}$ stranám hlavy, u terebrantií pak leží vedle sebe nahore na hlavě, konci vzájemně se dotýkajice (Tab. II., fig. 14.). Jen některé nỵmfy tubulifer (tak Phloeothrips brumea dle Jordana) ěiní v tom ohledu výjimku; tykadla jejich jsou jako u larev volná a do předu namiřená. Oko u nṿmf jest již značně větší než u larev, a očka v něm jsou četnější. U druhû, jichž imago má přední femora stlustlejší a přední tarsus opatřený zubem. má také nymfa tyto ěásti podobně vytvořené. Pochvy pro chlopnè kladélka dosáhly již skoro konce těla. Chlopně samy pak již prosvítají svými pochvami. Basalni cásti kladélka a chitinové výtvory s nimi souvisící berou dle Jordana pưvod svủj z ventralních šlítủ posledních dvou kroužkủ abdominalních, které dovnitř těla se vchlípí. Chlupy na těle nymfy bývaji někdy rozdíné od chlupû larvy. Tak mají nymfy druhu Purthenothrips dracaencie na těle chlupy paličkou ukončené (Tab. II., fig. 14.), kdežto chlupy larev ukonẽuji se trychtýrikem (fig. 13.). Nymfy tr̆ásněnek pohybuji se jen tenkrát, když byly k tomu přinuceny. V tom príípadě lezou velice volnè a neobratně. IT některých druhủ pak jest snad nymfa úplně nehybonou; tak aspoñ tvrdí to Heeger o nymfách druhu Phloeothrips coriacea. Barva nymf jest obycejně taková jako barva jejich larev, aneb aspoň jí se podobá. Zajímavo jest, že nỵmfy třásněnek potravy neprìijímají, a že ústroje ústní jsou pokryty blanou, již celé tělo jest potaženo. Z pronymfy "druhu Parthenothrips dracaenae, kterou Jordan uzavřel do skleněné rourky bez potravy, vylihla se po dvojím svlékání rrádně vyvinulí dospělá třásněnka. Svrhování pokožky dẹje se dle Degeera (L. č. 11.) tak, že nejdřive praskne stará cuticula nad hlavou. Otvorem vzniklým vỵleze nejdřive hlava. načež vycházejí následujíci články; zvíre pri lom strídavè se natahuje a smršluje, takže stará pokožka posunuje se do zadu, současnè na hr̉betní straně se trhajíc. Sbalené pokožky, která po nẹjakou dobu zůstává viseti na konci těla, zbavuje se třásněnka tim, ̌̀e několikkráte břichem zakroutí. Stadium nymfy trvá dle Heegra průmèrnè devět dni. 


\section{J. UZEL, MONOGRAFIE RADU "THYSANOPTERA“.}

Nymfa třásnènek byla objevena a vykreslena Degee rem r. 1773. (L. č. 11.; Tab. I.. fig. 8.), a sice od nèjakého zástupce tubulifer. Autor tento vidèl již tṿkadla nazpèt ke stranám hlary ohnutá i pochry křídelné. R. 1836. popisuje Haliday nỵmfy několika druhů terebrantií a praví o nich, że maji tykadla zpèt na hlavu ohnutá, a že jsou v tomto stadiu mnohem lenivèjši než r ostatních. R. 1837. podává tenty̌z autor popis nymfy druhu Phloeothrips ulmi. R. 1839. vỵobrazuje Dufour (L. č. 49.) nymfu druhu Thrips aptera (= Trichothrips ulmi). Télız̆ roku kresli Bur me ister (L. č. 50.) nỵmfu druhu Heliothrips haemorhoidalis a mỵlnè trrdí, že živí se štavami \% Jistủ. R. 1852. pozoroval Haliday (L. č. 61.) prrní. że nymfa nepríímá potravy a kieslí ji (zároveu se silnēji zvětšenými detaily) od druhü Phloeothrips (= Trichothrips) ulmi, Aptinothrips rufa a Limothrips cerealium. Téhož roku (L. е̌. 63.) a r. 1854. (L. ¿̌. 66.) vyobrazuje Heeger nỵmfỵ druhủ Phloeothrips coriacea. Parthenothrips dracaenae a Thrips sambuci. R. 1887. popisuje Lindeman nymfy druhu Thrips secalina (= Limothrips denticornis) a druhu Ploloeothrips frumentaria (=Anthothrips aculeata). Tento spisovatel tvrdi asi neprávem, že nṿmty nèkterỵch třásněnek prijímají potravu.

\section{DOSPĚLÁ TŘÁSNĚNKA.}

IMAGO.

Tř́ísnènka, která bỵla právẽ opustila pokožku nymfy a křídla svá i chlopně kladélka z príslušnỵch pocher vỵláhla, jest ještě velmi měkká a bledá. Taktéž pohlavní ústroje jeji nejsou ještě úplně ryvinulỵ. Teprv za 6 až 8 dní (?) jest dle Heegr a třásnènka úplnè vỵbarvená, jeji chilinové panciře stvrdly, chlopně kladélka se $\mathrm{k}$ sobě př̀ložily, oba postranní páry jejich známým způsobem se spojily, a ústroje pohlavní jsou k snoubení připraveny.

Tr̃ásněnka polřebuje $k$ úplnému svému vývoji prủměrně asi 50 dnů. Za čtyři až pět dní po oplození klade mladá samička (dle Heegra u druhu Heliothrips haemorrhoidalis) první svoje vajička (pravidlem parthenogeneticky rozmnožující se třásněnka Parthenothrips dracaenae klade dle Jordana rajička již třetiho dne po svrhnutí pokožky nymfý), a kruh, kterỵ príroda vỵtkla rozvoji trásněnek, jest uzavřen.

Uvedeme zde ještě hlavní znaky, jimiž se dokonalá tr̉ásněnka od larev rozeznává. Obyčejně poznáme imago dle tř́ jednoduchỵch oček na temeni hlary, jež larvám i nỵmfám scházejí, a dle př́tomnosti křídel. Jsou však dosti četné druhy, jež i v dospělém stadiu ani oček ani kǐídel nemají. Tyto druhy byly někdy skutečně, ač neprávem, za larvy považovány (Burmeisterem, Amyotem i Servillem). Pro tento př́pad nutno jest připomenouti, že dospělá třásněnka má chitinovou kostru značně silnější, hladší a tmavší než larva, a že kosıra ta vchlipuje se na urěitých místech hrudi dovnitř, tvoříc bodce, na ně̉ž se svaly prìkládaji. Dále jsou zde již středohrud a zadohrud spojeny $\mathrm{v}$ jediný celek (pterothorax). Tỵkadla mají rèlší počet článkú ně̌ u larer (stylus terebrantií ráanè jest 


\section{H. UZEL, MONOGRAPHIE DER ORDNUNG THYSANOPTERA.}

již rozlišen) a články jednotlivé jsou uhlazenèjší. Oči jsou větši a maji mnohem četnẹjši očka (slożitá). která zvláště v strưdní části oka tak hustě se seskupují, že tvoři mnohoboká polička (facelly). Nohy jsou štihlejši. Kkladélko u terebrantii jest vyvinulo. U samcủ tubulifer jest jiż desátý článek abdominalni na basi dole vykrojen, a u samic stoji laké na zadním kraji devátého článku dole kolmá krátká chilinová tyčinka.

\section{METAMORFOSA TŘÁSNĚNEK. METAMORPHOSE.}

Abychom porozumèli, jak máme promènu lìásněnek posuzovati a kam ji vřaditi, promluvime napred krátce o různých promènách hmyzu vưbec.

Hmyz dle proměny dèlíme na Ametabola a Metabola. U oněch neni promèny žádné; mládata, z vajička se vylíhnuvši, podobaji se již úphně hmyzu dospèlémü. Sem patří šupinušky (Thysamura) a kromè toho vši (Pediculidae) a čmeli (Mallophaga), kter̀i však teprv sekundarnè, následkem cizopasného živola srého, ametabolnimi se stali. Metabola dèlíme na Homomorpha a Heteromorpha. U onèch podobaji se larvová stadia, potravu prỉijimajicí, značně dospělému hmỵzu. rozeznávají se však od nèho hlavně tím, že nemaji krídel a príivèskủ genitalních. Poskední larvové stadium. kleré již má zálilady křídel, sluje nymfa. Hmỵz promènou svou sem náležejici dèlíme na Pamrometabola a Hemimetabola. Paurometabola jsou hmyzové, u nichž promèna dèje se successivnim vzrủstem těla, prì čemź se toto nèkolikkrále sriékí. Znenáhla dostává kìidla a vnèjší príněsky genitalni. Zpủsob živola larev jest tenḷ̣y, jako u dospělého hmyzu. Také kusadla jsou taláž. Sem náležeji Dermaptera (škvorii). Orthoptera gemina, Corrodentia (Psocidae i Termitidaes a Rhymchota. Ze zístupcù Rhyuchot ršak rod Aleurodes, samci ostalních coccid a křisi (Cicadidae) lím se vyznamenávaji, že mají promènu vyšši. Rod Aleurodes má larvy šlitovité a lím dospèlému hmyzu nepodobné. Tyto proměñují se v nehỵbnou kuklu (jež pokrỵla jest pokožkon larvovou), podobně jako larvy na samce ostatních coccid, jichž kukla často leží v zámotku. Larry krìisů pak, které žijí v zemi, maji přední nohy k hrabání přizpůsobené, v čemž od dospèlého hmyzu, rostliny obývajícího, se odchylují. - Hemimetabola maji larvy. které vyznamenávají se zvláštními provisorními ústroji. organy dychacími jinak utvor̀enými (dỵchaji žaberními prívèsky. prostoupenými vzdušnicemi. neb vnitr̆ní plochou konečnílü) a żivolem ve vodè. Sem náležeji Ephemeridae, Odonata a Plecoptera. - Heteromorpha pak maji larvy od dospělého hmỵzu tvarem velmi rozdilné. Způsob živola jejich bỵvá zcela jiný, a také ústroje ústní jsou jinak ulvořené. Larvy mèní so v nehỵbné, polravy nepřijímající kukly. Do tohoto oddèlení palrí Neuroptera. Panorpatas, Trichoptera. Lepidoptera, Diptera. Siphonaptera, Coleoptera a Hymenoptera.

Uvážime-li nyní, żc lì̌śsněnky maji larvy značně hmỵzu dospělému podobné, že proměna jejich dèje se successivním vrủstem těla, žc zpủsob żivola larev jest tentýz jako 
u dospělého hmỵzu, a že i kusadla jsou tatáž, nezbývá než vřaditi je mezi Paurometabola, ač promèna jejich ve dvou bodech od nich se odchyluje: jest totiž nymfa málo pohyblivá, ba někdy (dle Heegra) nehybná vủbec, a nepřijímá potravy. Trúśsněnky v tom ohledu radí se $\mathrm{k}$ samcům coccid.

\section{PARTHENOGENESIS U TŘÁSNĚNEK. PARTHENOGENESE.}

Pozorujeme často, že neoplozené samičky kladou vajička vývoje schopná, ktery̌žto úkaz zoveme samobřezností (parthenogenesis). Tento způsob rozmnožování jest u některých druhů třásnènek pravidlem; následujef u nich množství parthenogeneticky se množících generací za sebou, které jsou pravidelně samice. Jen někdy vyskytne se malý počet samců, který řadu samiček oplodí, nestačí však na přemnohé jiné, kiteréžto dále parthenogeneticky se množí. Tak jest tomu u druhủ Parthenothrips dracaenae, Heliothrips haemorrhoidalis, Aptinothrips rufa i Limothrips denticornis a zajisté též u druhủ Bolacothrips Jordani, Platythrips tunicata, Prosopothrips Vejdovskíi, Anaphothrips virgo a jiných, u nichy̆ jsou samci tak vzácní, že nebyli ještě nikdy nalezeni, ač samice jejich po celý rok se vyskytuji, a od poslední z uvedených třásněnek všude ve velikém množství žiji. - Aby o parthenogenesi u třásněnek vlastníma očima se přesvěděil, isoloval Jordan jednu samici druhu Parthenothrips dracaence a s vejikou pílí vypěstoval z ní tři parthenogenetické generace.

Samobřeznost třásnènek jest jiného druhu než samobřeznost některých motýlủ (Bombyx, Liparis), žlabatek a mšic. U oněch motýlủ jest parthenogenesis jen nahodilỵm zjevem, nebot' jen tenkráte nastane, když ta neb ona samička náhodou nebyla oplozena. U mšic pak a žlabatek přistupuje k samobřeznosti heterogonie. Tam totiž následuje $\mathrm{v}$ pravidelné posloupnosti na jednu neb více generací, parthenogeneticky rozmnožených, generace, tvarem od předešlých se lišící a pozûstávající ze samcův i samic, z jejichž oplozených vajiček opèt parthenogeneticky se rozmnožující generace vỵchází.

Jordan vyslovuje domněnku, že u třásněnek po generacích letních, parthenogeneticky se vyvijejících, následuje generace o dvou pohlavích, a že snad i zde jako u mšic vsunuje se mezi generace neokřídlené okřídlená generace téhož druhu, žijicí na jiných místech. - Dovolím si zde podati svá pozorování, která se těchto pomèrủ tỵkají.

U mnohých druhủ, jež po celý rok se vyskytují, nalézal jsem taktéž v každé době, neb aspoň $\mathrm{v}$ teplém čase ročním, samce $\mathrm{v}$ takovém počtu, že vystačili zajisté oploditi valnou většinů samic. Takové druhy jsou ku př. Thrips physopus, T. flava, Pliysopus atrata, Ph. vulgatissima, Sericothrips staphylimus, Aeolothrips fasciata, Trichothrips copiosa a zástupcové rodu Cryptothrips. U jinỵch druhủ objevují se samičky s dosti četnými samci na kratší neb delší čas. Tak ku př. Plıysopus robustı a Ph. primulae. U těchto dvou kategorií trásněnek nemủže ovšem býti reči o parthenogenesi. Ta vzta- 


\section{H. UZEL, MONOGRAPHIE DER ORDNUNG THYSANOPTERA.}

huje se jen na druhy, o nichž nahore jsme se zmínili, a kromě toho na druhy, jichž samci jsou sice mnohem hojnější, avšak prece ne tak čelní, aby všecky samice oplodili (ku př. u rodu Authothrips). U druhủ sem náležejících jest tedy rozšířeno rozmnožování parthenogenetické, které u některých po celé roky mủže trvati, až jednou náhodou se do nesčetných generací parthenogenetických vsune jedna generace, jež vylíbla se z vajiček oplozených. Dále podolýkám, že neznám druhu, jehož samice by po celé léto žily, a jehož samci by se vyskytli jen v některé době roční ve velikém počtu, takže by stačili oploditi skoro všecky samice současné. Dle toho soudim, že u třásněnek, jichž se týče, nestřídá se určitý počet (letních) generací parthenogenetických s generací, jež vznikla z oplozených vajiček, jak tomu jest u mšic.

Pokud se jednollivých okřídlenỵch samic týče, jež vsunují se u některých druhů třásněnek, skrỵtě $\mathrm{v}$ drnu neb pod korou žijicich, mezi generace samic neokřídlených, sluši podotknouti, že ani $\mathrm{v}$ tom pravidelnosti nebývá, jak tomu je u mšic, že úkaz ten shlédáváme u parthenogeneticky se rozmnožujících druhủ (ku pr̀. Thrips nigropilosa) právě tak jako u druhủ obojpohlavně se množících (ku př. Sericothrips staphylimus, rod Cryptothrips etc.), a že slouži křídla takové výminečně okřídlené samice k rozšírení druhu (jinak jen velmi pozvolna se dějícího) podobně jako čupřiny u semen rostlinných, vètrem unášených. Že $\mathrm{v}$ ohledu tom podobnosti mezi třásněnkami a mšicemi není, vysvítá nejlépe z toho, že okřídlené samice třásněnek nevyskytuji se $v$ určitém čase, nezdržuji se na určitých rostlinách ve vètším počtu a po delši dobu, a že také květủ zvláště nevyhledávají. Dovoluji si zde tyto samičky výminečně okřídlené, druh zeměpisně rozšiřující, nazvati feminae disseminantes.

Sem vztahuji se ještě úkazy, jež jsem pozoroval u druhủ Sericothrips staphylimus, Trichothrips pedicularia a Anaphothrips virgo. U druhu prvého, $\mathrm{r}$ drnu žijícího, jenž vždy obojpohlavně se rczmnožuje, a jehož obě pohlaví pravidlem kì̛ídel nemají, stává se též někdy, že jak samice, tak samci opatreni jsou dlouhỵ́mi kǐídly. Tato forma okřídlená pak vylélá ze svỵch skirýší také jen za účelem rozšiření druhu, nebot nenalezl jsem okřídlených samic a samcu pospolu a také nepozoroval jsem, že by některou rostlinu si bỵli oblibili, nỵbrž nalezl jsem je vždy těkající. - Podobný úkaz, že totiž obě pohlaví pravidelně neokřídlené stávají se okîídlenými, jeví se též u obojpohlavně rozmnožujićího se a pod korou žijícího druhu Trichothrips pedicularia. Druh Anaphothrips virgo, jehož okřídlené samice po celé léto velice četně se vyskytují, jehož samci však posud objeveni nebỵli, má tu zrláštnost', že na podzim stává se (jak již Haliday pozoroval) krátkokî́ídým, a že $\mathrm{v}$ takovém slavu ve velikém množství v drnu prezimuje, načež z jara vždy větší a větší počet exemplár̉u stává se zase dlouhokřídlým (v červnu už skoro všecky jsou dlouhokřídlé) a uchyluje se valnou většinou (někdy zároveň s malým počtem neokrídlených) na nejrůznèjší roslliny, na nichž pres léto parthenogeneticky se rozmnožuje. Některé, ač velmi sporé krátkokríidlé exempláře lze kromě toho nalézti skoro po celý rok v drnu. U toho druhu tedy asi pr̃ezimované sa- 


\section{J. UZEL, MONOGRAFIE RADU, „THYSANOPTERA“.}

mičky kladou vajička, z nichž vyvijeji se většinou okřidlené samice, žijicí na rostlinách, které (parthenogeneticky) množí se až do podzimu; poslední generace jest pak zase krátkokřídlá a uchyluje se do zimních skrýší.

Ze všeho vidíme, že není ve sledu parthenogeneticky a obojpohlavně se rozmnožujících a okřídlených i neokřídlených individuí téhož druhu podobnosti mezi třásněnkami a mšicemi, u nichž často některé parthenogenetické generace náhle slávají se okřídlenými a stěhují se na jiné rostliny (emigrantes), kdež se rozmnožují (alienicolae), a v následující generaci se vracejí na rostlinu původní (remigrantes). - Parthenogenesis třásněnek má ráz podobného úkazu u motýlủ Psyche a Solenobia, a též (dle p. prof. Klapálka) chrostíka Apatania, u kterýchžto hmyzů, jejichž samci velmi zrí́dka se vyskytují, pozorováno množství parthenogenetických generací, za sebou následujících.

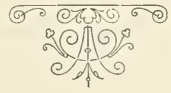




\section{Résumé des entwicklungsgeschicht= lichen Theiles.}

In diesem Theile wurde die Entwicklung der Thysanopteren vom $\mathrm{Ei}$ an bis zum vollkommenen Insect verfolgt. Um die Entwicklung im Ei selbst klar darzustellen, hat sich der Verfasser die Abbildungen aus Uljanins russischer Arbeil (Nr. 98), welche sich auf diesen Gegenstand bezieht, zu schematisieren (2.-6. Textbild auf S. 334-338) erlaubt. Den einzelnen Abschnitten dieses Theiles wurden auch die betreffenden historischen Data beigefügt.

Hier wollen wir nur einige Erscheinungen, welche sich auf die parthenogenetische Fortpflanzung der Thysanopteren beziehen, etwas ausführlicher besprechen. Jordan (Nr. 162) spricht die Vermuthung aus, dass bei den Thysanopteren nach den Sommergenerationen, welche sich parthenogenetisch fortpflanzen, eine Generation von Männchen und Weibchen erscheine, und dass sich vielleicht hier, ebenso wie bei den Blattläusen, zwischen die ungeflügelten Generationen eine geflügelte einschiebe, welche oft auf anderen Orten lebt. - Ich will meine Beobachtungen, welche sich auf diesen Gegenstand beziehen, hier anführen.

Bei vielen Arten, die das ganze Jahr hindurch vorkommen, fand ich ebenfalls jederzeit, oder wenigstens in der warmen Jahreszeit, Männchen in solcher Anzahl, dass sie jedenfalls im Slande waren, die grosse Mehrzahl der Weibchen zu befruchten. Solche Arten sind z. B. Thrips physopus, T. flava, Physopus atrata, Ph. vulgatissima, Sericothrips staphylimus, Aeolothrips fasciatr, Trichothrips copiosa und die Vertreter der Galtung Cryptothrips. Von anderen Arten erscheinen die Weibchen zugleich mit ziemlich zahtreichen Männchen auf eine kürzere oder längere Zeit. So z. B. von Physopus robusta und Ph. primulae. Bei diesen zwei Kategorien von Thysanopteren ist natürlich von Parthenogenese keine Rede. Dieselbe kommt bei denjenigen Arten als Regel vor, bei denen nur zu bestimmter Zeit eine kleine Anzahl von Männchen erscheint, welche nur eine Reihe von Weibchen befruchten. Viele andere Weibchen bleiben unbefruchtet und pllanzen sich weiter parthenogenelisch fort. Es sind die Arten Parthenothrips dracaenae, Heliothrips haemorrhoidalis, Aptinothrips rufa, Limothrips denticornis und jedenfalls auch die Arten Bolacothrips Jordani, Platythrips tunicata, Prosopothrips Vejdoestigi, Anaphothrips virgo und andere, bei denen die 


\section{J. UZEL, MONOGRAFIE RADU „THYSANOPTERA“.}

Männchen so selten sind, dass sie noch nie gefunden wurden, obwohl die Weibchen das ganze Jahr hindurch vorkommen und von der letzten der genannten Arten sogar überall in grosser Menge leben. Ausserdem setzen wir auch Parthenogenese bei Arten voraus, deren Männchen wohl viel häufiger, jedoch weit nicht so zahlreich sind, um alle Weibchen befruchten zu können (z. B. bei den Arten der Gattung Authothrips). Bei den erwähnten Arten ist also die parthenogenetische Fortpflanzung verbreitet, welche bei manchen derselben ganze Jahre hindurch andauern kann, bis sich einmal zufällig zwischen die unzähligen parthenogenetischen Generationen eine Generation einschiebt, welche aus befruchteten Eiern entstand. Dazu bemerke ich, dass ich keine Art kenne, deren Weibchen das ganze Jahr hindurch leben, und deren Männchen nur in einer bestimmten Jahreszeit in grosser Menge auftreten würden, so dass sie im Stande wären, die grosse Mehrzahl der gleichzeitig lebenden Weibchen zu befruchten. Darnach schliesse ich, dass bei den bezüglichen Thysanopteren eine bestimmte Anzahl von parthenogenetischen (Sommer-) Generationen mit einer Generation aus befruchteten Eiern nicht regelmässig abwechseln.

Was die einzelnen geflügelten Weibchen anbelangt, die sich bei einigen versteckt im Rasen oder unter Rinde lebenden Arten, zwischen Generationen ungeflügelter Weibchen einschieben, so ist zu erwähnen, dass auch darin keine Regelmässigkeit wie bei den Blattläusen herrscht, und dass wir diese Erscheinung ebenso bei den parthenogenetisch sich vermehrenden Arten (z. B. Thrips nigropilosa), wie bei den zweigeschlechtlich sich fortpflanzenden (z. B. Sericothrips staphylimus, der Gattung Cryptothrips etc.) beobachten. Die Flügel eines solchen ausnahmsweise geflügelten Weibchens dienen zur Verbreitung der Art (die sonst sehr langsam vor sich geht), ähnlich wie der Pappus der Pflanzensamen, die der Wind fortträgt. Dass in dieser Hinsicht keine Ähnlichkeit zwischen Thysanopteren und Aphiden existiert, geht daraus hervor, dass die geflügelten Weibchen der Thysanopteren nicht zu bestimmter Zeit auftreten und sich nicht auf bestimmten Pflanzen in grösserer Anzahl und längere Zeit hindurch aufhalten (auch Blüten suchen sie nicht besonders auf). Ich nenne diese ausnahmsweise geflügelten Weibchen, welche die Art geographisch verbreiten, feminae disseminantes.

Hierher beziehen sich noch die Erscheinungen, welche ich bei den Arten Sericothrips staphylimus, Trichothrips pedicularia und Auaphothrips virgo beobachtete. Bei der ersten der genannten Arten, die im Rasen lebt, sich immer zweigeschlechtlich fortpflanzt, und deren beide Geschlechter regelmässig flügellos sind, geschieht es auch manchmal, dass sowohl die Weibchen, als auch die Männchen mit langen Flügehn versehen sind. Diese geflügelte Form verlässt ihre Verstecke auch nur zum Zwecke der Verbreitung der Art; denn ich fand nie geflügelte Weibchen und Männchen beisammen und beobachtete auch nicht, dass sie bestimmte Pflanzen aufsuchen, sondern ich fand sie immer umherirrend, die Weibchen, wohl um auf entfernten Stellen ihre Eier abzusetzen, die Männchen, wohl um entfernte Weibchen zu befruchten. - Eine ähnliche Erscheinung, 


\section{H. UZEL, MONOGRAPHIE DER ORDNUNG THYSANOPTERA}

dass nämlich beide Geschlechter, die in der Regel flügellos sind, mitunter geflügelt werden, beobachten wir auch bei der zwęigeschlechtlich sich fortpflanzenden und unter Rinde lebenden Art Trichothrips pedicularia. - Die Art Awaphothrips virgo, deren geflügelte Weibchen das ganze Jahr hindurch sehr häufig vorkommen, deren Männchen jedoch bis jetzt noch nicht entdeckt wurden, hat die Eigenthümlichkeit, dass sie gegen den Herbst (wie schon Haliday bemerkte) nur mit Flügelrudimenten versehen auftritt und in solchem Zustande in grosser Nenge unter Rasen überwintert. Im Frühjahre wird eine immer grössere Anzahl von Individuen langgeflügelt (im Juni sind es fast alle schon). Dieselben begeben sich der grossen Mehrzahl nach (manchmal zugleich mit einer kleinen Anzahl ungeflügelter Exemplare) auf die verschiedensten Pflanzen, auf denen sie sich über den Sommer parthenogenetisch vermehren. Nur sehr selten finden wir einige kurzflügelige das ganze Jahr hindurch im Rasen. Bei dieser Art legen also die überwinterten Weibchen Eier, aus denen sich grösstentheils geflügelte Weibchen entwickeln, welche auf Pflanzen leben; die letzte Generation ist wieder kurzflügelig und begibt sich in die Winterquartiere.

Aus allem dem Gesagten ist es ersichtlich, dass es sowohl im Wechsel der parthenogenetisch und der zweigeschlechtlich sich fortpflanzenden, als auch der ungeflügelten und geflügelten Individuen keine Ähnlichkeit mit den Blattläusen gibt.

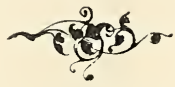




\section{V. ĆAST BIOLOGICKÁ.}

\section{BIOLOGISCHER THEIL.}





\section{OBYDLÍ TŘÁSNĚNEK. WOHNORTE DER THYSANOPTEREN.}

Valná většina třásněnek žije $\mathrm{v}$ různých květech, jiné zdržuji se na listech rostlin, opèt jiné pod korou stromů a ostatní $\mathrm{v}$ drnu a mezi hnijicími látkami rostlinnými.

Trúsněnky, které $\mathrm{v}$ květech žijí, patři většinou $\mathrm{k}$ terebrantím. Z tubulifer obývají květy zástupcové rodu Anthothrips. Pokud vím, není žádných třásněnek, jež by se ve větším počtu stále vỷhradně $\mathrm{v}$ jednom druhu květủ zdržovaly; obyčejně obývá jistý druh určitou radu rozličných květủ, dávaje však často některým z nich přednost. Tak žije Aeolothrips fasciata v rủzných květech lučních, dává však vždy přednost Inici (Linaria vulgaris); Thrips adusta dává přednost pampelišce (Taraxacum officinale) před jinými kvèty, Physopus pallipemis blínu, Ph. atrata máku a koukolu, Oxythrips ajugae popenci, O. parviceps vřesu. Nèkteré druhy nejsou nijak vybíravými a nalézáme je v květech nejrưznèjších. Neznám květu, klerý by byl třásněnkám tak odporným, že by jím úplně pohrdaly. Také $\mathrm{v}$ květech od Petasites officinalis a Hyoscyamus niger, ve kterých J ordan nikdy trásněnek nenalezl, vyskytuji se některé druhy, a to v onèch Anaphothrips virgo a Physopus vulgatissima, v tẻchto Physopus pallipennis, atrata, vulgatissima, temicornis, Thrips communis (ve velikém množství), flava, Limothrips denticornis a Phloeothrips aculeata. Trásněnkám zvláštẽ milé jsou květy bylin: Galanthus nivalis, Onobrychis sativa, Solanum tuberosum, Armeria vulgaris, Colchicum autumnale, Papaver somniferum, Agrostemma githago, Tragopogon pratense, Taraxacum officinale, Lycium barbarum, Valeriana officinalis, Eupatorium cannabinum, Beta vulgaris, Calluna vulgaris, Monotropa hypopitys, Salix fragilis, Armeria vulgaris a Chrysanthemum lencanthemum. Kvètenství travin oblibily si zvláštè druhy: Chirothrips manicata, Limothrips denticornis, Physopus temuicornis, Stenothrips gramimum, Aptinothrips mfa a Phloeothrips aculeata. Mezi dospělỵmi třásněnkami nalézáme $\mathrm{v}$ květech též množství larev, které však vždy hloubẽji do nich zalézají. Nymfy jsou $\mathrm{v}$ kvètech, jakož i jinde velmi řídké a nevím jiného pro úkaz ten vyssětlení, než tu okolnost, že třásněnky ve stadiu nymfy jen krátký čas žijí. Možno však je také, ač jsem to nikdy nepozoroval, že mnohé nymfy zalézají do země, podobně jak to udává Portschinsky u jistého druhu, na tabákových listech žijícího. 


\section{H. UZEL, NONOGRAPHIE DER ORDNUNG THYSANOPTERA.}

Na listech zdržuje se jen malý počet třásněnek. Výhradními obỵvateli listů jsou druhy Thrips sambuci, viminalis, Physopus ulmifoliorum, Dendrothrips tiliae, Dictyothrips betae, Drepanothrips Reuteri a škůdcové našich skleníku Parthenothrips dracaenae a Heliothrips haemorrhoidalis i femoralis. Z tubulifer pak nalezl jsem dosti značné množstrí exemplárủ druhu Liothrips setinodis na spodní straně listủ duborých, a jediný exemplár̆ druhu Liothr. hradecensis, který mám, sedèl na spodní stranè listu bolševníkového (Heracleum sphondylium). Exotický rod Idolothrips zdržuje se. jak major Hamilton udárá, na listech jistého druhu Anacardia. Na listech žijí dále některé druhy. jež i v kvẽtech neb r drnu neb pod korou se ryskytují; tak Plıysopus inconsequens, vulgatissima, uncinata, Thrips flava, major, nigropilosa, minutissima, Limothrips denticornis, Anaphothrips virgo, Dendrothrips Degeeri. Jiné druhỵ pak časem na jehličí lesnich stromú nalézáme (Physopus pini, vulgatissima, atrata, ulicis, Thrips flava. physopas, mimutissima, Oxythrips hastata, ajugae, Aeolothrips fasciata a Phloeothrips aculeata). - Též některé rostliny tajnosnubné jsou navštěvovány tr̆ásněnkami. Tak objevujeme na Equisetum areense časem druhy Physopus atrata, i vulgatissima, na Equisetum sileaticum druhy Anaphothrips virgo. Thrips flava a Aptinothrips rufa. Na Pteris aquilina sbiral jsem druhy Thrips flaca, Physopus pini a Oxythrips ajugae (poslední dva snad sem jen zbloudily), dále množství bèlavých larev třásnēnek. kiteré se štavami této kapradiny živí. Na houbách kloboukatỵch časem objevuje se Phloeothrips aculeata, Aptinothrips rufa a Pliysopus atrata; zdá se však, že tam jen zabloudily. - Ještě sluší podotknouti, že některé třásněnky jen vY̛minečně na listech se po nějakou dobu zdržují, bỵše tam náhodou rětrem zahnány.

Tr̃ásněnky, štavami listů se živící. zdržuji se pravidlem na spodní stranẽ jejich, kdež jsou pr̀ed větrem a dešlěm více chráněny, a kdež pletivo jest mèkěi. Výjimku v tom ohledu činí Plyssopus ulmifoliorum, literou jsem na hořejší straně listové nalézal.

Četné tr̀ásnènky žiji téź pod zpuchrelou korou rúzných stromủ. Jsou to predevším mnohá tubulifera, jež $\mathrm{k}$ životu takovému přizpưsobena jsou svỵ́m sploštilým tělem. které. mohou nejužšimi skulinami protahovati. Žijí zde se svỵmi larvami i nỵmfami bud ve větších neb menších společnostech (Trichothrips ulmi, pini, copiosa. pedicularia, Phloeothrips coriacea), aneb vyskytuji se jednotlivě (Megalothrips Bonamii, Cryptothrips lata, angusta, Trichothrips semicaeca, Acanthothrips nodicomis. Poecilothrips albopicta). Z terebrantií žiji také některé druhy časem pod korou, avšak jsou zde vždy jen více hostmi; tak Dendrothrips Degeeri a Thrips viminalis. Jiné trásněnky pak v kůře aneb v lišejnicích ji pokrývajicích hledaji jen úkrytu před nepohodami živelnimi.

V drnu žije celá rada třásněnek, a to jak terebrantií (Chirothrips Dudae, Limothrips denticornis, Sericothrips staphylinus, Physopus nigriventris, phalerata, unciuata, frontalis, pilosa, Oxythrips firma, Pachythrips subaptera, Anaphothrips virgo, Prosopothrips Vejdovskyi, Thrips nigropilosa, discolor, dilatata, Bolacothrips 
Jordani, Aeolothrips albocincta, Aptinothrips rufa) tak tubulifer, (Cryptothrips Icarus, dentipes, bicolor, Trichothrips caespitis). - Také pod spadaným listím a hnijicimi látkami rostlinnými nalézáme nèkteré druhy (tak Megalothrips lativentris, Limothrips denticornis a Sericothrips staphylimus).

Obydli svoje opouštěji trásněnky za různými přičinami. Druhy, jež v květech žiji, jsou nuceny je opustiti, jakmile tyto odkvétaji neb usvchaji, a vyhledati si kvètů jinỵ́ch. Tak nalézáme květy, kleré po senoseči $v$ keř́ch zùstaly státi, často trúśněnkami prẹlněné. Po žních uchỵluji se třásněnky, které dosud v obilí žily, na jiné druhy obilí, ještě neposečené, neb na traviny aneb rủzné květy luční.

Že tr̉ásnènky letem dostávají se na nová svoje bydliště, toho nejlepšim důkazem jest jejich prítomnost' v květech na vodè vzplývajicích (Nuphar luteum, Potamogeton natans, Polygonum amphibium), kdež i jejich potomstvo v podobě larev nalézáme. Také druhy, skryté pod korou, v drnu a pod listím žijíci, opouštēji někdy svoje skrýše a vyhledávají jiných. Stèhujici se exempláre bývají pravidlem samičky (u Sericothrips staphylinus také samci), které v novém obydlí svém nové pokolení zakládaji. Zvláštností je, že tyto stèhovavé samičky (feminae disseminantes) jsou opatřeny kîídly také u druhů, jež jinak křídel nemají.

$\mathrm{V}$ zajetí chováme ( $\mathrm{k}$ vůli studím anatomickým neb biologickým) nejsnáze třásněnky, v drnu, pod listím a pod korou žijicí. Dáme větší množství látek, ve kterých žiji, do sklenice se širokým hrdlem a pevně ji zavážeme nějakou řídkou tkaninou. aby vzduch měl do ní volný prístup. Nusíme pak toho dbáti, aby uvězněné třásněnky nevyschly; nutno jest tudiž obsah sklenice časem dủkladně pokropiti. Třásněnky v květech žijicí chováme v podobné sklenici, v níž však umístníme nèkolik kvetoucích rostlin tak, že stopky jejich nastrkáme do malých úzkohrdlých lahviček, vodou naplněných, jichž hrdla kolem stopky pevně bavlnkou ucpeme, aby třásnènky nemohly $k$ vodẽ proniknouti.

\section{POTRAVA TŔÁSNĚNEK.}

NAHRUNG.

O potravě třásněnek bylo již dosti napsáno. Jednotliví autoři udảvali, že třásněnky živí se nektarem květů, zrnky pỵlovými, štavami rostlinnými, plísni a konečně též štavami zvírecími.

Že nektar třásněnky poživají, to pokládal za pravdě podobno Degeer (L. č. 11.), k jehož minění též Burmeister (L. č. 45.) se přidával. Také Pergande (L. č. 127.) má za to, že nektar jest hlavní stravou třásněnek. Žádný z těchto tří autorů však prìi ssání nektaru jich nezastihl.

Dále byla zrnka pylová za potravu trásněnek považována. Prvni tvrdil to $\mathrm{New}$ man (L. č. 42.). Pozdèji pak Fernald (L. č. 136.) nalezl prý květinový pyl v jejich zaživací roure. 


\section{H. UZEL, MONOGRAPHIE DER ORDNUNG THYSANOPTERA.}

Že třásněnky štavami rostlinnými se živí, to tvrdil první Linué r. 1767. (L. č. 10.), ktery̆ praví, že škodí klasům žitným. Později dosvědčuji to hlavně Degeer, Sulzer, Haliday, Burmeister, Heeger, Pergande, Osborn, Lindeman. Jordan, Bohls a mnozi jiní bud výslovně, na základè vlastních pozorování, aneb neprímo tím, že mluví o škodách třásněnek, na rostlinách (zvl. pícních) zpủsobených. - O jejich ssání přesvědčují nás vyssáté listy mnohých rostlin jak v prírodě (zvl. od Sambucus nigra a Solanum dulcamara), tak ve sklenících. Na obilí pak shlédáváme dle Lindemana (L. č. 153.) na pochvách listovỵch, kde ssály, svẽtlé skviny (Thripsflecke); klasy pak, třásněnkami vyssávané dle téhož autora zvláštním způsobem se přetvořují, aneb stávají se více nebo méně hluclıými. V květech ssají třásněnky dle Jordana (L. č. 162.) ze všech částí kromè lístkủ okvětních a dávají, jak jsem mohl pozorovati, často staršim květủm přednost před zcela mladými. Také štáva z plodủ (jablek) slouží dle Fitche (L. č. 69.) třásněnkám za potravu. Dle Ladureaua (L. č. 114.) konečně ssaje prý larva třásnènky, kterou tento autor nazývá Thrips lini, z kořínkủ lnu, což třeba ještě potrrditi.

Tr̀ásněnky pod korou žijící ssají štávy odumřelých látek rostlinnỵch, zuláššě pak štávy rozkládajících se polyporu (jak Jordan pozoroval). - O těchto třásněnkách domnival se Haliday, že požíají plíseñ.

Některé třásněnky ryssávají časem štavnaté nádory různým hmyzem na rostlinách zpủsobené a byly považovány neprávem za pûvodce nádorú těch a často též za ničitele jejich obyvatelū. V následujicím sestavíme z literatury data k predmètu tomu se vztahující.

Již Degeer (L. č. 2.) nalezl svou tr̃ásnènku „Physopus fuscus, alis albicantibus“ v jistých nádorech na jalovci a udává, že živily se zde asi štavou nádorú těch, jichž původcem bỵl jiný hmyz. Linné pak r. 1767. (L. č. 10.) tvrdí, že Thrips physopus způsobuje nádory květové na štírovníku (Lotus corniculatus), což Degeer r. 1773. (L. č. 11.) ryvrací a dokazuje, že jsou jistou bejlomorkou vytrořeny. Haliday (L. č. 61.) nalézá r. 1852. druh Phloeothrips subtilissima na nádorech dubových. Také Targioni-Tozzetti (L. č. 150.) nalezl r. 1886. druh „Euthrips consociata“ (= Physopus ulmifoliorum) na nádorech lísky, neprohlašuje však třásněnku tu za původce nádorủ zmíněných. Fitch (L. č. 70.) objevil r. 1857. svìj druh Phloeothrips caryae na nádorech listových jisténo druhu or̉echủ a pochy̧buje, že je tr̉ásněnka pưvodcem nádorủ těch. Také Osten-Sacken (L. č. 75.) pozoroval nèkteré nádory, způsobené mouchou Lasioptera vitis 0 . S., jichž dutiny byly opuštěny pûvodními obyvateli, za to však obsazeny četnými tr̉ásněnkami. Dále vypravuje Walsh (L. č. 76.), že vidèl larvy tr̆ásněnek v nádorech, zpưsobených mšicí Phylloxera caryaefolia. O něco pozdèji podává tentýž autor zprávu o třásněnkách, nalezeny̧ch $v$ nádorech much bejlomorek (Cecidomyidae). Pordobně tvrdi Riley (L. č. 85.), že žiji larvy jisté třásněnky na nádorech mšice révové.

Také z masožravosti byly třásněnky častěji podezřivány a dvakráte z ní usvěděeny. Prvním, kdo tr̆́sněnky z masožravosti vinil, bỵl Walsh, jenž odůvodñuje náhled svůj 


\section{J. UZEL, MONOGRAFIE RADU „THYSANOPTERA“.}

následujicim pozorováním. Počátkem čerrna nalezl několik dospělých tǐásněnek $\mathrm{v}$ nádorech, způsobených mšicí Plıylloxera caryaefoliae, jak jsme se o tom již nahoře zmínili. Tyto nádory byly plny pủvodních svých obyvatelủ Ku konci června pozoroval však, že tytéž nádory byly phylloxerou skoro opuštěny; za to však obsahovaly množství nymf třásnènek, které, jak se mu zdálo, první obyvatele bud' vytlačily, nebo vyhubily. O něco pozdèji (L. č. 77.) podal týż pozorovatel jinou zprávu, predmètu našeho se týkající, ve které hledi vyssètliti úkaz, že často nádory much bejlomorek (Cecidomyidae) jsou prázdny. Myslí totiž, že asi třásněnky larvy oněch much sežraly. Pokud se týče tr̃ásněnek, jež na obilí žijí, domnívá se o nich, že jsou spíše přátely rolníkovými, než jeho neprátely, nebot niči asi vajička a larvy mouchy Cecidomyia tritici. Vủbec zastává se $\mathrm{v}$ této zprávě mínění, že třásněnky jsou $z$ veliké části neb snad výhradnè hmyzožravými. Nápadno však jest, že $v$ ní nenalézáme ani jediného fakta, které by hmyzožravost trásněnek určitè dokazovalo. O něco pozdèji zastává se poznovu svého dřivèjšího náhledı, a r. 1867. (L. č. 82.) oznamuje, že objevil více než dvacet prípadú, kidy třásněnky živily se larvami hmyzủ, nádory rostlinné způsobujících. Dále rypravuie, že jeteli škodi larva malých dřepčikủ (Haltica), mezi nimiž žiji také třásněnky. které bezpochyby je sežirají. Škody na jeteli však od rolníkủ tèmto posledním se přičítaji. Také v květech od Calystegia sepium. v nichž žije množství larev jistého malého broučka (Conotelus obscurus Err.), nalezl tr̂̉ásněnky ve velikém počtu a nepokládá to za nemožné, že ony těmto slouži za potravu. Také Riley (L. č. 85.), mluvè o prìrozených nepřátelech mšice révové $\mathrm{r}$ Sev. Americe, praví, že nejvíce ji hubí krvavě červená larva jakési černé třásnènky s bílými krídly, již popsal pod jménem Thrips phylloxerae. Ta líhne se \% vajiček, položených do nádorû, způsobených onou mšicí. Roku 1888. oznamuje naproti tomu Osborn (L. č. 163.), že nikdy nevidèl třásnènek na nádorech mšice révové, ač k tomu zvláště prìhlížel. - Všecky tyto udaje, které jsme až posud probrali, nejsou dosti určité, takže nevylučuji možnost, že třásněnky ssály pouze štávu nádorủ. Roku 1882. však Pergande (L. č. 127.) uvádí prvé skutečnj pozorováni jejich masožravosti. On sám vidèl $\mathrm{r}$ jednom prípadè, jak triásněnky požiraly roztoče Tetramychus telarius zvané, jež na platanech žiji. Z toho pak soudí, že také třásněnky, na jeteli v množství se ryskytujicí, asi živí se vajičky a larvami mouchỵ Cecidomyia leguminicola, jichž je tam obyčejně hojnost. Druhý autor, jenž třásněnky z masožravosti usvědčuje, a jenž při skutku je zastihl, jest Bohls. Koncem července pozoroval, že larvy jisté tr̉ásnènky, v kvètenstvích od Stachys germanica žijící, dokonce netráví život klidně vedle sebe, nỵbrž navzájem se napadaji(?), př̀i čemž napadené zvíre vylučuje z řiti jakousi štávu, která je má chrániti. Na poraněnỵch soudruzích neb na zabitých mouchách, jež položíme na květenství jimi obydlené, shromažduji se všecky larvy z nejbližšího okolí a setrvávají tam tak dlouho, až celé tělo vyssají. Skrze tvrdý chitin much nemohou prý arcif proniknouti mèkké jejich ústroje ústní, ssaji tedy jen na ranách po odtržených nohách a vnikají poznenáhla dovnitř těla, když toto vysychati počíná. Jest prý však 


\section{H. UZEL, MONOGRAPHIE DER ORDNUNG THYSANOPTERA.}

otázkou, zdali tyto larvy prece neživí se štavami rostlinnými, stávajíce se snad jen náhodou masožravými. Jisto však prý jest, že dávaji přednost štavám zviŕecím.

Uvážíme-li udaje jednotlivých autorủ, a přibereme-li $\mathrm{k}$ tomu vlastní zkušenosti, mỵslime, že od pravdy daleko se neodchýlíme, tvrdíce (částečnè s Osbornem [L. č. 163.]), že třásněnky jsou valnou většinou býložravými, že však nékdy, naskytne-li se jim sama príležitost, pohrouži rypáček svůj i do štavnaté dužniny mrtvého zvířete, a sice na místech, kde již je raněno. Že by živá zviŕata nějak honily a chỵtaly, tomu zajisté nenasvědčuje stavba jejich těla a ústrojú ústních; možno však ovšem, že časem vyssají nèjakou měkkou nebybnou larvu neb lenivou mšici, které jim odporu žádného nekladou. Pokud žraní pylu a plísně se týče, neodpovídá to taktéž ssavým jejich ústrojům ústním, které jen hmoty více nebo méně tekuté mohou prijímati.

\section{PŘEZIMOVÁNÍ TŘÁSNĚNEK. WINTERQUARTIERE.}

Druhy, které v létẽ $\mathrm{v}$ rủzných kvètenstvich žiji, zủstávaji z části v nich také pres zimu (tak zvláště Chirothrips manicata, Physopus vulgatissima, Thrips physopus, communis a rod Authothrips), aneb uchỵluji se do drnu, pod mech, pod spadané listí, neb zalézaji do skulin kủry. Druhy, které na listech se zdržuji, prezimují bud na zemi pod listím aneb $\mathrm{v}$ drnu a $\mathrm{v}$ mechu, jiné také $\mathrm{v}$ trhlinách kůry a mezi lišejníky na ní rostoucími (tak Thrips sambuci a Physopus ulmifoliorum; Dendrothrips saltatrix prezimuje jen $\mathrm{v}$ kưre). Druhy Parthenothrips dracaence a Heliothrips haemorrhoidalis, v našich sklenícich na listech žijící, nemaji ovšem př́činy vyhledávati zimních skrýší a zdržují se na týchž mistech po celý rok. Druhy, žijící v létě pod zpuchrelou korou, v drnu, pod spadaným listím a hnijícími látkami rostlinnými, zủstávají zde ovšem také v zimě; jen druh Sericothrips staphylinus z malé části uchyluje se do seschlých květenství všelijakỵch rostlin. Obilné třásněnky skrývaji se před zimou dle Lin demana (L. č. 153.) v dutinách strnů.

Zvláštní úkaz ze života třásnènek, sem se vztahující, vypravuje Cornelius (L. č. 92.). $\mathrm{V}$ krajinách na Dolním Rýně a $\mathrm{v}$ hrabství Mark stěbují se prý třásněnky na podzim $\mathrm{v}$ zástupech do domů a hledají tu pod čalouny, obrazy a ve skulinách úkryt před zimou. Poněvadž však zde nemohou skřehnouti a v tom stavu, spánku podobném, zimu přežiti, umírají prý vesměs hlady. $V$ krajinách zmíněných jest toto stěhování se třásněnek známým úkazem, a stěhovavý druh jest snad Chirothrips manicata. Vše to dlužno ještě blíže zkoumati.

Některé z třásnènek, na krytých mistech (zvláště pod korou) žijící, prezimuji ve všech stadiích vývoje a za počasí jen poněkud teplejšiho pohybuji se i během zimy a prijímají (dle Jordana) též potravu. Ostatní třásněnky přezimuji bud jen jako dospělé samičky (velmi mnoho druhủ), neb v obou pohlavích (tak většina tubulifer, Chi- 


\section{J. UZEL. MONOGRAFIE RADU, "THYSANOPTERA“.}

rothrips manicata. Oxythrips hastata. Sericothrips staphylimus a jiné), neb jakožto larvy více nebo méně dospělé. Yajiček prezimujicích jsem nevidèl; Ladureau (L. č. 112.) však tvrdí, že tř̆́snènka na lnu žijící kiterou nazývá Thrips lini, klade zimní vajička. Výhradně jakožto larvy prespávají zimu patrně (sám jsem jich v zimě neviděl) druhy, jež jen na kratši dobu v dospělém stavu v létě se objevuji (ku př. Thrips adusta a Stenothrips graminum). Avšak laké Aeolothrips fasciata, jenž po celé léto i podzim ršude se nalézá a hlarnẽ květy lnice a\% do prrních studených dnủ obỵvá, hyne krátce pred zimou, a jen larvy jeho (neb snad i rajička) jara se dočkávají. - Prezimující samičky trásněnek maji dle Jordana raječníky zakrnèlé a ne jinak ryvinuté než nymfy, samci však mají varlata naplnèná chámem.

Z jara, kdy̌z paprsky slunce jen poněkud prohrejí půdu a vyvolají první květy, také tr̉ásněnky se probudí $\mathrm{k}$ novému životu, takže některé $\mathrm{z}$ nich ěasto již $\mathrm{v}$ březnu v prrních snëženkách, bledulích, jalernících, sasankách, kî̀ivatcích, pampeliškách a chudobkách se rỵskytuji; sem patři Physopus primulae, atrata, nervosa, vulgatissima, Thrips communis, Limothrips denticornis a Anthothrips aculeata. Studené jaro nebo studenỵm větrùn prístupné stanovisko je ovšem zdıží déle $v$ jejich skrýších zimních, během dubna ršak, pokud rim, již všecky se probouzejí.

\section{POHYBY TŔÁSNËNEK. BEWEGUNGEN.}

Pohyby terebrantií jsou v celku dosti čilé. Zvláště druhy, které v květinách žijí, (tak predevším Thrips. Physopus a všechna coleoptrata) bēhají rychle a létaji snadno. Druhy na listech žijící mívají pohỵby volnější; tak zvl. Parthenothrips, Heliothrips, Dendrothrips; druhy pak, v drnu se zdržujicí, bývají velmi lenivé; tak Limothrips, Chirothrips, Prosopothrips, Platythrips. Druh Sericothrips staphylimus oršem činí výjimku, neunavnè tĕkaje $z$ místa na místo, při čemž ustaviěnè mění směr cesty a přes tu chvili se zastavuje (podobně jako brouček Trichopteryx). Limothrips denticornis dovede také pozpátku lézti.

Druhy, které jsou křidly opatreny, lítají vesměs a mohou směr letu svého samy říditi. V obratném letu preederším rỵnikají druhy v květech žijící, a to zvláště samečkové. $\mathrm{V}$ letu pristihl jsem je za dne i podvečer. C̆asem však, chtējice dostati se jen o málo rpred, neb unikají-li nepríteli, vzlétnou jen na krátko a opisují piri tom křivku hadovitou, jak to již Sulzer (L. ¿̌. 5.) pozoroval.

Mnohé rody terebrantií dovedou též poskakovati; tak Parthenothrips, Dendrothrips, Thrips, Physopus, Sericothrips. Skok děje se nēkolikerỵm způsobem. Z okřídlených některé skáčou za pomoci svých kř́ídel, jak to již Szaniszló (L. č. 116.) a Jordan (L. č. 162.) pozorovali. Skok, jejž jsem u druhu Parthenothrips dracaenae 


\section{H. UZEL, MONOGRAPHIE DER ORDNUNG THYSANOPTERA.}

sledoval, děje se následovně. Zprvu zvedne tato trásñěnka prvý a poslední pár noh do výše, takže stojí na prostředním a visí takřka ve vzduchu. Při tom ohýbá hlavu a abdomen značně nahoru. Špička abdomenu opírá se o konce tuhých křídel, které se tím taktéž značně prohnou v oblouk nahoru vypoukly. Náhle povolí třásněnka všecky svaly, a již unášena jest do výše následkem pružnosti křídel, které opèt rázem se narovnávají. Skákání tohoto druhu již Jordan podobny̧m asi zpủsobem ličí. U okřídleného rodu Dendrothrips dèje se skok za pomoci dlouhých zadních nohou, jejichž kyčle opírají se o zvláštní silné a pružné chitinové péro (Tab. VI., fig. 86.), v hrudi umistněné, a tak tělo na poměrně velikou vzdálenost odmrštuji. Jiné okřídlené třásněnky skáčí, podobně jako některé neokřídlené (ku př. Sericothrips staphylinus) dle Scopo-

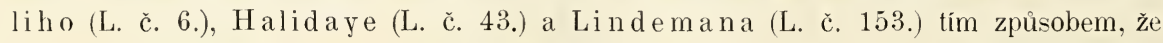
odrážejí se zadkem. Nesprávné jest tvrzení Burmeisterovo (L. č. 45.), jež i Brauer (L. č. 139.) opakuje, že totiž některé třásněnky skáčí tak, že náhle narovnávají ohnutý koneček abdomenu. - Některým třásněnkám pak, jak okřidlenỵ́m, tak neokǐridleným, mohutnost' skoku schází. Sem patři rodỵ Chirothrips, Limothrips (denticornis), Prosopothrips, Platythrips, Aeolothrips a Aptinothrips. Tento poslední sviji se hadovitě, byv dráżdèn.

Podivné pohyby konaji čistici se třásnènky. Otírají totiž nožičkami povrch těla i křidla na způsob much; rozježené třásně pak uvádějí v pořádek za pomoci zadku, a to tím způsobem, že několikkráte pohybují jím mezi složenỵmi kirídly nahoru a dolû.

Pohyby tubulifer jsou vždy velmi volné a nemotorné. Okrídlené druhy neb exempláre lítají zirídka a velmi těžce se do vzduchu vznášejí. Let u nich dèje se dle He egra (aspoñ u druhu Phloeothrips coriacea) v noci. Skákati nedovedou. Některé druhy však kráči často se zadkem nahoru ohnutým na zpûsob drabčikủ (zvl. Liothrips setinodis), jak to již Scopoli (L. č. 6.) pozoroval. Tubus na konci tèla se nalézající mají, jak myslím, k tomu, aby se jím při prolézáni úzkými skulinami pevně opíraly. Také prìi obracení těla naznak položeného jim platných služeb prokazuje.

\section{POHLAVNÍ ŽIVOT TŘÁSNĚNEK. GESCHLECHTSLEBEN.}

Již záhy z jara spějí některé druhy třásněnek $\mathrm{k}$ vyphnění hlavního úkolu svého, ku rozmnožení vlastního pokolení a zachování druhu. Tak již v březnu v kališcích prvních bledulí snoubí se třásněnka Physopus primulae. Bèhem celého jara a léta pak snoubí se ostatní třásněnky. a ještě pozdě na podzim nalézáme párky druhu Aeolothrips v kvètech lnice.

Párení dèje se obyčejně ve dne, někdy však i v noci, jak to pozoroval Heeger u druhủ Heliothrips haemorrhoidalis, Limothrips denticornis a Phloeothrips coriacea. Dle téhož autora sameček brzy po páření hỵne. 
U terebrantii vystoupi prì páření sameček na hřbet samičky, obejme její prothorax predními nohami a ohỵ́bá abdomen se strany pod její abdomen, taǩ̌e poslední jeho kroužky stranou hr̉betní dolýkaji se brỉšni strany samičky. Tím vỵsvělluje se, proč penis a jeho pochry ohnuty jsou nahoru, a také účel hákovitých prííèskủ nahoře na devátém clánku abdominalním u samečka druhu Aeolothrips fasciata stává se zřejmým; jest to totiž ústroj prìiržovací. Kopulace trvá delší dobu. - U tubulifer dèje se páření podobným zpủsobem; sameček ohýbá však svủj abdomen tak por abdomen salničky, že obě brỉšní strany se stýkaji. Spojení pak netrvá tak dlouho a sameček muže za krátký čas více samic oploditi. $V$ jednom prípadě oplodil dle Jordana jediný sameček šest samic za čtvrt hodiny. Kdy̌z na to byl zabit a rozrezán, shledáno, že jeho varlata byla ještě do polou semenem naplněná.

\section{KLADENÍ VAJÍČEK. EIERABLAGE.}

Několik dní po oplození položi samička tr̉áněnek svoje první vajičko. Samičky terebrantií udělaji ostrỵm svỵ́m kladélkem do pletiva rostlinného malou skulinu, do níz vždy po jednom vajičku vpraví. Druhy v květech žijíci kladou je do vnitr̀ní stěny lístku kališních, jak již Uljanin (L. č. 98.) pozoroval, aneb dle Jordana také do stèn semeníku. V líslcích korunních (plátcích) vajiček nalezeno nebỵlo, což Joldan zcela přirozeně vykládá tak, že tylo brzy opadnou, a tudì by i vajička nazmar přišla, kdežto kalich a semeník dlouho po tom ješlě štavnatými zủstanou. Následkem poranèní kiadélkem vypne se povrch rostliny v lesklý hrbolek, re kterém zrịme, proti svètlu-li se díváme, obyčejně jasnou tečku, lủy̌ko to embryonalní. Podobným zpûsobem kladou třásněnky na listech žijicí vajička svá do parenchymu listového neb i výjimkou do nádorû jiným hmyzem zpussobených, jak to Riley (L. ̌ 85.) pozoroval. Mỵlné jest trrzení Heegrovo, že druh Thrips Kollari (= Limothrips denticomis) je klade po dvou až šesti na spodní stranu listu podél jeho žeber, podobně jak to také udává pro druh Thrips sambuci a Heliothrips haemorrhoidalis, jehož samičky již Burmeister (L. č. 50.) pozoroval, jak kladélkem do listủ skuliny dèlaly, a do nich svoje vajičcka pokládaly. Též mylná jest zpráva Farwicka (L. č. 108.), který popisuje kladení vajiček druhu Melanothrips obesa (= fusca). Toto prý dèje se na podzim, a sice tak, že samiěka nalepuje svá černá (?) vajička na chlupy, nalézajíci se na prízemních listech rũzných druhỉ pryskyĩníkủ. List takový vypadá prý jako sazemi posypaný, Jordan domnívá se (asi právem), że to nebyla vajička trásněnek, kiterá Farwick vidèl, nỵbrž jejich trus (!). Já sám nalézal jsem na stoncích a žebrech listorých sasanek prečetné malé černé hrbolky, které snad také mohly zavdati prǐčinu k Farwickově omylu. Též veliká nalepená vajička s velikỵm otvorem ku vznikání chámu, která Lin deman (L. č. 153.) na stoncích obilných viděl, nenáležejí tr̀ásněnce Thrips secalina (= Limothrips denticornis), již je 
připisuje, ač jemu samému je pak nejasno, k čemu by ona tr̃ásněnka měla kladélko. Tvrzení některých autorû (ku pr̃. Szaniszlóa), že „Thrips cerealium" klade vajička volně na povrch rostliny, vysvětluje se tim, že pod oním jmenovaným druhem shrnuji se často všecky třásněnky na obilí žijící, tedy také druh Authothrips aculeata, kterỵ ovšem jakožto zástupce tubulifer, jak pozdēji uvidíme, vajička svoje nezapouští do pletiva rostlinného. Podobně jest Fitchủv (L. č. 69.) druh Thrips tritici pravé mixtum compositum, nebot vykreslené imago jest nĕjaký zástupce tubulifer, tykadlo pak rozhodnẽ náleží nějaké třásnènce terebrantialní, a stopkatá vajičcka bůh ví kterému hmyzu.

Vajička terebrantií uzrávají ve vaječnících jednotlivě, takže kladení jejich děje se taktéž jednotlivě a vyžaduje tudiž delší doby, čimž také se vykládá, že nalézáme některé třásněnky v téže době v nejrůznějšich stadiích vývoje.

Tubulifera nalepuji svoje vajička jednollivě neb v malỵch hromádkách na povrch částí rostlinných. mẹezi kterými žijí. Tak udává Lindeman, že Authothrips aculeata, v klasech žitných se zdržující, je umistñuje v hromádkách, až 27 kusû číajicích, mezi pluchami aneb na ose klasu. Tak pod zpuchrelou korou nálézáme hromádky vajíček rủzných druhů tubulifer.

\section{SPOLEČNOSTI TŘÁSNĚNEK. GESELLSCHAFTEN.}

Třásněnky jsou valnou vètšinou samotáři a jen lam ve vělšim, někdy v převelikém počtu ze všech stran se slétaji, kde hojnost zvlášlě lahodné polravy se jim naskỵlá. Zde tedy nemožno mluvili o vájemné lásce (povstavši ovšem z nabỵly̧ch vỵ́hod), která je vespolek poulí. Ve skutečnỵ́ch společnostech žije jen několik málo druhů. Z tubulifer jsou to, pokud je známo, druhy Trichothrips copiosa, pedicularia, Phloeothrips coriacea, ulmi a druh Jordan ûv Phloeothrips brunnea, resměs druhy, pod zpuchřelou korou stromovou se zdržující. Z terebrantii žiji ve stálých společnostech jen larvy některých druhủ, spodní stranu listů obỵvajicích, a to od Heliothrips haemorhoidalis. Parthenothrips dracaenae, Thrips sambuci a Thrips major.

\section{NEPŘÁTELÉ TŘÁSNĚNEK. \\ FEINDE.}

Tr̀ásněnky maji zvlášlě mezi hmyzem mnoho nepřátel. Tak hubí je dle Heegra brouci Scymmes ater a Gyrophaena manca a nĕkolik mušich larev. V Sev. Americe ryssává je dle Osborna.(L. č. 163.) štěnice Triphleps insidiosa, a u nás viděl jsem často štěnici Triphleps mimuta $L$., ve květech žijicí, jak nabodávala třásněnky na svưj sosák do predu vatýčený, a jak kořist takto si pojistivši, na útěk se dávala. Kromè hmyzu pronásleduje třásnènky dle Heegra několik druhủ malých pavoukủ. Mnoho 


\section{J. UZEL. MONOGRAFIE RADU, „THYSANOPTERA“.}

třásněnek, mezi lišejníky a v trhlinách kůry před zimou skrytých, pohubí zajisté sýkory, a druhy, pod korou žijící aneb před zimou pod ní se uchy̧livší, padají za obět datlům, kiteří silným svým zobákem snadno zpuchrelou kûru odtrhávají.

Třásněnky oblěžovány jsou také některými cizopasníky. Tak velmi zhusta vídáme, jak veliká šestinohá larva nějaké svilušky (Trombidium) pevně sc př̀idržuje těla nejrůznèjších druhù, a to pravidelně mèkké části za kyčlemi zadnihı páru noh. Také na larvách třásněnek se tato sviluška (pořídku) vyskyluje. Barva toho cizopasníka jest červená, v líhu však úplně vybledne, a to jest snad přičinou, že někteří autoři (Curtis, Haliday) mluví o bílém roztoči na třásnènkách cizopasícím. V dutině tělní nalezl jsem u několika tr̉ásněnek množství premalých nematodủ a jejich vajička. Tak napočílal jsem v jediném exemplár̆i druhu Thrips physopus as 200 nematodů a tolikéž vajiček jejich! Vaječníky télo tr̉ásněnky byly úphně onèmi červy sežrány.

Proti těm všem nepřátelům jsou třásnènky takĭka bezbrannými. Jen jistý druh larev dle Bohlse (L. č. 167.) vylučuje z riti jakousi ochrannou tekutinu. Nepozoroval jsem též, že by přizpủsobením se barvě květủ, v nichž žijí, nějak se chránily, a nemohu potvrditi udaj Halidayủv, že žlutý druh Thrips flava vyhledává zvláště žlutých květủ. Jest také zcela přirozeno, že třásněnky na květech žijící nepřijímají zbarvení svého obydlí, nebot nežijí na květech, nýbrž v jejich vnitřku, a nemusí se tedy nepřitele vnějšího obávati. Natrhal jsem, abych o poměrech těch se poučil, plnou botanickou torbu nejrůznějších žlutých květů a nalezl jsem v nich třásněnky všech barev; ba nebylo ani žlutých třásněnek tolik jako jinak zbarvených. Zcela podobně mèla se věc, když natrhal jsem jen květy červené a jindy jen bílé.

\section{HORIZONTALNÍ A VERTIKALNÍ ROZŠíŘENÍ TŘÁSNĚNEK. HORIZONTALE UND VERTICALE VERBREITUNG.}

0 předmětu tom nedá se ovšem mnoho ř́ci, poněvadž vědomosti naše $\mathrm{v}$ tom ohledu jsou ještě velmi kusé. Vždyt' v Evropě samé byly třásněnky posud velmi málo sbírány, o jiných dílech světa ani nemluvě. $Z$ toho mála, co posud známo, vychází na jevo, že jednotlivé druhy jsou po Evropě velice rozšířeny. Tak nalezeny byly některé na všech místech, kde bylo dosud hledáno. Nejlépe dokazuje stejnoměrné rozšiření jednotlivých druhů po Evropě okolnost, že z 53 druhủ z ní dříve popsaných bylo jich 37 nalezeno též v Čechách.Druh Chirothrips manicata a dle Perganda druh Thrips tabaci má Evropa se Sev. Amerikou společný.

Z mimoevropských zemí jest posud jen 18 druhů známo, ač není pochybnosti, že tam též veliké množství třásněnek se nalézá, které však nedošly dosud povšimnutí pro své malé rozměry těla a zdánlivou neúhlednost'. Zajímavým jest značné rozšiření rodu Idolothrips $\mathrm{v}$ tropických krajinách. Vyskytujit' se zástupcové toho rodu v Australii (Id. marginata Halid., spectrum Halid., lacertina Halid.), na Ceylonu (druh posud 


\section{H. UZEL, MONOGRAPHIE DER ORDNUNG THYSANOPTERA}

nepopsaný), ve Vých. Indii u Mysore (Id. Halidayi Newm.), v Brasilii (Id. Schotti Heeg.) a v Columbii (několik druhů nepopsanỵch).

Přičinou valného rozširení jednotlivých druhủ trásnènek jest zajisté ta okolnost, že pro svou lehkost a dlouze trásnitá kiř́dla snadno bývají rètrem rysoko zvednufy a podobně jako čuprínami opatrená semena rostlinná přes hory a doly unášeny. To platí pro druhy okř́ldlené. Víme však, że i mezi druhy, jež obyčejně křídel nemaji, vysskytá se časem okìídlená samička stěhovavá (femina disseminans), jež mủže druh srủj daleko rozšíriti, v kterémžlo ohledu pak trásněnkám nemálo prił̌niva jest mohutnost něklerých druhủ, že parthenogeneticky se mohou rozširovati. Druhy vždy neokřídlené, jako Aptinothrips rufa (v Anglii, na Helgolandě, ve Šédsku, u Berlína, v Čechách a u Moskvy nalezený), rozšiřily se ěasem asi jen lezením, při čemž podporoval je skrỵtý zpưsob života jejich (žjifit v drnu). Také cestou vodní třásnènky mohou se šîriti. což hlavně týká se tubulifer pod zpuchrelou korou žijicích. Do vody spadlý kmen ěasto jich chová veliké množství a mũže lak celou společnost trásněnek těch zanésli do vzdálenỵch krajủ, nebot mají dotyc̀né druhy vlastnost, této okohnosti velıni príznirou: snášejí totiž dobře značnỵ stupeň vllıkosti.

Také umèle bỵvají třásněnky rozširovány. Tak dostaly se s rostlinami exotickými druhy Heliothrips haemorrhoidalis. H. femoralis a Parthenothrips dracaenae do skleníku evropských i severoamerických. - Rozširování tr̃ásnènek obilim (jak Blan c ha rd [L. č. 59.] to prìpoušlí), slamou a suchými květinami nezdá se mi býti snadným, nebof larvy i dospělý hmỵz dlouho bez šlav rostlinných na żivu nezustanou a vajička jejich (aspoñ terebrantií) v seschlých rostlinách hynou. Mnohem spiše müze se rozširování některỵ́ch druhủ díti rozvážením zeleniny. Tak myslí Pergande, že zeleninu milující Thrips tabaci, který. byl nalezen $v$ Evropè (Lin de manem $v$ Bessarabii a L. Seifertem v Holštýně) i v Severní Americe (četně na nejrůznèjších místech) dostal se sem tím zpủsobem z Evropy. Listy tr̆ásněnkami poškozené, kleré obycejnè lodníci na březích prístavû pohodí, stávají se asi východisky jejich pozvolného rozširování se. Nnohem rychleji mohou širititi se ovšem všemi měry zároveň s rozváženou zeleninou po železnicích.

Pokud vertikalního rozšírení se týče, mohu jen o tom se zmíniti, co pozoroval jsem za svého dvojiho pobỵtu na Krkonošich. Ač jsem tam strávil v celku asi čtrnácte dní, ve kterých jsem ustavičně hledal, a to jak v květinách, tak v drnu a mechu, neobjevil jsem přece ani jediného druhu, který bych byl odjinud neznal. Jen étyrì variety byly dosud pouze na Krkonošich nalezeny; jsou to Physopus vulgatissima var. albicornis a var. fulvicomis, Therips najor var. adusta a Thrips communis var. anmulicomis. Nahoře na hřebenu Ḱrkonoš sbiral j:em kromè zmínèných trí druhủ ještě následujici trásnènky: Authothrips statices, aculeata. Thrips physopus, adusta, flaca. nigropilosa. Physopus pallipemis, atrata, tenuicomis, Auaphothrips virgo, Oxythrips parviceps, Aptinothrips rufa a Limothrips denticor ris, tedy celkem jen šestnáct druhủ, z nichž někleré (Physopus vulgatissima, pallipenuis, Thrips physopus, com- 


\section{J. UZEL, MONOGRAFIE RADU, "THYSANOPTERA“.}

munis, major a Aptinothrips rufa) byly tam velmi hojné. Vủbec tedy možno ř́ci, že nejvyšší partie lírkonoš jsou na druhy chudy, počet však individuí že tam jest veliký. Zuláštẽ nápadno jest, že pod drnem (jehož jsem dva pytle dal dopraviti domủ, kdež jsem je dủkladně prohledal) toliko dva druhy jsem nalezl (Aptinothrips rufa a Anaphothrips virgo).*)

*) Pr̃i této príležitosti dovoluji si mimochodem podotknouti, že jsem z celé Sněžky, zvláště pak z jižních svahû, prosíval (v záríi) plný pytel mechu a drnu v nadèji, že naleznu Steckerovo záhadné Gibboccllum sudeticum, což se mi však dosud nepodar̆ilo.

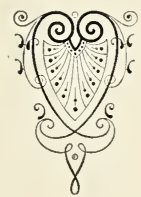




\section{Résumé des biologischen Theiles.}

In diesem Theile spricht der Verfasser von den Wohnorten der Thysanopteren. von ihrer Nahrung, ihren Winterquartieren, ihren Bewegungen (Flug, Kriechen, Sprung), ihrem Geschlechtsleben, ihrer Eierablage, ihren Gesellschaften, ihren Feinden und von ihrer horizontalen und verticalen Verbreitung. Alle bemerkenswerten Beobachtungen der einzelnen Autoren wurden angeführt, untereinander theilweise verglichen, theilweise durch eigene Beobachtungen bestätigt, und auch neue Thatsachen hinzugefügt. Da es zu weit führen würde, den Inhalt der einzelnen Artikel anzugeben, und einiges davon auch schon im systematischen Theile der vorliegenden Monographie enthalten ist, wollen wir nur die zwei letzten derselben, welche über die Feinde und die horizonlale und die verticale Verbreitung der Thysanopteren handehn, wiedergeben.

Die Thysanopteren haben hauptsächlich zwischen den Insecten Feinde. In NordAmerika saugt sie nach $\mathrm{Osborn}(\mathrm{Nr} .163)$ die Wanze Triphleps insidiosa aus. Bei uns sah ich oft die Wanze Triphleps mimuta L., welche in Blüten lebt, wie sie eizelne Thysanopteren mit ihrem Rüssel wie mit einer Lanze aufstach, und wie sie, nachdem sie sich ihrer. Beute auf solche Weise versichert hatte, eilig das Weile suchte. Nach Heeger werden die Thysanopteren durch die Käfer Scymmus ater, Gyrophaena manca und einige Fliegenlarven verfolgt. Nach demselben Autor stellen auch noch einige Arten kleiner Spinnen denselben nach. Viele Thysanopteren, die zwischen Flechten und in Rindenritzen vor der Kälte ihre Zuflucht suchten, werden von Meisen vertilgt, und die Arten, welche unter Rinde leben oder sich hier im Winter versteckt halten, fallen den Spechten und ähnlichen Vögeln zum Opfer, welche mit Hilfe ihres starken Schnabels leicht die morsche Rinde absprengen.

Die Thysanopteren werden auch durch manche Parasiten belästigt. So sehen wir sehr oft, wie sich die grosse sechsbeinige Larve eines Trombidium fest an den Körper der verschiedensten Arten (selten auch ihrer Larven) anheftet, und zwar regelmässig an die weichen Theile hinter den Hüften der Hinterbeine. Die Farbe dieses Parasiten ist roth, wird jedoch in Spiritus vollkommen bleich; dies ist vielleicht der Grund, dass einige Autoren (Curtis, Haliday) von einer weissen parasitischen Milbe auf dem Körper der Thysanopteren sprechen. In der Leibeshöhle fand ich bei einigen Arten eine Menge winzig kleiner Nematoden und ihrer Eier. So zählte ich in einem einzigen Exemplar 
der Art Thrips physopus etwa 200 Nematoden unl ebensoviel ihrer Eier! Die Eierstöcke dieses Individuums waren von den Würmern vollkommen aufgezehrt.

Gegen alle diese Feinde sind die Thysanopteren sozusagen wehrlos. Nur eine Phloeothrips-Larve scheidet nach Bohls (Nr. 167) aus dem After eine Schutzflüssigkeit aus. Ich habe auch nicht bemerkt, dass sie sich durch Anpassung an die Farbe der Blüten schützen würden, und kann die Angabe Halidays, welcher behauptet, dass die gelbe Art Thrips urticae (= flava) besonders gelbe Bläten aufsucht. nicht bestätigen. Es ist auch ganz natürlich, dass die Blütenbewohner unter den Thysanopteren nicht die Färbung ihrer Umgebung annehmen, denn sie leben nicht auf den Blüten, sondern in denselben und müssen infolge dessen den Feind von aussen nicht fürchten. Ich pflückte, um mich über diese Verhältnisse zu informieren, eine volle Botanisierbüchse der ver. schiedensten gelben Blüten und fand darin Thysanopteren aller Farben; ja es waren anders als gelb gefärbte in Nehrheit. Ähnliches ergab sich, als ich rothe und als ich weisse Blïten in Nenge untersuchte.

Was die horizontale Verbreitung der Thysanopteren anbelangt, so lässt sich daron freilich nicht viel sagen, weil unsere Kenntnisse in dieser Hinsicht noch sehr unvollständig sind. Es wurden ja die Thysanopteren in Europa selbst bis jelzt nur sehr wenig gesammelt! Aus dem Wenigen, was bis jetzt bekannt ist, geht hervor, dass einzelne Arten in ganz Europa verbreitet sind. So wurden einige an allen Orten, wo man bis jelzt Thysanopteren sammelte, aufgefunden. Am besten beweist die gleichmässige Verbreitung der einzelnen Arten in Europa der Umstand, dass ich von den 53 aus Europa bekannt gewesenen Arten 37 auch in Böhmen auffand. - Die Art Chirothrips manicata und nach Pergande die Art Thrips tabaci hat Europa mit Nordamerika gemein. Wahrscheinlich noch manche andere!

Aus den aussereuropäischen Ländern sind nur 18 Arten bekannt, obwohl dort ohne Zweifel viele Thysanopteren leben, welche jedoch bis jetzt wegen ihrer Kleinheit und scheinbaren Unansehnlichkeit unbemerkt blieben. Interessant ist die grosse Verbreitung der Gattung Inlolothrips in den Tropen. Es kommen nämlich Vertreter dieser Gattung in Australien (Id. marginata Halid., spectrum Halid., lacertina Halid.), auf Ceylon (eine noch unbeschriebene Art), in Ost-Indien (It. Halidayi Newm.), in Brasilien (Id. Schotti Heeg.) und in Columbia (einige unbeschriebene Arten) vor.

Der Grund der grossen Verbreitung vieler Arten ist jedenfalls darin zu suchen, dass die Thysanopteren wegen ihrer Leichtigkeit und ihrer langgefransten Flügcl leicht durch den Wind hoch aufgehoben und ähnlich wie die mit einem Pappus versehenen Pflanzensamen über Berg und Thal fortgeführt werden können. Dies gilt von den geflügelten Arten. Wir wissen jedoch, dass auch unter den Arten, die gewöhnlich der Flügel entbehren, mitunter ein wanderndes geflügeltes Weibchen - femina disseminans (sielı das Résumé des entwicklungsgeschichtlichen Theiles) auftritt, welche ihre Art weit verbreiten kann. In dieser Hinsicht ist den Thysanopteren das Vermögen mancher Arten, 


\section{H. UZEL, MONOGRAPHIE DER ORDNUNG THYSANOPTERA.}

sich parthenogenetisch fortpflanzen zu können, von nicht geringem Nutzen, da selbst einzelne Weibchen, vom Winde verschlagen, die Stammütter einer grossen Nachkommenschaft werden können. Die stets ungeflügelten Arten, wie Aptirothrips rufa (in England, auf Helgoland, in Schweden, bei Berlin, in Bölımen und bei Moskau gefunden) verbreiten sich wohl mit der Zeit hauptsächlich durch Kriechen, wobei ihnen ihre versteckte Lebensweise (sie leben im Rasen) zugute kommt. Auch auf dem Wasserwege können sich die Thysanopteren verbreiten; dies bezieht sich besonders auf die Phloeothripiden, welche unter morscher Rinde leben. Ein in das Wasser gefallener Stamm beherbergt oft eine grosse Menge dieser Thiere und kann eine ganze Gesellschaft von Thysanopteren in entfernte Gegenden übertragen; denn die betreffenden Arten haben eine diesem Umstande sehr günstige Eigenschaft: sie vertragen nämlich recht gut einen bedeutenden Grad von Feuchtigkeit.

Auch künstlich pflegen Thysanopteren verbreitet zu werden. So gelangten die exotischen Arten Heliothrips haemorrhoidal is, H. femoralis und Parthenothrips dracaenae in die eüropäischen und nởdamerikanischen Glashäuser. - Die Verbreitung der Thysanopteren durch Getreide (wie es Blanchard [Nr. 59] zugibt), durch Stroh und trockene Blumen scheint mir nicht leicht zu Stande kommen zu können, denn die Larren und die entwickelten Insecten bleiben nicht lange ohne Planzensäfte am Leben und ihre Eier (wenigstens die der Terebrautien) gehen in trockenen Pflanzen zu Grunde. Die Verbreitung durch frisches Gemüse ist schon viel wahrscheinlicher.

Was die vertikale Verbreitung anbelangt, so kann ich nur das erwähnen, was ich während meines zweimaligen Aufenthaltes auf dem Riesengebirge bemerkte. Obwohl ich dort im ganzen etwa vierzehn Tage forlwährend sammelte, und zwar sowohl in Blüten, als auch im Rasen und Moos, entdeckte ich doch keine einzige Art, welche ich nicht von anderen Orten her gekannt hätte. Nur vier Varietäten wurden bis jetzt ảusschliesslich auf dem Riesengebirge gefunden; es sind dies Pluysopus vulgatissima var. albicomis u. var. fulvicornis, Thrips major var. adusta und Thrips communis var. ammulcornis. Oben auf dem Kamme des Riesengebirges sammelte ich ausser den erwähnten drei Arten noch die folgenden: Authothrips statices, aculeata, Thrips physopus, adusta, Alava, nigropilosa, Physopus pallipennis, atrata, tenuicornis, Anaphothrips virgo, Oxythrips parviceps, Aptinothrips rufa und Limothrips denticornis, also im ganzen nur sechszehn Arten, von denen manche dort sehr zahlreich waren. Die höchsten Partien des Riesengebirges sind also an Arten sehr arm, die Zahl der Individuen ist dort jedoch gross. Sehr auffallend ist es, dass ich unter Rasen, von dem ich zwei Säcke nach Hause bringen liess, wo ich sie gründlich durchgesucht habe, nur zwei Arten auffand (Aptinothrips rufa und Anaphothrips virgo), wogegen in der Ebene die Beute aus Rasen immer gross ist.

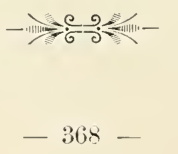




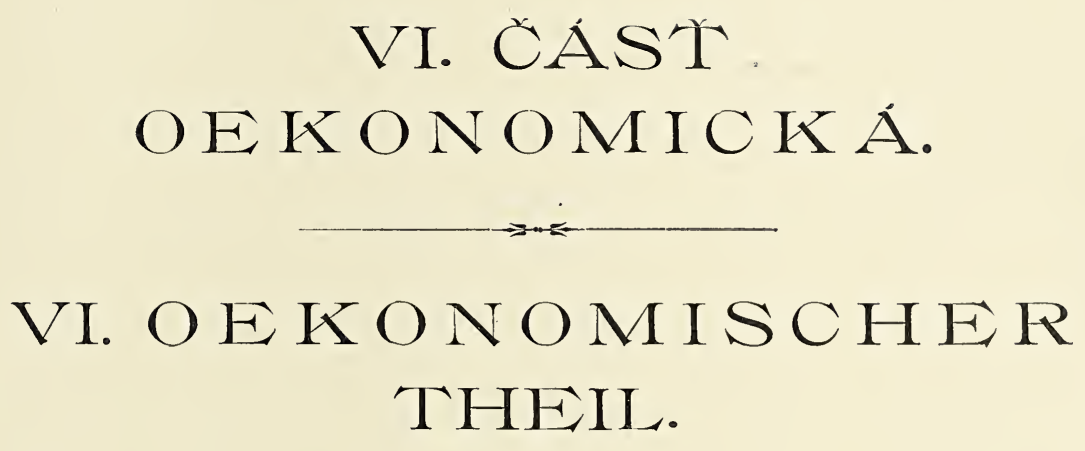





\section{J. UZEL, MONOGRAFIE RÁDU „THYSANOPTERA“.}

\section{ÚVODNÍ POZNÁMKY. EINLEITENDE BEMERKUNGEN.}

Škody třásněnkami zpủsobené jsou někdy značné; často však se přehánějí, a ještě častěji připisují se jim škody jiným hmyzem nadělané. Sestavíme v této části podstatné věci z jednotlivých zpráv, zájmů oekonomických se týkajících, v tom pořadí, v jakém za sebou uveřejñovány byly, a sice uvedeme je dle jednotlivých pěstovaných rostlin, na které se vztahují. Naše vlastní zkušenosti připojíme na príslušných místech. Vypočitáme také při jednotlivých rostlinách všecky druhy třásněnek, které jsme kdy na nich v Čechách nalezli, a o nichž předpokládáme, že mohou více nebo méně dotyčné rostlině škoditi. Nezmíníme se tedy o třásněnkách, pod zpuchřelou korou jednotlivých pěstovaných stromů žijících, poněvadž zde niijaké škody nezpůsobují. Za to jmenujeme všecky druhy, v květech neb na listech se zdržující, i když v nepatrném množství se vyskytují a tudíž škody citelné nenadělají, a to sice $z$ té př́činy, že mohou $v$ jiném čase neb na jiném místě ve velikém množství se vyskytnouti a pak ovšem značně škoditi. Sestavení třásněnek dle rostlin, na kterých žijí, může také sloužiti ku snažšímu určení jednotlivých druhů. Dovoluji si ješlě podotknouti, že jsem neohledal jen mimochodem některé pěstované rostliny, nýbrž že jsem věnoval té věci dlouhý čas, snášeje si od většiny vyjmenovanỵch rostlin plné botanické torby neb pevně uzavírající vaky, do nichž trhal jsem květy neb listy téže rostliny po celý den $\mathrm{z}$ nejrüznějších stanovisk, abỵch je večer nad bílým papírem vṿklepával.

\section{OBILÍ (ŽITO, PŠENICE, JEČMEN, OVES), - CEREALIA.}

Prvním, kdo škody třásněnek na obilí pozoroval, byl Linné. R. 1767. (L. č. 10.) píše tento autor, že Thrips physopus zpưsobuje hluchost klasủ žitných. První třásněnku v pšenici objevil v. Gleichen (L. č. 12.), a sice byl to druh Aptinothrips rufa. Roku 1790. pojednává Bjerkander (L. č. 25.) o jisté třásněnce, která ve Švédsku poškozovala vyrážející ječmen. O šest let později píše Kirby (L. č. 27.) o třásněnce, která škodila pšenici v Anglii. Nazývá ji Thrips physapus a poznamenává, že samec její jest bezkř́́dlý. Haliday později poznal v ní druh nový, který nazval Limothrips cerealium. Tato třásnènka sedá dle Kirbyho v rýze zrn pšeničných a ssaje tam mléčnou štávu jejich. Tím způsobem prý částečně neb v některỵch případech docela je vy- 


\section{H. UZEL, MONOGRAPHIE DER ORDNUNG THYSANOPTERA.}

ssává, takže se scvrknou; jest prý v Anglii nejhojnějším hmyzem na pšenici. R. 1797. mluví Marsham (L. č. 28.) o třásněnce, jež poškozovala dvě léta před tím žito v Anglii. Myslí, že je to Thrips physapus. Roku 1798. oznamuje tentýž autor (L. č. 29.) škody třásněnek na pšenici způsobené. Roku 1806. vypravuje Vassalli-Eandi (L. č. 33.), že druh Thrips physapus (dle Haliday e byl to druh Limothrips cerealium) r. 1805. v Piemontu v Italii ohlodával(?) mladá pšeničná stébla nad kolínky, následkem čehož se nevyvinul klas. Na ten zpủsob zničena bỵla třetina úrody. Walsh (L. č. 77.) však domnívá se, že vlastním škủdcem byla tenkrát bejlomorka obilní (Cecidomyia destructor). Roku 1836. popisuje Haliday (L. è. 43.) druh Limothrips cerealium, na obilí v Anglii žijící, a poznamenává, že druh Aptinothrips rufa též ve velikém množství tam se vyskytuje. Tentýž autor nalezl druh Thrips (= Physopus) ulicis v jednom exempláři na žitě a mimo to udává, že druh „Thrips obscura" (= Anaphothrips virgo) na pšenici jest obyčejný. Taḱtéž roku 1836. praví Burmeister (L. č. 45.), že druh Limothrips cerealium jest velmi hojnỵ na pšenici, a že pustoší její klasy. Brzy potom Westwood (L. č. 48.) promlouvá o škodách třásnènek na obilí v Anglii. Také Curtis (L. č. 55.) přičíá jim škody na žitu, v Anglii způsobené, a podává obšíný přrodopis druhu Limothrips cerealium. Roku 1847. upozorñuje v. Bülow-Rieth (L. č. 56.) na škody, jež jistý druh tr̉ásnènek v Německu zpủsobil na zimním i letním obilí. Poškození jevilo se tím, že prostředek klasu stal se hluchỵm. Téhož roku pojednává Dohrn (L. ě. 57.) o otázce, zdali trảsněnky json žitu škodlivy čili nic. V té dobẽ asi napsal Harris (L. č. 60.) zprávu o nějaké pomerančově zbarvené larvẽ třásnènky, jež žije na pšenici; soudí o ní, že patři k druhu Limothrips cerealium. Roku 1852. udává Haliday (L. č. 61.), že Thrips mimutissima v Anglii jest dosti hojná na obilí. Roku 1856. popisuje Fitch (L. č. 69.) druhy Thrips tritici a Coleothrips trifasciata. Prvý z nich nalezl v severoamerickém státu Wisconsinè jistý David Williams, jenž o něm udává, že ve velikém množství vyskytuje se tam koncem června na pšenici, kdež zaviñuje vadnutí klasû. Dle ėtyř výkresủ Fitchov ých lze snadno poznati, že tento autor spletl nèjakého zástupce podĩádu Tubulifera (dle výkresu zviřete celého a jeho křídla) s nějakou třásněnkou terebrantialní (dle tykadla). Drulıá škodlivá třáśněnka, tođiž Coleothrips trifasciata (velmi špatně popsaná), jest dle Fit che ve státẽ New-Yorku počátkem června na pšenici obyčejná. Kidyž tato uzraje, zdá se prý, že ji opouští a vyhledává kvetoucí rostliny, na pr̃. Tanacetum vulgare. Kromè této tr̉ásnènky nalezl Fitch v státu New-Yorku na pšenici ještě několik jiných druhů, které však nevyskytovalỵ se $\mathrm{v}$ takovém množství, že by žeň patrně ztenčovaly. Jeden z nich jest prý velmi podoben Halidayovu druhu Phloeothrips statices. Jiný severoamerický autor, B. D. Walsh (L. č. 77., 79. a 82.) vyslovuje několikkráte domněnku, že třásněnky jsou hmyzožravými, a myslí, že požirají na pšenici vajička a larvy bejlomorky Cecidomyia tritici, a tudǐz že jsou prátely rolnikovy. Pro svoji domněnku nemá však nižádných dủkazú! R. 1866. popisuje Deyrolle (L. č. 80.) nový přístroj, určený k tomu, aby ničil škodlivé třásněnky. 


\section{J. UZEL, MONOGRAFIE RADU, „THYSANOPTERA“.}

Roku 1869. pojednává Cohn (L. č. 87.) mezi jiným též o škodlivé třásněnce Thrips cerealium. Roku 1870. zmiňuje se Lindeman o škodlivé činnosti tìásnènek na obilí v okolí Moskvy.

R. 1872. popisuje Beling (L. č. 96.) třásněnku "Thrips frumentarius" (=Anthothrips aculeata) a liči její škody, na žitu, pšenici a ječmenu u Seesena na Harzu zpủsobené. Činnost této třásnènky jevila se zprvu tím, že z klasủ žilných, právě vymetaných, vypadávaly jednotlivé kvílky neb celé klásky; poněvadž byly jejich semeníky třásněnkami »ohlodávány«. U některých klasú jevily se škody hlavně na konci, u jiných uprostred. u vètšiny pak na basi. Jednotlivé klasy ztratily až i polovinu svých kvítků, u jiných pak jen některé klásky priššly na zmar. Nejčastèji odpadalo nejspodnèjších pèt kláskû a mohla tudíž škoda snadno býti přehléłnnta. Kidyž pak pozdēji i pšenice se metala, objevily se také na ní třásněnky nadřečeného druhu, škoda však, jimi zde způsobená. nebyla tak značná jako na žitě a jevila se jiným způsobem. Pluchy i plevy napadených kláskủ neopadávaly totiž a zmènily jen poněkud barvu, stavše se žlutějšími. Škody třásnènek bylo tedy v tomto prípadè zvenči těžko znamenati; ješlè nejsnáze bylo Ize je zpozorovati dle toho, že poškozené kvitky trochu vylézaly. V červenci konečně také na metající se ječmen třásněnka ona se dostavila. Také zde dělo se poškozování tím, że následkem ssání na semeníku opadávala jednotlivá kvítka i se svými pluchami, takže jen plevy státi zûstaly. Kdy̌̌ pak zrnka ječná počala tvrdnouti, dávaly se třásněnky do pluch, čímž však nijakých škod nezpûsobovaly. Ještě pozdèji stěhovaly se třásnènky do květủ chrp a do květenství rủzných travin. Škody na žilu a pšenici zpủsobené obnášely asi jedno, místy i více procent výtěžku. Na obili nalezl Beling také druh Limothrips denticornis, avšak jen $\mathrm{v}$ jednom exempláři. Druhu Limothrips cerealium nepozoroval.

R. 1875. podává Taschenberg (L. č. 99.) zprávu, že v roce předcházejícím vyskỵtlo se v Předních Pomořanech velmi mnoho třásněnek na žitě, takže jich v jednom klase 20-40 bylo nalezeno. Škoda, kterou způsobily, jevila se $\mathrm{v}$ tom, že prostredek klasủ, jimi napadených, stal se hluchým. R. 1876. mluví Szaniszló (L. ě. 104.) o třásnènce Thrips frumentarius Beling (= Authothrips aculeata), na obilí v Uhrách žijicí. R. 1876. pojednává Dimitriewicz (L. č. 106.) o třásněnce Limothrips cerealium, poškozující žito v Uhrách. V této době asi byla dle Lindemana (L. č. 153.) pozorována škodlivá činnost' třásněnek na obilí v Rusku, v gubernii charkovské. R. 1877. podává Becker (L. č. 109.) zprávu o škodách způsobených na žitě larvou (dle Beckera žlutavočervenou) třásněnky Limothrips cerealium na dolním Rýně, a to v okresu kempenském, zvláště pak v okolí Lobbericha. Tỵlo vyssávaly útlý semeník a zavinily, że mnohé klasy staly se na své dolejši ěásti hluchỵmi, kdež jednotlivé zaschlé kvílky bud zủstaly státi aneb opadaly. $V$ jednotlivých klasech bỵly často trìi, nèkdy pèt, ba i osm a více larer, jež prý zajisté mohou výtěžek o nemalé procento ztenčiti. Becker domnívá se, že asi mírná zima přispěla k rozmnožení tohoto hmyzu, který je i rolníkủm na 


\section{H. UZEL, MONOGRAPHIE DER ORDNUNG THYSANOPTERA.}

dolním Rýně znám pod jménem »Gewitterwürmchen«. Přezimované samičky kladou počátkem léta svoje vajička na klasy, načež pustošení jejich začíná. Za 14-20 dní po rozprášení pylu jsou zrnka již tak pokročilá, že nebỵvají třásněnkami více napadána. Proti lèmto udajům Beckerovým a zprávám Taschenbergovým z r. 1875. obrací se Ǩörnicke (L. č. 110.), pravè, že zakrnèlost nejspodnèjších kláskú u žita jest jen zjevem pathologickým, s nímž nemá hmyz co činiti.*) Poliud se pak jejich opadávání tỹce, poznamenává, že nemohly bỵti třásněnkami ohlodány (toho však Be cker netvrdi), poněvadž tỵto mají ústroje ústní ssavé. Proti tvrzeni Taschenbergovu, že totiž třásnẽnky způsobují hluchost' prostřední části klasů žitných, obrací se Körnicke, prípomínaje, že onoho autora asi oklamaly kvetoucí klasy žitné, které svým tvarem mohou zavdati př́činu k mylnému náhledu, že jejich prostředek jest hluchyy. Hluchost květů obilných konečně dá prý se vysvětliti následujícimi zjevy: u žita nedostatečnṿ́m oplozením pylem, u ječmene hypertrofií semeníku, při čemž zároveñ prášníky zůstávají uzavřenými, a konečně u pšenice prítomností larev bejlomorky Cecidomyia tritici, v kterémžto prípadè se prášníky rovněž neotvírají. Téhož roku podává ještě Dimitriewicz (L. č. 111.) zprávu o třásněnce Thrips cerealium, škodící žitu ve Slezsku, a Ladureau (L. č. 112.) zmiňuje se o tom, že třásněnky („Thrips lini“) stěhuji se ze lnu $\mathrm{v}$ době jeho květu, když totiž na něm více nenalézají útlỵch štavnatých ěástí, dávajíce prỵ se větrem unášeti na různé obilí, $\mathrm{k}$ jehož klasủm dosud nevymetaný̦m se protlačují a zde útlé části pletiva vyssávají. Zvláště oves je jim prý po lnu velmi milỵ́. - Též ve Finnsku často již pozorovány byly škody trásněnkami zpủsobené. jak o tom Reuter (L. č. 113.) mluví. Jednotlivé kiasy pšeničné, žitné a ječné vadnou totiž a bělaji, a to následkem vyssávání stébla, jež dělo se nad prrním kolénkem. Posud tam na osení nalezeny byly následujicí druhy: Phloeothrips (= Anthothrips) statices. Limothrips denticotnis (v pšenici), Thrips (= Physopus) vulgatissima a Thrips physopus. R. 1880. podává Szaniszló (L. è. 116.) zprávu o druhu Thrips frumentarius (= Anthothrips aculeata), kterỵ objevoval se od r. 1876. ve velikém množstvi na obilí u Kološe v Uhrách, a sice obzvláště na pšenici. Také $v$ jinỵch krajinách uherskỵch vyskytovala se tr̆ásněnka ła, a sice také nejvíce na pšenici, avŠak též na žitu a na ječmenu. Samičky objevují se \% jara a kladou svá malá podélná vajička vždy na dolejší čásf jednotlivých kláskù; larva jest zprvu šedá, pak žlutá a konečně barvy rumělkové. Ač se tato třxisněnka velmi četně vyskytovala, byla prý škoda ji zpủsobená sotva patrná; ano zdá se prý, že není škodnou vủbec. Udaj Szaniszlóův, že skáče za pomoci svỵch křídel. svědči o tom, že pozorování aulorova vztahuji se nejen na druh Authothrips aculeata (který, jakožto zástupce tubulifer neskáče), nỵbrž také na nějakou třásněnku terebrantialní (z nichž mnohé druhy skákati dovedou): R. 1882. vyslovuje Pergande (L. č. 127.) domněnku, że třásněnky nejsou tuze škodnými, nebof ač ve velikém

*) Úkaz, že nèkolik klásků nejspodnèjšich chybi, pozoroval jsem též u nás v Čechách a vím jistě, že není v nižádném vztahu k třásněnkám. 


\section{J. UZEL, MONOGRAFIE RADU, „THYSANOPTERA“.}

množství se vyskytují, přece úroda citelně se neztenčuje; ba snad i přenášením pylu na bliznu stávají se užitečnými. R. 1883. popisuje Osborn (L. č. 131.) jistou tîásněnku, ve Spojených státech na pšenici hojně se vyskytujicí, jež značně se podobá našemu druhu Thrips flava. Považuje ji za identickou s druhem T. tritici, Fitchem r. 1856. popsaným (!). R. 1884. podána jest v časopisu: En tomologisk Tidskrift, Stockholm, na str. 90., zpráva o třásněnce, která r. 1881. mladému osení velmi škodila. Téhož roku oznamuje se v časopisu: Sitzungsberichte der Naturforscher-Gesellschaft bei der Universität Dorpat, na str. 149., že vyskytla se larva jisté třásnènky, snad druhu Limothrips cerealium, v klasech zimní i letní pšenice. V tomto roce ještě objevily se dle Lindemana (L. č. 153.) třásněnky hojně $\mathrm{v}$ klasech žitných $\mathrm{v}$ Livonsku. R. 1885. pojednává Werner (L. č. 141.) o druzích Limothrips cerealium a Thrips frumentarius (Anthothrips aculeata) jakožto o škủdcích obilí. Téhož roku mluví též Ormerod (L. č. 143.) o škodlivé činnosti druhu Limothrips cerealium v Anglii. Asi v této době také zmiñuje se Packard (L. č. 145.) o škodách, jež působí severoamerický druh Thrips striatus na pšenici, což pozdèji má Osborn za omyl. R. 1886. byla dle Lindemana (L. č. 153.) pšenice na jižní Rusi, v gubernii tambovské, třásněnkami tou měrou navštívena, že skoro polovice klasu byla jimi více nebo méně poškozena.

Roku 1887. vydal Lindeman největší práci, pojednávajicí o škůdcích obilí z rádu hmyzu třásnokř́dlého. Nadepsána jest: Die am Getreide lebenden Thrips-Arten Mittelrusslands (L. č. 153.). Autor jedná zde o pěti druzích na Rusi, zvláště v okolí Moskvy na obilí se vyskytujicích. Jsou to Thrips secalina, Phloeothrips frumentaria, Aptinothrips rufa a Phloeothrips armata. - Thrips secalina nov. sp. (= Limothrips denticornis!) žije na žitě, ječmenu a pšenici. Činnost' její znamenati lze koncem května a začátkem června na žitě a $\mathrm{v}$ červenci na letní pšenici a ječmenu. Tato jeví se dvojím způsobem, jednak odumíráním a vadnutím konce klasu neb několika jeho konečných kvítků, jednak objevenín se žlutých nebo bílých skvrn na hořejší pochvẽ listové. Uprostřed kvētna objevuje se tato třásněnka někdy $\mathrm{v}$ ohromném množství na nevymetaném posud žitě a protlačuje se k nezralému klasu, ukrytému v pochvě hořejšiho listu. Zde ssaje na ose jeho a tím odnímá štávu všem výše položeným ěástem, takže tyto odumírají. To děje se $\mathrm{v}$ době, kdy plevy, pluchy a osiny nejsou ještě vyvinuty, čím̌̌ stává se, že poškozené části na vymetaném klasu berou na sebe podobu tenkých, bílých, všelijak skroucených a proplitajících se nití. Část klasu, jež leží pod napadeným místem osy, zůstává zdravou a vyvine se náležitě.*) Takovýto klas okreslil jsem z Lindemanovy práce a podávám ho na Obraze $7 *^{* *}$ ) Ssají-li třásněnky na

*) U Hradce Králové nalezl jsem počátkem června taktéž jeden právě tak znetvořený klas, avšak nechei sám nijak tvrditi, že byl opravdu třásněnkami znetvořen.

**) Za laskavé dovolení, jež jsem k tomu od Société Impériale des Naturalistes de Moscou obdržel, budiž této společnosti, v jejímžto časopisu práce Lindemanova vyšla, vysloven zde můj obzvláštni dik. 
mladých kvítcích, opadnou jen tyto (plevy někdy zủstanou státi), kdežto ostatní části klasu normalně vzrostou. Rolníci považovali tyto škody za následek mrazủ. Z vajiček, které samičky položily, vylíhnou se asi za 10 dní mladé larvy, ježto zůstanou pod pochvou hořejšího listu, i když klas se již vymetal. Následky jejich činnosti jeví se nyní ovšem jiným způsobem. Nassávajice vnitřní stěnu pochvy listové na mnohỵch místech, jsou príčinou vadnutí napadenỵch částí, které dostávají světlou barvu a splynou ve

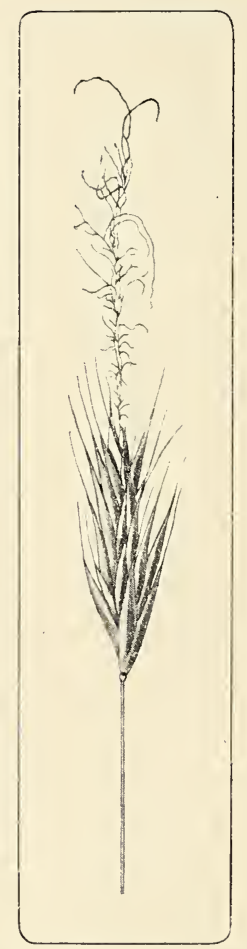

Obraz 7 . ŽITNÝ KLAS, DLE LINDEMANA TR̆ÁSNĚNKAMI POŠKOZENÝ.

(Dle téhož autora.)*)

skvrny, nèkdy až $6 \mathrm{~cm}$. dlouhé a často celý obvod pochvy zaujímající. Tyto skvrny nazývá Lindeman »Thrips-Flecke«. Asi po měsíci stávají se z larev nymfy, které, jak Lindeman mylně udává, také polravu přijímají a po pèti neb šesti dnech $\mathrm{v}$ dospělý hmyz se proměňují. To dẹje se koncem června. $V$ tu dobu tedy objeví se zástupy dospělých třásněnek, které se stěhují na nevymetané posud druhy obilí, a to sice na letní pšenici a ječmen. Tảm tvoří tytéž deformace klasủ jako u žita, nassávajíce je podobný̛m

*) EINE NAGH LINDEMAN DURGH THYSANOPTEREN BESGHÄDIGTE KORNÄHRE. (Nach demselben Autor.) 


\section{J. UZEL. MONOGRAFIE RADU „THYSANOPTERA“.}

způsobem. Také larvy z vajiček jejich se vylíhnuvší žiji pod pochvou listovou a prozrazují se velikými svètlỵmi skvrnami na ní. $V$ posledních dnech července a poěátkem srpna vylétá třctí generace dospèlých trúsnènek, kteráa vajiček již neklade, ny̧brž po nějakou dobu po polích se prohání, načě̆ vylıledává již zimni skíyšse; zalézá toliž do rourek strnú a pod různé předmèly na zemi ležicí, jako kaménkỵ a kousky dřeva. Lindeman přesrěděil se pokusem (vážením), že klasy jednollivỵch rosıllinek obilných, na jejicȟ̆ pochvách listových jevila se činnost třásněnek jen v podobě skvrn, neutrpèla škody žádné. Za to jsou ovšem škody, jež tr̀ásněnky na klasech samých způsobily, citelné, poněvadž nezrídka byl počet jimi až přes polovici zkažených klasủ velmi veliký. Jisto jest, že suché počasí škodlivou činnost jejich podporuje.

Phloeothrips frumentaria (= Anthothrips aculeata) žije na žitè, pšenici a ječmenu. Samičky tototo druhu objevují se v druhé polovici května, kdy již žito se vymetalo, a shromažduji se na mladých jeho klasech, kdež rypáček svůj zapouštějí do měkkého ještě pletiva semeníkủ, vyssávají je a zpủsobují tím jejich vadnulí a opadávání, při čemž však pluchy zủstávají státi, a tak škodlivou činnost třásněnek zrakủm rolníka zakrývají. Bèhem druhé polovice května a během celého června kladou samičky léto tr̉ásněnky svoje červenavá vajička na klasy obilné, a sice nalepují je v hromádkách až 27 kusú ěíajících mezi pluchỵ neb na osu klasủ. Mladé larvy vyssávají, podobně jako rodiče jejich, útlé semeníky. Během prvé polovice července mění se rudé larvy v nymfy a počátkem druhé polovice téhož měsíce objevuji se zástupové dospělých třásněnek, jež opouštěji klasy žitné, které již zráti počínají, a stěhuji se na mladé klasy pšeničné, kdež podobným způsobem vyssávaji semeníky jako na žitě. $V$ této ěinnosti pokračuji larvy z jejich vajiček se vylíhnuvší. Tyto žiji pak až do podzimu. Škody třásněnkou tou způsobené jsou neobyčejné. Napadené jimi klasy obsahovaly jen 6, 10 až 15 zrnek, kdežto zdravé klasy čítaly zrnek 60 až 85 !

Lindeman myslí, że by zaorání strništ na podzim a šlapání zorané plochy dalšímu rozmnožování obou těchto druhư tř́sněnek přítrž učinilo, poněvadž má za to, že přezimuji ve strnech. Mimo to bylo by prý dobře strny pak vyvláčeti a ihned spáliti.

Kromě těchto dvou druhủ nalezl Lindeman na obilí ještě druh Aptinothrips rufa, a to v druhé polovici června pod pochvou hořejšího listu ječmene, dále druh Chirothrips antennatus (=Ch. manicata) ke konci června v klasech žila a ječmene a náhodou též jednou druh Phloeothrips armata nov. sp. (= Anthothrips statices), jinak na složnokvětých ve velikém množství žijící.

R. 1888. jedná Lö w (L. č. 161.) o poškozování pšenice třásněnkami v Rakousku. Téhož roku popisuje J ordan (L. č. 162.) život »obilných phloeothripsủ « (= Authothrips aculeata) asi takto. Poč́tkem května dostavuji se třásněnky tyto na mladé rostlinky žitné (v Německu) a vnikají k mladým klasủm, kdež živí se štavami jak klasu, tak měkkého stébla. Na vymelaném klasu pozorujeme následkem toho, že jeho konec rovněž tak jako jeho basis, jsou více nebo méně poškozené. Vajička svá kladou trásněnky tyto bud' 


\section{H. UZEL, MONOGRAPHIE DER ORDNUNG THYSANOPTERA.}

jednollivě neb $\mathrm{v}$ malých hromádkách na plevy mladých klasủ. Po osmi až desíti dnech vyvinou :e z nich larvy, které jsou zpočátku šedé, a jež později stávaji se světle červenými. Ssají zároveň s dospělými trásněnkami na všech ěástech klasu, jenž posud jest měkiỵ. V červnu vyrine se z larev dospělý hmyz, který svoje vajička klade opẽt do klasủ. Vylihnuvší se z nich larvy mohou nyni skoro již jen ssáti na zrnkách, mléčnou štávu obsahujicich, poněvadž ostatní části klasu čím dále tím suššimi se stávají, a zdržují se za tím účelem hlavně v rýze zrnek. Podobně jako na žilě jsou i na pšenici škodlivými. Po žních larvy třásnènek hỵnou, a dospělý hmy̧ se rozprchne. Jednak stěhuje se na nezralý ještě oves, letní pšenici a traviny, kdež mnohá individua již dříve se zdıžovala, jednak na zelené klasy žilné a pšeničné. které porůznu na mezích a ve kr̃oví stojí, kdež nalézáme ho zároveň s larvami až do ríjna, načež vyhledává zimní skrýše. — Třásněnka Limothrips cerealium objeruje se dle Jordana na žitě obyčejně o něco pozdẽji než Authothrips aculeatu a žije s ní společně r tỷchz̆ klasech. Larry jeji vřak sedí na

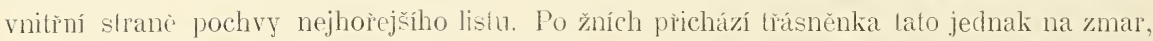
jednak prelélá, rovnèž jako Anth. aculeata, na oves a letni pšenici i travinỵ. kidež jiná individua taktéž jižz dříve v množlví žila. Tam kilade rajičkia, z nichž vỵvíjí se poslední generace tr̀ásněnek, jež prezinnje a na jaře opĕt na osení se objevuje.

$\mathrm{V}$ témže roce (1888.) praví Osborn (L. č. 163.) o trísnènce Limothrips gramineae, Perg̨andem tak pojmenorané, dosud však neuverejněné, že dle Perganda a Forbesa napadá žito a pšenici $\mathrm{v}$ Sev. Americe. - Konečně ureřejňuje $r .1891$. Hofmann (L. č. 169.) zpráru, v níž pričitají se trásněnkám veliké škody, na obilí ve Würtembersku zpuisobené lím, že místy, zvl. blízko lesů, všecky klasy někdy přes noc opadaly, sjakoby ostrỵm zubem bylỵ ukousnuty«, a że jindy stébla v polovici byla utržena; na zemi pak nalézalo se množství mèlu od pưvodee této spousty (!!). V lidu prý panovala domněnka. že škưdcem byla nyyš lesiní, což dle popisu škod těch jest velmi pravdèpodobno.

Já sám nalezl jsem v klasech žitných (Secale) následujicí druhỵ: Anthothrips aculeata ve velikém, někdy v prevelikém množství, Aptinothrips rufa v počtu daleko menším, Physopus tenuicomis a Anaphothrips virgo v nevelikém počlu, Limothrips denticornis, Chirothrips manicata a Physopus vulgatissima v menšim poètu, Acolothrips fasciuta, Thrips communis a Stenothrips gramimum pořídku.

V klasech pšeniěnỵch (Triticum) nalezl jsem druhy: Anthothrips aculeata nëkdy v neobyčejném množství, Stenothrips gramimum, Thrips communis a Aptinothrips rufa v počtu daleko menšim, Physopus temicornis, Thuips physopus a angusticeps v počlu ješlě menšim, Physopus vulgatissima, Limothrips denticornis, Anaphothrips virgo, Aeolothrips fasciata a Chrirothrips manicata v poělu nepatrném.

$V$ klasech jeěnỵch (Hordeum) sbíral jsem druhy: Stenothrips graminum v prevelikém innožství, Antholhrips aculeata, Physopus temicornis a Limothrips denticormis ve velikém množstrí, Anaphothrips virgo v poĕtu daleko menšim, Thrips 
J. UZEL, MONOGRAFIE RADU, "THYSANOPTERA“.

communis, Aptinothrips rufa v počtu ještě menšim, Thrips angusticeps, physopus. Chirothrips manicata, Physopus atrata a valyatissima v počtu nepatrném.

$\checkmark$ klasech ovesnych (Avena) sbiral jsem druhy: Stenothrips graminum a Anthothrips aculeata v neobyčejném množství, Physopus tenuicomis v počlu menším, Limothrips denticornis. Thrips communis, Aptinothrips rufu, Aeolothrips fasciata, Auaphothrips virgo v počtu nevelikém a Physopus vulgatissima v poc̀tu nepatrném.

Koukolem (Agrostemma githago) živí se hlavnè Physopus atrata, klerá někdy téměr̆ pokrývá mladé rostlinky jeho, a Ploysopus unlgutissinn, hojně v květu se vyskytujici.

\section{PROSO. - PANICUM MILIACEUMI L.}

Na kvetoucím prosu nalézal jsem druh Authothrips aculeatu v neobyčejném množství, Plyysopus vulgatissima, tenuicornis, Leolothrips fasciata v počtu nevelikém a Thrips communis zrídka.

\section{KUKUŘICE. - ZEA MAIS L.}

Roku 1867. popsal v. Frauenfeld (L. ¿.. 8t.) druh Thrips Benseleri, nalezený u Vídnè na kukuřici v zahıradě pèstované.

Já sám sbíral jsem v květenství kukurice druh Authothrips aculeata ve velikém počtu, Physopus vulgatissima, v dosti značném počtu, Chirothrips manicata a Physopus pallipemis zrídka. - Na listech kukurice nalézal jsem druh Authothrips aculeuta a Physopus tenuicornis v počlu nevelikém.

\section{KVĚTENSTVÍ TRAV LUČNÍCH. - GRAMINA PRATORUMI.}

Jǐ̌ roku 1790. mluví Bjerkander (L. č. 25.) o škodách třásněnkami na travinách lučních ve Švédsku způsobených. Roku 1836. poznamenává Haliday (L. č. 43.), že druhy Aptinothrips rufa, Chirothrips manicata, Limothrips denticornis a Baliothrips dispar żijí na travách v Anglii. a první z nich, že lam ve velikém množství se vyskytuje. Roku 1852. praví tentýz̆ autor (L. ̌̌. 61.), že Thrips fuscipemis zdržuje se na travinách. () škodách třásněnek na travinách v Dánsku pojednává roku 1875. Schöyen. Roku 1872. poznamenává Beling (L. ě. 96.), že druh Thrips frumentárius (= Anthothrips aculeata) zdrżuje se v srpnu v kvètenstvích r’üných travin na Harzu, kdež úllé semeníky vyssává, následkem čehož tỵlo opadárají podobně jako u obilí. Roku 1875. uveřejňuje Gomstock (L. č. 102.) některá pozorování vzhledem ke třásněnce Limothrips poaphagus (nominalní druh), poškozující trávu v Sev. Americe. Roku 1878. podotýká Reuler (L. č. 113.), že rủzné traviny mají ve Finnsku v době senoseče žluté, zvadlé klasy, cő̌ pochází od toho, že jejich slébla byla vyssáta, a sice nad hořejším kolénkem neb řídčeji nad předposledním. Pưvodcem léto škody jsou prý, 


\section{J. UZEL. MONOGRAFIE PADU .THYSANOPTERA“.}

ne-li výhradně, ledy aspoñ jistě vělším dilem tr̆ásnènky. Roku 1881. podává Lintner (L. č. 120.) zprávu o třásněnce Limothrips poaphagus, škodící v Sev. Americe travinám, a mluví též o jejím způsobu života. Roku 1883. popisuje Osborn (L. č. 131.) druh Chirothrips antenuahus (=Ch. manicata), o němž pravi, že je v Sev. Americe velmi hojný v kvělenství traviny Phleum pratense (timothỵ). Že autor považuje tento druh za neškodný, vỵplývá z jeho soukromého dopisu. napsaného Lindema novi. O nějaké trásněnce severoamerické, která poškozuje trávu, zmiñuje se též Fernald (L. č. 136.), jenž v žaludku jejím nalezl zrnka pylová(:). Také Gook (L. c. 137.) praví, že v Sev. Americe jsou asi pricinou vadnutí trávy dva druhy trásněnek ze tř́, jež na stéblech nalezl. Roku 1885. udává Ormerod (L. ě. 143.), že Thrips cerealimm škodí v Anglii travinám. R. 1887. poznamenává Lin deman (L. е̌. 153.), ̌̌e Thrips secaliua (=-Limothrips denticornis) żije u Moskvy pod pochvou hořejšiho listu traviny Pleleum pratense zároveñ se svými larvami, a že tam zpủsobuje žlulé skvrny, podobně jako u obilí. Na lèchže místech vídal také jednotlivé exempláře druhu Aptimothrips rufa. V klasech té traviny pak nalezl ve velikém počtu druh Chirothrips antemuahus (=Ch. manicata); stopy nějaké jeho činnosti škodlivé však nepozoroval. Za to zpưsobuje tam značné škody druh Phloeothrips frumentraria (= Anthothrips aculeata), jenž měkké semeníky vỵssává. takže pak opadávají. R. 1888. jedná Lintner (L. è. 157.) o trăsněnce, klerá vyskytuje se ve velikém množstrí na rủzných travinách v Sev. Americe a je poškozuje. Téhož roku tvrdí Comstock (L. č. 160.), že škůdcem lím jest Limothrips poaplacagus. Ješlě r tomto roce také praví Jordan (L. č. 162.), že na travinách (v Německu) žijí v množství druhy Authothrips aculeata a Limothrips cerealium, a že kromè toho po žních na ně stěhuji se ještě rástupy těchto druhủ, jež předtím na obilí žily. Dále poznamenává Osbo rn (L. č. 163.), že Limothrips gramimeae (nomináhí druh) dle Perganda a Forbesa napadá v Sev. Americe traviny. Konečně popisuje Trybom (L. č. 177.) škody, jež d’uh Aptinothrips rufa ve Švédsku na travinách zp ůsobuje.

Já sám nalézal jsem v kvètenstrí trav následující druhy: Anthothrips aculeata, Chirothrips manicata, Aptinothrips rufa a Stenothrips graminum ve velikém, nèkdy v neobyčejném množstrí, Thrips communis, Anaphothrips virgo v dosti značném množství, Physopus vulgatissima a tenuicornis v menšim počtu a druhy: Chirothrips Dudae, Limothrips denticomis, Thrips flaca. Physopus ulicis, pallipennis, Rhipidothrips gratiosa jen ziridka.

\section{CIBULE. - ALLIUM CEPA L.}

R. 1870. píše Packard (L. č. 90.) o jistém druhu lrásnènek, škodícím cibuli. R. 1872. zmiñuje se tenlýž spisovalel (L. č. 96. A) o jisté trásnènce, kterou nazývá Limothrips tritici (dle Perganda jest to Thrips tabaci), a jež nadèlala toho roku ve Spojených státech (Massachusetts) znaèných škod na cibuli. R. 1887. piše Shipley 
(L. č. 15̃6. A) o jisté trásněnce (dle Perganda laktě̌ Thrips tabaci), žijící na ostrovech bermudsky̧ch na cibuli, kdě̌ však, jak se zdá, jen malé škody způsobila. R. 1889. oznamuje Thaxter (L. č. 165. A), že jistý druh (dle Perganda T. tabaci) poškodil značně cibuli ve Spojených státech (Connecticut) tím, že zaviňoval udumírání listů, čímž rostlina ve vzrůstu byla zastavována. Od r. 1892. oznamuji se ze Spojených států mnohé škody zaviněné třásněnkami (dle Perganda vesmès druhem T. tabaci) na cibuli, a sice Gillettem (L. č. 172., L. č. 174.), Bakerem (L. č. 174.), Smithem (L. č. 175.), Osbornem a Mallym (L. č. 184.) i Pergandem (L. č. 185.) z nejrủznějších států (California, Colorado, Columbia, Illinois, Jowa, New Jersey, New York, Ohiu, Pennsylvania, Virginia) Škody jevily se hlavně tím, že vyssáté tř́ásněnkami listy cibulové ஜ̆loully, hnědly a konečně sesychaly neb za vlhkého počasí vodnatěly.

\section{PÓR. - ALLIUM PORRUM L.}

R. 1895. oznamuje Pergande (L. č. 185.), že mu zaslal L. Seifert z Holštýna trásnènky, jež tam velmi škodily póru. Má je za druh Thrips tabaci.

\section{CHŘEST. - ASPARAGUS OFFICINALIS L.}

R. 1883. nalezl Osborn (L. č. 131.) třăsněnky v kvètech chřestu v Sev. Americe.

\section{CHMEL. - HUMULUS LUPULUS L.}

R. 1888. poznamenává Osborn (L. č. 163.), že roku předcházejícího nalezl ve státu Wisconsině $v$ Sev. Americe na listech chmelorých jistý druh třásněnek, o němž myssí, že je nový.

Já sám nalezl jsem na mladých výhoncích pěstovaného chmelu u Lovosic několik exemplár̊u druhu Thrips communis. Na mladých výhoncích divokého chmelu nalézal jsem druhy Thrips flava var. obsoleta v mnačném množství, Physopus vulgatissima v menším počtu a Thrips communis i adusta v poc̀tu nepatrném. Z plodních šišek (hlaviček) divokého chmelu vyklepal jsem veliké množství druhu Thrips flava a malý počet jeji variety (obsoleta) a konečně nemnoho exemplářu druhu Thrips communis, Physopus atrata a vulgatissima.

\section{CUKROVKA. - BETA VULGARIS L.}

Na chr̀ásti cukrovky nalezl jsem v malém počlu následujicí druhy: Plyysopus atrata, Thrips communis, Aeolothrips fasciata a Dictyothrips betae. - V květenství jejím vyskytují se Thrips communis ve velikém množství a Physopus atrata, vulgatissima a Aeolothrips fasciata v počtu malém. 
H. UZEL. MONOGRAPHIE DER ORDNUNG THYSANOPTERA.

\section{POHANKA. - POLYGONUM FAGOPYRUM L.}

R. 1879. poznamenává Ladureau (L. č. 112), že „Thrips lini“ stèhuje se (ve Francii) z uzrávajícího lnu, kdež již dosti potravy nenalézá, kromě na obilí též na pohanku.

Já sảm nalézal jsem na pohance v malém počtu druhy Aeolothrips fasciata, Physopus atrata. vulgatissima a Thrips communis.

\section{OKURKA. - CUCUMIS SATIVUS L.}

R. 1895. píše Pergande (L. č. 185.), že mu zaslal R. D. Kline ze státu Illinois (Unie severoamerická) trùśnènky (dle nèho Thrips tabaci), jež tam škodily okurkám. Dále oznamuje, že v státech Columbii a Virginii bỵl nalezen tenty̌z druh na listech okurkových.

\section{MELOUN. - CUCUMIS MELO L.}

Westwood (L. c. 48.) mluvi o škodách druhu Thrips ochrocen, na melounech v Anglii zpúsobených, o nichž též Curtis (L. č. 55.) se zminuje. R. 1895. oznamuje Pergande (L. ¿. 185.), žc tr̈ásněnky (dle něho Thrips tabaci) objevily se v severoamerickém státě Illinois (dle zpráv Klineorých) na melounech.

\section{TOPINAMBUR. - HELIANTHUS TUBEROSUS L.}

Na topinamburu nalézal jsem v malém počlu druhỵ: Thrips communis, physopus, nigropilosa a Physopus vulgatissima.

\section{SLUNEČNICE, - HELIANTHUS ANNUUS L.}

R. 1852. ndává Heeger (L. ¿. 62.), že Melanothrips obesa (=M. fusca) žije u Vídně ve slunečnicich.

Já sám nalezl jsem v kvèlech slunečnic druh Aeolothrips fasciata.

\section{BRAMBOR. - SOLANUM TUBEROSUMI.}

Již Gurtis (L. ě. 55.) udává, že Thrips mimutissima škodí v Anglii bramborům. Pozdèji nalézá Osborn (L. č. 131.) v Sev. Americe lřásnènky v kvělech jejich. R. 1888. poznamenává Jordan (L. č. 162.), že druh Thrips mimutissima živí se v Nèmecku štavou z listů bramborových. V Nör dlingerově knize z r. 1855. (L. č. 68. A) čteme, že druh Thrips minutissima L. nalezen byl ve velikém množství na nemocných listech bram- 
borových. R. 1888. píše Lindeman (L. ‘. 158.), že nalezl pořidku druh Thrips tabaci na lislech brambororých r Besarabii. R. 1895. popisuje Pergande (L. č. 185.) druh Euthrips occidentalis, literý mu zasłal D. W. Coquillell z Kalifornie, kdež poškozoral listy brambororé.

Já sám shlédal jsem v květech bramborù veliké množství druhủ Thrips communis a Physopus atrata, dále dosti značné množství druhü Plıysopus vulgatissima a Aeolothrips fasciata a konečně malỵ počet druhủ Thrips physopus a flava. Na nati bramborové nalezl jsem druh Thrips communis v prevelikém počtu a v malém množstrí též druhy Stenothrips graminum, Thrips angusticeps, Anthothrips statices, Physopus rulgatissima a Aeolothrips fasciata.

\section{RAJSKÉ JABLKO. - SOLANUM LYCOPERSICUM L.}

R. 1888. oznamuje Lindeman (L. č. 158.), že rajská jablka byla trásněnkou Thrips tabaci v Besarabii značnè poškozena.

\section{TABÁK. - NICOTIANA.}

Škody na tabáku trásnènkami zpủsobené pozorovány posud jen r Besarabii. Po roce 1880 . počal tabák, $\mathrm{v}$ tamnějši krajině ve veliky̧ch rozmèrech pěstovaný, značně chřadnouti, ba hynouli docela. Komise, která ubirala se těmi krajinami na Kíim, aby tam škody mšicí révovou zpủsobené ohledávala, mimochodem zkoumala léž pole tabáková v Besarabii a nabyla přesvěděení, že trpi tr̉ásnènkami. Člen komise, M. Widgalm, pojmenoval dotyčný druh, který mimo na listech tabákorých nalezl též na jiných solanaceích: Thrips solanacearmm.

R. 1882. byl v tamnější koněiny vysstán úredník ministerstva domén ríšškých J. Portschinsky, který prìšel na základě svých zkoumání k náhledu, že třásněnky hrají při škodách na tabáku způsobenỵch jen zcela podrízenou úlohu, napadajíce listy již onemocnělé. Pravou př́icinou nemoci rostlin tabákovỵ́ch dlužno prỵ́ hledati v nepřiměr̉eném pèstování jejich. Třásnènku na tabákových listech žijící má za druh Thrips urticae $(=T$. flava $)$.

R. 1887. vyslán byl ministerstvem prof. Lindeman do Besarabie, aby znovu zkoumal příčny škod na tabáku způsobených. Ukázalo se, že hlavním škůdcem jsou larvy dvou broukủ: Opatrum intermedium Fisch. a Pedimus femoralis F., které jsou s to způsobiti odumírání jimi napadených rostlin, k čemuž mohou však též přispèti třásněnky, a mimo tyto jiná pohroma, totiž záhadná nemoc tabáku, t. zv. mosaiková. Pokud se třásněnek týče, udává Lindeman, že mưže na jedné rostlině po celý měsíc žíti 200-700 larev jejich, aniž by bylo škod obzvláštních pozorovati. Jen tenkrát, když mnoho set a tisíc jich na jednotlivých listech ssaje, jest nebezpečí vážné. Stopy jejich škodlivé činnosti jeví se v podobě bělavỵch neb žlutavỵch, nepravidelnỵch, stuhovitých 
H. UZEL, MONOGRAPHIE DER ORDNUNG THYSANOPTERA.

skvrn na listech labákorých, jež nejsou tmavši linií obmezeny. Tr̉ásněnky dotyčné nazývá Lindeman Thrips tabaci. - Jakožto prostredek k jejich zahubení radi posypati sazeničky tabákové perským práškem neb ponorìi je na krátko do slabé emulse petrolejové.

Z referalu, jejž Portschinsky podal ministerstvu domén řišských, učinil Dokhtouroff výiah, ktery̌z preložil na frančinu (L. č. 130.). Práce Lindemanova, pojednávající o nemocech tabáku, vyšla r. 1888. (L. č. 158.)

\section{MÁK. - PAPAVER SOMNIFERUM L.}

$\mathrm{V}$ kvètech makových nalézal jsem veliké množství druhu Physopus atrata, dále značný počet druhu Physopus vulgatissima a v nevelikém počtu drühy Thrips flava, communis, Physopus temicomis, Anthothrips aculeata a Aeolothrips fasciata.

\section{KŘEN, - ARMORACIA RUSTICANA Fl. Wett.}

V květech křenu nalezl jsem dosti značný počet druhu Plyysopus vulgatissima, menší počet druhủ Thrips flava i angusticeps a pořidku druhy deolothrips fasciata, Pliysopus atrata a Plloeothrips aculeata.

\section{KARFIOL. - BRASSICA OLERACEA L. 3. BOTRYTIS L.}

Roku 1892. píše Lintner (L. č. 173.), že dávaly se v severoamerickém státě Pennsylvanii trăsněnky (dle Perganda Thrips tabaci) ve velikém množství do karfiolu.

Na rüžch karfiolu nalézal jsem sám druh Thrips communis v dosti značném počlu a druh Pliysopus atrote v počtu malém.

\section{ZELÍ. - BRASSICA OLERACEA L. \% CAPITATA L.}

Roku 1892. oznamuje Lintner (L. č. 173.), že třásněnky v Pennsylvanii (ve Spojených státech) ve velikém množství dávaly se do zelí. R. 1894. podávaji Sirrine a L ove (L. č. 181.) dalši zpráry o šliodlivé činnosti tr̉ásnènek na listech zelných. Konečnĕ píše Pergande (L. č. 185.), ̌̌e v Columbii i Virginii a dle Ḱlinea v Illinoisu (ve Spojených státech) byly třásněnky na zelí nalezeny. Všecky tyło zelí škodlivé tr̆ásněnky jsou dle Perganda druh Thrips tabaci.

Já sám nalézal jsem na hlávkách zelí jen druh Thrips communis v malém počtu.

\section{ORANŽOVNÍK. - CITRUS AURANTIUM L.}

Roku 1895. popisuje Pergande (L. č. 185.) druh Euthrips occidentalis, který mu zaslal D. W. Coquillett z Kalifornie, kdež vyskyluje se v množství v květech pomerančovỵch. Z téhož státu poslán G. W. Harneyem jiný druh, na listech pomerančorých nalezený, jejž Pergande (L. č. 185.) nazývá Heliothrips fasciata. 


\section{J. UZEL, MONOGRAFIE RADU, „THYSANOPTERA“.}

\section{BAVLNÍK. - GOSSYPIUM.}

Roku 1895. mluví Ashmead (L. ¿̇. 179.) o třech trásněnkách, jež nalezl v státu Mississippi na bavlníku. Jsou to Tlwips tritici Fitch a Plloeothrips mali Fitch, kleré sídlejí v květech. kdež však vážných škod nenadělají, a konečně jistý druh. kteréhož prý vidèl, jak živil se červcem Aleurodes gossypii. Nazývá ho Tlırips trifasciatus. Roku 1895. oznamuje Pergande (L. е̌. 185.), že druh Heliothrips cestri $(=H$. femorcalis) škodí bavlníku, ve sklenicích u Washingtonu pěstovanému.

\section{LEN. - LINUM USITATISSIMUM L.}

Roku 1875. podává Wittmack (I. č. 101.) zprávu o škodách tr̃ásněnek. na lnu v Sasku způsobených. - Roku 1877. pojednává Ladureau (L. č. 112.) o pohromách na Inišlích francouzských. V létech sedmdesátỵch objevila se totiž ve Francii, zvláště v jejich severních departementech, jistá velmi zlá nemoc lnu, prìi které mladé rostlinkv svěsily své vrcholky, dostávaly skvrny, vadly a nevytvořivše květů poznenáhla odumíraly. Nemoc tuto zkoumal La durea u a prrišel k náhledu, že jeji přičinou jest nedostatek drasla $\mathrm{v}$ půdě, které se tato látka odjímá dlouhỵ́m pěstováním Inu na témže poli, čímž se rostlina, ježto k zdaru svému drasla potrebuje, seslabí; když pak přidruží se horké paprsky sluneční, vadne pod nimi takto zmalátnèlý len a zajde před uzráním. Rolníci príčilají toliko žhavému slunci pohromu lnu a řikají následkem toho nemoci jeho »úžeh (brûlure)". Mezi svými zkouškami nalézal Ladureau na lnu mnoho třásněnek. kterým z počátku pozornosti nevěnoval. Poněvadž však mu bylo nápadno, že vyskytovaly se ve velikém mnoźství na polích úžehem stižených. kdežto na polích zdravýth jich nebylo, obíral se roku 1877. důkladněji tím zjevem a nabỵl přesvědčení, že tento malý hmyz jest vlastně pravou príčinou úžehu. Převoliké množství třásněnek ssaje totiž v nerozvitém vrcholku mladých rostlinek, kde právě je nejútlejší a nejštavnatějši pletivo, a tím vysvětluji se veliké skvrny na rozvijejících se listech. Rostlinka takto napadená nemùže vždy odolati ssavým třásněnkám, a to zvlášsě tenkráte, kidyž není dosti pokročilá, a kdy̌̌ nenalézá se v půdẽ dosti nerostných látek, které potřebuje. Brzy chřadne. hlavička její se sklání $\mathrm{k}$ zemi, neroste více a nedostává květủ; kdyz̆ pak prijje jednoho dne neobyčejně horký paprsek slunce, zajde rostlinka zmořená docela.

La dureau také pozoroval, že všecka lniště trpěla úžehem, která ležela ve směru větru, jenž vál předcházejícího roku ze kveloucího lniště, nepřiliš třásněnkami navštíveného (jinak by bylo nevzkvetlo). Úkaz ten vysvětluje takto: Když len počíná kvésti, nenalézají třásněnky na něm již tak měkkého a štavnatého pletiva, jakého by si přály, a ohlízí se tedy po stravě jiné. Poněvadž však nemohou létati (?). ani pro svou nepatrnost cestu »pěšky konati «, vylezou na nejvyšší vrcholek rostlinky Iněné a čekají, až přijde vítr, načež rozepnou kř́dla a nechávají se unášeti. Silný vítr odnese je daleko, slabý jen na sousední pole. Nalézá-li se na novém bydlišti obili, jak obyčejně bývá,

$$
-385-
$$




\section{H. U\%EL, MONOGRAPHIE DER ORDNUNG THYSANOPTERA.}

vlezou do pochvy hořejšich listù $k$ nevymetanému tou dobou ještě klasu a pokračuji ve své škodlivé činnosti, vẹssávajice nejútlejší části pletiva. Na polích těch pak se páríi, kladou svoje zimni(?) vajička a umírají. Kidyž pak druhého roku zaseje se na la místa len, vylézají mladé larvy $z$ vajiček $\mathrm{v}$ zemi ukrytých(?) a dávají se do něho. O prítomnosti jejich nejlépe přesvědčíme se, když nèkolik chorobnỵch rostlinek vỵklepáme nad bílým papírem, jenž brzy jest pokrụt velikým množstvím larev.

Vzhledern k tomuto rozšiřování se třásněnek vzduchem odporučuje Ladureau postavení dosti vysokỵch plotủ, z pletené slámy zhotovenỵch, které letící trásnènky zachycuji a nepropoušlějí. Účinek těchto ochranných plotủ jest velmi nápadný zvláštẽ tam, kde jen část některého Inišlě obklopovaly. Část tato jest, jak, Ladureau a před ním již Corenwinder se přesvěděili, úžehu prosta, kdežto část druhá bývá někdy úplnè spálena.

Pravdivost svỵch Ivrzení hledi Ladureau dokázati pokusem. Zasil totiž v zahradë jistou plochu lnem. Když pak mladé rostlinky dosahovaly délky šesti neb sedmi centimentrů, rozdèlil tu plochu ve dvě poloviny slaměným plotem $1 \mathrm{~m}$ rysokỵm. Na jednu polovinu roztrousil několik kilogrammủ úžehem stižených rostlinek Iněných, obsahujicích množství třásněnek. Po pěti asi dnech počal nakaženỹ len chřadnouti. Když pak jednoho dne prišslo veliké horko, svěsily všecky rostlinky $\mathrm{v}$ obou polovinách své hlavičky. Do rána však byl len v zdravé polovici úplně zotavený, kdežto v nakažené části zůstaly hlavičky jeho nicími a nezdvihly se více. Zdravá čásf pole dosáhla $65 \mathrm{~cm}$. délky a kvetla po celé ploše, nemocná však dosáhla nejvýše $40 \mathrm{~cm}$. délky a měla jen nèkolik květů.

Z mnohých látek chemických, které Ladureau k zahnání třásněnek užíval, osvědčila se nejlépe vodou silně zředěná štáva tabáková; dále odporučuje $\mathrm{k}$ pokusủm ještě petrolej, značně s vodou smíchaný. a velmi slabý roztok kyseliny phenové. Kromě toho radí, aby rolníci nahrazovali draslo, půdẽ lnem odnímané, vhodně zhotoveným umèlỵm hnojivem, a aby po obilí pěstovali na témže poli cukrovku neb brambory, kterých prý třásněnky se netknou (?) pro tvrdost' jejich pletiva, takže pak larvy z vajiček se vylíhnuvší hlady umíraji. Následujicího roku bezstarostně mohou opět zaseti len.

R. 1879. opakuje Ladureau (L. č. 114.) svá pozorování dříeèšsi a přidává, že počátkem května líhnou se larvy z vajiček, položenỵch do země třásněnkou Thrips lini. Mladé larvy ssaji na korínkách lnu. Teprv dokonalý hmyz opouští zemi a živí se pak štavami hořejší části rostliny, načež rozšiří se po obilí a pohance, kdež klade svoje vajička. Generace pak \% těchto vajiček vzniklá klade již vajička zimní.

Také u nás pocítili jsme $\mathrm{v}$ posledních letech škodlivou činnost trásněnek na lnu způsobem velmi citelným. V okolí Hradce Králové byly (jak jsem teprve letos se dověděl) mladé rostlinky lnu třásněnkou (které sedláci říkají »černé mušky «) téměř obsypány. Tato »spálila "někdy celá pole, takže prý musela bỵti zaorána. Podivno, že některá pole lnu byla ušelřena, kdežlo jiná nedaleká úplně byla zničena. Jakožto dobry̧ pro- 


\section{J. UZEL, MONOGRAFIE RADU, "THYSANOPTERA“.}

středek $\mathrm{k}$ zapuzení třásněnek udávají sedláci dřevěný popel, jímž některí pole svá poprašovali. Lonského (vlhkého) roku třásnènky na lnu se neobjevily.

Já sám nalézal jsem $\mathrm{v}$ kvělech lnu druhy Physopus vulgatissima a Thrips communis v dosti značném množstvi a druhy Thrips linaria, Physopus atrata, Aeolothrips fasciata, Thrips physopus, angusticeps a Anthothrips aculeata v menším počtu.

\section{RÉVA VINNÁ. - VITIS VINIFERA L.}

Již Schrank (L. ̌̌. 15.) należl na spodní straně listů vinných třásněnku Thrips flava. Osten-Sacken (L. č. 75.), Walsh (L. č. 77., 79. a 82.) a Riley (L. č. 85.) pozorovali $\mathrm{v}$ Sev. Americe třásnènky na nádorech révy způsobených jednak bejlomorkou Lasioptera vitis O. S., jednak mšicí Schizoneura vitifoliae Fitch a jednak mšicí révovou (Phylloxera), a tvrdí, že tam požíraly larvy hmyzů nádory ty tvořících (viz o tom v Ćásti biologické). R. 1885. uvádí se v časopise "Bulletin Soc. Ent. Belg., XXIX « (na str. 70.), že třásněnka Heliothrips haemorrhoidalis jest velmi škodlivá vínu ve sklenících pěstovanému. R. 1888. poznamenává Osborn (L. č. 163.), že nalezl na listech vinných v Sev. Americe druh Fitchův Plloeothrips mali. Pokud se ničení mšice révové třásněnkami týce, poznamenává Jordan (L. č. 162.), že, ač k tomu (v Německu) prrihlížel, nemohl takovou činnost třásnènek potvrditi. Nalezl sice také larvy třásněnek na kořenech vína (jakož i na kořenech mnohỵch jiných rostlin), avšak na místech, kde mšice révové nebylo. Ba nezdá se mu ani, że by ony larvy zde štavou z kořenů vinných se živily, nýbrž myslí (poněvadž je nalezl na podzim), že tu před zimou se ukrývaly. R. 1895. oznamuje Pergande (L. č. 185.), že druh Heliothrips cestri (=H. femoralis) škodí cizím druhưm révy, ve sklenícich u Washingtonu chovaným.

\section{KMÍN. - CARUM CARVI L.}

V květenství kmínu nalezl jsem v množství druh Thrips communis a pořídku druh Authothrips aculeata.

\section{PETRŽEL. - PETROSELINUM SATIVUM Hoffm.}

Roku 1892. oznamuje Pergande (L. č. 185.), že v Columbii a ve Virginii (ve Spojených státech) objevovaly se třásnènky (dle něho Thrips tabaci) na listech petrželových.

\section{MRKEV. - DAUCUS CAROTA L.}

$\mathrm{V}$ květenství mrkve nalézal jsem $\mathrm{v}$ nevelikém počtu druh Physopus vulgatissima.

$$
\text { ANGREŠT. - RIBES GROSSULARIA L. em. }
$$

V květech angreštu objevil Haliday (v Anglii) svůj druh Thrips grossulariae.

$$
-387-
$$




\section{H. UZEL, NONOGRAPHIE DER ORDNUNG THYSANOPTERA.}

\section{RYBÍZ. - RIBES RUBRUM L.}

Z kvèlu rybizu ryklepal jsem velmi malý pocel druhủ Thrips minutissima a Physopus vulgatissima.

\section{JAHODNÍK. - FRAGARIA.}

Dle Osborna (L. č. 163.) byl na jahodnícich již několikkiát nalezen v Severní Americe druh Thrips tritici Fitch. Dle Fletchera (L. č. 171.) poškozuje lento druh v Kanadě tyčinky jejich.

Já sáın sbíral jsem v kvèlech jahodovỵch dosti značné množstvi druhu Physopus vulgatissima a malý počet druhû Thrips minutissima a Physopus primulae.

\section{JETEL. - TRIFOLIUM.}

Roku 1856. udává Fitch (L. č. 69.), ̌̌e David Williams poslal mu ze stálu Wisconsinu v Severní Americe jistý druh třásnènek (Thrips tritici Fitch), který tam kromě na pšenici se vyskỵtoval též na jeteli a zaviñoval vadnutí květú. Roku 1867. vyslovuje Walsh (L. ě. 82.) domněnku, že trásnènky požiraji larvy jistého dřepčíka (Haltica), které jelel v Sev. Americe značně poškozují. Roku 1880. praví Szaniszló (L. č. 116.), że $\mathrm{v}$ Uhrách po žních lze nalézti třásnènku Thrips frumentarius (= Anthothrips aculeata) v jeteli. Roku 1882. tvrdí Pergande (L. č. 127.), že jsou dva neb trĭi druhy třásněnek, zdržující se ve velikém množství na jetelu v Sev. Americe, částečně hmyzožravými, a další pozorování že asi dokáží, že hlavně živí se larvami a vajičky bejlomorky Cecidomyia leguminicola, jimiž obyčejnĕ květy jetele jsou naplnèny. Roku 1883. pravi Osborn (L. č. 131.), že Phloeothrips nigra žije v květech jelelových v Severní Americe. Tamtéž nalezl Cook (L. č. 137.) na jeteli tr̆i druhy třásněnek, jedny černé, druhé světle žlulé, třetí světle červené; nepozoroval však, že by nējak cilelně škodnými byly. Roku 1888. poznamenává Jordan (L. č. 162.), že květy jetele, kleré obsahují na sta třásněnek, nemohou dobrého semene vytvořiti, poněvadž tr̆ísněnky ty vyssávaji mladé semeníky. R. 1895. oznamuji Osborn a Mally (L. č. 184.), ð̌e lřásněnky (dle Perganda Thrips tabaci) objevovaly se v Jowě (ve Spojeny̧ch státech) na jeteli.

Já sám natézal jsem v květech jetele druh Physopus ulicis v převelikém množství, druh Physopus vulgatissima ve velikém počtu, Anthothrips statices a Thrips angusticeps v počtu menším, konečně druhy Thrips communis, Anaphothrips virgo, Aeolothrips fasciata a Aptinothrips rufa poskrovnu.

Kokoticí (Cuscutı epithymum) na jetelištích cizopasící živí se hlavně Thrips communis a Plıysopus vulgatissima, v květech jejich hojně se vyskytující. 
J. C\%EL, MONOGRAFIERADL "THYSANOPTERA“.

\section{ÚROĆNÍK. - ANTHYLLIS VULNERARIA L.}

$\mathrm{V}$ květech úročníku nalezl jsem druhy Aeolothrips fasciata, Thrips communis, Plyssopus vulgatissima v počtu nevelikém a druh Authothrips aculeato v počtu nepatrném.

\section{LIGRUS. - ONOBRYCHIS VICIÆFOLIA Scop.}

V květech ligrusu shledal jsem druh Plıysopus vnlgatissima v prevelikém množství, druhy Thrips communis, Limothrips denticornis, Anthothrips aculeata a Aeolothrips fasciata v počtu nevelikém, konečně druhy Thrips flaca a Plıssopus ulicis v počtu nepatrném.

\section{BOBY. - PHASEOLUS VULGARIS L.}

R. 1854. udává Heeger (L. č. 66.), že Thrips sambuci škodí listům bobú.

VIKEV. - VICIA SATIVA (L.) Presl.

R. 1837. udává Haliday (L. č. 46.). že Plyysopus phalerata jest obyčejná v květech viky seté $\mathrm{v}$ Anglii. R. 1852. (L. č. 61.) poznamenává tentýž autor, že též larvy onoho druhu ve vice se zdržují.

Já sám nalezl jsem v květech viky hojně druh Plıysopus vulgatissima, v menším počtu druhy Anthothrips aculeata, Thrips communis a v počtu nepatrném druhy Physopus atrata. Thrips flava a Aeolothrips fasciata.

\section{BOB SVIŇSKÝ. - VICIA FABA L.}

V květech bobu sviňského shledal jsem druh Thrips flava ve velikém množství, Ploysoprss vulgatissima a atrata v počtu malém a Aeolothrips fasciata i Thrips communis $\mathrm{v}$ počtu nepatrném.

\section{HRÁCH. - PISUM SATIVUM Poir.}

R. 1871. podává Müller (L. č. 94.) zprávu o třảsněnkách, jež nezralému hráchu $\mathrm{V}$ Anglii škodily.

\section{KVĚTINY ZAHRADNÍ. - FLORES HORTORUM.}

Již r. 1744. praví Deeger (L. č. 2.), že druh "Physapus ater, alis albis" (=Physopus vulgatissima) ve velikém množství vyskytuje se $\mathrm{v}$ létě na květinách zahradních. R. 1836. udává Haliday (L. č. 43.), že v Anglii Pluysopus ulicis zdržuje se někdy v květech od Crocus susianus, Physopus vulgatissima pak že žije přehojně v nejrủznějšich květinách zahradních po celý rok, a že v jeho společnosti hỹvá Thrips 


\section{H. UZEL, MONOGRAPHIE DER ORDNUNG THYSANOPTERA.}

flaca a minutissima. R. 1854. pripomíná Heeger (L. č. 66.), že Thrips sambuci škodí listùm růžovým. R. 1878. praví Reuter (L. ¿. 113.), že Thrips flava ve Finnsku v liliich často v neobyčejném množství se vyskytuje. R. 1888. udává Jordan (L. č. 162.), že Authothrips aculeata nalézá se v létẽ i na podzim vždy ve velikém množství v květenstvích vlnitých zahradních čistcủ, jako jsou Stachys germanica a intermedia.

Já sám nalézal jsem v květinách zahradních druh Physopus vulgatissima v prevelikém někdy množstvi, Thrips communis (také var. pulla) a Physopus atrata v značném počtu, druhy Thrips flava, physopus a Limothrips denticornis v menším množství a Authothrips aculeata, Thrips major a nigropilosa v počtu nepatrném. R. 1895. oznamuji Osborn a Mally (L. č. 184.), že v Jowé (ve Spojených státech) vy skytly se třásnènky (dle Pergan da Thrips tabaci) na nejrûznèjšich květinách zahradních.

\section{ROSTLINY VE SKLENÍCÍCH. - PLANTAE IN CALIDARIIS.}

Roku 1833. objevil Bouché (L. č. 40.) třásnènku Heliothrips haemorrhoidalis. škodící $\mathrm{v}$ teplých i sludených sklenících nèmeckých rủzným rostlinám, a vysslovuje domněnku, že druh ten pochází z Ameriky. Roku 1836. popisuje Haliday (L. č. 43.) druh Heliothrips adonidum (=H. haemorrhoidalis), jenž byl nalezen Fr. Walkerem ve sklenícich anglických. Téhož roku zmiňuje se Burmeister (L. č. 45.) o tom. že druh Heliothrips haemorhoidalis zdržuje se ve sklenících na spodní straně měkkých listủ, zvláště malvaceí, a vyssává je tak, že vadnou a hynou. O škodách téhož druhu. na rostlinách ve sklenicich anglických zpủsobených, mluví též Westwood (L. č. 48.). Roku 1852. udává Heeger (L. č. 63.), že nalezl ho také ve sklenícich viden̆ských ve velikém počtu, a že tam zdržıje se na spodni straně mladých listủ od Ficus retusa a Begonia cebrina, kiteré následkem hojného nabodávání hynou. Dále praví, že též Thrips Kollari (= Limothrips denticornis) na obou zmíněných rostlinách se objevuje, a że podobnè škodí jako Heliothrips haemorrhoidalis. Roku 1854. popisuje tentýž autor (L. č. 66.) druh Heliothrips (= Parthenothrips) diacaenae a praví o něm, že žije $\mathrm{v}$ neobyčejném množství ve sklenících vídeňských na spodní straně listủ rủzných dracén, a že způsobuje jejich vadnutí. Roku 185̃. píše Bremi (L. č. 67.) o škodách druhu Heliothrips haemorrhoidalis, jejž jmenuje »schwarze Fliege». Roku 1858. udává Regel (L. č. 72.), že Parthenothrips dracaenae v milionech vyskytuje se na rostlinách $\mathrm{v}$ teplých sklenících petrohradských, kdež značně škodi, a sice obzvláště dracénám. Roku 1867. zmiňnje se v. Frauenfeld (L. č. 84.) o škodlivé činnosti třásněnek ve sklenících vídeňských. Z několika druhů, jež tam se vyskytují, jsou Heliothrips haemorrhoidalis a Parthenothrips dracaenae nejhojnějšími. Zdá prý se pak, že jednotlivé druhy třásněnek na téže rostlině navzájem se vylučují. Podává také Benselerem uspořádaný seznam rostlin, jež obzvláště třásněnkami trpí. Jsou to: Cyanophyllum, Lasiandra, Staphidium, Octomeris, Centradenia, Eriocnema, Medinilla, 
Heterocentra, Melastoma, Monochaetum, Dichorisandra, Cordylime, Pontederia, Amaryllis, Kämpferia, Costus. Curcuma, Maranta, Anthurium. Philodendron, Ficus, Coccoloba, Triplaris, Hargasseria, Hemandia, Rhopala, Conoclinium, Psychotria, Ixora, IIamelia, Cephaelis, Rondeletia, Galipea. Gardenia, Mussaenda, Parmentiera, Brunfelsia. Torenia, Thumbergia, Dipteracanthus, Stephanophysum, Ardisia, Araliaceae, Passifloreae, Malvaceae, Impatiens Jerdoni, Combretaceae, Jussiena, Cuphea. Jehlia, Psidium, Eugenia. Roku 1882. poznamenává Pergande (L. č. 127.), že nalezl ve sklenících zemèdèlského ústavu washingtonského v Spojených státech druh Parthenothrips dracaenae. Roku 1885. nalézáme v časopisu Bulletin Soc. Ent. Belg., XXIX, na str. 70., zprávu o tr̉ásnènce Ileliothripshaemorrhoidalis, jež prỵ značné škody způsobila na vínu ve sklenícich pěstovaném. Roku 1886. zmiňuje se Cameron (L. č. 151.) o trásněnce Heliothrips adonidum (= H. haemorhoidalis) ve Škotsku. Roku 1888. piše Jordan (L. č. 162.) o druzich Heliothrips haemorrhoidalis a Parthenothrips dracaenae, $\mathrm{v}$ německých sklenících se vyskylujícich. Praví o nich, že živí se tam listy prostřední tuhosti, a že opovrhují, jak se zdá, měkkými a štavnatými rostlinami. Miluji zvlášlě mladé palmy, dracény, fikus, kamelie a aspidistry, starší palmy, Calla, Geranium a Coreus nebỵvají jimi napadány. Listy třásněnkami vyssávané odumirají. Roku 1891. oznamuje Reuter (L. č. 168.). že nalezl ve finnských sklenících trì druhy třásněnek. totiž: Heliothrips haemorrhoidalis, femoralis nov. sp. a Parthemothrips dracaenae. Roku 1895. popisuje Pergande (L. č. 185.) druh Heliothrips cestrum ( = H. femoralis). Zaslán mu byl B. P. Mannem z Massachusettsu, kdež nalezen byl na Cestrum nocturmum ve sklenících. Mimo to pozoroval ho Pergande sám ve sklenících u Washingtonu, a to zvl. nadmíru četnè na listech od Amaryllis, jež značně poškozoval. Z jiných rostlin, na kterých tam žije, jinenuje zvláště: Richardia aethiopica, Ficus grandiflora, F. elastica, Aralia, Gardenia, Phoenix, Dracaena, Hydrangea, Chrysanthemum. Též na cizich druzích révy a na bavlnících ve sklenících chovaných, jakož i na různém pleveli se tam vyskytoval. Zde též děje se zmínka o tom, že druh Iteliothrips haemorrhoidalis v Evropě a Sev. Americe jen ve sklenících žijící, nalezen byl $\mathrm{v}$ Brasilii mimo na pěstovanỵ́ch rostlinách také ve volné př́rodè.

\section{BOROVICE. - PINUS SILVESTRIS L.}

Na mladých borových vèlvičkách nalezl jsem druh Chirothrips manicata v nepatrném počtu, a z borového květu vỵklepal pan prof. Duda druh Oxythrips hastata.

\section{JEDLE. - ABIES ALBA Mill.}

R. 1878. udává Reuter (L. č. 113.), že Aeolothrips limbata (= Ae. vittata) vỵskỵluje se na mladých jedlich ve Finnsku. Také Jordan (L. č. 162.) udává, že druhy rodu Aeolothrips zdržují se na jehličnatých stromech. 
Já sám nalezl jsem na mladỵch vètvičkách jedlových nèkolik velikých larev nèjakého zástupce tubulifer. (Jsou bèložlulavé, pred koncem abdomenu světle żlutohnèdé; poslední dva články jsou černé. Hlava, tykadla a nohy̌ černošedé. Na predohrudi nahoře nalézají se dvě veliké skvrny téže barvy. Trretí člínek tykadel jest značně prodloužený.) Mimo to sbiral jsem na jedlich v nepatrném počlu druhy Physopus vulgatissima a atrater.

\section{SMRK. - ABIES PICEA Mill.}

Na mladých smrkových větvičkách nalezl jsem druh Authothrips aculeata v mnożství, druhy Oxythrips ajugae. hastata a Physopus pini v menším počtu, Physopus vulgatissima a Thrips physopus v poětu nepatrném.

\section{MODŘín. - ABIES LARIX Lamk.}

Na mladém jehliči modrínovém nalez! jsem druh Physopus vulgatissima v nevelikém a druhy Thrips flava, minutissima a Physopus ulicis v nepatmém počtu.

\section{DUB. - QUERCUS.}

Na listech dubových nalezl jsem druh Liothrips setinodis (12 exempl.) a Thrips flava v malém. druhy Physopus culgatissima a Thrips communis var. pulla v nepatrném množství.

\section{BUK. - FAGUS SILVATICA L.}

Na listech bukovỵch sbíral jsem druh Anthothrips aculeata v množství nevelikém.

\section{HABR. - CARPINUS BETULUS L.}

Na listech habrových nalezl jsem druh Authothrips aculeatı taktéž v množství nevelikém.

\section{LÍSKA. - CORYLUS AVELLANA L.}

Na spodní straně listủ lískových žije de Schranlia (L. č. 15.) druh Thrips flava. Roku 1886. oznamuje Targioni-Tozzetti (L. č. 149. a 150.), že nalezl na Sicilii na jistých nádorech lískových druh Euthrips consociata (= Physopus ulmifoliorum).

Já sám nalezl jsem na lislech lískových druh Physopus vulgatissima v malém a druhy Anaphothrips virgo, Anthothrips aculeata, Drepanothrips Reuteri a Thrips communis $\mathrm{v}$ nepatrném počtu.

\section{BŘíZA. - BETULA ALBA L.}

Na listech brezových nalezl jsem v nepatrném množství druhy Physopus ulmifoliorum, vulgatissima a Thrips physopus. 
J. UZEL, MONOGRAFIE RÁDU, "THYSANOPTERA“.

\section{OLŠE. - ALNUS GLUTINOSA Gärn.}

Na listech olšových nalezl jsem druhy Thrips alui, Physopus ulmifoliorum, vulgatissima, Dendrothrips tiliae, Degeeri a Anaphothrips virgo v nevelikém množství a druhy Authothrips aculeata, Physopus tenuicomis, Limothrips denticomis a Dendrothrips saltatrix v počtu nepatrném.

\section{VRBA. - SALIX.}

Roku 1878. udává Reuter (L. č. 113.), že jeho druh Thrips salicis (=Physopus ulmifoliorum) ve Finnsku vyskytuje se na vrbách.

Já sám sbíral jsem v jehnědách vrbových druh Pliysopus vulgatissima v pr̃evelikém množství a druhy Thrips flaca, Authothrips aculeata, Physopus atrata v počtu nepatrném. Na listech vrbových shledal jsem druhy Physopus ulmifoliorum a Thrips viminalis v značném počtu, druh Physopus vulgatissima v počtu menším (na zcela mladých, právě vyrážejících listech nèkdy ve velikém množství), a v nepatrném počtu druhy Limothrips denticornis, Thrips physopus, communis (též var. pulla) a Plysopus pallipennis.

TOPOL. - POPULUS.

V jehnèdách topolových nalezl jsem druhy Physopus incousequens v malém a druhy Anthothrips aculeata, Thrips flava a minutissima v nepatrném množství. Na listech topolových shledal jsem druh Physopus ulwifoliorum a Thrips viminalis $\mathrm{v}$ množství.

\section{JILM. - ULMUS.}

Roku 1888. udává Jordan (L. č. 162.), že vidèl jisté tř̉sněnky žjijicí na listech jilmových.

Já sám nalezl jsem na plodech jilmových druhy Physopus vulgatissima, Anthothrips aculeata a Aeolothrips fasciata v nepatrném počtu.

\section{OLIVA. - OLEA EUROPAEA L.}

Roku 1834. podává Passerini (L. č. 41.) zprávu o jisté tr̀ásnènce, kterou za druh Thrips physopus považuje, a jež v Italii velice škodí olivám, na jejichžto listech se zdržuje. Pozdèji také West wood (L. č. 48.) mluví o škodlivosti třásnènek na olivách. Roku 1842. zmiňuje se Tamburin (L. č. 53.) o škodách, jež jistá třásněnka na olivách ve Francii způsobila, a o prostredcích, jak by se daly zameziti. Roku 1880. nalézáme v časopisu: Bull. Soc. Entomolog. Ital., Vol. 12., Trim. 3., na str. 250., zprávu o dvou třásněnkách, poškozujících olivy. Jedna z nich popsána jest jakožto nový 
H. UZEL, MONOGRAPHIE DER ORDNUNG THYSANOPTERA.

druh pod jménem Phloeothrips oleae, druhá pak jest neurčená. Roku 1886. zmiňuje se Targioni-Tozzetti (L. č. 150.) o tom, že třásněnka „Euthrips consociata“ (=Plıysopus ulmifoliorum) žije jakožto larva hojně na kúrè vělví olivových na Sicilii.

\section{S̀EŘIK. - SYRINGA VULGARIS L.}

V knize Nördlingerově z roku 1855. (I. č. 68. A) čleme, že nemocné listy šeřikové napadány byly jistou velmi malou třásněnkou.

Na listech šřrikových zastihl jsem samičku druhu Dendrothrips tiliae, právě když kladla vajičko. Mimo to nalezl jsem ješlě na listech v nepatrném počlu druhy Dendrothrips Degeeri, Thrips flava a Physopus vulgatissima. V květech šeřiku shledal jsem veliké množstvi druhu Thrips flava, čelnè téż druh Plyssopus vulgatissima, v menšim počtu druh Thrips communis a ve skrovném jen druhy Physopus pallipemis, atrata, Thrips major a Aeolothrips fasciata.

\section{JASAN. - FRAXINUS EXCELSIOR L.}

R. 1888. poznamenává Jordan (L. č. 162.), že nalezl drulı Thrips sambuci na listech jasanových.

Já sám sbíral jsem na listech těch druhy Plyssopus vulgatissima a Dendrothrips Deegeri v malém počtu.

$$
\text { LIPA. - TILIA. }
$$

R. 1854. udává Heeger (L. č. 66.), že Thrips sambuci škodí lipám.

Já sám nalezl jsem na listech lípovỵch (zvl. na křovitých lipách) druh Deudrothrips tiliae v převelikém množství. druhy Thrips flaca, Dendrothrips Degeeri, Physopus vulgatissima a Thrips communis v malém počtu a druhy Thrips physopus, Anthothrips aculeata a Physopus atrata v počtu nepatrném. V květu lípovém shledal jsem druhy Thrips flava (také var. obsoleta). Thrips comımunis, Pliysopus atrata a vulgatissima v počtu malém.

\section{KLEN. - ACER PSEUDOPLATANUS L.}

Na listech klenorých nalezl jsem druhy Chirothrips manicata a Anaphothrips irigo v počtu skrovném.

\section{MLÉČ. - ACER PLATANOIDES L.}

$V$ kvètech mléče nalezl jsem druh Plıysopus inconsequens v množství a druhy Thrips flara a commumis poskrovnu. 


\section{KAŠTAN KOŇSKÝ. - AESCULUS HIPPOCASTANUM J.}

Na listech kaštanu koňského sbíral jsem druhy Deudrothrips Degeeri a Physopus inconsequens ve velikém množství, druh Thrips minutissima v poètu malém a druhy Thrips flava, communis, Authothrips aculeata, Physopus vulgatissima a Anaphothrips virgo v počtu nepatrném.

\section{JABLOŇ. - PIRUS MALUS L.}

R. 1856. popisuje Fitch (L. č. 69.) jakousi třásněnku (Phloeothrips mali), která prý ve Spojených státech (New-York) nažirá nezralá jablka, načež tato opadávají. Autor však nevylučuje možnost, že jabllka nažrána byla jiným zviřetem, a že třásněnky př̀išly jen ssát štávu, což jest pravděpodobnější. R. 1882. zmiňuje se Pergande (L. č. 127.) o tom, že nalezl $\mathrm{v}$ Sev. Americe (Washington) druh Heliothrips haemorrhoidalis, jenž žil v zahradě (bezpochyby přelétl z nedalekých skleníkú) na lislech jabliových. R. 1883. poznamenává Osborn (L. č. 131.), že pozoroval v Sev. Americe třásněnky v květech jablkových, a že $80 \%$ květủ těch bylo poškozeno bodáním jejich, jež dálo se zvláště do pestíkủ. R. 1888. praví tentýž spisovatel (L. č. 163.), že škůdcem tim byl Thrips tritici Fitch.

Já sám nalezl jsem v květech jablkových druhy Thrips mimutissima a physopus v nevelikém množství a druhy Thrips flaca a Physopus vulgatissima poskrovnu.

\section{JEŘÁB. - PIRUS AUCUPARIA Gärtn.}

Na listech jeřábových nalezl jsem v nepatrném počtu druh Dendrothrips tiliae a v květech jeho taktéž poskrovnu druhy Physopus ulicis, Anthothrips statices a jednou téż druh Zygothrips mimuta.

\section{BROSKEV. - PRUNUS PERSICA Baillon.}

Roku 1837. udává Haliday (L. č. 46.), že Thrips persicae vyskytuje se v Anglii na nemocných listech broskvorých.

\section{MERUÑKA. - PRUNUS ARMENIACA L.}

Roku 1895. popsal Pergande (L. č. 185.) druh Euthrips occidentalis, jenż mu byl A. Crawem zaslán z Kalifornie, kdež napadal mladé útlé listy meruňkové a znetvořoval je.

\section{ŠVESTKA. - PRUNUS DOMESTICA L.}

Roku 1883. praví Osborn (L. č. 131.), že žijí v Sev. Americe nějaké třásněnky v květech švestkových. 
H. UZEL, MONOGRAPHIE DER ORDNUNG THYSANOPTERA.

Já sám nalézal jsem v nich malý počet druhu Physopus vulgatissima a taktéž poskrovnu druh Thrips flava.

\section{TŘEŠNĚ. - PRUNUS CERASUS L.}

Roku 1883. poznamenává Osborn (L. č. 131.), že nalezl v Sev. Americe nějaké třásnènky $\mathrm{v}$ květech třešñových.

Já sám sbíral jsem $\mathrm{v}$ kvètech těch druh Physopus inconsequens $\mathrm{v}$ množství, druhy Thrips mimutissima, flava a Physopus vulgatissima v počtu nevelikém a druh Anthothrips aculeata v poètu nepatrném.

STŘEMCHA. - PRUNUS PADUS L.

Na mladých listech stremchorých nalezl jsem druhy Thrips flava a communis poskrovnu.

AKÁT. - ROBINIA PSEUDACACIA L.

V květu akátovém nalezl jsem druh Physopus vulgatissima v množství a druh Thrips flava i communis jen $\mathrm{r}$ malém počtu. 


\section{Résumé des oekonomischen Theiles.}

In diesem Theile hat der Verfasser die Beobachtungen der Autoren über die Beziehungen der Thysanopteren zur Oekonomie nach den einzelnen cultivierten Pflanzen zusammengestellt und ferner die Arten aufgezählt, die er selbst auf den betreffenden Pflanzen in Böhmen gesammelt hat, und von denen man voraussetzen kann, dass sie mehr oder weniger schaden. Es wird also von den unter morscher Rinde einzelner cultivierten Bäume lebenden Arten keine Erwähnung gemacht, weil sie hier keinen bemerkenswerten Schaden verursachen. Dafür werden alle Arten angeführt, welche sich in Blüten oder auf Blättern aufhalten, auch wenn sie in geringerer Anzahl vorkommen und infolge dessen keinen merklichen Schaden verursachen, und zwar aus dem Grunde, weil sie zu einer anderen Zeit und auf einem anderen Orte in grösserer Anzahl auftreten und dann natürlich mehr schaden können. Die Zusammenstellung der vom Verfasser auf den einzelnen cultivierten Pflanzen in Böhmen gefundenen Thysanopteren, welche wir hier im Deutschen wiedergeben, kann auch zur leichteren Bestimmung der einzelnen Arten dienen. - Was die Zusammenstellung der Beobachtungen der Autoren selbst anbelangt. so erlauben wir uns den der böhmischen Sprache Unkundigen wenigstens auf die Namen der Autoren, ihre Schriften (auf die durch eine Zahl in der Klammer, welche sich auf den historischen Theil der vorliegenden Monographie bezieht, hingewiesen wird) und auf die einzelnen von ihnen behandelten Arten im böhmischen Texte aufmerksam zu machen, und hoffen, dass auch daraus einiger Nutzen für ihn entstehe.

Der Schaden, welchen die Thysanopteren verursachen, ist manchmal bedeutend; oft wird er jedoch übertrieben, und noch öfter wird ihnen der von anderen Insecten verursachte Schaden zugeschrieben. Es bleibt hier daher noch viel zu erforschen und viel $\mathrm{zu}$ widerlegen übrig.

\section{VERZEICHNIS DER VOM VERFASSER IN BÖHNEN UNTERSUCHTEN CULTTVIERTEN PFLANZEN MIT DEN DIESELBEN BEWOHNENDEN THYSANOPTERENARTEN.*)}

Kornähren: **Anthothrips aculeata, *Aptinothrips rufa, Physopus tenuicornis, Anaphothrips virgo, Limothrips denticornis, Chirothrips manicata, Physopus vulgatissima, Aeolothrips fasciata, Thrips communis, Stenothrips graminum.

*) Die mit einem oder zwei Sternchen versehenen Arten fand ich in grosser oder sehr grosser Anzahl ; die übrigen sind nach der Stärke des Auftretens geordnet, so dass die zuerst aufgezählten die häufigeren, die zuletzt genannten die weniger häufigen und die selteneren sind. 


\section{H. UZEL, MONOGRAPHIE DER ORDNUNG THYSANOPTERA.}

Weizen:̈hren: **Anthothrips aculeata, *Stenothrips graminum, *Thrips communis, *Aptinothrips rufa, Physopus tenuicornis, Thrips physopus, T. angusticeps, Physopus vulgatissima, Limothrips denticornis, Anaphothrips virgo, Aeolothrips fasciata, Chirothrips manicata.

Gerstenäihren: **Stenothrips graminum, *Anthothrips aculeata, *Physopus tenuicornis, *Limothrips denticornis, Anaphothrips virgo, Thrips communis, Aptinothrips rufa, Thrips angusticeps, T. physopus, Chirothrips manicala, Physopus atrata, Ph. vulgatissima.

Haferihren: **Stenothrips graminum, **Anthothrips aculeata, *Physopus tenuicornis, Limothrips denticornis. Thrips communis, Aptinothrips rufa, Aeolothrips fasciata, Anaphothrips virgo, Physopus vulgatissima.

Panicum miliaceum (Blülen): **Anthothrips aculeala, Physopus vulgatissima, Ph. tenuicornis, Aeolothrips fasciata, Thrips communis.

Zea mais (Blülen): *Anthothrips aculeata, *Physopus vulgatissima, Chirothrips manicala, Physopus pallipennis; (Blätter) Anthothrips aculeata, Physopus tenuicornis.

Wiesengräiser (Blüten): **Anthothrips aculeata, ${ }^{* *}$ Chirothrips manicata, ${ }^{* *}$ Aptinothrips rufa, **Stenothrips graminum, Thrips communis, Anaphothrips virgo, Physopus vulgatissima, Ph. Lenuicornis, Chirothrips Dudae, Limothrips denticornis, Thrips flava, Physopus ulicis, Ph. pallipennis, Rhipidothrips gratiosa.

Humulus lupulus (junge cultivierte Pflanzen): Thrips communis; (junge wilde Pflanzen): *Thrips flava var. obsoleta, Physopus vulgatissima, Thrips communis, T. adusta; (Fruchtzapfen des wilden Hopfens): **Thrips flava, T. flava var. obsoleta, Thrips communis, Physopus atrata, $\mathrm{Ph}$. vulgatissima.

Beta vulgaris (Blätter): Physopus atrata. Thrips communis, Aeolothrips fasciata, Dictyothrips belae; (Blüten): Thrips communis, Physopus atrata, Ph. vulgatissima, Aeolothrips fasciata.

Polygonum fagopyrım: Aeolothrips fasciata, Physopus atrata, Ph. vulgatissima, Thrips communis.

Helianthus tuberosus: Thrips communis, T. physopus, T. nigropilosa, Physopus vulgatissima.

Helianthus anmuus (Blülen): Aeolothrips fasciata.

Solanum tuberosum (Blüten): **Thrips communis, **Physopus atrata, Physopus vulgatissima, Aeolothrips fasciata, Thrips physopus, T. flava; (Blätter): **Thrips communis, Stenothrips graminum, Thrips angusticeps, Anthothrips statices, Physopus vulgatissima, Aeolothrips fasciata.

Papaver somniferum (Blüten): **Physopus atrata, *Physopus vulgatissima, Thrips flava, T. communis, Physopus tenuicornis, Anthothrips aculeata, Aeolothrips fasciata. 
J. UZEL, MONOGRAFIE RADE, "THYSANOPTERA".

Armoracia rusticana (Blüten): Physopus vulgatissima, Thrips flava, T. angusticeps, Aeolothrips fasciata, Physopus atrata, Phloeothrips aculeata.

Brassica oleracea $\beta$. botrytis: 'Thrips communis, Physopus atrata.

Brassica oleracea $\gamma$ capitata: Thrips communis.

Limum usitatissimmm (Blüten): Physopus vulgatissima, Thrips communis, Thrips linaria, Physopus atrata, Aeolothrips fasciata, Thrips physopus, T. angusticeps, Anthothrips aculeata.

Carum carvi (Blüten): *Thrips communis, Anthothrips aculeata.

Daucus carota (Blüten): Physopus vulgatissima.

Ribes rubrım (Blüten): Thrips minutissima, Physopus vulgatissima.

Fragaria (Blüten): Physopus vulgatissima, Thrips minutissima, Physopus primulae.

Trifolium (Blüten): **Physopus ulicis, *Ph. vulgatissima, Anthothrips statices, Thrips angusticeps, T. communis, Anaphothrips virgo. Aeolothrips fasciata, Aptinothrips rufa.

Anthyllis vulneraria (Blüten): Aeolothrips fasciata, Thrips communis, Physopus vulgatissima, Anthothrips aculeata.

Onobrychis viciaefolia (Blüten): **Physopus vulgatissima, Thrips communis, Limothrips denticornis, Anthothrips aculeata, Aeolothrips fasciata, Thrips flava, Physopus ulicis.

Vicia sativa (Blüten): *Physopus vulgatissima, Anthothrips aculeata, Thrips communis, Physopus atrata, Thrips flava, Aeolothrips fasciata.

Vicia faba (Blüten): ${ }^{* * T h r i p s}$ flava, Physopus vulgatissima, $\mathrm{Ph}$. atrata, Aeolothrips fasciata, Thrips communis.

Gartenblumen: **Physopus vulgatissima, *Thrips communis, *Physopus atrata, Thrips flava, T. physopus, Limothrips denticornis, Anthothrips aculeata, Thrips major, T. nigropilosa.

Pinus silvestris (junge Zweige): Chirothrips manicala; (Blüten): Oxythrips hastata.

Abies alba (junge Zweige): Physopus vulgatissima, Ph. atrata.

Abies picea (junge $Z$ weige): *Anthothrips aculeata, Oxythrips ajugae, $O$. hastata, Physopus pini, Ph. vulgatissima, Thrips physopus.

Abies larix : Physopus vulgatissima, Thrips flava, T. minutissima, Phỵsopus ulicis.

Quercus (Blätter): Liothrips setinodis, Thrips flava, Physopus vulgatissima, Thrips communis var. pulla.

Fagıs silvatica (Blätler): Anthothrips aculeata.

Carpiuus betulus (Blätter): Anthothrips aculeata.

Corylus avellana (Blätter): Physopus vulgatissima, Anaphothrips rirgo, Anthothrips aculeata, Drepanothrips Reuteri, Thrips communis. 
H. UZEL, MONOGRAPHIE DER ORDNUNG THYSANOPTERA.

Betula alba (Bläller): Physopus ulmifoliorum, Ph. vulgatissima, Thrips physopus.

Alnus glutinosa (Blätter): Thrips alni, Physopus ulmifoliorum, Ph. vulgatissima, Dendrothrips tiliae, D. Degeeri, Anaphothrips virgo, Anthothrips aculeata, Physopus tenuicornis. Limothrips denticornis, Dendrothrips saltatrix.

Salix (Blüten): **asysopus vulgatissima, Thrips flava, Anthothrips aculeata, Physopus atrala; (Blätter): *Physopus ulmifoliorum, *Thrips viminalis, *Physopus vulgatissima, Limothrips denticornis, Thrips physopus, T. communis, Physopus pallipennis.

Populus (Blüten): Physopus inconsequens, Anthothrips aculeata, Thrips flava, T. minutissima; (Blätler): *Physopus ulmifoliorum, *Thrips viminalis.

Ulmus (grüne Früchte): Physopus vulgatissima, Anthothrips aculeata, Aeolothrips fasciala.

Syringa vulgaris (Blätter): Dendrothrips tiliae, D. Degeeri, Thrips flava, Physopus vulgatissima; (Blülen): **Thrips flava, *Physopus vulgatissima, Thrips communis, Physopus pallipennis, $\mathrm{Ph}$. alrala, Thrips major, Aeolothrips fasciata.

Fraxinus excelsior (Bläller): Physopus vulgatissima. Dendrothrips Degeeri.

Tilia (Blätter): ***Dendrothrips tiliae, Thrips flava, Dendrothrips Degeeri, Physopus vulgatissima, Thrips communis, T. physopus, Anthothrips aculeata, Physopus atrata; (Blüten): Thrips flava, T. communis, Physopus atrata, Ph. vulgatissima.

Acer psendoplatanus (Blätler): Chirothrips manicata, Anaphothrips virgo.

Acer platanoides (Błüten): *Physopus inconsequens, Thrips flava, T. communis.

Aesculus hippocastanum (Blätter): *Dendrothrips Degeeri, *Physopus inconsequens, Thrips minutissima, Thrips flava, T. communis, Anthothrips aculeata, Physopus vulgatissima, Mnapholhrips virgo.

Pirus malus (Blülen): Thrips minutissima, T. physopus, T. flava, Physopus vulgatissima.

Pirus aucuparia (Blätter): Dendrothrips tiliae; (Blüten): Physopus ulicis, Anthothrips statices, Zygothrips minuta.

Prunus domestica (Blüten): Physopus vulgatissima, Thrips flava.

Prunus cerasus (Blüten): Physopus inconsequens, Thrips minutissima, T. flava, Physopus vulgatissima, Anthothrips aculeata.

Prunus padus (Blätter): Thrips flava, T. communis.

Robinia pseudacacia (Blüten): *Physopus vulgatissima, Thrips flava, T. communis.

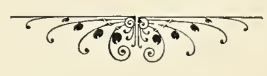




\section{VII. ĆAST HISTORICKÁ.}

\section{HISTORISCHER THEIL.}





\section{ÚVODNÍ POZNÁMKY.}

V této části podám seznam všech spisủ, V nichž o třásněnkách se jedná, pokud jsem mohl se o nich dovědèti, a sice $\mathrm{v}$ chronologickém pořádku; prìi každé práci pak oznámim krátce, co nového obsahuje, a co je vůbec v ní pamětihodného. Účel této stati jest nejen ten, aby sloužila za ukazatele literarního, nýbrž aby léž označovala cestu. kterou ubíralo se studium hmyzu třásnokîídlélio od prvnich dob až po dobu nejnovèjší. U některých prací méně dủležitých nepodarìlo se mi přes všechnu námahu dopátrati se letopočtu (kde je letopočet $\mathrm{v}$ závorce, obnáší možný omyl nejvýše jeden rok); i prosím, aby mi nejistota z toho plynoucí laskavě odpuštěna byla, jestit to prvý pokus vûbec sestaviti úphnou literaturu třásněnek. - Práce hvězdičkou poznamenané prostudoval jsem sám, opatrì si je z valné většiny koupí. V Praze nalezl jsem po knihovnách bohužel jen nepatrnou část literatury potřebné.

\section{C.. 1 .}

*1691. Ph. Bonanni, Observationes circa viventia, quae in rebus non viventibus reperiuntur. Cum Micrographia Curiosa sive Rerum minulissimarum observationibus, quae ope Microscopii recognitae ad vivum exprimuntur. His accesserunt aliquol Animalium Testaceorum Icones non antea in lucem editae. Omnia Curiosorum Naturae Exploratorum Utilitati et lucunditati expressa et oblata. Illustrissimo Domino D. Leoni Strozzae excellentissimi Ducis Strozzae filio. A patre Philippo Bonanni Societ. Jesu Sacerdote. Romae, Typis Dominici Antonii Herculis MDCXCI.

Spisovatel této knihy, jesuita Philippo Bonanni v Rímě, jest objevitelem tìásněnek. Fakitum to upadlo však skoro úphně v zapomenutí, takže panuje domnění, že Degeer je objevil, jakož tento sám pevně věřil. Jen Geoffroy (Histoire abrégée d. Ins. Paris, 1764. T. I., str. 384.) ví o práci Bonannově, ač, jak se zdá, ani on sám ji neviděl, nebot' píše v seznamu spisủ použitých: Bonanni Nicrographia, seu Animalia viva in vivis(!). Jméno Bonanniho čleme pak ještě v Linnéově Systema Naturae \% r. 1767. (Vindobonae), na str. 687., a to prì zmínce o měchýŕcích tr̀ásněnek, na konci chodidla se nalézajících. - Pokládám za prospěšné prvou zmínku o tr̀ásněnkách v literatuře doslovně uvésti, poněvadž věc je dủležita a kniha, v níž jest obsažena, těžce prístupna.

Ve svém článku, Musca nadepsaném, praví Bonanni (Micrographia Curiosa, str. 52. a 53.) doslovně: »Hanc observationem alia confirmat curiosissima. quam ei 


\section{H. UZEL, MONOGRAPHIE DER ORDNUNG THYSANOPTERA.}

superaddo. Dum observarem Cyanum Turcicum, vulgo Fior d'ambretta, ob odorem suavissimum, quo redolet, animadverti aliqua puncta nigerrima, et pigro motu per foliola discurentia. Microscopio opposita apparuerunt Insecta mihi anonima, ut exprimuntur num. 38. Tribus constabant partibus, capile, dorso, ventre, post quem sequebantur septem annuli adiecta cauda. Sex pedibus erant praedita, quorum duo infimi ventri copulabantur, quatuor alii Pectori, in articulos divisi, ut in figura exprimuntur. Capiti bini antennae prominebant, septem incisuris plicatiles. Dorso erant affixae duae alae in extremitatibus ita connexae, ut nunquam explicari possent. Membrana propterea carebant, longis et nigerrimis pilis tantum hirsutae, qui aliquando attollebantur, ut in histrice aculei. Sed ad rem nostram. Quatuor priorum pedum extremitates ita efformatae erant, ut crumenas simularent e membranula lucidissima compactas. His utebatur Animal applicando supra vitrum et quotiescunque reptatum geminaret, toties crumenulas illas dilatabat. premebatque iisdem vitri superficiem, cui hoc modo adhaerescens citissime progrediebatur, in quo motu inutiles erant pedes ultimi, utpote talibus pulvillis humectantibus orbati, et simul ac vitro impingerentur, illico propter levorem labebantur. Similes pedum lapsus notavi in Pediculis, Pulicibus, ceterisque huiusmodi insectis inter duo concava vitra inclusis, licet longis, aduncis, et firmis unguibus essent praedita. Experimentum sumat curiosus, ponendo aliquod huius generis supra laminam vitream perfecte levigatam; deinde si attollat, vertatque, ut ea pars, in qua est animal, planum orizontale respiciat, cadet profecto Animal, sed haerebit diu musca, laminamque pro libito sine ruinae metu percurret. "To jest: "Lpěji tedy mouchy na předmètech nejen drápy, nỵbrž i, tr̉eba-li toho jest na hladkých plochách. za pomoci lepkavého moku, který ze stlačených polšláỉkủ na nohách se vyřinuje a mezi chloupky jejich se zadržuje. Toto pozorování potvrzuje jiné; velmi pečlivẽ provedené. Dívaje se na kvètinu Cyanus Turcicus, v lidu Fior d’ambretta zvanou pro svou velmi príjemnou vủni, pozoroval jsem nèjaké velmi tmavé body, liknavě po listcích korunních různo pobíhající. Když jsem je proti mikroskopu postavil, objevili se mi hmyzové jména nemajici tak, jak obraz 38. ukazuje. Pozústávali ze tři éástí, z hlavy, z hrudi a z břicha, za nímž následovalo s připojením ocasu sedm kroužkủ. Byli opatřeni šesti nohami, z nichž dvẽ nejzadnější s břichem se spojovaly, čtyrì ostatní pak s hrudi na články rozdèlenou, tak jak to obraz znázorňuje. Z hlavy čněla dvě tykadla, ze sedmi článkủ složená. Na hřbetu připevněna byla dvě krídla na koncích tak spojená, že nikdy se rozložiti nemohla. Blány neměly, jsouce opatřená dlouhými a velmi tmavými chlupy, kteréžto někdy odstávaly jako na dikobrazu ostny. Avšak k věci! Konce ětyř přednějších noh tak vytvořeny byly, že napodobovaly měchýriky s přejasné blanky vytvořené. Tèch uživalo zviře, přikládajíc je ke sklu, a kdykoli znovu lezlo, měchýřky ony rozšiřovalo a pritlačovalo je na povrch skla, na nèmž takto lpějíc, velmi rychle ku předu lezlo, při kterémžto pohybu byly zadní nohy neužitečné, ježto takových polštářkỉ zvlažovacích neměly, a jakmile skla se dotkly, ihned pro hladkost se smekalỵ. Podobné klouzání nohou pozoroval jsem u vší, 


\section{J. UZEL, MONOGRAFIERADU "THYSANOPTERA“.}

blech a jiných toho zpủsobu hmyzủ. mezi dvè vydutá skla uzavřených, třeba dlouhými, ohnutými a silnými drápy byli opatřeni. Pokus necht zvolí, kdo to zvẻděti chce, tak, aby položil nějaké toho druhu zviŕe na desku skleněnou dokonale hlazenou, pak jestliže ji zvedne a obrátí, takže ona část, na kleré je zvíre, rovinu vodorovnou zří, padá zajisté zviŕe ono, avšak přilne dlouho moucha a přes desku dle chuti beze strachu před spadnutím poběhne. «

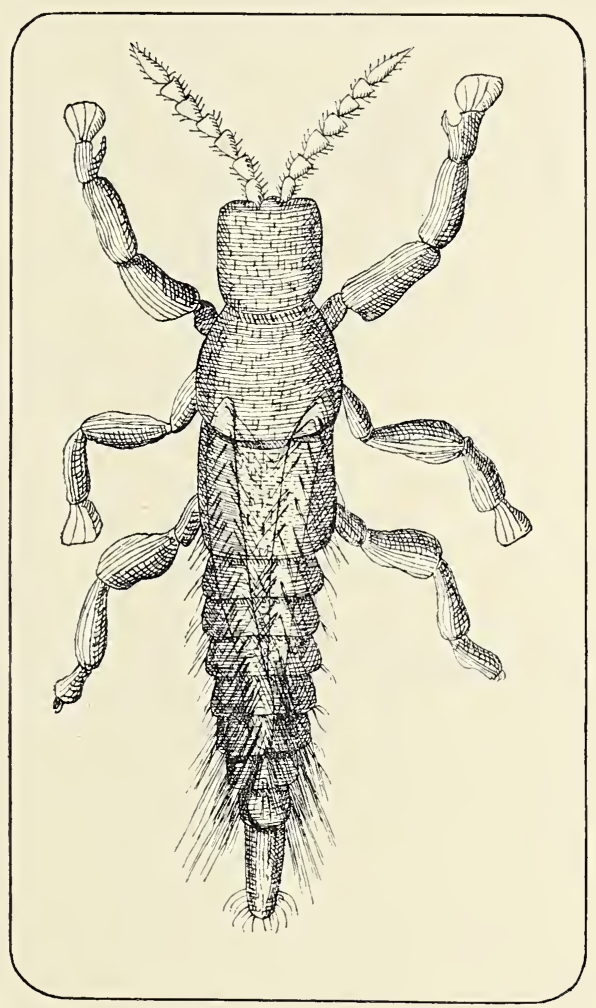

Obraz 8. PRVNi VYOBRAZENI T RÁSNENKY Z R. 1691. (Dle objevitele trásněnek jesuity Bonanniho.)*)

Dovolil jsem si pridati prvý obrázek tr̉ásněnky vủbec na vlas tak, jak jest vyobrazena na jedné tabuli díla Bonannova.**) Na téže tabuli vidime první vyobrazenou třásněnku zároveň s křidlem mouchy a chodidlem jisté ješlěrky, která dovede lézti po

*) DIE ERSTE ABBILDUNG EINES VERTRETERS DER THYSANOPTEREN AUS DEM JAHRE 1691. (Nach dem Entdecker der Thysanopteren, dem Jesuiten Bonanni.)

**) Druh Bonannim nakreslený jest najisto zástupce tubulifer a sotva lze o tom pochybovati, že jest to samec druhu Anthothivips statices. 


\section{H. UZEL, MONOGRAPHIE DER ORDNUNG THYSANOPTERA}

hladkých stènách a má dle Bonanniho dole na prstech dvě řadỵ podobných měchý̛rku, jako je nalézáme u mouchy neb lřásněnky. — Dále připojuji obraz mikroskopu, klerého užival Bonanni, a pomocí jehož jest trásněnka jeho nakreslena. Zařízení všech věcí, kromě mikroskopu samého, jest vynálezem jeho. Nepřidávám k obrazu tomu, který je v zmenšeném měrílku věrně okresilen z knihy Bonannovy, žádného vysvètlení, poněvadž jsem přesvědčen, že laskavý čtenár̆ snadno uhodne účel jednotlivỵch zařizení.

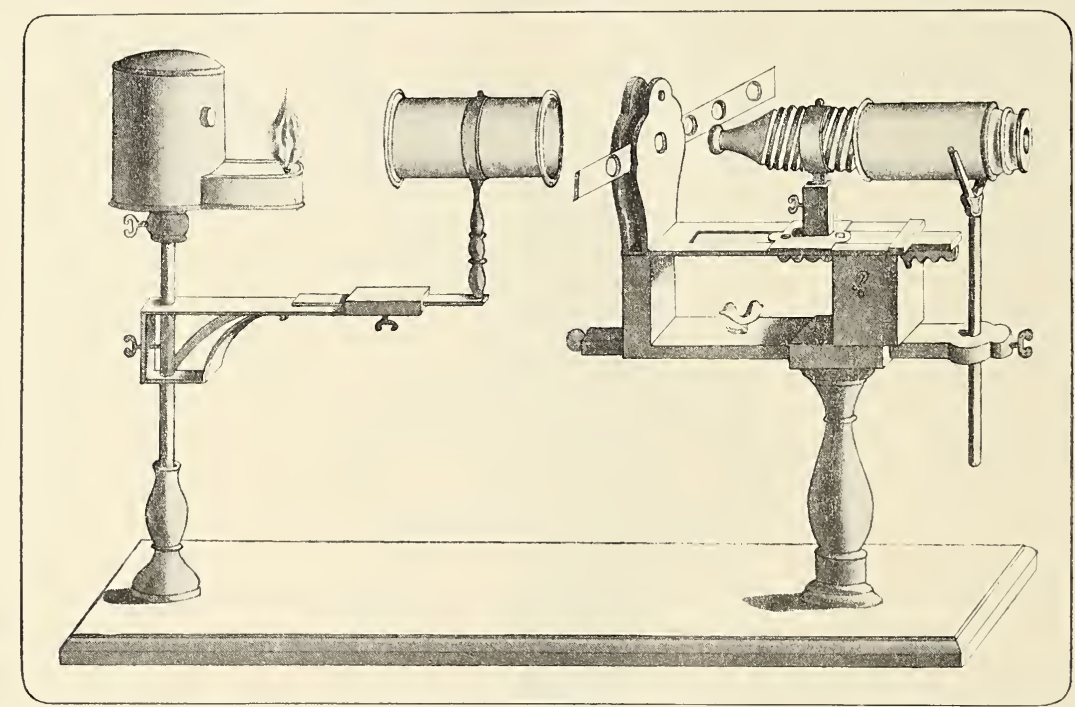

Obraz 9. MIKROSKOP, ZA JEHOZ POMOGI BONANNI PRVOU TR̈SNENKL POPSAL A NAKRESLIL.*)

\section{(.. 2}

*1744. C. De Geer, Beskrifning på en Insekt af ett nytt Slägte (Genus), kallad Physapus. Kongl. Swenska Welenskaps Akademiens Handlingar för monaderne Januar, Februar ock Mitrt. Vol. V. Str. 1.-9.

Dvorni maršálek královny švédské, baron Carl Degeer, domnívá se, jak z léto jeho práce jest patrno, že jest objevitelem třásněnek. Zprávu o svém domnělém objeru podává v cilorané práci v reči šrédské. \#myz dèlí se, " praví Degeer, "na rody právě tak, jako jiná zvírata a jako rostliny. Ze spisu pana professora Limnaea, Systema Naturae nadepsancho, je zrejmo, jakým zpussobem se rozdèluje. Tento slovulný autor dal nám jména pro všecky posud známé rody hmyzu; avšak veškeré vědy, zvláště pak vědy př́rodní. musi se doplñovati. Od té duby, kdy zminěné Systema Naturae vy̧šlo,

* DAs MKROSKOP, MIT HILFE DESSEN BONANN DEN ERSTEN VERTRETER DER THYSANOPTEREN BESGHRIEB UND AUFZEICHNETE. 


\section{J. UZEL, MONOGRAFIE RADU, "THYSANOPTERA“.}

nalezl jsem rozliěné rody hmyzu, které nemohou vřadèny býti do žádného rodu posud známého, následkem čehož musí obdrželi nová jména. Takovým je hmy̧z, který popíši, a jejž nazỵvárn Physapus. Připojená tabule ukazuje dva druhy toho hmyzu, nakreslené pomocí mikroskopu, nebof jsou tak malé, že bez pozornosti nelze jich spatřiti. Nejdříve podám všeobecný popis hmyzu, do tohoto nového rodu náležejícího, načež príkročím $\mathrm{k}$ popisu dvou jeho druhủ."

Degeer svùj nový rod charakterisuje takto: "Corpus elongalum. angustum. Clypeus duplex. Alae quatuor, abdomine angustiores. Pedes vesicula instructi. V dalšm textu popisuje tělo třasněnek dosti správně a výklad svîj objasñuje pẹ̆li obrazy. Mezi jinỵm praví. že tykadlo třásnĕnek skládá se ze šesti článkủ, že šestý \% nich jest nejdelší. nohy pak že ukončeny jsou malým blánitým měchýřkem, vylučnjicím snad lepkavou hmotu. jejižto pomocí lépe na předmětech Ipí. Z kořene hořcjšího křĩda vidí vycházeti žilku, která se brzy dèlí ve dvě vělve; na dolejšim kř́́dle pak pozoruje žilku jedinou. Ưstrojủ ústních nespalruje. Dále praví o třásněnkách, že lezou a skáčou hbitě, let jejich že však jest tak krátký, že mi̊že považován bỵ́ti za poskakování. Drážděny byvše vyzdvihuji abdomen do výše.

Po všeobecné části popisuje Degeer dva druhy třásněnek. Prvému, dle zpủsobu tehdejšího, dává jméno: „Physapus fuscus, alis albicantibus“. Jaký to druh jest, nelze dnes ríci. nebot jest popis jeho tuze kusý. Nalézá ho mezi lupínky malỵch nádorû na jalovci, podotýká však zvláště. že není jich pùvodcem, nỵbrž ð̌e se asi jen šfavou jejich živí. - Druhý druh nazývá: „Physapus ater, alis albis“. Nalézá ho ve velikém množství po celé léto v květinách zahradních a luěních. Trúsněnku tuto nazval pozdēji Haliday Thrips (= Physopus) vulgatissima.

Práci svou ukončuje Degeer těmito asi slovy: »Bylo by si přáti, abychom nalezli větší druh tohoto hmỵzu, na němø by lépe bylo lze zkoumati všecky jeho ěástky, nebot jest velice obtižno u tak malého hmyzu vše viděti. Ještě zbývá zvěděti, jakou asi mají proměnu; nebot' že proměnu mají, jakio veškeren létající hmyz, o tom pochyby není. To však není tak lehko vypátrati při tak nepatrných tvorech."

$$
\text { C.. } 3 \text {. }
$$

*1746. Caroli Linnaei Fauna Svecica Lugduni Batavorum. Str. 220.

Slavný Karel rytiř Linné byl třelím mužem, jenž o třásněnkách se zmiňuje. Jméno Physapus. těmto zviŕátkủm Degeerem pridělené, mění v nadrečené práci ve

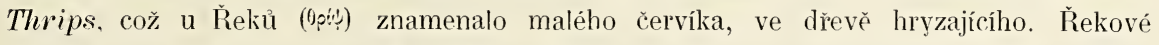
uživali jména 9ọ! v rodu mužském, Li nné však uživá ho v rodu ženském. - Ve své práci uvádí tr̆i druhy. Ku dvěma druhủm Degeerem objeveným přidává třetí nový. Jest to Thrips elytris albis nigrisque fasciis, corpore atro (= Aeolothrips fasciata). Degeerův druh: Physapus ater, alis albis stotožn̆uje Linné mylně s druhem, jejž nazývá: Thrips elytris glaucis, corpore atro (= Thrips physopus). Praví o něm, že 


\section{H. UZEL, MONOGRAPHIE DER ORDNUNG THYSANOPTERA.}

jest nejmenším hmyzem, menším než veš, a že dlouho se rozmýšlel, kam ho vraditi, kdy̌̌ pouhým okem jen dvě křídla rozeznati mohl. V květech heřmánku nalézá nachovou larvu a soudí mỵlnè, že to jest larva jeho. - Druhý Degeerův druh: Physapus fuscus, alis albicantibus překritivá ve: Thrips elylvis niveis, corpore fusco.

\section{4 .}

1761. Caroli Linnaei Fauna Svecica. Stockholmiae. Str. 266.

$\mathrm{V}$ této práci užito jest již nové nomenklatury, Linnéem samým zavedené. Dle této uvádí Linné svůj druh: Thrips elytris glancis. corpore atro jako Thrips physapus, Degeerův druh Physapus fuscus, alis albicantibus jako Thrips juniperina, svủj druh z r. 1746.: Thrips elytris albis nigrisque fasciis, corpore atro jako Thrips fasciata. Konečně přidán jest tu druh norý: Thrips mimutissima (Thrips elytris corporeque glauco, oculis fuscis).

$$
\text { C. } 5 .
$$

*1761. J. H. Sulzer, Die Kennzeichen der Insecten nach Anleitung des Königl. Schwed. Ritters und Leibarzts Karl Linnaeus, durch XXIV Kupfertafeln erläutert und mit derselben natürlichen Geschichte begleitet. Zürich. Str. 83.-85.

Doktor lékařství Joh. He inr. Sulzer podává nám zde všeobecný popis třásněnek, který z větši části doslovně překládá z Degeerovy práce (Č. 2.). »At jsem takové zvířátko«, praví mezi jinỵm, »jakkoli pod zvětšovacími skly zkoumal, nemohl jsem přece rozeznati, zdali má kusadla neb ssavý rypáček, a to ani tenkrát, kdỹz jsem je pomocí slunečného mikroskopu až na šest střevícủ zvětšil. "Přece však více kloní se k náhledu, že mají kusadla volná. Norým jest, že viděl chodidlo, skládající se ze tři dílů, z nichž poslední zakončen jest dvěma drápky a měchỵrîkem. Podárá také vyobrazení jedné třásnènky, v níž poznávám druh Acolothrips fasciata. Zde poprvé užito jest německého jména Blasenfuss.

$$
\text { c. } 6 .
$$

*1763. J. A. Scopoli. Entomologia Carniolica exhibens Insecta Carnioliae indigena et distributa in ordines, genera, species, varietates methodo Linnaeana. Vindobonae. Str. 141.

Horní rada a professor chemie a botaniky Joann. An t. Scopoli věnuje v této práci o hmyzu krajinském nèkolik řádkư třásněnkám. Uvádí jménem jen druh Tlırips physapus L. Poznamenává však, že nalezl ještě troje třásněnky; jedny v květech od Rammuculus palustris ( $T$. fusca, raris pilis adspersa; antennis obscuris, abdomen exiliens, segmentis margine mfis), druhé $\mathrm{r}$ kvètech od Hypochoeris maculata L. (T. tota nigra, petum unguiculis albidis; alis margine pilosis), třetí ve velikém množstrí v kvètech od Bellis major (Chrysanthemum leucanthemum; T. nigra tota, antemumm arliculis basi abidis, libiis amlicis crassioribus, compressis). 


\section{J. UZEL, MONOGRAFIE RADU "THYSANOPTERA“.}

\section{(̇. 7 .}

V této době vyšel také svazek díla Linnéova: Amoenitates academicae (1749-1790). obsahujicí (6. p. 401. 11. 48.) popis nového čínského druhu: Thrips paradoxa (fusca, alis abbreviatis, antennis pectinatis, fissilibus aliformibus), o nèmž soudim, že nepatrí mezi třásněnky rủbec (částečně laké o Grmelina [C̆. 22.] se opíraje).

$$
\text { Č. } 8 \text {. }
$$

Též do této doby snad spadá nèmecký překlad Kästnerûv Degeerovy práce o tr̉ásněnkách z roku 1744.

$$
\text { C. } 9 \text {. }
$$

*176t. E. L. Geoffroy, Histoire abrégée des Insectes, dans laquelle ces animaux sont rangés suivant un ordre méthodique. Tome premier. Paris. Str. 383.-386.

Doktor mediciny Etienne Louis Geoffroy popisuje zde tři druhy truásněnek. Jeden z nich jest rozhodnè zástupcem tubulifer. Jmenuje ho: Thrips elytris albidis, corpore nigro, abdominali seta; podává na tab. 7., obr. 6., jeho výkres a myslí, že to jest Thrips jumiperina L., cő̌ jest omylem, jak již Goeze (Č. 18.) poznamenává. V tykadle jeho vidí 7 článkủ. Druhá trásněnka jest dle něho Thrips pliysapus L. Tretí jest Thrips (= Aeolothrips) fasciata L.

\section{C.. 10 .}

*1767. Caro li a Linné Systema Naturae. Editio XIII. Vindobonae. Tomus I. Pars II. Str. 687 . a 743.

V této práci čteme, že třásnènky maji rypáček $k$ hrudi zahnutý. O druhu Tlrips physapus L. praví se, że zpûsobuje nádory kvètové na Lotus corniculatus (coz̀ později Degeer vyvrací), a że zaviňuje hỉuchost klasů žitných. Nového druhu tu není.

\section{11 .}

1773. Ch. De Geer. Mémoires pour servir à l'histoire des Insectes. Stockholm. III. Str. 1.-18.

V úvodu mluvi De Geer o systematickém postavení třásněnek a pririradiuje je ku hmyzu polokrídlému. Co se pak týče okolnosti, že Linné změnil jeho jméno Physapus ve Thrips, praví, že změna ta stala se z účelu mu neznámého; poněvadž mu však »na jméně nezáleži, jen když zvíre, které ho nésti má, r̀ádně se rożeznává«, chce přidržeti se pojmenování Linnéova, a to tím spíše, že již většině přírodníků z jeho slavných spisủ jest známo, a že ho Geoffroy také podıžel. - Vypočítav hlavní znaky třásněnek, dle něho na druhy jen málo ěetných. jedná o ětyřech tŕ̛ásnènkách zvláště, z nichž první jest Thrips atra etc. (Tab. I., obr. 1.), kterou již r. 1744. popsal (= Physopus vulgatissima). Opakuje zde svá dřívější slova a kromě toho praví o ní, že asi živí se medovou štavou květin. Co se týče noh této tŕ̛sněnky, zdá se mu někdy, jakobỵ pu-

$$
-409-
$$




\section{H. UZEL, MONOGRAPHIE DER ORDNUNG THYSANOPTERA.}

chỵ́rky svými, na konci chodidla se nalézajicimi, se přissávala k předmètủm, po kterých leze. Aby zjistil tvar ústrojů ústních, pozoroval ji, jak pravi, lak dlouho vodním mikroskopem, až se mu roku 1766. pošlěstilo objeviti, že hlava pod předohrudí se prodlužuje. a na konci téło prodlouženiny že má tupý, kuželovitý sosáček. Také na něm pozoroval malé vláskovité prívěsky, z článkủ složené, jež za makadla právem prohlašuje. Konečně popisuje larvy tohoto druhu lĩáněnek a podává jejich vyobrazení (Tab. I., obr. 4.). Praví o nich, že jsou bledé, tykadla že jsou čtyřčlenná, a zadek že skládá se z devíli až desíti článkủ. - Druhá uvedená třásněnka (Tab. I., obr. 5.) jest ta, kterou r. 1744. nazval Physapus fuscus, alis albicantibus, a kiterou Linné překr̆til ve Thrips juniperima. - Třetí tr̆ásnènkou jest Thrips (corticis) nigra, alis hyalinis niveis, barbis longissimis, antemis octonodiis. Myslí, že jest totožna s Geoffro yovou trúsněnkou: Thrips elytris albidis, corpore nigro. abdominali seta. R. 1748. nalezl celé společnosti nymfy toholo druhu (Tab. I., obr. 8. a 10.) pod korou olšovou. Hlava jejich byla obklopena na krajich prủhlednýı lemem, který tvořen bỵl, jak právem se domnívá, přiloženými tykadly, pokrỵlými světlou blankou. Abdomen skládal se ze sedmi až osmi článkủ. Bỵly bílé a červeně kropenaté. Nèkleré exempláre mèly k stranám hrudi prìiložené pochvy krridlové: jiným scházely. $Z$ prvých vytrořily se třásnènky okřídlené, z druhých neokîidlené. Toho přetrořování se $z$ nymf $r$ dospělỵ hmyz byl Degeer očitým svẽdkem. Zda mezi okřidlenými a neokřídlenými jest snad rozdil v pohlavi, to prý rozhodnouti nemohl. - Člvrtá tiásněnka, kterou uvádi, jest Thrips fasciata L. Ponẽvadž však o ní praví, že jest jedna z nejmenšich svého druhu, a že na hořejšich křídlech má tři bílé skrrny, je možno, že mèl před sebou třásněnku, kterou nazỵvám Dendrothrips tilicie.

\section{C.. 12 .}

1764. v. Gleichen, Das Neueste aus dem Reiche der Pflanzen. Str. 13. a 14.

Autor vyobrazuje v léto práci nový bezkrídlý druh: „der rothe Blaseufuss“, který Gmelin pozdèji (L. č. 22.) nazval Thrips (=Aptimothrips) rufa (Tab. 16., obr. 6. a 7.), a jenž žje v klasech pšeničných, a nový druh Thrips variegata (Tab. 21., obr. 6. a 7.). nazvanỵ pozdēji Gmelinem Thrips variegata, na Inici (Linaria) nalezený.

\section{c. 13.}

*1776. O. F. Müller, Zoologiae danicae Prodromus seu Animalium Daniae et Norregiae indigenorum Characteres, Nomina et Synonyma etc. Havniae. Str. 96.

Dánsky státni rada, zoolog a botanik Otto Friedrich Müller uvádí zde známé druhy: Thrips jumiperima L., T. physapıs L., T. mimutissima L. a přidává nový druh: Th. obscura flavescens, elytris pallidis, oculis abdominisque anmulis nigris (= Thrips discolor).

\section{C.. 14 .}

*1776. J. H. Sulzer, Abgekürzte Geschichte der Insecten. Nach dem Linnaeischen System. Winterthur. Str. 112. 


\section{J. UZEL. HONOGRAFIE RADU, „THYSANOPTERA“.}

V této práci píše Sul\%er, že také larvy trásnènek skácou, coż jest omỵlem. Popisuje a kresli (Tab. XI., obr. 12.) novou trüsněnku: Thrips (= Melanothrips) fuscus. Praví však, že jest to snad jen samička druhu Thrips (= Aeolothrips) fasciata L., jíž, kromè kǐídel, které nemají príičny̛ch slub, jako »vejce vejci se podobá. Mám za to, že to jest druh Melanothrips obesa, r. 1836. Halidayem popsaný.

\section{C.. 15 .}

1776. F. Schrank, Beyträge zur Naturgeschichte. Str. 31.

Ředitel mnichovské botanické zahrady, doktor theologie, Frant. Schrank popisuje zde nový druh třásnènek: T. flara, alis albidis a praví o něm, že navštěvuje listy kopřivy, vína a lísky. Jeho výkres podává na Tab. I. (obr. 25. a 26.).

\section{(c. 16 .}

1777. J. A. E. Goeze, Entomologische Beyträge. II. Aufl. Leipzig. Str. 346.-351.

Zde uvádí pastor a dvorní diakonus Johann August Ephraim Goeze, promluviv o třásněnkách všeobecnè, několik druhủ Degeerem (Č. 11.) a Gleichenem (亡̌. 12.) popisovaných.

$$
\text { C.. } 17 \text {. }
$$

1780. J. Ch. Schäffer, Elementa entomologica. 3. Aufl. Erlangen.

V této práci píše zoolog a botanik superintendent Jacob Christian Schäffer na str. 127. o tr̃ásnènce Thrips physapus L.

\section{18 .}

*1780. J. A. E. Goeze, Des Herrn Baron Karl von Geer Abhandlungen zur Geschichte der Insekten, aus dem Französischen übersetzt und mit Anmerkungen herausgegeben. Dritter Band. Nürnberg. Str. 1.-11.

Goeze překládá zde Degeerovy Mémoires pour servir à l'histoire des Insectes. $\mathrm{V}$ poznámkách, $\mathrm{k}$ tomuto překladu Goezem přidaných, souhlasí tento úplně s náhledem Degeerovým, že třásněnky puchýrìy svými na predměty, po kterých lezou, se př̀ssávají, a praví o nich, že mají podobu puchýrkú čmelíkủ (Gamasus coleoptratorum), jimiž se tito podobně přidržuji hladkého povrchu broukủ, na nichž cizopasně žiji. V jiné poznámce soudí Goeze, že okřidlené exempláre Degeerova druhu Thrips corticis dle analogie s jiným hmyzem, zvl. molýli, jsou samci, neokříllené samicemi. To arcit jest nesprávné, nebot víme, že tomu jest u třásněnek oby̌čejně naopak, ač i kromě okřídlených samic přicházeji neokřídlené.

$$
\text { C.. } 19 \text {. }
$$

*1781. F. Schrank, Enumeratio Insectorum Austriae indigenorum. Augustae Vindelicorum. 


\section{H. UZEL, MONOGRAPHIE DER ORDNUNG THYSANOPTERA.}

Schrank uvádí v léto práci následujíci druhy: Thrips physapus L., T. (= Aeolothrips) fasciata L., T. mimutissima (tento druh popisuje takto: T. nigra, capite, thorace, alisque subtestaceis - a dodává, že snad je to nèjaký jiný druh), T. flava Schrank

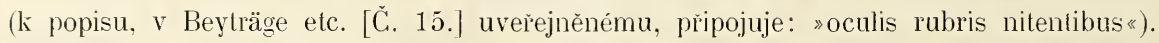
Trúsněnku, kterou Scopoli svélı času (Č. 6.) na kopretině nalezl a beze jména popsal, jmenuje, ohledar ji snad znovu, Thrips leucanthemi; jinou třásnènku, Scopolim v kivětech ad Ramunculus palustris nalezenou a laktéž nepojmenovanou, nazývá Thrips Ramunculi. Norè uvádí druh Thrips melanopa (T. flava, oculis nigris), klerouž nalezl v květech komposit. Jest to však T. flava téhož autora. - Schrank praví o třásněnkách. že jsou snad četným rodem, avšak že teprve, pokud on vi, jest 9 druhư popsáno (v pravdě było jich popsáno již více), které vypočitává.

\section{Č. 20 .}

1781. J. C. Fabricius, Species Insectorum. Hamburgi et Kilonii. Tom. 11. Str. 396. a 397.

Nejslavnējši entomolog 18 . století Dr. Joh. Christ. Fabricius uvádí r práci télo šest známých druhu trásněnek a připojuje ke každému krátkou diagnosı. Jsou to: 1. Thrips physapus L., 2. T. juniperina L., 3. T. Ulmi, (tak jmenuje Deegerùv druh: Thrips (corticis) nigra, alis hyalinis etc. z r. 1773.), 4. T. mimutissima L., 5. T. Wrticae (tak překritivá Schrankưv druh T. flava), 6. T. (=Aeolothrips) fasciata L.

\section{C.. 21 .}

*1787. J. Ch. Fabricius. Mantissa Insectorum sistens Species nuper detectas adiectis Synonymis, observationibus, descriptionibus, emendationibus. Tom. II. Hafniae. Str. 320 .

V této práci podává F abricius totéž jako ve své dřivẹjši: Species lns. z r. 1781.

\section{Cั. 22 .}

*1788. J. F. Gmelin, Caroli a Linné, Systema Naturae per Regna tria naturae secundum Classes, Ordines, Genera, Species cum Characteribus, differentiis, synonymis, locis. Editio decima tertia, aucta, reformata. Lipsiae. Tom. I. Pars IV. Str. 222.2. a 2223.

Dvorní rada a professor chemie J. Frid. Gmelin vypočitává v této kompilaci. která jest posledním dilem, všecky známé druhy živočichủ i rostlin obsahujícím. 11 známỵch druhu trísnènek a prìdává skoro ke všem králkou diagnosu. Jsou to: 1. Thrips paradoxa L., 2. T. physapus L., 3. Thrips mimutissima L., 4. T. juniperina L.. 5. T. ulmi Fabr.. 6. T. urticue Fabr. (= T. flava Schr.), 7. T. (= Aeolothrips) fasciata L., 8. T. frsca, omylem zde za nový druh Müllerùv považovaná, nebof popsána byla Sulzerem (Č. 14.), 9. T. obscura Müll. (= T. discolor Halid.). 10. T. (=Aptinothrips) rufa (tak nazývá autor v. Gleichenüv [C̆. 12.] druh: „der rothe Blasenfuss"), 11. T. variegata v. Gleichen. 


\section{J. UZEL. MONOGRAFIE PADU, "THYSANOPTERA“.}

\section{23 .}

1789. J. Berkenhout, Synopsis of the Natural History of Greal Britain and Ireland. London. Str. 122. a 123.

M. Dr. J. Berkenhout uvádí ve své práci druhy: Thrips pluysapus L., T. juniperina L. a T. (= Aeolothrips) fasciata L.

\section{C.. 24 .}

1789. C. de Villers, Caroli Linnaei Entonologia. Lugduni. I. Str. 564.-567.

Karel de Villers uvádí v télo práci 10 známỵch druhủ lrásnènek a prìává k druhu Thrips flava Schr. poněkud delší popis.

\section{25 .}

1790. C. Bje rkander, Om en Thrips, som skadar kornbroden. Kongl. Swenska Vetenskaps Academiens Nya Handlingar. Stockholm. Tom. 11. Str. 226.-229.

Clas Bjerkander pojednává zde ve švédské řeči o lřásněnce (dle něho Thrips plıysapus), která poškozuje vyrážejici ječmen a někleré traviny.

\section{Cั. 26 .}

*1794. J. Ch. Fabricius. Entomologia Systematica Emendata et aucta. Secundum Classes, Ordines, Genera. Species adjectis Synonymis, locis, observationibus, descriptionibus. Hafniae. Tom. IV. Str. 228.

V práci této podává Fabricius téměr̆ totéž jako ve svých drívějších pracích: Spec. Ins. a Mant. Ins. Také zde urádí jen šest druhủ.

\section{27}

1796. W. Kirby piše $\mathrm{v}$ časopisu Transactions of the Linnean Society, Vol. III., na str. 242. až 247. o třásněnce, klerá škodila pšenici v Anglii. Nazývá ji Thrips physapus L, a pozoroval, že samec její jest bezkrídlý. Haliday však r. 1836. poznal v ní druh nový, který nazývá Limothrips cevealium. Talo trăsnènka sedá dle Kirbyho v rỵze zrnek pšeničných a jest prý $\mathrm{v}$ Anglii nejhojnèjšim hmyzem na pšenici.

$$
\text { C. } 28 \text {. }
$$

1797. T. Marsham, Observation on the insect, that infested the corn in the year 1795. Transactions of the Limnean Socièly. Vol. III. Str. 242.-251. Tab. 22., fig. 5. -8 .

Thomas Marsham mluví zde o lǐásněnce, jež poškozovala žito roku 1795. v Anglii. Jmenuje ji Thrips plyysapus.

$$
\text { C. } 29 \text {. }
$$

1798. T. M arsham. Further observations on the wheat insects. Transactions of the Linnean Society. Vol. IV. Str. 224.-229.

Narsham zde mluví o škodách trúsněnek na pšenici.

$$
-413-
$$




\section{H. UZEL, MONOGRAPHIE DER ORDNUNG THYSANOPTERA.}

\section{C.. 29. A.}

1798. W. Kirby, History of Tipula 'Tritici and Ichneumon Tipulae, with some Observations upon other Insects, that attend to the Wheat. Transactions of the Linnean Sociely. Vol. IV. Str. 230.-238.

Kirby pojednává zde mezi jiným též o třásnènce, kterou nazývá Thrips physapus L.. a jež vyskylla se na pšenici v Anglii.

\section{30 .}

V této době snad vyšel XII. svazek Nicholsonova časopisu Journal of Nat. Phil., kdež na tab. 8. (obr. 1.) nalézáme velmi špatný výkres druhu Thrips (= Aptinothrips) rufa v. Gleichen.

$$
\text { C.. } 31 \text {. }
$$

1802. Stew, Elements of Natural History, being an Introduction to the Systema Naturae of Limnaeus. London and Edinburg. II.

Spisovatel télo knihy uvádi na str. 114. druhy: Thrips physapus L., T.juniperima L., T. (= Aeolothrips) fasciata L. a T. mimutissima L.

\section{(⿳. 32 .}

*1803. J. Ch. Fabricius, Systema Rhyngotorum secundum ordines, genera, species, adiectis synonymis. locis, observationibus, descriptionibus. Brunsvigae.

Kromè šesti známỵch druhủ, kiteré Fabricius také zde jako v drívějšich svých

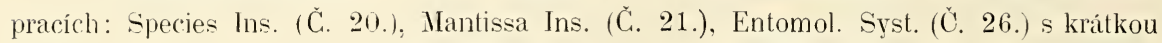
diagnosou uvádí. popisuje ješlě dva druhy nové, a to sice: Thrips (= Authothrips) aculeata (T. atra antennis pallidis. elytris albidis, aculeo brevi exserto) odkudsi z Rakous a druh Thrips conica (T. atra nitida alis ciliatis albis, abdomine conico) ze Severni Ameriky. - Pr̉i popisu druhu T. Ll mi Fabr. praví, že bezkřidlé exempláře jsou asi larvỵ.

$$
\text { č. } 33 \text {. }
$$

(1806.) Vassalli-Eandi popisuje v časopise Memorie della Accademia delle Scienze di Torino škodu třásněnek(?). na pšenici roku 1805. v Piemontu zpủsobenou. Zviř́tka ta dle něho ohlodávala(?) stćbla pšeničná nad kolénkỵ, následkem čehož se nevyvinul klas. Tím zpusobem zničila asi lretinu úrody. Dle Halida ye (C̆. 43.) byl škůdcem oním druh Limothrips cerealium Halid.

\section{Ċ. 34 .}

1806. W. Turton, A General System of Nature trough the three grand kingdoms of Animals, Vegetables, and Minerals. Translated from Gmelin's last edition of Systema Naturae. II.

Ned. Dr. W. Turton uvidi $v$ dile tom na str. 716. a 717. sedm známých druhủ lr̀ásnènek, a to: Thrips Ulmi Fabr., T. Urticae Fabr. (= T. flava), T. phy- 
sapus L., T. juniperima L., T. (= Aeolothrips) fasciata L., T. variegata v. Gleichen a T. mimutissima L.

\section{C.. 35 .}

1806. G. Shaw, General Zoology. Vol. 6. Insecta. Sir. 199.

Dr. George Shaw uvádí v této knize druh Thrips physapus L. a vyobrazuje ho na Tab. 63.

$$
\text { Č. } 36 \text {. }
$$

*1806. C. Duméril, Zoologie analylique ou Méthode naturelle de Classification des animaux, rendue plus facile à l'aide de tableaux synoptiques. Paris. Str. 268. a 269.

Ned. Dr. a professor anatomie i physiologie A. M. Constant Duméril povýšil v télo knize třásnènky z rodu na skupinu (familia), a to hmy̧zu polokř̌ílého, pod jménem Vésitarses ou Physapodes. Nalézáme tu jen velmi krátlí všeobecný popis jejich. Poněvadž pak Amyot a Serville ve své práci z r. 1843. trrói. že třásněnky sluší jmenovati Physopoda dle Dumérila, dovoluji si proti tomu namítati. že Dumérilova obě jména, která současně klade, jsou francouzská, nikoliv latinská. a tudíz že na prioritu žádného práva nemaji. Kromè toho pak Duméril ani bliže třásněnkami se nezaměstnává.

\section{C.. 37 .}

1821. W. Wood, Illustrations of the Linnaean Genera of Insects. London.

Autor této práce uvádí na str. 118. druh Thrips physapus L. a vyobrazuje ho na Tab. 42.

$$
\text { Č. } 38 . \quad \text {. }
$$

1829. Latreille: Cuvier, Règne animal. Paris. V. Str. 226.

Professor entomologie Pierre André Latreille uvádí ve svém zpracování hmyzu, v díle Cuvierově: Règne animal (1817-1848) obsaženém, pozorování anatoma H. Strauss-Dürkheima, které mu tento oznámil. Straus s-Dürkheim zkoumal ústroje úsıni trúsněnek a vidèl maxilly i palpy. Nerozeznal arcit, že maxilly jsou srostlé s hor̉ejším i dolejším pyskem, a že tvoří s těmi částmi dohromady ssavý rypák, nýbrž domnival se, že jsou volné, a z té přičiny řadí třásněnky $k$ orthopterům. Lat reille nazývá náš hmyz v této práci „Physapi“.

Č. 39 .

*1829. J. F. Stephens, A Systematic Catalogue of British Insects, being an altempt to arrange all the hitherto discovered indigenous insects in accordance with their natural affinities. London. Str. 363 .

James Francis Stephens vypočíává v této práci následujícich 9 druhủ trásněnek, a to bez popisu, toliko s připojením známé mu literatury o nich: Thrips $(=A n-$ thothrips) aculeata Fabr., T. Ulmi Fabr., T. Urticae Fabr. (= T. flava), T. Physapus L., T. Juniperina L., T. (= Aeolothrips) fasciata L., T. variegata v. Gleichen, T. 
H. UZEL, MONOGRAPHIE DER ORDNUNG THYSANOP'TERA.

obscura Müll. (= T. discolor) a T. minutissima L. -- Hegger praví r. 1854., že Stephens v tomto svém katalogu uvádí též nové druhy třásněnek (mezi jinými také Thrips sambuci); že však $\mathrm{k}$ nim neprìipojuje popisu. Tvrzení to zajisté zakládá se na omylu, nebof nových druhủ v Stephensovè kiatalogu není.

\section{40 .}

1833. P. F. Bouché, Nalurgeschichte der schädlichen und nülzlichen GartenInsecten u. die bewährtesten Mittel zur Vertilgung der ersteren. Berlin. I. Str. 206.

Obchodní a umèlý zahradník P. Fr. Bouché popisuje zde nový druh třásněnek Thrips (= Heliothrips) haemorrhoidalis. Nalézá ho na rủzných rostlinách v teplých i studenèjšich sklenících a mysli, že pocházi z Ameriky.

\section{Ċ. 41 .}

1834. C. Passerini. Alcune notizie sopra una specie d'Insetto del Gen. Thrips, dannoso agli olivi nel Territorio de Pietrasanta. Atti dell' Academia de Georgofili. Ton. XII.

Carlo Passerini mluví v této zprávẽ o veliké škodlivosli jistého druhu třásnènek, klerý žije na rubu lisłủ olivových a má ročnè několik pokolení. Aulor trásnènku tu nepopisuje a myslí, że to jest Thrips pluysapus L.

\section{(¿. 42 .}

*1835. E. Newman, Altempted Division of British Insects into Natural Orders. The Entomological Magazine. London. Vol. II. Art. XXXVII. Str. 379.

Eduard Newman zde uver̉ejǔuje nové rozdèlení hmyzu. Třásnènky uvádí mezi "Tetraptera Isomorpha“, kdě̌ je klade jakožlo "Natural Order « (majícíplatnost čeledi) Thripsites, jehož postaveni sṿstematické jest, jak sám praví, posud pochybné. - V krátkém popisu tr̆ásnének poznamenává, že maji tykadla složená z osmi článků, chodidla mají dvoučlenná, a žc živí se pylem rosllin. Když lezou po lidské kủži, zpủsobuji prý nesnesitelné šimrání.

\section{43 .}

*1836. A. H. Haliday, An Epitome of the British Genera in the Order Thysanoptera, with Indications of a few of the Species. The Entomological Magazine. London. Vol. III. Str. 439.-451.

Tato práce jest nejdủležitèjši ze všech, které o truásnènkách až po dnešní den vyšly, jestit základní prací v oboru tom. Spisovatel její Alexander Henry Haliday, Magister artium, známý anglický entomolog, jenž hlavně hmyzem blánokřídlým se zabýval, narodil se počátkem toholo stolelí a zdržoval se dlouhý čas v Londýně a pozdèji v Tucce, kdež r. 1870. zemřel.

Ve všeobecném úvodu popisuje autor nejdřive tělo třásněnek, pak zmiñuje se o larvách a nymfách, dále věnuje několik řádků biologii a konečnè mluví o systema- 


\section{J. UZEL, MONOGRAFIE RADU "THYSANOPTERA".}

tickém postavení jejich. Vytkneme zde některé dủležitęjší věci. — Pokud se ústrojů ústních týče, jest to, co o nich píše, skoro úplně správno. Bliže o tom zminili jsme se v Části anatomické. Tykadla mají prý 8 neb 9 ělánkù, avšak někdy se zdá, že jich jest jen 5 neb 6. Haliday poprvé též zmiñuje se o třech jednoduchých očkách, mezi očima se nalézajícich. Pterothorax jest složen ze dvou èlánkủ, které jsou bud skoro stejně dlouhé, nebo jest první z nich kratší. Abdomen skládá se z desíli ċlánkủ, z nichž prvý zakryt je dole zadohrudi. Dlouhé třásně na krìilech slouži k tomu, aby zvětšily plochu krídla při letu. Chodidlo jest dvoučlenné s puchýrikem na konci, bez drápkủ. Larvy mají mesothorax a metathorax zřetelný, ústroje ústni jejich jsou ústrojủm ústním dospělého hmyzu velmi podobné, jednoduchých oček tu není a složené oči jsou zde nahrazeny seskupenýıni (conglomeratae). Nymfy podobaji se dospèlému hmyzu, avšak ohbí údů jsou potažena blanou a kríidla vězí $\mathrm{v}$ pochvách. Jejich tykadla jsou zpět $\mathrm{k}$ hlavě přiložená. Lezou sice také, ale jsou mnohem klidnější než larva a dospēlý hmỹ. Haliday objevil, že některé druby třásnènek opatìeny jsou kladélkem (Terebrantia), jiné nikoliv (Tubulifera). Vajička těchto již také vidēl. Co se potravy třásněnek tỵce, praví, že jsou to štávy rostlinné. Některé prý objevuji se v dospělé podobě jen na krátký čas, a to $\mathrm{v}$ čas květu té které rostliny. na nǐ̌ žijí.

Rozdělení třásněnek, Halidayem podané, jest zcela nové a velmi pròměřené. Řád Thysanoptera dělí totiž na dvě Stirpes. První Stirpss (i zároveñ Familia) jsou Tubulifera, postrádající kladélka. Jediný rod sem náležející nazval Plıloeothrips. Druhá Stirps jsou Terebrantia, mající kladélko (terebra). Tuto dèlí ve dvě čeledi (familiae): ve Stenelytıa. s křídly, opatřenými jen podélnými žilkami, a s kladélkem dolủ ohnutým, a ve Coleoptrata, s krídly, opatr̉enými kromě podélných též pìičnými žilkami, a s kladélkem nahoru zahnutým. Stenelytra rozdèluje v rody Heliothrips, Sericothrips, Thrips a Belothrips. Rod Thrips zase $\mathrm{v}$ podrody (subgenera) Chirothrips, Limothrips, Aptinothrips a Thrips v užším smyslu; Coleoptrata pak v rody Melanthrips a Aeolothrips. Tento má podrody Coleothrips a Aeolothrips v užšim smyslu. - Stirps Tubulifera má následujíci znaky: osm článkủ v tykadle, makadla maxillarní o dvou článcích s prvním velmi králkým, křídla bez żilek a v klidu skĩízená a konečně poslední článek abdomenu u ơ i q tenký, rourovitý. Stirps Terebrautia pak má tyto znaky: devět (»pro typo«) článkủ v tykadle, makadla maxillarní o třech článcích, a krídla se tremi podélnými žilkami. Dále poznamenává o nich, že skáčí, zadkem se odmrštujíce.

$\mathrm{V}$ celku popisuje Haliday 11 rodì (podrody $\mathrm{v}$ to počítaje) \& 41 druhy. V následujícím uvádíme jména druhủ Halid a yo v ých na jména v naší monografii užívaná.

1. Phloeothrips pedicularia Halid. = Trichothrips pedicularia Halid.

2. - aculeata Fabr. = Anthothrips aculeata Fabr.

3. - Ulmi Fabr. = Trichothrips ulmi Fabr.

4. - flavipes Halid. = Trichothrips pedicularia Halid.

5. - - Statices Halid. = Anthothrips statices Halid. 
H. UZEL, MUNOGRAPHIE DER ORDNUNG THYSANOPTERA.

6. Phloeothrips coriacea Halid. = dto.

7. - annulicornis Halid. = dto.

8. Heliothrips Adonidum Halid. = Heliothrips haemorrhoidalis Bouché.

9. Sericothrips staphylinus Halid. $=$ dto.

10. Thrips (Chirothrips) manicala Halid.= Chirothrips manicata Halid.

11. - (Limothrips) denticornis Halid. = Limothrips denticornis Halid.

12. - (Limothrips) cerealium Halid. = Limothrips cerealium Halid.

13. - (Aptinothrips)rufa v. Gleichen.=Aptinothrips rufa v. Gleichen.

14. - - nitidula Halid. = Aptinothrips nitidula Halid.

15. - Ulicis Halid. = Physopus ulicis Halid.

16. - phalerata Halid. = Physopus phalerata Halid.

17. - obscura Müll. = Anaphothrips virgo m. - Müllerúv druh obscura (nedostatečnè popsaný) jest jak myslím, Halidayû druh discolor.

18. - ulmifoliorum Halid. = Physopus ulmifoliorum Halid.

19. - atrata Halid. = Physopus atrata Halid.

20. - vulgatissima Halid. = Physopus vulgatissima Halid.

21. - Gynorthodi Halid. pozbỵvá platnosti, nebyv dostalečnè popsán.*)

22. - grossulariae Halid. pozbývá platnosti z téhož dủvodu.*)

23. - physapus L. = Thrips physopus L.

24. - fuscipennis Halid. = dto.

25. - Ericae Halid. $=$ dto.

26. - Urticae Fabr. = Thrips flava Schr.

27. - corymbiferar u m Halid. pozbývá platıosti, nebyv dostatečně popsán.*)

28. - minutissima L. = do.

29. - discolor Halid. = dto.

30. - livida Halid. pozbýrá platnosti, nebygr dostatečně popsán.*)

31. - Primulae Halid. =- Physopus primulae Halid.

32. - decora Halid. = Physopus primulae Halid.

33. - dispar Halid. = Baliothrips dispar Halid.

34. - brevicornis Halid. = Baliolhrips dispar Halid.

35. - subaptera Halid. = Pachythrips subaptera Halid.

36. - pallens Halid. = Thrips discolor Halid.

37. - (Belothrips) acuminata Halid. = Belothrips acuminata Halid.

38. Melanthrips obesa Halid. = Nelanothrips lusca Sul\%.

39. Aeolothrips (Coleothrips) fasciala $\mathrm{L}$. = Aeolothrips fasciata L. 40. - - _ vitlata Halid. = Aeolothrips vilta ta Halid.

*) Nicht genügend beschrieben. 
41. Aeolothrips (Coleothrips) albicincta Halid. = Aeolothrips albocin c ta Halid.

$\therefore 44$.

1836. J. H. Curtis, British Entomology; being illustrations and descriptions of the genera of Insects found in Great Britain and Ireland. 1823-1840. London.

V této práci uvádí anglický malír John H. Curtis na str. 748 . druh Haliday ův Thrips dispar.

C.. 45 .

*1836. H. Burmeister, Handbuch der Entomologie. Berlin 1832-1847. II. Bd. 1835. Str. 404.-418.

Med. a Phil. Dr. Hermann Burmeister, professor zoologie a ředitel Zoologického musea v Halle, výborný entomolog, počilá trrásněnky v tomto díle mezi sviỏ nový rád Gymnoguatha, tedy mezi hmyz s volnými kusadly. v kterémžto náhledu ho nejvíce podporuje prílomnost makadel, pỉi čemž nepopírá príbuznost trásněnek s rhynchoty. Burmeister nazývá třásnẽnky Plıysopoda, kteréžto jméno utvor̆il z Dumérilova jména francouzského Physsapodes (viz Č. 36.), formalnẽ je opraviv. Co se ústrojû ústních týče, potvrzuje v celku pozorování Halidayova. Na noze vidí trochanter. Chodidlo, praví mezi jiným, končí se kožním lalủčkem či príssavkou, již za zvláštní článek nesluší považovati. Drápky scházejí úphně. Desátý článek abdominalní jest rourovitý, avšak správnēji za pohlavní ústroj považovati se prý musí. Tř̆ásněnky živí se jen polravou rostlinnou, a ty, které $\mathrm{v}$ květech žijí, ssaji asi nektar jejich. Jsou na druhy velmi četné, znaky generické jsou však málo rozmanité.

Burmeister prijímá rozdělení Halidayovo úplně a uvádí všecky druhy, tímto autorem popsané, pr̃̀idávaje $\mathrm{k}$ nim jeho diagnosy a jeho poznámky, jen málokde něco nepatrného měně neb doplňuje. K rodu Phloeothrips prìdává druh Phl. albipemis (= Authothrips aculeata) a pod jménem Phl. coriacea Halid. popisuje druh Acanthothrips nodicornis. O terebrantích praví, že skáčou prý, vymrštujice se koncem abdomenu, který nejdříve dolủ ohnou a rázem opèt narovnávají. - Skupinu Halidayovu Stenelytra překitivá Burmeister na Stenoptera, nebot jest jméno Stenelytra zadáno, byvši priděleno Latreillem jisté skupině broukù. Halidayuuv druh Heliothrips Adoridum stotožñuje právem s Bouchéo vým druhem Thrips (= Heliothrips) haemorrhoidalis, již dřive popsaným. Podrod Halidayûv Aptinothrips vynechává, poněvadž soudí (neprávem): že zástupcové jeho jsou larvy, ježto jim scházejí křídla i očka, a ježto mají jen šest článků $v$ tykadle. K podrodu Chirothrips prìdává druh longipemis (=Ch. manicata).

$$
\text { Č. } 46 \text {. }
$$

*1837. A. H. Haliday, Additional Notes on the Order Thysanoptera. The Entomological Magazine. London. Vol. IV. Str. 144.-146. 


\section{H. U\%EL. MUNOGRAPHIE DER ORDNUNG THYSANOPTERA.}

V tomto ělánku uveřejňuje Haliday některé dodatky k práci své dřivější. Zprvu zmiňuje se o drou cizopasnicich třásněnek (Ocypete a malí bilí rozločové). Pak praví, že bezkrídlá forma druhu Phloeothrips Ulmi jest samec, okǐídlená pak samice, a popisuje larvu i nymlu jeho. Polom následuje popis nového druhu Phl. pini (- Trichothrips pini) a vajička i larvy jeho. Dále popisuje žlutou larvu a nymfu druhu Thrips (Limothrips) cerealium, doplñuje popis druhu Aptinothrips nitidula a mluví o larvè druhu Thrips phalerata a jakéhosi druhu, jejž nazývá Thrips Persicae, k němuž však popisu neprìdává.

\section{47 .}

*1837. Dr. W. F. Erichron podárá referal o práci Halidayovè (Č. 43.) a rytýká spisovateli, že pojinenoval rodỵ proti pravidlum Linéem (Philosophia Bolanica, \$. 225.) vylknulým. Archir lür Naturgeschichte. 3. Jahrg. Berlin. 2. Str. 332.

$$
\text { C.. } 47.4 \text {. }
$$

1837. G. Dahlbom, Kort underrältelse on Skandinaviska Insekters allmännare Skada och Nylla. Lund. Str. 149.

Dahlbom mliví zde téz̆ o obyčejné tr̂̀ásněnce«, která způsobuje na obilí bílé skvrny, jež mají za následek, že zmnkia vadnou, a že klasy stávají se hluchými.

\section{48 .}

1838-1840. I. (). Westwood. Introduction to the modern classification of Insects. London.

J. O. Westwood. výborný entomolog a inspector sbirek prírodovědeckých v Oxfordu. klade trásnènkỵ v tomto svém dile jakožto prechodní ràd (Ordo Thysanoptera) mezi Orthoptera a Nemroptera a rozdèluje je dle Halida ỵe. - Mlluvě o biologii jejich (II), trrdí, že živí se pletivem l'ostlinným a uvádí četné připady jejich škodlivosti. Tak rypočiláví zvlášlĕ škody jimi zpủsobené na obili. melounech (jakịsi Thrips ochracea), olivách a na rostlinách ve sklenicich. V posledním pìípadè jest škûdcem Heliothrips adonidum Halid. (= H. haemorhoirlalis). Osborn však (Č. 163.) domnívá se, že škůdcem oním byl snad Heliothrips (=- Parthenothrips) dracaenae Heeg.

$$
\text { C. } 49 \text {. }
$$

1839. L. Dufour, Description et figure d'une nouvelle espèce de Thrips. Annales des Sciences Naturelles. 2. Sér. Zoologie. Tom. 11. Str. 320.-324.

Lékař Léon Dufour popisuje nový, jak se domnívá, druh tr̉ásnènek, kterỵ jest bezkríidlỵ a vỵznamenává se trnem na konci predních tibií a chodidly priedních noh, pozoistávajícimi prý jen \% měchýriku. Dále vyobrazuje larvu a nỵmfu této třásnènky (Tab. 8., obr. 8.) a praví, že nalęa na nỵmfẽ pochry kríidel. ač dospělỵ hmyz jest bezkridlỵ. Popsaný druh. 


\section{J. UZEL. NONOGRAFIE RADU, "THISANOPTERA“.}

klerý Dufour nazývá Thrips aptera, jest nëjaký Phloeothrips (Halida y [Ċ. 61.] trón, že to jest jeho Plll. pini), a pochvy kr̂ídelné u nỵmf vṿsětlí se snadno, kidy̌z uvážíme, že dospèlý hmyz u zástupců rodu Phloeothrips mivá kromě bezkřídlé formy, kterou Dufour toliko vidèl, též formu okřídlenou, od níž jen nỵmfy nalezl.

\section{C.. 50.}

*1839. H. Burmeister, Genera Insectorum. Iconibus illustravil et descripsit H. Burm. Berolini. 1838.

V této stkvostné práci, v níž mnoho hmyzů překrásně jest vymalováno, podává nám Burmeister obrázky tří třásněnek, výborně provedené a kolorované; také připojuje mnohé podrobné výkresy jednotlivỵch částí jejich. Tr̉ásněnky ty jsou: Heliotlırips haemor roidalis Bouché, Thrips longipennis Burm. (=Chirothrips manicata) a Phloeothrips coriacea (= Acanthothrips nodicornis). Ke každému druhu vztahuje se článek latin:ky sepsanỵ. Tuto Burmeisterovu knihu nenalézám cilovanou, kromě v kompilaci Amyotovè a Servillově (Č. 54.), v žádné pozdèjší práci o třásněnkách.

Pokud se ústrojủ ústních týče, jest Burmeister prvním, klerý je rỵobrazuje, a to ode všech trí vỵmalovaných druhů; od druhu Ileliothrips haemorrhoidalis na Tabuli »Heliothrips«, obr. 2., 4. a 5., a na Tabuli »Phloeothrips«, obr. 10._-14.; od druhu Thrips longipennis na Tabuli »Thrips", obr. 2.-7.; od druhu „Phloeothrips coriacea" (= Acanthothr. nodicornis) na Tabuli »Phloeothrips", obr. 3.-5. O studiích Bu rmeisterových v ohledu tom promluveno na příslušném místě v Ćásti analomické.- Kladélko vyobrazuje Burmeister od druhu Heliothrips haemorrhoidalis (Tabule »Heliothrips«, obr. 6. a 7.) a od druhu „Thrips longipenmis“ (Tabule »Thrips«, obr. 9.). Praví, že jím samičky nařezávaji listy rostlin, a že kladou do těchto skulin svá vajička. Bližši zprávy o kladélku, jak Burmeister si ho prodstavoval, viz v Části anatomické. Tarsus shledává u rodu Meliothrips jednočlenným (Tabule »Heliothrips«, obr. 3.), u rodu Thrips tríčlenným (Tabule »Thrips", obr. 8. a 13.) a u rodu Phloeothrips (s. l.) droučlennỵ́m (Tabule »Phloeothrips«, obr. 6. a 7.). Měchỵrek, na konci tarsu se nalézající. má také Burmeister za príssavku. - O tykadlech praví, že u rodů Heliothrips (Tabule »Heliothrips«, obr. 8.) a Thrips jsou osmičlenná, u rodu Phloeothrips (Tabule »Phloeothrips«, obr. 2.) devítičlenná. - Od rodu Heliothrips popisuje larvu. nỵmfu (t. j. pronỵmfu) a pupu (t. j. nymfu) a tvrdí neprávem, že »pupa « prijímá potravu. Larvu a nymfu od druhu Heliothrips haemorrhoidalis kresli na Tabuli »Thrips", obr. 10. a 12. - Od rodu Phloeothrips první vyobrazuje krídlo (Tabule »Phloeothrips", obraz 15.).

\section{Č. 51.}

*1840. Rylí̂́ J. W. Z etter st ed t, Insecta lapponica descripta. Lipsiae. Str. 312. a 313. Professor zoologie a botaniky rytír Joh. Wilh. Zetterstedt nezná ještě studií Halida yových a Burmeisterových, takže čteme ještě v jeho krátkém všeobecném 


\section{H. UZEL, MONOGRAPHIE DER ORDNUNG THYSANOPTERA.}

popisu trásnènek: Rozdíl pohlaví jest neznám. "Zetterstedt uvádí z lesního a subalyinního pásma Laponska tr̃i druhy trásněnek, totiž Thrips physapus L. (?), Thrips Fungi (atra, hemelytris glaucis immaculatis, antennis pallidis fusco-annulatis, tarsis tibiisque testaceis, his medio nigris, ... capite subquadrato, ... stylo anali elongato) a Thrips picipes (nigra, nitida; hemelytris subulatis fuscis, basi albidis, pedibus rufopiccis, tarsis pallidis, ... minutissima, antennis basi pallidis. O dvou posledních má za to, że jsou nové. Thrips Fungi, kiterou Zelterstedt nalézá zároveň s jejími červenými larvami v polyporech, na břizách rostoucích, jest najisto Plloeothrips, a bezpochyby Phloeothrips pini. Thrips picipes. ve květech nalezená, jest nedostatečně popsána, takže nelze ji opèt poznati.

\section{Č. 5.2.}

*1840. W. F. Erichson podává referat o práci Dufourovẽ (Č. 49.) a upo-

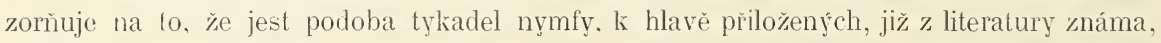
že však velmi zajímava jest prítomnost pochev křídelních u druhu, jehož dospělé zvire stopy po kř́dlech nemá. Archiv für Naturgeschichte. 6. Jahrg. Berlin. 2. Str. 324.

\section{(̇. 53.}

1842. F. Tamburin. Némoire sur le Thrips olivarius (Thrips de l'olivier), et sur les movens de prévenir les ravages de cet Insecte. Draguignan.

V této práci o pèti stránkách mluví F. Tamburin o třásněnce, škodicí olivám. a o prostředcich. jak předejíti lze jejímu pustošení.

\section{C.. 54.}

*1843. B. Amyot et Audinet Serville, Histoire naturelle des Insectes Hémiptères. Paris. Str. 9. a Appendice, str. 637.-646.

B. Amyot, advokát soudního dvora královského v Pařiži, a pařižský entomolog A u dinet de Serville prìdávají stat’ o trásněnkách jakožto dodatek k svému prírodopisu hmyzu polokřidlého. Jak ze slov jejich na str. 9. jest patrno, pochỵbují o tom, že náležejí tr̀ásněnky mezi hmyz polokřídlý, a za hlavní prričinu toho uvádějí, že třásněnky mají makadla. Proto také jen dodatečně o nich mluví. - V této práci nenalézáme žádného nového fakta. Autoři sami žádné třásněnky ani neohledali. I jest sebráno vše pouze z literatury, a to hlavnè z práce Halid a yovy (ૅ̌. 43.) a obou prací Burmeisterových

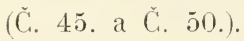

V úvodu podávaji několik nejvšeobecnějších literarních poznámek a věnují nezcela jeden list popisu těla jejich i zpúsobu života. V systematické části prĭijali rozdèlení Halidayovo a jen v tom změnu zavedli, že některým skupinám druhủ dali nová jména rodová. Pokud se tubulifer týče, dèlí Halidayủv rod Phloeothrips na rod Iloplothrips (sem radí druhỵ aculeata Fabr., corticis Deg. [= Acanthothrips nodicornis], flavipes Halid. [= Trichothrips pedicularia] a statices), na rod Haplothrips (k nèmu kladou Burmeisterủv druh albipennis $[=$ Anthothrips aculeata $]$ ) a na 


\section{J. UZEL. MONOGRAFIE RADU, "THYSANOPTERA“.}

rod Phloeothrips s. str. (sem čítají druhy: coriacea Halid. a anmulicornis Halid.) Halidayơ druh Phloeothrips pedicularia, jenż jednoduchỵch oček ani křidel nemá, pokládají naši autoři ve sbodě s Burmeislerem za larvu; prarí však, že v prípadě, že by se mýlili, bỵl by zmínèný druh zástupcem čtvrtého rodu tubulifer. Rozdèlení to jest patınè pochybené (viz též prìslušné mislo v Části systematické). Terebrantia dèli na Stenoptera (Burmeisterem opravené jméno Halida yovo: Stenelytra) a na Coleoptrata Halid. Stenoptera rozděluji na následující rody: Heliothrips, Sericothrips, Chirothrips, Limothrips, Odontothrips, Physapus, Thrips, Taeniothrips, Tmetothrips, Belothrips. Halidayovy rody Heliothrips a Sericothrips zachovali totiž i s druhy jejich. Podrod Haliday ưv Chirothrips povyšují na rod a čítají k němu Aruhỵ manicata Halid. a Burmeisterùv druh lomgipemis (= manicata). Podrod Halidayủv Limothrips povýšují taktéž na rod a počítají sem druhy denticormis Halid. a physapus Kirby (= cerealium). Hali da y ův podrod Thrips rozdělují v rody Odontothrips*). Physapus, Thrips, Taeniothrips*) a Tmetothrips*), které maji tyto společné znaky: obě pohlaví jsou okřidlená, není žádnỵch zvláštních šlètin na posledním článku abdominalním. Rod Odontothrips (zosós = zub) má tylo znaky: prední tibie a tarsy ozbrojeny jsou uvnitř širokým zubem. Sem čítaji druhy ulicis Halid. a phalerotu Halid. Rod Plıysapus (tim k platnosli privádějí jméno již Degeerem zavedené): přední tibie a tarsy neozbrojeny. Stylus tykadel zřetelně droučlenný. Sem kiladou druhy: obscurus Müll. (= Amaphothrips virgo), ulmifoliorum Halid., otratus Halid., ater Deg. (= vulgatissima) a cynorrhorli Halid. Rod Thrips má tyto znaky: přední tarsy neozbrojeny. Stylus tykadel velmi krátký, články jeho stěži rozeznatelné. Sem radi druhy: grossularice Halid., physapus L., fuscipemis Halid., ericae Halid., urticae Fabr., corymbiferarmm Halid., mimutissima L.. discolor Halid., livida Halid. Rod Taeniothrips

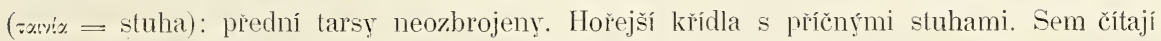

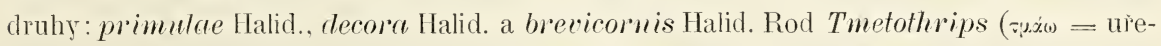
závám. t. j. kř́idla): přední tarsy neozbrojené, oba páry křidel kratší než pterothorax. Sem kladou druhy: subaptera Halid. a pallens Halid. Halida yùv rod Belothrips i s druhem arumincatı Halid. autoři zachovali. Podrod Halida y ův Aptinothrips rovněž jako Burmeister považují za larvy. Druhou čeled lerebrantií, Coleoptrata totiž, děli naši autoři na rody Melanothrips, Coleothrips a Aeolothrips. Halidaỷu rod Melanothrips zachovali i s druhem jeho obesa Halid. Podrod Haliday ův Coleothrips porýšili na rod a čítají sem druhy: fasciata L. a vittata. Halid. Takléž porýšili Halida vִ ůr podrod Aeolothips na rod a kladou sem Halidayủ druh albocincta.

\section{55.}

V té době tušim napsal Gurtis v časopise Journal of the Royal Agricullural Socieț̣, Vol. VI. (str. 499.), článek o třásněnkảch, škodících žitu (Thrips cerealium),

*) Rody ty zakládaji se na znacich nepodstatných. 


\section{H. UZEL, MONOGRAPHIE DER ORDNUNG THYSANOPTERA.}

bramborủm (T. mimutissima), melounủm ( $T$. ochracea) a jiným hospodáŕským rostlinám. Autor podává zde léž obširný prírodopis druhu T. cerealium.

$$
\text { Cั. } 56 \text {. }
$$

1847. v. Bülow-Rieth upozornil v časopise »Stettiner Entomologische Zeitung «, str. 377., na škody, které jistý druh třásněnek na obili nadèlal, a sice jak na zimnim, tak na letním. Poškozeni jevilo se tím, že prostředek klasu stal se hluchým. Jakým způsobem však zmínèné trìsnènky škodu tu dèlají, nemohl autor pro nedostatek prostředkủ pozorovacích se dovědèti.

$$
\text { C. } 57 .
$$

1847. C. A. Dohrn, Thrips ein Kornschädiger oder nicht? Stettiner Entomologische Zeitung. 8. Jahrg.

C. A. Dohrn pojednává zde na str. 377.-381. o otázce, zdali trásněnky jsou žilu škodlivy čili nic.

\section{Cั. 58.}

*1849. Dr. H. Schaum podává referat o práci v. Bülow-Riethově (Č. 56.). Archiv lür Naturgeschichte. 15. Jahrg. Berlin. 2. Str. 315.

$$
\text { C.. } 59 .
$$

*1851. E. Blanchard, Tisanopteros. Historia fisica y politica de Chile segun documentos adquiridos en esta republica durante doce años de residencia en ella y publicada bajo los auspicios del supremo gobierno por Claudio Gay, ciudano chileno etc. Zoologia Tomo sesto. Paris. Chile. Str. 143. - 152.

Emile Blanchard, professor na Musée d'histoire naturelle v Pařiži, napsal ve španèlské reeci článek o trásněnkách v Ga yo vě dile pro výzkum jihoamerické republiky Chili. - Ve všeobecném úvodu popisuje tělo tr̉ảsněnek (tanou mu však vždy jen na mysli Tubulifera), promlouvá o larvách a nỵmfách, o jejich zpủsobu žití a o jejich systematickém postavení. To vše sestavuje jen z literatury a v celku nepřidává nic nového. Mezi jiným praví, že jest pamětihodný̧m faktem, že každý (?) druh volí za svou polravu určitou rostlinu nebo aspoň rostliny príbuzné. Třásněnek, obilí $\mathrm{v}$ Chili škodících, nezná, avšak mysli, že se rozšírí po všech zemích, kde se obilí pěstuje, a tak, že zavlečeny budou svého času také do Chili. - Také Blanchard považuje tr̃ásněnky za řád, který dobře rozeznávia se jak od Hemipter, tak od Orthopter, a dẽlí je dle Halidaye na dvě skupiny, kleré nazývá španělsky Phloeothrípides (píše však Pleotprides! = Tubulifera Halid.) a Thripides (= Terebrantia Halid.).

Po všeobecnè části popisuje Blan chard sedm nových, náhodou sebraných druhủ, náležejícich vesměs $\mathrm{k}$ terebrantiim. Ke králké latinské diagnose jednotlivỹch druhủ přidává delší španělský popis. Tyto druhy jsou: 1. Thrips striaticeps, 2. Thrips rugicollis, 3. Thrips femoralis, 4. Thrips annulicomis, 5. Thrips tibialis, 6. Thrips 


\section{J. UZEL, MONOGRAFIE RADU "THYSANOPTERA“.}

laevicollis, 7. Aeolothrips fasciatipenuis. Od prvého druhu (T. striaticeps) prìipojuje Blanchard výkres celého těla, pak tykadlo a přední nohu značnèji zvětšené (Átlas zoológico, Entomologia, Nevropteros, lám. 2., fig. 12. $a, b, c)$.

\section{C.. 60 .}

V léto době tuším napsal Dr. Harris (Treatise, str. 205̃.) zprávu o larvě nějaké tr̆ảsněnky, jež žije na pšenici; sondí o ní, že to jest larva druhu Thrips cerealium. Má prý barvu pomerančovou. Fitch (Č. 69.. str. 306.) domnivá se, že je to snad jeho Thrips tritici.

\section{C.. 61 .}

*1852. A. H. Haliday, Fr. Walker: List of the specimens of Homopterous insects in the collection of the British Museum. Part IV. London. Order III. Physapoda.

Fr. Walker prídává k své práci o homopterech, v sbírkách britického musea se nalézajících, též pozdèjšílukopisy a výkresy Ha lid a y o v y tr̉ásněnek se týkající. Vzhledem k prvé práci Halidayově (Č. 43.) lecos je zde zmèněno. K četnỵ́m druhủm připojena úplnèjší diagnosa, některé druhy dřicejjši spojeny s jinými v jeden, a některým skupinám druhů dána zoláśtní jména. Také několik nových druhủ je zde popsáno.

$\mathrm{V}$ krátkém úvodu jedná Haliday velmi stručně o všeobecných vlastnostech tr̃ásněnek a pr̃idává popis některých ústrojủ vnitřních, což zde poprvé v literatuře shledáváme. Udaje anatomické jsou však misty poněkud nejisté. Podáme zde dotyčné vỵ́zkumy Halida y o y y. Nervová soustava skládá se ze čtyr̃ směstnaných zauzlin a z provazce břišního, snad jednoduchého. Slinné žlázy jsou miškovitého tvaru; nalézáme jich dva páry, z nichž každý má jinou podobu. Jejich vývody jsou nitkovité. Zažívací roura jest o polovici delší než tělo, v oklikách složena; žaludek blánitý nemá slepých výběžkủ; tenké střevo jest velmi krátké; mnalpighické žlázy, počtem čtyrì. jsou v přeslenu jedním koncem k střevu narostlé. Varlata skládají se z jediné miškovité schránky (na každé straně). Vaječníky jsou prstovitẽ rozložené a maji (na každé straně) čtyrì vaječné rourky o četných vaječných komủrkách. Vzdušnice jsou tu jen rourovité (vzdušných vakủ totiž není). V popisu tubulifer čteme pak zvláště (vybral jsem jen nové a pamětihodné): Nakadla labialní skládají se ze šesti (?) článkỉ. Kusadla prvého páru jsou zpèt zakịivená a daleko vymrštitelná. Zažívací roura jest skoro o polovinu delší těla; žaludek jest tvaru hruškovitého a od jícnu hlubokou rýhou oddělený; tlusté střevo menší svěllostí od něho se rozeznává, a tenké střevo jest sotva delši svého prumměru. Sádlo v těle jest krvavě červenými, v klubíčka shluklými zrnky smišeno. Nalpighické žlázy jsou tmavě žlutočervené. Samec má dva páry príidavných žláz. Vajičko jest tvaru skoro válcovitého, neprohnuté. Larva má 7 článkủ v tykadle; její maxilly jsou rovnoběžné, její mandibule předlouhé. »Propupa má tykadla rozložená, tupá. »Pupa má tykadla k stranám hlavy zpět přiložená a prirostlá. - V popisu terebrantií čteme ještě: Terebra jest skryta v rýze článku před- 
H. UZEL. MONOGRAPHIE DER ORDNUNG THYSANOPTERA.

poslednílı a posledniho. Kíidla lıorejši opatrena jsou žilkou okružni a dvěma rovnoběžnými, blízko base pak kirátkou žilkou šikmou. Kusadla prvého páru jsou sotva delší než labium. Tỵkadla jsou »vlastně « devítičlenná, avšak různého tvaru.

K tubuliferum přidán jest nový rod, totiž Idolothrips, jenž má tř̀ druhy (marginata, spectrum a lacertina) žijicí v Australii. - Rod Phloeothrips dělí Haliday na tři skupiny. Do první skupiny (Apterce) náleźeji druhy, jimž křídla i očka scházejí. Sem číá svủj druh Pllloeothrips tristis. Do druhé skupiny (Ileteropterae) palři druhy, jež jednoduchỵch oček a kríídel nèkdy nemaji. jindy však je mají. Sem radí druhy pedicularia Halid. (= dle něho flavipes Halid.), ulmi Fabr. a pini (= dle nèho aptera Duf.) Do lr̉etí skupiny (Macropterae) náležejí druhy, jejichž obě pohlaví vždy mají křídla. Sem čítá druh Statices, svủj nový druh subtilissima a Burmeislerův druh albipemis (= dle nèho aculeata Fabr.). Koneěnè uvádi zde ješlě dva druhy: coriacea a anuulicornis, vyslovuje však domněnku, že náležeji do skupiny Heteropterae. - Rozdèlení to jest nevhodné, jak jsem ukízal v Ċásti systematické.

Terebrantia rozděluje Halidạ právě tak jako v práci své z r. 1836. K popisu podrodu Aptinothrips přidává Walker Halidayovo ohrazení proti Burmeisterori. poněradż tento pokládal záslupce rodu Aptinothrips za larvy. Zní asi takło: Mủj králký popis druhu Aptinothrips rufa zavdal Burmeisterovi príčinu k ukvapenému tvrzení, že to jest najisto larva, a sice prolo, že konec tykadla jest nečlánkoraný. Druh mûj jest ršak dokonale rỵvinutým hmyzem, nebot má složené oči, hladkou, korovitou pokožku, meso- a metathorax spojené $\mathrm{v}$ pterothorax, prední rohy mesothoraxu vyěnívající a mimo to dokonalým kladélliem jest opalren. K větší jistolě vypěstoval jsem ho z larvy, klerou jsem nakreslil rovnèz̆ jako propupu a pupu. Dlouho hledal jsem samce, avšak nadarmo; konečně $r$ době senoseče nalezl jsem ho. avšak velice pořídku, takže prípadal jeden na několik set samic. Co se týče mého druhu Plloeothrips pedicularia, praví Haliday dále. př̀znal mu Burmeister oprárněnost, A myot a Serville však neprávem jej za larvu prohlašuji." - Rod svůj Thrips rozdèluje zde na sedm »Sectiones«. Jsou to: Sect. 1. Gymnopterce (Prothorax omnino glaber: antennae apicula 3-articulata; hemelytra venis glabris). Sect. II. Eudactyli (Alae evolulae; tibiae anticae apice interno denticulis 2. Antennae apicula 2-articulata). Sect. III. Homopterae (Alae evolutae in mare et fem.; tibiae mulicae). O télo sekci praví, že pro množství druhủ. kleré obsahuje, bude treba ji dále rozděliti. Sect. IV. Neogami (Alae evolutae. maribus rudimenta; antennae apicula quasi exarticulata). Sect. V. Ieterogynae (Nares apteri, ocellis nullis; feminae alatae, antennae apicula biarticulata. Vasa hepalica infescentia. quod in hac familia fere singulare). Sect. VI. Micropterce (Alarum tantum rudimenta thorace breviora, fem.: abdomen subdepresum subtilissime verticillatum; ocelli nulli). Sect. VIl. Brachyderi (Alae plane nullae; thorax brevissimus; abdomen convexum verticilato-ciliatum; ocelli nulli, fem.). - Do Sect. Г. čílá druh obscura Müll. (= Anaphothrips virgo). Do Sect. II. Ǐadí druh Ulicis Halid.. phaterata Halid. a noṛ̣ druh Loti. K Secı. III. počitá druḥ̣ Primulae Halid., 


\section{J. UZEL, MONOGRAFIE RADU „THYSANOPTERA“.}

decora Halid., atrata Halid., vulgatissima Halid., cynorrhodi Halid., grossulariae Halid., ulmifoliorum Halid., physapus L., fuscipennis Halid., discolor Halid., corymbiferarum Halid.. mimutissima L., urticae Fabr. a nový druh aspera. Sect. IV. obsahuje druh dispar Halid. (= dle Halidaye brevipermis Halid.). Sect. V. obsahuje druh evicae Halid. Sect. VI. pozủstává z druhů subaptera Halid. a pallens Halid. Konečně tvoři Sect. VII. nový druh tunicata. - Coleoptrala obsahuji podobně jako v práci z r. 1836. rod Melanthrips s druhem obesa Halid. a rod Aeolothrips s podrody Coleothrips a Aeolothrips. Podrod Coleothrips má druhy fasciata L., vittata Halid. a nový melaleuca. Podrod Aeolothrips obsahuje druh albicincta Halid.

K této práci přidány jsou čtyři tabule Halidayem kreslené (Tab. V., Vl., VII. a VIII.), na kterỵch ěástečně poprvé znázomèna jest anatomie třásněnek a kresleny s velikou pilí mnohá sładia vývoje i dospělé lřásnènky a ruzné ěásti jejich. Jednotlivá vyobrazení, kterých je přes 170, jsou malá a nĕkdy nedosti jasná; poukázali jsme k nim na príslušných mistech. K tabulím připojena jsou vysvěllení**)

$$
\text { Cั. } 62 .
$$

*1852. E. Heeger, Beiträge zur Naturgeschichte der Physopoden (Blasenfüsse). Sitzungsberichte der math.-naturw. Classe der kais. Akademie der Wissenschaften. Wien. VIII. Bd. Juni. Str. 123.-144.

Tuto práci počíná Ernst Heeger hned popisem druhủ, nepřipojiv všeobecného popisu třásněnek. Uvádí zde druhy následující: Phloeothrips aculeata Fabr. (Tab. XIV.), „Pll. Ulmi Fabr." (Tab. XV.; = Phl. coriacea), „Pll. flavipes Halid.“ (Tab. XVI.; = Authothrips statices), Phl. statices Halid. (Tab. XVII.), Thrips Ulicis Halid. (Tab. XVIII.). T. phalerata Halid. (Tab. XIX.), Melanothrips obesa Halid. (Tab. XX.), Aeolothrips fasciata L. (Tab. XXI.), „Aeol. vittata Halid." (Tab. XXII.; = Aeol. fasciata) a nový brasilský druh Thrips (= Idolothrips) Schottii (Tab. XXIII.). - Ke každému z těchto druhủ (nový druh Schottii vyjímaje) prìdává krátký latinský popis, z Burme isterovy práce (Č. 45.) vyjmutý, a dlouhý německý (též u Schottii), který má mnoho zbytečného, lecos dủležitého však neobsahuje. - Obrazy jednotlivých druhủ jsou velmi veliké, avšak rovněž jako popisy nepresné.

\section{Č. 63.}

*1852. E. Heeger, Beiträge zur Insecten-Fauna Österreichs. V. Sitzungsberichte der math.-naturw. Classe der kais. Akademie der Wissenschaften. Wien. IX. Bd. October. Str. 473. a další.

Zde popisuje Heeger na prvém místè druh Heliothrips haemorhoidalis Bouché (Tab. XVII.). Nalézá ho ve sklenících botanické zahrady schönbrunnské u Vídně,

*) Podotýkáme tuto okolnost zvláštè, poněvadž Jordan (C̆. 162.) výslovnè praví, že takových vysvětleni neni, čimž by ovšem cena tabulí valně utrpěla.

$$
-427-
$$


kdež zaviňuje radnutí mladých výhonkủ dvou druhư rostlin. Oplozená samička klade svá vajička obyčejnẽ jednotlivẽ na spodní stranu střední žilky listủ(?). Z těch po $8-10$ dnech se vylihnne mladá larva, která svléknuvši třikráte svou pokožku, promèñuje se v nỵmfu a konečně v dokonalý hmyz. Pak popisuje larvu a nymfu a velmi obšímě imago. Rod Plloeothrips dèlí ve shodè s Burmeisterem (Č. 45.) na druhy bez očck a bez křídel (jě̆ tu nazývá Aptera) a na druhy s očky a kǐ́idly (Elyoptera Heeg.). Z prvé skupiny popisuje zde velmi obšírnè dva nové druhỵ: Phl. (= Cryptothrips) bicolor (Tab. XVIII.) a Plıl. (= Megalothrips) lativentris (Tab. XlX.). Z druhé skupinỵ podává popis larvy a nymfy druhu „Phl. Ulmi“ (= Plil. coriacea), jež zobrazuje na Tab. XX. Panèthodno jest tvrzení Heegerovo, že vajičko tohoto druhu jest červené. larry že mají sporé a na konci kuličkou opatrené chlupy na tèle, a že nỵmfy jsou nehybné a potravy neprijímají. Skoro po celý rok nalézáme u tohoto druhu všecka stadia vývoje. Živí se vlhkými hnijícími hmotami. pod korou stromovou se nalézajicimi, a páří se tak, že samec bỵvá nošen samicí, a oba tuby, že při tom k sobě prilíhají. Lítá jen za teplých tichých nocí, a to jen na krátko. Dále popisuje Heeger nový druh Thrips Kollari (Tab. XXI.; = Limothrips denticormis). jenž vyskytuje se pořídku na rostlinạ́ch ve skleníku schönbrunnském, a o nèmž praví. že jeho samička klade vajičcka na spodní stranu listů vedle žilek. Kónečně nalézáme zde popis druhu Thrips (= Physopus) mulgatissima (Tab. XXII.), jenž ryskỵtuje se se svými larvami a nỵmami v mnohỵch druzích krètin, avšak prý jen jednotlivě. - Obrazy Heegerovy jsou také zde relmi veliké a rovněž nesprávné.

Této práce Heegerovy existuje také exemplár (bezpochỵby jediný) s obrazy tr̃ásněnek J. Tulipanem kolorovanými.

\section{Ċ. 64 .}

*1853. H. Schaum podává referat o prvé práci Heegerovè (Č. 62.). Archir für Naturgeschichle. 19. Jahrg. Berlin. 2. Str. 285.

\section{6 5.}

1853. Westwood mluví v časopise Proceedings of the Entomological Society na str. 78. o práci Halidayově (Č. 43.) a nazývá ji »admirable« (obdivuhodnou).

\section{Č. 66 .}

*1854. E. Heeger, Beiträge zur Naturgeschichte der Insecten Österreichs. Vierzehnte Fortsetzung. Sitzungsberichte der math.-naturw. Classe der kais. Akademie der Wissenschatten. Wien. XIV. Bd. December. Str. 365. a další.

Heeger popisuje $\mathbf{v}$ tomto článku dva nové druhy třảsněnek. totiž Heliothrips (=- Parthenothrips) Dracaencue a Thrips Sambuci. Onen druh nalézá se ve velikém množstrí na dracénách ve vídeňskỵch sklenících. Samičky, klerýchž je vždy více než 


\section{J. UZEL. MONOGRAFIE RADU, "THYSANOPTERA“.}

samcủ, nařezávaji kladélkem svým povrch listú a do vzniklé skuliny položi svá vajička. Pak podává popis a velmi nepresné obrazy larvy, nymfy a dospělého hmy̧zu, jehož kladélko taktéž kreslí. - Druhý popisovaný druh jest Thrips Sambuci. Jméno T. Sambuci nalézá prỵ v katalogu Slephensovè (Č. 39.), kdež uvedeno jest bez popisu druhu, na nèjž se vztahuje. V zimě žije tento druh pod korou rostlin. na nichž se v lélě zdržuje (bez, boby, rủže atd.) a pod spadaným listím jejich. Vajička klade samička na silnější žilky listové(?). Nymfy neprịimaji potravy a pohỵbuji se jen, když byly znepokojovány. Pak popisuje obšírně tyto nỵmy a též larvu i dokonalỵ hmyz a kreslí je velmi zvětšeně zároveň s jedním listem bezovým, jimi poškozeným.

\section{C.. 67 .}

1855. B r e m i, Über die schwarze Fliege (Thrips haemorrhoidalis). Stettiner Entomologische Zeitung. 16. Jahrg. Str. 313.-315.

Bremi mluví o škůdcích zahradních rostlin z třídy hmyzú, o zavlečování jich novými rostlinami, o prostředcích, kterými je ničiti lze, a uvádi mezi jiným také druh Thrips (- Heliothrips) haemorrhoidalis. Tato stat o hmyzu jest otištěna v práci téhož autora: »Die Gartenflora Deutschlands und der Schweiz«.

\section{Č. 68 .}

*1855. E. Newman, Characters of Two undescribed Species of Thrips. Transact. of the Entomolog. Soc. of London. New Series. Vol. III. London. 1854-1856. Str. $264 .-267$.

Autor popisuje zde dva nové druhy tubulifer, zaslané majorem Hamiltonem z Východní Indie, kdež je tento nalezh u Mysore na jistém druhu Anacardia. Jsou to Idolothrips Halidayi a Phloeothrips Anacardii. Také uvádí v práci té poznámku Halidayovu, tỵkající se zeměpisného rozšiření rodu Idolothrips (vzhledem k tomu viz přislušné místo v Části biologické). Námítky New manovy, proti samostatnosti rodu Idolothrips tu pronesené, jsou neoprávněny.

\section{Cั. 68. A.}

1855. H. Nördlinger, Die kleinen Feinde der Landwirthschaft. Stuttgart.

Nördlinger mluví v této knize též o třásněnkách a praví mezi jiným, že Thrips mimutissima byl pozorován $\mathrm{v}$ množství na nemocných listech bramborových. Také zmiňuje se o nemocném keři šeříkovém, jenž napaden byl zcela malou třásněnkou.

\section{Č. 69 .}

*1856. A. Fitch, I. Report on the noxious, beneficial and other insects of the state of New-York. Str. 102.-104. a 304.-309.

V této knize věnuje Med. Dr. As a Fitch, entomolog zemědělské společnosti státu New-Yorského. dva články, $v$ nich\%̆ popisuje tr̆i nové škodlivé třásněnky. První 


\section{H. UZEL, MONOGRAPHIE DER ORDNUNG THYSANOPTERA.}

jest Plloeothrips Mali, která prý bezpochyby způsobuje opadávání nezralých jablek, nažirajíc je. Touto třásněnkou nažrané jablko nalézá se na str. 103. vyobrazeno. Druhou třásněnku, která škodí na pšenici v severoamerických státech New-Yorku a Wisconsinu (zde dle Williamse též na jeteli), nazval Thrips Tritici. Na str. 308. kreslí obraz zvírete celého a některých jeho částí silněji zvětšeny̧ch. Zviŕe celé $(c)$ jest jistẽ nějaký zástupce tubulifer, jemuž též kîídlo (e) náleží tykadlo $(f)$ však svẽděí o tom, že Fitch spletl ve svém druhu Thrips Tritici druhy dva, z nichž každý jest záslupcem jiného podřádu třásněnek. Vajička pak $(a)$, na stopkách upevněná, která Fitch za vajička jeho má, nenáležejí třásněnkám vủbec. - Konečnè uvádí ješlě třetí nový druh: Coleothrips trifasciata, na pšenici velmi hojný a kromè toho tėž na Tanacetum vulgare nalezený, jenž jest velmi nedostatečně popsán. Jakožto zvláštní znak uveden jest nedostatek třásní na křídlech (bezpochyby viděl Fitch jen přední okraj jejich). Také přičných žilek prý nemá (?). Hlava jeho s tykadlem nakresleny jsou na str. 308.

\section{¿̀. 70 .}

(1857). A. Fitch, II. Report on the noxious, benefical and other insects of the state of New-York. Str. $127^{\circ}$.

Fitch popisuje zde nový druh Phloeothrips caryae, který nalezl na nádorech listových jistého druhu ořechủ, avšak pochybuje o tom, že jest pủvodcem tèch nádorủ.

\section{Č. 71 .}

*1857. K. E. Gerstaecker podává referat o práci Fitchovè (Č. 69.). Archiv für Naturgeschichte, 23. Jahrg. Berlin. 2. Str. 383.

\section{Cั. 72.}

*1858. E. Regel, Ein noch unbeschriebener Thrips, der die Gewächshauspflanzen der St. Petersburger Gärten bewohnt. Bulletin phys.-mathém. de l'Académie imp. des Sciences de St. Pétersbourg. II. Str. 627.-633.

E. Regel popisuje zde nový prý druh: Thrips (= Heliothrips) Dracaenae, který se vyskytuje $\mathrm{v}$ milionech na rosllinách $\mathrm{v}$ teplých sklenících petrohradských a zle tu řádi, zvláště na dracénách. Od tohoto druhu vyobrazuje dospělý hmyz s kirídly složenými a s kǐílly rozloženými, pak jeho larvu (jest to nỵmfa), pak hlavu, kǐídlo a nohy, a to nesprávně a velmi primitivně. Také popisuje velmi stručně zpủsob jeho života a praví, že »zurivě巛 se rozmnožuje. Zmíněná trásněnka jest Heegerův druh, popsaný

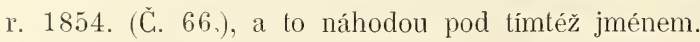

\section{Ċ. 73 .}

*1859. F. Walker, Characters of some apparently undescribed Ceylon Insects. Annals and Magazine of Natural History. London. Third Series. No. 21. XXIII. Str. 224. 
Autor popisuje zde mezi jiným »jak se zdá« (!) novým hmyzem ceylonským také nový druh tr̉ásněnek, jejž nazỵvá Phloeothrips stenomelas.

\section{74 .}

*1860. Kolenati, Einige neue Insecten-Arten vom Altvater. Wiener Entomologische Monatschrift. Wien. IV. Band. Physapoda. Str. 390.

Professor Dr. Kolenati nalézá pod kameny na Pradědu nový prị druh třásnènek, který zde popisuje. Jest to Phloeothrips Malidayi (= Phl. annulicornis).

\section{c. 75 .}

V této době snad píše Osten-Sacken (Dept. N. A., str. 201.), že pozoroval některé nádory, zpủsobené mouchou Lasioptera vitis $\mathrm{O}$. S., jichž dutinỵ bỵly opuštěny původními obyvately, za to však obsazeny četnỵmi třásněnkami.

C. 76 .

$\mathrm{V}$ této době asi také B. D. Walsh napsal $\mathrm{v}$ časopise Proceedings of the Entomological Society of Philadelphia (Vol. I. na str. 310.) zprávu, jakožto přispěvek k svému náhledu, že některé třásněnky jsou masožravými. Zprávu tuto viz na příslušném místě v Části biologické.

\section{Cั. 77.}

O něco pozdẽji podal B. D. W alsh v tomtéż časopise (Vol. III. na str. 611.-612.) zprávu jinou, ve které hledí vysvětliti úkaz, že často nádory much bejlomorek (Cecidomyidae) jsou prázdny. Viz o tom v Cásti biologické.

\section{Č. 78 .}

$\mathrm{V}$ této době snad popsal He er jednu fossilní třásněnku, nalezenou $\mathrm{v}$ třetihorním útvaru u města Aix v jižní Francii.

\section{Č. 78. A.}

1865. C. L. Taschenberg, Naturgeschichte der wirbellosen Thiere, die in Deutschland sowie in den Prov. Preussen und Posen den Feld-, Wiesen- und WaldeCulturpflanzen schädlich werden. Leipzig. Str. 195.-197. Tab. IV., fig. 23.

Taschenberg mluví v této knize o třásněnkách škodících obili v Německu. Dle 'Tryboma (亡̌. 183.) jsou zde spleteny dva druhỵ, totiž Anthothrips aculeata a Limothrips cerealium.

\section{č. 79 .}

1866. B. D. Walsh poznovu vyslovuje $\mathrm{v}$ časopise Practical Entomologist (Vol. I. na str. 21.) svou domněnku, že třásněnky jsou masožravými (»cannibal «), nebot asi žerou škodlivé larvy jiného hmyzu, čímž rolníkovými přátelỵ se stávají. 


\section{H. UZEL, MONOGRAPHIE DER ORDNUNG THYSANOPTERA.}

\section{Č. 80 .}

1866. E. De y rolle, Sur un nouvel appareil servant à détruire les Thrips. Annales de la Société Entomologique de France. 4. Série. T. 6. Bulletin, p. LIV.

E. Deyrolle popisuje nový přístroj, určený $\mathrm{k}$ tomu, by ničil škodlivé třásněnky.

\section{81 .}

1866. M. Girard pridává v témž časopise k článku Deyrollovu (Č. 80.) poznámku.

\section{Ċ. 82 .}

1867. B. D. Walsh, The true Thrips and the Bogus Thrips. Practical Entomologist. Vol. II. Nr. 5. (S dřevoryty). Str. 49.-52.

V této práci hledí Walsh dokázati opèt hmyzožravost trásněnek; pravě, že objevil více než dvacet př́padů, kdy třásněnky živily se larvami hmyzủ, nádory rostlinné způsobujicích, čimž prý je dokázána jejich masožravost. To by bylo prvé skutečné pozorování hmyzožravosti třásněnek, které $\mathrm{W}$ alsh ve svỵch zprávách uveřejñuje, nevidèl-li snad jen třásněnky, živící se štavami nádorủ. Dále poznamenává, že třásněnky snad požírají také larvy malỵch broučkủ (viz o tom též v Části biologické).

\section{Č. 83 .}

1867. F. Löw poznamenává v časopise »Verhandlungen der k. k. Zool.-bot. Gesellschaft. Wien. XVII. Bd. (na str. 747.), že Heliothrips haemorhoidalis byl nalezen na Viburmum timus.

\section{Ċ. 84 .}

*1867. Georg Ritter von Frauenfeld, Über Aleurodes und Thrips, vorzüglich im Warmhause. Verhandlungen der k. k. Zool.-bot. Gesellschaft. Wien. XVII. Bd. Zoologische Miscellen. XIII. Str. 793.-801.

Rytî́ Frauenfeld podává zde zprávu o třásněnkách, způsobujících škody ve vídeňských sklenících. Jest jich prý několik druhủ, z nichž nejčelnèjši jest Heliothrips haemorrhoidalis Bouché a $H$. dracaenae Heeg. Uvádí pak seznam rostlin (Benselerem sestavený), na nichž třásněnky ve sklenících zvláště se zdržují, a dodává, že se zdá, jakoby jednotlivé druhy třásněnek na téže rostlině na vzájem se vylučovaly. Konečně popisuje nový druh Thrips Benseleri, nalezený na kukuřici, v zahradě pod šírým nebem pěstované.

$$
\text { Č. } 85 \text {. }
$$

V léto době snad, praví prof. Dr. C. V. Riley, pojednávaje o nepřátelích mšice révové (Phylloxera) v Sev. Americe (Mo. Repl. VI. Str. 50. a 51.), že nejvíce hubí ji krvavě červená larva nějaké černé trrásněnky s bílými křídly, již popsal pod jménem Thrips phylloxerae, a jež líhne se z vajiček, položených do nádorủ onou mšicí způsobených. 
J. UZEL, MONOGRAFIE RADU, "THYSANOPTERA“.

\section{87 .}

(1869). Ferd. Cohn, Untersuchungen über Insektenschaden auf den schlesischen Getreidefeldern im Sommer 1869. Eine ernste Iahnung an unsere Landwirthe.

Spisovatel mluví zde. kromé o jiných na obilí škodlivých druzich hmyzú, také o trảsnènce Thrips cerealium.

$$
\text { C. } 88 \text {. }
$$

V této asi době popsal S. H. Scudder v časopisech »Proc. Bost. Soc. Nat. Hist., VI (str. 117.) a »Geological Magazine, $\mathrm{V}$ (str. 221.) fossilní třásněnku Palaeothrips fossilis ze severoamerických tretihor, kterou pozdèji vyobrazuje v Zittelovè knize: Handbuch für Palaeontologie, I. Abth., 2. Bd. (str. 784., obr. 999.).

\section{č. 89 .}

1869-70. T. J. Bold, Great abundance of Thrips. The Entomologist's Monthly Magazine. London. Vol. 6.

Zde mluví Bold na str. 171. o třásněnkách, ve velikém množství se vyskytnuvších.

$$
\text { Cั. } 90 .
$$

1870. A. S. Packard, New and Injurious Ins. Little Known.

Dr. A. S. Packard píše zde o jistém druhu třásněnek škodícím cibuli.

\section{č. 91.}

1870. K. Lindeman zmiňuje se o škodlivé činnosti třásněnek na obilí v okolí Moskvy.

$$
\text { Cั. } 92 .
$$

1870. C. Cornelius, Massenhaftes Auftreten eines Insekts aus der Zunft der Blasenfüsse. Stettiner Entomologische Zeitung. 31. Jahrg.

Spisovatel vypravuje zde na str. 325 . a 326 , že třásněnky na podzim $\mathrm{v}$ zástupech stèhují se do domủ a hledají tu pod čalouny, obrazy, ve skulinách a podobně úkryt před zimou. V krajinách na dolním Rỵ́ně a v hrabstvi Mark jest toto stèhování třásněnek. pro člověka prý nemilé, známỵm úkazem. Stěhovavý ten druh jest snad Thrips longipennis Burm. (= Chirothrips manicata).

\section{93 .}

V této době tuším popsal Menge trì druhy třásněnek z pruského jantaru.

\section{Cั. 94 :}

1871. A. Müller, Thrips destructive to green peas. Transactions of the Entomological Society. London. Proc., str. XL.

Albert Müller mluví zde o truásnènkách škodlivỹch nezralému hráchu. 


\section{Č. 95 .}

1871. J. G. de Man, Thrips fasciata Hal. nieuw voor de islandsche fauna. Tijdschr. v. Entomol. XIV. Jaarg. (2. Ser. 6. D.).

Spisovatel podává na str. 147. zprávu o nové třásněnce pro faunu islandskou: Thrips (= Aeolothrips) fasciata Halid.

\section{Č. 96.}

*1872. T. Beling, Ein dem Gefreide schädliches Insekt. Verhandlungen der k. k. Zool.-bot. Gesellschaft. Wien. XXII. Bd. Str. 651.-654.

Theodor Beling popisuje velmi obšíně nový prý druh Thrips frumentarius (=Authothrips aculeata Fabr.) a oznamuje škodỵ, které způsobil r. 1872. v okolí Seesena na Harzu, a to zvláště na žitě a pšenici, méně na ječmeni. Kromě této třásněnky nalezl ještě na obilí druh Thrips (= Limothrips) denticornis. Thrips cerealium tam se nevyskytuje. - Bližší zprávy o tom viz v Části oekonomické.

$$
\text { C.. 96. A. }
$$

1872. A. S. Packard píše (Second Ann. Rept. Insects Mass., p. 5.-8.) o jisté tìásnènce, kiterou nazývá Limothrips tritici (dle Perganda jest to Thrips tabaci), a jež nadělala toho roku ve Spojenỵ́ch státech (Massachusetts) značných škod na cibuli.

\section{97 .}

1872-73. A. Müller, Thrips soiling framed engravings. Entomologist's Monthly Magazine. Vol. 9.

Spisovatel zde mluví o nějaké tř̌́sněnce pošpiňujicí rytiny (!).

$$
\text { C. } 97 . \text { A. }
$$

1873. A. E. Holmgren, Om åkerns skadligaste insekter.

Holmgren mlurí zde na str. 5็̆. o škodlivosti třásněnek zvl. na pšenici a ječmeni.

$$
\text { Č. } 98 .
$$

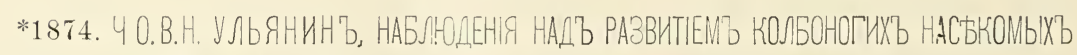

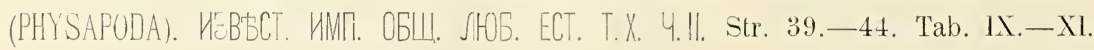

Spisovatel sleduje zde zmèny ve vajičku tř̌śsněnek od prvního objevení se blastodermu až k vývoji mladé larvy. Pochody tyto studoval hlavně na vajičku druhu Tlırips physopus. Obšímě promluvili jsme o práci této v Č́ásti vỵvojepisné.

$$
\text { Cั. } 99 .
$$

(1875). Taschenberg podává zprávu, že v r. 1874. vyskytlo se v Predních Pomořanech velmi mnoho třásněnek na žitě, takže jich $\mathrm{v}$ jediném klase bylo lze 20-40 nalézti. Následek škodlivé čmnosti jejich bỵla hluchost prostřední části klasủ jimi napadených. 


\section{J. UZEL. WONOGRAFIE RADU „THYSANOPTERA“.}

\section{100}

*1875. S. H. Scudder, The Tertiary Physopoda of Colorado. Bulletin of The United States Geological and Geographical Survey of The Terrilories. Washington. No. 4. Second series.

Sammuel H. Scudder popisuje zde dva nové fossilní druhy, nalezené professorem Dentonem v tretihornim útvaru v Chagrin Valleyi a Fossil Canonu ve Spojených státech severoamerických. Jeden z nich, totiž extincta, náleži dosud žijícímu rodu Melanothrips. Druhý, vetusta, náleži do nového fossilniho rodu Lithadothrips. Dále prìdává diagnosu druhu Palaeothrips fossilis, z Fossil Canonu již dříve (Č. 88.) Scudderem popsaného. O druzích těchto promluvili jsme obšíně v Části palaeontologické.

\section{101 .}

1875. L. Wittmack, Blasenfüsse (Thrips) als Schädiger des Flachses. Zeitschrift des landwirtschaftlichen Centralvereins der Provinz Sachsen. 32. Bd.

Autor podává zde na str. 185̃.—187. zprávu o třásněnkách škodících Inu.

\section{102 .}

1875. J. H. Comstock, A. Syllabus of a Course of Lectures Delivered at the Cornell University. Ithaca.

$\mathrm{V}$ této knize uveřejñuje Comsto $\mathrm{k}$ některá pozorování, vztahující se ke třásněnce Limothrips poaphagus, ježto poškozuje trávu. K třásněnce té všali popisu řádného pridáno není.

$$
\text { Cั. } 102 . \text { A. }
$$

1875. W. M. Schöyen, De for Ager, Eng och Have skadeligste Insekter og Smaakryb. Kristiania.

V této knize, dánsky sepsané, mluvi Schöyen dle Reutera (Č. 113.) o třásněnkách škodících travinám.

$$
\text { Č. } 103 .
$$

(1875). Oustalet uveřejňuje v časopise »Bulletin de la Société Philomatique de Paris« několik fossilních druhư třásněnek, nalezených ve vrstvách třetihorního útvaru u města Aix v jižní Francii.

\section{104 .}

1876. A. Szaniszló, Apró fekete rovaraink. Erdélyi gazda. Koloszvár. 24. sz. Autor mluví zde o třásněnce „Thrips frumentarius Beling." Viz též Č. 116.

\section{Č. 105 .}

1876. A. Dohrn, Notizen zur Kenntniss der Insectenentwicklung. Zeitschrift für wissenschaftliche Zoologie. Leipzig. 26. Bd.

Autor zmiňuje se zde o tom, že proužka zárodečná u třásněnek se vchlipuje do vnitř vajička (invaginovaná proužka zárodečná). 


\section{H. I ZEL. MONOGRAPHIE DER ORDNUNG THYSANOPTERA.}

\section{C.. 106 .}

1876. E. Dimitricwic\%. Kártékony rovarok. Földmiv érdek. Budapest. 25. sz. Dimitriewicz jedná tu o třásněnce Thrips cerealium Halid. poškozující žito.

\section{107 .}

*1876. A. G. Butler, J'reliminary Notice of new Species of Orthoptera and Heniptera collected in the Island of Rodriguez by the Naluralists accompanying the Transitof-Venus kxpedition. Annals and Magazine of Nalural Hislory. London. Fourth Series. No. 101. Xlvill. Str. 412. Phỵsopoda.

Autor urádi zale novỵ druh, jejž nazývá Aptiuothrips fasciatus, a kterỵ bỵl na ostrově Rodriguez Gulliverem nalezen. S bezpríkladnou lehkomyslností podává však popis nčjakého zástupce tubulifer. kiterỵ k největšimu překvapení členáre kirídlỵ i očḳ jest opatřen, kdežto rod Aptiwothripss nedostalkem obou se vyznamenává. Bilé přičné stuhy, kiteré Butler na abdomenu vidèl, j:ou asi spojovací blány mezi jednollivými clánky jeho.

\section{108 .}

1877. Farwick. Eierablage ron Melanothrips obesa Halid. Verhandlungen des naturhistorischen Vereins der preussischen Rheinlande und Westfalens. Bonn. 34. Jahro. Vierte Folge: 4. Jahrg. Str. 57.

Aulor popisuje kladení rajičk druhu Melanothrips obesa Halid. (= M. fusca). Samicka hustě prý nalepuje (?) vajičkia svá na listy pryskyrrnikủ. Jordan (Č. 162.) asi prárem má za to. že Far wick poražoval trus třásnènek za jejich vajička.

\section{(ั. 109 .}

*1s7т. G. Becker. Üher Thrips cerealium im Kreise Kempen. Verhandl. d. naturh. Vereins d. preuss. Rheinlande u. Westfalens. Bonn. 34. Jahrg. Vierte Folge: 4. Jahrg. Str. 168 . a 169.

Autor podává zpráru o škodách, zpủsobených na žilè larvou třásněnky Thrips cerealium na dohnim Rýně, a to v okresu kempenském, zvlášlě pak v okoli Lobbericha. Škoda jevila se $\mathrm{r}$ tom. že dolejši èást klasu stala se hluchou.

\section{110 .}

*1 $九 7$. Körnicke, Über den angeblichen Schaden des Getreideblasenfusses Thrips cerealium. Verhandl. d. naturh. Vereins d. preuss. Rheinlande u. Westfalens. Bonn. 34. Jahrg. Vierte Folge: 4. Jahrg. Str. 330.

Prolessor Körnicke domnívá se, że lî́sněnky žitu neškodi, a hledi vysvěllili zjery, které Becker (Č. 109.) a Taschenberg (Č. 99.) za škody tř́snènkami zpúsobené mèli, jednak pathologickị́mi úkazỵ. jednak nedostaleěnỵ́m oplozením pylem a jednak púsobením jiného hmỵu. 


\section{J. UZEL. MONOGRAELE RADU, THISANOPTERA".}

\section{C.. 111 .}

1877. N. Dimilriewicz, Der Gelreide-Blasenfuss auf Roggenfeldern in Schlesien. Österreichisches landwirtschaftliches Wochenblatt. 3. Jahrg. No. 46.

Autor podává zprávu o lrăsněnce Thrips cereulium, škodicí žitu ve Slezsku.

\section{112 .}

*1877. A. Ladureau, Etudes sur les maladies du lin. Le Thrips lini. Association Francaise pour lavancement des sciences. Comple rendu de la $6^{\text {e }}$ session. Le Havre 1877 , Paris 1878.

Redilel laborator̀e stilní a stanice agrononické departementu "Nord « A. Ladureau jedná v léto práci obšírnè o jakési lì̉sněnce, klerá bỵla nalezena v severní Francii na lnu. zkižneném jistou nemocí, kileré tam ríkiají »brûlure«, I. j. užeh. Podrobně o télo nemoci pojednali jsme v Ćásti oekonomické. Trúisněnku, klerá ony škody zpúsobila, nazỵ́vá Ladureau Thrips limi a podává velmi neúphṇ́ popis (tanou mu v nèm na mỵsi lř̉isněnkỵ rủbec) a relmi špalná vyobrazení larvy i dospèlého hmyzu. takže jeho druh nemožno dle toho opěl poznali. Od druhn Thrips cerealium rozeznává se prý lím. že má pěl ělánkủ v tỵkadle, kdežto $T$. cerealium prý má jen tr̉i (!).

Ve všeobecné části, kterou Ladureau svým pozorováním biologickým piedesỵlá, popisuje tělo trásněnek dle udajủ \% literatury a dle něklerỵch pozorování vlastních, a sice r mnohém ohledu chybně. Tak ěleme, kromè mnohỵch jiných nesprávnoslí, že u larer lr̂̀isnènek nenalézáme mísku na konci chodidel. a že maji jen 2 neb a článkṿ v tỵkadle. Na jednom místè praví Ladureau, že samci třásněnek. Kleři prý jsou tmarší než samice, mají na konci abdomenu rourovilou prodlouženinu. klerou vnikají do kladélka samic a oplodñuji je. Z lélo věly by se snadno mohlo soudili, že Ladurea u považuje Tubulifera (jichž postední clánek abdom. má podobu rourovilou) za samce a Terebrautia za samice li̛ásněnek. Dle velmi primitivních vỵobrazení lionce abdomenu samce a samičliy (slr. 953., obr. 6. a 7.) nelze si o pravém názoru Laduleauovè predstary učinili.

\section{113.}

*1878-79. 0. M. Reuler, Diagnoser öfver nya Thysanoptera från Finland. Ölversigt af Finska Vetenskaps-Socieletens Förhandlingar. Helsingfors. XXI. Str. 207. a další.

Ṿ̣borṇ̣ hemipterolog, prof. Dr. O. M. Reuter v Helsingforse, uvádi v télo práci 21 druhu lřásněnek, jež ve Finnsku nalez. Mezi nimi popisıje devèt druhủ jakožlo nové. a sice: Phloeothrips longispina (= Megalothrips lativentris Heeg., ơ), Phl. tibialis (= Megalothr. lativentris Heeg., \&), Phl. pallicornis (= Antiothrips aculeata Fabr., Thrips (Limothrips) bidens (= Limothrips denticomis Halid.. o), Thrips basalis (= Physopus ulicis Halid.). T. flacicomis, T. Salicis, (= Physopus ulmifoliom Halid., T. (Belothrips) bicolor (= Oxythrips hastata m. val. bicolor Reut.). 
H. UZEL, NONOGRAPHIE DER ORDNUNG THYSANOPTERA.

Aeolothrips (Coleothrips) limbata (= Aeol. vittata Halid.). Jeden drụh jest neurěený. Rozměry hlavy, které autor u jednollivých druhủ udává, ukazuji často k tomu, že měřil ji ve stavu, kdy jedna ěást' její byla do prothoraxu vtažena. Reuter uživá úplně rozdèlení Halidayova a cituje patnáct prací, dle nichž své druhy určil. K novým druhủm pìidává obšírnou diagnosu latinskou.

V krátkém švédském úvodu praví, že též ve Finnsku byly přiležitostně pozorovány škody třásněnkami zpủsobené, a to na pšenici, ječmeni. žitě a na travinách lučních. Také zmiňuje se o tom, že Dr. Thomson ve své příruční knize o skandinavském hmyzu uvádí 6 druhù švédskích.

\section{114}

1879. A. Ladureau, Etude sur la maladie dite brûlure du lin. Lille 1879.

V této práci opakuje Ladureau svojẹ pozorování, konaná r. 1877. na třásněnce. klerou nazval Thrips lini, a pridává, že larvy prvé generace jeji žiji na kořínkách Inu, a teprv dospělý hmyz že ssaje štávy hořejších částí této rostliny. Druhá generace pak žije prý na jiných rostlinách pěstovaných, kidež klade do země svá zimní vajička(?).

\section{115 .}

*1879-80. O. M. Reuter, A new Thysanopterous Insect of the Genus Phloeothrips found in Scotland and described. The Scottish Naturalist. Vol. 5. July.

Autor popisuje zde na str. 310. a 311. nový druh třásnènek: Plhloeothrips setinodis, který v červenci a srpnu nalezl u Aberdeenu a Morayshire ve Skotsku.

C.. 116 .

1879. A. v. Szaniszló, Beiträge zur Lebensweise von Thrips frumentarius Beling. Verhandlungen der k. k. Zool.-bot. Gesellschaft. Wien. XXIX. Bd. Sitzungsberichte, str. $33 .-36$.

Albert v. Szaniszló podává zde zprávu o druhu „Thrips frumentarius Beling“(?), který se objevil ve velikém množství v některých krajinách uherských, zvláštẽ pak u Kološe, a sice na obilí, a hlavně na pšenici. Ač objevil se tak četně, byla prý škoda jím způsobená sotva patrná, ano zdá prý se, že není škodnỵm vủbec. Viz také přislušné místo v Části oekonomické.

\section{Č. 117 .}

1880. V časopise: Bull. Soc. Entomolog. Ital., Vol. 12., Trim. 3., podána jest na str. 250. zpráva o dvou třásněnkách škodících olivám, z nichž jedna, totiž Phloeothrips oleae, jest popsána jakožto nový druh, kdežto druhá jest neurčená.

\section{Č. 118 .}

*1880. O. M. Reuter, Thysanoptera fennica. I. Tubulifera. Bidrag till Kännedom af Finlands Natur och Folk. 40. H. Str. 1.-26. 


\section{J. UZEL, MONOGRAFIE RADU, „THYSANUPTERA*.}

Reuler zamỹšlí dle švédské předmluvy k této práci systematicky zpracovati tr̀ásnènky finnské a v prílomném spisku podává čási jich, toliž Tubulifera. Po latinské definici řádu Thysanoptera popisuje obšírně 12 zástupcủ rodu Plıloeothrips s. l., mezi nimiž uvádí 8 druhư jakožlo nové; jsou to Phl. nigripes, dentipes, parvipennis, nodicomis (druh tento byl již znám Burmeisterovi, jenž však mylně domnívá se jednou, že jest to Plıl. Ulmi [С̆. 45̃.], podruhé Phl. coriacea [Č. 50.]), simillima (= Plıl. coriacea Halid.), anmulipes, monilicornis a apicalis (= Trichothrips pedicularia Halid.). Druh Phl Ulmi, který dříve (Č. 113.) z Finnska zaznamenal, v této práci vynechává.

\section{Č. 119 .}

*1880. Dr. Philip p Bertkau podává referal o práci v. Szaniszlóově (Č. 116.). Archiv für Naturgeschichte. 46. Jahrg. Berlin. 2. Str. 386.

\section{120 .}

1881-82. Lintner, An Unknown Grass-Pest. Report of New York Agricultural Sociely.

Professor Dr. Lintner podává zde na str. 192. zprávu o třásněnce, škodící travinám (Limothrips poaphagus). Mluví o jejím zpủsobu života, popisu třásněnky samé však žádného nepřidává.

\section{Cั. 121 .}

*(1882). Dr. Hermann Krauss podává referat o práci v. Szaniszlóovè (C̆. 116.). Zoologischer Jahresbericht für 1880. Leipzig. II. Abth. Str. 185 .

\section{C.. 122 .}

*1882. A. Frič, Př́rodopis živočišstva pro vyšší gymnasiahní a realní školy. Druhé skrácené rydání. Praha.

$\mathrm{V}$ této knize, professorem Dr. Antonínem Fričem sepsané, nalézá se na str. 113. původni vỵobrazení druhu Heliothrips haemorrhoidalis Bouché. — Zde, jakož i v próm vỵdání z r. 1875., nazvána jsou Thysanoptera puchý ìnalkami, kteréžlo

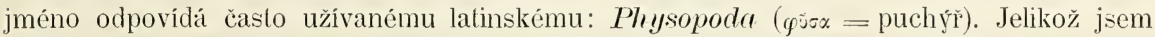
však doložil prioritu jména Thysanoptera (Č. 36.), dovolil jsem si i české jméno zaříditi podle latinského a nazýváin náš hmyz třásněnkami, dle tráásní (tószos:), jimiž kî́ídla jejich jsou zdobena.

\section{Č. 123 .}

1882. T. Pergande, A request for European Thysanoptera. Entomol. Monthly Magazine. XVIII.

Theodor Pergande prosí v tomto časopise na str. 235. entomologú, aby mu poș̣lali evropské tr̆ásněnky. Chce je se sereroamerickými srovnati a tak zameziti, aby nepopsal některé americké druhy, které již z Evropy známy jsou, jakožlo nové. K své 
prosbè prìdává seznam evropských druhủ z literatury sestavený, připojuje k nim jména rostlin, na kterých žiji, a prosí, aby mu také při zaslaných druzich rostliny je živící udány byly a zároveñ nalezišlè jejich.

\section{(๖. 124 .}

1882. T. Pergande, Thripidae wanted. Entomologist. Vol. 15. April.

Pergande prosí zde opèt (na str. 94. a 95.) entomologů, aby mu zasýlali triásněnky.

\section{C.. 125 .}

1882. Professor Herbert Osborn uveřejñuje $v$ casopise: Psyche, organ of the Cambridge Entomological club. Vol. 3. Cambridge, na str. 369. zprávu, že jakýsi zástupce rodu Phloeothrips, jejž nepopisuje, vyskịtl se v množství na všech květech ovocných, kicré zkoumal, a že způsobuje velikou škodu tím, že outlé pestíky vyssává a tak úrodu ničí.

\section{C.. 126 .}

*1882. V časopise: Wiener Entomologische Zeitung. Wien. I. Jahrg. -.- opakuje se na str. 104. krátce prosba Pergandova z Entom. Monthly Nag. (Č. 123.), aby mu třásněnky bỵly posýlány. Vynechán jest tu však seznam druhủ evropských a seznam rostlin, na kterýchž žijí, jak je Pergande z literatury sestavil a k prosbẽ své připojil.

\section{C.. 127 .}

*1882. T. Pergande, Habits of Thrips. Psyche. Cambridge. Vol. 3. No. 100. August. Correspondence. Str. 381.

Pergande pojednává zde o potravẽ třásněnek a praví, že tỵto sice ve květech všeho druhu ve velikých zástupech se vyskytuji, množství semena však z těchto květủ že tím patrně se nezmenšuje. Z toho soudi, že třăsněnky hlavně nektarem květủ se żiví, a připojuje, že ještě prospivaji, prenášejíce mimovolnè pyl na svých nožkách na bliznu. čimž prì zúrodnění květu jakousi účast mají. Že rostlinnou stravu príijímaji, o tom praví Pergande, není pochyby, nebot sám je pr̃i tom zastihl. Vidèl však též v jednom případě, že požiraly roztoče, Tetranychus telarius zvané a na platanech žijicí. Na konci zmiňuje se o tom, že nalezl třásnènku Heliothrips haemor hoidalis Bouché poprvé ve volné prírodè, a to na lislech jablkových v sadě zemèdèlského ústavu washingtonského. Myslím, že se tam dostala náhodon z blízkých skleníkủ, v nichž nalezl též druh Heliothrips dracaenae Heeg.

\section{128.}

1883. J. Gurtis, Farm Insects. London.

V télo knize pojednává se zvl. na str. 285.-289. o škodlivỵch třásněnkách, nepodává se však $\mathrm{v}$ celku nic nového. 


\section{J. UZEL, MONOGRAFIE RADU, „THYSANOPTERA“.}

\section{129 .}

1883. A. S. Packard, On the Classification of the Linnean Orders of Orthoptera and Neuroptera. The American Naturalist. Philadelphia. Vol. 17. Str. 820._829.; Annals and Nagazine of Natural History. London. (5). Vol. 12. Str. 145.-154.

Packard klade zde třásněnky, pak Mallophaga, Heteroptera a Homoptera do oddilu hmyzu, který nazývá Eurhynchota.

\section{Č. 130 .}

*1883. J. Portschinsky, Histoire naturelle d'un Thrips observé sur les feuilles de tabac en Bessarabie en 1882. Extrait du rapport présenté au Ministère des Domaines. Traduit du Russe par W. Dokhtouroff. Revue mensuelle d'entomologie pure et appliquée. Vol. 1. Première année. No. 3. St. Pétersbourg. Str. 44.-53.

Autor vyslán byv r. 1882. ministerstvem domén ř́ǐškých do Besarabie, aby tam zkoumal nemoc tabáku, přišel $\mathrm{k}$ náhledu, že vina spočívá na nepřiměřeném pěstování jeho. Třásněnky pak jen napadají listy již onemocnèlé. Druh třásněnek na tabáku žijící, který dríve Widgalmem byl pojmenován Thrips solanacearum, má za identický s druhem Thrips urticae (= T. flava). Rozmnožuje se dle něho velmi rychle, takže od 1. května do 1. září mủže míti skoro osm generací. Zajímavá jest zpráva, že ve stadiu nymfy nežije na listech, kdež jen larvy a imagines lze nalézti, nýbrž v zemi. Portschinsky také zmiñuje se o larvách jistého trombidia, které na třásnènce té cizopasí.

\section{Č. 131 .}

*1883. H. Osborn, Notes on Thripidae, with descriptions of new species. The Canadian Entomologist. London. Volume XV. Str. 151.-156.

Ve všeobecném úvodu věnuje autor zvláště pozornost' potravě trásněnek a praví, že pozủstává pravidlem z rostlinných štav. Že by třásněnky bỵly hmyzožravými, jak to z nèkterých stran bylo tvrzeno, to může pr̉ipustiti jen jakožto výjimku a myslí, že snad některé tr̀ásněnky nejspíše ještě někdy štavnatou mšici vyssají, protože jest v pohybech velmi lenivá a odporu žádného jim neklade, ač nikdy nic podobného neviděl. Že by jiným hmyzem se živily, tomu odporuje tvar a poloha jejich ústrojủ ústních. Osborn popisuje dále čtyřri třásněnky sbírané ve Spojených státech (Ames. Jowa, Manchester, Delaware), z nichž uvádí tři jakožto nové. Jsou to Phloeothrips (= Anthothrips) nigra, nalezená v květech jetele, Chirothrips antennatus (=Ch. manicata), vyskytující se v trávě timothy zvané, Thrips striata a Thrips Tritici, která však nemá se soujmenným druhem Fitchovým (Č. 69.) nic společného.

\section{Č. 132 .}

*1883. A. Costa, Notizie ed osservazioni sulla geo-fauna sarda. Nemoria seconda. Risultamento di ricerche fatte in Sardegna nella primavera del 1882. Tisanotteri. Atti Acad. Napoli. (2). Vol. 1. Str. 71. 


\section{H. UZEL, MONOGRAPHIE DER ORDNUNG THYSANOPTERA.}

Achille Costa, uvádí ze Sardinie trì druhy třásněnek, z nichž dva jsou nové a třetí neurčený. Nové jsou: Phloeothrips bigemmata a Thrips croceicollis, které však Costa jen jmenuje, popisu žádného nepridávaje.

\section{Č. 133 .}

*1884. O. M. Reuter popsal v časopise Revue d'Entomolog., Caen, na str. 290., nový druh trásněnek Phloeothrips albosiguata, nalezený u Tlemcena v Alžíru.

\section{C.. 134 .}

1884. V časopise Entomologisk Tidskrift, Stockholm, jest na str. 90. podána zpráva o třásněnce, která roku 1881. mladému osení velmi škodila.

\section{Cั. 135 .}

1884. V časopise Sitzungsberichte der Naturforscher-Gesellschaft bei der Universität Dorpat, Dorpat. oznamuje se na str. 149., ð̌e vyskylla se larva jisté třásněnky, snad druhu Thrips cerealium Halid., v klasech zimní i letní pšenice.

\section{C.. 136 .}

$V$ této době snad podává professor Fernald zprávu o jisté trásněnce severoamerické, která poškozuje trávu. V żaludku jejím nalezl zrnka pylová(?).

\section{(¿. 137 .}

$\mathrm{V}$ této době snad také píše professor A. J. Cook v díle professora W. J. Beala »Grasses of North America«, na str. 375., v oddílu hmyzu se týkajícího, že nalezl na jeteli tři druhy tr̃ásněnek, že však nepozoroval zvláštní škody, která by od nich pocházela. Dále praví na str. 401., mluvě o vadnulí trávy v létě, že toho prričinou jsou asi dva druhy třásněnek ze tří, které na stéblech nalezl.

\section{(.) 138 .}

1885. A. Costa, Notizie ed osservazioni sulla geo-fauna sarda. IV. Tisanotteri. Atti Acad. Napoli. Str. 12.

V této práci oznamuje Costa, že druh, Reuterem r. 1884. (Č. 133.) pod jménem Phloeothrips albosignatı popsaný, jest totožný s jeho druhem Plll. bigemmata.

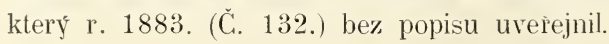

\section{139.}

*1885. F. Brauer, Systematisch-zoologische Studien. Sitzungsberichte der math.naturw. Classe der Akademie der Wissenschaften. Wien. 91. Bd. V. Heft.

$\mathrm{V}$ této práci, ve které dủkladně systematickým postavením jednotlivých skupin hmyzových se zamèstnává, uznává Brauer oprávněnost rádu hmyzu trásnokrídlého 
(Thysanoptera) a staví ho mezi Corrodentia a Rhynchota. Definice třásnènek jakožto rádu jest však plna chỵb, což vysvětluje se tím, že toho času anatomie jejich nebyla ještě dosti známa. Na omỵl Brauerûv, kiterý čitá mezi Insecta Menorhyncha (hmyz, jehož larvy mají tytéž ssavé ústroje ústuí jakio imagines) jen Rhynchota, ač třásněnky sem také náležejí, již Jordan (Č. 162.) upozornil.

\section{140}

1885. A. Schneider, Die Entwickelung der Geschlechtsorgane der Insecten. Zool. Beiträge von A. Schneider. 1. Bd.

V této práci nalézáme malou zmínku o pohlavních ústrojích třásněnek.

C. 141.

1885. H. W erner pojednává v dodatku (Die Unkräuter und thierischen Feinde des Getreides) ke knize »Handbuch des Getreidebaues. Von F. Körnicke und H. Werner, Bonn", o druzích Thrips cerealium Halid. a T. frumentarius Beling, jakožto o škủdcích obilí.

\section{C.. 142 .}

*1885. Dr. H. Krauss podává referat o práci Pergandovè (Č. 127.). Zoologischer Jahresbericht für 1883. Leipzig. II. Abth. Str. 160.

\section{C.. 143.}

1885. E. A. Ormerod, Report of observations of injurious insects and common farm pests during the year 1884, with methods of prevention and remedy. London.

V této práci uveden jest Thrips cerealium jakožto škủdce obilí a travin.

\section{144 .}

(1885). V časopise »Bulletin Soc. Ent. Belg., XXIX», podána jest na str. 70. zpráva o třásněnce Heliothrips haemorrhoidalis Bouché, která jest velmi škodlivá vínu ve sklenících pěstovanému.

\section{145 .}

$\mathrm{V}$ této dobẽ asi zmiňuje se Packard ve svém spisu »Entomol. for Beginners", na str. 197., mluvẽ o třásněnkách, též o severoamerickém druhu Thrips striatus Osborn a praví, že škodí pšenici, což později Osborn za omyl pokládá.

\section{Č. 146 .}

1886. J. Pérez, Sur l'histogénèse des éléments contenus dans les gaines ovigères des Insectes. Compte rendu etc. Paris. Tome 102. 2.

Autor promlouvá zde př́ležitostně též o vznikání vajíček v rourkách vaječných u třásněnek.

\section{Č. 147 .}

*1886. H. Krauss podává referat o Portschinskyho práci (Č. 128.) Zoologischer Jahresbericht für 1886. Berlin. II. Abth. Str. 222. 


\section{H. UZEL, MONOGRAPHIE DER ORDNUNG THYSANOPTERA.}

\section{Č. 148 .}

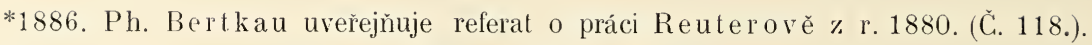
Archiv für Naturgeschichte. Berlin. 52. Jahrg. 2. Str. 126.

\section{Č. 149}

1886. A. Targioni-Tozzetti pojednává v časopise »Atti della R. Accademia de Georgofili. Ser. IV. Vol. VIII." o téže látce jako v časopise »Bull. d. Soc. ent. ital.» (Č́s. 150.).

\section{C.. 150 .}

*1886. A. Targioni-Tozzetti, Notizie sommarie di due specie di Cecidomidei; una consociata ad un Phytoptus, ad altri Acari e ad una Thrips in alcune galle del Nocciolo (Corylus avellana L.), una gregaria sotto la scorza dei rami di Olivo, nello stato larvale, Bulletino della Società entomologica italiana. Anno diciollesimo. Trimestre IV. Firenze. Str. 425 . a 426.

Zde jedná autor o dvou druzich bejlomorek (Cecidomyidae), které zároveñ s jistým phytoptem, nějakým jinỵm roztočem a jistou třásnènkou (jey̆ žije jakožlo larva hojně na kưrè větví olivových), obývaji jakési nádory na keři lískovém na Sicilii. Třásněnku zmínènou nazývá autor Euthrips consociata (= Physopus ulmifoliorum) a popisuje ji jakožto novou. Jméno Euthrips tvoři sám a dává je zástupcủm podrodu Halidayova Thrips. O téže látce pojednal autor již dịíve, a to $\mathrm{v}$ časopise "Atti d. Acc. d. Georgofili (Čís. 149.).

\section{151.}

1886. Cameron píše v časopise "Transact. Natur. Hist. Soc. Glasgow. (N. S.) I , na str. 300., o třásněnce Heliothrips aidonidum Halid. (= H. haemorrhoidalis).

\section{Č. 152 .}

1887. H. Osborn oznamuje v Rile yově »Rep. U. St. Depart. of Agriculture« že viděl, jak štěnice Triphleps insidiosa hubí třásněnky.

\section{Č. 153 .}

*1887. K. Lindeman. Die am Getreide lebenden Thrips-Arten Mittelrusslands. Bulletin de la Société Impériale des Naturalistes de Moscou. Publié sous la Rédaction du Prof. Dr. Ch. Lindeman. Année 1886. No. 4. Moscou. Str. 296.-337.

Třásněnky jeví dle pozorování Lin demanových, u Mosikvy konaných, činnost svou na obili tím, že zaviňuji odumírání konce klasu (str. 299., obr. 1.), neb že dělají ho částečně hluchým (str. 299., obr. 2.), aneb konečně, že způsobuji na pochvách listových žlutavé skvrny. Jen prvé dva způsoby jejich činnosti jsou škodlivými.

Autor jedná o pěti druzích třásněnek, jež nalezl ve stredním Rusku na obilí a na bojínku (Phleum pratense); dva z nich popisuje jakožto nové. Druhỵ uvedené 
jsou: Thrips secalina nov. sp. (= Limothrips denticornis), Phloeothrips frumentaria Beling (= Anthothrips aculeata), Thrips (Chirothrips) antennatus Osborn (= Chirothrips manicata), Thrips (Aptinothrips) rufa Halid. a Phl. armata nov. sp. (二Anthothrips statices). Pro rolníka düležilost maji prý jen druhy T. secalina a Phıl. frumentaria Beling; pročež pojednavá velmi obširnè o nich a zvl. o jejich biologii (viz Čásf oekonomickou). - Trásněnky T. cerealium Halid. Lindeman v Rusku nenalézá.

Připojime zde k jednotlivýın druhům některé poznámky. „Thrips secalina“ prìlepuje(?) svoje vajička ${ }^{1 / 4} \mathrm{~mm}$. dlouhá na stébla. Okolnost la jest Lindemanovi samému nápadnou, nebof nemůže si pak vysvělliti. k čemu by mèly kladélko. K popisu toho druhu jsou pridány výlkresy, a to na str. 308. obr. 4., na str. 309. obr. 5., na str. 310. obr. 6. a 7. (larva), na str. 311. obr. 8. a 9. (pyjový apparat) a na str. 312. obr. 10. Mezi nimi jsou obrazy kladélka a ještě více ústroju ústních zcela nesprávné. Co se těchto poslednich týče, kresli Lindeman také maxilly štětinovité(!!). Za rok má tato tr̃ásněnka tr̆i generace. Nymfy lezou pomalu. prijijimají prý potravu(?) a velmi brzy proměn̆uji se se v dokonalý hmyz. - „Phloeothrips frumentaria" jest ze všech nejvice škodnou lr̆ảsněnkou. K popisu jejímu připojeny jsou taktéž výkresy, a to na str. 329. obr. 15. a 16., na str. 330. obr. 17. a na str. 331. obr. 18. Tato třásněnka má přes léto dvě generace. Nymfy pohybuji se pomalu a prijímají prý taktéž potravu(?). - K třásněnce "Thrips (Chirothr.) antennatus" náleži na str. 322. obr. 12. a na str. 324. obr. 13. a 14. Larva, kterou pr̃ipisuje druhu tomuto, náleži druhu Aeolothrips fasciata. Thrips (Aptinothr.) rufa provádí prý značné skoky(?) za pomoci zadku. K tomuto druhu vzlahuje se na str. 320. obr. 11. - „Phloeothrips armata“ objevila se na obilí jen jednou nahodile. Od druhu toho kreslí nohu na str. 336., obr. 19. a 20.

Práce Lin de ma nova jest velmi obšíná až rozvláčná a obsahuje bezpochyby lecos dobrého; jest však v celku povrchni a plna rúzných nesprávností. (Úsudek o pracích Lindemanových vủbec podán jest $v$ časopise Archiv für Naturgeschichte. 1864. 30. Jahrg. 2. Str. 316. a 363., a 1866. 32. Jahrg. 2. Str. 369.)

\section{Č. 154 .}

*1887. Ph. Bertkau podává referat o pojednání Lindemanově (Č. 153.). Archiv für Naturgeschichte. Berlin. 53. Jahrg. 2. Str. 131.

\section{Č. 155 .}

1887. J. Redten bach er, Das Flügelgeäder der Insekten. Annalen des k. k. Naturh. Hofmuseums. Wien.

Autor promlouvá zde také o žilkách v kîídlech třásněnek. Viz přislušné misto v Části anatomické.

$$
\text { Č. } 156 .
$$

*1887. D. v. Schlechtendal, Physopoden aus dem Braunkohlengebirge von Rolt am Siebengebirge. Zeitschrift für Naturwissenschaften. Halle a. S. LX. Bd. Sechstes 


\section{H. UZEL, MONOGRAPHIE DER ORDNUNG THYSANOPTERA.}

Heft. Arbeiten aus dem Königl. mineralogischen Institut zu Halle (Palaeontologische Abtheilung). Str. 551.-592.

D. v. Schlechtendal popisuje zde velice podrobně dvanáct fossilních druhů třásněnek z hnědého uhlí u Rotta. Druhy svoje počítá do tří posud žijicích rodù, a to do rodu Phloeothrips jeden druh (Phl. Pohligi, Tab. Ill., obr. 1.), do rodu Thrips 7 druhủ (T. excellens, Tab. III., obr. 2.-8.; T. longula, Tab. III., obr. 9.; T. pennifera, Tab. III., obr. 10.-12.; T. breviventris, Tab. IV., obr. 13.-15., T. minima, Tab. IV., obr. 16., 17.; T. pygmaea, Tab. IV., obr. 18., 19.; T. capito, Tab. V., obr. 20.) a do rodu Heliothrips 4 deuhy, totiž: H. cucullata (= Lithadolhrips cucullata), Tab. V., obr. 21., 21. a, 21.b. 21. c, 21. d, 22. A, 22. B, 22. a; II. longipes (= Palaeothrips lon ipes, Tab. IV., obr. 23., 23. a; H. (= Thrips s. l.) clypeata, Tab. V., obr. 24.; H. (= Thrips s. l.) Frechi, Tab. IV., obr. 25., 25. a, 25. b.). Popis osvětluje dvaceti čtyřmi obrazy, na třech tabulích velmi pečlivě do podrobností provedenými. Pokud se rodu Phloeothrips týče, jest v. Schlechtendal prvním, který z nèho fossilního zástupce popsal. Do rodu Thrips a Kleliotlrips jsou dotyčné druhy arcif vřaděny jen prozatímnè. Zvláště pak príslušnost do rodu Heliothrips jest odủvodněna jedině sítovitou strukturou chitinu, kterýžlo znak jest jen vedlejší, a mimo to, jak v. Schlechtendal sám pr̃ipomíná, processem zkameněni zpủsoben byyti mohl. Bližši udaje obsaženy jsou v Části palaeontologické.

\section{156 A.}

1887. A. E. Shipley piše o jisté třásnènce (Bulletin 10 of Miscellaneous Inform., Royal Gardens, str. 18.), žijicí na ostrovech bermudských na cibuli, kdež však, jak se zdá, jen malé škody způsobuje. Pergande (L. č. 185.) má ji za Thrips tabaci.

\section{Č. 156. B.}

1887. K. Lindeman, Om de på säd lefvande arterna af slägtet Thrips i medersta Russland. Entomologisk Tidskrift. Stockholm. 8. Årg. 2./3. Hft. Str. 119.-127.

Práce tato, švédsky sepsaná, jest jen výtahem dřívější, Li indemanem r. 1886. (Č. 153.) vydané.

\section{157 .}

1888. Lintner, An Unknown Grass-Pest. Report of New York Agricultural Society.

Autor jedná zde o třásněnce, která vyskytuje se ve velikém množství ve Spojených státech na rủzných travinách, je poškozujíc. Comstock (Uั. 160.) praví, že škůdcem tím jest Limothrips poaphagus, o jehož škodách on sám psal roku 1875. (С̆. 102.), popisu však třásněnky samé neuveřejnil.

\section{Č. 158 .}

*1888. K. Lindeman, Die schädlichsten Insekten des Tabak in Bessarabien. Moskau. Str. 15. a $61 .-75$. 


\section{J. UZEL, MONOGRAFIE RADU "THYSANOPTERA“}

Krátlý obsah Lindemanovy práce podán na str. 383. a 384. této monografie (v Cásti oekonomické). Prípojíme zde ještę nèkteré poznámky. - Tr̉ásněnku, jež na tabáku škody způsobuje, nazval Lindeman Thrips tabaci. Popisuje ji (na str. 73.) takto:

Thrips tabaci Lindeman. "Der erwachsene Thrips ist $1 \mathrm{Mm}$. gross oder etwas grösser. Blassgelb. Augen und Rüsselspitze schwarz. Die Hinterränder der Bauchringe in der Mitte schwarz (q). Körper mit seltenen, kurzen Haaren, welche nur an den beiden letzten Bauchringen etwas länger erscheinen. Körperoberfläche ungedornt. Am Scheitel stehen drei kleine Ocellen. Stirne zwischen den hart aneinanderstehenden Fühlern ohne Zahnfortsatz. Fühler siebengliedrig. Glied 1 dick, walzenförmig; 2 tonnenförmig, etwas länger als 1, undeutlich geringelt. Glieder 3, 4. 5 und 6 länglich-elliptisch, beinahe gleichlang und nur 6 etwas länger; alle undeutlich geringelt. Glied 7 schmal, kegelförmig. mehr als um die Hälfte kürzer als das vorhergehende. Beine einfach; Schenkel nicht aufgeblasen; Flügel farblos; den Hinterrand des sechsten Bauchringes erreichend. Ihre Oberfläche sehr fein gedornt. Der Vorderflügel mit zwei Adern; die hinteren nur mit einer. Der Hinterrand der Flügel trägt lange, dunkle, gewellle Haare; deren Reihe blos bis an die Mitte des Randes reicht. Der Vorderrand trägt kurze Borsten. Der Bauch des q besteht aus 10 Ringen. Die beiden letzten nach hinten allmählich zugespitzt, ohne einen röhrenförmigen Ansalz zu bilden. Der frei vorstehende Ovipositor besteht aus vier säbelförmigen gelben Platten init gesägtem Rande. Das Receptaculum seminis liegt im sechsten Bauchringe als birnförmiges braunes Bläschen*). Die Männchen sind kleiner und schmäler als die Weibchen. Ihr Bauch ist nur neungliedrig**). Im sechsten und siebenten Bauchringe liegt ein Paar brauner löffelförmiger Chitinplatten von unbekannter Bedeutung ***). An der Spitze des Bauches befindet sich das warzenförmige Copulationsorgan, dessen Spilze zwei farblose Haken trägt und welches von unten durch eine halbrunde Platte (das 9. Segment) zugedeckt wird."

Z tohoto popisu seznáváme, źe druh Lindemanův jest bezpochyby zástupce rodu Thrips. Od mého druhu Thrips communis, jemuž zdá se býti blízký, rozeznává se zbarvením článkûv abdominahnich, jejichž zadní okraje nejsou u druhu T. communis nikdy uprostřed černé, nýbrž celé stejnoměrně více nebo méně šedè zkalené. — Pokud se doby vývoje této třásněnky týče, udává Lindeman, že trvá 47 dní, a sice vývoj vajička 10 dní, vývoj larvy 30 dní a vývoj nymfy 7 dní. Nymfy prý uchylují se na stopky a na svrchní stranu listů (srovnej udaj Portschinskyho [Č. 130.], dle něhož nymıfy tráví život svůj $\mathrm{v}$ zemi). Bèhem teplé doby roční mohou se na ten zpủsob jen tr̆i generace vyvinouti (Portschinsky udává, že během léta může až osm generací po sobě následovati). Dle Lindemana uchyluji se larvy i dospělé třásněnky po 20. srpnu na hořejši stranu listovou, poněvadž spodní strana stává se jim asi tuze chladnou.

*) Tento váček není receptaculum seminis, nýbrž žláza mazová.

**) To jest omyl; abdomen samců skládá se též z desíti článků.

***) Patrnè varlata. 
V květech tabáku četně prý žije nějaká černá třásnènka, která líže med a tudíž škod žádných nezpủsobuje.

\section{C.. 159 .}

*1888. E. Bergroth, Diagnose d'une nouvelle espèce de Thysanoptères. Comptes rendus de la Société Entomologique de Belgique. Bruxelles. (3.) No. 98. Avril.

Autor zde popisuje na str. XXX. a XXXI. (latinsky) novou třásněnku z Brasilie: Phloeothrips angustifrous.

\section{C.. 160.}

1888. Prof. J. H, Gomstock podává referat o zprávě Lintnerovè, týkající se třásnènky Limothrips poaphagus (Č. 157.) a praví, že mu jest o ní známo více, než ve zprávě zmíněné je podáno, a že uveřejnil svá pozorování již r. 1875. (Č. 102.).

\section{C.. 161 .}

1888. F. Löw, Beschädligung des Weizens durch Thrips. Wiener Landwirtschaftliche Zeitung (Briefkasten).

\section{162.}

*1858. K. Jordan, Anatomie und Biologie der Physapoda. Zeitschrift für wissenschaftliche Zoologie. 47. Bd. Leipzig. Str. 541.-620. Tab. XXXVI., XXXVII. a XXXVIII.

$\mathrm{V}$ anatomické části této práce podal J ordan obraz anatomie tř́snènek a objasnil své výklady 91 výkresy na třech tabulích. K těmto studiím vyvolil si hlavně druhy Parthenothrips dracaence a Phloeothrips brunnea. Toto poslední jméno, jakož i jméno Thrips asperulae, kterého v práci své také uživá, pocházejí od Jordana samého a vztahují se na dva druhy třásněnek, které tento autor za nové má, $\mathrm{k}$ nimž však bližšího popisu znakủ systematických nepřidává. O výzkumech Jordanových mluvili jsme velmi často během svých výkladů anatomických. $\mathrm{V}$ biologické éásti své práce mluví Jordan zvláště o kladení vajiccek (mimochodem zde podotýká, že viděl také obrat zárodku ve vajičku tr̉ásnènek), o larvách a nymfách, o parthenogenesi třásněnek, kterou pokusem dokázal, o obydlích třásněnek v létě i v zimě a konečně o potravě, letu i skoku jejich. Také uvádí svá pozorování, jež konal na dvou druzich na obilí žijících. O rủzných pozorováních biologických, jež Jordan uvádí, promluvili jssme v Cásti biologické. $\mathrm{V}$ doslovu jedná autor o proměně třásněnek, o systematickém postavení jejich a líči príbuzenské vztahıy třásněnek s jinými řády hmyzû, srovnávaje je zvláště s orthoptery a rhynchoty. Konečně podává definici řádu hmyzu třásnokřídlého, který neprávem nazývá Physapoda. domnívaje se, že jméno to jest starší.

Budiž ještě podotknuto, že jest zde práce Halidayova z roku 1852. (L. č. 61.) značně podceněna, ač mnohou věc Halida y první objevil i nakreslil *). Poněkud omluvou Jordanovi je okolnost', že nemèl náhodou jeho exemplár práce zmíněné výsvětlivky k tabulím, takže tyto na srozumitelnosti utrpèly.

*) Viz historické poznámky v Části anatomické. 
(.) 163.

*1888. H. Osborn, The food habils of the Thripidae. Insect Life. U. S. Department of Agriculture. Division of Entomology. Washington. Vol. I. No. 5. November. Str. $137 .-142$.

V této práci mluví Osborn o potravě tỉásnènek a uvádi pečlivè všecka data, z literatury jemu známá, pokud se týkají tohoto preedmętu. Miśsty cituje z některých amerických autorû celé články, čímž nás seznamuje s pracemi, kiteré z veliké éásti jsou těžce př́stupnými, a od nichž od mnohých ani titulu nenalézáme v seznamech literatury. Srovnav udaje cizí se svými vlastnimi zkouškami, přicházi k vọ́sledku, že tr̉ásnènky jsou pravidlem bejložravými. Jednak prý živí se nektarem květủ neb rủznỵmi výměšky rostlin vủbec, jednak pylem jejich a jednak ssaji primo z pletiva. Posledním zpủsobem vy̌̆iry stávají se pro člověka někdy porážlivě škodlivými. Pokud se týče hmyzožravosti Iřásnènek, připoušlí ji sice v něklerých připadech, poznamenává ršak, že vzhledem k prípadu, kdy trásněnky živily se prý phylloxerou, myslí, že tyto pr̆išly ssát štávy phylloxerami vypocené, a že pak i do mšic se daly, za rostlinnou polraru je majíce.

\section{164 .}

1889. K. Jordan, Anatomy and Biology of Physapoda. Journal of the Royal Microscopical Society. London. P. 2. Str. 203.-204.

Zde stručnè podány j:ou nejdůležitějši výsledky práce Jordanovy z r. 1888 . (С̆. 162.)

\section{165 .}

*1889. J. Uzel, Puchýŕnatky (Phỵsopoda). Vesmír. Praha. Ročník osmnáctý. Č́slo 21., str. 241. - 243. a 245. ; číslo 22., str. 258. a 259.

Po králkém všeobecném úvodu promluveno jest zde o anatomii tr̆ásnènek, ke kiteréžto stati připojeny jsou dva obrazy s 11 výkresy, dle Jordanovy práce (Č. 162.) zholovenými. Pro Čechy zjišlĕny byly následujicí druhy: 1. Parthenothrips dracaenae, 2. Meliothrips haemorrhoidalis, 3. Thrips flava, 4. Thrips physopus, 5. Physopus primulae, 6. Ph. vulgatissima, 7. Limothrips denticornis, 8. Thrips sambuci, 9. Aeolothrips fasciata. 10. Anthothrips aculeata, 11. Megalothrips lativentris, 12. Cryptothrips bicolor.

\section{(ั. 165.1 .}

1889. R. Thaxter píše (Ann. Rept. Conn. Agr. Exp. St. for 1889, p. 180.) o jistém druhu třx́snènek (dle Perganda Thrips trabaci), který ve Spojenỵch státech (Connecticut) značné šliody zpủsobil na cibuli.

\section{166 .}

*1890. Dr. Paul Mayer podává referat o práci J or da no vě (C. 162.). Zoologischer Jahresbericht fǜ 1888. Berlin. 1890. Str. 69.-62. 


\section{H. UZEL, MONOGRAPHIE DER ORDNUNG THYSANOPTERA.}

\section{167 .}

*1891. J. Bohls, Die Mundwerkzeuge der Physopoden. Inaugural-Dissertation. Göttingen.

V télo práci podává Dr. Bohls vỵsledky svỵch studií ústrojú ústních třásněnek. Uživaje methody r̀ezu seriovỵch, vyložil vzájemnou polohu jednotlivỵch částí v sosáku a mohl nèkterá pozorování Jor,danova v tom ohledu opraviti neb doplniti. To z.vláště týká se hypopharynxu, slinné rourky a požeráku. K práci své pr̆idává vỵkres průřezủ kusadel prvého páru a jednoho přícného řezu, na němž poznati lze složení požeráku a polohu bodce ústního i obou šlětinovitỵch kusadel prvého páru. Bliže zamèstávali jsme se studiemi Bohlsorými v Cásti anatomické. - Mimochodem poznamenává Bohls. že vidèl, jak larvy jisté tr̃ásněnky vyssávaly předhozený jim poraněný hmỵz.

\section{C.. 168 .}

*1891. O. 11. Reuter, Thysanoptera, funna i finska orangerier. Meddel. af Societas pro Fauna et Flora Fennica. 17. Str. 161.-167.

Aulor jedná v práci té o třásnènkách, které nalezl na rostlinách ve finnských sklenících. Jsou to trì druhy, které počíta do rodu Heliothrips. Podar diagnosu rodu toho, popisuje (latinsky i švédsky) trì zminěné druhy, totiž 1. Heliothrips haemorrhoidalis Bouché, 2. Hel. (= Parthenothrips) dracaenae Heeg. a 3. Hel. femoralis nov. sp. Od prvého druhu nalezl ještè novou varietu: abdominalis.

\section{-}

*1891. E. Holmann, Über einige dem Getreide schädliche Thripse. Jahreshefte des Vercins lär vaterl. Naturkunde in Würtemberg. Str. 24.-28.

$V$ této zprávẽ přičilaji se třásněnkám veliké škodỵ na obili ve Würtembersku zpüsobené, kiteré asi my̧ši zavinily (viz príslušné místo v Gásti oekonomické). - V tom, co autor o tr̉isněnkách praví, jeví se neznalost věci a porrchnost tak veliká. že mi laskaṛ̣ čtenaír nezazlí. nehodlám-li množstrí omỵlû rṿraceti.

\section{(.) 170.}

(1891). H. Garman, The Nouth-parts of the Thysanoptera. Bulletin of Essex Instil. Vol. 22. Str. 24.-27.

I tomto článkı popisuje autor velmi stručně ústroje ústní třásněnek a připojujo jeden výlires.

\section{(.) 171 .}

1892. J. Fleteher, Notes on injurious insects in Canada 1892. Insect Life. Washington. Vol, V. No. 2. Str. 126. a 127. 


\section{J. UZEL. HONOGRAFIE RADU, "THYSANOPTERA“.}

Autor piše zde mezi jiným též o jistém druhu třásněnek (dle nèho Thrips tritici), že napadá, mimo jiné ěásti rostlinné, též tyěinky zahradních jahodníku a że i jiným pěstovaným rostlinám škodí.

C. 172.

1892. C. P. Gillette piše (Annual Report of the Colorado Experiment Station for 1892 , p. 36.) o jisté třásněnce (dle Perganda Thrips tabaci), která nadèlala škod ve Spojených státech (Colorado) na cibuli.

C.. 173.

1892. J. A. 'Lintner zmiňuje se (Ninth New York Report for 1892, p. 445.) o jisté tr̆ásněnce (dle Perganda Thrips tabaci), jež zpủsobila škody ve Spojených státech (Pennsylvania) na zelí a karfiolu.

\section{174 .}

1893. G. P. Gillette podává zprávu (Bulletin 24 of the Agr. Exp. Station Colorado, p. 15.) o jisté třásněnce, kterou nazývá Limothrips allii (dle Perganda jest to Thrips tabaci), a jež uškodila ve Spojeny̧ch státech (Colorado) cibuli. Pr̃idán jest té̌̆ obraz dotyčné tr̆ásněnky. V této zprávě děje se zminka o článku, jednajicím o téže látce a uveřejněném C. F. Bakerem v VIl. sešitu časopisu American Florist (str. 168.).

\section{c.. 175 .}

1893. J. B. Smith sděluje (Annual Report of the New Jersey Agricultural College Experiment Station for 1893 , p. 441.), že v tomto roce vyskytla se jistá třásněnka (dle Perganda Thrips tabaci) v úžasném množství na cibuli ve Spojených státech (New Jersev) a značně ji poškodila.

\section{Č. 176 .}

1893. V casopise: Annual Report of the Colorado Experiment Station for 1893 mluvi se na str. 55. o nesmirně četném objevení se jisté třásněnky (dle P erganda Thrips tabaci) ve Spojených státech (Colorado) na cibuli.

$$
\text { C. } 177 \text {. }
$$

*1894. F. Trybom, lakttagelser om blåsfotingar (Physapoder) från sommaren 1893. Föredrag vid Entomologiska Föreningens sammanträde den 14 December 1893. Entomologisk Tidskrift. Str. 41.-58.

Trybom pojednává zde obšírně o škodách druhu Aptimothrips rufa (v. Gleichen), jež ve Švédsku jeví se hlavně na následujících travinách: Avena pratensis, Agrostis stolonifera, Dactylis glomerata, Poa trivialis, P. pratensis, Festuca mbra, Triticum repens. Poznamenává též, že velmi četné zvadlé a bílé klasy rưznỵch travin lučních, o kterých Schöyen (Indberetning fra Landtbrugsentomologen 1891; str. 15. a 16.) 


\section{UZEL, MONOGRAPHIE DER ORDNUNG THYSANOPTERA}

se zmiñuje, bezpochyby tr̉ásněnkou onou bỵly zpusobeny. - Aulor popisuje exempláre druhu Aptimothr. rufa, které ryznamenávají se prítomností stỵlu (7. a 8. čl. tỵkadla) jakožto nový drulı a jmenuje ho A. stylifera. Dle mého pìesvědčení jsou ršak exempláre se slylem vyvinulým (které Lindeman popré vidèl) formou typickou a exempláre bez stỵlu (kiteré, jak Trybom sám pr̃ipomíná, r ničem jiném se od oněch neodchỵluji) jen varietou, kterou nazývám comnaticormis. Autor rěnuje zvláštní pozornost práci Li n demano vè (Č. 153.) a trrdí právem, že Thrips secalina Lindeman jest toložná s druhem Limothrips deuticornis Halid. Konnečně poznamenává též, že Reuteriuv Limothrips bideus (C். 113.) jest tmarý sameček druhu L. denticomis, což jest náhled správný.

\section{178}

1894. J. Jablonowski. Thysanoptera nova. Természetrajzi füzetek kiadja a Magyar nemzeli músenm. Budapest. Vol. XVII. 1-2. füzet. Silr. 4t.-47. Tab. III.*)

*) Jablonowski beschreibt hier zwei neue Arten, nämlich Pllocothrips crassipes und Limothrips angulicormis. Die erstere (sieh deren rerkürzte Beschreibung im böhmischen Texte) ist ein Vertreter der von mir aufgestellten Gattung Zygothrips, welche der Gattung Authothrips am nächsten steht und auch wie diese in Blüten rorkommt. Jablonowski hält sein Exemplar für ein Männchen. Es ist jodoch in der That ein Weibchen. weil die bei den Männchen dieser Gattung an der Tubusbasis jederseits liegende Schuppe fehlt. Die Krallen. welche er auf den Tarsen aller' Beine zeichnet, sind kein besonderes Merkmal dieser Gattung. Sie kommen vieImehr bei allen von mir untersuchten Phlocothripiden vor, und zwar auf der nach unten gewendeten Seite des Tarsus (bei Trichothrips coprosu sind sie besonders stark entwickelt). Bei Jablonowskis Art zeichnen sie sich dadureh aus, dass sie etwas abstehend sind. wogegen sie sich sonst überall platt an den Tarsus anlegen, so dass sie leicht übersehen werden können. W'eil sie überall rorkommen. habe ich sie auch nicht in meine Diagnosen aufgenommen. Diese Krallen der Phlocothiquiden entsprechen jedenfalls den Krallen ihrer Larven (sieh Taf. VII, Fig. 152-155). und zwar erhielt sich, wie schon gesagt. nur die untere (welche beim Kriechen wichtiger ist. wogegen die obere rerkümmerte. Jablonowski zeichnet dic Krallen oben; man muss sie daher als durchscheinend auffassen. Auf dem Vordertarsus finden wir bei den Phlocothripiden ausser dieser Kralle oft noch einen grösseren oder kleineren Zahn, und zwar auf seinem inneren Rande. Einen solchen kleinen Zahn haben auch die Männchen der Gattung Zygothrips. Bei den Weibchen der letztgenannten Gattung kommt kein Zahn vor (ein neuer Beweis, dass J ablon ow skis Exemplar, welches keinen solchen Zahn aufweist, ein Weibchen ist). - Meine Art: Zygothrips mimuta unterscheidet sich von $/$. rrossipes durch das weniger gedrungene und auch nicht so schmal gestielte 4. u. 5. Fühlerglied. durch das 4. Glied. welches am breitesten im ganzen Fühler ist (das 2. ist um ein klein wenig schmäler), durch das zugespitzte 8 . Glied, durch die reniger zahlreichen und bedeutend schwächeren Dörnchen auf den Wangen und den Schenkehn, durch die weniger abstehenden Kralten auf der Unterseite der Tarsen. durch die abweichende Fübung der Beine und endlich durch das Vorhandensein der Flügel (letztere dürften jedoch \%uweilen fehlen).

Dic zwcite sehr interessante Art heisst Limothrips angulicornis (die rerkürzte Beschreibung derselben befindet sich im böhnnischen Texte). Bei ihr ist nerkwürdigerweise das zweite und nicht, wie bei L. denticornis, das dritte Fühlerglied mit einem grossen Zahne rersehen.

Endlich sei noch erwähnt, dass Jablonowski die Art Phloeothrips firmentarins Beling (=Anthothrijss arelecuta Fabr.) nicht mit Recht mit Phloeothrips (= Anthothrips) statimes Halid. identificiert; dafür werden richtig Thrips seculina Lindeman und Thrips Kollari Heeg. zu Limothrips denticomis Ilalid., weiter Chirothrips antenuatus Osborn und C\%. Tomgipennis Burm. \%u Ch. manicata als Synonyma gezogen. 
Jablo nows ki popisuje zde dva druhy tìásněnek, totiž: Phloeothrips crassipes n. sp. a Limothrips angulicornis n. sp. Prvý z nich jest zástupce nového mnou navrženého rodu Zygothrps. Popis druhu toho jest následujicí (méně důležité věci jsou vynechány):

Zygothrips crassipes Jablonowski: »Nigra, nitida, laevis. Caput subquadratum (long. 14: lat. 13.65), retrorsum paullo angustatum; ocellis tribus; lateribus capitis spinulis $6-7$ fuscis, antrorsum vergentibus praeditis. Antennae moniliformes, octo articulatae, articulis primo et secundo nigris, tertio dilule picescente, sequentibus sensim obscurioribus, piceis; articulo primo brevi, articulo secundo subrotundato, omnium crassissimo, apice truncato, basin versus graciliore, articulis tertio-sexto pyriformibus, tertio minimo. Prothorax trapezoidalis; mesolhorax cum metathorace connatus, simul sumpti longitudine circiter duplo latiores. Femora antica crassa, nigra, tantum apice paullo testacea, ante apicem constricla et deinde nonnihil dilatata spinulisque armata; tibiae basi graciles, picescentes apicem versus incrassatae, nigrae; tarsi flavo-testacei, articulo tarsorum secundo unco introrsum curvato armato. Pedum femora tibiaeque posteriores anticis similes sed paullo graciliores. Alae nullae. Abdomen thorace latius, fusiforme, segmento ultimo (long. $10 \cdot 2$, lat. ant. 5, lat. post. $2 \cdot 2$ ) apice fuscescente. Longit. $1 \cdot 75 \mathrm{~mm}$. Fem. Patria: Badacsoṇ (Hungaria). Habitat verisimiliter in floribus Ononidis arvensis.

Jablonowski považuje svùj exemplář za samce. Je to však samička, a sice z té př́íčiny, že nemá na basi tubu lupínkủ postranních. Drápky, jež autor na tarsu všech noh kresli, nejsou jen zvláštním znakem rodu Zygothrips, vyskytujit' se u všech mnou ohledanỵch zástupcủ lubulifer, a sice jen na spodní straně (druh Trichothrips copiosa má je neobyccejně silné). U druhu Jablonowskim popsaného vyznamenávají se tím, že poněkud odstávají, kdežto všude jinde těsně př̀léhají $\mathrm{k}$ tarsu, takže je snadno lze prehlédrouti. Ponèvadž v:̌ude se vyskytuji, neuváděl jsem je také ve svých diagnosách. Tỵlo k tarsu prìléhající drápky u tubulifer odpovídaji zajisté drápkům u larev jejich na tarsu se nalézajicím (viz Tab. VII., obr. 152.-155.). Ovšem zachoval se, jak již reečeno, jen dıáptk spodní (který je při lezení důležitější), kdežto hořejší zakmèl. Jablonowski kreslí drápky ty omylem nahoře. Na predním tarsu vyskytuje se u tubulifer mimo lento drápek často ještě větší nebo menši zub, a sice na vnilřním okraji jeho. U samcu rodu Zygothrips nalézáme na tom místě malý zoubek, u samic však nikoliv. Na fig̣. d., priedstavujicí pr̉ední nohu exempláre Jablonowskim nalezeného, zubu toho není. což je opèt dủkaz, že je 10 samice.

Mùj druh Zygothrips mimuta rozeznává se od druhu Z. crassipes těmito znaky: Čtvrtý a pátý článek tỵkadel nejsou ani tak zavalité, ani tak nápadnè stopkaté. Čtvrtỵ článek je nejšsirším článkem v celém tykadle, jsa ještě o poznání širší než druhý. Osmý článek jest prìišpičalèlý. Osténky na tvárích a na stehnech nejsou (zvl. na oněch) tak silné a ne tak četné. Drápky na spodní straně tarsu (všech noh) se nalézající nejsou tak odsláyajicími. Samice mají kǐ̛ídla (ač je možno, že nalezeny budou také bezkřídlé). Délka těla jest menší. Barva noh zcela jiná. 
Druhý Jablonowskim popsaný druh jest Limothrips angulicornis. Popis jeho jest následujici (laké zde jsou ménè dủlězilé znaky vynnechány):

Limothrips angulicornis Jablonowski. Castaneo-fusca. Articulo antennarum primo fusco, articulo secundo primo fere triplo longiore, basi constricto, margine externo undulato anguloque antico in processum producto, articulo tertio oblongo. basi angustissimo, hyalino, dilute-fuscescente, apicem versus incrassato, articulo quarto tertio subaequali et paullo obscuriore, articulo quinto praecedenti subaequali sed obscuriore, articulo sexto praecedenti obscuriore. Pedes corpore concolores. Tibiae anticae dilute-fuscae, apice imo flavescentes; tarsi flavi. Hemelytra lurida, alae posticae subhyalinae, albidae. Segmento abdominis nono lateribus et postice bisetoso, segmento decimo conico, apice denticulis duobus minimis armato et ante hos spinoso et setoso (setis his spinis duplo longioribus). Long. $1.45 \mathrm{~mm}$. Fem.-Patria: Eriwan (Armenia rossica, Dr. Horváth). Budapest (Jablonowski).

Velmi zajímavá třásněnka lato podobá se v celku znaèně druhu Limothrips denticornis, rozeznává se však od něho hlavně tím, že 2. článek tỵkadla jest na rnějši straně ve veliký zub prodloužen, kidežto Lim. denticomis má podobný zub na tretím článku.

\section{C.. 179 .}

*1894. W. H. Ashmead. Noles on cotton insects found in Mississippi. Insect Life. Washinglon. Vol. VII. No. 1. Str. 27.

V télo práci, pojednáxajici o škủdcích bavlniku ve Spojeny̧ch státech (Mis-is-ippi), uvádí Ashmead také tři druhy třásněnek. Praví, že v květech bavlníku nalezl druh Thrips tritici Fitch a Phloeothrips mali Fitch. kdež však škod vážṇ̣ch nezdaji se způsobovati. Třelí dıuh (nový) prý vidèl, jak živil se cervcem bavlnikovým (Aleurodes gossypii). Autor popisuje ho takto:

"Thrips trifasciatus n. sp. Female- - Length $0.8 \mathrm{~mm}$. Light bruwn: eyes strongly faceted, purplish-brown in certain lights; three basal segments of abdomen above, dark brown; segments 4, 5, and 6 white; apical segments light brown, the sulures dusky; legs, except hind femora towards tips, white; wings, linear, strongly fringed. without nervès, the ground color brown or fuscous, with three transverse white bands, i. e., the front wings have a white band at base, another at about two-thirds their length, and with the apices while. - Habitat. Near Utica, Miss.«*)

Z tohoto popisu nedá se soudili na lood, kterému tato třásněnka přináleži.

\section{(.) 180 .}

1894. F. M. Webster. Insects of the Year. Insect Life. Washington. Vol. VII. No. 2. Sir. 206.

*) Nach dieser Beschreibung lässt sich nicht beurtheilen, welcher Gattung die Art angehört. 


\section{J. UZEL, MONOGRAFIE RADE, "THYSANOP'TERA“.}

Zde dèje se zmínka o spoustách, jež zpûsobila jakási tr̉ásněnka (dle Perganda Thrips tabaci) na cibuli r Ohiu (Spojené státy).

\section{181 .}

1894. Sirrine a Lowe urerejn̆uji (Bulletin 83, new series, of the New York Agricultural Experiment Station, p. 680.-682.) zprávu o škodách zpûsobených jistou trásnènkou (dle Perganda Thrips tabaci) a podávají popis i výkresy toho druhu.

\section{182 .}

1894. E. Rieuter. Berättelse . . beträffande ängsinasken och andra skadeinsekter.

Finska Landtbruksstyrelsens Meddelanden. No. VII.

Aulor pojednává zde na str. 32.-34. o škodách třásnènkami na obilí zpủsobených.

\section{Č. 183 .}

*1 895 . F. Trybom. Jakttagelser om vissa blåsfotingars (physapoders) uppträdande i gräsens blomställningar jämte några drag ur släktel Phloeothrips utvecklingshistoria. Föredrag rid Entomologiska Föreningens sammanträde den 27 April 1895. Entomologisk Tidskifift. Str. 157.-194.*)

*) Trybom beschreibt in dieser Arbeit vier Arten, nämlich: Phloeothips frumenturia Beling, Belothrips brevistylis nov. sp., Chirothrips leamuta nov. sp. und Thrips intonsa nov. sp. - Phloeothrips frumenturiu Beling ist ein Vertreter der von mir aufgestellten Gattung Anthothrips. Ich nenne jedoch diese Art A. aruleata Fabr. Meiner Neinung nach ist nämlich Belings Pll. frumenturia identisch mit Burmeisters Art Pll. albipemis, mit der Haliday seine Art, welche er für Fabricius' Phl. uculeata hält, identificiert. Wohl leugnet Burme is ter für seine Art das Vorkommen eines Zahnes auf den Tarsen der Vorderbeine, indem cr jedenfalls das dort wirklich vorhandene, bei den Weibchen winzige Zähnchen übersah. Die schwarze Linie, die er am Rande der Oberflügel angibt, lässt sich dadurch erklären, dass eine wasserklare Lamelle, wie es der Flügel dieser Art ist, manchmal am Rande (zumal in einer Flüssigkeit) mit einer solchen versehen erscheint, obwohl dieselbe in der That nicht vorhanden ist. Dass B urmeisters Art der Gattung Anthothrips angehört. bestätigt der Umstand, dass sie in Wiesenblüten ziemlich zahlreich vorkommt und dass ihr Kopf und ihr Prothorax gleichlang sind. Die vollkommen wasserhellen Flügel, von denen nur die oberen am Grunde etwas getrübt sind. überzeugen uns. dass wir es nicht mit Authothr. statices zu thun haben, dessen Oberflügel filst ganz graubraun getrübt sind. Weil Haliday seine Art aculeata mit Burmeisters allipemis identificiert, corrigiert er dadurch seine frühere Behauptung (Entom. Mag., 1836, S. 441), dass diese Art durch einen besonders langen Kopf ausgezeichnet sei. - Trybom erwähnt bei dieser Gelegenlueit eine Zeichnung Lindemans aus dem Jahre 1887 (Nr. 153, Fig. 20), welche den Vordertarsus der Art Phlorothrips armatu Lindem. (= Anthothrips statices) vorstellt, und sagt, dass der Zahn darauf grösser als bei seinen Exemplaren derselben Art sei. Dieser Zahn ist jedoch nicht identisch mit dem kleinen Zähnchen, welches sich bei den Weibchen auf der Innenseite der Vordertarsen befindet: es ist jene Kralle. welche bei den Phlocothripiden unten an allen Tarsen rorkommt, und sich gewöhnlich knapp an dieselben anlegt, so dass sie übersehen werden kann. Bei Lindemans Exemplar wurde sie jedoch zufällig durch die Praeparation abstehend und in dieser Stellung ron demselben gezeichnet: das Zähnchen blieb dafür unberücksichtigt.

Die Art Belothriqs brexistylis, welche Trybom beschreibt, gehört nicht der Gattung Belothrips. sondern der von mir aufgestellten Gattung Orythrips an, und ist identisch nit Reuters 
Na str. 158.-168. sestavuje Trybom v jazyku švédském zkráceně vše, co mu známo je z literatury o škodách třásněnek na obili, načež podává na str. 169._-182. vlastní své zkušenosti, pojednávaje zvláště o škodách tr̉ásněnkami na travinách způsobených. Na str. 190.-194. píše o larvách a nỵmfách tubulifer (druhı̆ ITmi, aculeata a statices). Mimo to podává (na str. 182.-190.) šédský popis druhû Phloeothrips frumentaria Beling. Belothrips brevistylis nor. sp.. Chirothrips hamata nov. sp. a Thrips intonse nov. sp.

Pliloeothrips frumentaria Beling jest rástupce mnou nově narrženého rodu Authothrips. Jmenuji však druh ten A. aculeata Fabr. Mvasím totǐ̆. že Belingùv druh Phl. frumentaria jest toložný s Burmeisterovým Plol. albipenuis. s nímž Haliday stotožñuje svủj druh, který má za Fabriciủv Phl. aculeata. Oršem upírá Burmeister pro svůj druh prílomnost zubu na prednich tarsech; zajisté však přehlédl malinký zoubek u samic tam se nalézajici. Černou linii pak, klerou na okraji hor̆. krídel udavá, možno vysvěllili úkazem. że jeví se nám někidy na okrajích ěirỵch blanek (jakou je kr̂́idlo toho druhu), obzvláště jsou-li v nèjaké tekutině, černý lèm, ač tento ve skutečnosli se tam nenachází. Z̆e Burmeisterùv druh jest Authothrips, v tom nás značně polvizuje okolnost, že na lukích $\mathrm{v}$ kvètech dosti čehnè se vyskytuje a že má hlavu a prothorax slejně dlouhé. Úplně čirá kî́ídla, z nichž jen horejši jsou na basi trochu zkalená, nás přesvědčují o tom, že to není Authothrips statices, jenž má kirídla skoro celí šedohnědẽ zkalená. Poněvadž Hali da y svủj druh aculecıtu stotožn̆uje s B u r m e isterovím albipennis opravuje tím své tvrzení v èasopise Entomological Magazine (z r. 1836.) na str. 4t1., totǐ̌ že vyznamenává se dlouhou hlavou. - Trybom zmi-

Belothrips bicolor (= Oxythrips hastatum.). Trybom gibt als Unterschierl zwischen den beiden genannten Arten die verschiedene Länge des Stylus und des 6. Fühlergliedes an. Was die Länge des Stylus anbelangt, vergl. die Bemerkung auf S. 135. R euters Angabe, dass das 6. Fühlerglied so lang wie das 5. sei. beruht jedenfalls auch auf einem Irrthum, da bei den übrigen Vertretern der Gattung Oxythrips, ja bei allen Vertretern der Thripiden überhaupt (nur die exotischen Gattungen Heliothrips und Parthenothrips ausgenommen). das 6. Glied an Länge das 5. immer übertrifft. Trybo ms Exemplare haben in der zweiten Hälfte der vorderen Längsader $3-5$ Borsten, wogegen unsere Exemplare ebendort regelmässig mit j Borsten versehen sind.

Die Art Chirothrips hamata ist identisch mit meiner C\%. Duclae.

Tryboms Art Thrips intonsa ähnelt stark der Art, welche ich Physopus vulgutissima Halid. nenne. Körperfarbe, Fühlerform, Behaarung des Prothorax und beider Längsadern inn Oberflügel sind dieselben. Nur die Färbung der Bcine ist sehr verschieden. Trybom gibt nämlich an, sie sei braun, und regelmässig seien die Tarsen und ein kleinerer oder grösserer Theil der Vordertibien gelbbraun. („Brun. . . O Oftast äro tarserna samt mer eller mindre stor del af framtibierna gulbruna“.) Auch geschieht in Tryboms Beschreibung keine Erwähnung von dem auffallenden Charakter meiner Exemplare, nïmlich von der Verengung des Kopfes nach hinten.

Es sei noch bemerkt, dass Trybom Halidays Art Cirirothrips manieata nach Burme ister Ch. longipemis nennt, da ihm Halidays Beschreibung aus dem Jahre 1836 zu unvollkommen erscheint. Meiner Meinung nach ist jedoch die betreffonde Ait durch das von Haliday gegebene Kennzeichen: „antennae breves compressae" hinlänglich charakterisiert, da die zweite bekannt gewordene Art der Gattung Chirothrips weit nicht so breite und nicht so kurze Fühler aufweist. 
ňuje se zde téż o výkresu Lindemanově (Č. 153., str. 336., fig. 20.), predstavujícím tarsus prední nohy od druhu Phloeothrips armata lindem. (= Anthothrips statices) a praví, że zub na onom tarsu je větší, ně̌ u jeho exemplárủ. Zub ten není však totožný s malinkým zoubliem na vnitr̀ní straně předních tarsu u samic se nalézajícím; jest to onen drápek, který u tubulifer na všech tarsech dole se nalézá a obyčejně těsně k nim prìléhá, takže bývá pìehlédnut. Zde náhodou se pr̉i praeparaci odchlípil a tak byl Lindemanem nakreslen; menší zoubek za to byl vynechán.

Druh Belothrips brevistylis. Trybo mem popisovaný, nenáleži do rodu Belothrips, nýbrž do novẽ mnou navrženého rodu Oxythrips a jest totožný s Reuterovým druhem Belothrips bicolor (= Oxythrips hastata). Trybom udává jakožto rozdíl mezi oběma jmenovanými druhy délku stylu a šestého článku tykadel. Pokud se délky stylu týče, srovnej poznámku na str. 134. Udaj Reuterủ v pak, že 6. čl. v tykadle jest tak dlouhý jako 5., jest zajisté taktéž omylem, nebot žádný zástupce toho rodu, ba žádný zástupce stenopter vủbec (exotické rody Heliothrips a Parthenothrips vyjimaje), nemá 6. článek $\mathrm{v}$ délce rovný pátému, nýbř̌ vždy delší. Exempláře Trybomovy mají v druhé polovině hor̂. žilky $3-5$ chlupủ, kdežto naše exempláre pravidelně pèti chlupy tam json opatreny.

Druh Chirothrips hamata jest totožný s mým druhem Ch. Dudae. Trybom udává ho mimo ze Š̃védska též z okolí Jeniseje y Sibírii.

Trybomův druh Thrips intousa podobá se značně druhu, jejž pokládám za Physopus vulgatissima Halid. Barva těla, tvar tykadel, chlupatost prothoraxu a obou podélných žilek $\mathrm{v}$ hor̉. křídle jsou tytéž. Jen barva noh jest velmi odchylná. Trybom udává totiž, že je hnědá, a že pravidlem jsou tarsy a menší nebo větši část předních tibií žlutohnědé. Také nedèje se $\mathrm{v}$ popisu Trybomově zmínky o nápadném znaku mých exemplár̆ů, totiž o zúžení hlavy nazad. Dle Tryboma vyskytuje se ten druh v klasech pšeničných, v pochvách nejhořejšího listu žita i v různỵch květinách, a sice od konce května až do konce zár̆í.

Pokud se týče druhu, jejž Trybom nazývá Thrips vulgatissima, poznáváme z uvedených znakủ (tykadla tmavá, jen třetí článek jejich světlý; prothorax na předních rozích bez dlouhých štětin; hlavní žilka v hořejším křídle v druhé polovině se tremi chlupy), že jest velmi podobný mému druhu Pluysopus pallipennis, který však od Halidayova druhu vulgatissimı zcela jiným zbarvením noh se rozeznává.

Budiž zde též podotknuto, že Trybom nazývá Halidayův druh Chirothrips manicata dle Burmeistera Ch. longipennis, poněvadž se mu zdá býti popis Ha-

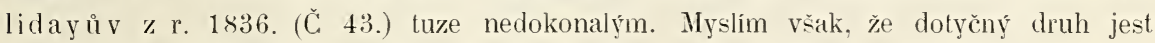
dostalečně charakterisován slovy Halida yovými: »an tennae breves compressae«, poněvadž druhý druh rodu Chirothrips, jejž jsme poznali, nemá daleko tak širokých ani lak králkých tykadel. 


\section{H. UZEL, MONOGRAPHIE DER ORDNUNG THISANOPTERA.}

Konečně chci ještě zmíniti se o nematodech, jež Trybom u druhư Anthothrips statices a "Thrips vulgatissima" nalezl. I jednotlivỵch exemplárích shledal 10, 20 az̃ 40 kusù těchto červíkủ.

\section{C.. 184 .}

1895. Osborn a Mally udáraji (Bulletin 27 of Jowa Agricultural College Experiment Station for 1895. p. 139.-142.) że Thrips allii Gillette (dle Perganda Thrips tabaci) žije mimo na cibuli a zelí též na bílé r̀epè, jeteli a na nejrủznèjšich květinách zahradnich. - Při této př́ležitosti chci zmíniti se o tom, že na zemědělském ústavě v Jowě zabývá se téz̆ Miss Alice M. Beach studiem trásněnek.

\section{¿̇. 185 .}

*1895. T. Pergande. Observations on certain Thripidae. Insect Life. Vol. VII. No. 5. Str. 390.-395.*)

Pergande popisuje zde ètyrĭ druhy tr̉ásněnek: Ileliothrips cestri nov. sp., $I$. fasciata nor. sp., Euthrips occidentalis nor. sp. a Thrips tabaci Lindem.

Prvá z jmenovanỵch třásněnek popsána již Reuterem r. 1891. (С̆. 168.) pod jménem Heliothrips femoralis. Bỵla Pergandovi zaslána už před léty z Massachusettsu (kdežžla ve skleníku na ('estrum nocturumm) a Reu ter em ze skleníků finnskỵch. Mimo to pozoroval ji Pergande sám ve sklenících u Washingtonu, a to zvl. nadmíru ěetně na listech od Amaryllis. jejiž listy značně poškozovala.

Druhá tr̃ásněnka. Heliothrips fasciata nov. sp., byla Pe rgandovi zastána G. WV. Harneyem z Kalifornie ( ('uba County), kdež jen v malém počtu vyskytla se na listech pomerančových. Dle popisu nelze rozhodnouli, zdali patři opravdu do rodu Heliothrips

*) Pergande beschreibt in dieser Arbeit vier Arten aus Nordamerika, nämlich: Heliothrips cestri nov. sp., II. fasciata nor. sp., Enthrips occidentulis nov. sp. und Thrips tabaci Lindem.

Heliothrips cestri (aus Massachusetts und aus Glashäusern bei Washington) ist identisch mit der von Reuter im J. 1891 beschriebenen Art Heliothrips femoralis.

Von Pergandes Meliothrips fasciata lässt sich nach dessen Beschreibung nicht mit Bestimntheit angeben, ob sie der Gattung Heliothrips oder Purthenothrips angehört. Sie lebt in Californien auf Orangenblättern.

Linthrips ocridentulis ist wohl eine Art der Gatlung Physopus. Sie kommt in Cialifornien in Orangenblälen und auf Aprikosen- und Erdäpfelblättern vor.

Thrijs: taluaci lindem., welche Pe rgan de von vielen Orten in den Vereinigten staaten angibt, ähmelt meiner Art Thrips commmis, unterscheidet sich jedoch von ihr durch die Form des Prothorax, welelıe nath Pergande (der auch Exemplare von Lindeman erhielt) mehs lang als breit ist (bei Thrips rommunis ist der Prothorax ausgesprochen mehr breit als lang). und durch die Färbung der Abdominalsegmente, auf deren Hinterrande sich eine breite dunkle Binde befindet (die Aldominalsegmente meiner Irt sind ginz gleichmäsig gefürbt). - Ich will hier noch auf den Umstand aufmerksan mathen, ob un॰lht viclleichıt sehr in die Länge gezogene (in schwachen Spiritus gequollene) Ex(mplare untersurht worken seien. Bei solehen kann freilich der Prothorax etwas mehr lang als breit vorkommen, weil rom und hinten Weichtheile heraustrelen: auch werden die breiten und lichten Verbindungshäule zwischen den einzehen Abdominalsegmenten sichtbar und lassen dann dat Abdomen licht und dunkel gebindert erseheinen. (Vergl. Butlers ,Aptimothrips fascintus"s:) 


\section{J. UZEL. MONOGRAFIE RADU "THYSANOPTERA".}

nebo snad do rodu Parthenothrips. Pri lélo príležitosti zmiñuje se Pergande též o tom, że druh Heliothrips haemorhoidalis bỵl nalezen na pẽstovaných i divokých rostlinách v Brasilii. Popis druhu Heliothrips fasciata Pergande jest ná-ledujicí:

Heliothrips fasciata Pergande. Length. about $1 \mathrm{~mm}$. General color, black. Head and thorax dark brown; the anterior margin of the prothorax and more or less of the mesolhorax yellowish-brown. Eyes black. Ocelli clear. yellowish. Antennae whitish; a broad band on joints 3 and 4, apex of the fifth and the remaining joints black. Legs black, with apex of femora, base and apex of tibiae, and the tarsi, except the apex yellow. Anterior wings blackish; their base and a broad band beyond the middle transparent white. Posterior wings taintly and uniformly yellowish. Fringes blackish. Head and thorax reliculated and furnished rather sparsely with short, slightly curved hairs. Some short and stiff hairs, becoming more numerous toward the end of the body. may also be observed near the posterior lateral angle of the abdominal segment; one or two larger ones on segments 5 to 8 and a number of long bristles along the posterior margin of the ninth."

Treli diuh, Euthrips occidentalis nov. sp., jest asi zástupce rodu Plyysopus. Nalezen byl A. Crawem a D. W. Goquillettem v Kalifornii, kdež poškozuje listy bramborû i meruněk a žije četně $v$ květech pomerančových. Popis jeho, Pergandem podaný, jest následujicí:

Euthrips occidentalis Pergande. , Length, 0.9 to $1.2 \mathrm{~mm}$. General color, orange yellow, with the posterior margin of the abdominal segments broadly dusky or blackish. Eyes hairy. black. Ocelli reddish. Antennae dusky, with base and tip of the joints paler. Wings yellowish, the spines and fringes blackish. Head twice as broad as long. Eyes very large, occupying about two-thirds or more of the sides of the head, and coarsely granulated. Head and pronotum transversely striated. Joints 3 and 6 of the antennae longest and nearly subequal in length; the third with a shorth though distinct pedicel. Joints 2, 4, and 5 next in length, also subequal. The last two joints, usually termed the stylus, are smallest, though the last is considerably longer than the penultimale one. Joints 2 to 5 bear each about six bristles around the apex and the sixth about the same number around the middle. Besides these bristles, there may be noticed a pair of slout, bluntly pointed, curved, sensorial spines, near the end of joints 3 and 4, originating from a rather large, membranous spot, similar to those organs in Thrips tritici. *

O čtvrtém druhu, t. zv. trásněnce cibulové (the onion thrips), snáší Pergande vše, co o něm dověděti se mohl, a cituje četné udaje jednotlivých oekonomů severoamerických, roztroušené po tamnějšich oekonomických časopisech. Praví, že třxisnènka ta žije na nejrozmanitējších mistech ve Spojených státech, a sice hlavně na zelenině (zvl. cibuli značně poškozuje), mimo to však také na květinách zahradních, na meruňkách atd. Stotožñuje ji s trrásněnkou, kterou Lindeman roku 1888. (C̆. 158.) pod 
jménem Thrips tabaci z Besarabie popsal, a kterou mu tento také poslal. Též z Holšna od L. Seiferta ji obdržel. Pergande myslí, že trásnènka Thrips tabaci dostala se s cerstrou zeleninou z Evropy do Ameriky, kdež se pak velmi rozšíitila. - Podáváme zde ony l'ergandem rỵlknuté znaky toho druhu, které popis Lindemanủr z r. 1888. (Ċ. 158.) doplñuji :

(Thrips tabaci Lindem.) »Color pale yellow, the thorax somewhat darker; sides of thorax and an elongated squarish spot on the meso-nolum more or less distinctly dusky. Abdominal segments marked with a rather broad. darker. or lighter dusky band posteriorly. . . Antennae and legs pale dusky, with tip of larsi somewhat darker. Wings faintly rellowish. their fringes and bristles dusky. . . Head about as broad as long, and transversely striated. Prothorax longer than broad, slightly narrowed in front; its anterior and posterior angles rounded, and provided wilh two backward-directed diverging spines at each posterior angle. . . .

Thrips tabaci podobá se značnè mému druhu Thrips communis, rozeznává se však od ncho tvarem prothoraxu, jenž je dle Pergánda delši než širăí, keležlo u druhu mého pravý toho opak se shledává: mimo to má T. tabaci zadni okraje élánkủ abdominalnich zdobené nahoìe širokiou tmavou sluhou, čehož u druhu Thrips communis nespatrujeme. 


\section{Résumé des historischen Theiles.}

In diesem Theile hat der Verfasser ein Verzeichnis aller ihm bekannt gewordenen Arbeiten (194 Nummern) über die Thysanopteren geliefert, und zwar in chronologischer Anordnung. Bei jeder Arbeit wurde angegeben, was sie Neues enthält, und was überhaupt in ihr Bemerkenswertes vorkommt. Dieser Theil soll nicht nur als literarischer Anzeiger dienen, sondern auch den Weg andeuten. den das Studium der Thysanopteren rom Anfange an bis zur allemeuesten Zeit gegangen ist. Wenn es dem Verfasser hier und da bei einigen wenig wichtigen Aufsätzen nicht gelang, die genaue Jahreszahl ihres Erscheinens zu erfahren, so bittet er es damit zu entschuldigen, dass dies das erste nach Vollkommenheit strebende Verzeichnis der Thysanopterenliteratur ist, und dass er durch die Verhältnisse ausschliesslich auf eigene Kräfle angewiesen war. Die Arbeiten, welche mit einem Stern bezeichnet sind, wurden vom Verfasser durchstudiert.

Von diesem Theile werden dem der böhmischen Sprache Unkundigen wenigstens die Titel der 194 angeführten Arbeiten von Nutzen sein: auch im Texte ist manches allgemeinverständlich. Besonders mache ich auf das auf S. 417 u. 418 befindliche Verzeichnis aufmerksam, in dem die Artennamen Halidays mit den in dieser Monographie gebrauchten verglichen werden.

Dem fast vergessenen Aufsatz, entnommen der Micrographia Curiosa Bonannis, des Entdeckers der Thysanopteren, wurden zwei Textbilder ( 8 u. 9 auf S. 405 u. 406) hinzugefügt, und zwar ein von dem erwähnten Autor im Jahre 1691 hergestelltes Bild einer Fransenfliege (wohl Authothrips statices) und das Mikroskop, mit Hilfe dessen Bonanni dieselbe aufzeichnete.

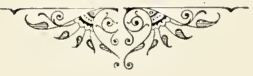





\section{REJSTRIK DRUHU, ROJU atd.") Register der Arten, Gattungen etc.*)}

\author{
A. \\ abdominalis (var.) 169 \\ Acanthothrips 259 \\ aculeata $240,455,456$ \\ acuminata 155 \\ adonidum 168 \\ adusta 185 \\ adusta (var.) 73,75 \\ adusta (var.) 81, 83 \\ adusta (var.) 96. 98 \\ adusta (var.) 99, 101 \\ adusta (var.) 108, 109 \\ adusta (var.) 110, 111 \\ adusta (var.) 120. 121 \\ adusta (var.) 175. 176 \\ adusta (var.) 180 \\ Aeolothripidae 62 \\ Aeolothrips 68, 278 \\ ajugae 136 \\ albicincta 75 \\ albicornis (var.) 96. 98 \\ albipennis 240, 455, 456 \\ albocincta 75 \\ albopicta 264 \\ albopilosa 190 \\ albosignata 271 \\ allii 451 \\ alni 189 \\ anacardii 269 \\ Anaphothrips 142
}

angulicornis 452,454

angusta 231

angusticeps 191

angustifrons 272

annulicornis (Thr.) 218

annulicornis (Phl.) 269

annulicornis (var.) 177, 178

annulicornis (var.) 123, 124

annulipes 258

antennata $\$ 1$

antennatus $\$ 1$

Anthothrips 237

apicalis 247

Aptera 223

aptera 251

Apterae 223

Aptinothrips 151, 279

armata (Anaph.) 145

armata (Phl.) 238, 455, 457

aspera 105

asperulae 280

atrata 107

atratus 107

\section{B.}

Baliothrips 204

basalis 115

Belothrips 154. 134, 135, 455

Benseleri 219

betae $15 \mathrm{~s}$

bicolor (Bel.) 134, 135, 456 bicolor (Crypt.) 235

bicolor (rar.) 123, 124

bicolor (var.) 134, 135

bicolor (var.) 136, 137

bidens 87

bigemmata 271

biuncata 208

biuncinata 207

Blasenfüsse 282

Bolacothrips 211

Bonamnii 227

Brachyderi 79

brevicornis 205

brevistylis $45 \tilde{5}, 457$.

brunnea 280

\section{(.)}

raespitis 245

calcarata 195

caryae 279

Cephalothrips 244

cerealium 89, 210, 211

cestri 458

Chirothrips $79,218,456,457$

Coleoptrata 6.2

Coleothrips $71.72,73,278$

communis $176,447,458,459$

concolor (var.) 172, 173

conical $2 \pi i$;

connaticolnis (var.) 153, 154

ronsociata 12.2

*) Císla znamenaji strany této monogratie.

**) Die Nummern zeigen die Seiten der vorliegenden Monographie an. 
H. UZEL, MONOGRAPHIE DER ORDNUNG THYSANOPTERA.

copiosa $252,452,453$

coriacea 254,260

corticis 260

corymbiferarum 276

crassipes 452, 453

croceicollis 27!

Cryptothrips 208

cynorrhodi 276

I).

decora 119

Degeeri 162

Dendrothrips 159

denticornis 86

dentipes 234

Dictyothrips 157

dilatuta 202

discolor 200

dispar 205

distincta 121

distinguenda 239

dracaenae 1\%1

Drepanothrips 213

Dudae $83,456,457$

E.

Elyoptera $2 \cdot 23$

ericae 216

Eudactyli 79

euphorbiate 146

Euthrips 122, 458, 459

F.

fasciata (Aeol.) 72

faseiata (Phl.) 279

fasciata (Hel.) 458,459

fasciatipennis 78

fasciatus (Apt.) 279

femolalis (Hel.) 170, 458

femoralis (Thı.) 217

ferruginea $14: 3$

firma 135

flava 186,220

flavicornis 219

flavipes $235,246,247$
Fransenfliegen 282

Fransenflügler 282

Fr'iči 126

frontalis 128

frumentaria $241,455,456$

frumentarius 240,241

fulvicornis (var.) 96, 98

fungi 251

fusca 64

fuscipennis 204

fuscus 64

G.

gracilicolnis (var.) 180. 181

gramineae 449

graninum 210

gratiosa 67

grossulariae 276

Gymnopterae 79

H.

haemor'hoidalis 168

Halidayi (Idol.) 267

Halidayi (Plil.) 269

hamata 456,457

Haplothrips 240

hastata $134,456,457$

Heliothrips 167, 171, 458, 459

Heterogynae 79

Heteropterae 223

Homopterae 79

Hoplothrips 237, 240, 247, 260

hradecensis 262

\section{I.}

Icarus 232

Idolothrips 265

inconsequens 117

intermedia 114

intonsa 4.6. 457

\section{J.}

Jordani 212

juniperina 274 il.

Klapáleki 203

Kollari $s 7$

I.

lacertina 266

laevicollis 21 .

laevior (var.) 199, 200

lata 230

lativentris 225

leucanthemi 275

limbata 72

Limothrips 85, 279, 451, 454

linaria 192

lini 279

Liothrips 261

livida 277

longicollis 197

longipennis $80,456,457$

longispina 225

longistylosa 131

loti 115

\section{II.}

major 179

mali $27 \AA, 45 t$

manicata $80,456,457$

marginata 266

Megalothrips $22 t$

melaleuca 71

melanopa 186

Melanothrips 63

Melanthrips 64

Micropterae 79

minor 256

minuta $243,452,453$

minutissima 193

monilicornis 245

\section{N.}

Neogami 79

nervosa 102

nigra 242

nigra (var.) 185, 186

nigripes 229 


\section{J. UZEL, MONOGRAFIE RADU, "THYSANOPTERA“.}

nigriventris 106

nigropilosa 198

nigropilosa (var.) 96, 98

nitidula 154

nodicornis 260

\section{0.}

obesa 64

obscura 148

obseura (var.) 123, 124

obscurus 148

obsoleta (var.) 187, 188

occidentalis 458,459

ochracea 277

Odontothrips 112, 115

oleae 438

olivaria 277

olivarius 277

Oxythrips 133

\section{$P$.}

Pachythrips 141

pallens 200

pallicornis 240

pallida 101

pallipennis 110

pallipes (var.) 233

paradoxa 275

Parthenothrips 170

parva 257

parviceps 139

parvipennis 270

pedicularia 246,247

persicae 277

phalerata 112

Phloeothripidae 223, 452

Phloeothrips 254, 225, 229, 234, $235,237,238,240,241$, $242,245.246,247,250$, 251, 254, 258, 260, 263, $269,270,271,272,277$, $278,279,280,452,453$

phylloxerae 432

Physapi 24

Physapoda 24
Physapodes 24, 252, 415

Physapus 24, 95, 107, 122, 14\%, 276

physapus 89, 95, 174

Physopoda 24, 282

Physopus 94, 458, 459

physopus 174

picipes 277

pilosa 129

pini (Phys.) 125

pini (Trich.) 251

Platythrips 214

poaphagus $279,439,446,448$

Poecilothrips 264

pragensis (var.) 263,264

primulae 119

Prosopothrips 165

puchýrnatky 439

pulla (var.) 177, 179

R.

ranunculi 275

Reuteri 213

Rhaphidothrips 131

Rhipidothrips 66

robusta 104

rufa 152

rugicollis 217

\section{S.}

salicaria 182

salicis 122

saltatrix 164

sambuci 181

Schotti 266

secalina 87

semicaeca 249

Sericothrips 90

setinodis 263

similis 145

sinillima 254

Sminyothrips 206

solanacearum $187,383,441$

sordida 150

spectrum 266 staphylinus 91

statices $237,238,243,455$,

457

Stenelytra 78

stenomelas 270

Stenoptera 78

Stenothrips 209

striata 220

striaticeps 216

stylifera 152

subaptera 141

subtilissima 269

T.

tabaci $447,458,459$

Taeniothrips 119, 205

tenuicornis 99

Terebrantia $\mathbf{6 1}$

Thripidae 78, 24

Thripididae 24

Thrips 17:3, 24, 64, 72, 73, 80, 81, 86, 87, 89, 95, 105, 107, $112,115,119,122,141,14 x$, 152, 154, 155, 168, 171, 174, 181, 186, 187, 193, 194, 200, 204, 205, 214, 216, 217, 218. 219, 220, 240, 241, 250. 251, 266, 274, 275, 276, 277, 278 , 279, 280, 447, 454, 456, 457, 458

Thripsina 24

Thripsites 24

Thysanoptera 24, 282

tibialis (Thr.) 218

tibialis (Phl.) 225

tiliae 160

Tmetothrips 141, 200

Trichothrips 246

trifasciata 278

trifasciatus 454

tristis 277

tritici 220, 278, 434, 451, $4 \check{5} 4$

tr̀ásněnky 439 


\section{H. I\%EL, MONOGRAPHIE DER ORDNUNG THYSANOPTERA}

Tubulifera 22\%, 223

tunicata 214

I.

ulicis 115

uhmi $250,254,260$

ulnifoliorum $1 \%$

urticae 186, 187
V.

valida 183

variegata 275

Vejdovskýi 166

versicolor 69

Vésitarses 24, 282, 415

viminalis 196 virgo 148

vittata 71,73

vulgatissima $95,111,456,457$

Z.

Zygothrips 243, 452,453 
J. UZEL, MONOGRAFIE RADU, THYSANOPTERA“.

\section{REJSTHÍR AUTORL.*) Register der Autoren.**)}

A.

Amyot 422

Aslimead 454

B.

Baker 451

Beach 458

Beal 442

Becker 436

Beling 434

Bergroth 448

Berkenhout 413

Bertkau 439, 444, 445

Bjerkander 41 ;

Blanchard 424

Bolils 450

Bold 433

Bonanni 403

Bouché 416

Brauer 442

Bremi 429

Bülow-Pieth 424

Burmeister 419,421

Butler 436

\section{i.}

Cameron 444

(Gohn 43:)

Comstock 435, 448

Cook $4+2$
Cornelius 433

Costa 441. 442

Curtis $419,423,440$

Cuvier 415

D.

Dahlbom 420

De Geer 406, to9

Degeer 406, 409

Deyrolle 432

Dimitriewicz 436, 437

Dohrn 424, 435

Dokhtouroff 441

Dufour 420

Duméril 415

E.

Erichson 420,422

F.

Fabricius 412, 413, 414

Farwick 436

Fernald $4+2$

Fitch 429, 430

Fletcher 450

Frauenfeld 432

Frič 439

\section{G.}

Garman 450

Geer 406, 409
Geoffroy 409

Gerstaecker 430

Gillette 451

Girard 432

Gleichen 410

Goeze 411

Gmelin 412

II.

Haliday 416, 419, 425

Hanis 425

Heeger 427, 428

Heer 431

Hofmann tio

Holmgren 434

J.

Jablonowski 452

Jordan 448,449

K.

Kästner 409

Kirby 413,414

Körnicke 436,443

Kolenati $4: 31$

Krauss 439, 443

I.

Ladureau 437, 438

Latreille +15

Lindeman 4:3. 444,446

*) Cisla znamenaji strany tèto monografie.

**) Die Nummern zeigen die seiten der vorliegenden Monographie an. 
H. U\%EL, MONOGRAPHIE DER ORDNUNG THYSANOPTERA.

Linnaeus 407, 408, 409, 412

Linné 407, 408, 409. 412

Lintner 439, 446, 451

Löw 432,448

Lowe 455

\section{II}

Mally 458

Man 434

Marsham 413

Mayer 44 ?

Menge 433

Mülleı (A.) 433, 434

Müller (O. F.) 410

\section{N}

Newman 416, 429

Nicholson 414

Nördlinger 429

\section{0.}

Orinerod 443

Osborn 440. 441. 444. 449, 458

Osten-Sac!ien 4:31

Oustalet 435

\section{1}

Packard 433, 434, 441, 443

Passerini 416

Pérez 443
Pergande 439. 440, 458

Portschinsky 441

R.

Redtenbacher 445

Regel 430

Reuter (E.) 455

Reuter (O. M.) 437. 438. 442. 450

Riley 432

S.

Schäffer 411

Schaum 424, 428

Schlechtendal 445

Schneider 443

Schöyen 435, $45 \mathrm{~L}$

Schrank 411

Scopoli 408

Scudder 433, 435

Serville 42.2

Shaw 415

Shipley 446

Sirrine 455

Simitl 451

Stephens 415

Stew 414

Strauss-Dürkheim 415

Sulzer 40s. 410

Szaniszló 435, 438
T.

Tamburin 422

Targioni-Tozzetti 444

Taschenberg 431, 434

Thaxter 449

Thomson 438

Trybom 451, 455

Turton 414

I.

Uljanin 434

Uzel 449

V.

Vassalli-Eandi 414

Villers 413

IV.

Walker 425,430

Walsh 431, 432

Webster 454

Werner 443

Westrood 420, 428

Widgalm 441

Wittmack 435

Trood 415

\section{7.}

Zetterstedt 421

Zittel 433 


\section{REJSTRIK OBYDLI TKASNENEK.* Register der Wohnorte.**)}

A.

Abies alba. str. 391., S. 399.

Abies larix str. 392., S. 399.

Abies picea str. 392., S. 399.

Acer platanoides str. 394.. S. 400.

Acer pseudoplatanus str. 394., S. 400.

Aesculus hippocastanum str. 395., S. 400.

Agrustenma githago (krèty. Blüten) 14, 67 ;

(mladé listy, junge Blätter) 21.

Ajuga 36.

Alnus glutinosa str. 393., s. 400.

Anemone nemorosa 26, 27.

Anthyllis vulneraria str. 389., S. 399.

Armeria vulgaris 14 .

Armoracia rusticana str. 384., S. 399.

Avena sativa str. $371 ., 379$, S. 398.
B.

Bäume, Blätter, s. „Blätter der Bäume und

sträuche" ; Rinde, s. „Rinde, abgestorbene".

Berge S. 368 .

Beta vulgaris str. 381., S. 398.

Betula alba str. 392., S. 400 .

Blätter der Bäume und Sträuche 14, 26, 29, $30,44,50,51,52,5 \%, 60,64,65,69,71$,

$83,106,122$.

Blätter niederer Pflanzen 3, 7. 11, 13, 14, 15, $21,25,28,30,34,35,39,44,58,59,64$, $69,73,78,106$.

Blüten auf Wiesen und Feldern 1, 6,9, 14, 18, $21,22,25,57,58,62.63 .64,67,104$, 105, 106.

Blüten in Gärten str. 3\$9.. S. 399.

*) Všecky zde obsaženẻ udaje vztahuji se jen na vlastni pozorováni autorova, v Čechảch konanả. 一 Cifry znamenaji čisla, pod kterými jednotlivẻ druhy v Ċảsti systematické tèto monografie a $v$ obsahu jsou uvedeny. V mnohých připadechı však poukázảno je tẻž $\mathrm{k}$ straně, na niž se nalèzả seznam druhů, na dotyčnè rostlině žijicich. - Veliký počet rozličných květů, ve kterých jsem třásněnky nalezl, nevypočitảvảm zde jednotlivě, nýbrž shrnujii je v různẻ skupiny: v květy lesni, kvêty lučni, polni atd. Z těch skupin uvảdim ještě zvláštẽ jen jmèna těch rostlin, kterẻ hosti nějaký dıuh vzảcný, aneb které jsou jinèmu hojnẻmu neobyẻejnè milỷm pŕ̛ibytkem, takže tam velmi četně se vyskytuje, a připojuji jen tyto druhy, ač tam i jiné obývati mohou. Tak dlužno ku přx. hledati různè druhy tř̉sněnek, v pampelisce (Taraxacum) żijici, mezi ,květy lučnini a polnimi“ neb ,květy jarnimi“, poněvadż v rejstr̉iku nalezneme u pampelisky jen dva druhy zaznamenané, z nichž jeden jest vzảcný, druhý pak v množstvi kvẻt jeji obývả,

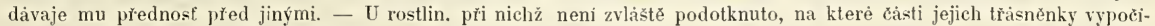
tanè se zdržuji, jest miněn vżdy květ.

**) Alle hier enthaltenen Angaben beziehen sich nur auf die vom Verfasser selbst in Böhmen gemachten Erfahrungen. - Die Ziffern zeigen die Nummern an, unter welchen die einzelnen Arten im Systematischen Theile der vorliegenden Monographie (und in Inhalte) angeführt werden. Oft wird jedoch auch auf die Seite hingewiesen, auf der sich ein Verzeichnis der auf der betreffenden Pflanze lebenden Thysanopteren befindet. - Die mannigfaltigsten Blüten, welche ich untersucht habe, werden hier nicht einzeln aufgezählt, sondern in verschiedene Gruppen zusammengefasst; so in: „Blüten in Wäldern“, ,Blüten auf Wiesen und Feldern“ etc. Aus diesen Gruppen habe ich nur einzelne Pflanzenarten noch besonders angeführt, und zwar jene, welche eine seltene Art beherbergen oder für eine gewöhnliche ein besonders angenehmer und daher viel besuchter Aufenthalsort sind. So wird man z. B. die zahlreichen Thysanopterenarten, welche in Löwenzahn (Taraxacum) vorkomnen, unter „Blüten auf Wiesen und Feldern" oder unter „Frühlingsblumen“ zu suchen lıalın, weil wir hei Taraxacum im Register nur zwei Arten verzeichnet finden, und zwar eine ziemlich seltene und eine häufig vorkommende, welche jedoch diese Blüten anderen vorzieht. - Wo nicht der Pflanzentheil besonders angegehen ist, meine ich immer die Blüte. 


\section{H. UZEL. WONOGRAPHIE DER ORDNUNG THYSANOPTERA.}

Blüten in Wäldern $14,21,22,24,27,30,31$, $38,42,45,57,59,62,63,64,84,75,104$. 106.

Blütenstände, trockene (im Winter) 9, 13, 14 . $21,57,58,59,106$.

Brassica oleracea str. 384., S. 399.

Butomus umbellatus 21, 58, 106.

\section{C.}

Calluna vulgaris 38,64 .

Carpinus betulus str. 392., S. 399.

Carum carvi str. 387., S. 399.

Centaurea cyanus 67 .

Cerastium arvense 1.

Cerealia str. 371., s. 371, 397, 398.

Chenopodiun 58.

Chrysanthemum leucanthenum 25, 104.

Cirsium palustre 15 .

Colchicum autumnale 1t, 21.

Cornus mas 64

Corydalis cava 27.

Corylus avellana str. 392., S. 399.

\section{D.}

Daucus carota str. 387., S. 399.

Drn 7, 10, 11, 13. 14, 20, 21, 23, 25, 32, 33, $34,37,39,44,45,46,48,53,62,72,73$. $74,75,82,101,102,103,106,111$; v zimè mino to $9,15,27,29,57,58,84$.

\section{E.}

Epilobium angustifolium 64 .

Equisetum 14, 21, 44, 46, 64 .

Erythraea centaurium 58 .

Eupatorium cannabinum 58, 59 .

Euphorbia $43,79$.

\section{F.}

Fagus silvatica str. 392., S. 399.

Felder, s. die Namen einzelner cultivierten Pflanzen oder „Blüten auf Wiesen und Feldern".

Flechten an Bäunen 11, 14, 29, 52, 59, 61, $106,116,120$.
Fragaria str. 388., S. 399.

Fraxinus excelsior str. 394., S. 400.

Frühlingsblumen (die ersten) 14, 16, 17, 21, 26. $27,43,46,57,58,63,64,69,106$.

\section{G.}

Gärten, s. „Blüten in Gärten“.

Galanthus nivalis 14

Galium 84.

Gebirge S. 368.

Gerste S. 398, 371.

Getreide S. $371,397,398$.

Glashäuser S. 390.

Gräser auf Wiesen S. 379, 398.

\section{H.}

Hafer s. 398, 371.

Helianthus annuus str. 382., S. 398.

Helianthus tuberosus str. 382., S. 398.

Heracleum sphondylium (listy, Blätter) 121.

Hordeum str. 371.. 378 , S. 398.

Hor'y str. 364 .

Humulus lupulus str. 381., S. 398.

Hyoscyamus niger $6,11,14,15,21,22,58$, $64,106$.

\section{I.}

Iris pseudacorus 14,106 .

\section{J}

Jec̀nen str. 371.. 378.

Juncus 9.

\section{K.}

Keře, kvèty 14, 21, 57, 58, 59, 63, 64, 106 ; listy, viz „Listy stromů a keř̀u“.

Korn s. $397,371$.

Kůra zpuchřelá 29, 51. 99, 100, 108, 110,112, $115,116,120 ; \mathrm{v}$ zimě mimo to $11,14,21$, $52,59,60,61,104,105,106$.

Kvètenství seschlá ( $\mathrm{v}$ zimè) $9,13,14,21,57$, $58,59,106$.

Kvèty jarni (proni) 14, 16, 17, 21, 26, 27, 43, $46,57,55,63,64,69,106$.

Kvèty lesni ' $14,21,22,24,27,30,31,38,42$, $45,57,59.62,63,64,75,84,104,106$. 


\section{J. I\%EL, MONOGRAFIE RAIU, "THYSANOPTERA*.}

Kvèty lučni a polni $1,6,9,14,18,21,22,25$, $57,58,62,63,64,67,104,105,106$.

Květy zahradni str. 389 .

\section{I.}

Lappa tomentosa (listy, Blätter) 11, 14, 5๙, 106. Laub, abgefallenes 11, 13, 96; im Winter ausserdem 14, 21, 27, 35, 57. 58, 60, 104, 106.

Lesy, viz "Kvèty lesni“ a „Drn“.

Leucojum vernum 27.

Linaria vulgaris 6.

Linum usitatissimum str. 385., S. 399.

Listi spadané $11,13,96 ; \mathrm{v}$ zimě mimo to 14 , 21, 27, 35. 57, 58, 60, 104, 106.

Listy rostlin nizkých $3,7,11,13,14,15.21$, $25,28,30,34,35,39,44,58,59,64,69$, $73,78,106$.

Listy stromú a keřů $14,26,29,30,44,50,51$, $52,58,60,64,65,69,71,83,106,122$.

Lišejníky na stromech $11,14,29,52,59,61$, $106,116,120$.

Louky, viz „Kvèty luční a polni" nebo „Drn“. Lycium barbarum 14, 21, 58.

\section{II.}

Malva alcea 21 .

Mech 96,102 ; v zimè mimo to $11,21,29,35$, $106,122$.

Melandryum pratense 21, 67.

Mercurialis perennis 70 .

Monotropa hypopitys 21, 27, 64 .

Moos 96. 102; im Winter ausserdem 11. 21, 29, 35. 106,122 .

\section{N.}

Nuphar luteum 14, 58.

\section{0 .}

Obili str. 371.

Onobrychis viciaefolia str. 389., S. 399.

Orchis sambucina 76 .

Ores str. $371 ., 379$.

Oxalis acetosella 27 .

\section{P.}

Panicum miliaceum str. 379., S. 398.

Papaver somniferum str. 384., S. 398.

Papilionaceae 14, 25.

Paseky, viz „Kvèty lesni“, „Krèty luěni“ a „Drn“.

Pedicularis palustris 75 .

Petasites officinalis 14.

Pflanzen in Glashäusern S. 390.

Phragmites communis 9, 58, 106.

Pinus silvestris str. 391., S. 399.

Pirus aucuparia str. 395., S. 400.

Pirus malus str. 395., s. 400.

Pole, viz jména jednotlivých rostlin pèstovaných neb „Kvèty lučni a polni".

Polygala amara 40.

Polygala vulgaris 1 .

Polygonum amphibium 14.

Polygonum fagopyrum str. 38\%., S. 398.

Polypori 110.

Populus str. 393., S. 400.

Potamogeton natans 14, 106.

Potentilla 16.

Prunus cerasus str. 396., S. 400.

Prunus domestica str. 395., S. 400.

Prunus padus str. 396., S. 400.

Pšenice str. 371., 378.

Pteris aquilina 64.

Pulsatilla pratensis 64 .

\section{Q}

Quercus str. 392., S. 399.

\section{R}

Ranunculus aquatilis $11,14,21,25$

Ranunculus ficaria 63 .

Rasen $7,10,11,13,14,20,21,23,25,32,33$, $34,37,39,44,45,46,48,53,62,72,73$, $74,75,82,101,102,103,106,111$ : im Winter ausserdem 9, 15, 27, 29, 57, 58, 84 . Ribes rubrum str. 388., S. 399.

Rinde, abgestorbene 29, 51, 99, 100, 108, 110 , 112. 115, 116. 120; im Winter ausserdem 11, 14, 21, 52, 59, 60, 61, 104, 105, 106. Robinia pseudacacia str. 396., S. 400. 


\section{H. UZEL, MONOGRAPHIE DER ORD NUNG THYSANOPTERA.}

Role, viz jména jednotlivých rostlin pèstovaných neb „Kvèty luèni a polni".

Rostliny ve sklenicich str. 390.

Rybniky, viz „Butomus, Iris, Juncus, Nuphar, Phragmites. Polygonum. Potamogeton, Ranunculus aquatilis, Sagittaria, Solanum dulcamara, Sparganium".

\section{S.}

Sagittaria sagittaefolia 14 .

Salix str. 393., S. 400.

Sambucus nigra (listy, Blätter) 60.

Sambucus racemosa (listy, Blätter) 60.

Scabiosa arvensis 18 .

Secale rereale str. 371., 378., S. 397.

Senecio nemorensis 59 .

Sesleria coerulea 70 .

Skleniky str. 390 .

Solanaceae 58

Solanum dulcamara (kvèty, Blüten) 58, (listy, Blätter) 59.

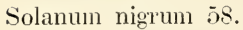

Solanum tuberosum str. 382., S. 398.

Sorbus aucuparia 108.

Sparganium ramosum 106.

Sphagnum 102.

Stellaria holosericea 27.

Sträuche, Blüten 14, 21, 57, 58, 59, 63, 64, 106 ; Blätter, s. „Blätter der Bäume und Sträuche".

Stromy, květy, viz jména jednotlivých stromů : listy, vìz „Listy stromů a ker̀ư : kůra, viz „Kùra zpuchřelä.

Syringa vulgaris str. 394., S. 400.
T.

Taraxacum officinale 43,63 .

Teiche, s. „Butomus, Iris, Juncus, Nuphar, Phragmites, Polygonum, Potamogeton, Ramunculus aquatilis, Sagittaria, Solanum dulcamara, Sparganium".

Tilia str. 394., S. 400.

Tragopogon pratensis 57.

Traviny luèní str. 379.

Trifolium str. $388 .$. S. 399.

Triticum sativum str. 371., 378., S. 398.

U.

Ulmus str. 393., S. 400 .

\section{V.}

Valeriana officinalis 58 .

Vicia faba str. 389., S. 399.

Vicia sativa str. 389.. S. 399.

Viola 27

Viscaria vulgaris 4 .

\section{W.}

Wälder, s. „Blüten in Wäldern“ und „Rasen“. Waldhaue, s. „Blüten in Wäldern“, „Blüten auf Wiesen" und "Rasen".

Weizen S. 371, 398.

Wiesen, s. „Blüten auf Wiesen und Feldern" oder "Rasen".

\section{Z.}

Zahrady, viz „Kvèty zahradni“. Zea mais str. 379., s. 398.

\section{L.}

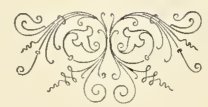




\section{Opravy a doplíky.}

Casu. který se mi naskytl během sazby této monografie, ǔ̌il jsem k opètornému (čtvrtému) srovnání svého materialu s popisy a mimo to k zpracování nově nasbiranyých zásob. Výsledkem těchto studii jest vètšina následujicích oprav a doplñkû:

Str. 32., ř. 11. zdola čti ,zřetelnè nezúžená“ místo "nezúžená".

S. 61., r.. 2. shora "neb" misto "nèkdy“.

S. 66., ř. 13. shora „značně“ má býti vynecháno.

S. 78.. Ǐ. 17. shora "neb" místo "nèkdy".

S. 87., ř. 11. zdola doplǹ: „Délka těla až i 1.5 inm."

S. 97., ř. 13. shora "skoro pohrdaji“ místo "pohrdaji".

S. 106. r.

S. 123., İ. 4. shora „kroužky bývají celé“ místo "kronžky celé".

S. 125., ì. 15. shora "ponèkud" místo „dosti značnè".

S. 128., r̀. 9. shora "taktéź, místo "mírnèji“.

S. 143 , ř. 6 . shora "nèkdy (u druhî amutu a euphorbiac)" místo "obyčejnè".

S. 145 ., r̀. 2. zdola ,asi tak douhý jako 3." místo „trochu delši než 3."

S. 151., r̀. 5. zdola „rufa a $\mathrm{n}$ druhu $A$. nitidulı scházi“ místo „rufa scházi".

S. 155., ř. 3. zdola „a tibie“ má býti vynechámo.

S. 157., ì. 10. shora "sbližena " iná býti vynecháno.

S. 159 .. ř. 8. shora "někdy po jednom" misto po jednom krảtkém slabším“; - г. 12. shora "dva" misto ,jeden".

S. 160 ., İ. 3. \%dola "sbihající místo "rozbíhajici".
S. 164., ì. 16. zdola "tibie“ místo "nohy".

S. $16 \pi .$, r̀. 14. shora „Na . . ěichovém" má býti vynecháno.

S. 170., ř. 10. zdola „Na . . ěchovém" má býti rynecháno.

S. 172. . ̌̀. 18. shora doplì: „Délka tèla někdy $1.3 \mathrm{~mm}$."

S. 177., Ǐ. 2. shora „tento článek, pak“ má býti vynecháno.

S. 184.. ř. 15. shora doplň: "Nèkteří ze sameů, jež jsem letos nalezl, mèli tykadla podobnè zbarvená jako samice".

S. 185 ., r̀. 16. zdola „èastèji“ místo „pravidlem“.

S. 193., r̀. 3. shora doplì: "výjimkou 2 neb 4 chloupky".

S. 197., r. 6. shora doplñ : „U několika samců novè mnou nalezených byly přední dvě prohlubiny dlouhé a úzké".

S. 199., ř. 5. shora doplñ: "nebo tìi chlupy".

S. 252 ., ř. 12. zdola doplñ : „Dèlka těla nèkdy až $2.5 \mathrm{~mm}$."

S. 255., זั. 7. shora doplì : „Někdy je ji\% 7 . cl. celý tmavý" : - ì. 3. shora ,tento a" má býti vynecháno.

S. 263., ř. 8. shora "pred koncem" misto „na konci". 


\section{Berichtigungen und Zusätze.}

Die Zeit, welche sich mir während des Druckes dieser Monographie bot, verwendete ich zu nochmaliger (vierter) Vergleichung meines Materials mit den Beschreibungen und ausserdem zur Bearbeitung neu eingesammelter Vorräthe. Das Resultat dieser Studien sind die meisten der folgenden Berichtigungen und Zusätze:

S. 48 , Zeile 10 von oben lies „nicht deutlich verengt" statt "nicht verengt".

S. 61, Z. 3 von unten lies „oder" statt "manchmal".

S. 66. Z. 7 v. o. "Pterothorax" statt, dieser" ; - Z. 7 v. u. „mehr lang“ statt "bedeutend länger".

S. 69, Z. 17 v. o. „stärksten“ statt „längsten“.

S. 74, Z. 7 v. u. "Arten Nr. 3 u. 4“ statt "zwei vorherg. Gatt."

S. 77, Z. 14 v. o. „Hintersehenkel“ statt „Hinterschienen".

S. 79 , Z. 13 v. o. „oder“ statt „manchmal“.

S. $88, \% .1$ v. u. setze hinzu: "Körperlïnge auch bis $1.5 \mathrm{~mm}$."

S. 99, Z. 7 v. o. "selten jedoch" s att „nur nicht" : - Z. 9 v. o. "IVien (Heeger)" ist wegzulassen.

S. 106 , Z. 6 v. 11. „wenig länger" statt „länger“ .

S. $121, \%$. j v. o. „anfangs" statt „an der Basis".

S. $124, \% .7$ v. o. „manehnral dic letzten" statt "die letzten".

S. 126, Z. 3 v. o. ,hinten ziemlich stark halsförmig eingeschnürt" ist wegzulassen.

S. 128, \%. 6 v. u. „ebenfalls“ statt „mässiger“.

S. 143, Z. 16 v. u. ,manchmal (armate u. cuphorbiace " statt "gewölınlich".

S. 146, \%. 17 v. o. "etiva so lang" statt „etwas länger".

S. 152, Z. 9 v. o. "mifa und bei A. mitidula fehlt" stat "rufa fehlt".

S. 156, Z. 8 v. 1. "und Vordertibien" ist wegzulassen.

S. 157, \%. 13 v. u. "einander genähert" ist wegzulassen.
S. $160,7.2$ v. o. „kein, oder ein“ statt „je ein kurzer dünnerer oder": - Z. $6 \mathrm{r}$. o. „zwei" statt "einem“.

S. 161, Z. 2 v. u. "convergierende" stalt "divergierende"

S. 165 , Z. 12 v. o. "Hintertibien" stalt „Hinterbeine".

S. 167, Z. 2 v. u. "Am ... Geruchszapfen" ist. wegzulassen.

S. 171, \%. 11 v. o. "Am . . Geruchszapfen" ist wegzulassen.

S. $173, \%$. 10 v. o. setze hinzu: „Körperlänge atch bis $1.3 \mathrm{~mm}$."

s. $178, \% .16$ v. o. "dieses, dann" ist wegzulassen".

S. 185. \%.5 v. o. setze hinzu : "Einige neuerdings gesammelten Exempl. hatten ihre Fühler zientich so wie die Weibchen gefürbt".

S. 186, Z. 9 v. o. "öters" statt ,regelmässig“.

s. 193 , \%. 17 v. u. setze hinzu: „ausnahmsweise 2 oder 4 Härchen."

S. $197, \%$. \& v. u. setze hinzu: ,Einige neuerdings gesammelten Exenpl. hatten die zwei vorderen Vertiefungen lang u. schmal."

S. 199, z 1 r. 1 . setze hinzu: ,oder drei Borsten".

S. 201, Z. 11 v. u. ,sehenkel in der Mitte" statt "sichenkel"

S. 205, \%. 4 v. o. "Ocellen " statt "Augen".

S. 253, \%. 15 v. u. setze hinzı: „Körperlänge manchmal bis $2.5 \mathrm{~mm}$."

S. $255, \mathrm{Z} 8$ v. u. "dieses und" ist wegzulassen; - Z. 5 v. u. setze hinzu: "Manchmal schon das 7. Glied ganz dunkel."

S. 263, \%. 9 v. u. "vor dem Ende“ statt „an Ende." 


\section{OBSAH. \\ INHALTSVERZEICHNIS.}

PŘEDMLUVA. - VORREDE.

I. Č́st゙ systematická. - I. Systematischer Theil ${ }^{\text {Pag. }} 9$

Úvodni poznámky. - Einleitende Bemerkungen . . . . . . . . . . . . . . 11

Sbírání třásněnek. - Über das Sammeln der Thysanopteren . . . . . . . . . 13

Úprava třásnènek pro pozdèjší studium. - Über das Präparieren der Thysanopteren 15

Seznam stanovisk, na kterỵch mé zásobỵ třásněnek sebrány bỵly. - Verzeichnis

der Fundorte . . . . . . . . . . . . . . . . . . . . . . . 17

Systematické postavení třásněnek. — Systematische Stellung der Thysanopteren . 18

Podoba prvotných třásněnek. - Gestalt der ursprünglichen Thysanopteren . . . . 20

Ordo Thysanoptera Halid. . . . . 24

Kliče k určování českých trásněnek . . . . . . . . . . . 27

Schlüssel zum Bestimmen der europäischen Thysanopteren . . . 42

I. SUBORDO TEREBRANTIA HALID. . . . . . . . 61

1. Fam. Aeolothripidae . . . . . . . . 152

1. Genus Melanothrips Halid. . . . . . . . . . . . . . . . 63

*1. Melanothrips fusca Sulz. . . . . . . . . . . . . . . . . . . . . . 64

2. Genus Rhipidothrips. (Nov. gen.) . . . . . . . . . . . . 66

*.2. Rhipidothrips gratiosa nov. sp. . . . . . . . . . . . . . . . . . 1 ;

3. Genus Aeolothrips Halid. . . . . . . . . . . . . . . . 68

*3. Aeolothrips versicolor nov. sp. . . . . . . . . . . . . . . . . . . 139

*4. Aeolothrips melaleuca Halid. . . . . . . . . . . . . . . . . . . . . 71

5. Aeolothrips vittala Halid. . . . . . . . . . . . . . . . . . . . . . 71

*6. Aeolothrips fasciata L. . . . . . . . . . . . . . . . . . . . . . . . 72

* 7. Aeolothrips albocincta IIalid. . . . . . . . . . . . . . . . . . . . 75

8. Aeolothrips fasciatipennis Blanch. . . . . . . . . . . . is

* Druhy hvězdičkou označené náležeji do launy české.

* Die ınit einem Stern versehenen Arten gehören der Fama von Böhmen an. 
4. Genus Chirothrips Halid. . . . . . . . . . . . . . . . . . 79

*9. Chirothrips manicata Halid. . . . . . . . . . . . . . . . . 80

*10. Chirothrips Dudae nov. sp. . . . . . . . . . . . . . . . . . . . . 83

5. Genus Lim othrips Halid. . . . . . . . . . . . . . . . . . 85

*11. Limothrips denticornis Halid. . . . . . . . . . . . . . . 86

12. Limothrips cerealium Halid. . . . . . . . . . . . . . . . . . . . . 89

6. Genus Sericothrips Halid. . . . . . . . . . . . . . 90

*13. Sericothrips staphylinus Halid. . . . . . . . . . . . . . 91

7. Genus Physopus (Deg.) Am. et Serv. . . . . . . . . . . . . . 94

*14. Physopus vulgatissima Halid. . . . . . . . . . . . . . . . . . . . . 95

*15. Physopus tenuicornis nov. sp. . . . . . . . . . . . . . 99

*16. Physopus pallida nov. sp. . . . . . . . . . . . . . . . 101

*17. Physopus nervosa nov. sp. . . . . . . . . . . . . 102

*18. Physsopus robusta nov. sp. . . . . . . . . . . . . . . . . . 104

19. Phrsopus aspera Halid. . . . . . . . . . . . . . . . . . 105

*20. Phrsopus nigriventris nor. sp. . . . . . . . . . . . . . . . . . . 106

*.1. Phrsopus atrata Halid. . . . . . . . . . . . . . . . 107

*.2. Physopus pallipennis nov. sp. . . . . . . . . . . . . . 110

*23. Phrsopus phalerata Halid. . . . . . . . . . . . . . . . . . . 112

*.24. Physopus intermedia nor. sp. . . . . . . . . . . . . . . . . . . . 114

*25. Physopus ulicis Halid. . . . . . . . . . . . . . . . . . . . . . 115

*26. Phrsopus inconsequens nov. sp. . . . . . . . . . . . . . . 117

*.7. Plysopus primulae Halid. . . . . . . . . . . . . . . . . . . . . . 119

*.๖. Physopus distincta nor. sp. . . . . . . . . . . . . . . 121

*29. Phrsopus ulmifoliorum Halid. . . . . . . . . . . . . . . . . . . 122

*30. Phrsopus pini nor. sp. . . . . . . . . . . . . . . 125

*31. Phrsopus Frièi nov. sp. . . . . . . . . . . . . . . . . . . 126

*3.. Phrsopus frontalis nor. sp. . . . . . . . . . . . . 128

*33. Phỵsopus pilosa nov sp. . . . . . . . . . . . . . . . . . . . . . 129

\&. Genus Rhaphidolhrips. (Nov. gen.) . . . . . . . . . . . . . 131

*34. Rhaphidothrips longistvlosa nov. sp. . . . . . . . . . . . . 131

9. Genus Oxythrips m. . . . . . . . . . . . . . 133

*35. Oxrthrip hastata m. . . . . . . . . . . . . . . . . . . . . . 134

*36. Oxvlhrips ajugate nov. sp. . . . . . . . . . . . . . . . 136

*37. Oxpthrips firma nov. sp. . . . . . . . . . . . . . . . 138

*3.. Oxythripe parviceps nov. sp. . . . . . . . . . . . . . . . 139

10. Genus Pachythrips m. . . . . . . . . . . . . . 141

*39. Pachythrips subaptera Halid. . . . . . . . . . . . . . . . 141 
11. Genus Anaphothrips m. . . . . . . . . . 142

*40. Anaphothrips ferruginea nov. sp. . . . . . . . . . . . . 143

*41. Anaphothrips similis nov. sp. . . . . . . . . . . . . . . . . 145

*42. Anaphothrips armata nov. sp. . . . . . . . . . . . . . . . . . 145

*43. Anaphothrips euphorbiae nov. sp. . . . . . . . . . . . . . . . . . 146

*44. Anaphothrips virgo m. . . . . . . . . . . . . . . . . . . . . . . 148

*45. Anaphothrips sordida nov. sp. . . . . . . . . . . . . . . 150

12. Genus Aptinothrips Halid. . . . . . . . . . . . . . 151

*46. Aptinothrips rufa Gmel. . . . . . . . . . . . . . . . . . 152

47. Aptinothrips nitidula Halid. . . . . . . . . . . . . . . . . 154

13. Genus Belothrips Halid. . . . . . . . . . . . . . 154

*48. Belothrips acuminata Halid. . . . . . . . . . . . . . . . . . . . 155

14. Genus Dictyothrips. (Nov. gen.) . . . . . . . . . . 157

*49. Dictyothrips betae nov. sp. . . . . . . . . . . . . . 158

15. Genus Dendrothrips. (Nov. gen.) . . . . . . . . . . . 159

*50. Dendrothrips tiliae nov. sp. . . . . . . . . . . . . . . . 160

*51. Dendrothrips Degeeri nov. sp. . . . . . . . . . . . . . . . . . 162

*52. Dendrothrips saltatrix nov. sp. . . . . . . . . . . . . . . 164

16. Genus Prosopothrips. (Nov. gen.) . . . . . . . . . . 165

*53. Prosopothrips Vejdovskýi nov. sp. . . . . . . . . . . . . . 166

17. Genus Heliothrips Halid. . . . . . . . . . . . . . 167

*54. Heliothrips haemorrhoidalis Bouché . . . . . . . . . . . . . 168

55. Heliothrips femoralis Reut. . . . . . . . . . . . . . . 170

18. Genus Parthenothrips m. . . . . . . . . . . . 170

*56. Parthenothrips dracaenae He g. . . . . . . . . . . . . . . . 171

19. Genus Thrips (L.) . . . . . . . . . . . . . . . 173

*57. Thrips physopus L. . . . . . . . . . . . . . . . . . . . 174

*58. Thrips communis nov. sp. . . . . . . . . . . . . . . . . 176

*59. Thrips major nov. sp. . . . . . . . . . . . . . . . . . . . . . 179

*60. Thrips sambuci Heeg. . . . . . . . . . . . . . . . . . . . . . . 181

*61. Thrips salicaria nov. sp. . . . . . . . . . . . . . . . 182

*62. Thrips valida nov. sp. . . . . . . . . . . . . . . . 183

*63. Thrips adusta nov. sp. . . . . . . . . . . . . . . . . . 185

*64. Thrips flava Schr. . . . . . . . . . . . . . . 186

*65. Thrips alni nov. sp. . . . . . . . . . . . . . . . . . . . 189

*66. Thrips albopilosa nov. sp. . . . . . . . . . . . . . . 190

*67. Thrips angusticeps nov. sp. . . . . . . . . . . . . . . . 191

*68. Thrips linaria nov. sp. . . . . . . . . . . . . . . . . . . . . 192

*69. Thrips minulissima L. . . . . . . . . . . . . . . . . . . . . 193 
Pag

"70. Thrips calcarata nov. sp. . . . . . . . . . . . . . . . . . 195

*71. Thrips viminalis nor. sp. . . . . . . . . . . . . . . . 196

*72. Thrips longicollis nov. sp. . . . . . . . . . . . . . . . . 197

*73. Thrips nigropilosa nov. sp. . . . . . . . . . . . . . . . . . 198

*74. Thrips discolor Halid. . . . . . . . . . . . . . . . . . . . . . 200

*75. Thrips dilatata nov. sp. . . . . . . . . . . . . . . . . 202

*76. Thrips Klapáleki nov. sp. . . . . . . . . . . . . . . . 203

77. Thrips fuscipennis Halid. . . . . . . . . . . . . . . . . . . 204

20. Genus Baliothrips m. . . . . . . . . . . . . . . . . . 204

*78. Baliothrips dispar Halid. . . . . . . . . . . . . . . . . 205

21. Genus Sminyothrips. (Nor. gen.) . . . . . . . . . . . . . 206

*79. Sminyothrips biuncinata nov. sp. . . . . . . . . . . . . 207

*80. Sminyothrips biuncata nov. sp. . . . . . . . . . . . . . . 208

22. Genus Stenothrips. (Nor. gen.) . . . . . . . . . . . . . 209

* s1. Stenothrips graminum nov. sp. . . . . . . . . . . . . . . . 210

23. Genus Bolacothrips. (Nor. gen.) . . . . . . . . . . . 211

*82. Bolacothrips Jordani nov. sp. . . . . . . . . . . . . . . . . . . . 212

24. Genus Drepanothrips. (Nor. gen.) . . . . . . . . . . . 213

*83. Drepanothrips Reuteri nov. sp. . . . . . . . . . . . . . . . . . . . 213

25. Genus Platythrips m. . . . . . . . . . . . . . . 214

*84. Platythrips tunicata Halid. . . . . . . . . . . . . . . . . . 214

85. Thrips ericae Halid. . . . . . . . . . . . . . . . . 216

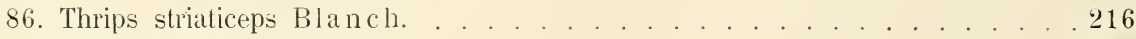

87. Thrips rugicollis Blanch. . . . . . . . . . . . 217

88. Thrips femoralis Blanch. . . . . . . . . . . . . 217

89. Thrips annulicornis Blanch. . . . . . . . . . . . 218

90. Thrips tibialis Blanch. . . . . . . . . . . . . . 218

91. Thrips laevicollis Blanch. . . . . . . . . . . . 218

92. Thrips Benseleri r. Frauenf. . . . . . . . . . . . . . . . 219

93. Thrips flavicornis Reut. . . . . . . . . . . . . . . 219

94. Thrips tritici Osborn . . . . . . . . . . . . . . . . . 220

95. Thrips striata Osborn . . . . . . . . . . . . . . . 220

II. SUBORDO TUBULIFERA HALID. . . . . . . . . . 222

3. Fam. Phloeothripidae . . . . . . 223

26. Genus Megalothrips m. . . . . . . . . . . . 224

*96. Megalothrips lativentris He e. . . . . . . . . . . . . . 225

*97. Megalothrips Bonannii nor.sp. . . . . . . . . . . . 227 
Par.

27. Genus Gryptothrips m. . . . . . . . . . 22s

98. Cryptothrips nigripes Reut. . . . . . . . . . . . . 229

*99. Cryptothrips lata nov. sp. . . . . . . . . . . . . . . 230

*100. Cryptothrips angusta nov. sp. . . . . . . . . . . . . . 231

*101. Cryptothrips Icarus nov. sp. . . . . . . . . . . . . . . 232

*102. Cryptothrips dentipes Reut. . . . . . . . . . . . . 234

*103. Cryptothrips bicolor Heeg. . . . . . . . . . . . . . . 235

28. Genus Anthothrips m. . . . . . . . . . 237

*104. Anthothrips statices Halid. . . . . . . . . . . . . . . . 237

*105. Anthothrips distinguenda nov. sp. . . . . . . . . . . . . . 239

*106. Anthothrips aculeata Fabr. . . . . . . . . . . . . . 240

107. Anthothrips nigra Osborn. . . . . . . . . . . 242

29. Genus Zygothrips. (Nov. gen.) . . . . . . . . . . . . 243

*108. Zygothrips minuta nov. sp. . . . . . . . . . . . . . 243

30. Genus Cephalothrips m. . . . . . . . . . . 244

*109. Cephalothrips monilicornis Reut. . . . . . . . . . . 245

31. Genus Trichothrips m. . . . . . . . . . . 246

*110. Trichothrips pedicularia Halid. . . . . . . . . . . . . 246

*111. Trichothrips caespitis nov. sp. . . . . . . . . . . . . . . . 248

*112. Trichothrips semicaeca nov. sp. . . . . . . . . . . . . 249

113. Trichothrips ulmi Fabr. . . . . . . . . . . . . 250

114. Trichothrips pini Halid. . . . . . . . . . . . . . . 251

*115. Trichothrips copiosa nov. sp. . . . . . . . . . . . . 252

32. Genus Phloeothrips Halid. . . . . . . . . . . . 254

*116. Phloeothrips coriacea Ha lid. . . . . . . . . . . . . . 254

*117. Phloeothrips minor nov. sp. . . . . . . . . . . . . . 256

*118. Phloeothrips parva nov. sp. . . . . . . . . . . . . 257

119. Phloeothrips annulipes Reut. . . . . . . . . . . 258

33. Genus A canthothrips m. . . . . . . . . . 259

*120. Acanthothrips nodicornis Reut. . . . . . . . . . . 260

34. Genus Liothrips m. . . . . . . . . . . . 261

*121. Liothrips hradecensis nov. sp. . . . . . . . . . . . . . 262

*122. Liothrips setinodis Reut. . . . . . . . . . . . . . 263

35. Genus Poecilothrips. (Nov. gen.) . . . . . . . . . 264

*123. Poecilothrips albopicta nor. sp. . . . . . . . . . . . 264

36. Genus Id ol othrips Halid. . . . . . . . . . . 265

124. Idolothrips marginata Halid. . . . . . . . . . . . . . 266

125. Idolothrips spectrum Halid. . . . . . . . . . . 266 
Pag.

126. Idolothrips lacertina $\mathrm{Halid}$. . . . . . . . . . . . 266

127. Idolothrips Schotti Heeg. . . . . . . . . . . . . . . 266

128. Idolothrips Halidayi Newm. . . . . . . . . . . . . . . . . 267

129. Phloeothrips annulicornis Halid. . . . . . . . . . . . . 269

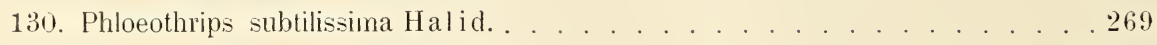

131. Phloeothrips anacardii Newm. . . . . . . . . . . . . . . . . . 269

132. Phloeothrips stenomelas Wlk. . . . . . . . . . . . . 270

133. Phloeothrips parvipennis Reut. . . . . . . . . . . . . . . . 270

134. Phloeothrips albosignata Reut. . . . . . . . . . . . . . 271

135. Phloeothrips angustifrons Bergroth. . . . . . . . . . 272

PŘÍVĚSEK. (Druhy neplatné.) - ANHANG. ('nngüllige Arten.) . . . 27t Závěrečné poznámky. - Schlussbemerkungen . . . . . . . 281

II. Část̉ palaeontologická. - II. Palaeontologischer Theil .....................

Résumé des palaeontologischen Theiles . . . . . . . . . . 293

\section{Cásṫ anatomická. - III. Anatomischer Theil . . . . . . . . . . . . . . . 297}

Úvodní poznámky. - Einleitende Bemerkungen . . . . . . . . . . . . . . 299

Integument. - Das Integument . . . . . . . . . . . . . 299

Ústroje pohybu. - Organe der Locomotion . . . . . . . . . . . . . . . 303

Soustava nervová. - Nervensystem . . . . . . . . . . . 308

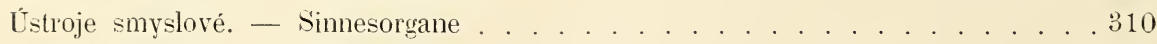

Ústroje zaživaci. - Verdauungsorgane . . . . . . . . . . . . . . . 31t

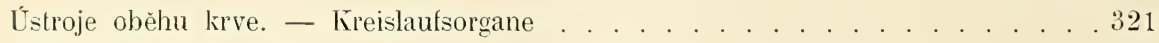

Ústroje dychací. - Athmungsorgane . . . . . . . . . . . . . . 322

Ústroje vyměšovací. - Excretionsorgane . . . . . . . . . . . . . 323

Ústroje pohlavní - Geschlechtsorgane . . . . . . . . . . . . . . 323

Sekundarní znaky pohlavní — Sekundäre Geschlechtscharaktere . . . . . . . . 327

Résumé des anatomischen Theiles . . . . . . . . . . 330

\section{IV. Část̉ vývojepisná. - IV. Entwicklungsge- schichtlicher Theil}

Vajičko. - Ei . . . . . . . . . . . . . . . . . . . . 333

Vỵvoj vajička. - Embryonalentwicklıng . . . . . . . . . . . . . 334

Larva. - Larve . . . . . . . . . . . . . . . . . . . . . 339

Nymfa. - Nymphe . . . . . . . . . . . . . . . . . . . . 341 
Page

Dospělá tîásněnka. - Imago . . . . . . . . . . . . . . . . 343

Metamorfosa tr̆ásněnek. - Metamorphose . . . . . . . . . . . . . 344

Parthenogenesis u třásněnek. — Parthenogenese . . . . . . . . . . . . . . . 345

Résumé des entwicklungsgeschichtlichen Theiles . . . . . . . . 348

\section{V. Část' biologická. - V. Biologischer Theil . . 351}

Obyydi třásněnek. - Wohnorte der Thysanopteren . . . . . . . . . . . 353

Potrava třásněnek. - Nahrung . . . . . . . . . . . . . . . 355

Přezimování třásněnek. - Winterquartiere . . . . . . . . . . . . 358

Pohỵby třásnènek. - Bewegungen . . . . . . . . . . . . . . . 359

Pohlavní ǧivot tr̆ásnènek. - Geschlechtsleben . . . . . . . . . . . . 360

Ǩladení vajiček. - Eierablage . . . . . . . . . . . . . . 361

Společnosti tř́sněnek. - Gesellschaften . . . . . . . . . . . 362

Nepřátelé tr̆ásněnek. — Feinde . . . . . . . . . . . . . . . . 362

Horizontalni a vertikalní rozširiení třásněnek. - Horizontale und verticale Verbreitung 363

Résumé des biologischen Theiles . . . . . . . . . . . 366

\section{VI. Část' oekonomická. - VI. Oekonomischer}

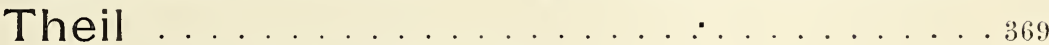

Résumé des oekonomischen Theiles ....................... . .

VII. Část' historická. - VII. Historischer Theil 401

Résumé des historischen Theiles ...............461

Rejstřík druhů, rodů atd. - Register der Arten, Gattung etc. 463

Rejstř́k autorů. - Register der Autoren . . . . . . . . . . . 467

Rejstřík obydlí třásněnek. - Register der Wohnorte . . . . . . 469 

ATLAS. 
. 


\section{TABULEI.}

Fig. 1. Sericothrips staphylinus Halid. G. Zvětšeni 19násobné.

Fig. 2. Chirothrips manicata Halid. J゙. Zvětš. 19nás.

Fig. 3. Aeolothrips albocincta Halid. Q. Zvètš. 19nás.

Fig. 4. Aeolothrips fasciata L. Q. Zvètš. 19nás.

Fig. 5. Physopus phalerata Halid. Q. Zvètš. 19nás.

Fig. 6. Physopus atrata Halid. Ơ. Zvělš. 19nás.

Fig. 7. Chirothrips Dudae nov. sp. q. Zvètš. 19nás.

Fig. 8. Limothrips denticornis Halid. Q. Zrètš. 19nás. 


\section{TAFELI.}

Fig. 1. Sericothrips staphylinus Halid. q. Vergrösserung 19.

Figg. 2. Chirothrips manicata Halid. $\sigma^{7}$. Vergr. 19.

Fig. 3. Aeolothrips albocincta Halid. \&. Vergr. 19.

Fig. 4. Aeolothrips fasciata L. ๆ. Vergr. 19.

Fig. 5. Physopus phalerata Halid. Ғ. Vergr. 19.

Fig. 6. Physopus atrata Halid. O'. Vergr. 19.

Fig. 7. Chirothrips Dudae nov. sp. f. Vergr. 19.

Fin. s. Limothrips denticomis Halid. q. Vergr. 19. 


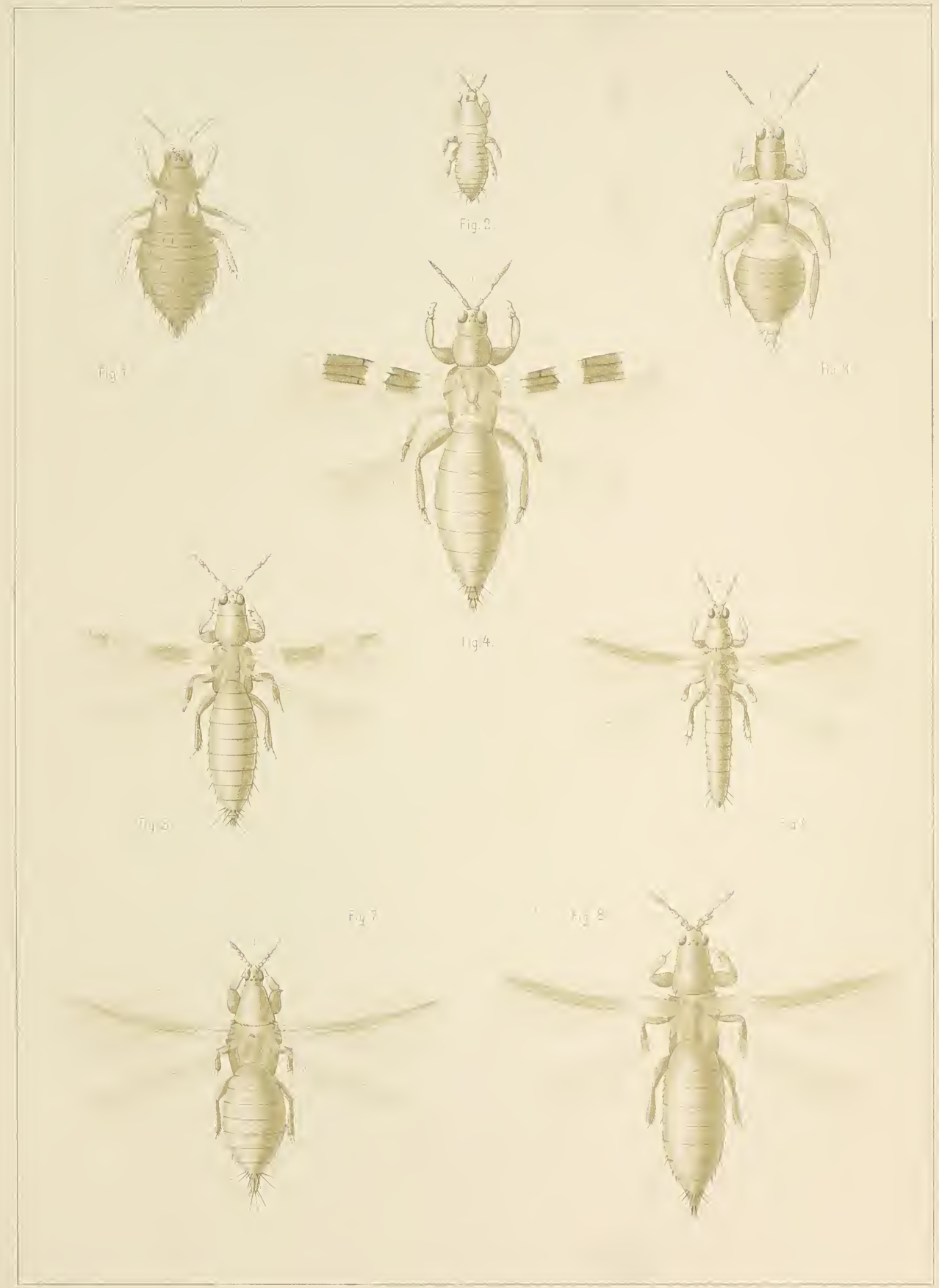





\section{TABULE I.}

Fig. 9. Prosopothrips Vejdoeskịi nov. gen., nov. sp. Q. Zvětš. 19nás.

Fig. 10. Belotlurips acuminatu Halid. ํ. Zvětš. 19nás.

Fig. 11. Anaphothrips virgo m. ‡. Zvětš. 19nás.

Fig. 12. Parthenothrips dracaenae Heeg. †. Zvètš. 19nás.

Fig. 13. Parthenothrips dracaenae Heeg. Larva. Zvětš. 19nás.

Fig. 14. Parthenothrips dracaenae Heeg. Nymfa. Zvětš. 19nás.

Fig. 15. Dendrothrips tiliae nov. gen., nov. sp. O. Zvètš. 19nás.

Fig. 16. Stenothrips gramimum nov. gen., nov. sp. Q. Zvètš. 19nás.

Fig. 17. Aptinothrips rufa Gmel. G. Zvètš. 19nás.

Fig. 18. Trichothrips pedicularia Halid. ơ. Zvětš. 19nás. 


\section{TAFEL II.}

Fig. 9. Prosopothrips Vejdovskýi nov. gen., nov. sp. \&. Vergr. 19.

Fig. 10. Belothrips acuminata Halid. Q. Vergr. 19.

Fig. 11. Anaphothrips virgo m. q. Vergr. 19.

Fig. 12. Parthenothrips dracaenae Heeg. C. Vergr. 19.

Fig. 13. Parthenothrips dracuenae Heeg. Larve. Vergr. 19.

Fig. 14. Parthenothrips dracaenae Heeg. Nymphe. Vergr. 19.

Fig. 15. Deudrothrips tiliae nov. gen., nov. sp. ॄ. Vergr. 19.

Fig. 16. Stenothrips gramimum nov. gen., nov. sp. Q. Vergr. 19.

Fig. 17. Aptinothrips rufa Gmel. q. Vergr. 19.

Fig. 18. Trichothrips pedicularia Halid. $\sigma^{\lambda}$. Vergr. 19. 


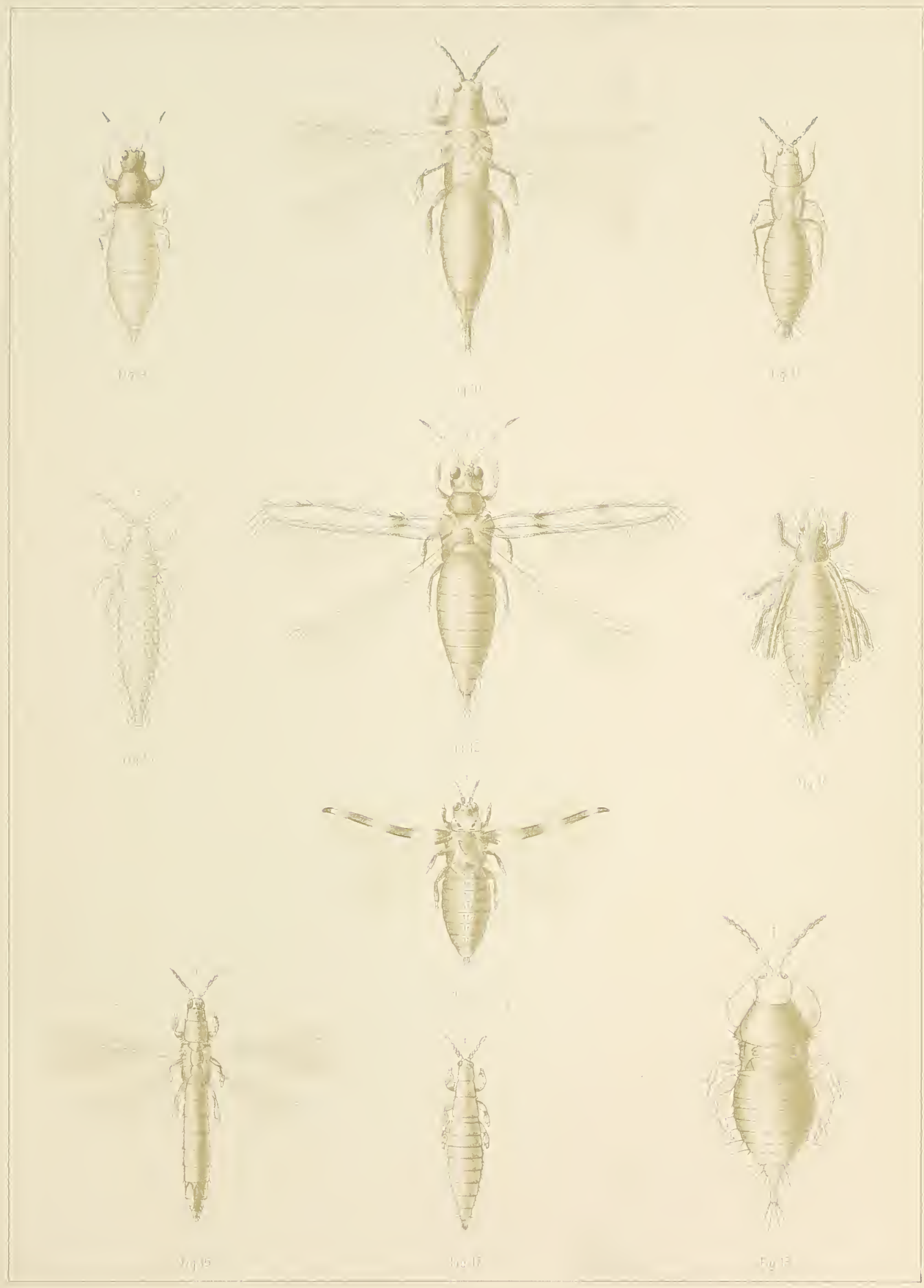





\section{TABULE III.}

Fig. 19. Megalothrips Bonamuii nov. sp. OJ. Zvětš. 19nás.

Fig. 20. Hegalothrips lativentris Heeg. \&. Zvètš. 19nás.

Fig. 21. Platythrips tunicata Halid. G.Zvètš. 19nás.

Fig. 22. Megalothrips lativentris Heeg. OJ. Zadní část abdomenu s hora. Zvètš. 17 nás. $a$, rourovitý výrostek na 6 . čl. abdom.

$b$, lupinek, prriléhající $\mathrm{k}$ basi tubu.

Fig. 23. Megalothrips lativentris Heeg. J . Zadní část abdomenu ze strany. Zv. 17 nás.

Fig. 24. Cryptothrips lata nov. sp. ‡. Zvětš. 19nás.

Fig. 25. Poecilothrips albopicta nov. gen., nov. sp. Hlava a prothorax. Zvèł. 33nás.

Fig. 26. Authothrips statices Halid. +. Hlava. Zvètš. 33nás.

Fig. 27. Plloeothrips para nov. sp. I. Hlava. Zvètš. 33nás. 


\section{TAFEL III.}

Fig. 19. Megahothrips Bonamii nov. sp. J . Vergr. 19.

Fig. 20. Megalothrips lativentris Heeg. 오. Vergr. 19.

Fig. 21. Platythrips tunicata Halid. ․ Vergr. 19.

Fig. 22. Megalothrips lativentris Heeg. $\sigma^{\nearrow}$. Hinterer Theil des Abdomens von oben. Vergr. 17.

a. röhrenförmiger Anhang auf dem 6. Abdominalsegmente.

b. Schuppe an der Basis des Tubus.

Fig. 23. Megalothrips lativentris Heeg. $\sigma^{\top}$. Hinterer Theil des Abdomens von der Seite. Vergr. 17.

Fig. 24. Cryptothrips lata nov. sp. . Vergr. 19.

Fig. 25. Poecilothrips albopicta nov. gen., nov. sp. Kopf und Prothorax. Vergr. 33.

Fig. 26. Authothrips statices Halid. +. Kopf. Vergr. 33.

Fig. 27. Phloeothrips paria nor. sp. \&. Kopf. Vergr. 33. 


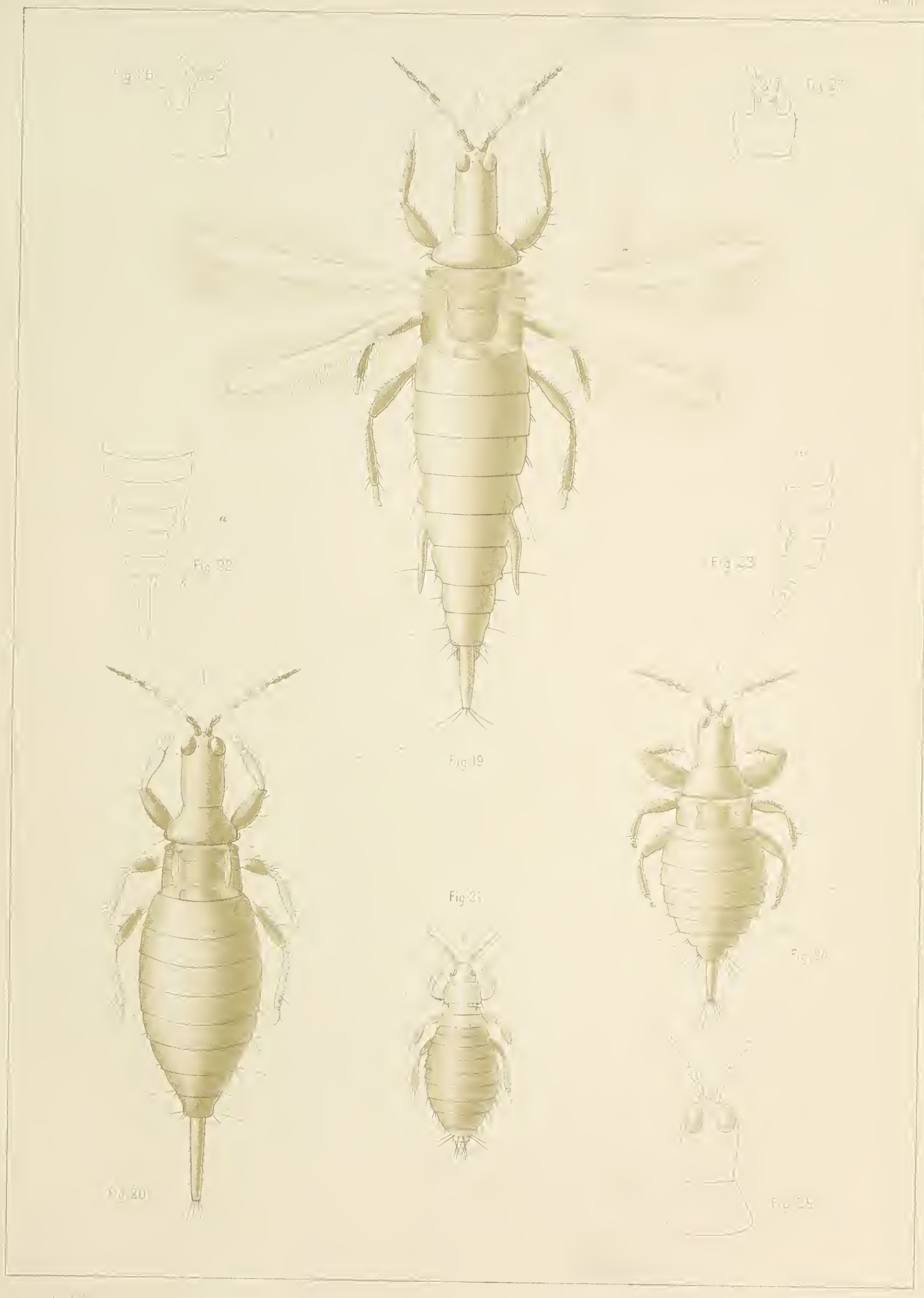





\section{TABULE IY.}

Fig. 28. Acanthothrips nodicornis Reut. + . Zvètš. 19nás.

Fig. 29. Phloeothrips coriacea Halid. \&. Zvětš. 19nás.

Fig. 30. Poecilothrips albopicta nov. gen., nov. sp. Hlava s kuželem ústním ze spodu. Zvětš. 33nás.

$a$, basalní rozšírenina bodce ústního,

$b$, maxilla,

$c$, submentum,

$d$, mentum,

$e$, makadlo labialní.

Fig. 31. Cryptothrips dentipes Reut. $\subsetneq$. Hlava s kuželem ústním ze spodu. Zvětš. 33 nás.

a, basalní rozšířenina bodce ústního.

Fig. 32. Trichothrips copiosa nov. sp. Hlava shora. Zvètš. 33nás.

Fig. 33. Cryptothrips dentipes Reut. ‡. Hlava shora. Zvètš. 33nás. 


\section{TAFEL IY.}

Fig. 28. Acanthothrips nodicomis Reut. $q$. Vergr. 19.

Fig. 29. Phloeothrips coriacea Halid. \&. Vergr. 19.

Fig. 30. Poecilothrips albopicta nov. gen., nov. sp. Kopf mit dem Rüssel von unten. Vergr. 33.

a, basale Erweiterung des Mundstachels,

$b$, Maxille,

$c$, Submentum,

d, Nentum,

e, Labiallaster.

Fig. 31. Cryptothrips dentipes Reut. q. Kopf mit dem Rïssel von unten. Vergr. 33. $a$, basale Erweiterung des Mundstachels.

Fig. 32. Trichothrips copiosa nov. sp. Kopf von oben. Vergr. 33.

Fig. 33. Cryptothrips dentipes Reut. q. Kopf von oben. Vergr. 33. 

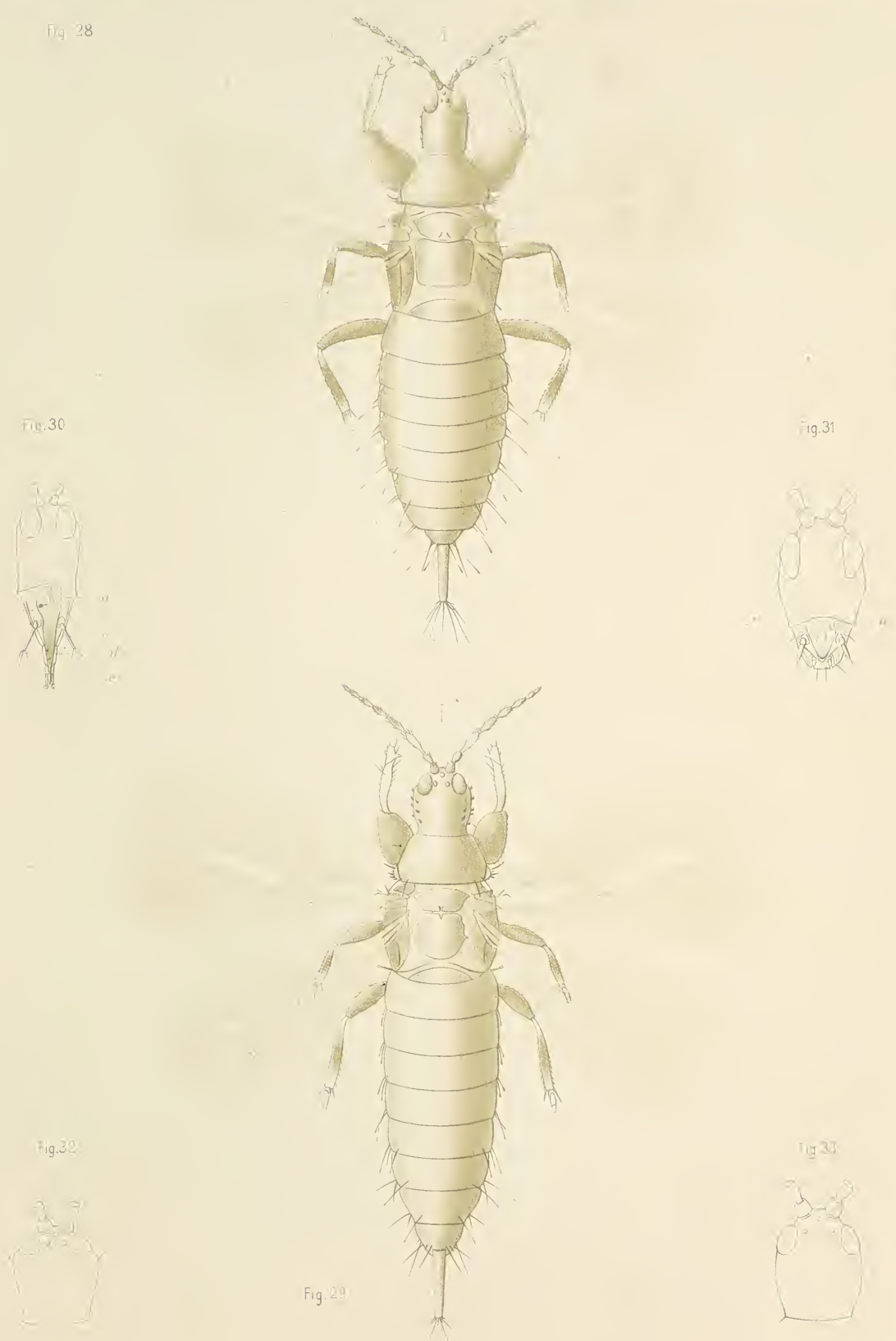



\section{TABULE Y.}

Fig. 34.-41. Melanotlerips fiesca Sulz.

Fig. 34. Hlava a prothorax. (37.) *)

Fig. 35. Tykadlo. (56.)

Fig. 36. Makadlo maxillarni. (325.)

Fig. 37. Makadlo labialní. (325.)

Fig. 38. Pr̀ední noha. (37.) — $a$. kyčel : b, stehno: $e$, lıoleñ ; $d$, $e$, oba ěl. chodidla; $f$, mèchýr̀ek.

Fig. 39. Q. Kř̀idlo. (33.) - $a$, pr̀edni, 7, zadní část žilky okružní; $e$, hořejší, d, dolejši żilka podélná; $e$. s̀upinka.

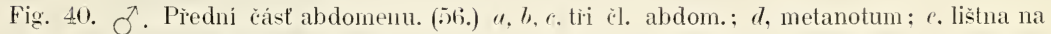
prvém èl. abdom.

Fig. 41. Cást přední nohy. (115.) - $\iota$. zub s postranními lupinky; $b$, tarsus; $c$, konec tibie.

Fig. 42. a 43. Rhipridothrips gratiosa nov. gen.. nov. sp.

Fig. 42. Hlava a prothorax. (37.)

Fig. 43. Tykadlo. (56.)

Fig. 44. Aeolotherips versicolor nor. sp. Hlava a prothorax. (37.)

Fig. 45. Acolothrips melatenca Halid. Kíidlo. (33.)

Fig. 46.-48. Aeolotherips fasciata L.

Fig. 46. Tykadlo. (56.)

Fig. 47. Pr̀edni tarsus. (56.) - a, konec tibie; 7, $c$, oba čl. tarsu; d, měchýřek; $e$, háčky.

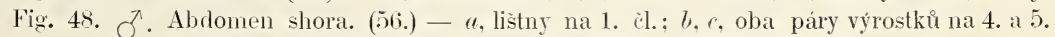
čl.; d, deska chitinová na 9. c̀l.: e, dvouhrotý výtvor přidržovací.

Fig. 49. Chirothrips manieata Halid. Levé tykadlo. (115.)

Fig. 50. Chirothrips Dudae nor. sp. Levé tykadlo. (115.)

Fig. 51. Limothrips denticornis Halid. §. Konec abdomenu. (56.) - 8, 9, 10, tři poslední c̀lánky abdom.; a, trny; b, klikatá lištna.

Fig. 52. Sericothrips stapleylimus Halid. Hořejši kǐidlo. (37.)

Fig. 53. a 54. Plyssopus vulgutissimu Halid.

Fig. 53. \&. Hlava a prothorax. (37.)

Fig. 54. 万ु. Konec abdomenu. (56.) - - . pochry pyje.

Fig. 50̃. a 56. Physopus robusta nov. sp.

Fig. 55. Predni noha. (56.) - $a$, zoubek na konci tarsu.

Fig. 56. 万. Konec abdomenu. (33.) - a, pochry pyje; $\downarrow$, trny na 8. èl. abdom.

Fig. 57. Plyysopus pallipemis nov. sp. 3. a 4. c̀l. tykadla. (56.)

Fig. 58.-60. Pliysopus phaterata Halid.

Fig. 58. Sestý čl. tykadla. (115.) - - . èirá šupinka.

Fig. 59. ૧. Pì̀ední noha. (56.)

Fig. 160. đ̆. 4. a 5. èl. abdom. (33.)

Fig. 61. Plyysopus ulicis Halid. O. Přední noha. (56.) - a, hrbolky na tarsu.

Fig. 62. Plyysopus primulae Halid. O. Hlava. (37.)

Fig. 63. Plyysopus ulmifoliorm Halid. †. Tykadlo. (70.)

Fig. 64. Physopus frontulis nor. sp. ‥ Hlava a prothorax. (37.)

Fig. 65̃. Plıysopus pilosa nor. sp. ठ․ Konec tykadla. (115.)

Fig. 66. Oxythrịs hustata m. f. Konec abdomenu. (33.) - Vzájenná délka dvou poslednich článků abdom. je rủzná, ponèvadž tyto články mohou býti více nebo ménè zataženy.

Fig. 67. Oxythrips ajugae nov. sp. ค. Prothorax. (37.)

Fig. 68. a 69. Oxythrips firme nov. sp.

Fig. 68. Makadlo maxillarni. (115.)

Fig. 69. Předni noha. (56.)

*) Cislo v závorce udává zvêtšeni. 


\section{TAFEL $Y$.}

Fig. 34-41. Mclanothips firsca Sul\%.

Fig. 34. Kopf und Prothorax. (37.)*)

Fig. 35. Fühler. (56.)

Fig. 36. Maxillartaster. (325.)

Fig. 37. Labiallaster. (325.)

Fig. 38. Vorderbein. (37.) - - , Hüfte; $b$, Schenkel; $c$, Schiene; $d$, $c$, beide Tarsalglieder ; $f$, Haftblase.

Fig. 39. $千$. Oberflügel. (33.) - $a$, vorderer, $b$, hinterer Theil der Ringader ; $c$, obere, $d$, untere Längsader; $e$, Schuppe.

Fig. $40 \pi$. Vorderer Theil des Abdomens. (56.) - $a, b, c$, drei Abdominalsegmente: $d$, Metanotum: $e$, Leiste auf dem ersten Abdominalsegmente.

Fig. 41. Ein Theil des Vorderbeines. (115.) - $a$, Zahn mit zwei anliegenden Blättchen am Grunde; $b$. Tarsus; $c$, Ende der Schiene.

Fig. 4u u. 43. Rhipidothrips gratiosa nov. gen., nov. sp.

Fig. 42. Kopf und Prothorax. (37.)

Fig. 43. Fühler. (ว6.)

Fig. 44. Aeolothrips versicolor nov. sp. Kopf und Prothorax. (37.)

Fig. 45. Aeolothrips melaleuca Halid. Flügel. (33.)

Fig. 46-48. Aeolothrips fasciata L.

Fig. 46. Fülıler. (ö6.)

Fig. 47. Vordertarsus. (56.) $-a$, Ende der Schiene; $b, c$, beide Tarsalglieder: $d$, Haftblase: e, Krallen.

Fig. 48. 万. Abdomen von oben. (56.) - $a$, Leisten auf dem 1. Segmente; $b, c$, beide Parare Auswächse auf dem 4. u. 5. Segm.; $d$, Chitinplatte auf dem 9. Segm.; $e$, zweizinkiges Klanmergebilde.

Fig. 4!. Chirothrips manicuta Halid. Linker Fühler. (115.)

Fig. 50. Chirotlurips Durlac nov. sp. Linker Fühler. (115.)

Fig. 51. Limothrips denticornis Halid. ơ. Ende des Abdomens. (56.) - 8, 9, 10, die drei letzten Abdominalsegmente; $a$, Dornen: $b$, Chitinleiste.

Fig. 52. Sericothrips staphylinus Halid. Oberflügel. (37.)

Fig. 53 u. 54. Physopus vulgatissime Halid.

Fig. 53. f. Kopf und Prothorax. (37.)

Fig. 54. 7 . Linde des Abdomens. (56.) - a, Penisscheiden.

Fig. 5j u. 56. Pleysopus robustu nov. sp.

Fig. 5.). Vorderbein. (56.) - $-a$, Zälınchen am Ende des Tarsus.

Fig. 5̇6. đ’. Ende des Abdomens. (33.) - $a$, Penisscheiden; $b$, Dornen auf dem 8. Abdominalseginente.

Fig. 57. Pliysopus pallipennis nov. sp. 3. u. 4. Fühlerglied. (56.)

Fig. 58-60. Pleysopus phuterutu Halid.

Fig. 58. Sechstes Fühlerglied. (115.) - $a$, helle Schuppe.

Fig. 59. ค. Vorderbein. (56.)

Fig. 60. 万人. 4. u. 5. Abdominalsegment. (33)

Fig. 61. Physomus ulicis Halid. \&. Vorderbein. (56.) - $u$, Höckerchen auf dem Tarsus.

Fig. 62. Pleysopus primulae Halid. Q. Kopf (37.)

Fig. 6i3. Physopus ulmifoliorum Halid. Q. Fühler. (70.)

Fig. 154. Pleysopus frontalis nov. sp. . $^{+}$. Kopf und Prothorax. (37.)

Fig. 65. Plıysopus pilosı nov. sp. ơ. Ende des Fühlers. (115.)

Fig. 6it. Oxythrips hastata m. O. Ende des Abdomens. (33.) - Die verhältnismässige Länge der zwei letzten Abdominalsegmente erscheint verschieden, da dieselben mehr oder weniger eingezogen werden können.

Fig. 157. Oxythrips ajugue nov. sp. $\subsetneq$. Prothorax. (37.)

Fig. (is u. 69. Oxythirips firma nov. sp.

Fig. 68. Maxillartaster. (115.)

Fig. 69. Vorderbein. (56.)

*) Die Zahal in der K'lammer gibt die Vergrösserung an. 




\section{TABULE II.}

Fig. 70. Rhaphidothrips longistylosa nov. gen., nov. sp. Hlava a prothorax. (70.)*)

Fig. 71. Oxytlerips firmu nov. sp. $\delta$. Konec abdomenu. (70.) - a, dva páry ostnů na 9. čl.

Fig. 72. Oxythrips parviceps nov. sp. Hlava a prothorax. (33.

Fig. 73. a 74. Pachythrips subuptera Halid.

Fig. 73. Hlava a prothorax. (3i.)

Fig. 7t. O. Konec abdomenu. (37.)

Fig. 75.-77. Anaphothrips virgo $\mathrm{m}$.

Fig. 75. Konec tykadla. (115.) - u, šikmá přehrádka v 6. c̀l.

Fig. 76. Křidlo. (37.)

Fig. 77. Q. Konec abdomenu. (37.)

Fig. 78. a 79. Aptinothrips rufa Gmel.

Fig. 78. Tykadlo osmiclennè. (115.)

Fig. 79. Konec tykadla šestičlenného. (115.)

Fig. 80. Belothrips acuminata Halid. Konec tykadla. (115.)

Fig. 81. - 83. Dictyothrips betur nov. gen., nov. sp.

Fig. 81. Hlava a prothorax. (56.)

Fig. 82. Makadlo maxillarni. (325.)

Fig. 83. Kìílo. (56.)

Fig. 84.-86. Dendrotherips tiliae nov. gen., nov. sp.

Fig. 84. Hlava. (56.)

Fig. 85. Zadni nolı. (56.)

Fig. 86. Péro skákací. (56.)

Fig. 87. Dendrothrips Degerri nov. sp. Makadlo maxillarni. (325.)

Fig. 88. Dendrothrips saltatris nov. sp. Prothorax. 156.1

Fig. 89. Prosopothrips Vejdovskigi nov. gen., nov. sp. Hlava. (56.)

Fig. 90.- 92. Heliothrips hacmorrhoidalis Bouché.

Fig. 90. Hlava. (56.)

Fig. 91. Tykadlo. (56.)

Fig. 92. Kríllo. (33.)

Fig. 93. Parthenothrips draenenae Heeg. Tykadlo. (56.)

Fig. 94.-99. Thrips pliysopus L.

Fig. 94. Hlava a prothorax. (33.)

Fig. 95. Makadlo maxillarni. (325.)

Fig. 96. Makadlo labialni. (325.)

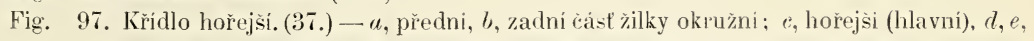
dolejši (vedlejší) žilka podélná; $p$, żilka príčná: $f, g$, nezřetelné żilky příčné; $h$, šupinka.

Fig. 98. Křídlo dolejší. (3i.) - u, šupinka.

Fig. 99. 万’. 3.-7. èl. abdom. ze spodu. (33.)

Fig. 100. Thrips communis nov. sp. Hlava. (37.)

Fig. 101. a 102. Thrips angusticeps nov. sp.

Fig. 101. Hlava. (3i.)

Fig. 102. T. Prohlubiny na spodni straně abdomenu.

Fig. 103. Thrips minutissima L. J Jedna prohlubina ze spodni strany abdomenu.

Fig. 104. Thrips calcarata nov. sp. Předni noha. (56.)

Fig. 105. a 106. Therips nigropilosa nov. sp.

Fig. 105. Hořejši zkrácené krìdlo. (56.) - - a, přední, b, zadní část żilky okružní; c, żilka hlavní; $d$, šupinka.

Fig. 106. Dolejší zkrácené křidlo. (56.) - a, zbytek žilky podélné; $b$, šupinka.

Fig. 107. Thrips Klapáleki nov. sp. Hlava. (56.)

*) Čislo v závorce udává zvêtšeni. 


\section{TAFEL, YI.}

Fig. 70. Rhaphidothips lomgistylose nor. gen., nor: sp. Kopf und Prothorax. (70.)*)

Fig. 71. Oxythrips firma nor. sp. $\delta$. Ende des Abdomens. (70.) - a, zwei Paar Dornen auf dem !. Segmente.

Fig. 72. Oxythrips parviceps nov. sp. Kopt und Prothorax. (33.)

Fig. 73 u. 74. Pachythrips selbaptria Halid.

Fig. 73. Kopf u. Prothorax. (37.)

Fig. 74. Ende des Abdomens. (37.)

Fig. 75-77. Anapllothips virgo m.

Fig. 75. Ende des Fühlers. (115.) - ". schräge Querwand im 6. Gliede.

Fig. 76. Flügel. (37.)

Fig. 77. . . Ende des Abdomens. (37.)

Fig. 78 u. 79. Aptinothrips rufa Gmel.

Fig. 78. Achtgliedriger Fühler. (115.)

Fig. 79. Ende des sechsgliedrigen Fühlers. (115.)

Fig. 80. Belothrips acuminatu Halid. Ende des Fühlers. (115.)

Fig. 81-83. Dictyothrips betue nor. gen.. nor. sp.

Fig. 81. Kopf und Prothorax. (56.)

Fig. 82. Maxillartaster. (325.)

Fig. 83. Flügel. (öb.)

Fig. 84-86. Dendrothrips tiliue nor. gen.. nor. sp.

Fig. 84. Kopf. (56.)

Fig. 85. Hinterbein. (56.)

Fig. $\quad$ 66. Sprungfeder. (56.)

Fig. 87. Demdrothrips Degeeri nov. sp. Maxillartaster. (325.)

Fig. 88. Dendrothitips sultutrix nov. sp. Prothorax. (56.)

Fig. 89. Prosopothrips Vejdoeskigi nor. gen., nov. sp. Kopf. (56.)

Fig. 90-92. Heliothips huemorrhoidalis Bouche.

Fig. 90. Kopf. (56.)

Fig. 91. Fühler. (56.)

Fig. 92. Flügel. (33.)

Fig. 93. Purthenothrigs dracuenar Heeg. Fühler. (56.)

Fig. 94-99. Thiips pliysopus L.

Fig. 94. Kopf und Prothorax. (33.)

Fig. 95. Maxillartaster. (325.)

Fig. 96. Labialtaster. (325.)

Fig. 97. Oberflügel. (37.) - $a$, vorderer, $b$, hinterer Theil der Ringader; $c$, obere (Haupt-), d. $e$, untere (Neben-) Längsader ; $l^{\prime}$, Querader; $f . g$. undeutliche Queradern; h, Schuppe,

Fig. 98. Unterflügel. (37.) - $a$, Schuppe.

Fig. 99. 万. 3.-7. Abdominalsegment von unten. (33.)

Fig. 100. Thips eommunis nov. sp. Kopf. (37.)

Fig. 101 u. 102. Thrips anyusticeps nov. sp.

Fig. 101. Kopf. (37.)

Fig. 102. T. Vertiefungen auf der Unterseite des Abdomens.

Fig. 103. Thrips mimutissima L. $\precsim$. Eine der Vertiefungen auf der Unterseite des Abdomens.

Fig. 104. Thrips culcurata nov. sp. Vorderbein. (56.)

Fig. 105 u. 106. Thrips nigropitosa nov. sp.

Fig. 105. Verkürzter Obertlügel. (56.) - $a$, vorderer, $b$, hinterer Theil der Ringader: $e$, Längsader; $d$, Schuppe.

Fig. 106. Verküıter Unterflügel. (56.) - $a$, Längsader: $b$, Schuppe.

Fig. 107. Thrips Klapáteli nov. sp. Kopf. (56.)

*) Die Zahl in der Klammer gibt die Verorösserung an. 


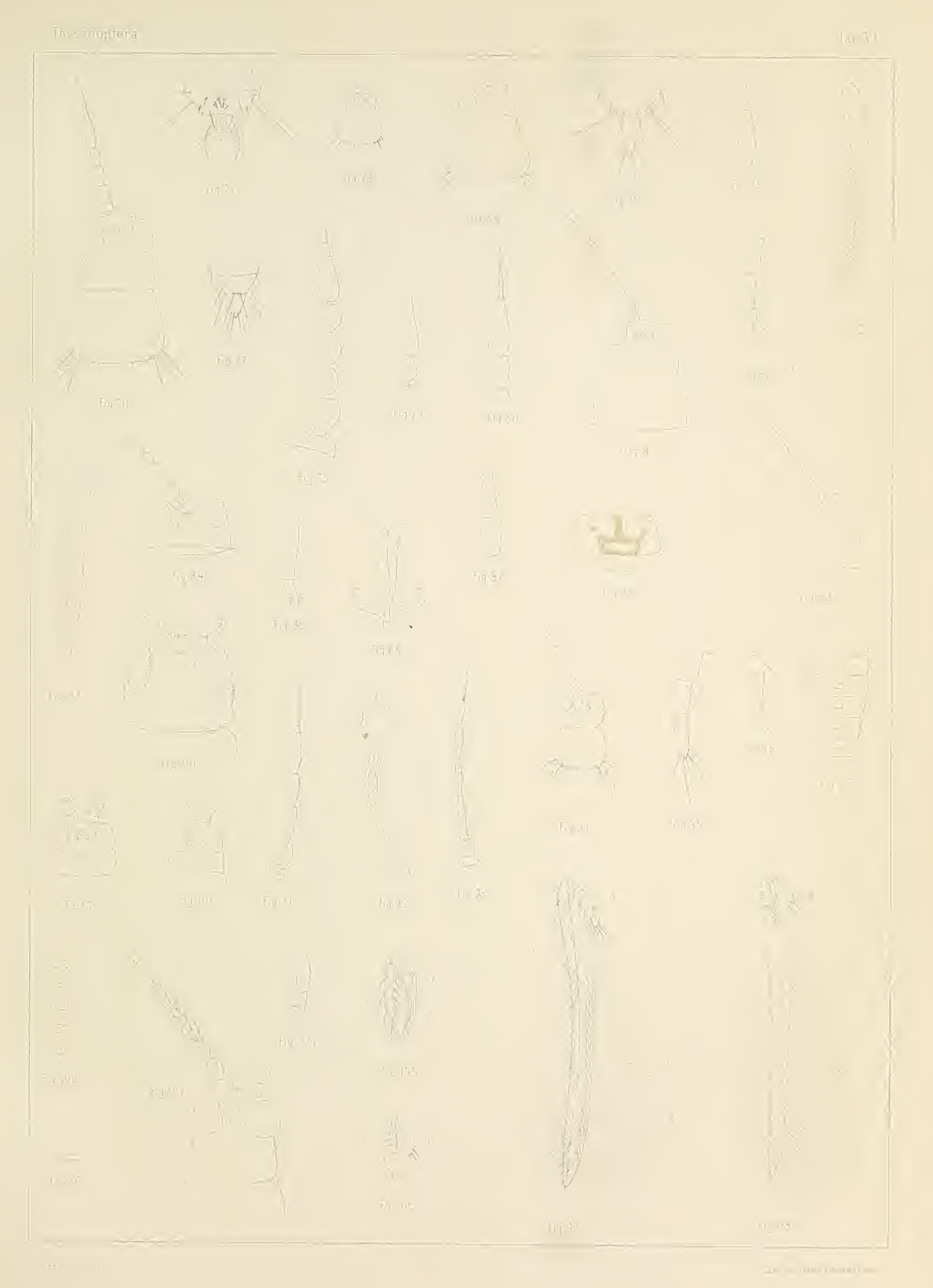





\section{TABULE VII.}

Fig. 10s. a 109. Baliothrips dispar Halid.

Fig. 108. Tykadlo. $\left.(70 .)^{*}\right)$

Fig. 109. ILakadlo maxillarní. (325.)

Fig. 110. Smingothrips biuncimata nov. gen., nov. sp. Pj̉edni noha. (56.)

Fig. 111. Sminyothrips biuncatu nov. sp. Předni noha. (56.)

Fig. 112. Bolucothrips Jordani nov. gen., nov. sp. Piedni polovice tèla. (33.)

Fig. 113. a 114. Diepunothips Reuteri nov. gen., nov. sp.

Fig. 113. Konee tykadla. (115.)

Fig. 114. ऊJ. Konec abdomenu. (70.) - $u$, srpovitý přivèsek.

Fig. 115.-117. Mcyalothrigs lativentris Heeg.

Fig. 115. Makadlo maxillarní (115.)

Fig. 116. Makadlo labialní. (115.)

Fig. 117. Tykadlo. (56.)

Fig. 118.-122. Cinptothrips late nov. sp.

Fig. 11ヶ. Tykadlo. (56.)

Fig. 119. Makadlo maxillarní. (115)

Fig. 120. Makadlo labialni. (115.)

Fig. 121. Konec s̀tětinovitélı kusadla prvèho páru. (325)

Fig. 122. $\delta$. Předni noha. (17.)

Fig 123. a 124. Cryptothrips ancyeste nov. sp.

Fig. 12:3. Hlavi. (56.)

Fig. 124. Tykadlo. (56.)

Fig. 125. a 126. Cryptothrips Tearus nov. sp.

Fig 125) Hlavit. (j).

Fig. 126. Tykadlo. (56.)

Fig. 127. Cryptothrips dentipes Reut. Tykadlo. (56.)

Fig. 128.-130. Anthothrips statiees Halid.

Fig. 128. Tykadlo. (56.)

Fig. 129. Tubus. (56)

Fig. 130 $\delta^{7}$. Konec abdomenu s vychlipenou pyji. (33.) - a, vychlipenỳ lichý chámovod; b, dvè chitinové tyěinky.

Fig. 131. Anthetherips aculcata Fabr. Tubus. (56.)

Fig. 132. a 133. Zygothrips minuta nov. gen., nov. sp.

Fig. 132. Hlava a prothorax. (33.)

Fig. 133. Tykadlo. (56.)

Fig. 134. a 135. Cephulothrips monilicomis Reut.

Fig. 134. Hlava a prothorax. (56).

Fig. 135. Tykadlo. (56.)

Fig. 136. a 137. Trichothips pedicularia Halid.

Fig. 136. Tykadlo. (56.)

Fig. 137. . . Přední noha. (17.)

Fig. 138.-140. Trichothrips ropiosa nov. sp.

Fig. 138. Tykadlo. (56.)

Fig. 139. Q. Devátý èl. abdom. a tubus ze spodu. (33.) - a, chitinová tyèinka.

Fig. 140. đ’. Devátý c̀l. abdom. a tubus ze spodu. (33.) - a, výkrojek.

Fig. 141. a 142. Plelocothrips coriacen Halid.

Fig. 141. Tykadlo. (56.)

Fig. 142. Složená křidla. (17.)

'Fig. 143. Phlocotlerips minor nov. sp. Tykadlo. (56.)

Fig. 144. Plloeothrips parva nov. sp. Tykadlo. (56.)

Fig. 145. Acanthothrips nodicornis Reut. Tykadlo. (56.) - a, ěipky ěichovè.

Fig. 146. Liothrips hradeecnsis nov. sp. Tykadlo. (56.)

Fig. 147. Liothrips setinodis Reut. Hlava a prothorax. (33.)

*) Čislo v zàvorce udàvả zvêtšeni. 


\section{TAFEI YII.}

Fig. 108 u. 109. Buliothips dispar. Halid.

Fig. 10\%. Fühler. (70.)*)

Fig. 109. Maxillartaster. (325.)

Fig. 110. Sminyothrips biuncinatu nov. gen., nov. sp. Vorderbein. (56.)

Fig. 111. Smimyothrips binncuta nov. sp. Vorderbein. (56.)

Fig. 112. Bolacothrips Jordani nor. gen., nov. sp. Vordere Körperhälfte. (33.)

Fig. 113 u. 114. Drepunothrips Reuteri nov. gen., nov. sp.

Fig. 113. Ende des Fühlers. (115.)

Fig. 114. Ende des Abdomens. (70.) - a, sichelförmiger Anhang.

Fig. 115-117. Megalothips lativentris Heeg

Fig. 115. Maxillartaster. (115)

Fig. 116. Labialtaster. (115.)

Fig. 117. Fühler. (56.)

Fig. 118-122. Cryptothips lata nov. sp.

Fig. 118. Fähler. (506.)

Fig. 119. Maxillartaster. (115.)

Fig. 120. Labialtaster. (115.)

Fig. 121. Ende einer der borstenförmigen Mandibeln. (325.)

Fig. 122. $\delta$. Vorderbein. (17.)

Fig. 123 u. 124. Cryptothips angusta nov. sp.

Fig. 123. Kopf. (56.)

Fig. 124. Fühler. (56.)

Fig. 125 u. 126. Cryptothrips Icarus nov. sp.

Fig. 125. Kopf. (56.)

Fig. 126. Fühler. (56.)

Fig. 127. Ciyptothips dentipes Reut. Fühler. (56.)

Fig. 128-130. Anthothrips stutices Halid.

Fig. 128. Fühler. (56.)

Fig. 129. Tubus. (56.)

Fig. 130. $\delta$. Ende des Abdomens mit hervorragenden Penis. (33.) - $a$, der hervorgestülpte unpaare Samenleiter (ductus ejaculatorius); $b$, zwei Chitinstäbchen.

Fig. 131. Anthothrips aculcuta Fabr. Tubus. (56.)

Fig. 132 u. 133. Zygothips mimuta nov. gen., nor. sp

Fig. 132. Kopf und Prothorax. (33.)

Fig. 133 Fühler. (๖6.)

Fig. 134 u. 135. Cephalothrips monilicornis lieut.

Fig. 134. Kopf und Prothorax. (56.)

Fig. 135. Fühler. (56.)

Fig. 136 u. 137. Trichothrips pedicularine Haliọ.

Fig. 136. Fühler. (56.)

Fig. 137. q. Vorderbein. (17.)

Fig. 138-140. Trichothirips copiosa nov. sp.

Fig. 138. Fülıler. (56.)

Fig. 139 q. Neuntes Abdominalsegment und Tubus von uinten. (33.) - $a$. Chitinstäbchen.

Fig. 140. 万ु. Neuntes Abdominalsegment und Tubus von unten. (33.) — a, Ausschnitt.

Fig. 141 u. 142. Phlocothrips coriacen Halir.

Fig. 141. Fühler. (56.)

Fig. 142. Zusammengelegte Flügel. (17.)

Fig. 143. Plilocothrips minor nov. -j. Fühler. (56.)

Fig. 144. Plelocothips parva nov. sp. Fï̈leler. (56.)

Fig. 145. Acunthothrips nodiconis Rent. Fühler. (5x.) - ". Geruclssolben.

Fig. 146. Liothrips hrudecensis nor. sp. Fühler. (5)i.)

Fig. 147. Liothrips setimodis lient. liopf und Prothorax. (33.)

*) Die Zahl in der Klammer yiht die Vergrosserung an. 




\section{TABULE VIII.}

Fig. 14^. Podẻlný prû̀̃ez kolmý pìedni polovinou tèla druhu Trichothripss copiosc nov. sp. (37.)*) a, témè; b, týl: c, celo; d, spojovaci blána mezi okrajen celním a sosákem; $e$, sosák; $f$, usta ; $g$, hrdlo ; $h$, pronotum : $i$, prosternum; j. mesonotum ; $h$, mesosternum ; l, metanotum, m, metasternum: 1, 1', prvni cl. abdom.; 2, 2', druhý c̀. abdom.

Fig. 149.-151. Pohled na pterothorax a počatek abdomenu druhu Acolothrijss fasciuta L. shora, ze strany a zdola.

Fig. 14!. " mesonotum: $b, c$, metanotum; $d$, e, postranni stíty; $f$, prehnuté okraje metasterna;, , prìièsný plátek; 1,2 , prvé dva ěl. abdom.; h, postranní destička prvniho cl. abdominal.; i, j, mista, kde křidla json vkloubena.

Fig. 150. ' . postranni stitek: $m$, mesosternun : 1 ', brìsni deska prvniho c̀l. abdom. Ostatní pismena znamenaji toté\% jako u fig. pǐedcházejici.

Fig. 151. $m$, mesosternum ; o, metasternum; $n, p$, chitinové vclllipeniny: $d$, postranní stit; $r$, pánve pro kyčle střednich nolı; $s, t, u$, kyčel, prikyčli a stehno zadni nohy.

Fig. 152.-155. Chodidlo larvy druhu Trichothrips copiosa nov. sp. (325.) - u, mèchýřek: b, drápky; $c$, kořen: $d$, výbèzek jejich; $c$, hákovitá stluštènina chitinová; $f$, obruč chitinová: g, tyè chitinová: h, konec tibie; i, chlup smyslový.

Fig. 152. Polled na chodidlo v klidu.

Fig. 153. Pohled na chodidlo polorozevìené.

Fig. 154. Pohled na chodidlo se strany.

Fig. 15.5. Pohled na chodidlo úplnè rozevřené.

Fig. 15í. Zláza (larry druhu Trichothripss copiosrt), opatrujici mèchýřek tekutinou. — a, konec stehna: b, tibie; $c, c$, vývod żlázy.

Fig. 157. Soustava nervová druhu Trichothipiss copiosa z brisni strany. (56.) - u, nervus opticus: $b$, mozek: $c$, kruh jicnový; $d$, splynulá zauzlina podjicnová a prothorakalní ; $e$, nerv jdouci do predni nohy; $f$, zauzlina mesothorakalni; $g$, nerv jdouci do hořejsiho kríida: $h$, nerv jdouci do stredni nohy; i, zauzlina metathorakalni: j, nerv jdouci do dolejssiho kiridla: li, nerv jdonci do zadni nohy: $l$, splynurši zauzliny abdominalni: 1-11, vètvičky, vychazejici z lichého provazce břišního $\mathrm{m}$.

Fig. 158. Slinná žláza vètšiho páru od druhu Trichothrips copiosu. (115.) - b, veliké bunky, obklopujici vývod żlázy $c$.

Fig. 159. Slinná żláza menšiho páru od druhu Trichothrips copiosu. (115.) - a, dutina jeji ; c, buǹky, obklopujici vývod żlázy $b$; $d$, nitka na distalnim konci żlázy.

Fig. 160. Část żlázy třetiho (nejvètšiho) páru samce druhu Trichothrips copiošc. - a, dutina, naplnèná látkou silnè svètlo lámajici.

*) Císlo v zảorce udảvá zvètšeni. 


\section{TAFEL YIII.}

Fig. 148. Verticaler Längsschnitt durch die vordere Körperhälfte von Trichothrips copiosa nov. sp. $\left.(37 .)^{*}\right)-a$, Scheitel; $b$, Hinterhaupt; $c$, Stirn; $d$, Verbindungshaut zwischen dem Stirnrand und dem Rüssel: $c$, Rüssel; $f$, Mund; $g$, Kehle; $h$, Pronotum; $i$, Prosternum; j, Mesonotum; li, Mesosternum; l, Metanotum ; $m$, Metasternum; 1.1 . erstes Abdominalsegment; 2, 2', zweites Abdominalsegment.

Fig. 149-151. Pterothorax und ein Theil des Abdomens von Aeolothrips fasciata L. ron oben, von der Seite und ron unten.

Fig. 149. $a$, Mesonotum; $b, c$, Metanotum; $d, e$, Seitenstücke; $f$, die herumgebogenen Ränder des Metasternum; $y$, Anhangsstückchen; 1, 2, die ersten zwei Abdominalsegmente; $h$, Seitenstück des ersten Abdominalsegm.; $i, j$, Einlenkungsstellen der Flügel.

Fig. 150. ', Seitenstück; m, Mesosternum : 1', Bauchschiene des ersten Abdominalsegnientes. Die übrigen Buchstaben haben dieselbe Bedeutung, wie in der vorhergehenden Figur.

Fig. 151. $m$, Mesosternum; $o$, Metasternum; $n, p$, Chitineinstülpungen; $d$, Seitenstück; $r$, Gelenkpfannen der Mittelbeine; $s, t, u$, Hüfte, Schenkelring und Schenkel des Hinterbeines.

Fig. 152-155. Tarsus der Larve von Trichothrips copiosa nov. sp. (325.) - a. Haftblase; b, Klauen: $c$, ihre Wurzel; $d$, ihr Ast: e, hakenförmiges Chitingebilde; $f$, Chitinreif ; $g$, Chitinstab: h, Ende der Schiene; i, Sinnesborste.

Fig. 152. Tarsus in der Ruhe.

Fig. 153. Tarsus halbgeöffnet.

Fig. 154. Tarsus von der Seite.

Fig. 155. Tarsus vollkommen geoffnet, mit strotzender Haftblase.

Fig. 156. Die Drüse (der Larve von Trichothrips copiosa), welche die Haftblase mit Flüssigkeit versorgt. - $a$, Ende des Schenkels; $b$, Schiene ; $c, c$, Ausführungsgang der Drüse.

F'ig. 157. Centrales Nervensystem von Trichothrips copiosa von der Ventralseite. (56.) — a, Nerrus opticus : $b$, Gehirn ; $c$, Schlundring; $d$, Prothoracalganglion; $e$, der in das Vorderbein abgehende Nerv ; $f$, Mesothoracalganglion; $g$, der in den Oberflügel abgehende Nerv; $h$, der in das Mittelbein abgehende Nerv; $i$, Metathoracalganglion; $j$, der in den Unterflügel abgehende Nerv: $k$, der in das Hinterbein abgehende Nerr; 1, die zu einer Masse verschmolzenen Abdominalganglien, 1-11, die ron dem umpaaren Bauchstrang $(m)$ abgehenden Nervenästchen.

Fig. 158. Speicheldrüse des grösseren Paares von Trichothrips copiosa. (115.) - b, grosse, den Ausführungsgang $(c)$ der Drüse umgebende Zellen.

Fig. 159. Speicheldrüse des kleineren Paares von Trichothrips ropiosa. (115.) — a, ihr Lumen: $c$, die den Ausfülurungsgang (b) umgebenden Zellen; $d$, Faden am Ende der Drüse.

Fig. 160. Ein Theil der Drüse des dritten (grössten) Paares vom Männchen der Art Trichothrips copiosa. - $a$, ihr mit stark lichtbrechendem Stoffe gefülltes Lumen. 

<smiles>[18OH]</smiles> 


\section{.}

\section{TABULE IX.}

Fig. 161. Hlava druhu Acolothrips fasciata L. s kużelem ústnim (sosákem). (175̆.)*) - a, hořejši pysk (světlé blánité misto, před koncem jeho se nalézajici, jest vynecháno, aby obraz byl názornèjsim) ; $b$, kusadla druhého páru (maxillae) : $c$, makadla maxillarni; $d$, blánité místo mezi maxillou a mentem; $e$, mentum, prodlužujíci se $\mathrm{v}$ osten $f ; g$, blánité místo, na němž nalézaji se makadla labialni $l$; i, ligula (paraglossae); $j$, štětinovitá kusadla prvého páru (mandibulae) $; k$, stlustlá jejich basis; $l$, chitinová páka; $m$, bodec ústní; $n$, basalní jeho rozšiirenina; $o$, misto, kde tato souvisí s okrajem čelním $r ; p$, otvor, kterým vchází sval; $s$, vchlipenina okraje čelního; $t$, podobná vehlipenina, spojeni s okrajem čelnim přerušivší; $u$, prodlouženiny tváři; $b l$, spojovací blána mezi okrajem čelním a basí sosáku.

Fig. 162. Bodec ústni diuhu Acolothrips fasciata L. v poloze volné. - $a$, basalni jeho rozšiřenina; b, vlastni bodec; $c$, otvor, kudy veházi sval.

Fig. 163. Zaživaci roura samce druhu Trichothrips copiosa nov. sp. (33.) - $a$, jicen; $b$, rozšírenina jienu; $c$, předni, $d$, zadni odstavec žaludku; $e, f$, rozšiřeniny tohoto; $g$, naduřenina střeva, do něhož vcházeji malpighické žlázy $h ; i$, tenké, $j$, tlusté střevo; $k$, żlázy slinné většiho, $l$, menšiho, $m$, třetiho (nejvètšího) páru.

Fig. 164. Zaživaci roura druhu Acolothrips fuscintu L. (33.) - $u$, jicen; $b$, rozsišrenina jicnu; $c$, přední, $d$, zadní odstavec žaludku; $e$, rozširìnina tohoto; $f, g$, malpighickè žlázy ; $h$, tenké, $t$. tlusté střevo ; $l$, slinná żláza krátká; $i$, slinná żláza dlouhá; $j$, rozšsiřenina jeji ; $k$, konec jeji, kterým se $\mathrm{k}$ żaludku prìkládá.

Fig. 165. Saměi ústroje pohlavni druhu Trichothrips copiosu. (37.) - $a$, varlata; $b$, vas deferens; $c$, $d$, rozšiř̌eniny jeho; $e, f$, oba páry żłáz príidavných; $g$, rozsisirenina na konci vývodu vnèjšiho páru; $h$, vedlejši dutinka na basi společného chámovodu $i$.

Fig. 166. Saměi ústroje pohlavni druhu Thrips plyssopus L. (115.) - $a$, varlata; $b$, vas deferens; $c$, rozšiřenina jeho; $d$, rozšiřenina společného chámovodu $c ; f$, żlázy přidarné.

*) Císlo $\mathrm{v}$ závorce udává zvêtšení. 


\section{TAFEL IX.}

Fig. 161. Kopf ron Aeolothrips fusciatu L. mit dem Rüssel ron rorn. (175.)*) - u, Oberlippe (die lichte häutige Stelle ror ihrem Ende wude der Übersichtlichkeit wegen ausgelassen); b. Maxillen: $c$, Maxillartaster: $\boldsymbol{d}$. häutige Stelle zwischen der Maxille und dem Mentum; $e$, Mentum in einen Stachel $(f)$ auslaufend: g, häutige Stelle. auf der sich die Labialtaster (l) befinden; i, ligula (paraglossae): j. borstentörmige Mandibeln; $k$, ihre rerdickte Basis; 7. Chitinhebel: $m$, Mundstachel; $n$, seine basale Erweiterung: $o$. Stelle, wo dieselbe mit dem Stirnrand ( $r)$ zusammenhängt; $\rho$. Öfnumg. durch welche ein Muskel eintritt; $s$, Einstülpung des Stirnrandes; $t$, ähnliche Einstülpung. die sich rom Stirnrande entfernte: u, Verlängerungen der Wangen; 7, , Verbindungshaut zwischen dem Stirnrande und der Basis des Rüssels.

Fig. 162. Mundstachel ron Aeolothrijs fasciutı L. frei. - ^, seine basale Erweiterung: ‘, Öfinung, durch welche ein Muskel eintritt.

Fig. 163. Verdauungsröhre des Männchens ron Trichothrips copiosa nor. sp (33.) - $u$. Oesophagus: $b$, seine Erweiterung; $c$, rorderer, $d$, hinterer Abschnitt des Vagens: $c, f$, Erweiterungen desselben; $g$, Darmverdickung, in welche die Malpighischen Gefässe $(h)$ münden; $i$, Dünndarm; j, Dickdarm: $k$. Speicheldrüsen des grösseren, 7 , des kleineren, $m$, des dritten (grössten) Paares.

Fig. 164. Verdauungsröhre von Aeolothrips fusciutu L. (33.) - a. Oesophagus: b, seine Erweiterung; c, vorderer; $d$, hinterer Abschnitt des Magens: $\boldsymbol{e}$. Erweiterung des letzteren: $f$, $\boldsymbol{y}$. Malpighische Gefüsse: h. Dünndarm. $t$. Dickdarm: 7 . kurze Speicheldrüse: i, lange Speicheldrüse: $j$, Erweiterung der letzteren: $k$. ihr Ende, mit dem sie sich an den Magen anlegt.

Fig. 165. Männliche Fortpflanzungsorgane von Trichothrips copiosu. (37.) - a. Hoden: b. Vas deferens; $\boldsymbol{c}$, seine Erweiterungen: $\boldsymbol{c} . t$. beide Pare der accessorischen Drüsen: $y$, Erweiterung auf dem Ende des Ausführungsganges des äusseren Paares; $h$, kleine Nebenhöhlung am Grunde des gemeinschaftlichen Samenleiters i.

Fig. 166. Männliche Fortpflanzungsorgane ron Thrips plyysopu. L. (115.) - u, Hoden ; b, Vas deferens; $c$ seine Erweiterung: $d$. Erweiterung des gemeinschaftlichen Samenleiters $e$ : $f$, accessorische Drüsen.

") Die Zahl in der Klammer gibt die Vergrösserung an. 
7an. PI

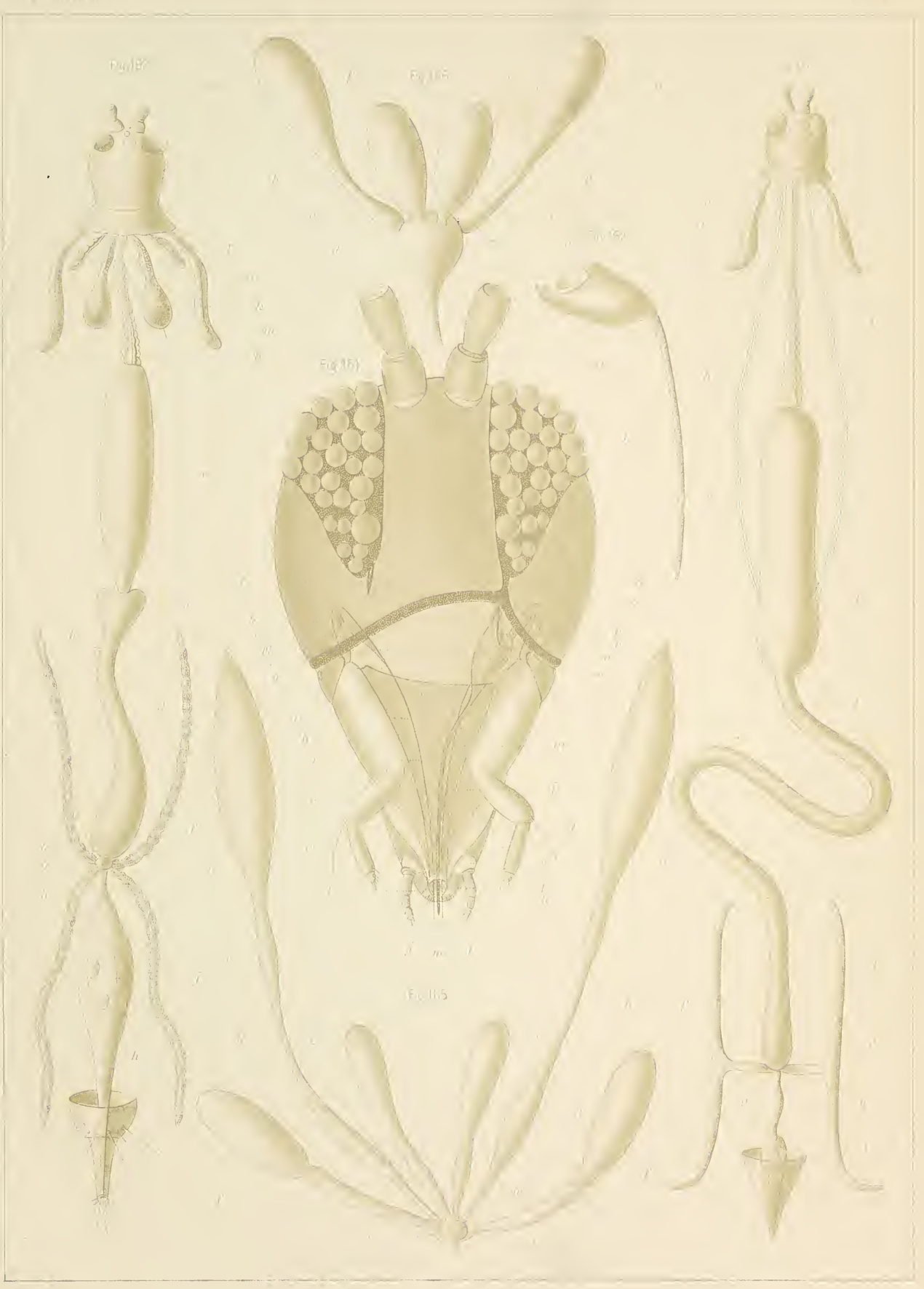





\section{TABULE X.}

Fig. 167. Samiči ústroje pohlavni druhu Trichothrips copjosa nor. sp. (37.)*) - a, rourky raječné; b, komůrka nejzralejšiho rajička; $e$, vejcovod: $l$. polı́rovitá jeho rozšiřenina; $e$ lichý rejcorod: $f$, hlavička, $g$, krěek, $h$, tèličko, i, rývod zásobárny chámové; j, srazky chámů: $l$, $l$, vlákna, jimiž zavěšeny jsou vaječniky na slinné žláze $m$.

Fig. 168. Samičí ústroje pohlavní druhu Acolothrips fasciata L. (37.) Písmena a-e mají tentỵž význam jako u fig. předcházející: $f$, zásobárna chámová; $g$, její výrod s rozśíreninou na konci $h$ : $i$ žláza mazová; $j$, jeji vývod; $k$, nitky zakonc̀ujíci rourkv raječné.

Fig. 169. Zásobárna chámová druhu Physopms atrate Halid. (115.) — a, vlastní zásobárna s dutinou podoby retorty $c$; b. vývod zásobárny.

Fig. 170. Konec abdomenu druhu Physopus vnlyntissima Halid. s kladelkem, ze strany. (115.) 7-10, poslední 4 c̀l. abdom.; g, postlanni destičky èlánku 7.; a, pravá přední, d. pravá zadni chlopeñ kladélka; $7, e$, stlustlé okraje jejich; $f$, rỵlıa, do které se muże kladélko uki'yti.

Fig. 171. Kladélko druhu Physopus vulgatissima Halid. z přèdu. (265.) - a, b, prední chlopnè; $c$, šikné zuby na nich. Význam ostatnich pismen vyložen jest $\mathrm{r}$ textu.

Fig. 172. Soustara vzdušnic samce druht Thriqs pllysopus L. (60.) - 1. 2.3.4, čtyrì páry otrolû dychacich. Význam písmen vylożen jest r textu.

*) Císlo v závorce udává zrètšeni. 


\section{TAFEL X.}

Fig. 167. Weibliche Fortpflanzungsorgane von Trichothrips copiosa nov. sp. (37.)*) - $u$, Eiröhren : $b$, Kammer des reifesten Eies; $c$, Eileiter; $d$, seine kelchförmige Erweiterung; $e$, Eiergang; $f$, Kopf, g, Hals, h, Köıper, $i$, Ausführungsgang des Receptaculum seminis ; j, Samenfädenbündel; $k, l$, Fäden, mit deren Hilfe der Eierstock an der Speicheldrüse $(m)$ hängt.

Fig. 168. Weibliche Fortpflanzungsorgane von Aeolothrips fasciata L. (37.) Die Buchstaben $a-c$ von derselben Bedeutung wie in der vorhergehenden Figur; $f$, Receptaculum seminis; $y$, Ausführungsgang desselben mit der Erweiterung $(h)$ auf dem Ende; $i$, Schmierdrüse; $j$, ihr Ausführungsgang; $k$, Endfäden der Eiröhren.

Fig. 169. Receptaculum seminis von Physopus atrata Halid. (115.) - a, der Samenbehälter mit retortenförmiger Höhlung $c ; b$, Ausführungsgang des Behälters.

Fig. 170. Ende des Abdomens von Physopus vulyatissima Halid. mit dem Legebohrer von der Seite. (115.) - 7-10, die vier letzten Abdominalsegmente, g, Seitenstücke des 7. Segm.: $a$, vordere rechte, $d$, hintere rechte Klappe des Legebohrers; $b, e$, ihre verdickten Ränder; $f$, Furche, in die der Legebohrer eingezogen werden kann.

Fig. 171. Legebohrer von Physopus vulyatissima Halid. von vorn. (265̃.) - $a, b$, beide vordere Klappen ; $c$, schiefe Zähne auf denselben. Erklärung der übrigen Buchstaben im Text.

Fig. 172. Tracheensystem eines Männchens von Thrips physopus L. (60.) - 1, 2, 3, 4, vier Paar Stigmen. Erklärung der übrigen Buchstaben im Text.

*) Die Zahl in der Klammer gibt die Vergrösserung an. 


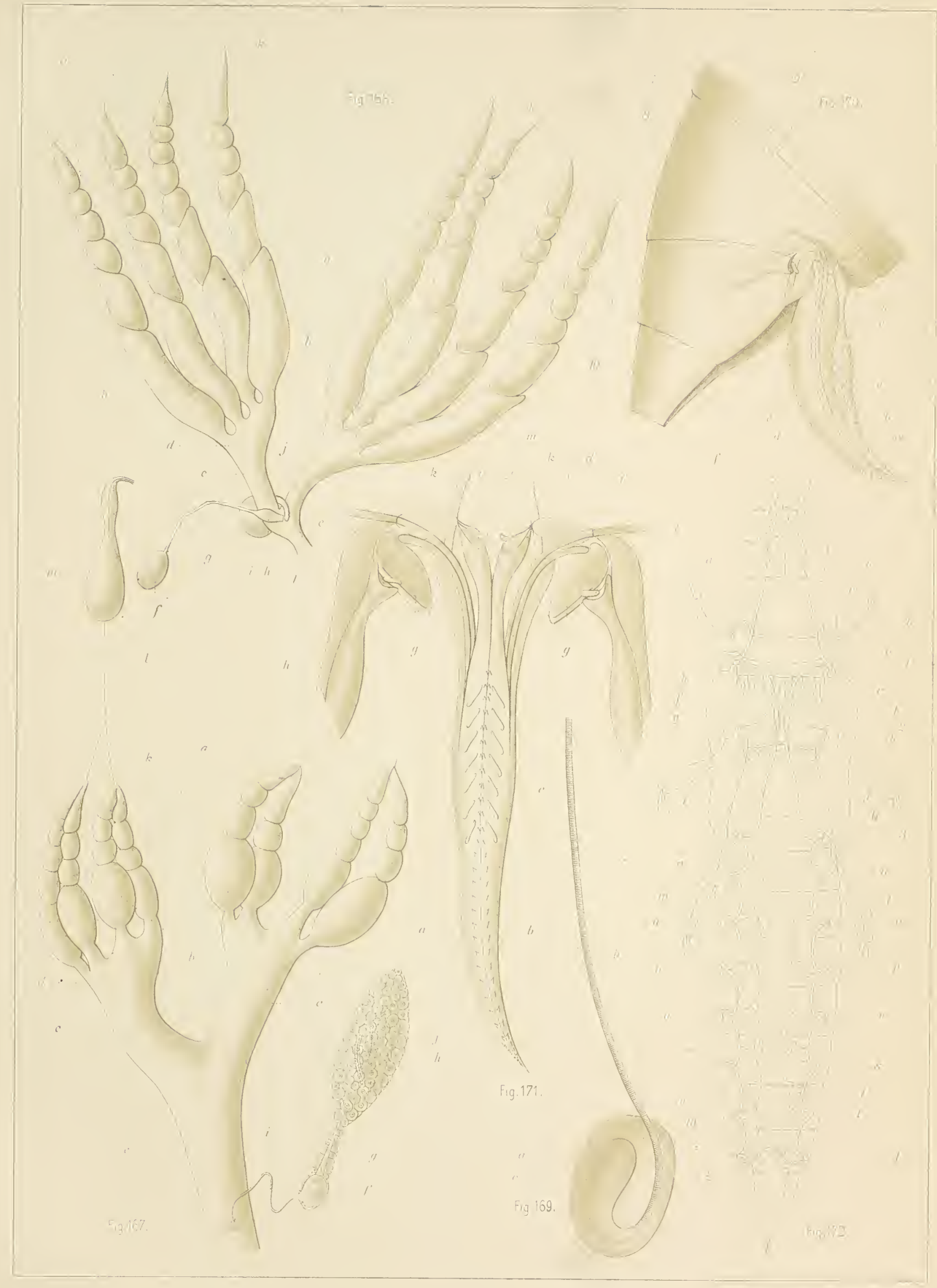



Od téhož spisovatele ryšly:

\section{SUUPINUŚKY ZEMË ĆESKÉ. THYSANURA BOHEMIAE.}

Sedvèma tabulemi, z nichř jedna jest kolorovaná.

Dissertace poctěná cenou universitní.

V PRAZE 1890.

Zvláštni otisk z Vèstníka Král. české společnosti náuk.

(Obsahuje biologická pozorováni a pưrodni popisy 76 druhů českỵch, z nichž 12 je norých.)

\section{C'ena 1 zl. $20 \mathrm{kr}$.}

V kommissi u Fr. Rirnáce v Praze,

Ferdinandora trída, èis. 25. 
Von demselben Verfasser erschienen:

\section{SUUPINUŚKY ZEMË ĆESKÉ. THYSANURA BOHEMIAE.}

Mit zwei Tafeln, yon denen eine coloriert ist. .

Dissertation, gekrönt mit dem Preise der Karl-Ferdinands-Universität in Prağ.

PRAG 1890.

Separatabdruck aus den Sitzungsberichten der Königl. böhm. Gesellschaft der Wissenschaften.

(Enthält biologische Beobachtungen und Originalbeschreibungen von 76 böhmischen Arten. Die 12 nov. sp. und die Erklärung der Tafeln lateinisch.)

Preis 1 fl. $20 \mathrm{kr}$. ̈. W. $=2 \mathrm{M}$.

In Commission bei Fr. Rivnáč in Prağ,

Ferdinandstrasse, Nr. 25. 







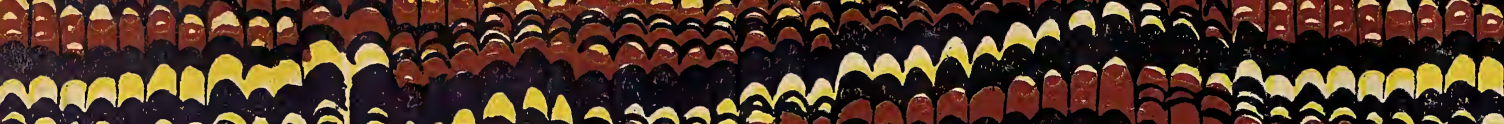

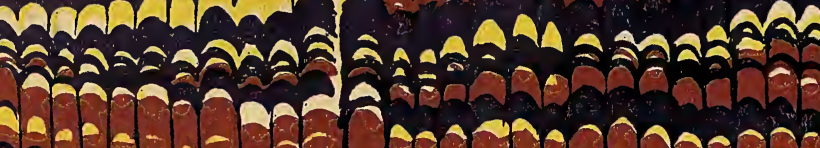

\section{$17-1-2-2=\sqrt{2}$}

anavana

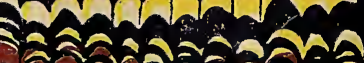

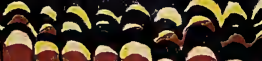

ชิ Hat U-

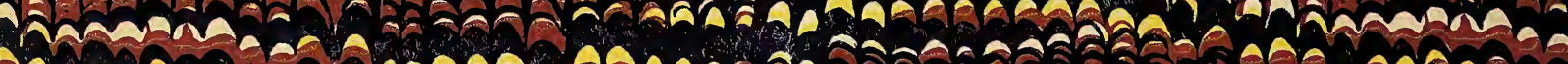

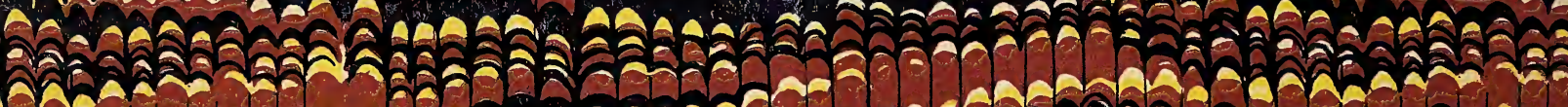

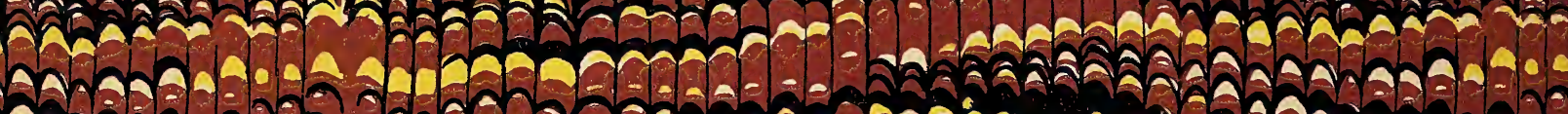

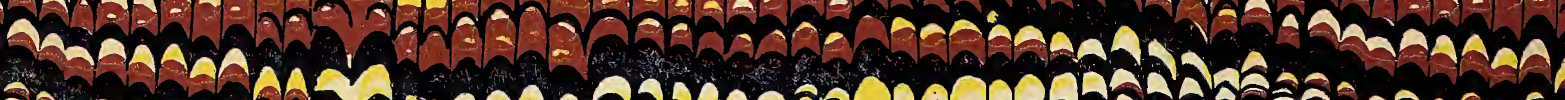

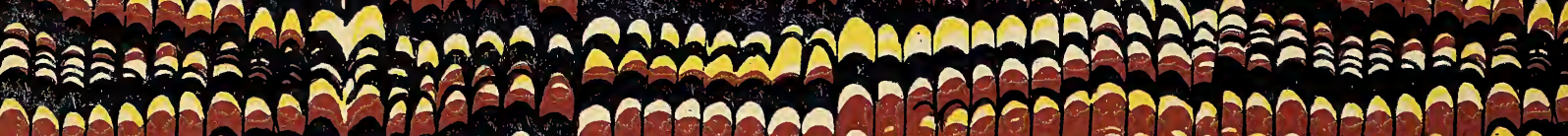

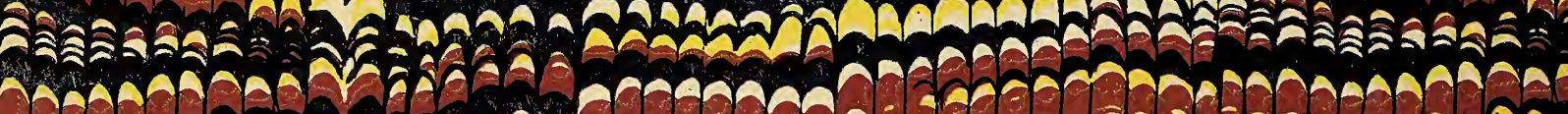

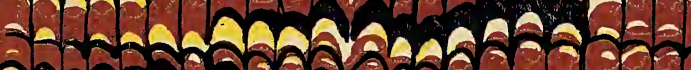

\section{mainen}

COCA

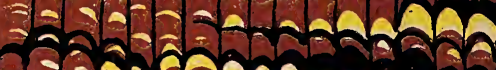

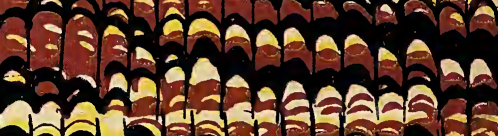

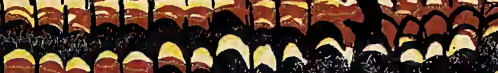

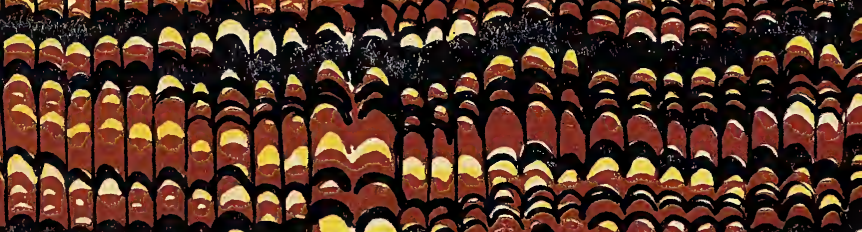

Panomane $2 \mathrm{sa}$

sap. 12 2

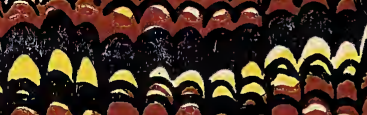

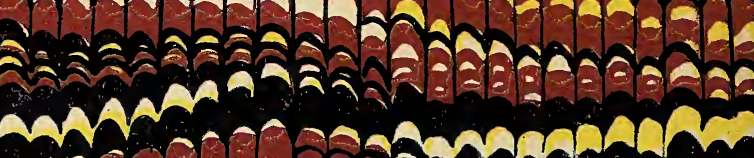

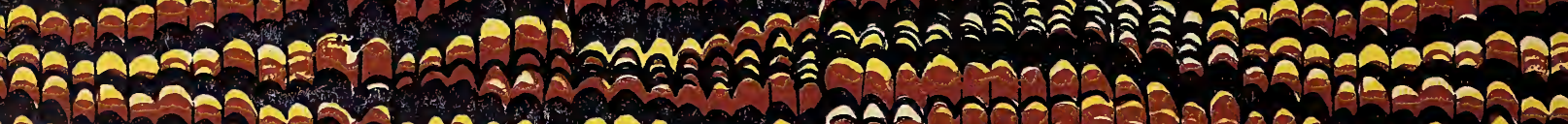

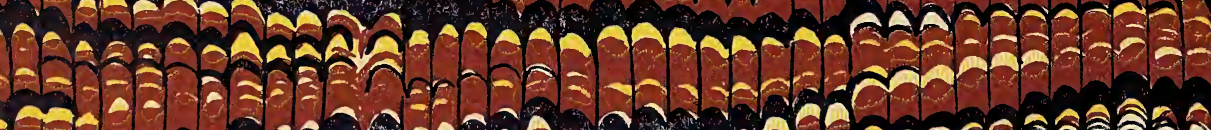

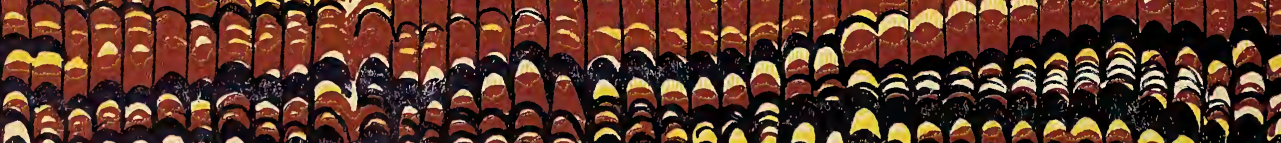

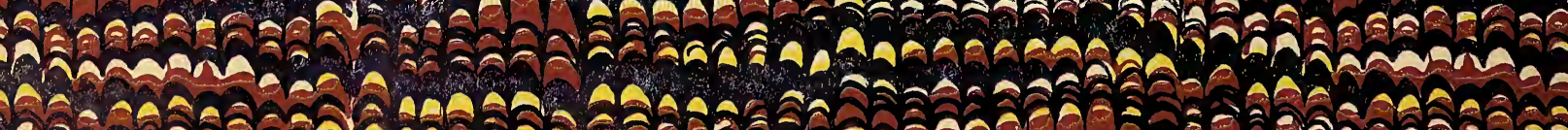

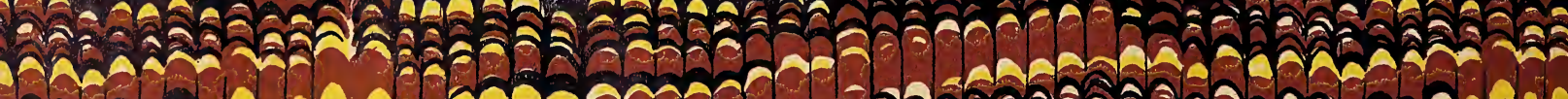

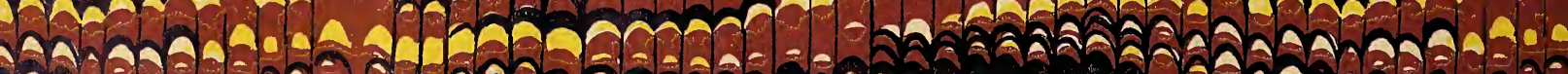

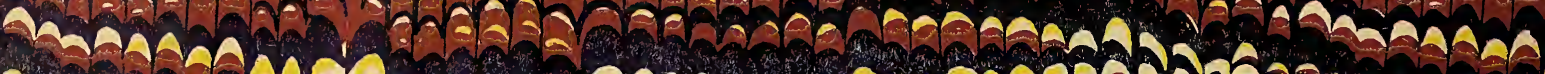




\section{AấaA}

$n \cap$

10ลคคล

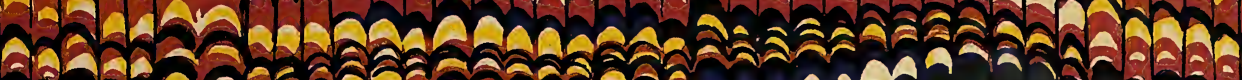
- न.

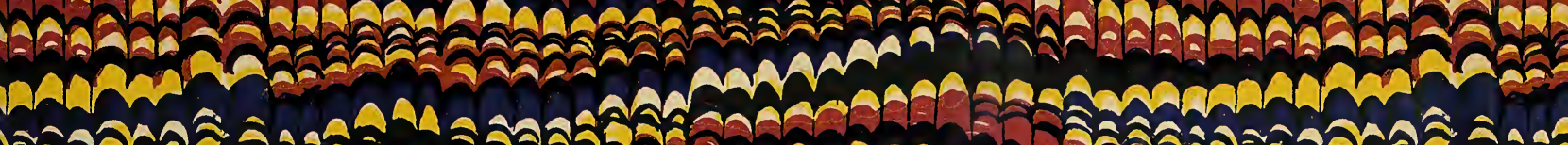
$\because-20$ -

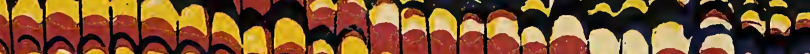

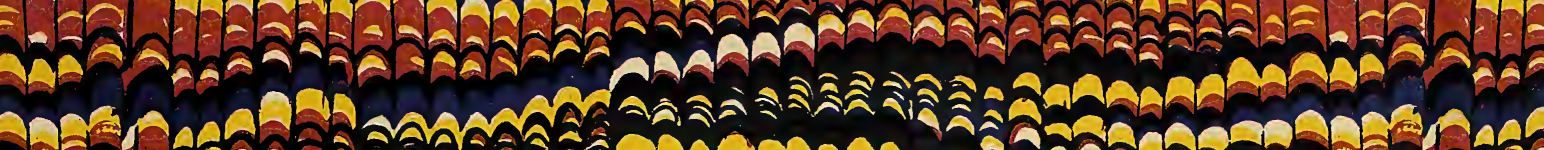

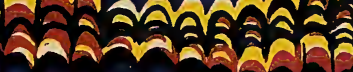

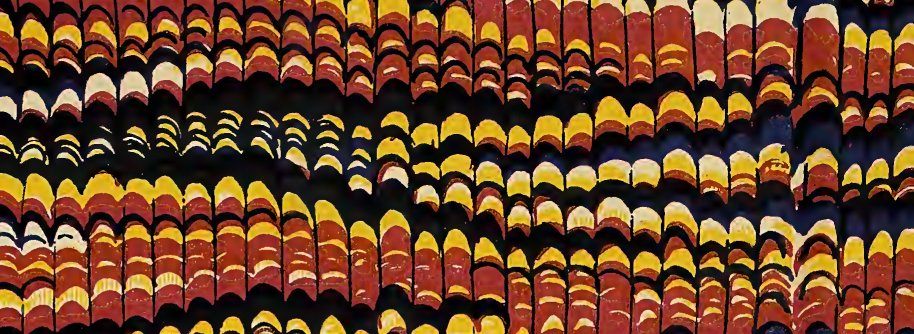
Sล

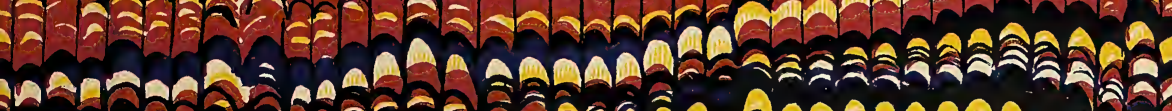
Mn

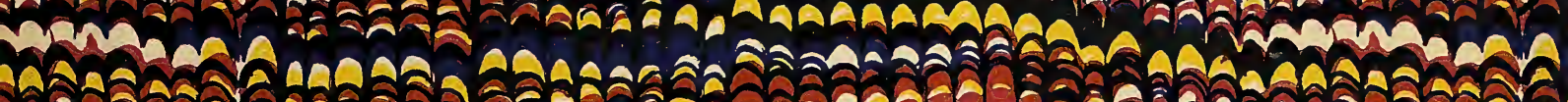

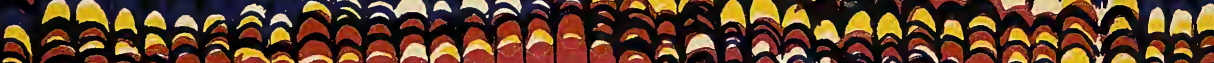

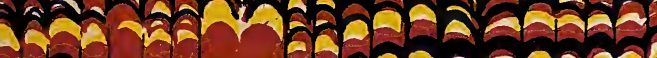

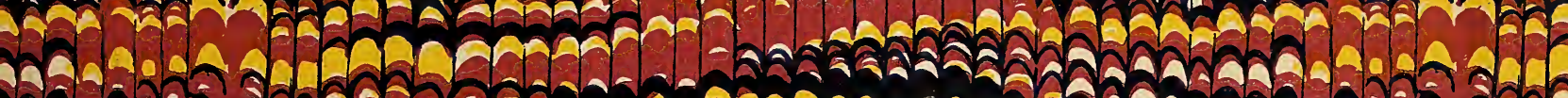

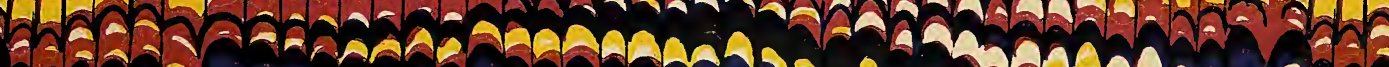

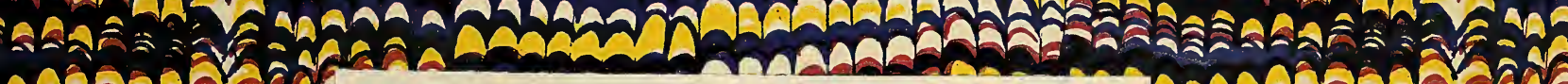
Tीanaिâ

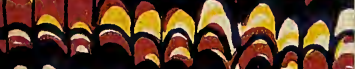
ADAिति

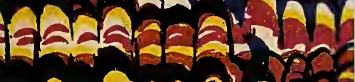
Dana iaraf

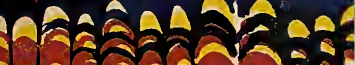
Ana An

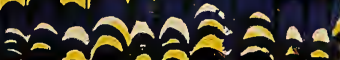
ลิ

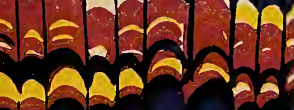

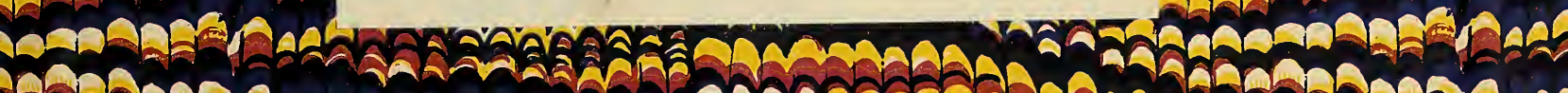

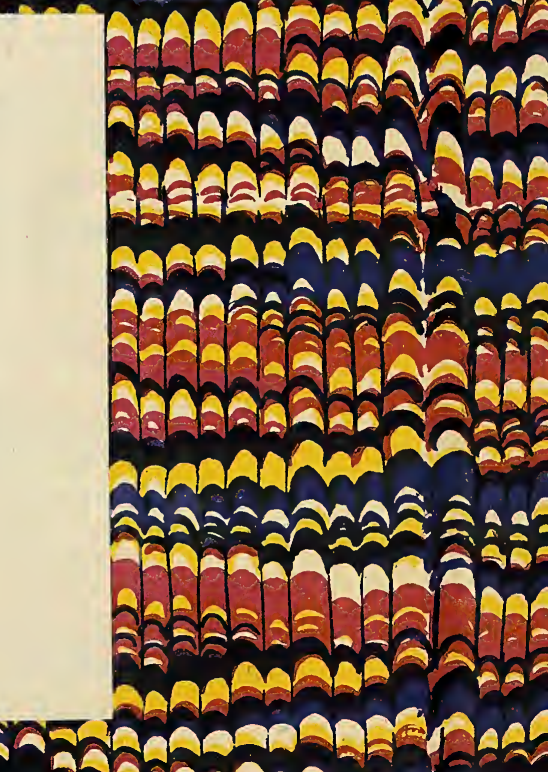

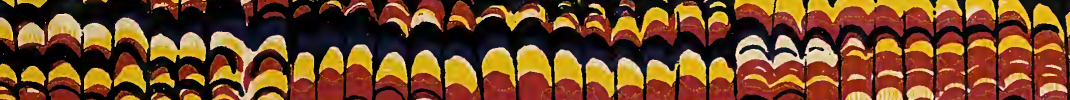

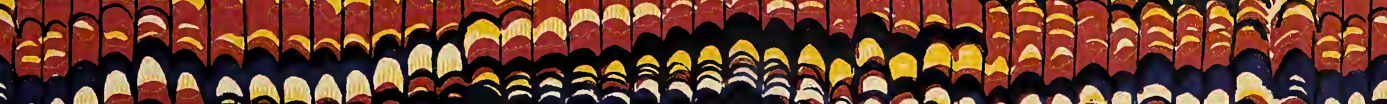

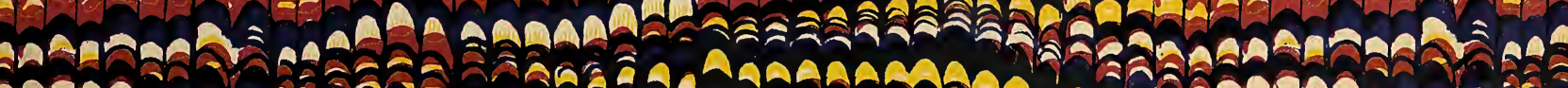

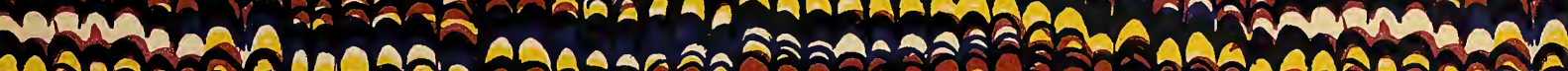

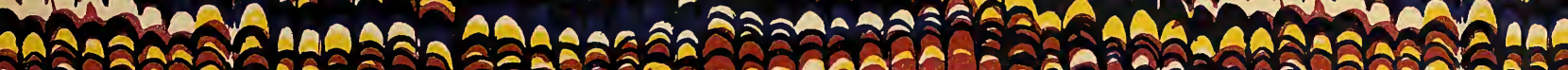

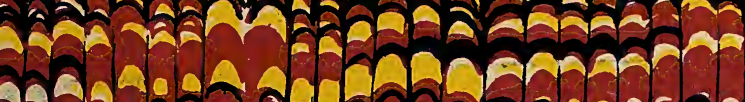


